The Form and Function of Headwater Streams Based on Field and Modeling Investigations in the southern Appalachian Mountains

\author{
Rebecca Kavage Adams \\ Thesis submitted to the faculty of the \\ Master of Science \\ in \\ Geological Sciences \\ James A. Spotila, Chair \\ Kenneth A. Eriksson \\ Panayiotis Diplas \\ E.F. Benfield
} Virginia Polytechnic Institute and State University in partial fulfillment of the requirements for the degree of

November 21, 2002

Blacksburg, Virginia

Keywords: headwater, stream morphology, bankfull, sediment transport Copyright 2002, Rebecca K. Adams 


\title{
The Form and Function of Headwater Streams Based on Field and Modeling Investigations in the southern Appalachian Mountains
}

\author{
Rebecca Kavage Adams
}

\begin{abstract}
(ABSTRACT)
Headwater streams drain the majority of the landscape, yet little is known about their form and function in comparison to lowland rivers. Better understanding of their morphology and sediment transport processes will improve understanding of landscape evolution and promote a more complete view of fluvial systems. Therefore, the goal of my project was to determine controls on headwater channel form and function in the humid, moderate-relief drainage basins of the Valley and Ridge and Blue Ridge provinces in the southern Appalachian Mountains. I surveyed nine headwater $\left(0.33-2 \mathrm{~km}^{2}\right.$ drainage area) streams in a variety of bedrock, climate, base level, and land use conditions and produced a high-resolution dataset on their longitudinal and cross sectional form. This data was analyzed empirically to determine controls on channel form, and used in hydrologic modeling to determine the ability of the channels to erode their beds during regularly recurring flows as well as the recurrence interval of bankfull flows. Field survey results demonstrate that the channels are dominantly alluvial and vary greatly between and within channels in their overall longitudinal form, channel slope values, and grain size. These variations are due to differences in bedrock resistance at the formation level as well as at short wavelengths. Bedrock also controls channel form through its influence on local and regional base level, channel initiation processes, and log jam abundance. Hydraulic geometry, steam competence and bankfull flow recurrence also vary greatly between and within channels. This variation is due to the high sensitivity of the streams to hillslope influences such as bedrock resistance, boulder influx, and soil profile development. Increases in bedrock resistance within a channel create knickpoints that lower stream competence and slow hilllslope erosion. Stream competence is generally higher in channels with erodable bedrock and lower in channels with resistant bedrock, but most channels could entrain the majority of the grains on their bed at 2-year stormflows. Bankfull is a larger, less frequent flow than the 2-year storm at very small
\end{abstract}


drainage areas $\left(<0.4 \mathrm{~km}^{2}\right)$, but is approximately a 2-year recurrence flow at larger drainage areas. Bankfull occurs less frequently in North Carolina Blue Ridge streams, due to deep soils that form on metamorphic bedrock under an more intense precipitation regime and have high rainfall storage capacity. Results indicate that variability is a fundamental feature of headwater streams and that they do not follow channel slope, hydraulic geometry, and bankfull relations developed in lowland river systems. 


\section{Acknowledgements}

Many people contributed to my thesis work. Dr. Pamela Edwards and Gary Kappesser, of the U.S. Forest Service, originally planted the seed in my mind that study of headwater steams was an important but neglected area of research in forest hydrology. My advisor, Dr. James Spotila, contributed a great deal to the thesis as its "producer", providing financial support as well as guidance and advice. I also thank my committee members, Drs. Eriksson, Diplas, and Benfield, for their guidance and time spent in digesting a large, complex thesis project.

Jeffrey Adams, my husband, provided invaluable computer programming support and friendly patience, in addition to crawling through several miles of rhododendron as a field assistant. Doug Marchakitus and Lee Taylor also contributed many difficult volunteer hours as field assistants in steep, rhododendron-filled terrain. I also thank my family - my parents, grandma, sister, Mini, and Meg, for their support and cuteness. I especially thank my mother Virginia Kavage, for taking me to camp every summer along the Jackson River, so I could learn to appreciate the magic of a cold mountain stream. 


\section{Table of Contents}

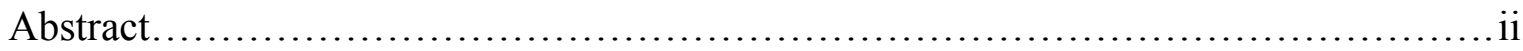

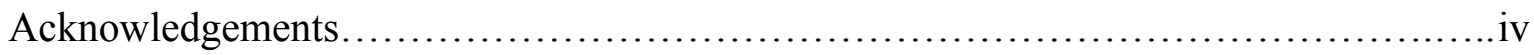

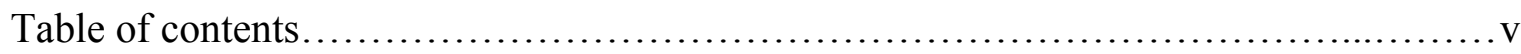

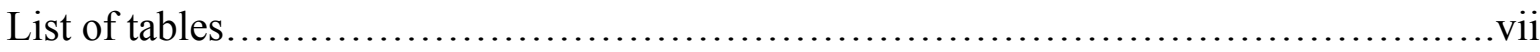

List of figures..................................................................... vii

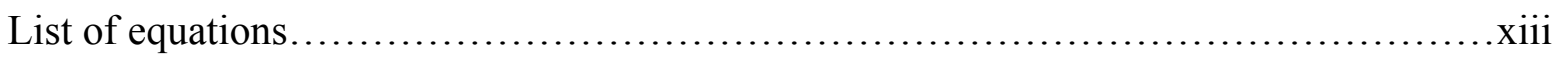

Chapters page

1. Introduction....................................................................... 1

2. Empirical Analysis......................................................... 7

2.1. Introduction........................................................... 7

2.2. Data Collection Methods............................................. 8

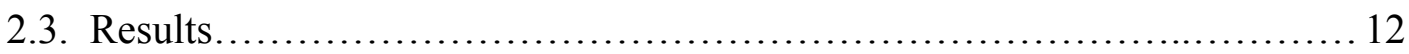

2.4. Interpretations and Discussion......................................... 15

2.5. Conclusions.......................................................... 20

3. Modeling Analysis............................................................. 34

3.1. Introduction.......................................................... 34

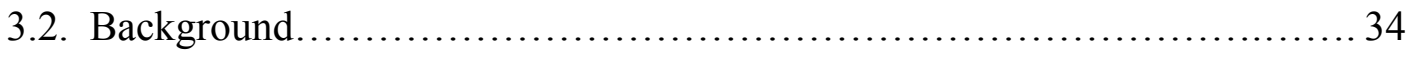

3.3. Methods......................................................... 36

3.4. Modeling Inputs....................................................... 54

3.5. Evaluating the Model.................................................. 69

3.6. Discharge Modeling................................................ 86

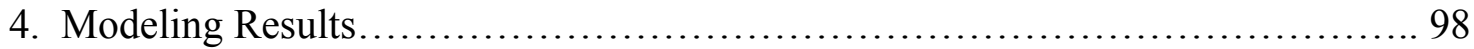

4.1. Discharge Magnitude and Bankfull Height...................................98

4.2. Channel Form and Width-Depth Ratio.................................... 100

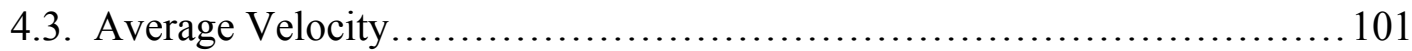

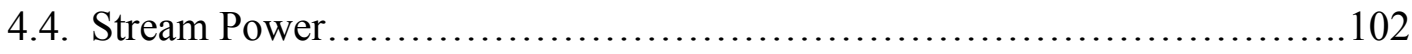

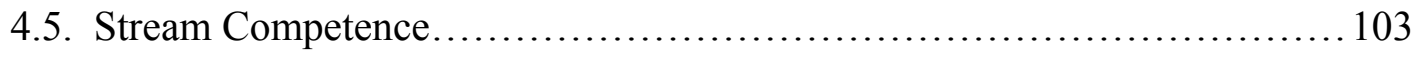

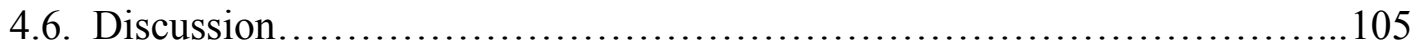




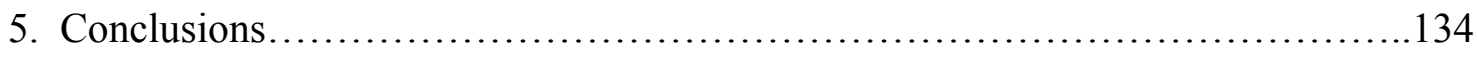

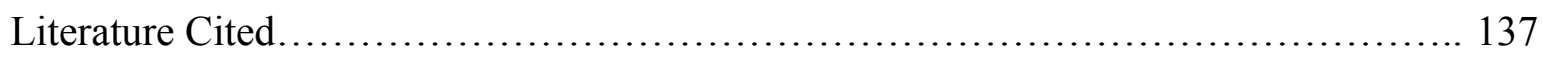

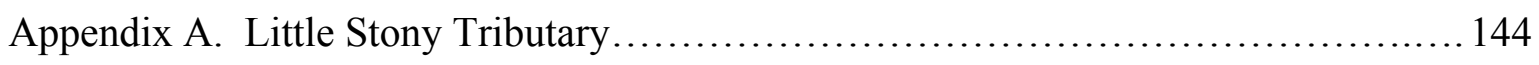

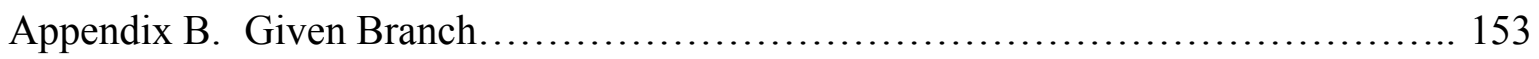

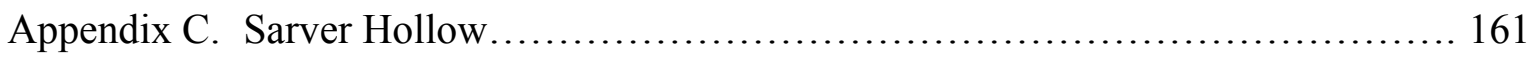

Appendix D. Allen Hollow....................................................... 170

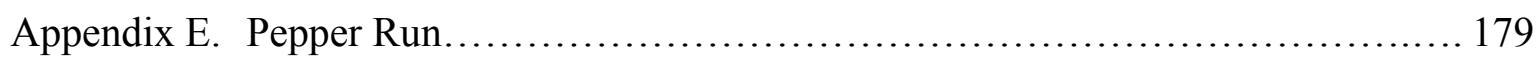

Appendix F. Indian Spring ........................................................ 187

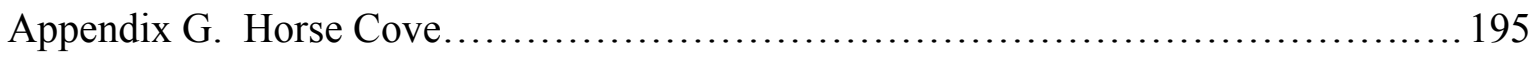

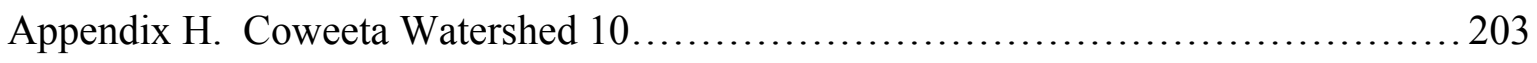

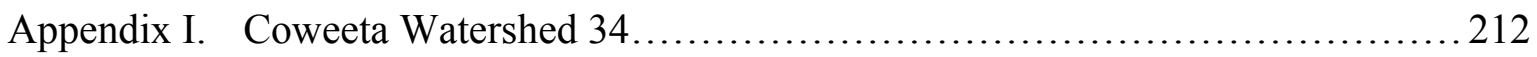

Appendix J. Bedrock Geology Legend..........................................219

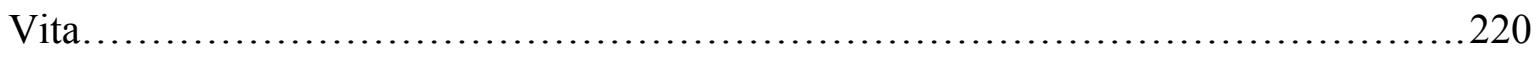




\section{List of Tables}

Table 2.1. Summary statistics of all streams surveyed............................. 32

Table 2.2. Summary statistics of channel substrate distribution for all streams

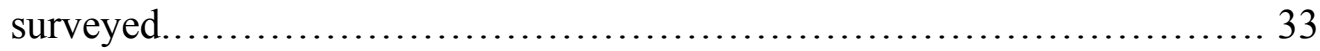

Table 3.4.1. Descriptions of hydrologic soil groups used in curve number selection..... 67

Table 3.4.2. Summary soil and land cover data used in hydrologic modeling for each basin......................................... 67-68

Table 3.5.1. Peak discharge calibration for observed storm, September 5, 2000 at Allen Hollow .................................... 84

Table 3.5.2. Data from Coweeta Watershed 10 peak discharge calibration.............. 84

Table 3.5.3. Data from Coweeta Watershed 34 peak discharge calibration............... 84

Table 3.5.4. Data from Coweeta Watershed 10 volume calibration prior to baseflow addition to model .................................. 85

Table 3.5.5. Data from Coweeta Watershed 10 volume calibration after baseflow addition to model ...................................... 85

Table 3.6.1. Comparison of hydraulic parameters produced in discharge modeling using different methods of calculating Manning's $n$ for Allen Hollow x1 ........................................ 96

Table 3.6.2. Comparison of hydraulic parameters produced in discharge modeling using different methods of calculating Manning's $n$ for Allen Hollow x4 97 


\section{List of Figures}

Figure 2.1. General location of streams surveyed in Virginia Valley and Ridge and North Carolina Blue Ridge....................................... 21

Figure 2.2. Longitudinal profiles of all streams, from survey data.................. 22

Figure 2.3. Longitudinal profiles of all streams, from survey data, with channel initiation point set to 1000 m elevation ........................ 23

Figure 2.4. Channel slope by length for Virginia and North Carolina channels.............24

Figure 2.5. Photographs of bedrock and boulder channel sections .................. 26

Figure 2.6. Channel substrate by percent of channel length ........................... 27

Figure 2.7. $\quad \mathrm{D}_{84}$ grain size vs. drainage area for all cross section locations .............. 27

Figure 2.8. Average $\mathrm{D}_{50}$ and $\mathrm{D}_{84}$ grain size for all cross sections in each channel...... 28

Figure 2.9. Slope vs. $\mathrm{D}_{84}$ grain size for all cross section locations $\ldots \ldots \ldots \ldots \ldots \ldots \ldots . \ldots 28$

Figure 2.10a. Average $\mathrm{D}_{50}$ and $\mathrm{D}_{84}$ grain size for all cross sections in each channel...... 29

Figure 2.10b. Average $\mathrm{D}_{50}$ and $\mathrm{D}_{84}$ grain size for all cross sections in each channel....... 29

Figure 2.11a. Comparison of slope vs. channel length to $\log$ jams vs. channel length for Allen Hollow ........................... 30

Figure 2.11b. Example of log jams trapping sediment and breaking slope in lower gradient, alluvial reaches of Allen Hollow..................... 30

Figure 2.12. Slope vs. drainage area for all channel initiation points ................... 31

Figure 3.3.1. Comparison of DEM-generated slope values to field surveyed slope values........................................ 46

Figure 3.3.2. Example of DEM-generated drainage network in Allen Hollow............. 46

Figure 3.3.3. Example of HEC-HMS basin schematic for Allen Hollow................ 47

Figures 3.3.4.-3.3.12.

Maps of modeling inputs for each basin. $48-53$

Figure 3.4.1. Hyetograph for 3.25-inch storm recorded at Butt Mountain.............. 61

Figure 3.4.2. Hyetograph for 3.5-inch storm used as two year 24 hour rainfall in Virginia 61

Figure 3.4.3. Hyetograph for 4-inch storm used as two year 24 hour rainfall in North Carolina. 
Figure 3.4.4. Hydrograph for Coweeta Watershed 10 during 4-inch storm used as two year 24 hour rainfall in North Carolina.................... 62

Figure 3.4.5. Hyetograph for 1.8-inch storm recorded at Brush Mountain.............. 63

Figure 3.4.6. Hyetograph for 2.8-inch storm recorded at Robbinsville.................. 63

Figure 3.4.7. Hyetograph for 4.1-inch storm recorded at Coweeta Hydrologic Laboratory rain gauge 6 , used in calibration.

Figure 3.4.8. Hyetograph for 6.6-inch storm recorded at Coweeta Hydrologic

Laboratory rain gauge 6 , used in calibration.

Figure 3.4.9. Hyetograph for 3.4-inch storm recorded at Coweeta Hydrologic

Laboratory rain gauge 6 , used in calibration

Figure 3.4.10. Hyetograph for 3.6-inch storm recorded at Coweeta Hydrologic

Laboratory rain gauge 6 , used in calibration....

Figure 3.4.11. Hyetograph for 4.9-inch storm recorded at Coweeta Hydrologic

Laboratory rain gauge 6 , used in calibration.

Figure 3.4.12. NEXRAIN Corporation digital rainfall data from observed

September 4, 2000 storm, used for calibration at Allen Hollow

Figure 3.5.1. Predicted hydrograph for Allen Hollow cross section 1,

during September 5, 2000 storm................................. 78

Figure 3.5.2. Observed and predicted hydrographs for Coweeta 10,

January 5,1949 storm.......................................... 78

Figure 3.5.3. Observed and predicted hydrographs for Coweeta 10,

July 10, 1949 storm.

Figure 3.5.4. Observed and predicted hydrographs for Coweeta 10,

June 15, 1949 storm .79

Figure 3.5.5. Observed and predicted hydrographs for Coweeta 34,

January 31,1957 storm.

Figure 3.5.6. Observed and predicted hydrographs for Coweeta 34,

June 28, 1957 storm.

Figure 3.5.7. Observed and predicted hydrographs for Coweeta 34,

April 4, 1957 storm. 
Figure 3.5.8. Relation of optimized curve number to rainfall amount for Coweeta Watershed 10.

Figure 3.5.9. Relation of optimized curve number to rainfall amount for Coweeta Watershed 34.

Figure 3.5.10. Relation of predicted peak discharge to curve number and 24-hour rainfall amount for Allen Hollow...

Figure 3.5.11. Relation of predicted peak discharge to curve number and 24-hour rainfall amount for Indian Spring.

Figure 3.5.12. Relation of predicted peak discharge to curve number and 24-hour rainfall amount for Coweeta Watershed 10.

Figure 3.6.1. Costa's (1983) regression (dotted line) and envelope (solid line) curves for unit stream power-particle size data 95

Figure 4.1a. Discharge vs. drainage area for VA-2 stormflow at each cross section .... 116

Figure 4.1b. Discharge vs. drainage area for 2-year stormflow at each cross section ....116

Figure 4.1c. Discharge vs. drainage area for bankfull flow at each cross section

Figure 4.2a. Percent increase in discharge from 2-year stormflow to bankfull

flow vs. drainage area at each cross section

Figure 4.2b. Percent increase in discharge from 2-year stormflow to bankfull flow vs. channel slope at each cross section

Figure 4.3. Average bankfull discharge of all cross sections in a channel vs. total basin relief . .

Figure 4.4.a. Width-depth ratio vs. drainage area for VA-2 stormflow at each cross section

Figure 4.4.b. Width-depth ratio vs. drainage area for 2-year stormflow at each cross section

Figure 4.4.c. Width-depth ratio vs. drainage area for bankfull flow at each cross section 120

Figure 4.5.a. Width-depth ratio vs. channel slope for 2-year stormflow at each cross section

Figure 4.5.b. Width-depth ratio vs. channel slope for bankfull flow at each cross section 
Figure 4.6.a. Width-depth ratio vs. $\mathrm{D}_{84}$ grain size for 2-year stormflow at each cross section

Figure 4.6.b. Width-depth ratio vs. $\mathrm{D}_{84}$ grain size for bankfull flow at each cross section

Figure 4.7.a. Average velocity vs. drainage area for VA-2 stormflow at each cross section

Figure 4.7.b. Average velocity vs. drainage area for 2-year stormflow at each cross section

Figure 4.7.c. Average velocity vs. drainage area for bankfull flow at each cross section

Figure 4.8.a. Average velocity vs. channel slope for 2-year stormflow at Virginia cross sections.

Figure 4.8.b. Average velocity vs. channel slope for 2-year stormflow at North Carolina cross sections

Figure 4.9.a. Average velocity vs. channel slope for bankfull flow at Virginia cross sections...

Figure 4.9.b. Average velocity vs. channel slope for bankfull flow at North Carolina cross sections

Figure 4.10.a. Average velocity vs. $\mathrm{D}_{84}$ grain size for 2-year stormflow at Virginia cross sections.

Figure 4.10.b. Average velocity vs. $\mathrm{D}_{84}$ grain size for 2-year stormflow at North Carolina cross sections.

Figure 4.11.a. Stream power vs. drainage area for VA-2 stormflow at each cross section 127

Figure 4.11.b. Stream power vs. drainage area for 2-year stormflow at each cross section

Figure 4.11.c. Stream power vs. drainage area for bankfull flow at each cross section. 128

Figure 4.12.a. Stream power vs. discharge for 2-year stormflow at each cross section. 128 
Figure 4.12.b. Stream power vs. discharge for

bankfull flow at each cross section.

Figure 4.13.a. Stream power vs. channel slope for

2-year stormflow at each cross section

Figure 4.13.b. Stream power vs. channel slope for bankfull flow at each cross section

Figure 4.14.a. Stream power vs. $\mathrm{D}_{84}$ grain size for

2-year stormflow at each cross section

Figure 4.14.b. Stream power vs. $\mathrm{D}_{84}$ grain size for

bankfull flow at each cross section

Figure 4.15.a. Stream competence vs. drainage area for

VA-2 stormflow at each cross section

Figure 4.15.b. Stream competence vs. drainage area for

2-year stormflow at each cross section

Figure 4.15.c. Stream competence vs. drainage area for bankfull flow at each cross section

Figure 4.16.a. Stream competence vs. $\mathrm{D}_{84}$ grain size for 2-year stormflow at each cross section

Figure 4.16.b. Stream competence vs. $\mathrm{D}_{84}$ grain size for bankfull flow at each cross section 


\section{List of Equations}

Equation 3.3.1. Soil Conservation Service - excess precipitation based on soil moisture storage capacity and initial abstraction

Equation 3.3.2. Soil Conservation Service - excess precipitation based on empirical soil moisture storage relation 40

Equation 3.3.3. Soil Conservation Service - relation of soil moisture storage capacity to curve number.

Equation 3.3.4. Soil Conservation Service - segmental travel time for sheet, shallow concentrated, and channel flow

Equation 3.3.5. Soil Conservation Service - sheet flow travel time.

Equation 3.3.6. Soil Conservation Service - shallow concentrated flow velocity for unpaved surfaces.....

Equation 3.3.7. Soil Conservation Service - shallow concentrated flow

velocity for paved surfaces.

Equation 3.3.8. Manning's channel flow velocity.....

Equation 3.3.9. Limerinos' flow roughness based on hydraulic radius and grain size ...................................................... 44

Equation 3.3.10. ModClark transform for basin time of concentration................... 44

Equation 3.6.1. Manning's channel discharge....................................... 89

Equation 3.6.2. Limerinos' flow roughness based on hydraulic radius

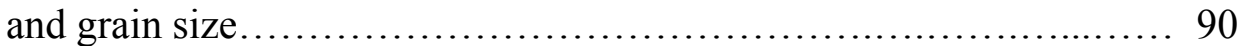

Equation 3.6.3. Jarrett's flow roughness based on hydraulic radius

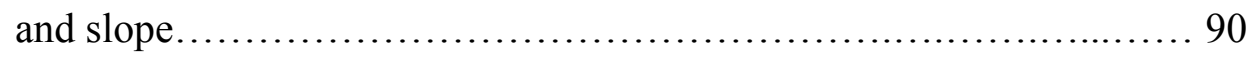

Equation 3.6.4. Costa's' unit stream power - particle size entrainment relation 


\section{Chapter 1}

\section{Introduction}

Non-perennial headwater channels commonly dominate water and sediment transport in mountainous regions, which cover $36 \%$ of the land surface in North America (Bridges, 1990). These small streams have long been recognized as ecologically significant, as they cumulatively create the larger rivers and lakes downstream (Ickes, 1935). Despite this importance, the form and function of headwater channels have been studied very little in comparison to lowland rivers. To understand landscape evolution and erosive processes in mountainous regions, controls on headwater channel form and function must be more tightly constrained. In addition, increased knowledge of headwater channel form and function will promote a more complete view of fluvial systems.

In the Appalachian Valley and Ridge, for example, drainage networks form a trellis pattern that consists of perennial trunk streams draining the narrow valleys, while ephemeral/intermittent tributaries are responsible for draining all of the adjacent hillslopes. Classical treatment of fluvial systems in the Appalachians considers these ridges and valleys to be in equilibrium. Relief and form are essentially governed by lithology, and the channel slope is graded to rock type and drainage area (Hack, 1957).

To date, studies of Valley and Ridge fluvial systems have focused largely on valley trunk streams. Non-perennial headwater streams, generally with drainage areas less than 2.0 $\mathrm{km}^{2}$, carry out hillslope erosion processes. Alternating stratigraphy with mixed resistance underlies these streams, in contrast to the trunk streams, which flow over bedrock with similarly weak resistance. The general form of headwater basins has previously been described (Hack and Goodlet, 1960), as well as differences in their character due to variations in bedrock type and structure (Mills et al., 1987). However, detailed studies of longitudinal profiles and fluvial process in these small basins are largely absent and controls on ridge erosion are unknown.

The equilibrium hydraulic geometry and channel forming flows in perennial trunk streams are also well examined. Lowland alluvial rivers have been described as "architects of their own geometry" (Leopold, 1994), adjusting their channel geometry in order to convey the water and sediment load from the upstream drainage basin. Channel hydraulic geometry 
- width, depth, velocity, and width-depth ratio - increases regularly downstream as discharge increases (Leopold and Maddock, 1953). The majority of sediment in perennial systems is transported in discharges that recur every one to three years and shape the channel by moving material that comprises the bed and banks of the stream (Wolman and Miller, 1960). This discharge typically fills the channel form to its banks, and is therefore commonly referred to as the "bankfull" discharge.

In contrast, the equilibrium geometry of small headwater streams is unknown. Due to small contributing drainage areas, headwater streams may require more extreme and infrequent storms to generate bankfull discharge and channel forming flows. The large sediment sizes in headwater streambed and bank material may be transported as bedload, in contrast to predominantly suspended load transport of fine particle sizes in lowland rivers. This difference in particle size and entrainment could require different equilibrium channel geometry and larger flows to shape the channel.

Some previous studies suggest that recurrence intervals for bankfull discharge in headwater streams are similar to lowland rivers, approximately 1-2 years (Carling, 1988; Whiting et al., 1999), and that finer sediment sizes are selectively transported during these flows. Other studies have found that channel-forming discharge in small drainage basins is dominated by extreme flows (Ashmore and Day, 1988), and that channel morphology is created in flows with a 50-year recurrence interval that move coarse $\left(\mathrm{D}_{90}\right)$ particles (Grant et al., 1990). Although studies such as these have begun to address sediment transport processes in mountainous regions, few of the studied channels have drainage areas less than $2.0 \mathrm{~km}^{2}$. Drainage areas studied typically range from $2.0-80.0 \mathrm{~km}^{2}$, presumably due to a lack of discharge and sediment data in smaller basins. Channels with very small drainage areas lie directly at the interface between hillslope and fluvial processes, and better constraints on their channel geometry and bankfull discharges are needed. Research in this area will improve understanding of what time scales are important in hillslope erosion and thus in the evolution of mountainous terrain.

The interaction between hillslope and fluvial processes has been explored recently in studies of channel initiation. The channel head marks the beginning of fluvial erosion processes on the hillslope, and determines the degree of landscape dissection. Field studies of channel initiation have viewed it as a geomorphic threshold controlled by slope, drainage 
area, and climate (Montgomery and Dietrich, 1988). The erosive processes observed in these studies are shallow landsliding, seepage erosion, or saturated overland flow (Montgomery and Dietrich, 1989). Predictive models using digital elevation data have also examined the role of climate, relief, vegetation, and slope curvature in channel initiation (Dietrich et al., 1993; Tucker and Bras, 1998). However, there is great spatial and temporal variability in the controlling conditions and processes, making channel initiation difficult to predict (Wohl, 2000). Further observations of channel initiation points in varying boundary conditions will be useful in determining controls on the erosive thresholds that form them, and thus controls on hillslope and headwater stream evolution.

There are several boundary conditions that should influence the form and function of Appalachian headwater streams. Climate, particularly precipitation amount and timing, may affect the overall channel form and relief, bankfull flow recurrence interval, and channel head location. Along the axis of the southern Appalachian Mountains, there is considerable change in precipitation timing and amounts - from southwest Virginia to western North Carolina, for example, annual precipitation nearly doubles (Spatial Climate Analysis Service, 2000) and a two-year recurrence 24-hour rainfall is 2 inches greater (Swift et al., 1988).

Bedrock may also be an important control on headwater channel form. Various bedrock conditions exist throughout the southern Appalachians as well, from tilted sedimentary Paleozoic strata in the Valley and Ridge Province to highly deformed metamorphic and metasedimentary rock in the Blue Ridge Province. Bedrock resistance to erosion has been shown to create the relief and altitude in the Appalachian Highlands (Hack, 1980). Specifically, control of base level by resistant bedrock has been hypothesized as the cause for slower erosion rates on the west side of the eastern drainage divide (Hack, 1973). Local drainage forms in the southern Appalachians have also been attributed to bedrock control (Hack, 1982).

Lastly, the effect of land use must be considered as a potential factor in the current form and function of stream channels. Bull (1979) hypothesized that human impact could change the equilibrium form of a channel if the stream crossed a threshold of stream power critical to erosion or sedimentation. Land use such as logging, grazing, or homesteading causes changes in a channel's water and sediment load, which may result in stream power and channel geometry changes. Timber harvest and associated road building has been shown 
to cause increases in peak discharge (Patric, 1972; Swank et al., 1988) and sediment output (Lieberman and Hoover, 1948; Swank et al., 2001), as well as soil loss from the surrounding drainage basin (Jones, 2000). Woody debris removal has been shown to increase sediment transport in mountain streams (Beschta, 1979; Bilby, 1981), and a lower volume of woody debris in logged Appalachian headwater streams than unlogged has been documented (Wagner, 2001). Although this research suggests that logging may have initiated a change in Appalachian drainage basins, its effect on headwater stream form and sediment transport has not been documented quantitatively. In order to interpret the current form of the headwater channels studied; the possibility of recent change in their equilibrium state must be considered.

Thus, the goal of our study is to gain an overall understanding of controls on headwater channel morphology, both in longitudinal and cross sectional form, as well as their function in discharge and sediment transport from the hillslopes. I collect and compare field data on Appalachian headwater channels in a variety of geologic, climatic, base level, and drainage area conditions to determine controls on their longitudinal form, hydraulic geometry, and channel initiation processes. To better understand channel forming flow recurrence in headwater streams, I use empirical stream channel and precipitation data to model discharge and sediment transport and estimate the recurrence interval of channel forming flows under varying boundary conditions. Finally, by comparing streams with different logging histories, I examine the sensitivity of headwater channel form and function to increases in discharge and decreases in channel roughness as caused by logging and woody debris removal.

Nine southern Appalachian headwater channels were surveyed in a range of geologic, climatic, and base level environments. The channels are first to third order, with drainage areas of $0.33-1.6 \mathrm{~km}^{2}$ and relief of $134-559 \mathrm{~m}$. Five of the channels are in the Valley and Ridge province, where resistant sedimentary bedrock layers form long ridges and erodable layers form valleys between them. The headwater streams flow down the ridges, crossing variations in bedrock resistance. Different ridges vary in the degree and orientation of dip in their geologic layers, as well as in the base level of the valley below.

Four channels are in the Blue Ridge Province in North Carolina. The North Carolina Blue Ridge consists of mixed resistance metamorphic bedrock on which dendritic drainages 
form, and has higher annual rainfall rates than the Virginia Valley and Ridge. Therefore, the Blue Ridge sites provide an important geologic and climatic comparison to the Valley and Ridge sites. In addition, our Blue Ridge sites offer control on logging history, which occurred across the entire Appalachian landscape and must be considered as a potential agent of short-term channel change.

Ideally, a comparative study of controls on headwater channel morphology would include at least 50-100 channels. Direct comparison could be performed on channel pairs that differed in only one boundary condition and were constant in all others. However, there are a multitude of boundary conditions to address: bedrock, climate, base level, relief, aspect, drainage area, basin shape, and land use history. Within these categories there are multiple variables. For example, bedrock can vary in its type, structure, jointing, and orientation, and land use can vary from a single historic logging to long-term grazing. Additionally, field data is difficult and time-consuming to collect, limiting this study to nine channels. Although the nine channels do not represent the full range of conditions in each variable, they still allow for examination of the potential controls in headwater channel morphology.

The first component of this project is an empirical study of headwater channel form, in order to reveal associations within and between channels. Each channel was surveyed longitudinally from the trunk stream to its initiation point, typically 1.0-2.0 kilometers in distance and 200-500 meters in relief. Channel slope was recorded along the length of the channel, generating a high-resolution dataset on channel profile that could not be obtained from topographic maps. Channel substrate (alluvial, bedrock, or mixed) and woody debris occurrence were surveyed simultaneously. Longitudinal profiles were compared for differences in their first and second-order form, as well as in their channel substrate, log and root jam populations, and channel initiation points. Bedrock resistance appears to be a major influence and creates great variability in all of these headwater channel characteristics through its control of channel slope and substrate.

The second component of the project uses hydrologic modeling techniques to route storm rainfall through each channel and examine differences in sediment transport and the channel-forming flows. In order to model channel flows, cross sections and pebble counts were taken at four to eight locations over the length of each channel. Channel cross-section 
and pebble count data are used in combination with Digital Elevation Models (DEMs), precipitation data, and GIS techniques to model the peak discharge of the nine basins during real storms on a cell-by cell, gridded basis. Modeled flows are then analyzed for their ability to fill the channel form and erode the channel bed. Hydraulic geometry, channel forming flow recurrence, and stream competence were compared within and between channels. Bedrock was found to create immense variation in channel discharge, form, and sediment transport, and there is also evidence that climate and hillslope interaction affect the recurrence interval of bankfull flows. 


\section{Chapter 2}

\section{Empirical Analysis}

\subsection{Introduction}

Nine headwater streams were surveyed to represent a variety of geologic, climatic, base level, and land use boundary conditions. A number of characteristics were summarized in Table 2.1. Five of these streams were in the Virginia Valley and Ridge, and four were in the North Carolina Blue Ridge (Fig. 2.1). The Virginia streams flowed from the top of long trending ridges down over tilted sedimentary Paleozoic strata to valleys with varying base level conditions. The lithology and structure of the bedrock layers each stream crosses from ridge to valley varied (Appendices A-E.). All five streams were logged, cleared, grazed, or homesteaded in the past, and two had current grazing and home sites.

The four North Carolina streams were comprised of metamorphic bedrock and had a wetter climate than the Virginia streams (Appendices F-I, Table 2.1). The four streams were chosen as paired sites, two pairs with similar bedrock and climate but different known logging histories. Only one basin, Indian Spring, had no historic logging, grazing, or homesteading.

A detailed dataset on slope, substrate, and log and root jam population over the length of each channel was obtained, as well as detailed cross-section and pebble count information at several locations in each channel. The resulting datasets were used to compare the influence of geology, climate, drainage area, and land use on headwater channel form and sediment transport both empirically and through hydrologic modeling. However, the comparison of these datasets was only qualitative, as the number of streams sampled was too small for statistical analysis. 


\subsection{Data Collection Methods}

\subsubsection{Longitudinal Profile}

Distance and elevation were surveyed for each channel from its bottom or confluence with a larger tributary to its initiation point. The survey was performed at 0.1 -meter precision using a measuring tape, rod, and laser level to track distance and elevation along the streambed. The survey was undertaken in order to obtain a finer resolution dataset than standard USGS $7 \frac{1}{2}$ minute topographic maps or Digital Elevation Models (DEMs), which fail to image short-wavelength (10-20m) changes in channel slope (see section 3.3.1). Rod and laser-level surveying was chosen because total station surveying was too time consuming to use over the length of the channel, and obtaining topographic data from LIDAR was prohibitively expensive.

The average distance of each laser level measurement was approximately 15 meters, generally longer in lower gradient areas and shorter on steep slopes. Actual ground distance was measured in the field, but was converted to horizontal distance for the final plots of longitudinal profiles. The average vertical gain in each laser level measurement was 1.5 meters. Two surveyors were required for distance-elevation measurements, one pulling the tape and holding the rod, and one anchoring the tape downstream and leveling the laser for elevation measurements. The laser level measurements were always taken by the primary surveyor (Kavage), whereas three different surveyors held the rod and tape over the course of the data collection. Although vegetation, rain, and fatigue reduced laser-level precision below the $0.01 \mathrm{~m}$ possible on the rod, $0.1 \mathrm{~m}$ precision was maintained.

Cumulative field surveyed elevation and distance for each channel were within approximately $10 \%$ of cumulative elevation and distance obtained from DEM's, and did not appear to have systematic error. For example, total surveyed relief and distance for Sarver Hollow were $443 \mathrm{~m}$ and $2658 \mathrm{~m}$, whereas DEM values (respectively) were $457 \mathrm{~m}$ and 2835 $\mathrm{m}$. Given Branch relief and distance were surveyed at $166 \mathrm{~m}$ and $1060 \mathrm{~m}$, while DEM generated relief and distance were $148 \mathrm{~m}$ and $1014 \mathrm{~m}$. 


\subsubsection{Substrate type}

Channel substrate was surveyed qualitatively along the length of the channel simultaneous to the longitudinal profile survey. The substrate was classified as either bedrock ( $>80 \%$ bedrock), alluvial ( $>80 \%$ alluvial), or mixed, based on visual estimates. Available maps were used to classify bedrock lithology and structure, as original bedrock mapping was beyond the scope of the study. Bedrock data and references are in Appendices A-I.

\subsubsection{Log and root jams}

Log and root (live or dead) jams that acted as sediment traps in the main channel were tabulated as the longitudinal profile was measured. The height, width, and length of each jam were measured to 0.1 -meter precision. The width and length were then multiplied by half the height to model a wedge of trapped sediment behind the jam and estimate its volume. The diameter of each log or root was also recorded.

\subsubsection{Cross sections}

Sites were selected for discharge and sediment entrainment estimation in all streams, distributed over the length of the stream. Locations representing different drainage areas were initially chosen, and then representative sections within those reaches were selected. Some reaches were located directly above waterfalls or logjams in order to capture variations in channel shape (details in Appendix A-I cross section figures). Criteria for choosing channel reaches in these locations in the field, intended to reduce potential discharge estimation error, were: (i) straight, uniform channel geometry that could be most effectively modeled using a step-backwater program (Brunner, 2001), (ii) a lack of woody debris jams or other channel obstructions creating complex flow hydraulics (Blizzard and Wohl, 1998), and (iii) a lack of channel aggradation/degradation characteristics such as mounded sediment deposits or bank scour (Jarrett, 1986). Oftentimes these requirements were simply boiled down to straight reaches that were accessible. Rhododendron was thick and made cross sections impossible in a great portion of the North Carolina streams (see Appendices F-I).

A laser level was used to survey three cross sections at each site, with the exception of the Allen Hollow x2, x3, and x4, which were surveyed by total station. The total station 
was not used in the majority of the streams, as it was too difficult to transport across the steep terrain. Cross sections were surveyed with 0.01-meter precision. Three cross sections were surveyed at each reach, located at the upper, middle, and lower end of the reach. Cross sections included some of the floodplain or hillslope on either side of the channel. The nonchannel portions were surveyed to a lower resolution, but to a level of detail that would demonstrate slope breaks in the channel banks that would be of interest as geomorphic features. Ocular estimation of the active channel bed and the first slope break that would approximate bankfull (see section 3.6.1, Bankfull selection) were recorded. Channel slope over the entire reach, as well as upstream and downstream of the reach, was recorded. Qualitative observations about flow, vegetation, bank stability, and particle size were made.

\subsubsection{Pebble counts}

Pebble counts were performed to quantify particle size distribution of the surface, or armor layer, at each reach. A modified version of the Wolman (1954) sampling technique, as suggested by Fripp and Diplas (1993), was used. This method groups particle sizes smaller than the observer's fingertip (16 mm) into a single class, in order to reduce error associated with differentiation between smaller particles on the streambed. Calipers were used to measure the intermediate axis of each particle.

The sampling grid was evenly spaced over the width of the active channel (usually 1$3 \mathrm{~m})$ and the length of the entire reach $(10-15 \mathrm{~m})$ in order to sample all sediment populations present (Diplas and Lohani, 1997) and obtain 100 - 200 bed particle measurements in a narrow channel. Particle sizes were transcribed to a grid that recorded their exact location and enables analysis of their spatial distribution (Crowder and Diplas, 1997).

\subsubsection{General Observations}

Qualitative observations of characteristics such as basin topography, vegetation, rock outcrops, and channel flow were also made along the length of each channel. These observations are described in Appendices A-I. 


\subsubsection{Flow Observations}

In the short duration of this study, it was not possible to observe storm discharge at each of the channels. However, Allen Hollow was observed the morning after a September 4, 2000 storm (see Appendix D). The observations of storm flow peak and particle movement at Allen Hollow were used in calibration of the hydrologic model (see section 3.5.1) and as a test of sediment transport estimates (see section 3.6.1).

Qualitative channel flow observations were also made at each channel with respect to recent weather conditions (Appendices A-I, Qualitative Observations), and were used to infer general characteristics of basin hydrology. For example, Sarver Hollow was surveyed the morning after a rainstorm, and flow was heard underneath boulders in the upper section of the basin (Appendix C). However, since surveys were completed during different seasons and rainfall conditions, flow information was not recorded for use as a comparative variable or for calibration of baseflow in the hydrologic model. 


\section{$2.3 \quad$ Results}

The bulk of the data is compiled in Appendices A-I for easier utilization.

\subsubsection{Longitudinal Profiles}

Field-surveyed longitudinal profiles of each creek illustrate the tremendous variation in slope both between and within headwater channels (Figs. 2.2 and 2.3). The profiles are generally concave, but major knickpoints are present in some of the channels. These knickpoints are likely due to bedrock control of channel slope.

Channel slope exhibits an overall decrease in slope with drainage area, but the decrease is highly irregular (Appendices A-I, Figs. A-I.5). Aberrations in slope over the length of the channels are common in all channels, but their magnitude is less in Pepper Run and Given Branch (Fig. 2.4). Most of these slope aberrations are at bedrock steps and falls, or boulder-mantled areas (Fig. 2.5).

Blue Ridge channels generally have higher slopes than Valley and Ridge channels, with the exception of Little Stony Tributary (Table 2.1). Sarver Hollow has moderate slopes, while Allen Hollow, Given Branch, and Pepper Run have lower average slope values. In both Sarver and Allen Hollow, average slope is lower due to long, low gradient run-outs to the valley trunk stream (Fig. 2.2).

\subsubsection{Substrate Type - Grain size}

Channel substrate is dominantly (75\%) alluvial for all the channels, while bedrock substrate only comprises four percent of the channel length overall (Table 2.2). Bedrock reaches are more than twice as steep as mixed or alluvial reaches, on average. The Blue Ridge channels have a greater percentage of channel length as bedrock and mixed, whereas Virginia Valley and Ridge streams generally have a greater percentage of alluvial substrate (Table 2.1, Fig. 2.6).

Grain size shows no systematic variation with drainage area (Fig. 2.7). This relation is true for all channels collectively, as well as for individual channels, due to aberrations in grain size. Average grain size varies greatly between channels, as Horse Cove and Little Stony Tributary have $\mathrm{D}_{50}$ and $\mathrm{D}_{84}$ grain sizes that are nearly an order of magnitude greater 
than Given Branch and Coweeta Watershed 10 (Fig. 2.8). The remaining five channels have intermediate average grain sizes, due in part to a wide variation in grain sizes along the length of the channel. For example, Sarver Hollow has an average $\mathrm{D}_{84}$ grain size of $990 \mathrm{~mm}$ at three upper cross sections, but the $\mathrm{D}_{84}$ averages $122 \mathrm{~mm}$ at the remaining five cross sections.

Grain size has a weak relation to channel slope, as there is a considerable amount of scatter at smaller particle sizes (Fig. 2.9). However, larger particles seem to occur only above a certain slope threshold.

\subsubsection{Woody Material}

The total number and average diameter of log or root jams in each channel is highly variable, particularly in the Valley and Ridge (Table 2.1). Similarly, the number of jams per channel length varies greatly between channels (Fig. 2.10a), as Given Branch averages only 1.5 jams per 100 m, while Sarver Hollow and Coweeta Watershed 34 average 6-7 jams per $100 \mathrm{~m}$. Jams are most abundant in alluvial reaches and least abundant in bedrock reaches (Table 2.2).

The volume of sediment stored in jams per basin area is highly variable (Fig. 10b). These volumes are very small (approx. 0.005-0.08 mm) when converted to a soil depth distributed across the entire basin area. The total volume of sediment trapped in each channel scales roughly with the total number of jams, but has no relation to log diameter (Table 2.1). Comparison of jam occurrence by channel length (Appendices A-I, Figs. A-I.6) to slope by channel length demonstrates that the dominant controls on slope are bedrock and drainage area, and jams only control channel slope locally (Figs. 2.11a and 2.11b).

\subsubsection{Channel Initiation}

Channel initiation points occur over a wide range of slope and drainage area values, reflecting the site-specific nature of channel initiation processes (Fig. 2.12). Three channel initiation points for Pepper Run, Sarver Hollow, and Little Stony Tributary cluster with larger drainage areas than the rest of the channel heads. In Sarver Hollow and Little Stony Tributary, the stream channel reappears upstream of the first channel initiation point. Both streams have their final initiation points in low gradient areas, as does Indian Spring. 
Coweeta Watershed 10 and Given Branch initiate at wide, wet, cobbly areas, and Horse Cove and Allen Hollow initiate on steep, dry slopes. Three of the four channels in North Carolina have the smallest drainage areas above the channel head of all streams.

\subsubsection{Cross Section Shape}

Cross sectional channel shape varies greatly between and within channels (Appendices A-I). Cross section form is typically wider in reaches with large grain sizes such as Little Stony Tributary x1-x6, and narrower in reaches with finer particle sizes such as Given Branch x1, x3, and x4. North Carolina channels tend to widen near the initiation point, while Virginia channels tend to narrow. A complete analysis of cross sectional form, including width-depth ratios and bankfull heights, is carried out in chapters 3 and 4. 


\subsection{Interpretations and Discussion}

\subsubsection{Climate and Base Level}

The North Carolina basins generally have steeper slopes than the Virginia basins, as well as higher elevations and greater relief (Table 2.1). It is difficult to determine whether the steeper slopes in North Carolina are due to a more intense precipitation regime, a baselevel change due to localized Blue Ridge uplift, or greater resistance in the metamorphic Blue Ridge bedrock. Climate could be a factor, as the Valley and Ridge receives only about half the annual rainfall of the Blue Ridge (Spatial Climate Analysis Service, 2000), but no difference in regional erosion rates due to climate have been documented. Nor is there any evidence for greater uplift in the Blue Ridge than the Valley and Ridge. Both local and downstream bedrock strength has been shown to control topographic form in the Blue Ridge (Hack, 1982) and the Valley and Ridge (Hack, 1973). However, potential uplift and climate effects cannot be dismissed, and therefore it is hard to resolve the cause of the overall slope difference in Virginia and North Carolina.

The smaller drainage areas required for channel initiation in North Carolina may indicate a climatically influenced difference in the hillslope-fluvial transition (Montgomery and Dietrich, 1988) (Table 2.1). Previous climate regimes may also exert residual control of the landscape. Boulder fields in Little Stony Tributary and Sarver Hollow are similar to boulder fields in Pennsylvania (Tucker and Bras, 1998) and Virginia (Hack and Goodlet, 1960) that have been hypothesized to be relict landslides that were active in a previous periglacial climate.

Regional and local base level also influences the shape and relief of headwater streams. Streams draining to the Atlantic (Pepper Run, Allen Hollow, Sarver Hollow) flow into valley trunk streams with lower elevations than streams that drain to the New River (Little Stony Tributary and Given Branch), and generally have greater relief (Appendices AE). However, the streams that drain to limestone valleys (Pepper Run and Given Branch) have less relief on the ridge because the valleys are wide, and the streams do not meet the valley trunk stream at the base of the ridge. The remainder of their profile (not surveyed in 
this study) is in long, low-gradient stretches that flow across the valley to the trunk stream (Appendices B and D).

This wide valley morphology is due to limestone and dolomite bedrock dissolution, which creates underground flow paths. The predominant underground flow in limestone valleys limits surficial sediment transport, and therefore slows lowering of local valley elevation. In contrast, impermeable bedrock typically characterizes shale valleys. The lack of infiltration results in high peak discharges with greater power to move surficial sediment and erode the valley. These valleys are narrow, and the headwater streams that drain into them have greater relief and steeper slopes.

\subsubsection{Bedrock}

The first-order form of the channels is clearly controlled by bedrock. For example, a bed of resistant flat-lying Tuscarora quartzite creates a low gradient plateau upstream of over-steepened, boulder-mantled hillslopes, and maintains the high relief at Little Stony Tributary (Fig. 2.2). Coweeta Watershed 10 also has two dramatic knickpoints that dominate the channel profile and create long, low gradient reaches upstream (Fig. 2.2). Resistant gneiss bedrock bodies that are highly massive and lack jointing cause these knickpoints, while the intervening bedrock, observed in nearby road cuts, is schistose and weak. Basins with predominantly less resistant lithologies, such as the Juniata sandstone and Martinsburg limestone in Given Branch, generally have a more regular slope decrease with drainage area (Fig. 2.2). Overall channel slope and relief is also consistently higher in channels with resistant bedrock such as quartzite or gneiss, and lower in channels with easily eroded bedrock such as shale and limestone (Table 2.1).

Slope variations also correlate with fine scale variations in bedrock resistance. For example, in Allen Hollow, steep bedrock knickpoints occur at meter-thick massive sandstone intervals within the erodable shale of the Braillier and Chemung formations (Figs. 2.4 and Fig 2.5). Slope aberrations are most abundant in the metamorphic Ocoee Supergroup and Tallulah Falls Formations of the Blue Ridge basins. Resistant quartzite and gneiss bodies

within weaker phyllite and schist outcrop in the form of bedrock steps, chutes, or waterfalls (Figs. 2.4 and 2.5). 
The effect of bedrock is seen in channel substrate and grain size as well. Steep slopes in Little Stony Tributary and Sarver Hollow are caused by input of large, resistant boulders from local bedrock outcrops of Tuscarora and Keefer sandstones (Figs. 2.4 and 2.5). Large grain sizes are found only above a certain slope threshold (Fig. 2.9), illustrating the effect of bedrock on grain size through its control of channel slope. Slope has considerable scatter at smaller grain sizes, because there are reaches where the channels are steep but the grain size is small. Two conditions cause this: a high influx of fines under transport-limited conditions, or a channel substrate of bedrock that maintains channel slope, but is overlain by smaller particles.

Bedrock resistance also controls channel initiation in Appalachian headwater streams through its control of grain size and channel slope. The three channel initiation points with exceptionally large drainage areas all occur in the middle of slopes mantled with large, resistant boulders (Fig. 2.12). The large drainage area required for channel initiation in these large boulders may indicate that the erosive process is one of mass movement during large storms, or solifluction that occurred in the last glaciation (Tucker and Bras, 1998).

The two initiation points with the lowest slope values both occur in erodable geology that lies above a resistant bedrock break. Both of these points were observed during and after storms (Appendices A and C), and appear to have been created by saturated overland flow (Montgomery and Dietrich, 1989) that occurs only during or shortly after rainfall. Although it occurs at a higher slope, Indian Spring's initiation point appears similar in its morphology. The channel head occurs at a small hole with a narrow channel downstream, and is lying above a resistant bedrock break. The resistant bedrock breaks present in these channels lower channel slope above them, forcing water to pond and saturate these areas during storms. Hydrophytic vegetation observed in these low gradient areas (Appendices A, C, and F) supports this hypothesis.

Bedrock is a major control on headwater channel morphology, in their overall profile, local slope values, substrate, and initiation points. Bedrock structure has been shown to control regional topography (Hack, 1980), but it also controls hillslope erosion, even at minute variations in strata. Most of the channels are alluvial or mixed, and less than $10 \%$ of their substrate is bedrock (Table 2.2). Thus, only a small fraction of the landscape is being lowered, and at these points bedrock is exposed because it is resistant to erosion. These 
localized resistant rocks limit erosion in headwater channels, and in turn control where ridges are found. For example, in the Valley and Ridge, topography is not controlled by equal distributions of resistant and weak rock, as the equal distribution of valleys and ridges might indicate. Instead, the ridges are dependent on local rocks, which hold up the hillslope by their resistance to erosion or by mantling the channel with boulders.

It would logically follow that the overall difference in the relief and slope of Virginia and North Carolina streams is therefore due to bedrock. However, there is no way to compare the erodability of Blue Ridge and Valley and Ridge lithologies, so climate and baselevel history cannot be eliminated as potential factors in channel evolution. Furthermore, as all the basins in the study (apart from the paired North Carolina basins) vary in their bedrock type and structure, other comparisons between them could be greatly affected by the major control that bedrock exerts on their form.

\subsubsection{Woody debris and land use}

Log and root jams lower channel slope and widen its cross sectional form, but only within two to three meters above the jam (Fig. 2.11a and 2.11b). The total sediment trapped by jams in each basin $(0.008-0.05 \mathrm{~mm})$ is low compared to the average annual erosion rate for the Appalachians (0.04 mm/year (Hack, 1980)). The volume of sediment stored in jams, when spread over the basin area, would equal a depth equal to or less than one year's worth of erosion (Table 2.1). Thus, jams do not store enough sediment in any basin to limit the overall erosion rate of the basin. It is more likely that they act as temporary storage for hillslope sediment as it travels out of the basin.

Jams are most abundant in low gradient, shale bedrock sections of Allen and Sarver Hollow (Table 2.1 and Appendices C and D). Generally, jams are most effective in areas of non-resistant bedrock with smaller particle sizes or directly above over-steepenings that buttress the channel and create low-gradient reaches upstream. In reaches with large grain sizes, logs are less effective as jams because they often fall on top of boulders and remain above the active channel (Appendix F, Fig. 1).

Indian Spring, the only unlogged stream in the survey, has over three times more sediment trapped in jams than Horse Cove, its neighboring basin, while having only one-fifth

more jams (Table 2.1). The average diameter of the logs in Indian Spring is larger, due to the 
recruitment of older, larger trees to the stream channel. Field observations also indicate that Indian Spring is qualitatively different than Horse Cove. Its main channel was much more difficult to discern, particularly in the lower-gradient $1 / 3$ of the channel, as water appeared in an intertwined network of channels throughout the basin floor (Appendix F, Qualitative Observations). Large trees were also more prevalent along and in the channel, stabilizing channel banks in a manner not quantified by jam measurements.

However, Indian Spring does not have the highest sediment storage, or the highest number of jams in the study, due to bedrock influence. In Indian Spring, sediment is often boulder-sized and slopes are steep, thus limiting the role of woody debris in sediment storage and channel form. In contrast, Sarver Hollow has long, low-gradient sections with small particle sizes that promote the ability of jams to trap sediment. Furthermore, the total amount of sediment stored in a channel relates better to the total number of jams than the diameter of the logs, so the effect of logging or grazing on in-channel sediment storage is due to total tree removal as opposed to reduction in tree size. Accordingly, sediment accumulation in jams could occur just as effectively as second-growth forest covers an area, such as in Sarver Hollow.

Although no basin in Virginia is free of logging or grazing, the more heavily impacted (grazed) streams in Virginia generally have fewer log and root jams. For example, Given Branch is the most heavily impacted by grazing and land clearing, and has the lowest number of jams and volume of sediment trapped. Field observations of Given Branch indicate that the channel morphology is most affected by land clearing (not including backhoe effects) in steep, confined reaches. For example, $\mathrm{x} 4$ has a deep, gullied form that is exceptionally larger than the surrounding reaches (Appendix B, Fig. 1). The erodable geology and fine sediment present at Given Branch also make $\mathrm{x} 4$ more sensitive to incision than channels with resistant bedrock and large grain sizes. 


\subsection{Conclusions}

Bedrock is a major control on first and second-order headwater channel form. Changes in bedrock resistance occur at the formation level, as well as at fine scale variations in resistance that control channel slope, substrate, and grain size. Bedrock also controls regional and local base level elevation and channel initiation processes, therefore controlling the channel relief and average slope. Climate plays a smaller role in headwater channel form, possibly reducing the drainage area threshold required for channel initiation and creating steep channel slopes at relict periglacial landslide features. Greater overall channel relief and slope in the Blue Ridge than the Valley and Ridge channels may also be due in part to differences in climate as well as uplift, as bedrock erodability between these two regions cannot be compared. Log and root jams do not control first-order channel form or basin erosion rates, but land clearing has reduced the number and size of log and root jams, and has impacted the local form of headwater channels. 


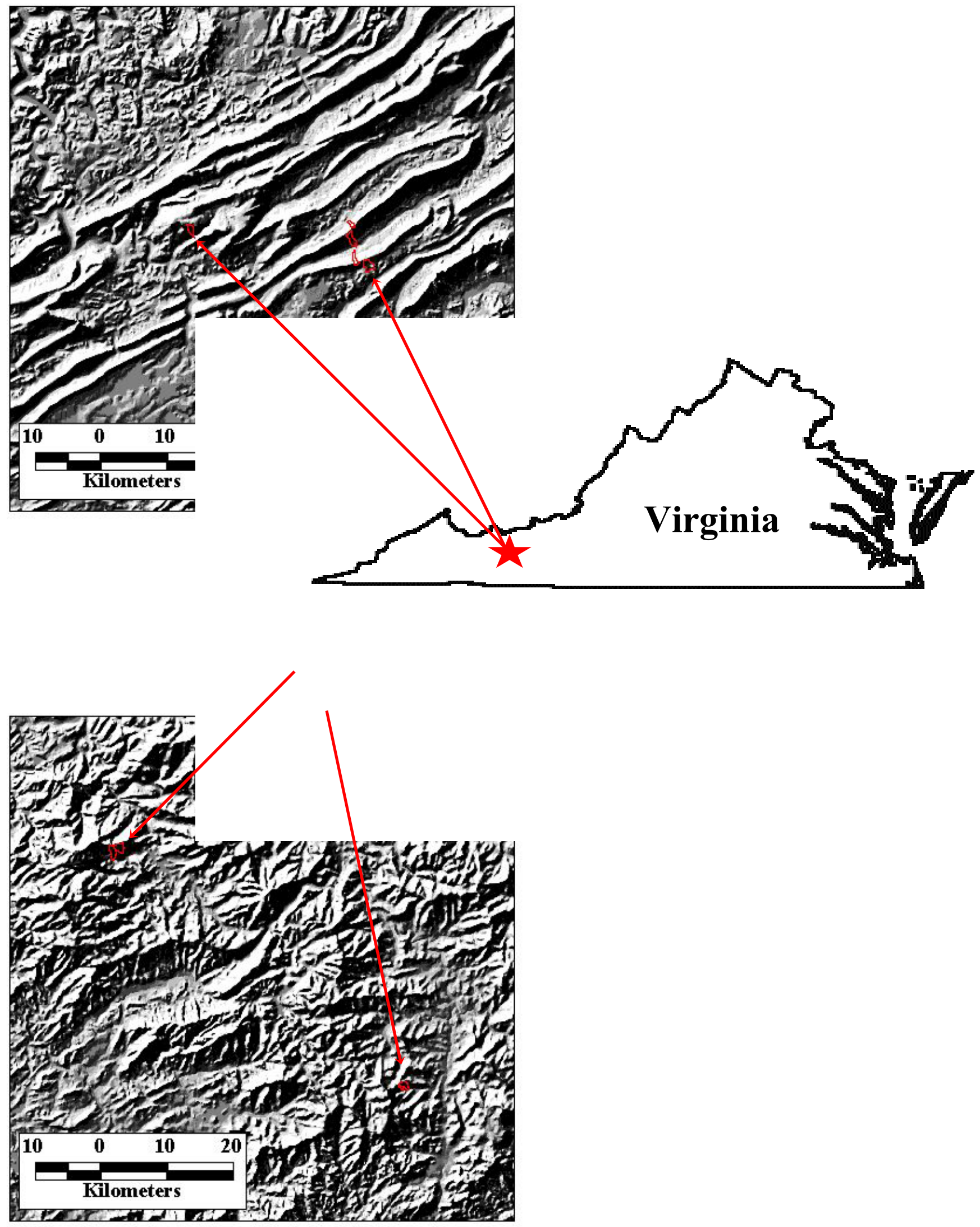

Figure 2.1. General location of streams surveyed in Virginia Valley and Ridge and North Carolina Blue Ridge. 


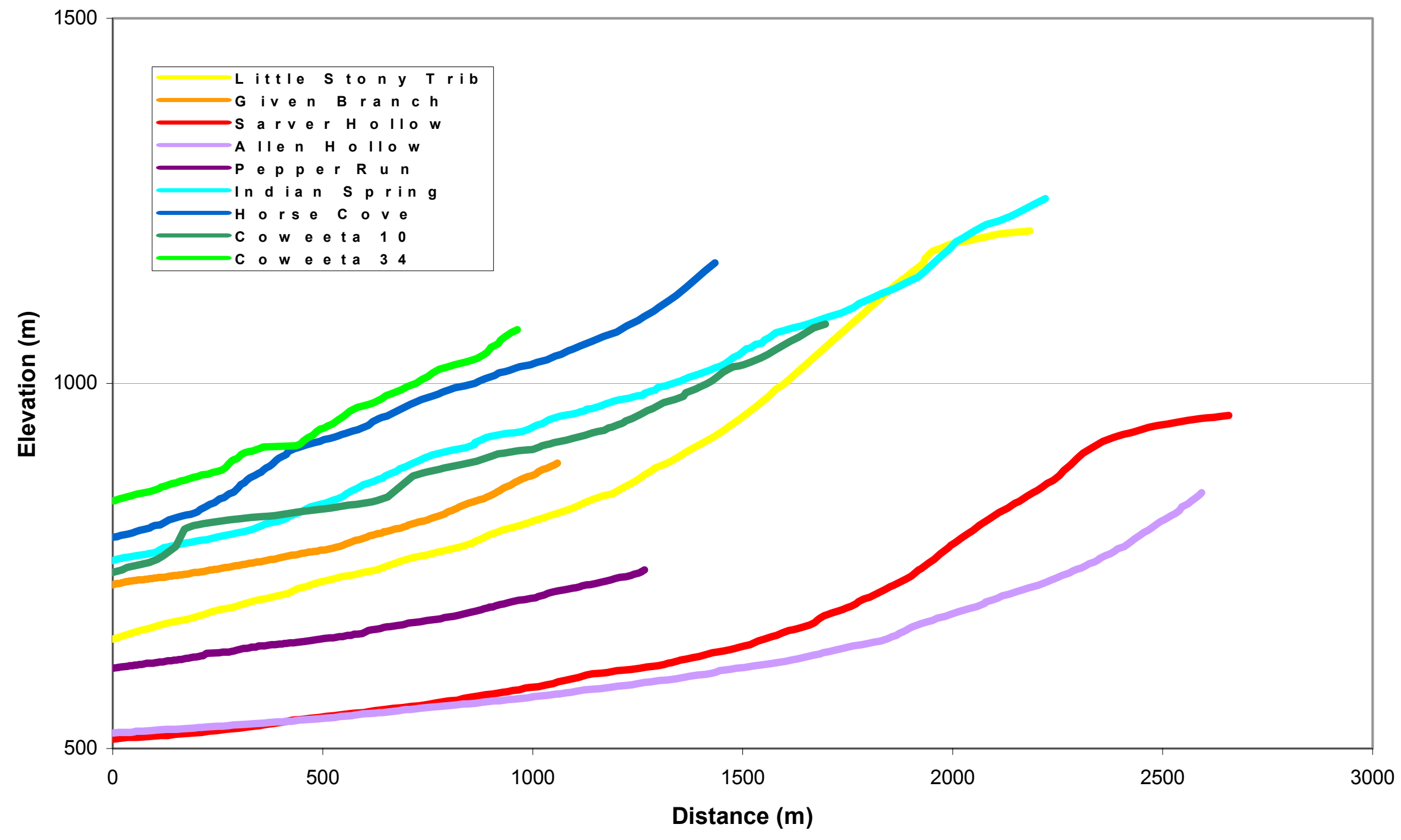

Figure 2.2. Longitudinal profiles of all streams, from survey data. 


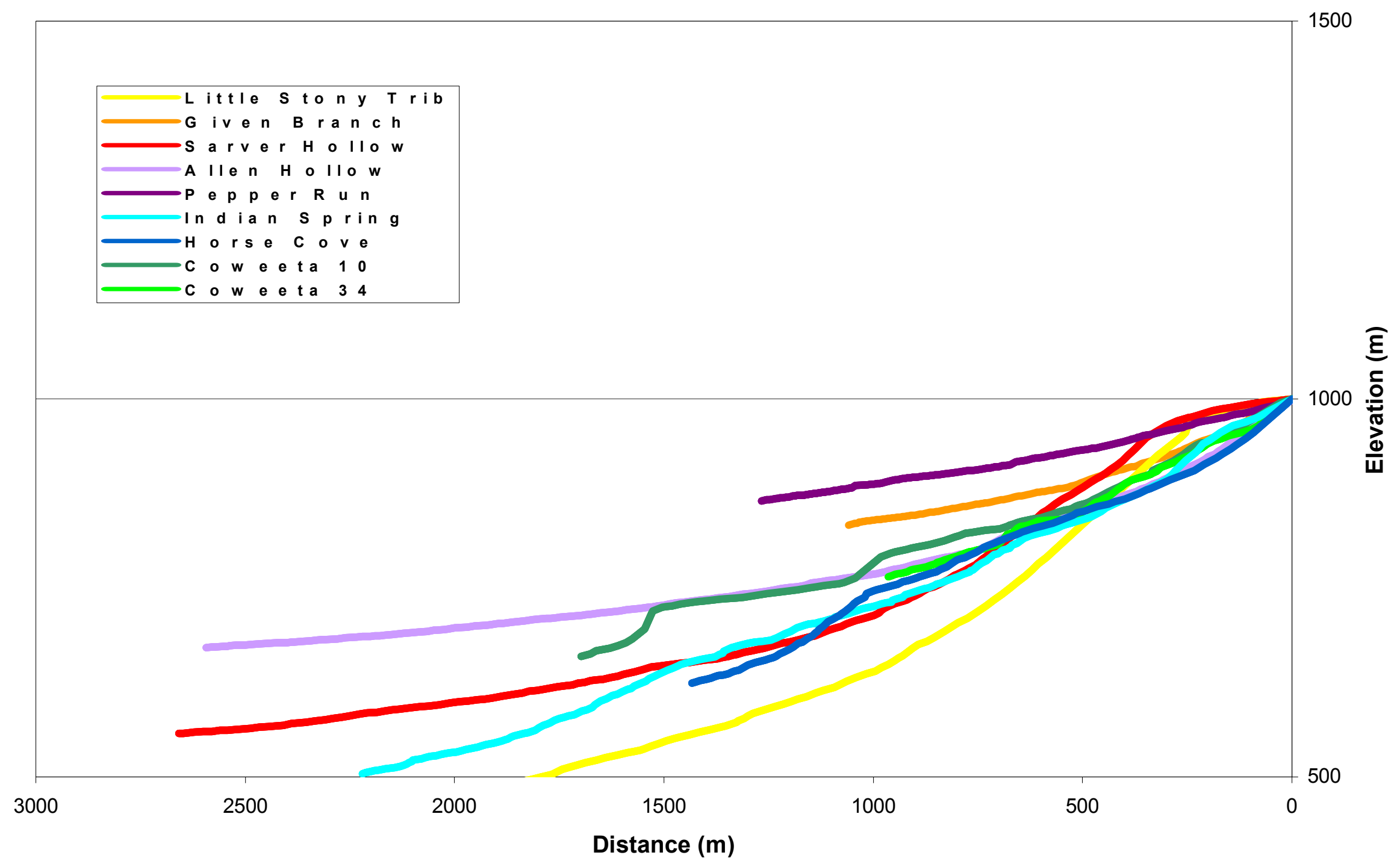

$\underline{\text { Figure 2.3. }}$ Longitudinal profiles of all streams, from survey data. Channel initiation point set to $1000 \mathrm{~m}$ elevation. 

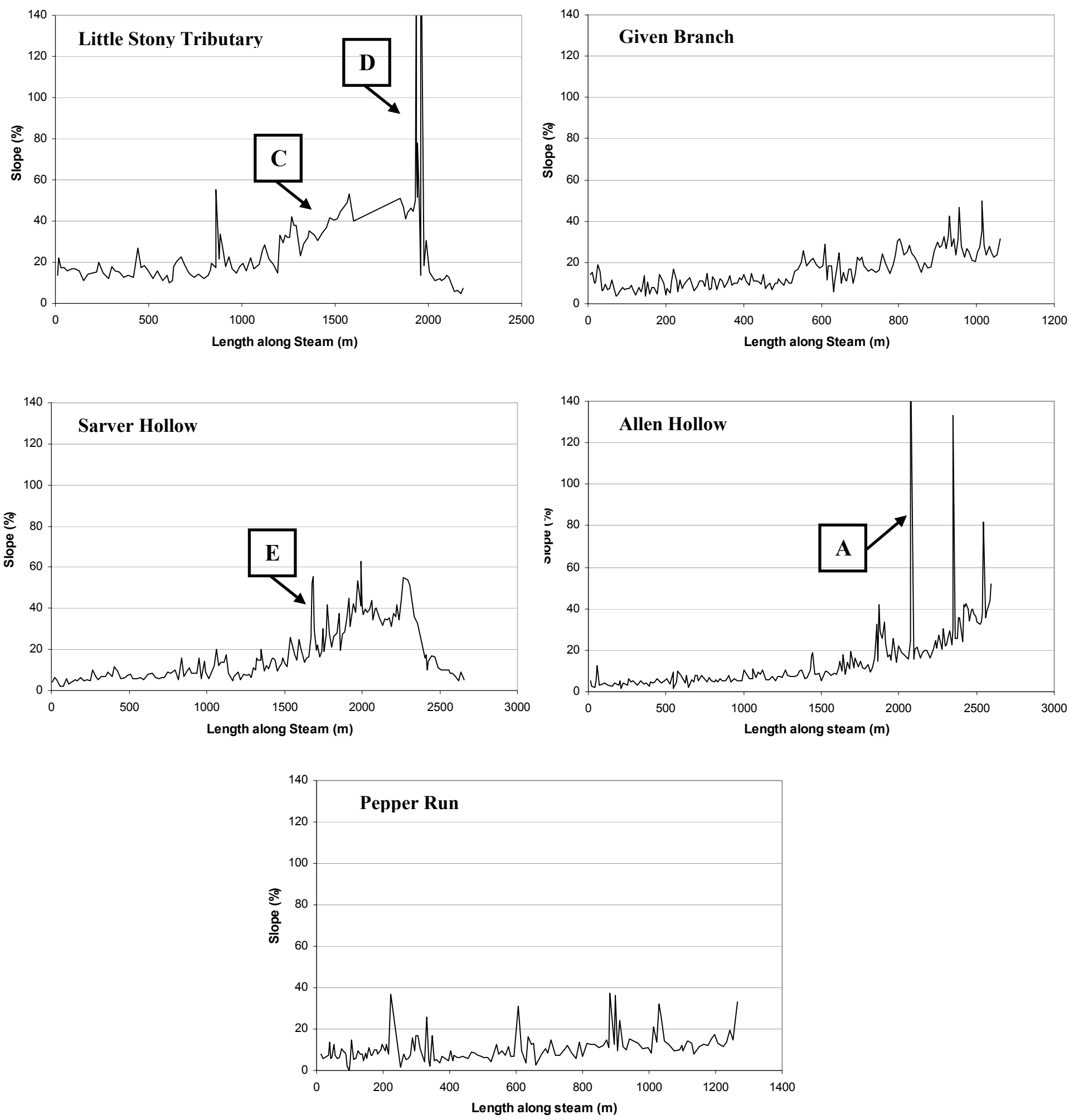

Figure 2.4. Channel slope by length for Virginia channels, starting at base of channel (survey start point). Abrupt increases in slope are the result of short-wavelength coarsening sequences from shale to sandstone in sedimentary Chemung formation. Slope increases appear as steep, bedrock-floored steps, shown in picture to right. 

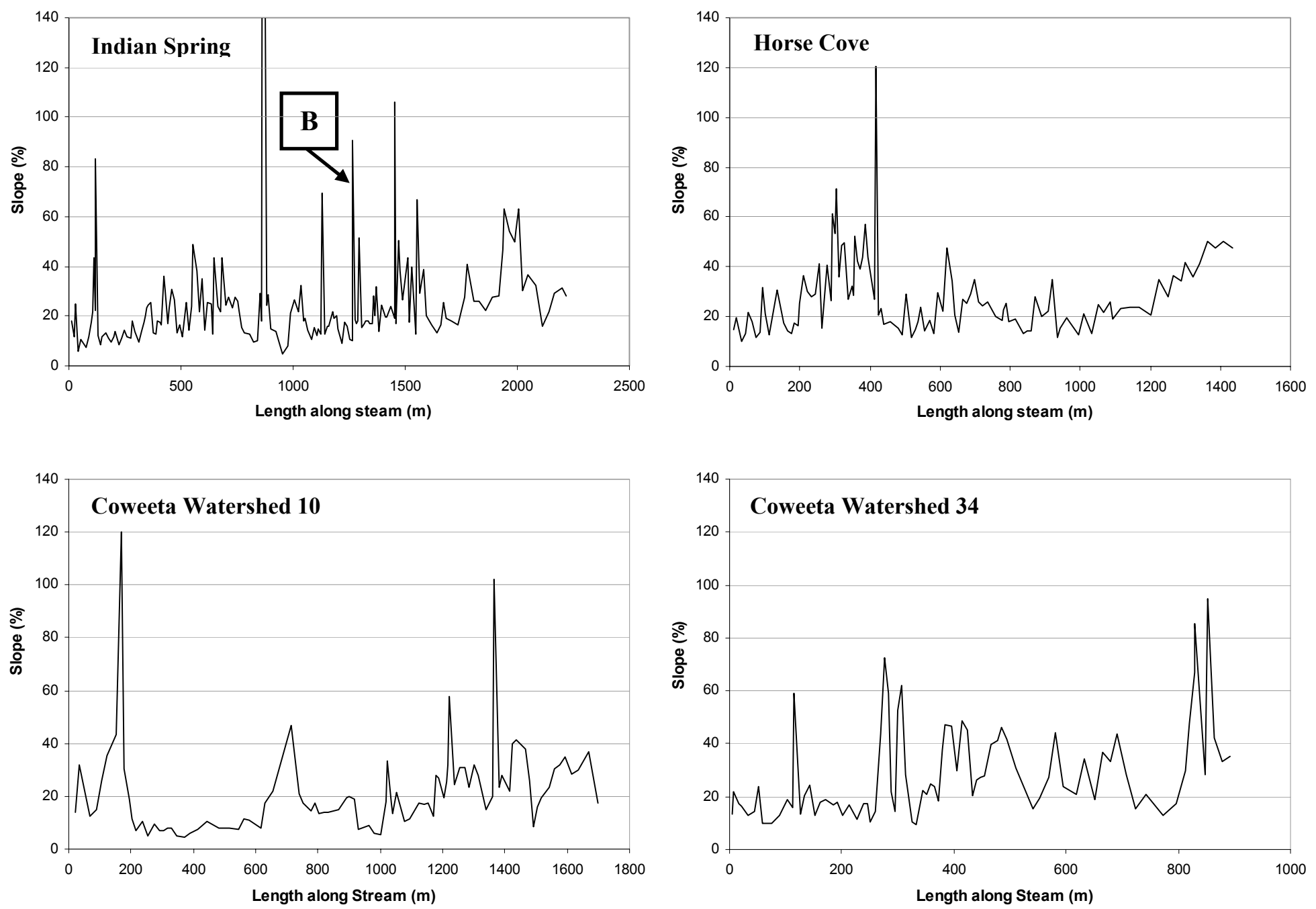

Figure 2.4 con't. Channel slope by length for North Carolina channels, with length values starting at base of channel (survey start point). 

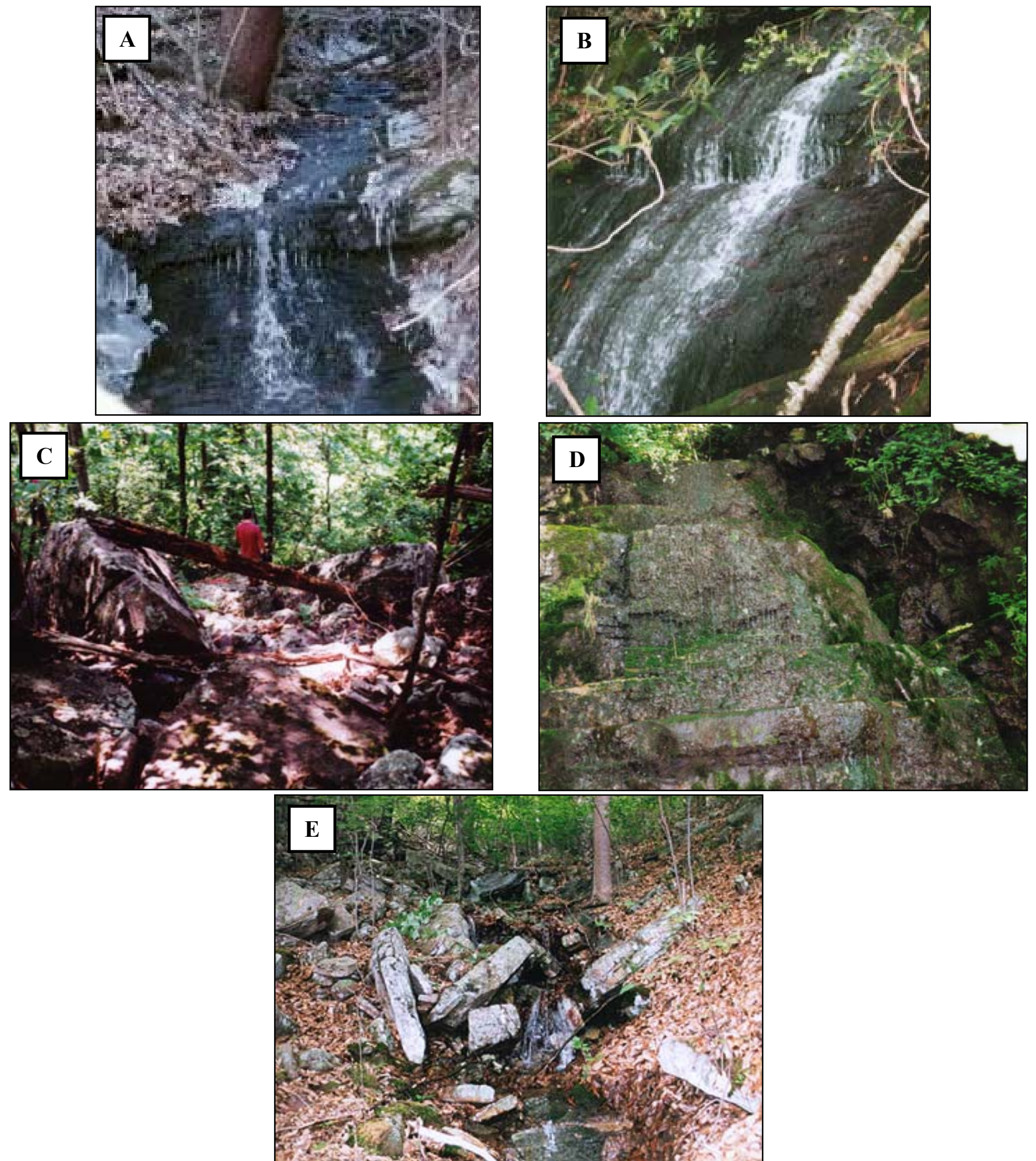

Figure 2.5. A. Abrupt increases in slope at Allen Hollow are the result of short-wavelength coarsening sequences from shale to sandstone in sedimentary Chemung formation. Slope increases appear as steep, bedrock-floored steps. B. Abrupt increases in slope at Indian Spring are the result of short-wavelength variations from phyllite to quartzite in metamorphic bedrock. Slope increases appear as steep bedrock falls. C. Little Stony Tributary steepens as it nears the Tuscarora sandstone outcrop (D.) due to large quartzite boulders that mantle the hillslope. E. Sarver Hollow also has a steep upper section due to boulder influx from Keefer sandstone outcrops. 


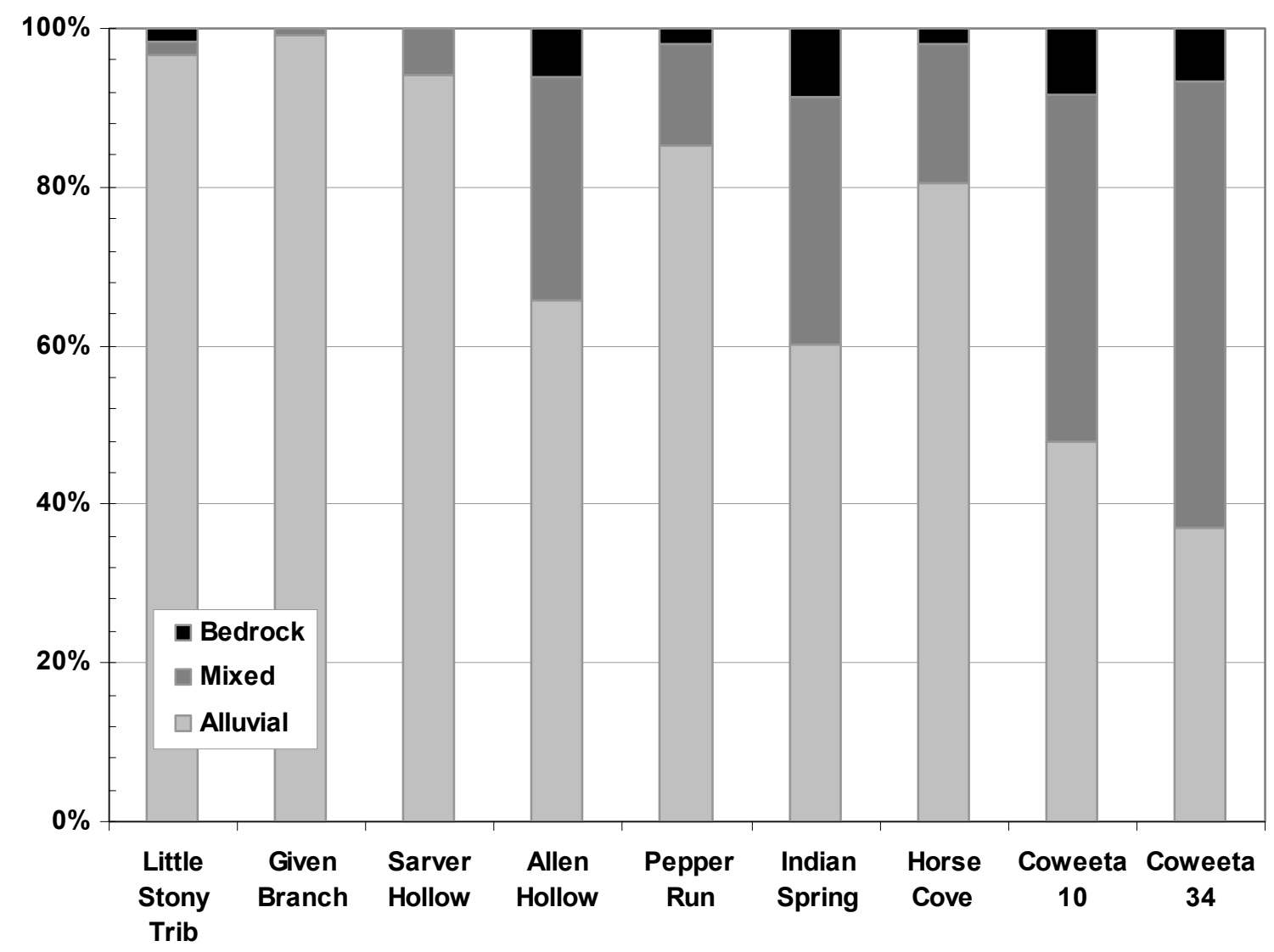

Figure 2.6. Channel substrate by percent of channel length.

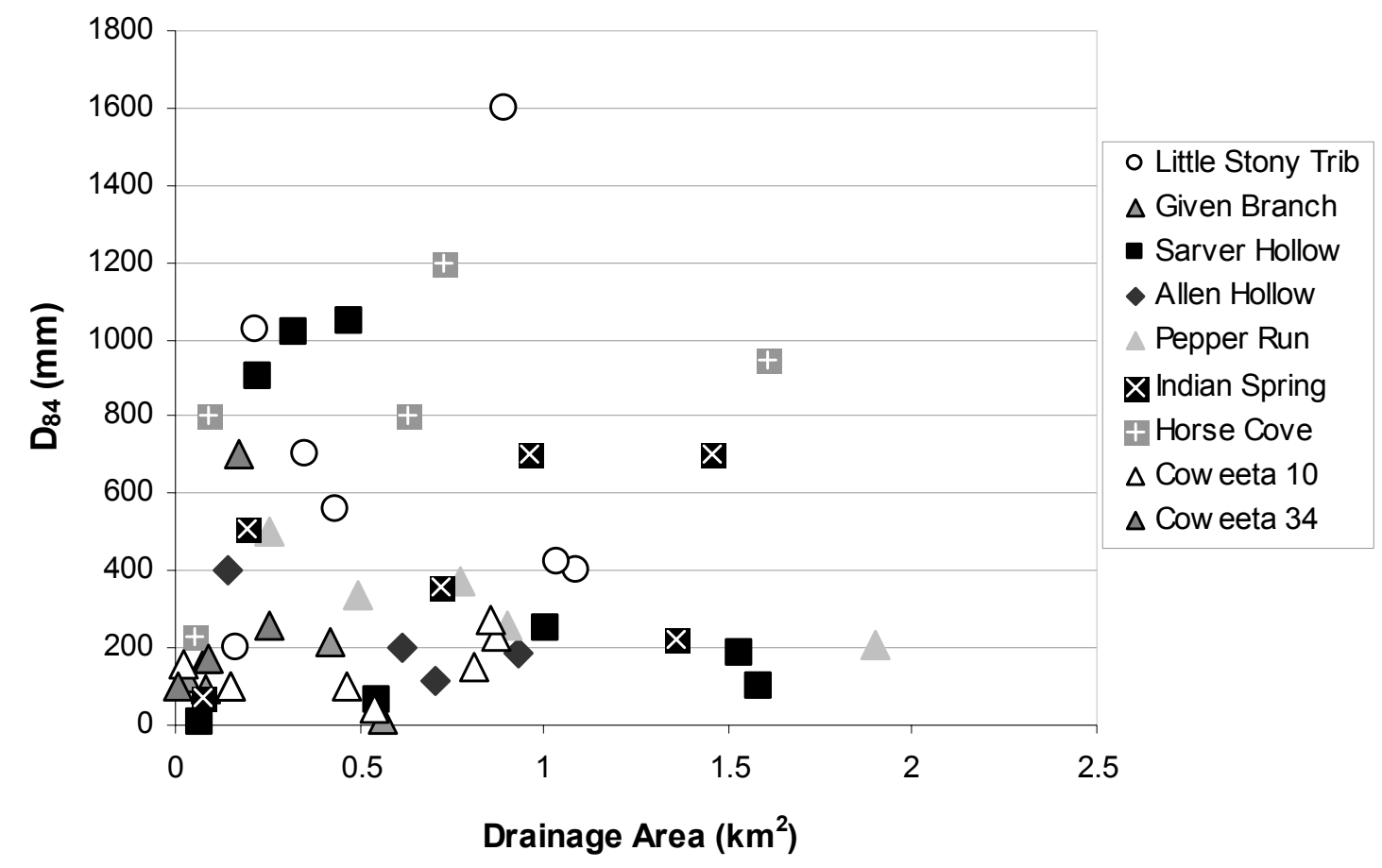

Figure 2.7. $\mathrm{D}_{84}$ grain size vs. drainage area for all cross section locations in all steams surveyed, sorted by stream channel. 


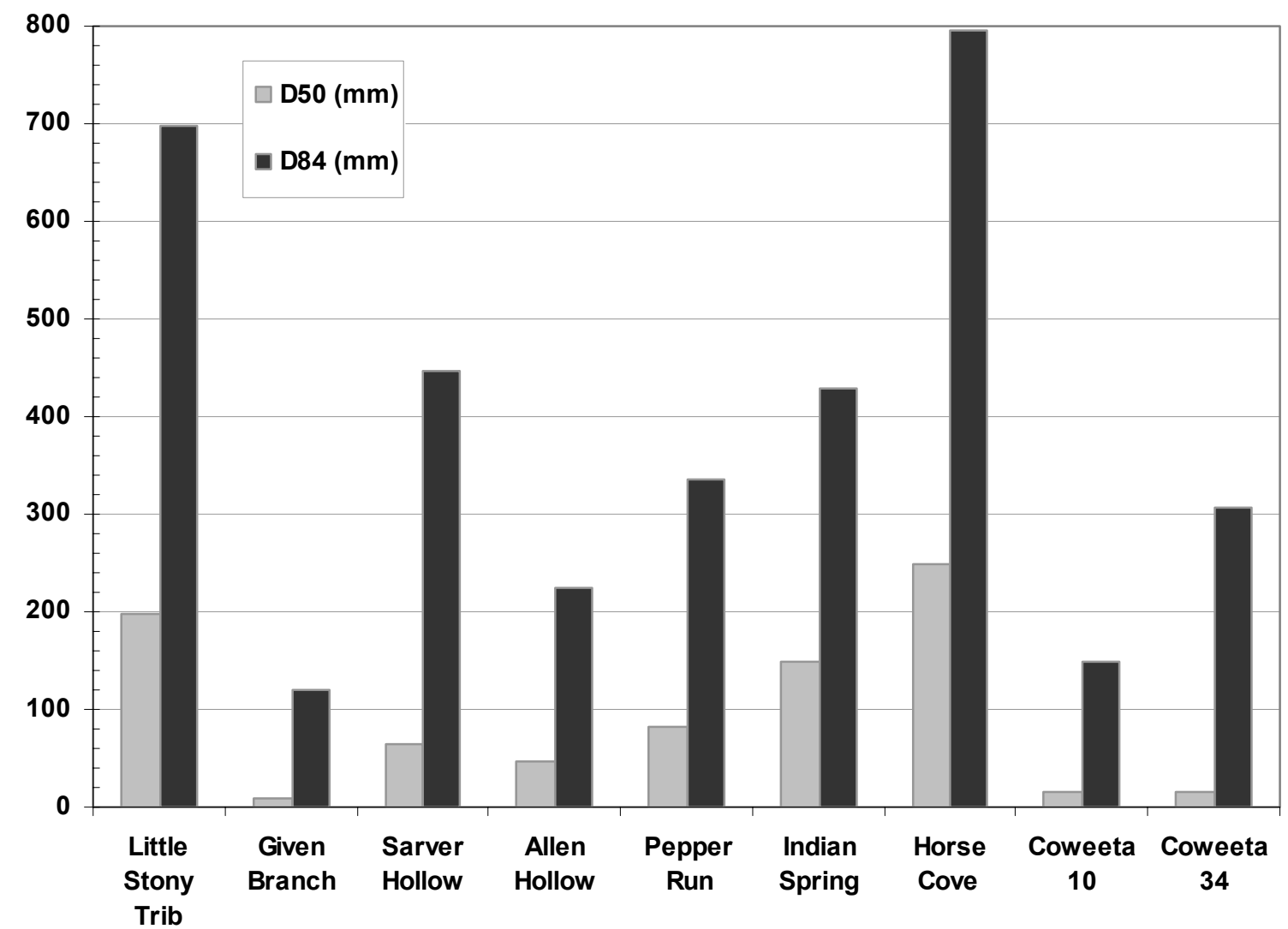

Figure 2.8. Average $D_{50}$ and $D_{84}$ grain size for all the cross sections in each channel.

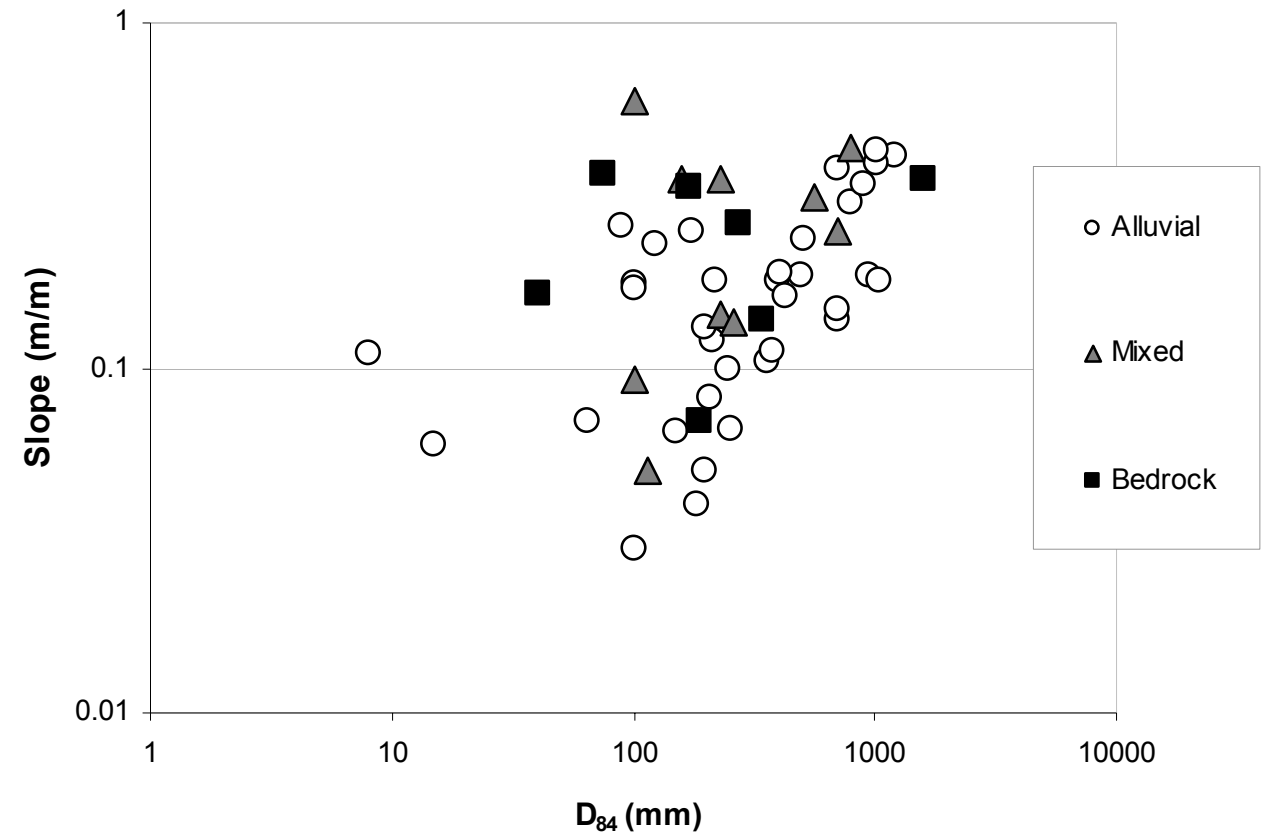

Figure 2.9. Slope vs. $D_{84}$ grain size for all cross section locations in all steams surveyed, sorted by channel substrate. 


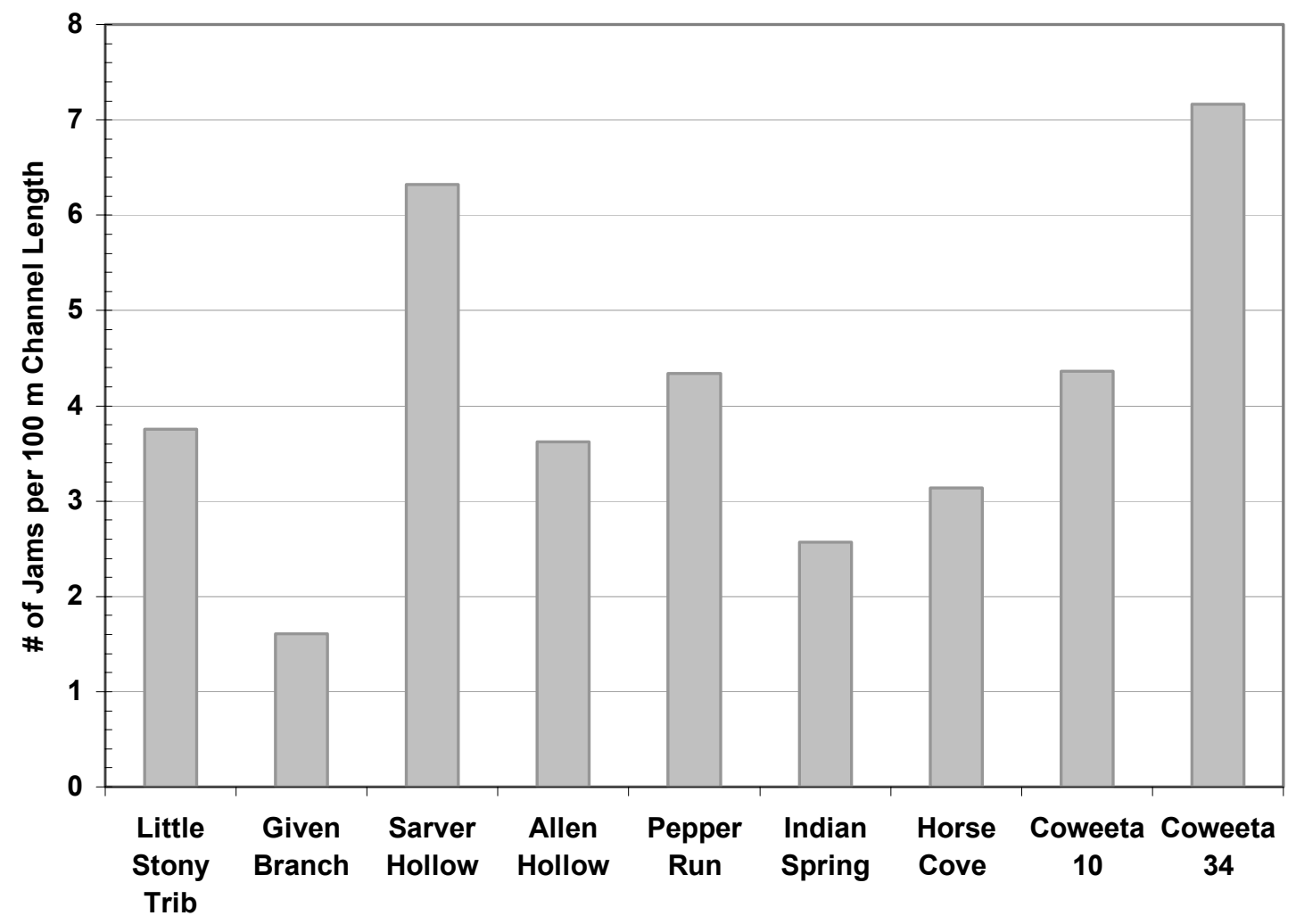

Figure 2.10a. Number of $\log$ and root jams per $100 \mathrm{~m}$ of channel length.

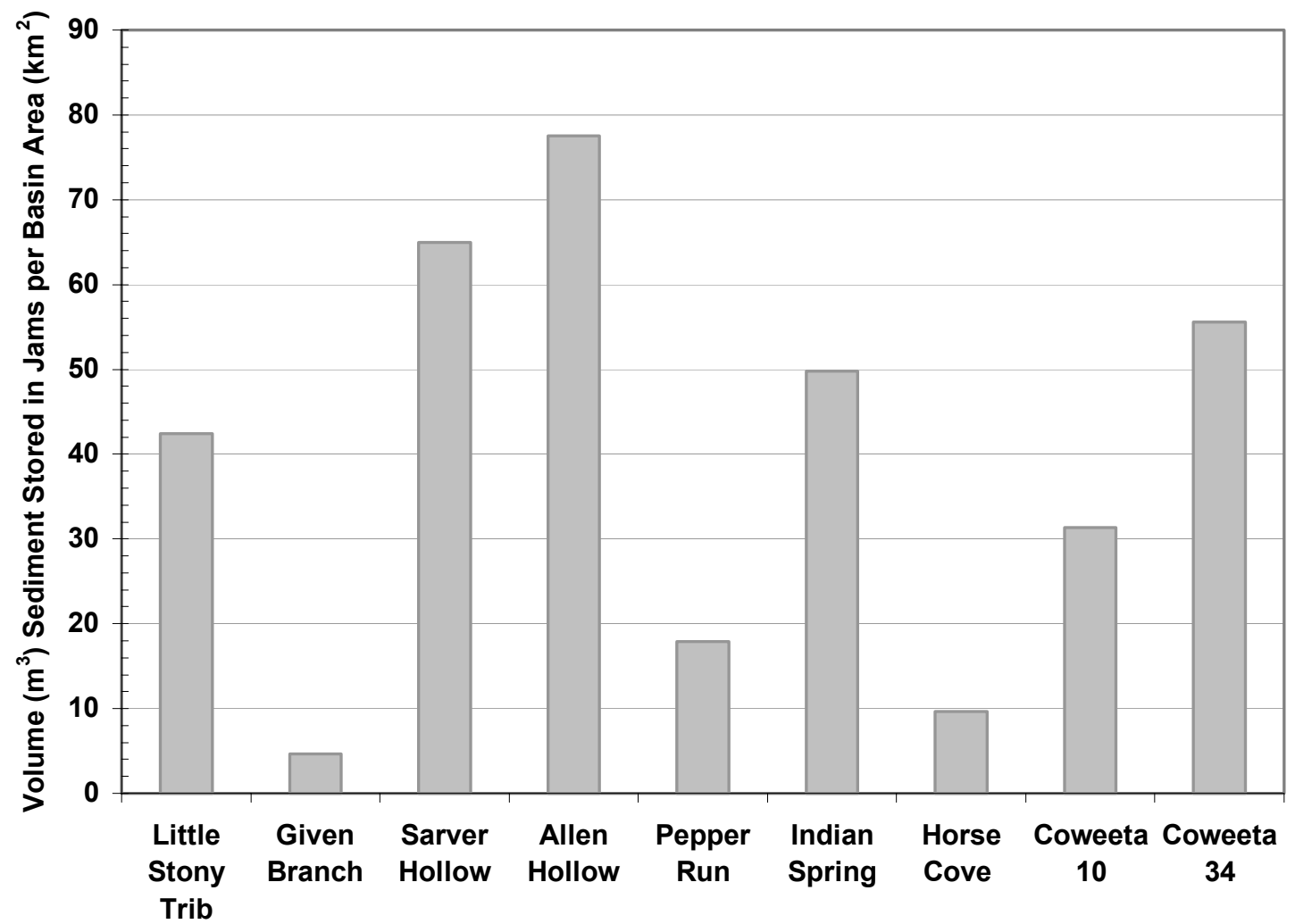

Figure 2.10b. Volume of sediment stored in log and root jams per basin area. 


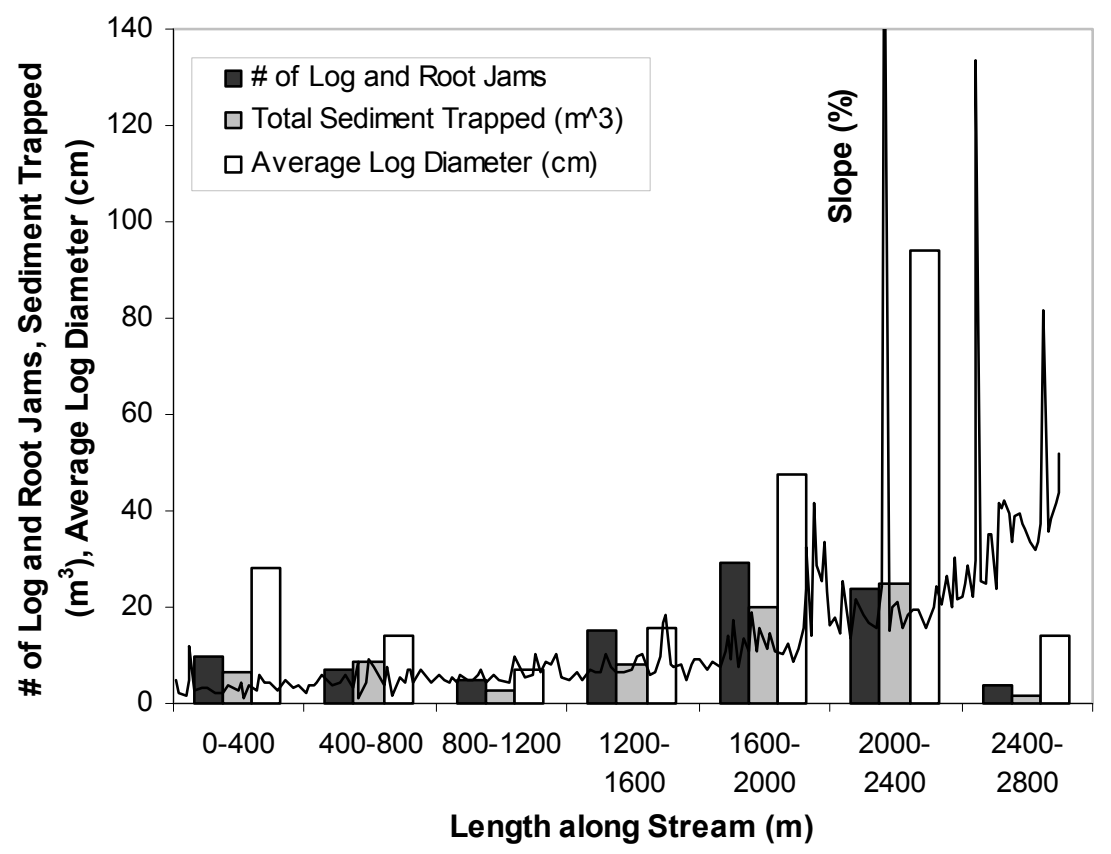

Figure 2.11a. Comparison of slope vs. channel length to log jams vs. channel length for Allen Hollow, with length values starting at base of channel (survey start point). Bedrock and drainage area controls overall channel slope and log jams provide only local slope breaks.

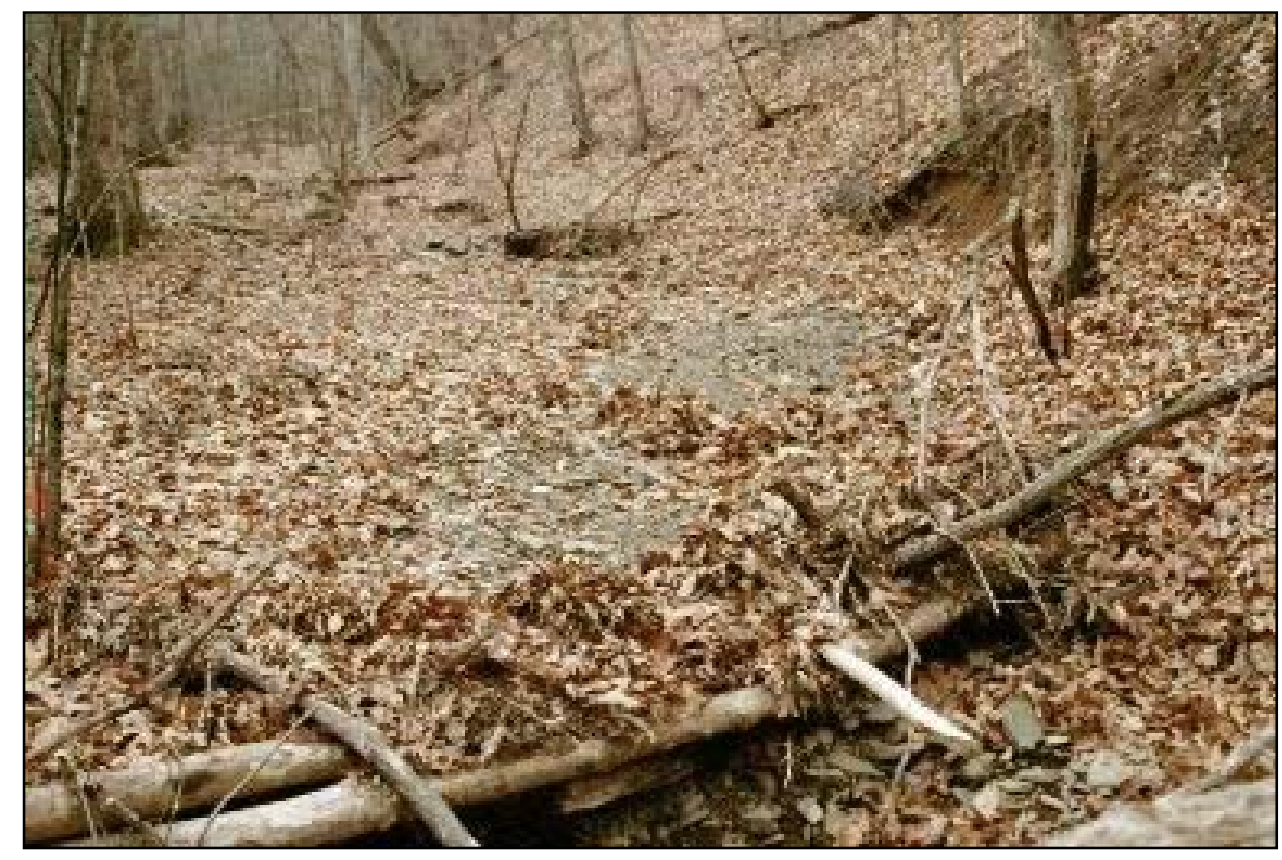

Figure 2.11b. Example of log jams trapping sediment and breaking slope in lower gradient, alluvial reaches of Allen Hollow. 


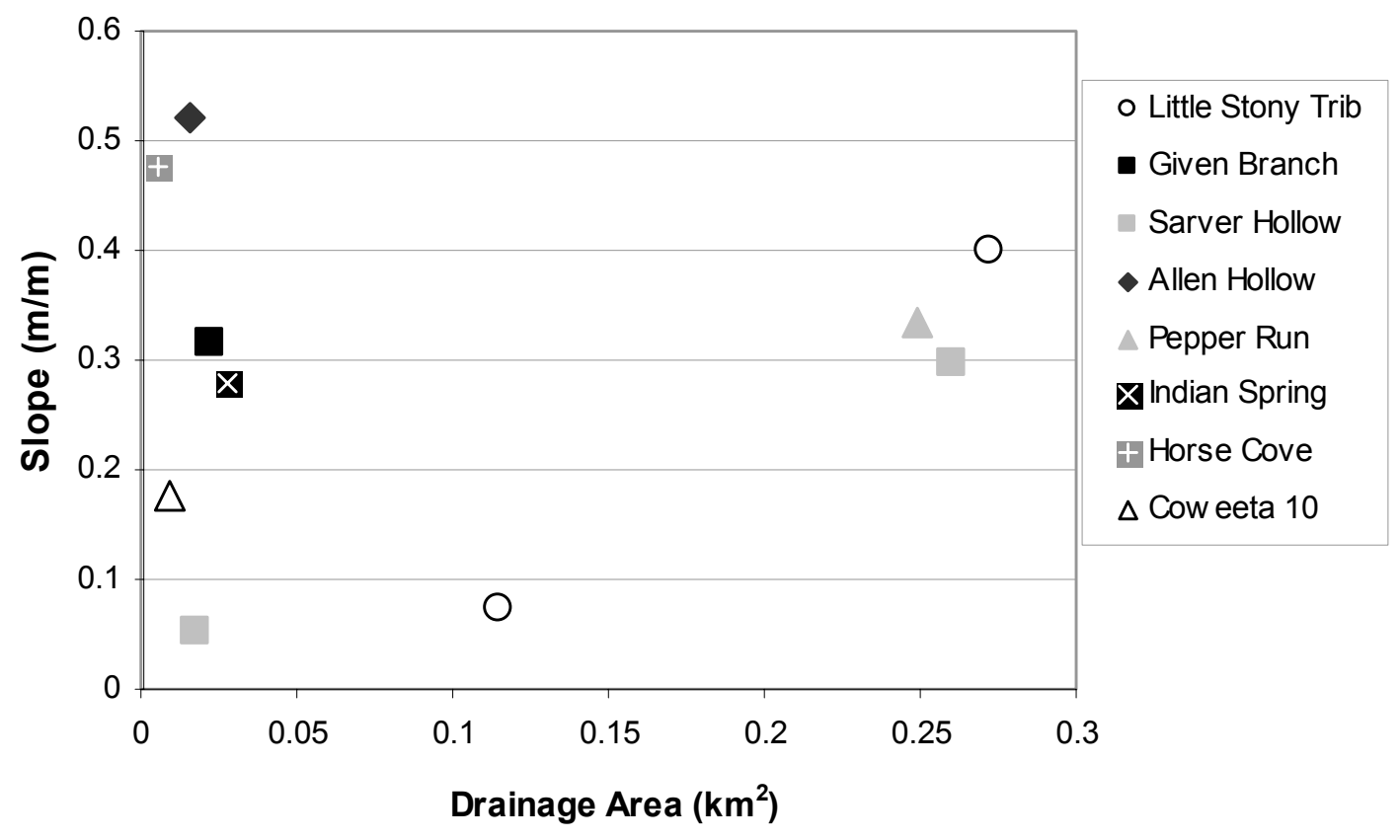

Figure 2.12. Slope vs. drainage area for all channel initiation points, including two secondary channel initiation points in Sarver Hollow and Little Stony Tributary. No channel initiation point was surveyed for Coweeta Watershed 34 due to impassable downed vegetation and briars. 
Table 2.1. Summary statistics of all streams surveyed.

\begin{tabular}{|c|c|c|c|c|c|c|c|c|c|}
\hline Basin Characteristics & $\begin{array}{l}\text { Little } \\
\text { Stony } \\
\text { Trib }\end{array}$ & $\begin{array}{l}\text { Given } \\
\text { Branch }\end{array}$ & $\begin{array}{l}\text { Sarver } \\
\text { Hollow }\end{array}$ & $\begin{array}{c}\text { Allen } \\
\text { Hollow }\end{array}$ & $\begin{array}{l}\text { Pepper } \\
\text { Run }\end{array}$ & $\begin{array}{l}\text { Indian } \\
\text { Spring }\end{array}$ & $\begin{array}{l}\text { Horse } \\
\text { Cove }\end{array}$ & $\begin{array}{c}\text { Coweeta } \\
10\end{array}$ & $\begin{array}{c}\text { Coweeta } \\
34\end{array}$ \\
\hline Drainage Area $\left(\mathrm{km}^{2}\right)$ & 1.09 & 0.57 & 1.60 & 0.94 & 1.92 & 1.42 & 1.61 & 0.90 & 0.34 \\
\hline $\begin{array}{l}\text { Area above Initiation } \\
\text { Point }\left(\mathrm{km}^{2}\right)\end{array}$ & 0.1150 & 0.0223 & 0.0174 & 0.0159 & 0.2490 & 0.0274 & 0.0060 & 0.0088 & 0.0080 \\
\hline Total Length (m) & 2184 & 1060 & 2658 & 2593 & 1267 & 2220 & 1433 & 1697 & 963 \\
\hline Total Relief (m) & 559 & 167 & 443 & 329 & 134 & 496 & 376 & 350 & 235 \\
\hline Average Slope (rise/run) & 0.28 & 0.16 & 0.19 & 0.16 & 0.11 & 0.26 & 0.28 & 0.22 & 0.29 \\
\hline Ave. Annual Precip. (cm) & \multicolumn{2}{|l|}{$\left[107-117^{*}\right][$} & \multicolumn{2}{|c|}{$97-107^{*}$} & \multicolumn{3}{|c|}{][} & \multicolumn{2}{|c|}{$178-250 * *$} \\
\hline \multirow{3}{*}{$\begin{array}{l}\text { By channel } \\
\text { length: }\end{array}$} & 2 & 0 & 0 & 6 & 2 & 9 & 2 & 8 & 7 \\
\hline & 96 & 99 & 94 & 66 & 85 & 60 & 80 & 48 & 37 \\
\hline & 2 & 1 & 6 & 28 & 13 & 31 & 18 & 44 & 56 \\
\hline $\begin{array}{l}\text { Particle Size } \\
\text { Range at }\end{array}$ & $70-350$ & $2-30$ & $1.5-245$ & $27-63$ & $14-125$ & $2.3-250$ & $80-380$ & $2.3-65$ & $3-50$ \\
\hline $\begin{array}{l}\text { Cross Sections } \\
(\mathrm{mm})\end{array} \quad \mathbf{D}_{84}$ & 200-1600 & $15-215$ & $8-1050$ & $115-400$ & $210-500$ & $75-700$ & $230-1200$ & $40-270$ & $100-700$ \\
\hline \# Log and Root Jams & 82 & 17 & 168 & 94 & 55 & 57 & 45 & 74 & 69 \\
\hline $\begin{array}{c}\text { Number of Jams per } 100 \mathrm{~m} \\
\text { of Channel Length }\end{array}$ & 3.75 & 1.60 & 6.32 & 3.63 & 4.34 & 2.57 & 3.14 & 4.36 & 7.16 \\
\hline $\begin{array}{l}\text { Total Sediment Trapped } \\
\qquad\left(\mathrm{m}^{3}\right)\end{array}$ & 46.18 & 2.64 & 103.96 & 72.72 & 34.39 & 70.84 & 15.50 & 28.07 & 18.63 \\
\hline $\begin{array}{l}\text { Total Sediment Trapped } \\
\text { per Basin Area }\left(\mathrm{m}^{3} / \mathrm{km}^{2}\right)\end{array}$ & 42.41 & 4.64 & 64.94 & 77.50 & 17.91 & 49.75 & 9.66 & 31.32 & 55.57 \\
\hline $\begin{array}{c}\text { Sediment in Jams per } \\
\text { Channel Length }\left(\mathrm{m}^{3} / \mathrm{m}\right)\end{array}$ & 0.0211 & 0.0025 & 0.0391 & 0.0280 & 0.0271 & 0.0319 & 0.0108 & 0.0165 & 0.0193 \\
\hline $\begin{array}{c}\text { Average Diameter of Logs } \\
\text { in Jams (cm) }\end{array}$ & 11.89 & 16.36 & 11.51 & 31.45 & 8.16 & 29.67 & 26.15 & 22.70 & 27.47 \\
\hline Land Use History & $\begin{array}{c}\text { logged } \\
\text { early } \\
1900 \text { 's, } \\
\text { USFS/priv } \\
\text { ate }\end{array}$ & $\begin{array}{l}\text { logged, } \\
\text { grazed, } \\
\text { private } \\
\text { property }\end{array}$ & $\begin{array}{l}\text { logged } \\
\text { and } \\
\text { farmed } \\
\text { early } \\
\text { 1900's, } \\
\text { USFS }\end{array}$ & $\begin{array}{c}\text { logged, } \\
\text { farmed, } \\
\text { and burned } \\
\text { early } \\
1900 \text { 's, } \\
\text { USFS }\end{array}$ & $\begin{array}{l}\text { logged, } \\
\text { grazed, } \\
\text { private } \\
\text { property }\end{array}$ & $\begin{array}{l}\text { unlogged } \\
\text { old growth, } \\
\text { USFS }\end{array}$ & $\begin{array}{l}\text { logged } \\
\text { early } \\
1900 ' s, \\
\text { USFS }\end{array}$ & $\begin{array}{l}\text { logged } \\
1927 \text { and } \\
1940 \text { 's, } \\
\text { USFS }\end{array}$ & $\begin{array}{l}\text { logged } 1927, \\
\text { USFS }\end{array}$ \\
\hline $\begin{array}{l}\text { age Annual Precipitation } \mathrm{f} \\
\text { te: http://www.ocs.orst.ed }\end{array}$ & b/maps/1 & Univer & $p$ & rate Anary & erv1 & 2000 & P1 & ion dat & m 1961 \\
\hline
\end{tabular}


Table 2.2. Summary statistics of channel substrate distribution for all streams surveyed.

\begin{tabular}{|c|ccc|}
\hline Substrate Statistics & Alluvial & Mixed & Bedrock \\
\hline Total Length (m) & 12097 & 3335 & 644 \\
Total Elevation (m) & 2272 & 690 & 249 \\
\% Length & 75.3 & 20.7 & 4.0 \\
\% Elevation & 70.8 & 21.5 & 7.7 \\
Average Slope (m/m) & 0.18 & 0.23 & 0.53 \\
\hline $\begin{array}{c}\text { Total Sediment } \\
\text { Trapped (m^3) }\end{array}$ & 265.3 & 41.4 & 3.7 \\
$\begin{array}{c}\text { Sediment in Jams per } \\
\text { Channel Length } \\
\text { (m^3/m) }\end{array}$ & 0.022 & 0.012 & 0.006 \\
\hline
\end{tabular}




\section{Chapter 3}

\section{Modeling Analysis}

\section{$3.1 \quad$ Introduction}

Hydrologic modeling was used in this study to examine the ability of the stream channel to erode its bed during storms or flows with a two year recurrence interval. Storms and flows with a two-year recurrence interval were chosen as a best approximation of the one to three year recurrence for channel-forming flow in larger, perennial streams (Wolman and Miller, 1960). Bankfull discharge was also modeled, and the hydraulic geometry and stream competence, or ability to erode the channel bed, were analyzed. The flow height and the ability of the headwater channels studied to erode their bed at two year and bankfull flows revealed the recurrence of flows that are important for channel formation. Differences between and within the studied channels indicated what geologic, climatic, and land use conditions are important for channel adjustment. However, differences and trends in the modeled flows were analyzed qualitatively, as the number of streams sampled was too small for statistical analysis.

\section{$3.2 \quad$ Background}

The general goal of hydrologic modeling is to produce hydrographs in response to precipitation input. Specifically, modeling of hydrology in urban areas is often undertaken with the goals of building bridges and roads that will withstand major floods, regulating floodplain activities, and operating water-control structures. Modeling of forested and agricultural basins is performed for similar reasons, as well as to predict the increase in runoff and sediment loads that may occur with changes in land use or land cover. These modeling efforts are often focused on predicting discharges from floods, or storm flow, and therefore have been developed to use meteorological and basin input that reflects the shortterm response of a basin to storms. More recently, models have been developed that attempt to predict basin runoff on a continuous basis, by balancing long-term moisture storage.

Predicting runoff from storms or yearly flow is difficult, as it requires the simulation of complex hydrologic processes within a basin. Hydrologic models are generally comprised of several components that, in combination, model the hydrologic process within a basin. 
Typically, the first component is a runoff-volume model that predicts that amount of precipitation that is retained on or in the land surface and the amount that exits as runoff. The predicted runoff must then be routed through the basin to the stream channel, based on an estimation of travel time through various flow paths. Finally, stream channel flow routing models runoff through channel reaches to the basin outlet by "lagging" the runoff according to channel dimensions and instream storage capacity. Options for modifying or customizing models are available, such as including a baseflow component to add subsurface drainage to the channel flow or reservoir storage in basins that contain water-control structures. These models estimate a hydrologic response to precipitation based on soil, vegetation, stream network, and topography data for a particular basin.

Various hydrologic modeling methods are available. Storm models predict system response to a short rainfall, whereas continuous models account for long-term system changes in runoff forecasting. Both empirical and conceptual models are available; empirical models use previous input-output observations to predict basin response, while conceptual models use knowledge of hydrologic processes to mimic basin response. Models can also be measured, in which the properties of the system can be sampled and used to define model parameters; or fitted-parameter, in which basin characteristics are calibrated to match observed values of input and output data. Lumped models, which disregard or average spatial variation within a basin, have long been standard for use in hydrologic modeling. However, advancements in geographic information system (GIS) technology have made distributed models a viable option. Distributed models capture spatial variation within a basin by considering it on a gridded basis. No model is appropriate in all situations, as the model chosen must fit the goals and available data for the system being studied.

HEC-HMS, free hydrologic modeling software produced by the Army Corp of Engineers, was used for modeling in this study. It is enabled for use on a gridded basis, and has been shown to produce peak flows that compare well with observed flows (Doan, 2000; Hoblit and Curtis, 2001; Johnson et al., 2001). Only two runoff-volume models are available within HEC-HMS for use as distributed models; the curve number method and the soil moisture accounting system. The two approaches provide a good contrast in model capabilities and data requirements. The curve number model is for use in short storm-flows with negligible infiltration recovery. It is largely based on fitting input-output values to 
empirical data and requires only soil hydrologic group and land cover characteristics for an estimation of runoff. The soil moisture accounting system is at the other extreme. It is a long-term precipitation input/output model that tracks soil moisture inputs and losses over the course of a year or more. It is based on an understanding of basin processes and requires detailed data on canopy interception, evapotranspiration losses, groundwater flow and storage, and infiltration rates. While the curve number model is simple, predictable, and well established in the US hydrologic community, it is a drastic simplification of precipitationrunoff relations. It does not respond to storm duration, intensity, or timing. On the other hand, the soil moisture accounting method models soil and groundwater movement in a manner that replicates actual hydrologic processes under dry and wet conditions, but requires long-term flow observations for the basin being modeled and is not appropriate for modeling a single storm.

\section{$\underline{3.3 \quad \text { Methods }}$}

Seven of the nine basins are ungauged, and there are wide variations in slope, soil type and land cover in most of the basins. Therefore, an empirical, fitted-parameter storm model was chosen, using distributed modeling in a GIS to capture basin heterogeneity. Runoff volume was predicted using the curve number method, basin runoff travel time was estimated using Soil Conservation Service flow equations, and instream flow routing was modeled with lag times estimated using Manning's equation. Predicted runoff volumes were then routed from each cell in a basin to the basin using the ModClark transform, which delivers runoff from each cell according to its distance from the basin outlet and basin travel time estimates. In a GIS environment, basin variables such as geology and soils have been translated into runoff coefficients, while variables such as slope, land cover, and channel form have been translated into basin and channel travel times for runoff. HEC-HMS software was used to combine model components, perform calculations, and produce final hydrographs. The modeling that I pursue is a greatly simplified representation of basin hydrology and is directly controlled by interpretations and assumptions about basic basin conditions. 


\subsubsection{Flow path extraction}

Prior to simulating the interaction between precipitation and the basin surface, the basin drainage network must be defined. Formerly, this was accomplished by hand with topographic maps, in a lumped fashion. Basin parameters such as slope, stream length, and drainage area had to be averaged over the entire basin or some basin segment. The advent of GIS technology and widely available USGS Digital Elevation Models (DEMs) has enabled this process to occur on a cell-by-cell basis within a basin and improved the detailed representation of drainage networks and basin topography in runoff delivery. This is especially true in regard to the recent availability of $10 \mathrm{~m}$ resolution DEMs, as smaller scale DEMs did not have resolution required to image low-order stream networks. $10 \mathrm{~m}$ DEMs provide the scale of resolution required for small basins (Garbrecht and Martz, 1994).

DEMs are used in this study to develop HEC-HMS input files for runoff volume estimation and routing and to estimate travel times using ArcView Spatial Analyst. An ArcView extension (HEC-GeoHMS) developed for use with HEC-HMS was used to create cell parameter files from DEMs. DEMs were reprojected from Universal Transverse Mercator into an equal-area, Albers conical projection, to be consistent with NexRain radar rainfall data. The resampling required for reprojection creates slight spatial changes in the DEM values that affect hydrologic characteristics of the basin, such as drainage area, flow network configuration, and flow network length. Bilinear interpolation of DEM data clipped to the basin boundaries is used in this study, as it has been shown to produce drainage features are more consistently similar to UTM drainages than nearest neighbor or cubic convolution interpolation of unclipped DEM data (Kavage, 2001).

One of the most important uses of the DEM is the generation of drainage network flowpaths. Reprojected DEMs are imported into ArcView for flowpath delineation, which requires several processing steps. First, the DEM is 'filled', artificially raising the elevation of any spurious pits or sinks in the data to ensure that each cell has a neighbor with an elevation value lower than itself. The flow direction of each cell is then determined by the Jenson-Dominique algorithm, which chooses downstream flow direction from each cell as its lowest neighbor (Jenson and Dominique, 1988). Drainage network flowpaths are then determined by following the flow direction determined for each cell from the ridge to the basin outlet. Basin cells are then divided into stream cells and hillslope cells using a 
drainage area threshold for channel initiation. In this study the threshold was determined empirically for each basin based on field surveyed channel heads.

DEMs are also used to generate the slope values for the basin surface, which are necessary in runoff travel time equations. The basin surface is calculated in ArcView Spatial Analyst by fitting a plane to the elevation of the eight cells surrounding the cell of interest (3x3 neighborhood), and using the direction this plane faces as the center cell's aspect (ESRI, 1999). The average maximum technique (Burrough, 1986) is then used to calculate slope of the center cell. Slope values derived from DEMs can be underestimated because values are averaged over nine cells, and the divisor used in the averaging equation has a lower limit equivalent to the DEM resolution. Furthermore, DEMs used in this study are Level 2, which means they were produced from contour lines of elevation on the corresponding 7.5-minute topographic quadrangle (U.S. Geological Survey, 1997). The contour lines on topographic quadrangles sometimes fail to image sharp elevation changes, and this smoothing is evident in comparison of DEM slope values to field surveyed slope values in the Coweeta 10 stream channel (Fig. 3.3.1). DEM slope is typically higher when field surveyed slope is below 15\% but fails to represent sharp spikes in slope at waterfalls (slope $>30 \%$ ). Overall, the two effects may cancel, but the comparison demonstrates the potential error in sheet, shallow concentrated, and channel flow travel time estimates due to erroneous DEM slope values. Unfortunately, there is no viable alternative to DEMs for generating basin slope values. However, field measured slope values are used to model discharge at surveyed cross section locations (Section 3.6), so DEM slope error does not contribute to discharge modeling uncertainty.

Other hydrologic parameters needed as HEC-HMS input are also determined from DEMs for each cell, such as its distance to the basin outlet and area. In this study, each basin was broken up into smaller sections based on the location of cross sections taken in the field (Fig. 3.3.2). All the cells upstream of the uppermost cross section drain into that cross section and are modeled as a basin subset. That subbasin then adds flow to the channel, which is routed through the downstream channel reaches. The basin for the next crosssection downstream in the channel includes the contributing cells above it minus those that drain into the first cross section. Each subbasin contributes flow to the channel at its outlet 
(the cross section location), which is then routed through the DEM-defined stream channel network to the final basin outlet.

\subsubsection{Runoff-volume estimate}

Runoff coefficients determine the amount of rainfall that leaves the land surface as runoff for each time-step in the model. Runoff coefficients for the basins in this study were determined using the curve number method developed by the Soil Conservation Service. The curve number was originally developed by the Soil Conservation Service to estimate the effects of land treatment and land use on direct runoff. It predicts the runoff response curve from varying amounts of precipitation for certain soil and land cover types. It is easy to apply in ungauged basins, as it is based on soil and land cover characteristics easily obtained from soil surveys and field observations. Its other strength is that it was developed from empirical data from small rural basins (Beven, 2000). Thus, although it does not explicitly model infiltration and runoff processes, they are imbedded in its runoff estimation. For example, the curve number does not necessarily assume that all runoff reaching the basin outlet traveled as overland flow, since it may not have been in original basins studied. The

curve number is generally recommended for small $\left(>2.6 \mathrm{~km}^{2}\right)$ basins with homogenous land use and soil type, it can be used on a grid cell basis; with spatially heterogeneous soil and land cover conditions.

Curve number $(\mathrm{CN})$ runoff prediction uses soil and land cover conditions to estimate the ability of the soil to store precipitation. It can also incorporate antecedent moisture conditions. Curve number values for soil, land cover, and antecedent moisture types are usually obtained from charts included in publications such as Urban Hydrology for Small Watersheds (TR-55) (Soil Conservation Service, 1986) and Design of Small Dams (U.S. Department of the Interior Bureau of Reclamation, 1960). Once a curve number is selected, it is translated to a storage value for use in a predictive runoff equation that calculates the excess precipitation ( $\mathrm{P} e=$ runoff or precipitation excess that the basin cannot store) as a function of precipitation $(\mathrm{P})$, initial abstraction $(\mathrm{I} a)$, and soil storage $(S)$ :

$$
\mathrm{P} e=\frac{(\mathrm{P}-\mathrm{I} a)^{2}}{\mathrm{P}-\mathrm{I} a+S}
$$

Where: $C N=$ Curve Number 


$$
\begin{aligned}
& \mathrm{P} e=\text { Accumulated Precipitation Excess at Time } \mathrm{T} \\
& \mathrm{P}=\text { Accumulated Rainfall Depth at Time } \mathrm{T} \\
& \mathrm{I} a=\text { Initial Abstraction (initial loss) } \\
& S=\text { Potential Maximum Retention (ability to abstract/store precipitation) }
\end{aligned}
$$

Initial abstraction ( $\mathrm{I} a$ ) consists of interception, infiltration, and surface storage (ponding), and has been shown empirically to $=0.2 \mathrm{~S}$. Adjustment of $\mathrm{I} a$ is not recommended unless data on its three components is available (U.S. Department of the Interior Bureau of Reclamation, 1960). There fore, equation 3.3.1 can be reduced to:

$$
\mathrm{P} e=\frac{(\mathrm{P}-0.2 S)^{2}}{\mathrm{P}+0.8 S}
$$

The ability of the soil to store moisture $(S)$ is defined as (Feldman, 2000):

$$
S=\frac{25400-254 C N}{C N} \text { (SI units) }
$$

As the curve number becomes higher (less absorptive soils), $\mathrm{S}$ drops and $\mathrm{P} e$ is higher, and as the curve number decreases (more absorptive soils), $\mathrm{S}$ increases and $\mathrm{P} e$ decreases.

A drawback of curve number runoff volume estimation is that does not contain any expression for time. It is intended for use in single storms in 24-hour intervals and not to reproduce historical runoff data. The basin curve number has been shown to decrease with an increase in storm duration, indicating an increase in precipitation storage that is not represented by a single curve number (Rallison and Miller, 1982). This is because the curve number method assumes that infiltration decreases and eventually stops after a certain rainfall accumulation regardless of its temporal distribution. This assumption fails in soils with high storage, as infiltration will not stop but reach a constant rate at some point during the storm. However, infiltration recovery is assumed negligible if the breaks in precipitation are less than one hour (Rallison and Miller, 1982). For this reason, short, intense storms have been chosen for precipitation input and any zero precipitation values in the rainfall data have been increased to $0.1 \mathrm{~mm}$ for that 15 -minute time step.

\subsubsection{Basin travel time}

Runoff from storm precipitation is routed through the basin, from the point where rainfall hits the ground to the basin outlet, by approximating travel time. I assume all runoff 
travels as overland flow for simplicity, although subsurface flow is possible in the environment. Therefore, land slope, roughness, and precipitation depth have a major effect on overland runoff travel times.

The approach used is the Soil Conservation Service "segmental" approach (Feldman, 2000), which calculates travel time out of a watershed as the sum of overland flow travel time in sheet $\left(\mathrm{T} t_{1}\right)$, shallow concentrated $\left(\mathrm{T} t_{2}\right)$, and channel flow $\left(\mathrm{T} t_{3}\right)$ :

$$
T c=T t_{1}+T t_{2}+T t_{3}
$$

The longest flow path out of the basin, typically from a ridgeline cell in mountainous areas to the basin outlet, is then used as the time of concentration for that basin (Tc).

Once basin runoff reaches the local outlet (i.e. channel cross section location) based on the time of concentration, it is routed as channel flow to the basin outlet (Fig. 3.3.3). The travel time in each reach between basin outlets was calculated using Manning's equation as described in the channel flow section, and summed for all cells in a stream reach. The length of these stream reaches between outlets is typically 200-300 meters. The travel time is used to "lag" the movement of the runoff through the system in order to produce the approximate delay between storm peaks and hydrograph peaks.

Data derived from DEMs using ArcView Spatial Analyst were used to calculate travel time on a cell-by-cell basis along previously delineated (see drainage network section) topographic flow paths. Data layers such as slope, flow distance, flow direction, land roughness, and channel geometry were used in flow equations (see sheet, shallow concentrated, and channel flow sections) that calculated a travel time for water across each cell, and cumulatively from each cell to the basin outlet.

\section{Sheet flow}

Sheet flow is defined as overland flow that is not channelized and typically occurs in the first 100 meters of flow before flow converges into concentrated flow paths (Soil Conservation Service, 1986). Sheet flow travel time is calculated by an approximation of Manning's kinematic solution for overland flow (Feldman, 2000):

$$
t_{\text {sheet }}=\frac{0.007(N L)^{0.8}}{\left(\mathrm{P}_{2}\right)^{0.5} S^{0.4}}
$$

Where: $t_{\text {sheet }}=$ travel time of sheet flow in hours 
$N=$ overland roughness coefficient

$L=$ flow length in feet

$\mathrm{P}_{2}=$ two-year 24-hour rainfall depth in inches

$S=$ slope of land surface (rise/run)

Sheet flow travel times were calculated for the first $100 \mathrm{~m}$ of flow in each DEMdefined flow path in each basin. Flow length and slope were calculated for each grid cell from a DEM. Flow length for each cell is the distance traveled across the cell in the DEM generated flowpath, either straight across $(10 \mathrm{~m})$ or diagonally $(14.14 \mathrm{~m})$.

Field observations of vegetation type, height, and density were used to determine overland Manning's N from Table 3.1 in Urban Hydrology for Small Watersheds (TR-55) (1986). Basins in this study typically had high overland $\mathrm{N}$ values (0.4-0.9), as they are forested basins with light to dense underbrush, as described by Table 3.1 in TR-55. Grazed areas, households, and paved and gravel roads varied from 0.011-0.4 for overland N (Figs. 3.3.4d-3.3.12d). As the assessment of overland $\mathrm{N}$ is subjective, the assigned values have a $10 \%$ level of confidence. $\mathrm{P}_{2}$ replaces rainfall excess rate in the original equation for sheet flow travel time (Overton and Meadows, 1976). It is an approximation of sheet flow depth that is used regardless of the storm return period being analyzed (Kibler, 2002), and is based on the intensity for a Soil Conservation Service type II distribution rainfall (see precipitation section). The two-year 24-hour rainfall depth was estimated using National Weather Service report TP-40, which maps rainfall depths for various recurrence intervals across the US (Hershfield, 1961). $\mathrm{P}_{2}$ is greater at Coweeta $(4.5$ inches or $114.3 \mathrm{~mm}$ ) than all the other basins ( 3.5 inches or $88.9 \mathrm{~mm}$ ).

\section{Shallow concentrated flow}

Shallow concentrated flow is overland sheet flow that has converged into rills and rivulet, and is moving at higher velocities than shallow flow (Soil Conservation Service, 1986). It is assumed to occur in flow paths after $100 \mathrm{~m}$ of sheet flow, prior to reaching the stream channel. It can be estimated using a solution of Manning's equation for channel flow (Eqs. 3.3.6 and 3.3.7) with values of $n$ and $\mathrm{R}$ assumed to be 0.05 and $0.4 \mathrm{ft}(0.12 \mathrm{~m})$ for unpaved surfaces and 0.025 and $0.2 \mathrm{ft}(0.06 \mathrm{~m})$ for paved surfaces (Soil Conservation Service, 1986): 


$$
t_{\text {shallow }}=\frac{L}{V}
$$

Where: $V=16.1345 \sqrt{S}$ for unpaved surfaces

$V=20.3282 \sqrt{S}$ for paved surfaces

$t_{\text {shallow }}=$ travel time of shallow flow in seconds

$L=$ flow length in feet

$V=$ shallow concentrated flow velocity $(\mathrm{ft} / \mathrm{sec})$

$S=$ slope of land surface (rise/run)

Slope for each cell is derived from the DEM. The vast majority of the surface in this study was unpaved, so equation 3.3.6 was used to calculate shallow concentrated flow velocity. Once velocity was calculated, cell flow length was divided by cell flow velocity to get the travel time for each cell.

The assumption of overland flow in the sheet and shallow concentrated flow travel time calculations is not in keeping with the mechanics of infiltration and storage in forested watersheds as observed at Coweeta (Hewlett, 1961; Hibbert and Troendle, 1988). Storm flow typically travels through the subsurface until it reaches the stream channel network, at velocities much slower than overland flow velocities (Nutter, 1971). This difference in travel time may produce a more sharply peaked hydrograph that over predicts peak storm flow.

\section{Channel flow}

Channel flow is the final component of basin time of concentration, and occurs once runoff reaches the stream channel and is still within the basin where it originated. After flow passes out of this basin, it is also routed through the subsequent stream reaches using channel flow travel times (lag times). The channel flow travel time is determined by Manning's equation (Feldman, 2000):

$$
\begin{aligned}
& t_{\text {channel }}=\frac{L}{U} \\
& U=\frac{R^{2 / 3} S^{1 / 2}}{n} \text { (SI units) }
\end{aligned}
$$

Where: $t_{\text {channel }}=$ travel time of channel flow in seconds

$L=$ flow length in meters 
$U=$ average channel flow velocity

$n=$ Manning's roughness coefficient

$\mathrm{R}=$ hydraulic radius (area/wetted perimeter)

$\mathrm{S}=$ slope of energy grade line (approximated by slope of channel bed)

Hydraulic radius and flow roughness (Manning's $n$ ) were determined from fieldsurveyed channel cross-sections and pebble counts assumed to be at a bankfull flow. Manning's $n$ was calculated using Limerinos' equation, which bases roughness on a ratio of hydraulic radius to the $D_{84}$ (Eq. 3.3.9) (Limerinos, 1970):

$$
n=\frac{(0.0926) R^{1 / 6}}{1.16+2.0 \log \left(\frac{R}{D_{84}}\right)} \quad \text { (English units) }
$$

Where: $D_{84}=84^{\text {th }}$ percentile particle size in cumulative grain size distribution

Channel slope was determined from the DEM for each stream cell. Values for R and $n$ were extrapolated beyond the cross section location over parts of the channel similar in drainage area and form. Unsurveyed tributaries were given $\mathrm{R}$ and $n$ values identical to surveyed cross sections with similar drainage area (Figs. 3.3.4b-3.3.12b). Reaches within the main channel between cross section surveys were given $\mathrm{R}$ and $n$ values identical to the cross section most similar in form, as recorded in field survey notes. There is great variation in $\mathrm{D}_{84}$ along most of the channels, however, so this extrapolation is an approximation that does not represent all the changes in channel roughness. Velocity was calculated for each stream channel cell and divided into cell length to get travel time.

\subsubsection{Hydrograph routing}

The ModClark transform is used to route excess precipitation for each time step (determined by curve number) to the basin outlet (i.e. cross section location) based on the basin's time of concentration. The ModClark transform determines runoff delivery timing from each cell to the basin outlet based on the cell's distance from the basin outlet and the basin time of concentration (Feldman, 2000):

$$
\frac{T t_{\text {cell }}}{T t_{\text {farthestcell }}}=\frac{\text { Dist } t_{\text {cell }}}{\text { Dist } t_{\text {farthestcell }}}
$$

Where: $\mathrm{T} t_{\text {cell }}=$ Runoff travel time from cell to basin outlet 
$\mathrm{T} t_{\text {farthesteell }}=$ Runoff travel time of cell from basin outlet for most distant cell (same as time of concentration $\mathrm{T} c$ )

Dist $t_{\text {cell }}=$ Distance of cell to the basin outlet

Dist $_{\text {farthesteell }}=$ Distance of cell to the basin outlet for most distant cell

After runoff from each cell is delivered to the basin outlet, it is routed through the stream channel to the next basin outlet (cross section location) based on a reach lag time (see basin travel time and channel flow sections). Flow attenuation coefficients for instream flow routing were chosen in order to simulate channel storage that occurs after the initial abstraction and infiltration. The inability to calibrate hydrograph timing for the ungauged basins in this study required a best guess for this parameter. Since the basins are steep, narrow, and lacking a floodplain, it was assumed that the channel storage values were small ( 0.1 hour). Finally, a hydrograph is produced at the basin outlet that shows channel discharge for each 15-minute time step. It also produces values for peak discharge, time to peak, and total storm runoff volume for the entire storm. 


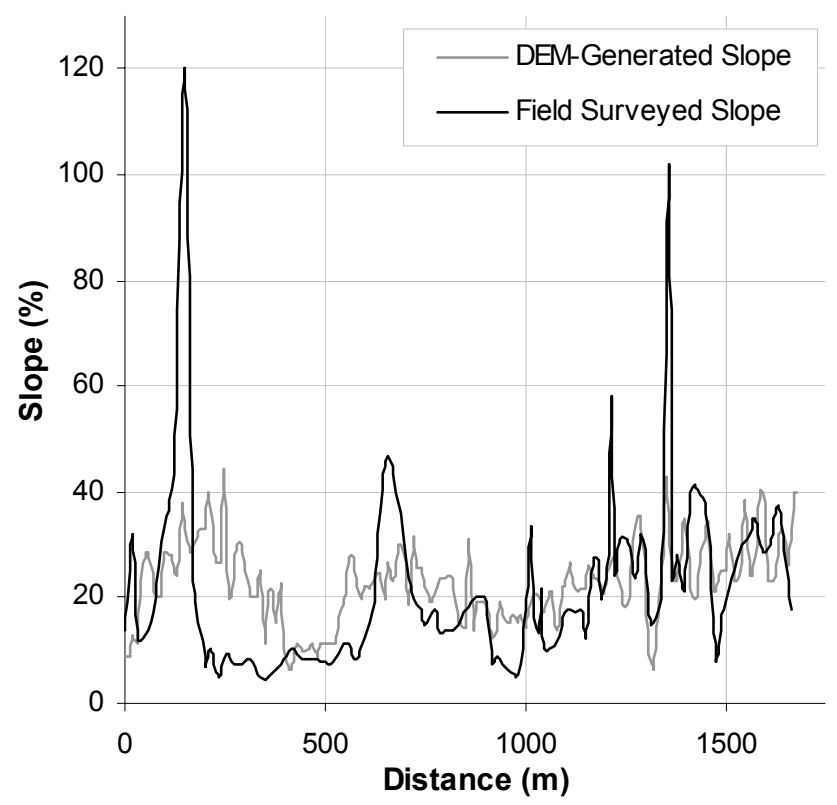

Figure 3.3.1. Comparison of DEM-generated slope values to field surveyed slope values along Coweeta 10 stream channel. Slope values from field survey have a range 3.5 times that of the DEM slope values, demonstrating the potential for error in travel time calculations using DEM slope values.

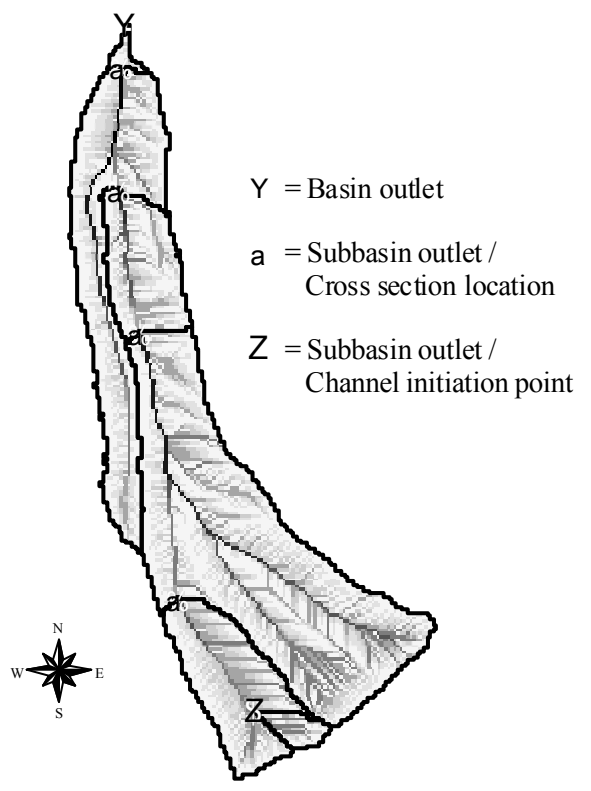

Figure 3.3.2. Example of DEM-generated drainage network in Allen Hollow, with subbasins delineated at channel head and cross section locations. 


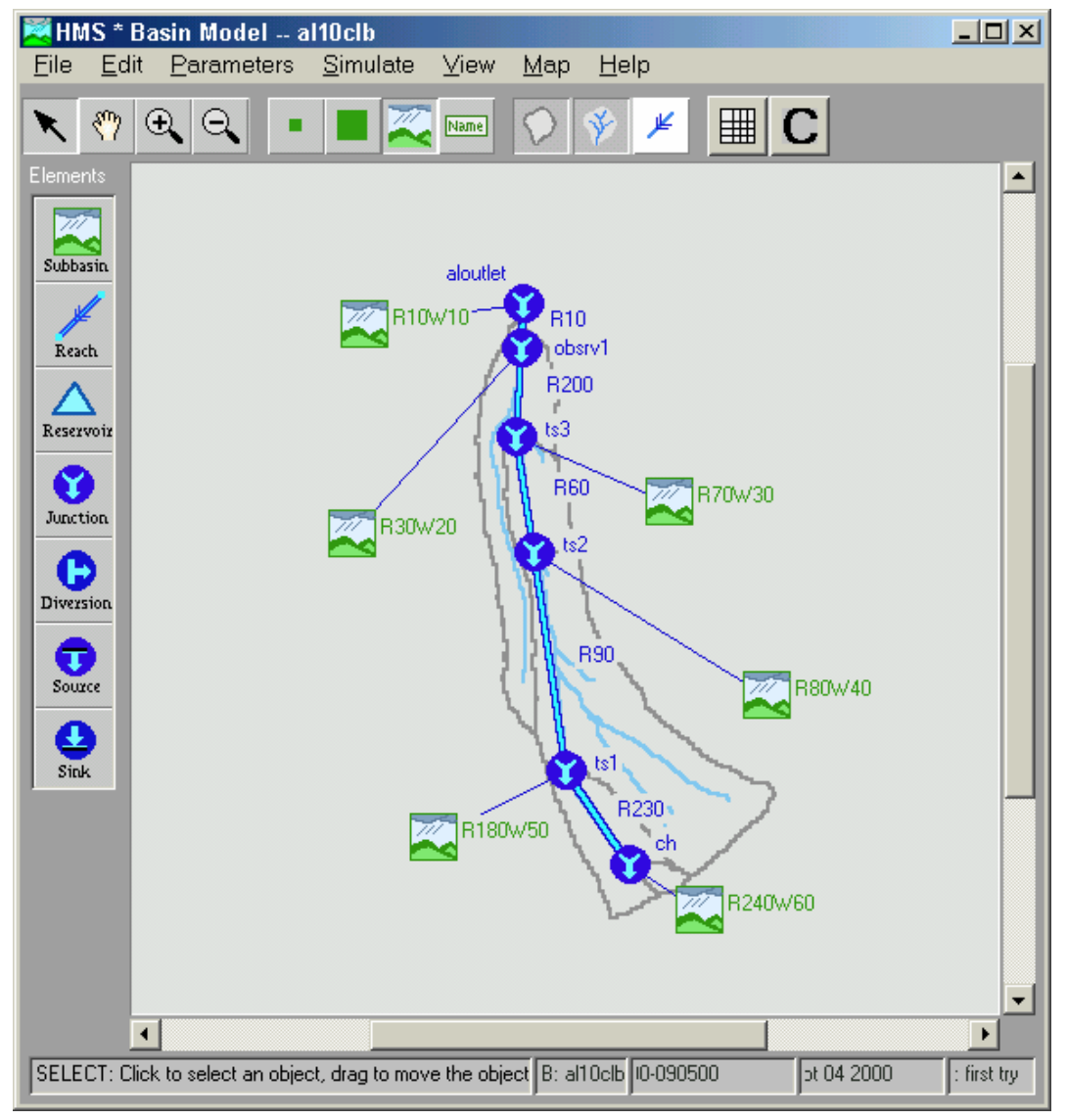

Figure 3.3.3. Example of HEC-HMS basin schematic for Allen Hollow showing flow routing pattern from subbasin (ex: R240W60) to channel reach (R230). Flow then continues through downstream reaches (R50, R60, R200, and R10) until exiting at basin outlet (aloutlet). 


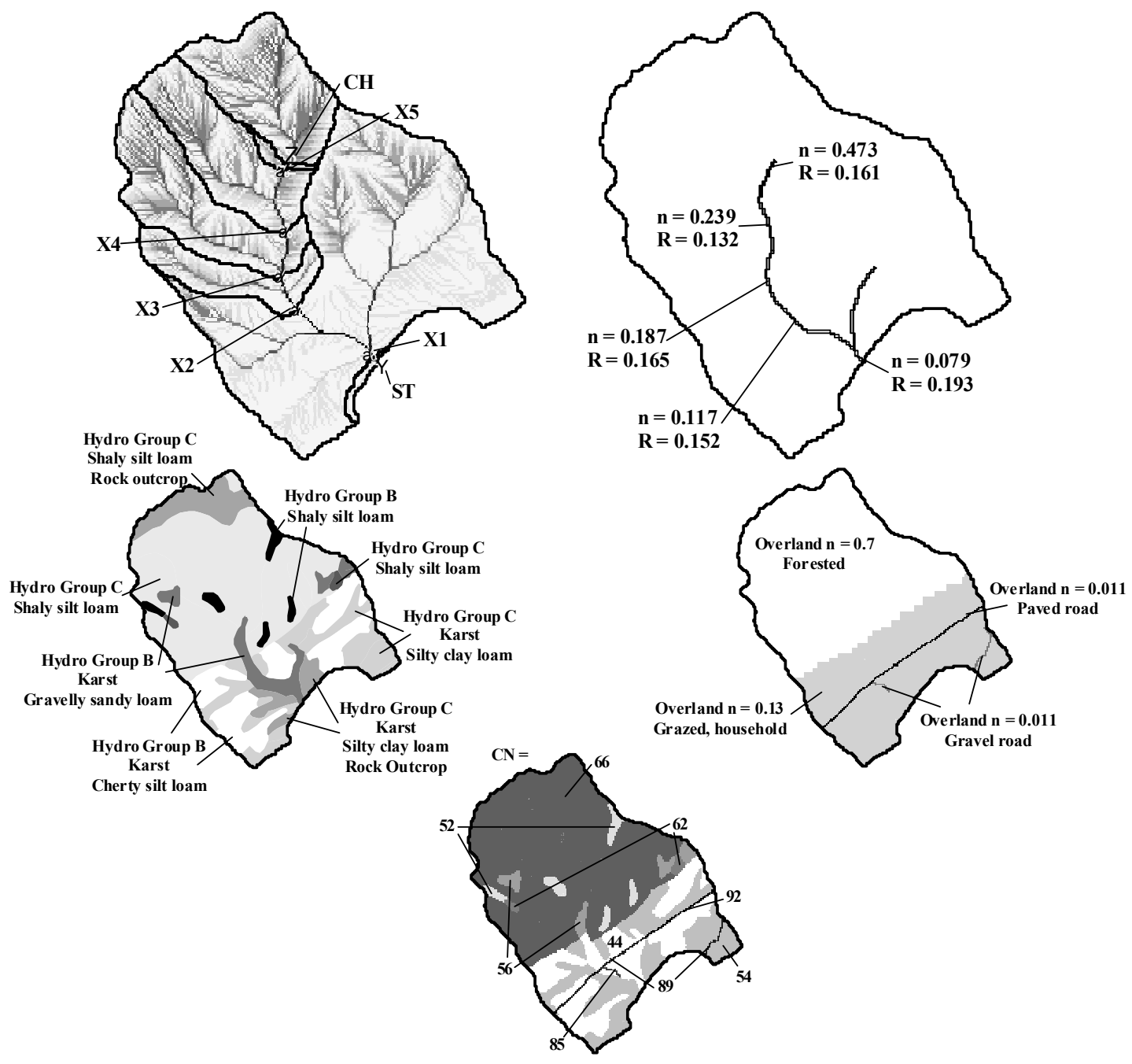

Figures 3.3.4a-e. Pepper Run modeling inputs: a) drainage flowpath network (darker gray $=$ greater flow accumulation) and cross section locations; $\mathrm{b}$ ) $n$ and $\mathrm{R}$ values for stream segments corresponding to surveyed cross sections; c) soil types and hydrologic groups (Creggar et al., 1985); d) overland $\mathrm{N}$ values and land cover types; e) curve number values (values do not correspond to grayscale). 


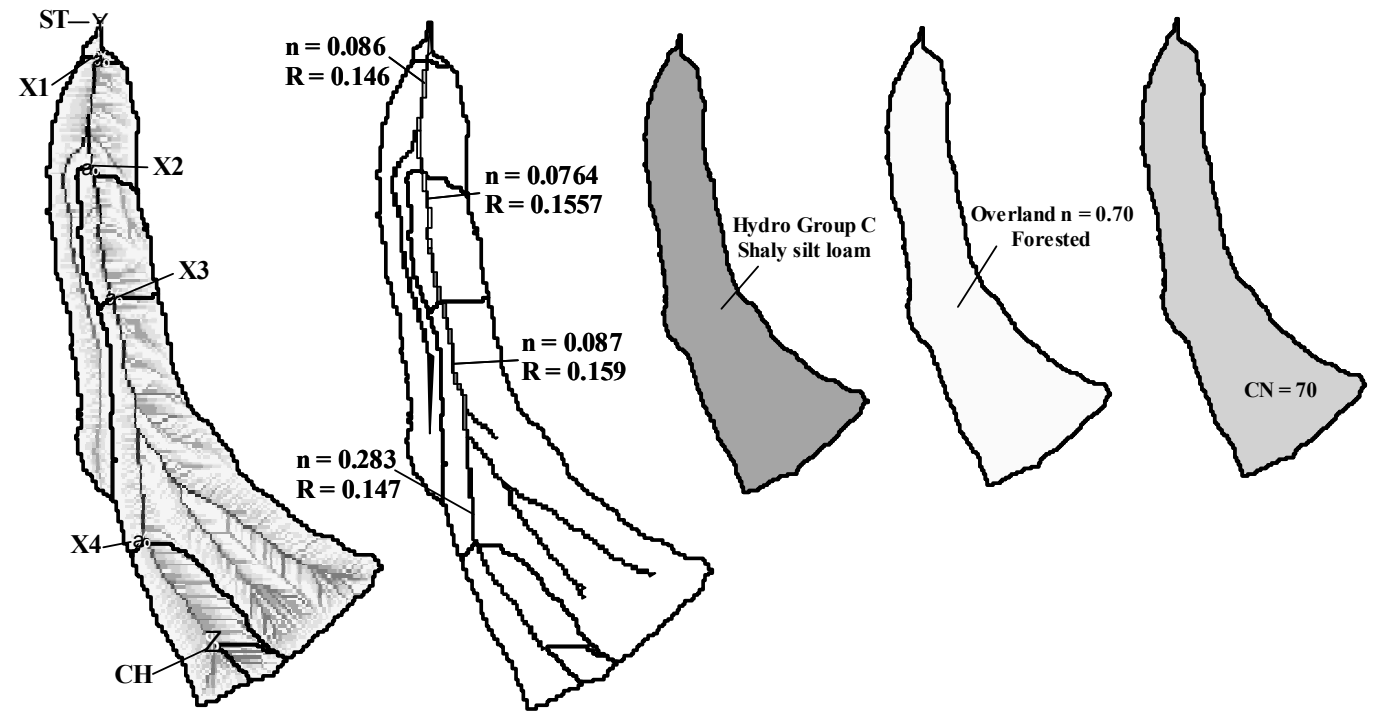

Figures 3.3.5a-e. Allen Hollow modeling inputs: a) drainage flowpath network (darker gray $=$ greater flow accumulation) and cross section locations; b) $n$ and $\mathrm{R}$ values for stream segments corresponding to surveyed cross sections; c) soil types and hydrologic groups (Creggar et al., 1985); d) overland $\mathrm{N}$ values and land cover types; e) curve number values (values do not correspond to grayscale). 


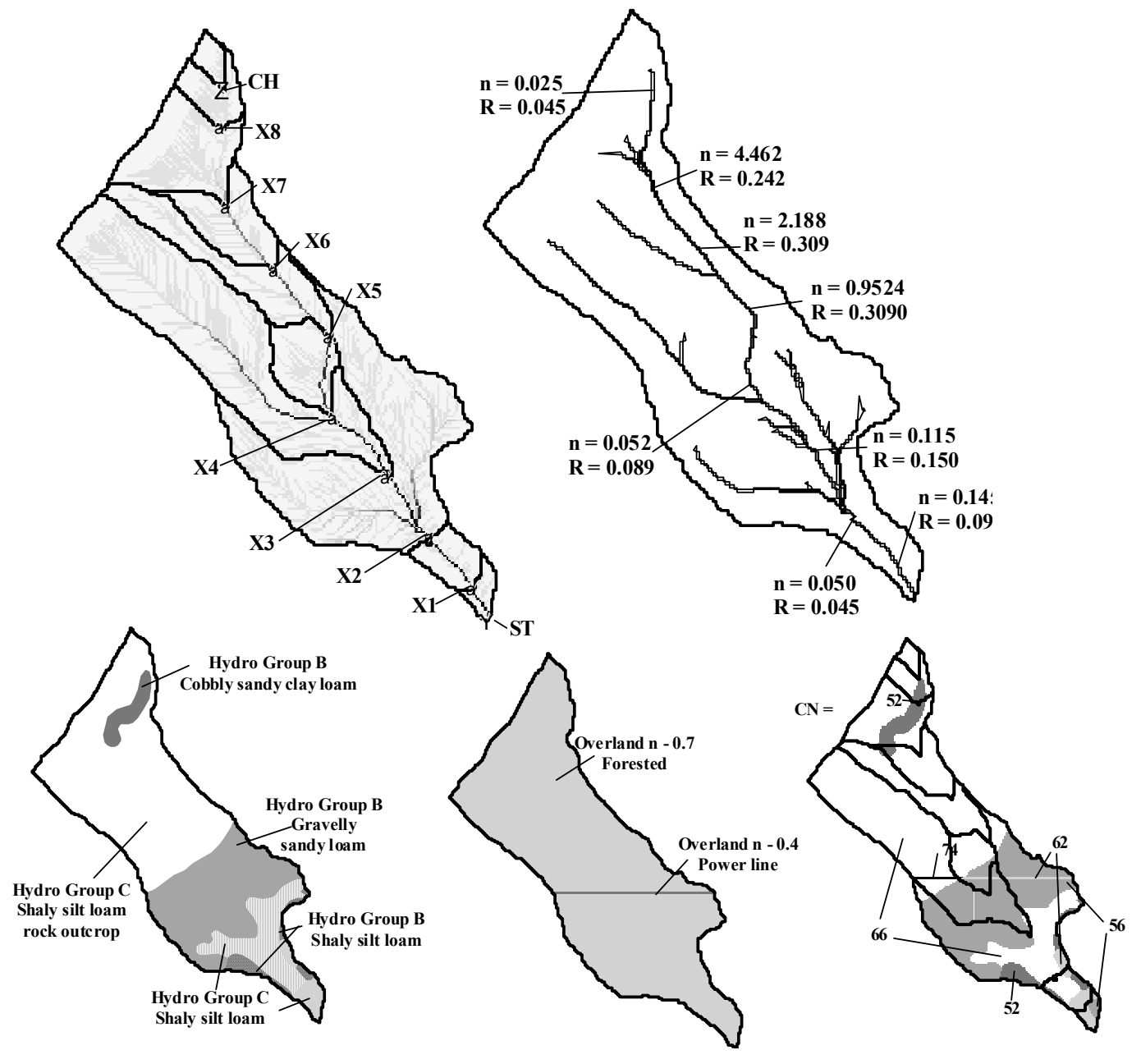

Figures 3.3.6a-e. Sarver Hollow modeling inputs: a) drainage flowpath network (darker gray $=$ greater flow accumulation) and cross section locations; $\mathrm{b}) n$ and $\mathrm{R}$ values for stream segments corresponding to surveyed cross sections; c) soil types and hydrologic groups (Creggar et al., 1985); d) overland $\mathrm{N}$ values and land cover types; e) curve number values (values do not correspond to grayscale). 


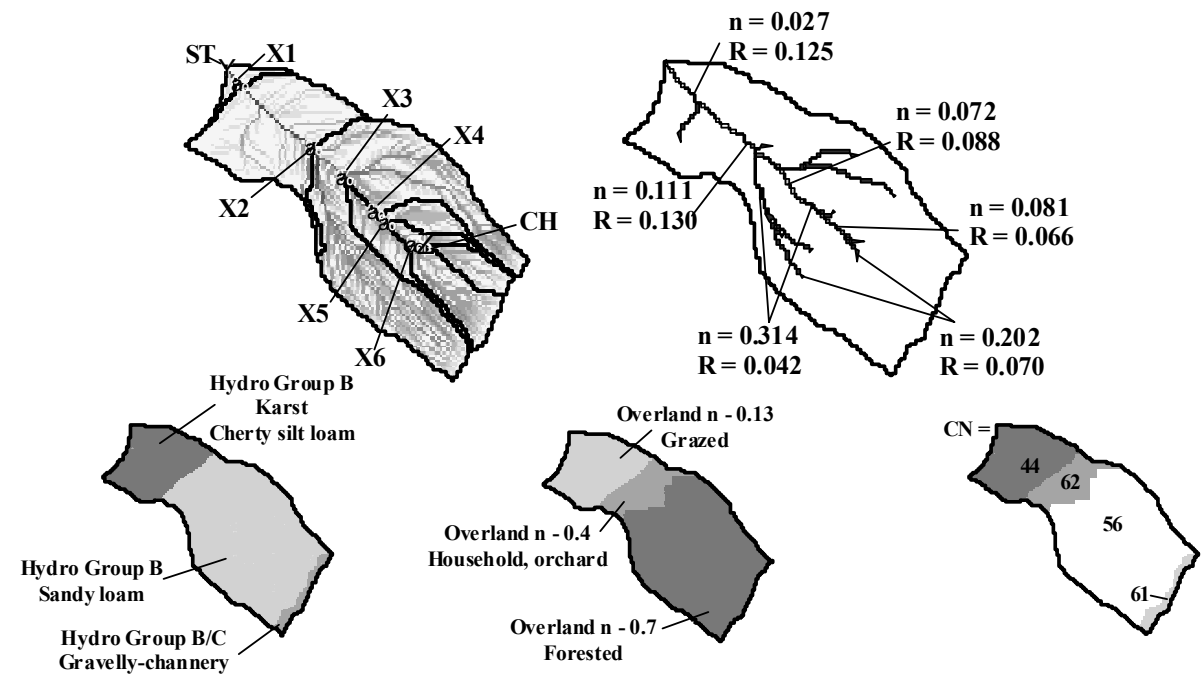

Figures 3.3.7a-e. Given Branch modeling inputs: a) drainage flowpath network (darker gray = greater flow accumulation) and cross section locations; b) $n$ and $\mathrm{R}$ values for stream segments corresponding to surveyed cross sections; c) soil types and hydrologic groups (Swecker Jr. et al., 1985); d) overland N values and land cover types; e) curve number values (values do not correspond to grayscale).
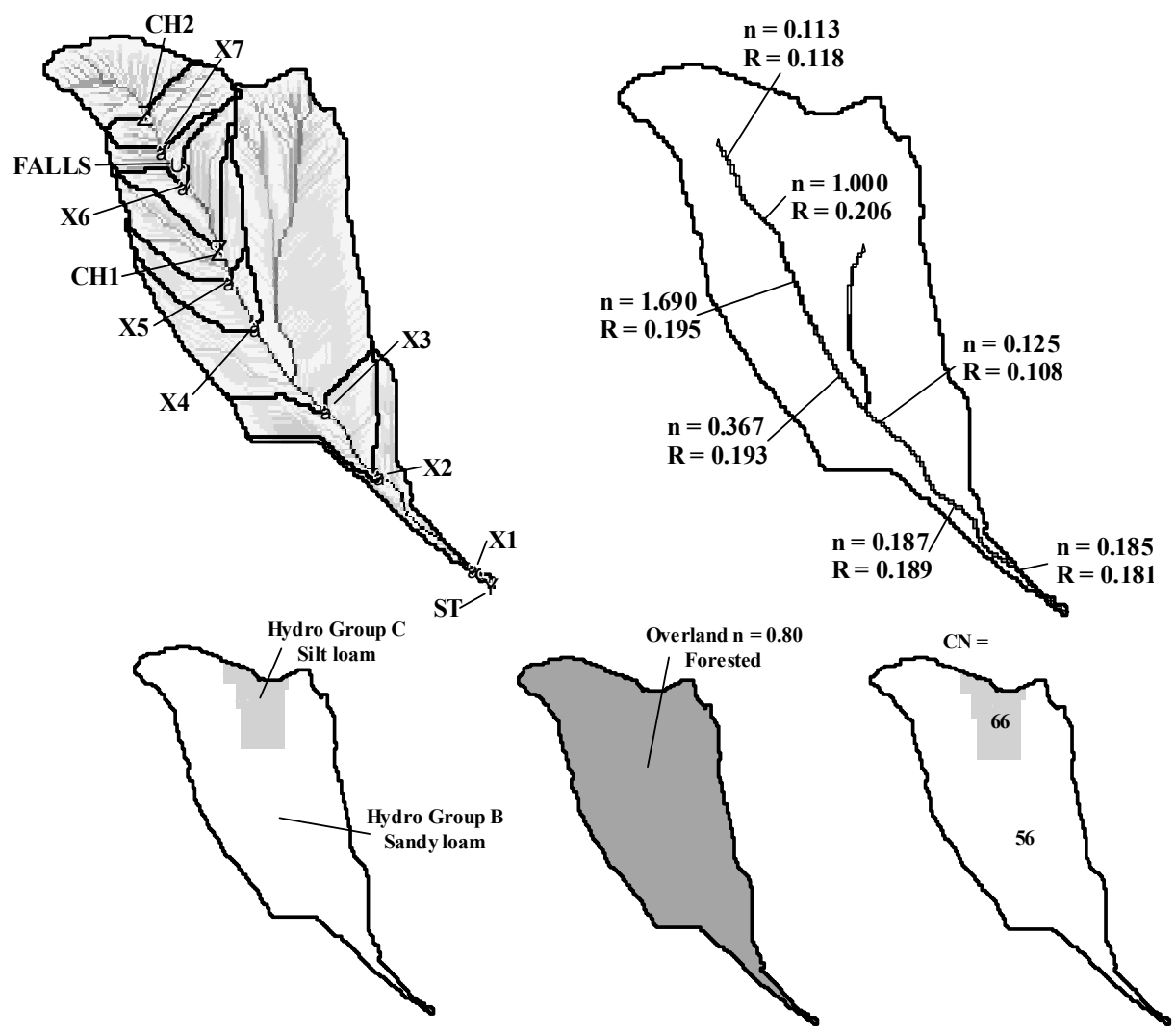

Figures 3.3.8a-e. Little Stony Tributary modeling inputs: a) drainage flowpath network (darker gray = greater flow accumulation) and cross section locations; b) $n$ and $\mathrm{R}$ values for stream segments corresponding to surveyed cross sections; c) soil types and hydrologic groups (Swecker Jr. et al., 1985); d) overland N values and land cover types; e) curve number values (values do not correspond to grayscale). 


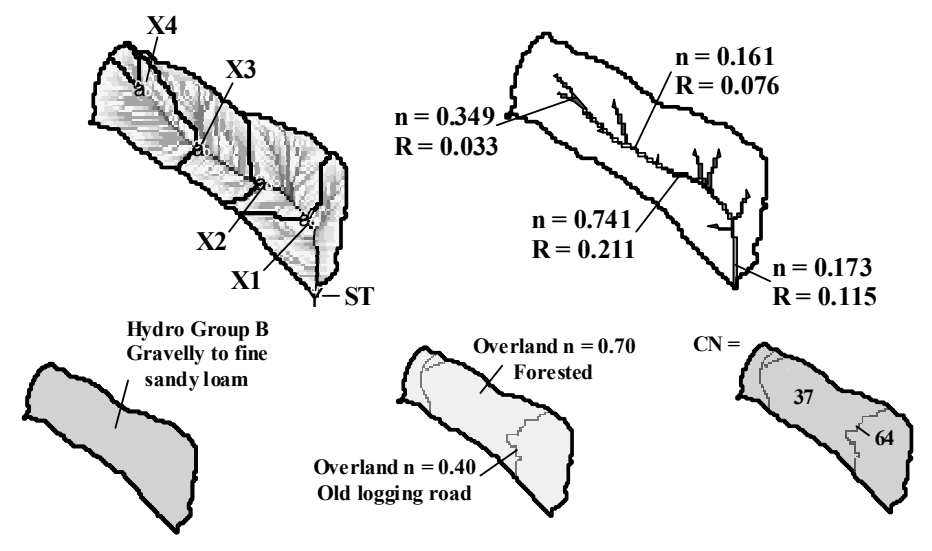

Figures 3.3.9a-e. Coweeta 34 modeling inputs: a) drainage flowpath network (darker gray $=$ greater flow accumulation) and cross section locations; b) $n$ and $\mathrm{R}$ values for stream segments corresponding to surveyed cross sections; c) soil types and hydrologic groups (Thomas, 1996); d) overland $\mathrm{N}$ values and land cover types; e) curve number values (values do not correspond to grayscale).

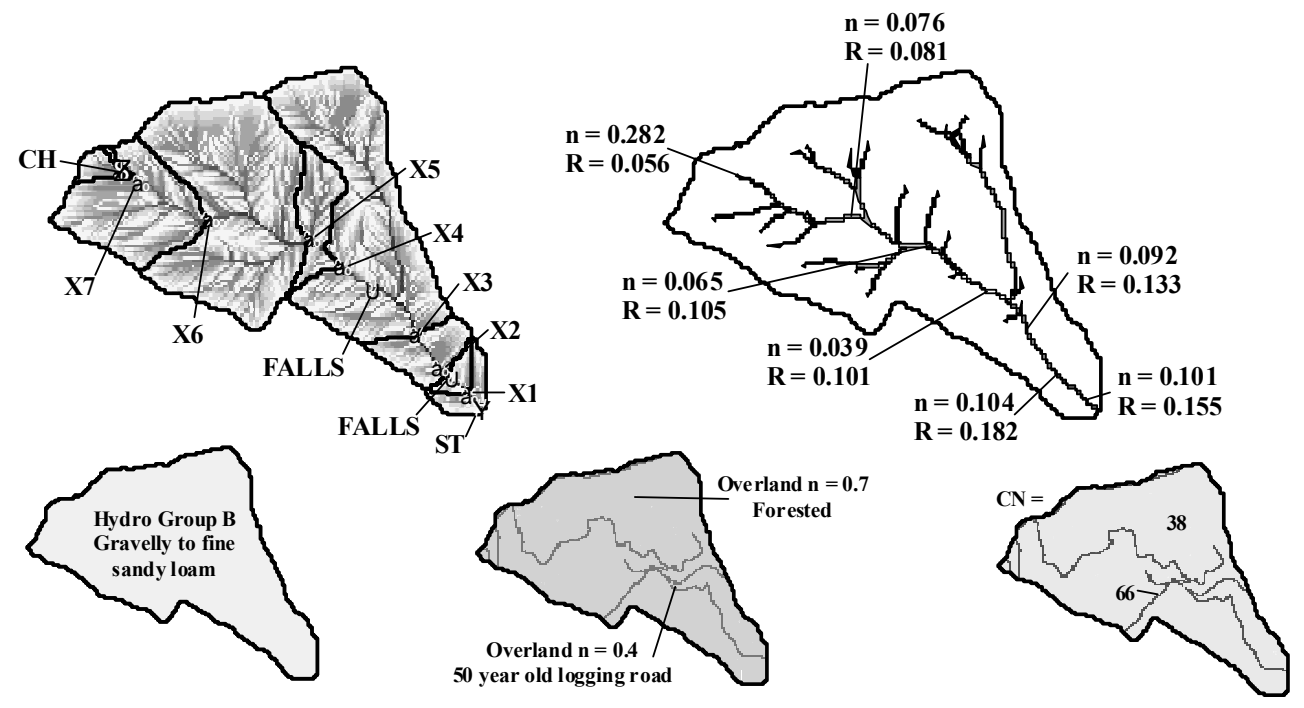

Figures 3.3.10a-e. Coweeta 10 modeling inputs: a) drainage flowpath network (darker gray $=$ greater flow accumulation) and cross section locations; b) $n$ and $\mathrm{R}$ values for stream segments corresponding to surveyed cross sections; c) soil types and hydrologic groups (Thomas, 1996); d) overland N values and land cover types; e) curve number values (values do not correspond to grayscale). 

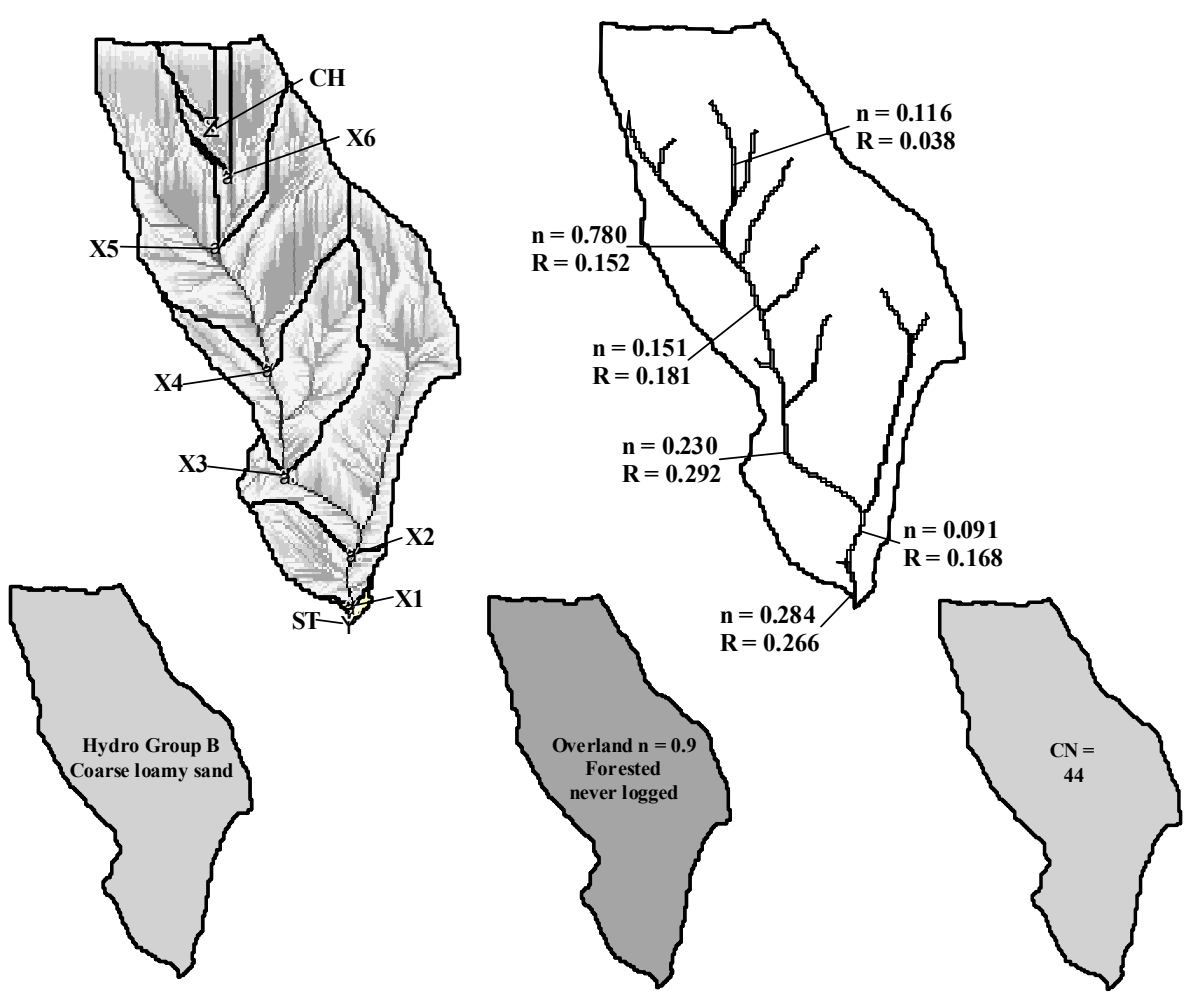

Figures 3.3.11a-e. Indian Spring modeling inputs: a) drainage flowpath network (darker gray $=$ greater flow accumulation) and cross section locations; b) $n$ and $\mathrm{R}$ values for stream segments corresponding to surveyed cross sections; c) soil types and hydrologic groups (Goldsten and Gettys, 1953); d) overland N values and land cover types; e) curve number values (values do not correspond to grayscale).
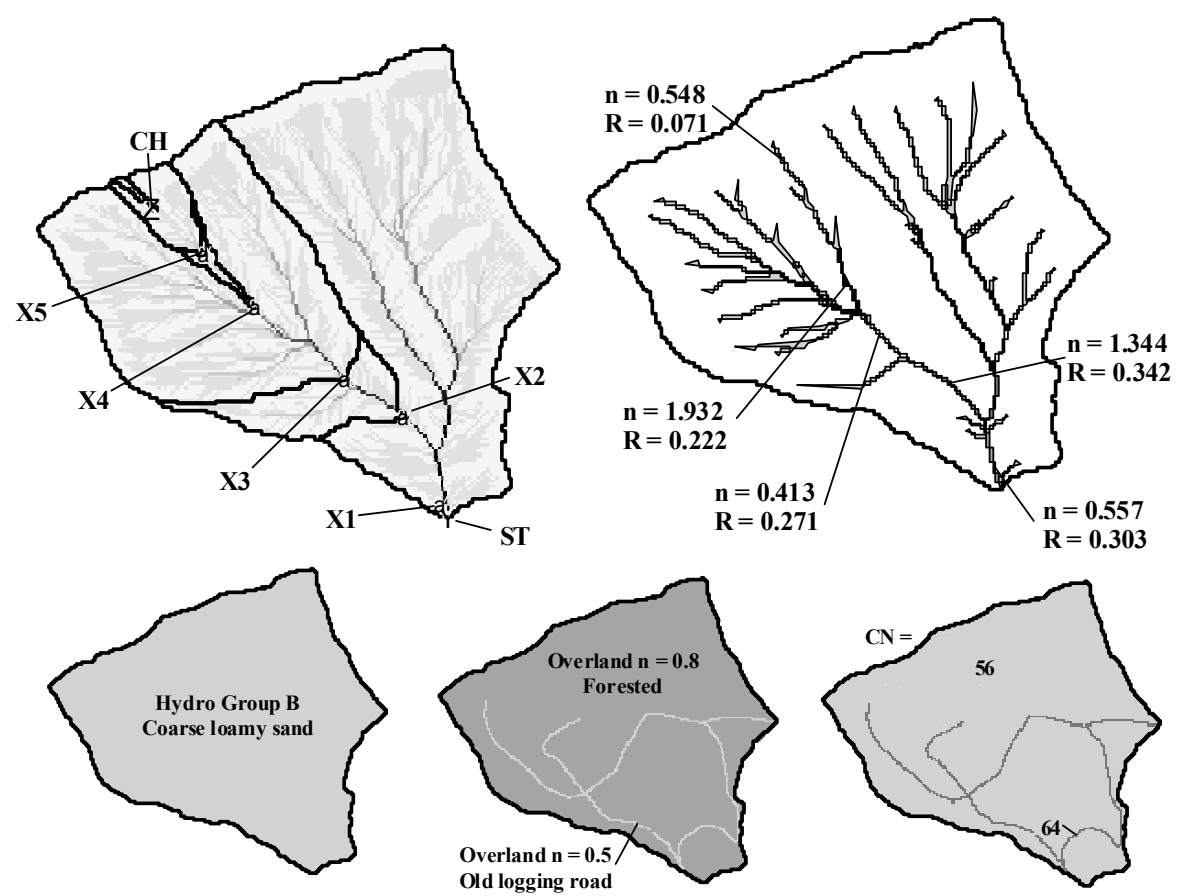

Figures 3.3.12a-e. Horse Cove modeling inputs: a) drainage flowpath network (darker gray $=$ greater flow accumulation) and cross section locations; b) $n$ and $\mathrm{R}$ values for stream segments corresponding to surveyed cross sections; c) soil types and hydrologic groups (Goldsten and Gettys, 1953); d) overland N values and land cover types; e) curve number values (values do not correspond to grayscale). 


\subsection{Modeling inputs}

\subsubsection{Precipitation}

Short, intense storms were selected from data for precipitation input to models of runoff volume using the curve number method. The curve number method typically is used with "design" storms, or synthetic precipitation amounts that approximate a certain recurrence interval storm in both daily rainfall amount and hourly intensity. Design storms can be obtained from regional rainfall-time distributions such as the Soil Conservation Service type distributions (Soil Conservation Service, 1986). Rainfall amount can be derived from National Weather Service report TP40, which maps rainfall amounts for recurrence intervals of 1-100 years across the United States (Hershfield, 1961). Four Soil Conservation Service types represent maximum rainfall intensities for 24-hour storms with different recurrence intervals in different regions of the United States. Basins in this study are within type II, the most intense, short duration rainfall. The majority of the United States is represented by type II storms.

To obtain storms representative of the local area but still within the confines of peaked, 24-hour distribution, storms from rain gauge and gauge-adjusted radar data were obtained for all of the basins. The data were used to create precipitation input to the basins for 15-minute time slices over a 24-hour period, with distributions and intensities appropriate for the study area.

Gridded hydrologic modeling in HEC-HMS allows modeling of spatial differences in precipitation over a basin, as each $10 \mathrm{~m}$ cell can receive a different rainfall amount for each 15-minute time step. However, spatial heterogeneity in rainfall can only be modeled where numerous rainfall gauges or radar are available. Since the basins in this study lack rain gauges directly within their boundaries, storm data from the gauge closest to each basin was used. Due to the lack of distributed spatial rain gauge coverage, point rain gauge data was modeled as spatially uniform over the entire grid of each basin for most storms. In actuality, it is unlikely that the storms were uniform, due to orographic variation in steep mountainous terrain. In some cases, gridded radar data were also used. Gauge-adjusted radar data (NexRain) was purchased for one observed storm that occurred on September 4-5, 2000, in three of the Virginia basins (Given Branch, Sarver Hollow, and Allen Hollow). This data 
enabled modeling of spatial heterogeneity in precipitation as it actually occurred at a $2-\mathrm{km}^{2}$ scale, and allowed for model calibration of a flow observed in Allen Hollow the morning of September 5, 2000 (Appendix D, Fig. D.12).

Three 24 hour storms were modeled for each basin: a storm with a total 24 hour precipitation amount equal to the two year, 24 hour rainfall for the Virginia basins (VA-2 storm) (National Weather Service publication TP-40) (Hershfield, 1961); a storm recorded at Coweeta that produced a two year discharge as defined by flood frequency equations for western North Carolina streams (NC-2 storm) (Douglass, 1974); and a storm local to each basin with rainfall amounts typically less than the "two year" storms (Local storm). From herein, these storms are referred to as the VA-2, NC-2, and Local storms, respectively.

\section{VA-2 and NC-2 storms}

The VA-2 storm was recorded by a rain gauge on Butt Mountain, Virginia, on May 22, 2001, northeast of Little Stony Tributary. The data used are from IFLOWS, a collection

of rain gauges that are part of a National Weather Service flood-warning network that records rainfall accumulation every 15 minutes. This storm was 3.25 inches $(82.6 \mathrm{~mm})$ over 24 hours, with the majority of the rainfall occurring in two peaks about 18 hours apart (Fig. 3.4.1). To adjust this to match the expected two-year, 24-hour rainfall amount of 3.5 inches $(88.9 \mathrm{~mm})($ Hershfield, 1961), rainfall amounts in three of the time slices before the second peak were increased arbitrarily by $1.016 \mathrm{~mm}$ (Fig. 3.4.2). The greatest hourly intensity for the storm, at 1.3 inches $(33.0 \mathrm{~mm})$, is slightly less than the two-year, one-hour rainfall of 1.5 inches $(38.1 \mathrm{~mm})$ in the Virginia basins (Hershfield, 1961). It is also less than the two- year, one-hour rainfalls for Joyce Kilmer and Coweeta, which are 1.7 and 2.0 inches (43.2 and $50.8 \mathrm{~mm}$ ), respectively (Frederick et al., 1977).

The NC-2 storm was obtained from Coweeta Hydrologic Laboratory rain gauge 6 data for July 10, 1949. Rain gauge 6 is located near the laboratory headquarters, at a lower elevation, to the southeast of Watersheds 10 and 34. It does not represent exact rainfall in each basin or account for orographic variation, but was the closest available rainfall data. Rainfall amounts at Coweeta gauges were recorded at irregular time intervals, as changes in rainfall intensity occurred. For modeling use, these rainfall amounts were divided into 15minute intervals. The July 10, 1949 storm delivered 4.1 inches $(104.1 \mathrm{~mm})$ of rain in a 24- 
hour period, 3.8 inches $(96.5 \mathrm{~mm}$ ) of which fell within one hour-long peak (Fig. 3.4.3). The storm produced a two-year recurrence discharge in Watershed 10 (Fig. 3.4.4) as predicted by regression equations developed from streamflow data in Coweeta and western North Carolina (Douglass, 1974). Although the 24-hour rainfall amount falls short of the 5.5-5.75 inches (139.7-146.1 mm) required for a two-year storm at Coweeta (Bradford, 1977; Hershfield, 1961), the one-hour rainfall amount is between the 50 and 100-year recurrence interval in the Coweeta area (Bradford, 1977; Hershfield, 1961). It is also greater than the 100-year one-hour recurrence rainfall in Virginia and is approximately equal to the 100-year one-hour rainfall at Joyce Kilmer (Frederick et al., 1977). Modeling of a storm with short duration and high intensity such as this one provides an opportunity to study channel erosion during more rare, extreme storms.

\section{Local storms}

Local storms for each basin were obtained from IFLOWS and Coweeta rain gauge data, as well as NexRain radar rainfall data. IFLOWS data from gauges at Butt Mountain, Brush Mountain, and Robbinsville (North Carolina) were used to model local 24-hour storms ranging from 1.8 to 3.25 inches ( 45.7 to $82.6 \mathrm{~mm}$ ) in 24-hour rainfall amount for Little Stony Tributary, Pepper Run, and Horse Cove and Indian Spring (Figs. 3.4.1, 3.4.5, 3.4.6). Local storms at Coweeta watersheds 10 and 34, ranging from 3.5 to 6.6 inches ( 88.9 to $167.64 \mathrm{~mm}$ ) in 24-hour rainfall amount, were modeled from data at Coweeta rain gauge 6 (Figs. 3.4.73.4.11). Local storms for the remaining Virginia basins were obtained from gauge-adjusted radar rainfall data for September 4-5, 2000. This storm yielded 1.17 to 2.66 inches (29.7 to $67.6 \mathrm{~mm}$ ) rainfall in Allen Hollow, Sarver Hollow, and Given Branch. Gridded rainfall for the storm was modeled in the three basins at 15 -minute time slices at 2-km2 resolution provided by the NexRain radar rainfall data (Fig. 3.4.12).

National Weather Service Radar (WSR-88D) is available for most of the US from vendors in the NEXRAD Information Dissemination Service. The radar data is a measure of atmospheric reflectivity from an S-band signal that is translated to estimates of particle (raindrop) size and density (Feldman, 2000). Estimates of rainfall can then be generated. However, small changes in the raindrop size can greatly affect rainfall volume estimates, so 
vendors generally scale the radar to actual rainfall volumes measured on the ground (Hoblit and Curtis, 2000) and sell the result as a value-added product.

\subsubsection{Soil group}

The hydrologic group of a soil represents its ability to absorb moisture, and is defined in soil surveys as A, B, C, or D for each soil unit classified. A represents high infiltration capacity, D represents low to zero infiltration capacity (Table 3.4.1) (U.S. Department of the Interior Bureau of Reclamation, 1960). County-level soil surveys and GIS coverages (SSURGO) (USDA-NRCS, 1995) mapped at a scale of 1:24000 or better were used to designate hydrologic groups for each 10-m2 cell in the basins (Figs. 3.3.4c-3.3.12c). Apparent differences in the resolution of soil data within soil surveys (e.g. Montgomery County) is due to variable detail in the original soil map units. Where SSURGO data were available, cells falling within soil polygons were designated a hydrologic group matching that of the soil polygon. In the case of soil survey maps, soil polygons were created to represent the mapped polygons in the soil survey, and cells within them were designated with the same hydrologic group as listed for that soil unit. This was straightforward in all but two cases. In one instance (Weikert soils, Sinking Creek Mountain and Brush Mountain) the hydrologic group was designated in the soil survey as B/D (Creggar et al., 1985), and in the Ssurgo soils coverage as C/D (USDA-NRCS, 1995), depending on depth to bedrock. There was no depth-to-bedrock mapping available, however, field observations indicate that bedrock depth/soil development ranges from 0-8 inches on these soils. Therefore, Weikert soils were designated as hydrologic soil group $\mathrm{C}$, which represents average runoff potential within the soil group.

\subsubsection{Land cover}

Once a hydrologic group of a soil has been selected, a curve number value within that soil group is chosen based on the land cover or land use in the area. The designated curve number becomes higher as the land cover becomes less vegetated, more compacted, and therefore less able to store precipitation. In general, curve numbers for forested conditions are among the lowest possible, while the highest values are for paved surfaces (Soil Conservation Service, 1986). 
Two published protocols were used to adjust curve numbers based on land use. For forested areas, a USDA Forest Service curve number alignment chart was employed (U.S. Department of the Interior Bureau of Reclamation, 1960), which uses humus depth, litter depth, and soil compactness to choose one of five soil conditions (best, good, medium, poor, or poorest). The deeper the humus layer and litter depth and lower the compaction, the greater soil storage capacity and hence the lower the curve number. For example, soils of hydrologic group B that are forested and rate in "best" condition (deep humus and litter layer, no compaction) are given a curve number of 44, whereas the same soils in "poorest" condition (humus and litter layer removed, high compaction) are given a curve number of 75 . Another widely used chart for curve number selection was also used (Soil Conservation Service, 1986), which offers curve number values for forested areas as well as developed and urban areas. In Urban Hydrology for Small Watersheds (TR-55), land cover types are rated as one of three categories (good, fair, or poor) and are rated on qualitative characteristics that are slightly different from the Forest Service alignment chart. For example, soils of hydrologic group B that are forested in "good" condition, defined as woods that are protected from grazing with brush and litter covering the soil, are given a curve number of 55 . Woods in "poor" condition, defined as woods where forest litter, small trees, and brush are destroyed by heavy grazing or regular burning, are given a curve number of 66. The USDA Forest Service chart was used to select curve number in forested areas, while the TR-55 chart was used to select curve number in grazed, paved, graveled, or mowed areas.

Determination of land cover type was based on field observations as well as historic records of logging, grazing, and home site history (Swank and Crossley, 1988), topographic maps, and GIS road coverages (Figs. 3.3.4d-3.3.12d). GIS coverages of land cover for each basin were created; delineating areas of forested, grazed, and household (mowed) cover types. Roads (paved or gravel) were then delineated as 10 meters ( 1 cell) wide, a width appropriate for the roads present in the study area (logging roads, driveways, small country roads). These GIS coverages were then overlain on GIS coverages of soil type and a curve number was selected for each cell based on its land cover - soil type combination (Figs. 3.3.4e-3.3.12e).

The majority of the land area in this study is forested and ungrazed and was designated curve numbers using the USDA Forest Service alignment chart. Humus and litter 
layer depth were obtained from soil survey data (Table 3.4.2) and soil compaction values were based on sources of land use history (Swank and Crossley, 1988). Historic log roads are mapped in three of the North Carolina basins and were designated curve numbers using the Forest Service alignment chart with lower organic matter depth (assumed to be partially removed by road building) and medium to high compaction, depending on how recently the $\log$ road was established. This method of curve number selection provided a more quantitative, reproducible method for determining curve number in forested areas that incorporates the impact of logging and road building on soil storage capacity (Lieberman and Hoover, 1948). It also uses a wider range of curve number values than the Urban Hydrology for Small Watersheds chart, better representing the large variation in storage capacity observed in forest basins (Hewlett and Helvey, 1970). The remainder of the land area, whether grazed, paved, or mowed, was given curve numbers based on the chart in TR-55, which is more appropriate for grazed and developed areas. A power line, a paved road, gravel driveways, houses, and grazed areas are present in three of the basins. The power line easement, without a matching category in TR-55, is classed as "brush-brush weed grass mixture with brush the major element - fair to poor" for land cover type.

There are two Valley and Ridge basins, Given Branch and Pepper Run, which contain karst topography in their basal sections (Hayman, 1972; Miller and Hubbard, 1986). Soil hydrologic groups A-D cannot represent the loss of runoff into the underground karst aquifer system at the contact of the more resistant ridge geology and the valley limestone and dolostone. Due to lack of an established curve number for karst terrain, curve numbers in these cells mapped as karst have been reduced to the lowest possible for their soil hydrologic group, ignoring the influence of land cover and assuming that there is storage potential equivalent to that of a forest in best condition. Although this is an approximate solution, the absence of stream gauge data precludes calibration of the model to changes in runoff production due to karst conditions.

\subsubsection{Antecedent moisture conditions}

Curve number values can vary up to 20 due to antecedent moisture conditions that increase or decrease soil moisture storage capacity. For our modeling, I adopted the treatment of moisture storage of the US Department of Interior Publication Design of Small 
Dams (1960). In this approach, antecedent moisture conditions (AMC) are based on the amount of rainfall 5 to 30 days prior to the storm being modeled. AMCI conditions are driest, when soils are dry (but not to the wilting point). AMCII conditions are the average of conditions preceding the annual flood. AMCIII conditions are the wettest, when heavy rainfall and little evapotranspiration has occurred in the days prior to the storm and the soil is saturated. AMCII conditions are typically used to model design storm flows, since they represent average conditions (Soil Conservation Service, 1986). Since the goal of modeling in this study is to recreate a regularly recurring storm flow, average antecedent moisture conditions were assumed and AMCII curve numbers were used (Table 3.4.2, Figs. 3.3.4e3.3.12e). 


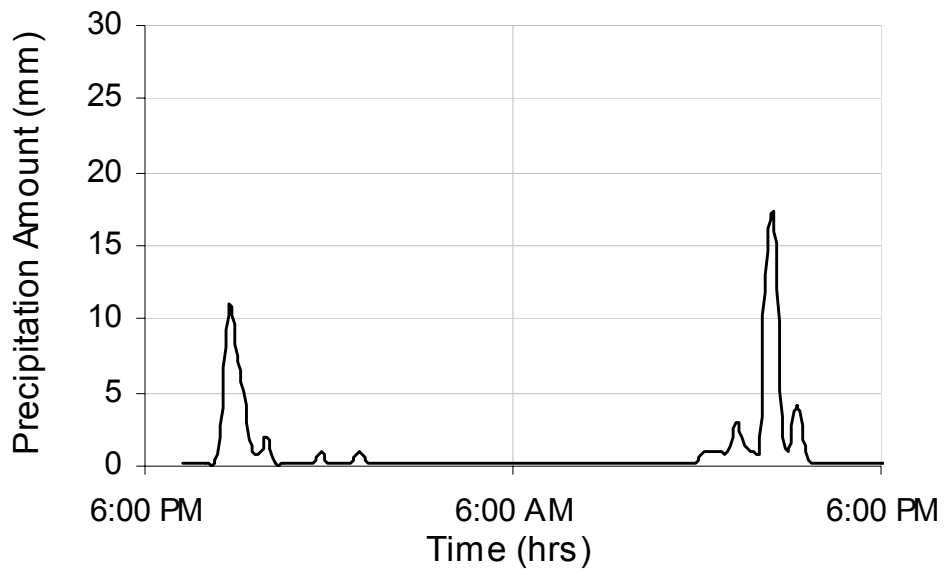

Figure 3.4.1. Hyetograph for 3.25-inch storm recorded at Butt Mountain IFLOWS rain gauge on May 22, 2001. This rainfall was used as a local storm for Little Stony Tributary.

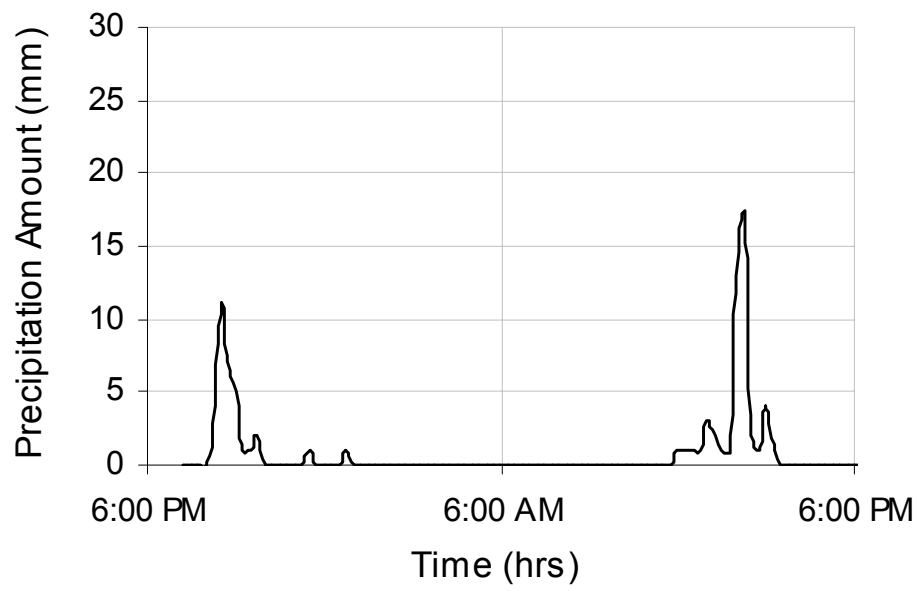

Figure 3.4.2. Hyetograph for 3.5-inch storm used as two year 24 hour rainfall in Virginia. Modified from storm recorded at Butt Mountain IFLOWS rain gauge on May 22, 2001. 


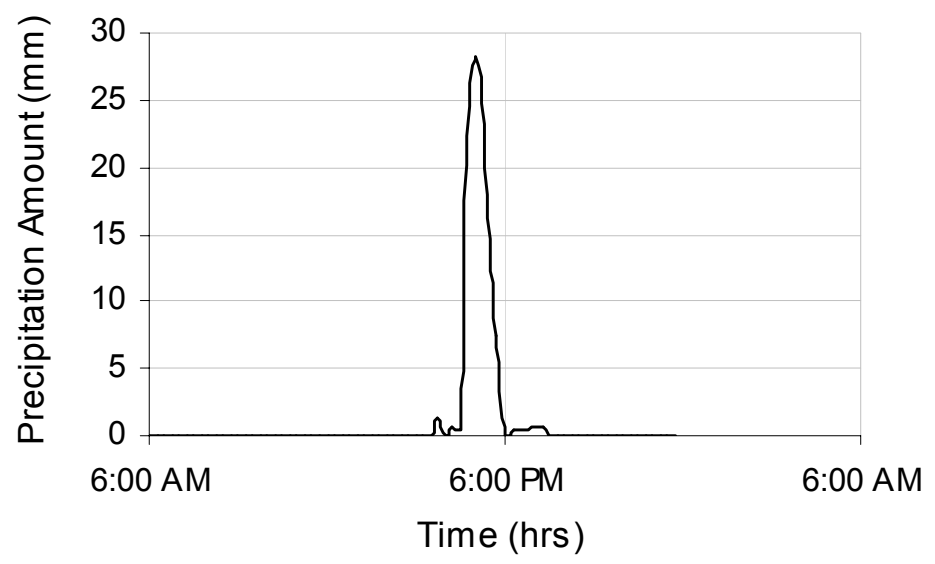

Figure 3.4.3. Hyetograph for abrupt 4-inch storm recorded at Coweeta Hydrologic Laboratory rain gauge 6 on July 10, 1949. This rainfall was used to model the two-year discharge in North Carolina.

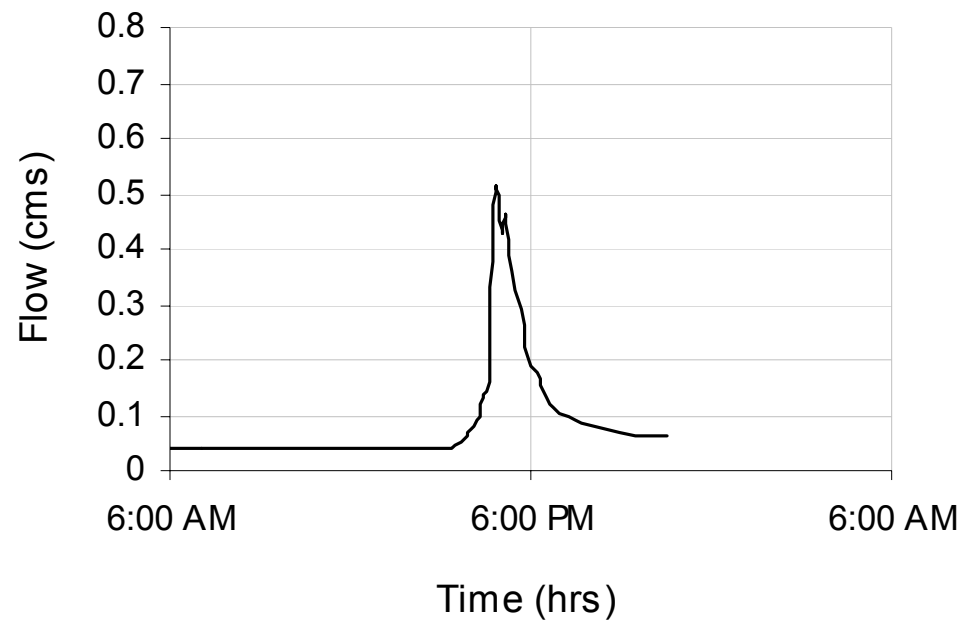

Figure 3.4.4. Hydrograph for Coweeta Watershed 10 stream gauge on July 10, 1949, corresponding to a twoyear recurrence interval peak discharge (Douglass, 1974). 


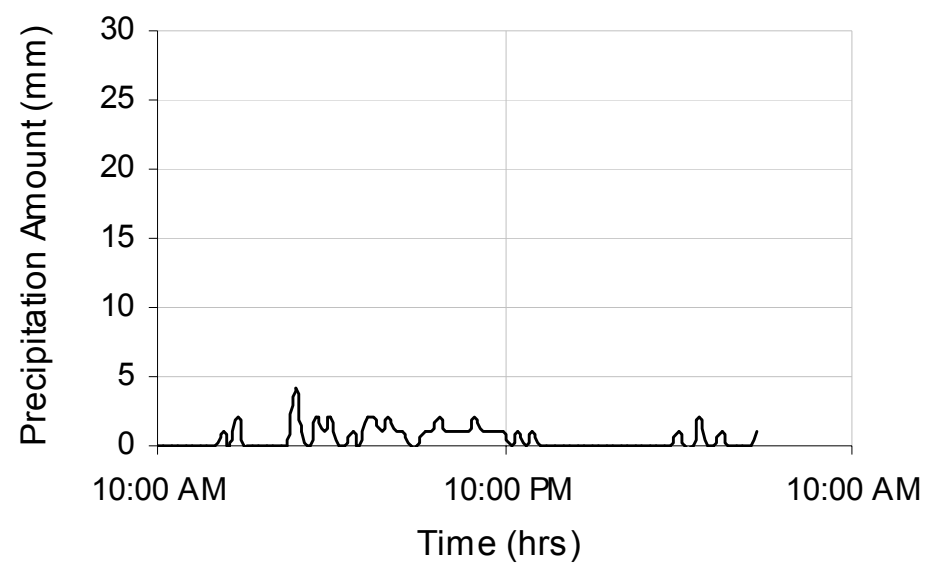

Figure 3.4.5. Hyetograph for 1.8-inch storm recorded at Brush Mountain IFLOWS rain gauge on April 18, 2000. This rainfall was used as a local storm for Pepper Run.

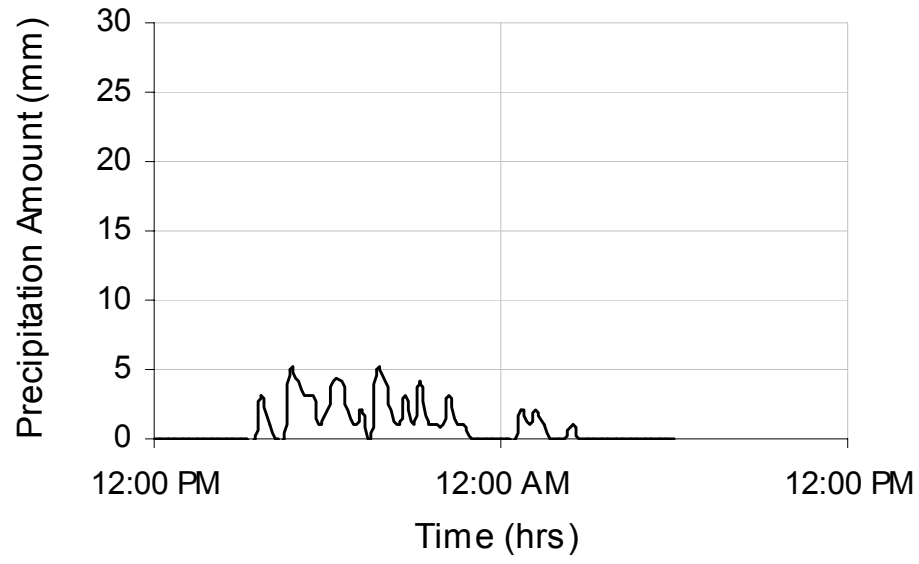

Figure 3.4.6. Hyetograph for 2.8-inch storm recorded at Robbinsville IFLOWS rain gauge on January 23, 2002. This rainfall was used as a local storm for Indian Spring and Horse Cove. 


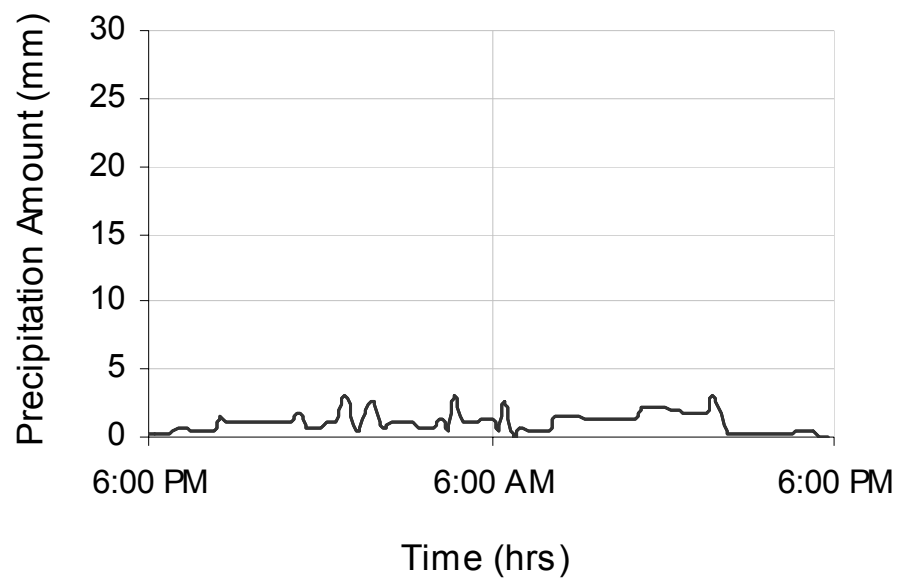

Figure 3.4.7. Hyetograph for 4.1-inch storm recorded at Coweeta Hydrologic Laboratory rain gauge 6 on January 5, 1949. This rainfall was used for model calibration and as a local storm in Coweeta Watershed 10.

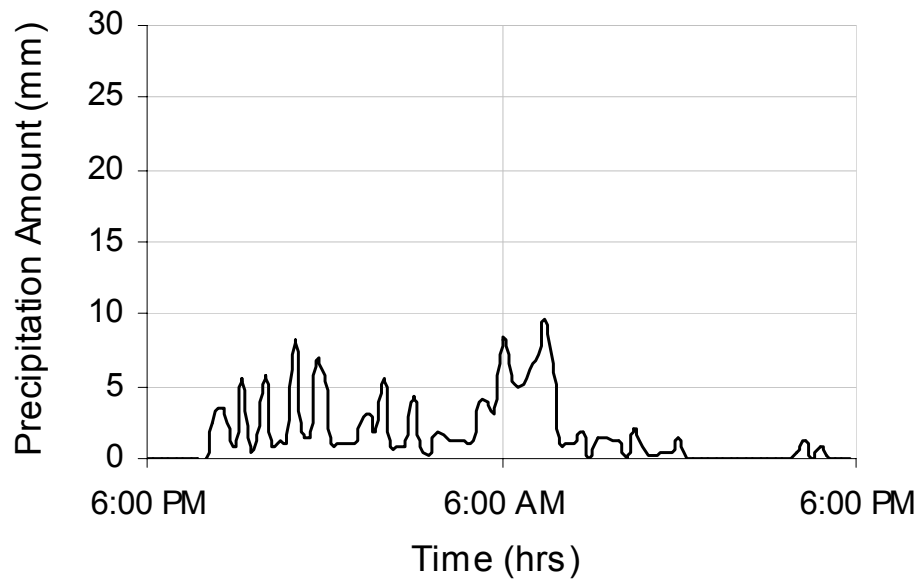

Figure 3.4.8. Hyetograph for 6.6-inch storm recorded at Coweeta Hydrologic Laboratory rain gauge 6 on June 15, 1949. This rainfall was used for model calibration in Coweeta Watershed 10. 


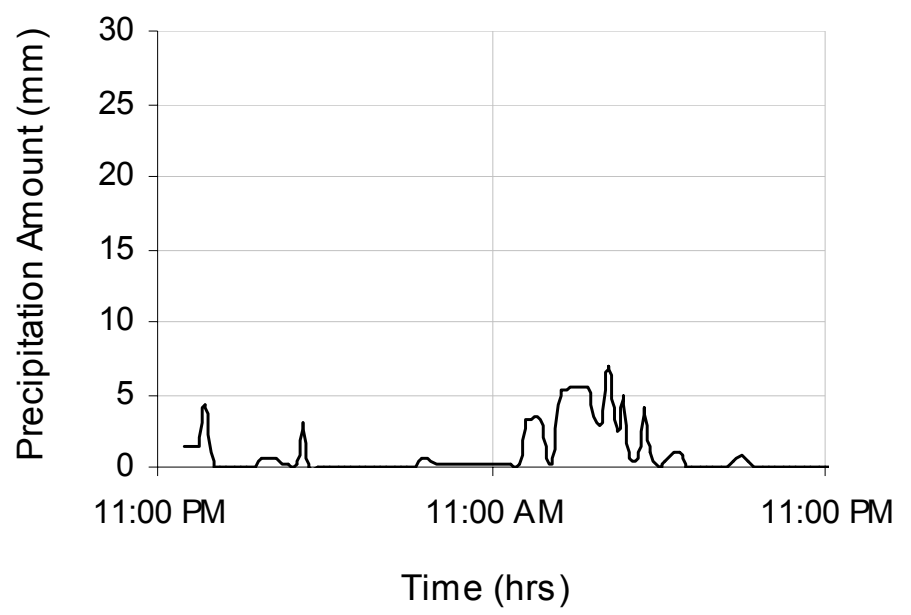

Figure 3.4.9. Hyetograph for 3.4-inch storm recorded at Coweeta Hydrologic Laboratory rain gauge 6 on June 28,1957 . This rainfall was used for model calibration and as a local storm in Coweeta Watershed 34.

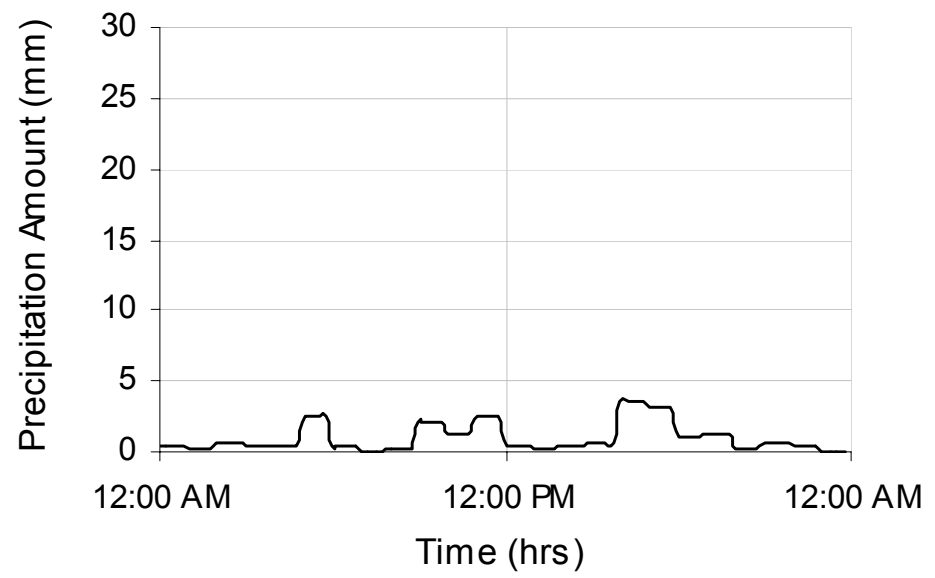

Figure 3.4.10. Hyetograph for 3.6-inch storm recorded at Coweeta Hydrologic Laboratory rain gauge 6 on January 31,1957 . This rainfall was used for model calibration in Coweeta Watershed 34.

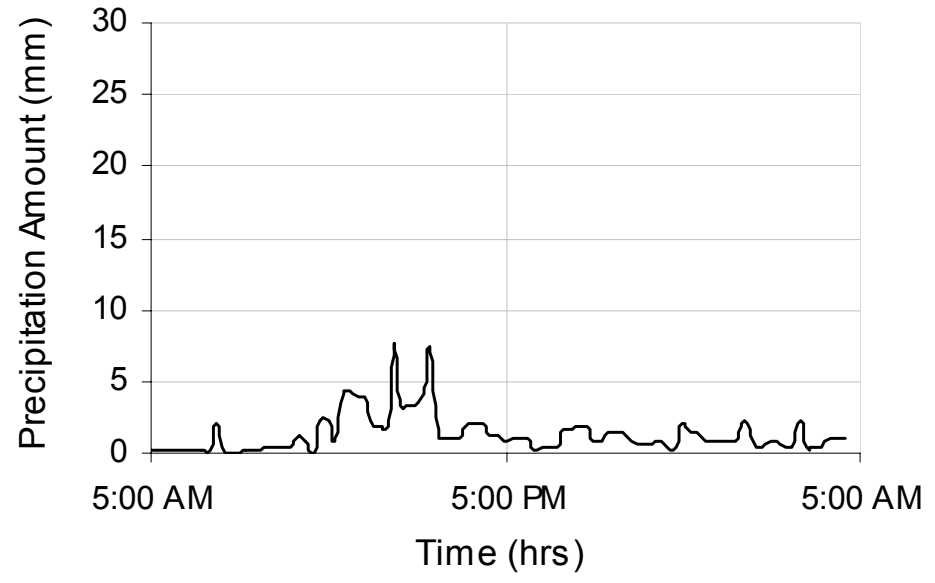

Figure 3.4.11. Hyetograph for 4.9-inch storm recorded at Coweeta Hydrologic Laboratory rain gauge 6 on April 4, 1957. This rainfall was used for model calibration in Coweeta Watershed 34. 
Total Storm Rainfall Amounts

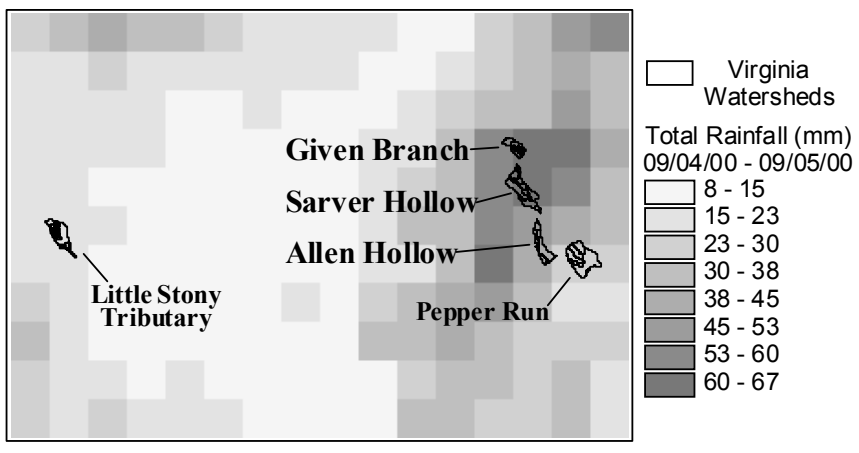

Fifteen Minute Rainfall Amounts
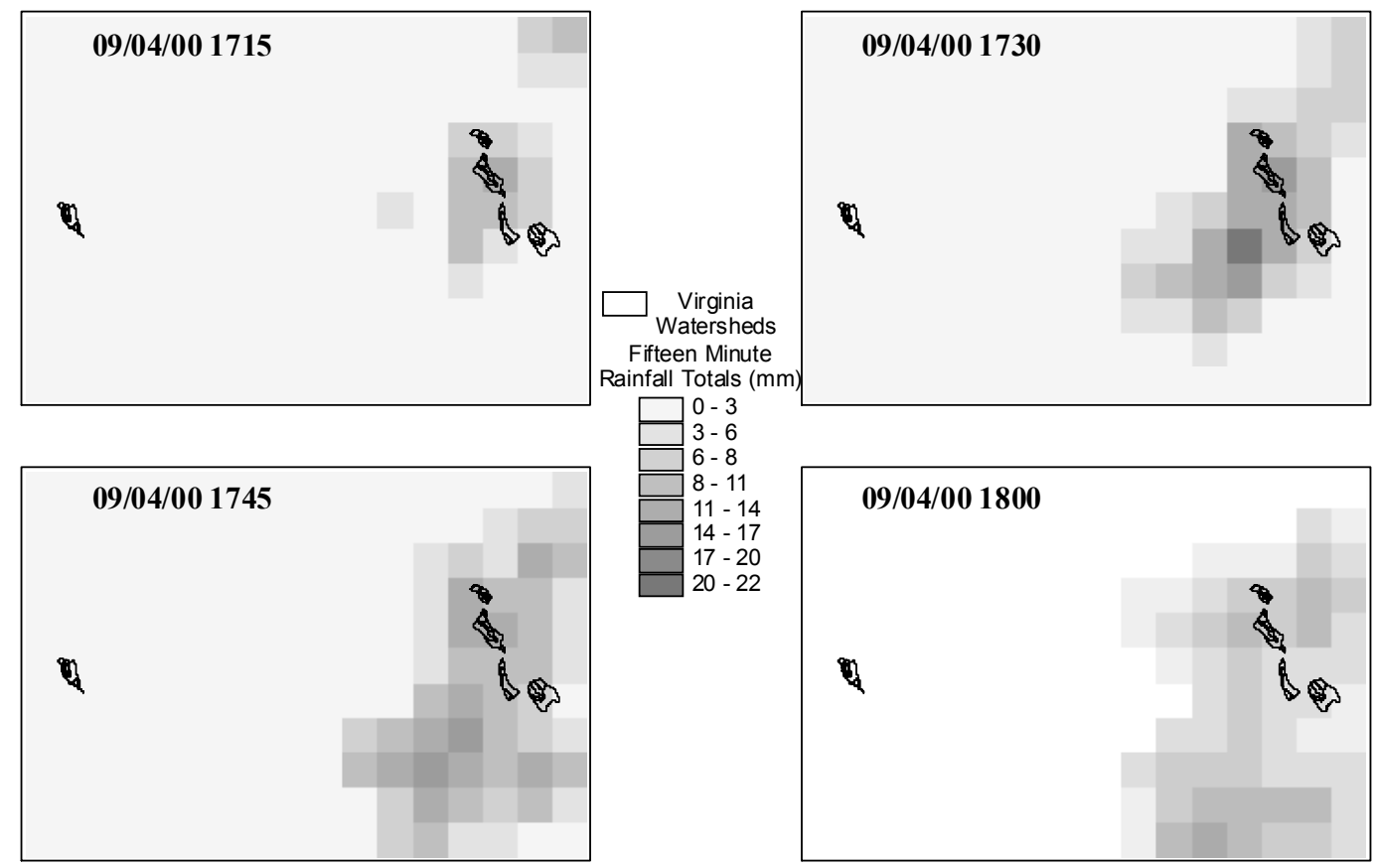

Figure 3.4.12. NEXRAIN Corporation (Orangevale, CA) digital rainfall data from observed September 4, 2000 storm, used for calibration at Allen Hollow and local storms for Allen Hollow, Sarver Hollow, and Given Branch. Grid cell resolution is $2 \mathrm{~km}^{2}$. 
Table 3.4.1. Descriptions of hydrologic soil groups used in curve number selection.

\begin{tabular}{|c|c|c|}
\hline $\begin{array}{l}\text { Hydrologic } \\
\text { Soil Group }\end{array}$ & Soil Characteristics & Runoff Potential \\
\hline A & $\begin{array}{c}\text { Deep sands with little silt and clay, rapidly permeable } \\
\text { loess }\end{array}$ & Lowest runoff potential \\
\hline B & $\begin{array}{l}\text { Mostly sandy soils less deep than group A, and loess } \\
\text { less deep or less aggregated than group A }\end{array}$ & $\begin{array}{c}\text { Above-average infiltration after } \\
\text { thorough wetting }\end{array}$ \\
\hline $\mathbf{C}$ & $\begin{array}{l}\text { Shallow soils and soils containing considerable clay } \\
\text { and colloid, though less than those in group D }\end{array}$ & $\begin{array}{l}\text { Below-average infiltration after } \\
\text { presaturation }\end{array}$ \\
\hline D & $\begin{array}{l}\text { Mostly clays of high swelling percent, some shallow } \\
\text { soils with nearly impermeable subhorizons near the } \\
\text { surface }\end{array}$ & Highest runoff potential \\
\hline
\end{tabular}

Table 3.4.2. Summary soil and land cover data used in hydrologic modeling for each basin.

\begin{tabular}{|c|c|c|c|c|c|c|}
\hline Basin & $\begin{array}{c}\text { Soil Series / } \\
\text { Classification }\end{array}$ & $\begin{array}{c}\text { Soil } \\
\text { Description }\end{array}$ & $\begin{array}{c}\text { Hydrologic } \\
\text { Group }\end{array}$ & $\begin{array}{c}\text { Humus } \\
\text { Depth (in) }\end{array}$ & Land Cover/Use & $\begin{array}{c}\text { Curve } \\
\text { Number }\end{array}$ \\
\hline \multirow{4}{*}{$\begin{array}{l}\text { Coweet } \\
\underline{\text { a } 10}\end{array}$} & Chandler & $\begin{array}{l}\text { Gravelly } \\
\text { fine sandy } \\
\text { loam }\end{array}$ & B & 5 & \multirow{4}{*}{$\begin{array}{l}\text { Forested, } 40 \text { 's } \\
\text { and } 50 \text { 's log } \\
\text { roads }\end{array}$} & \multirow{4}{*}{$\begin{array}{c}44 / 68 \\
\text { From } \\
\text { calibratio } \\
\text { n: } \\
30 / 64 \text { to } \\
40 / 69\end{array}$} \\
\hline & Fannin & $\begin{array}{l}\text { Fine sandy } \\
\text { loam }\end{array}$ & B & 4 & & \\
\hline & Cashiers & $\begin{array}{l}\text { Gravelly } \\
\text { fine sandy } \\
\text { loam }\end{array}$ & B & 8 & & \\
\hline & Tuckasegee & $\begin{array}{l}\text { Fine sandy } \\
\text { loam }\end{array}$ & B & 13 & & \\
\hline \multirow{4}{*}{$\begin{array}{c}\text { Coweeta } \\
34\end{array}$} & Chandler & $\begin{array}{l}\text { Gravelly } \\
\text { fine sandy } \\
\text { loam }\end{array}$ & B & 5 & \multirow{4}{*}{$\begin{array}{l}\text { Forested, old log } \\
\text { roads }\end{array}$} & \multirow{4}{*}{$\begin{array}{c}44 / 64 \\
\text { From } \\
\text { calibratio } \\
\text { n: } \\
35 / 63 \text { to } \\
44 / 67\end{array}$} \\
\hline & Fannin & $\begin{array}{l}\text { Fine sandy } \\
\text { loam }\end{array}$ & B & 4 & & \\
\hline & Cashiers & $\begin{array}{l}\text { Gravelly } \\
\text { fine sandy } \\
\text { loam }\end{array}$ & B & 8 & & \\
\hline & Tuckasegee & $\begin{array}{l}\text { Fine sandy } \\
\text { loam }\end{array}$ & B & 13 & & \\
\hline $\begin{array}{l}\text { Indian } \\
\text { Spring }\end{array}$ & $\begin{array}{c}\text { Umbric } \\
\text { Dystrochrept }\end{array}$ & $\begin{array}{c}\text { Coarse } \\
\text { loamy sand }\end{array}$ & B & 8 & $\begin{array}{c}\text { Forested - never } \\
\text { logged }\end{array}$ & 44 \\
\hline $\begin{array}{c}\text { Horse } \\
\text { Cove }\end{array}$ & $\begin{array}{c}\text { Umbric } \\
\text { Dystrochrept }\end{array}$ & $\begin{array}{c}\text { Coarse } \\
\text { loamy sand }\end{array}$ & B & 4 & $\begin{array}{c}\text { Forested, old log } \\
\text { roads }\end{array}$ & $56 / 64$ \\
\hline Little & Jefferson & Sandy loam & $\mathrm{B}$ & 5 & \multirow{3}{*}{$\begin{array}{l}\text { Forested - logged } \\
\text { historically }\end{array}$} & 56 \\
\hline Stony & Nolichucky & Sandy loam & B & 2 & & 56 \\
\hline Tributary & Gilpin & Silt loam & $\mathrm{C}$ & 2 & & 66 \\
\hline \multirow{3}{*}{$\begin{array}{l}\text { Given } \\
\text { Branch }\end{array}$} & Nolichucky & Sandy loam & B & 2 & $\begin{array}{c}\text { Forested, } \\
\text { household, } \\
\text { orchard, lawn }\end{array}$ & $56 / 62$ \\
\hline & $\begin{array}{l}\text { Lehew and } \\
\text { Wallen }\end{array}$ & $\begin{array}{l}\text { Gravelly- } \\
\text { channery } \\
\text { sandy loam }\end{array}$ & $\mathrm{C} / \mathrm{B}$ & $2-3$ & $\begin{array}{l}\text { Forested- logged } \\
\text { historically }\end{array}$ & 61 \\
\hline & Frederick & $\begin{array}{l}\text { Cherty silt } \\
\text { loam }\end{array}$ & B & 8 & Grazed & $\begin{array}{c}69 \\
\text { As karst: } \\
44\end{array}$ \\
\hline
\end{tabular}


Table 3.4.2 con't.

\begin{tabular}{|c|c|c|c|c|c|c|}
\hline Basin & $\begin{array}{c}\text { Soil Series / } \\
\text { Classification } \\
\end{array}$ & $\begin{array}{c}\text { Soil } \\
\text { Description }\end{array}$ & $\begin{array}{c}\text { Hydrologic } \\
\text { Group }\end{array}$ & $\begin{array}{c}\text { Humus } \\
\text { Depth (in) }\end{array}$ & Land Cover/Use & $\begin{array}{c}\text { Curve } \\
\text { Number }\end{array}$ \\
\hline \multirow{6}{*}{$\begin{array}{l}\text { Sarver } \\
\text { Hollow }\end{array}$} & Hayter & $\begin{array}{c}\text { Cobbly } \\
\text { sandy clay } \\
\text { loam }\end{array}$ & B & 10 & $\begin{array}{c}\text { Forested - } \\
\text { historic } \\
\text { homestead }\end{array}$ & 52 \\
\hline & $\begin{array}{l}\text { Rock Outcrop } \\
\text { / Berks }\end{array}$ & $\begin{array}{l}\text { Shaly silt } \\
\text { loam/rock } \\
\text { outcrop }\end{array}$ & $\mathrm{C}$ & $0-7$ & $\begin{array}{l}\text { Forested -logged } \\
\text { historically, } \\
\text { power line }\end{array}$ & $66 / 74$ \\
\hline & Jefferson & $\begin{array}{c}\text { Gravelly } \\
\text { sandy loam }\end{array}$ & B & 5 & $\begin{array}{l}\text { Forested -logged, } \\
\text { power line }\end{array}$ & $56 / 62$ \\
\hline & Weikert & $\begin{array}{l}\text { Shaly silt } \\
\text { loam }\end{array}$ & $\mathrm{C}$ & $0-4$ & Forested-logged & 66 \\
\hline & Berks & $\begin{array}{c}\text { Shaly silt } \\
\text { loam }\end{array}$ & $\mathrm{C}$ & 7 & Forested -logged & 62 \\
\hline & Clymer & $\begin{array}{l}\text { Shaly silt } \\
\text { loam }\end{array}$ & B & 9 & Forested -logged & 52 \\
\hline $\begin{array}{l}\text { Allen } \\
\text { Hollow }\end{array}$ & Weikert & $\begin{array}{l}\text { Shaly silt } \\
\text { loam }\end{array}$ & $\mathrm{C}$ & $0-4$ & $\begin{array}{l}\text { Forested, logged } \\
\text { historically, } \\
\text { burned }\end{array}$ & 70 \\
\hline \multirow{7}{*}{$\begin{array}{l}\text { Pepper } \\
\text { Run }\end{array}$} & $\begin{array}{c}\text { Rock } \\
\text { Outcrop/Berks }\end{array}$ & $\begin{array}{c}\text { Shaly silt } \\
\text { loam/rock } \\
\text { outcrop }\end{array}$ & $\mathrm{C}$ & $0-7$ & $\begin{array}{l}\text { Forested -logged } \\
\text { historically }\end{array}$ & 66 \\
\hline & Weikert & $\begin{array}{l}\text { Shaly silt } \\
\text { loam }\end{array}$ & $\mathrm{C}$ & $0-4$ & $\begin{array}{l}\text { Forested -logged } \\
\text { historically }\end{array}$ & 66 \\
\hline & Clymer & $\begin{array}{l}\text { Shaly silt } \\
\text { loam }\end{array}$ & B & 9 & $\begin{array}{l}\text { Forested-logged } \\
\text { historically }\end{array}$ & 52 \\
\hline & Jefferson & $\begin{array}{c}\text { Gravelly } \\
\text { sandy loam }\end{array}$ & B & 5 & $\begin{array}{l}\text { Forested -logged } \\
\text { historically, } \\
\text { grazed } \\
\text { (fair)/household, } \\
\text { paved road, } \\
\text { gravel road }\end{array}$ & $\begin{array}{c}56 / 69 / 89 / \\
85 \\
\text { As karst: } \\
69=44\end{array}$ \\
\hline & Berks & $\begin{array}{l}\text { Shaly silt } \\
\text { loam }\end{array}$ & $\mathrm{C}$ & 7 & $\begin{array}{l}\text { Forested -logged } \\
\text { historically }\end{array}$ & 62 \\
\hline & Vertrees & $\begin{array}{l}\text { Cherty silt } \\
\text { loam }\end{array}$ & B & $\mathrm{n} / \mathrm{a}$ & & $\begin{array}{c}69 / 89 / 85 \\
\text { As karst } \\
69=44\end{array}$ \\
\hline & $\begin{array}{l}\text { Groseclose } \\
\text { Ernest } \\
\text { Poplimento } \\
\text { Opequon } \\
\text { Rock Outcrop }\end{array}$ & $\begin{array}{l}\text { Silty clay } \\
\text { loam } \\
\text { Silty clay } \\
\text { loam/rock } \\
\text { outcrop }\end{array}$ & $\mathrm{C}$ & $\mathrm{n} / \mathrm{a}$ & $\begin{array}{c}\text { Grazed } \\
\text { (fair)/house-hold, } \\
\text { paved road, } \\
\text { gravel road }\end{array}$ & $\begin{array}{c}\text { 79/92/89 } \\
\text { As karst: } \\
79=54\end{array}$ \\
\hline
\end{tabular}




\subsection{Evaluating the model}

The modeling process requires many process assumptions and input data that contain the potential for error. Using an empirical, fitted parameter approach such as the curve number is an approximation of actual conditions based on a large volume of empirical data. Model inputs also provide only an estimate of actual field conditions, as demonstrated with DEM-generated slope values. Therefore, some error can be expected in the predicted hydrographs, but it is important to quantify the magnitude of this error. Furthermore, differences in prediction error between the basins are useful for determining the applicability of the model under various conditions, as well as comparing geomorphic characteristics of the basins.

\subsubsection{Calibration}

The curve number runoff volume estimation method depends heavily on interpretation of basin characteristics that control soil moisture storage capacity as well as assumptions about changes in soil storage capacity over the course of a storm. Therefore, it is useful to examine differences in predicted and observed discharges where observed storm flow data is available. Although the lack of gauge data makes testing of predicted storm discharge impossible in the majority of the basins, data from one observed storm flow at Allen Hollow and six gauged storm flows at Coweeta enable testing and calibration of the model in three basins.

\section{Allen Hollow - Peak discharge}

R. Kavage observed the September 5, 2000 storm at Allen Hollow at cross section 1, approximately 12 hours after the peak rainfall intensity (Appendix D, Fig. D.12). This storm was simulated using methods outlined in the two previous sections. Spatially distributed (2 $\mathrm{km}^{2}$ resolution), gauge-adjusted radar rainfall data from this storm was used as precipitation input. Basin runoff volume was predicted using a spatially homogenous curve number of 70 , based on selection parameters described above. A peak discharge of $0.55 \mathrm{~m}^{3} / \mathrm{s}$ at cross section 1 was predicted on the first model iteration (Fig. 3.5.1, Table 3.5.1), only $0.01 \mathrm{~m}^{3} / \mathrm{s}$ different from the observed peak discharge of $0.56 \mathrm{~m}^{3} / \mathrm{s}$, which was estimated from 
qualitative observations of peak discharge height and scour marks on both banks and methods outline in Appendix D.

Although only one flow was available for calibration, it indicated that a curve number of 70 represents rainfall-runoff relations well for the September storm at Allen Hollow. Furthermore, the method of curve number selection from soil and land cover data was effective in generating an appropriate curve number for Allen Hollow. It is possible that the success in Allen Hollow is in part due to basin characteristics that have physical processes in line with curve number assumptions. It is a shale basin with low depth to bedrock, and therefore has a precipitation storage capacity that is exceeded at some point during an intense storm. Therefore, the assumption that infiltration stops completely after some rainfall amount may mimic actual basin processes in Allen Hollow. The low soil moisture storage capacity also indicates a greater likelihood of overland flow, which is in keeping with runoff travel times as calculated by the SCS equations.

This calibration test suggest that the model is generally appropriate in the Valley and Ridge basins in this study, as they have low depths to bedrock, shallow soils, and low infiltration rates. This differs from the Blue Ridge basins, which have weathered bedrock, deep soils, and a high capacity for moisture storage. Good analogs to the Valley and Ridge basins in this study are watersheds at the Fernow Hydrologic Research Laboratory in West Virginia, which are forested and have similar lithologic and soil characteristics. They are located in flat-lying Paleozoic strata, have silty loam soils designated as hydrologic group C, and produce about $35 \%$ of storm precipitation as storm discharge (Hewlett et al., 1977). Apart from the Fernow data, the only flow available to gauge the model's applicability in the Valley and Ridge streams is the one in Allen Hollow.

\section{Coweeta-Peak discharge}

Gauged flows from 1949 and 1957 (Figs. 3.5.2-3.5.7) were used to examine differences in observed and predicted stormflow and optimize basin curve numbers to reproduce gauged storm flow data for Coweeta Watersheds 10 and 34. Unfortunately, stream gauge records were not available for both watersheds in either year; so different storms were modeled in the two basins. Rainfall was modeled as spatially homogenous, produced from Coweeta rain gauge data (see section 3.4.1). Basin curve numbers were heterogeneous 
(Coweeta $10=44 / 68$ and Coweeta $34=44 / 64$ ), selected according to parameters described previously. Watershed 10 received higher curve number values for roaded areas as it was logged twice (and more recently than watershed 34 ), which was only logged once prior to 1920.

Lag between the observed and predicted peak discharges is apparent in all the modeled flows because the rainfall data used for storm simulation was recorded in the valley below Coweeta Watersheds 10 and 34. The watersheds (northwest of the rain gauge) likely received the rainfall before it passed over the rain gauge, so the use of the rain gauge's time record for precipitation causes the modeled flows to lag behind the observed flows.

Peak discharges predicted by these curve numbers consistently overestimate peak storm flows for Coweeta Watershed 10. Curve numbers that produced peak flows with the best fit (optimized) were lower, indicating greater soil moisture storage exists in this basin. Curve numbers also varied according to rainfall amount (Fig. 3.5.8) and intensity, and possibly antecedent moisture conditions. For example, peak flow from a distributed 24-hour, 4.1 inch Coweeta Watershed 10 storm (Fig. 3.5.2, Table 3.5.2) in January was reproduced using curve numbers of 41 and 66, while peak flow for a short, intense 4-inch storm in July (Fig. 3.5.3, Table 3.5.2) was predicted using lower curve numbers 35 and 66. This could indicate higher antecedent soil moisture in January than July, or the inability of the curve number method to reproduce soil moisture storage differences during storms of varying temporal distribution. Infiltration rate probably reaches a steady state in deep sandy soils like those at Coweeta instead of reaching a rainfall threshold at which it stops. Therefore, lower curve numbers must be used in order to simulate greater infiltration rates. For example, curve numbers had to be lowered to 30 and 64 to reproduce peak flows for a well-distributed 6.6-inch storm in June (Fig. 3.5.4, Table 3.5.2).

Peak discharges for Coweeta Watershed 34 were not consistently over- or underestimated using the original curve numbers selected. Rather, peak discharge for two storms was slightly underestimated, but was overestimated in the third and largest storm. Similar to Coweeta Watershed 10, the optimized curve numbers for these storms vary according to total storm depth (Fig. 3.5.9) and intensity, as well as antecedent moisture conditions. A January storm of 3.6 inches (Fig. 3.5.5, Table 3.5.3), which required the highest curve numbers (45/67) to reproduce peak flow, was also the most evenly distributed 
over 24 hours and had lowest peak intensity (0.14 in/15 min). A 3.4 inch June storm (Fig. 3.5.6, Table 3.5.3) required similar curve numbers to the January storm (44/67) but the majority of the rainfall was delivered in only two hours and the maximum intensity was higher (0.27 in/15 minutes). Another important but less apparent difference may have been antecedent moisture conditions, which were higher in January and reduced the available soil moisture storage capacity. An April storm, with the highest rainfall amount (4.86 inches) and intensity (0.28in /15 minutes) (Fig. 3.5.7, Table 3.5.3), required much lower (37/64) curve numbers to reproduce peak flows recorded at the gage. Again, it is possible that different antecedent moisture conditions are partially responsible for the difference.

The lower curve numbers required to obtain best fit hydrographs in four of six storm flows at Coweeta are not surprising considering previous studies have produced similar results. Coweeta basins required a different range of curve numbers than other basins in a curve number optimization test performed by Hjelmfelt (1982). Hjelmfelt tested the range in curve number due to antecedent moisture by optimizing curve numbers for recorded rainfallrunoff data, and found that the $10 \%$, mean, and $90 \%$ of curve numbers generated corresponded well to AMCI, AMCII, and AMCIII curve numbers, respectively. Therefore, in most basins, modeling of AMCII conditions is modeling the mean of antecedent moisture conditions. However, the result was different in a Coweeta watershed, as $10 \%$ and $90 \%$ values fell above the AMCI and below AMCIII condition, suggesting that storage capacity at Coweeta varies less with antecedent moisture and average conditions may be better represented by lower curve numbers. Coweeta's deep, sandy loam soils have been attributed with infiltration rates of 10-50 inches per hour (Hewlett and Cunningham, 1977), and Watershed 34 , in particular, has been shown to produce only $3.4 \%$ of storm flow as storm discharge (Hewlett et al., 1977). Lower elevation watersheds in the Coweeta basin, such as Watersheds 10 and 34, have also been shown as having the lowest average storm peaks of the gauged Coweeta basins (Hoover and Hursh, 1943).

Previous work has similarly illustrated the importance of high soil moisture capacity in deep loamy soils of Western North Carolina for rainfall-runoff response. These basins have responded differently than other basins in studies that have tried to find an optimized curve number for storm rainfall-runoff data (Bales and Betson, 1982). Most basins in the Blue Ridge, Valley and Ridge, Cumberland Plateau, Highland Rim, Central Basin, and 
Mississippi embayment had optimized curve numbers that fit better with AMCIII (high antecedent moisture) conditions than AMCII (average antecedent moisture) conditions. However, five basins in western North Carolina had optimized curve numbers that were better fit by AMCII conditions. Bales attributed the rainfall response difference in these basins to deep sandy loam soils that have such high water holding capacity that they rarely experience saturated, AMCIII conditions.

Another possible reason for difference in predicted and observed hydrographs at Coweeta is error in runoff travel time estimation using the Soil Conservation Service equations for sheet and shallow concentrated flow (see section 3.3.3). The overland flow travel times may be much faster than actual subsurface flow paths operating in the Coweeta basins (Nutter, 1971). This difference in travel time could be partially responsible for the sharply peaked predicted hydrographs that over predict peak storm flow.

The results of the calibration demonstrate that Coweeta basins have greater storage capacity than the hydrologic soil group would indicate, particularly during distributed storms with high total precipitation. Their infiltration rates are not well represented by the curve number, as they probably approach a steady state during distributed storms. The uncertainty in antecedent moisture conditions for the modeled storms also contributes to modeling inaccuracy, and demonstrates the weakness of the curve number method for use in reproducing historical rainfall/runoff data. The calibration results also illustrate the problem with the fitted parameter modeling method of the curve number. The curve number was developed to represent average basin response, and atypical basins such as Coweeta Watershed 10 are poorly represented by average input and output conditions.

Optimized curve number values obtained through calibration will be used for final discharge modeling of Coweeta Watersheds 10 and 34 (Tables 3.5.2 and 3.5.3), instead of values chosen through standard procedures, in order to obtain discharge estimates in keeping with gauged storm flow data. The two other North Carolina basins, Indian Spring and Horse Cove, also have deeper soils than the Virginia basins and may possess higher soil moisture capacity than predicted by the curve number. However, these two watersheds lack stream flow data, and it is hard to forecast an appropriate decrease in curve number, particularly considering the variable curve number success in Coweeta Watershed 34. Therefore, the 
original curve numbers selected for these two basins will be used for final discharge modeling.

\section{Coweeta - Volume}

At the same time, Coweeta Watershed 10 hydrographs were analyzed for their success in predicting storm flow volumes. In all cases, optimized curve numbers that predicted the observed peak discharge under predicted total storm flow volumes. Greater prediction error occurred for two widely distributed storms (Figs. 3.5.2 and 3.5.4, Table 3.5.4), while lower prediction error occurred for an abrupt storm that delivered 3.8 inches of rain in one hour, with a total 24-hour rainfall of 4 inches (Fig. 3.5.3, Table 3.5.4). This is likely due in part to curve number assumptions about infiltration rates as discussed previously, but is also due to the lack of baseflow addition to the hydrograph. Therefore, constant baseflow was added to the storm flow prior to its reaching the basin outlet in order to create less sharply peaked hydrographs that better replicated actual Coweeta 10 hydrographs. Constant baseflow amounts were based on stream flow data prior to and after the storm, as follows:

4.1 inch $(104.1 \mathrm{~mm})$ January storm $-\mathrm{CN}=40 / 64$; baseflow $=0.06 \mathrm{cms}$ 4 inch (101.6 mm) July storm $-\mathrm{CN}=35 / 64$; baseflow $=0.04 \mathrm{cms}$ 6.6 inch (167.6) June storm $-\mathrm{CN}=30 / 59$; baseflow $=0.04 \mathrm{cms}$

Baseflow addition increased storm flow volumes in all cases, but in widely distributed storms (4.1 and 6.6 inch) the observed volumes were still under predicted by 50$100 \%$, whereas in an abrupt 4-inch storm the volume was predicted within 5\% (Table 3.5.5). The abrupt 4-inch storm hydrograph was best matched by curve number modeling due to its sharply peaked distribution, demonstrating the importance of "design storm" use with the curve number method (Fig. 3.5.3, Table 3.5.2). Therefore, this storm was chosen as an example of a two-year North Carolina (NC-2) storm for modeling use in all the basins (Fig. 3.4.3). A sharply peaked rainfall was also chosen for the VA-2 storm (Fig. 3.4.2).

Since the addition of baseflow requires stream flow data and curve number calibration that is not possible in any basins but Coweeta, it is not incorporated into any basin for the final rainfall-runoff models. Only instantaneous peak discharge rates will be used in final sediment transport modeling, and are not be affected by the lack of baseflow in the 
hydrograph. Still, the choice of sharply peaked storms for modeling should reduce the error in storm flow volume due to the absence of baseflow. The storm flow volume error would likely be greatest in the North Carolina basins, particularly Coweeta, as baseflow from storage is a greater component of runoff than in the Virginia basins. Field observations during the summer of 2001 and anecdotal evidence (McTammany, 2001) suggests that the streams at Coweeta have constant baseflow from storage, even at the channel heads. The Virginia basins, however, were frequently dry during summer months. The Joyce Kilmer basins are somewhere in-between, with occasional dry reaches in their upstream sections.

\subsubsection{Sensitivity Analysis}

To further evaluate the applicability of this modeling, an analysis of the importance of assumed parameters on the model result was conducted. Sensitivity of peak discharge prediction to curve number selection under different precipitation, soil hydrologic group, and drainage area conditions was examined for three basins (Allen Hollow, Indian Spring, and Coweeta Watershed 10) to determine the potential error in discharge estimates. Allen Hollow and Indian Spring each have homogenous soil and forest conditions and represent the variation in curve number for different hydrologic groups and forest conditions. Coweeta Watershed 10 represents a basin with heterogeneous curve number due to differences in land use. A range of curve numbers was chosen for each basin based on possible curve number variation due to errors in estimation of soil infiltration capacity, land cover conditions, and antecedent moisture conditions. Storms modeled were local storms, the VA-2 storm, and the NC-2 storm. The difference in discharge is tracked for incremental steps of curve number value equal to five (Figs. 3.5.10-3.5.12).

Within each basin, the percent difference between predicted peak discharges for different curve numbers increases as rainfall amount decreases, as smaller storms produce very small peak discharges. However, the absolute difference in predicted peak discharges for different rainfall amounts increases as curve number increases. This result indicates that basins with high infiltration capacity (lower curve numbers) will have a higher percent error in discharge prediction than basins with lower infiltration capacity (higher curve numbers), particularly during small storms. There is no consistent relation between difference in peak 
discharge and drainage area, which may be due in part to individual basin geometry and flow timing.

Land use change in a small portion of a watershed does not appear to influence peak discharge greatly, as changes in curve number in a small portion of Coweeta Watershed 10 have minimal effect compared to a change in curve number in the rest of the watershed (Fig. 3.5.12). For the June 6.6-inch storm, the relation between predicted peak discharge and curve number becomes linear, as the storage capacity is exceeded even for the lowest curve numbers (Fig. 3.5.12).

Generally, there is a $20 \%$ difference in peak discharge prediction with a curve number difference of five, and a maximum difference of 50\%. However, the magnitude of absolute difference may be more meaningful than percent difference, as a $100 \%$ increase in a very small peak discharge will not correspond to an equivalent increase in sediment transport capacity.

\subsubsection{Conclusion}

The greatest limitation to modeling hydrology in the nine headwater basins is the oversimplification of forest hydrology by the curve number and Soil Conservation Service travel time calculations. Curve number values selected from charts overestimate runoff and do not account for a steady-state infiltration rate occurring during storms. It is well established that forested basins rarely experience rainfall amounts that exceed their infiltration capacity, and therefore overland flow is not the typical route for runoff through these basins. It is therefore possible that gauged data on the seven basins besides Coweeta would indicate a similar relation for precipitation and curve number that was seen in the Coweeta calibration. However, the success in calibration at Allen Hollow using charted curve number values contradicts these findings and together with previous research suggests that the deep sandy soils at Coweeta are an anomaly - although certainly they may represent soils at the two other North Carolina basins better than the five Virginia basins.

The use of peaked storms and average antecedent moisture conditions gives discharge predictions that can be viewed as approximations of average peak discharge response to intense storms, along the lines of a "design flood". The selected curve numbers represent an average value, which could vary by five with rainfall distribution, antecedent moisture 
conditions, and soil type differences. This potential error in curve number, the greatest source of uncertainty in the model, produces about a $20 \%$ difference in predicted peak discharge, generally larger in basins with greater storage capacity. Therefore, the absolute difference in predicted discharge magnitude is limited to this error.

\begin{tabular}{|c|c|}
\hline $\begin{array}{c}\text { Allen Hollow - } \\
\text { Peak Discharge }\end{array}$ & $\begin{array}{c}\text { Mesult: Selected curve number works for observed peak flow and } \\
\text { will be used in other Virginia basins. }\end{array}$ \\
\hline $\begin{array}{c}\text { Coweeta - Peak } \\
\text { Discharge }\end{array}$ & $\begin{array}{c}\text { Result: Selected curve number over predicts peak flow in all flows } \\
\text { at Coweeta Watershed 10 and one flow at Coweeta Watershed 34. } \\
\text { Optimized curve numbers (Tables 3.5.2 and 3.5.3) will be used for } \\
\text { final peak flow modeling. }\end{array}$ \\
\hline $\begin{array}{c}\text { Coweeta - } \\
\text { Volume }\end{array}$ & $\begin{array}{c}\text { Result: Storm flow volume for Coweeta Watershed 10 predicted } \\
\text { within 5\% with baseflow addition to hydrograph, but will not be } \\
\text { used in final peak flow modeling as it should not affect peak } \\
\text { discharge rates and requires curve number calibration and baseflow } \\
\text { data, not available in any other basins. }\end{array}$ \\
\hline Sensitivity \\
Analysis & $\begin{array}{c}\text { Result: An error in curve number selection of +or- 5 results in a } \\
\text { peak discharge error of approximately 20\%, with a maximum error } \\
\text { of 50\%. The potential error will be greatest in basins with high } \\
\text { storage capacity during small storms. }\end{array}$ \\
\hline
\end{tabular}




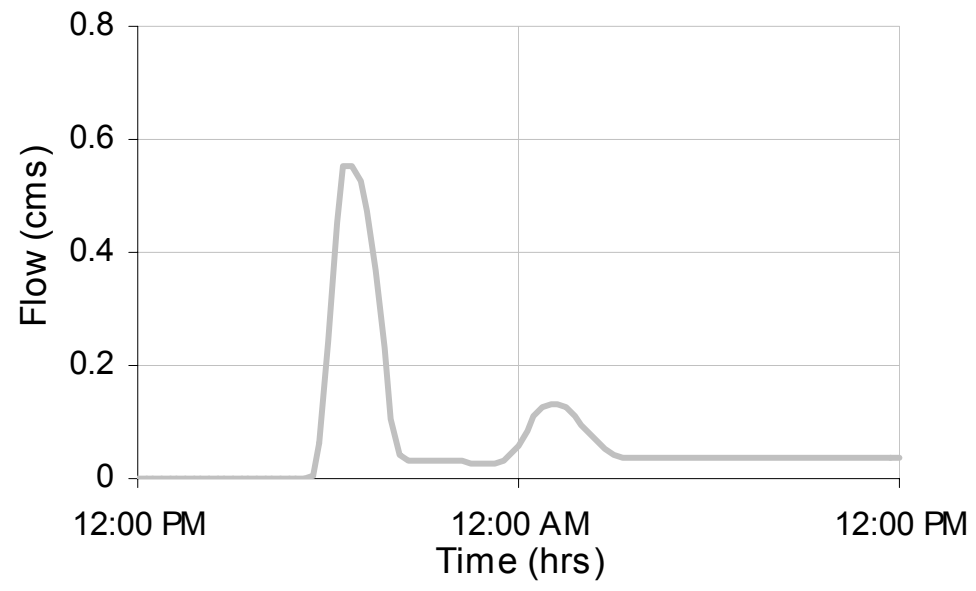

Figure 3.5.1. Predicted hydrograph for Allen Hollow cross section 1, during September 5, 2000 storm.

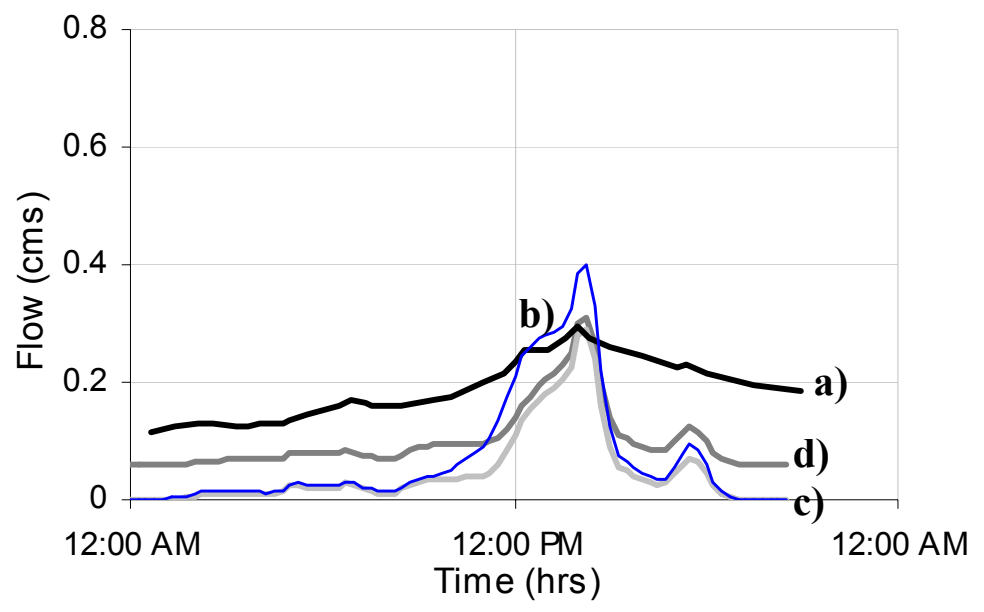

Figure 3.5.2. Observed and predicted hydrographs for Coweeta 10, January 5, 1949 storm: a) observed hydrograph (black line); b) predicted hydrograph with original curve numbers (blue line); c) predicted hydrograph with optimized curve numbers (light gray line); d) predicted hydrograph with baseflow addition (dark gray line). 


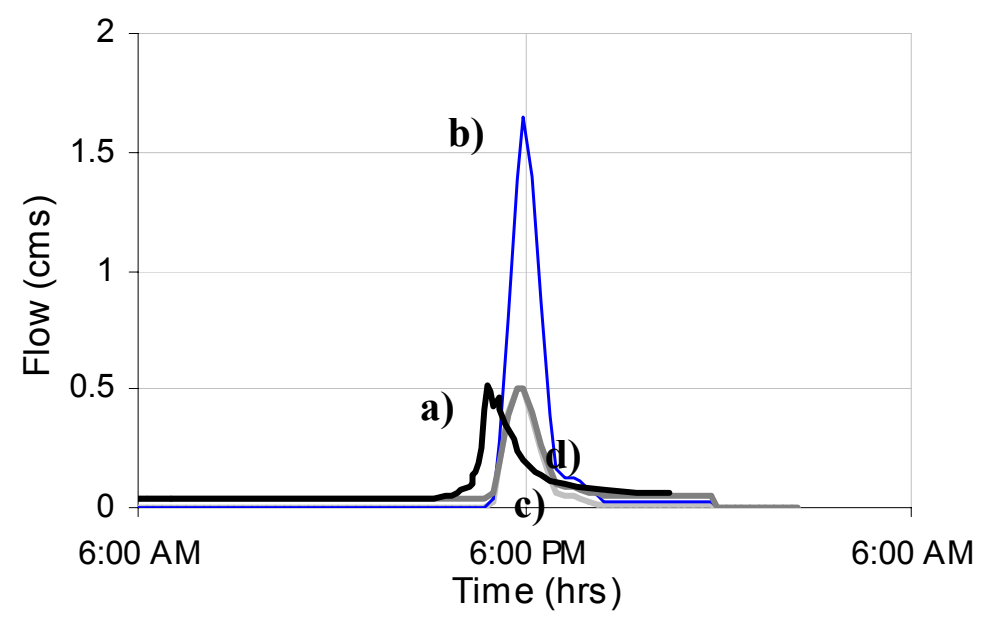

Figure 3.5.3. Observed and predicted hydrographs for Coweeta 10, July 10, 1949 storm: a) observed hydrograph (black line); b) predicted hydrograph with original curve numbers (blue line); c) predicted hydrograph with optimized curve numbers (light gray line); d) predicted hydrograph with baseflow addition (dark gray line).

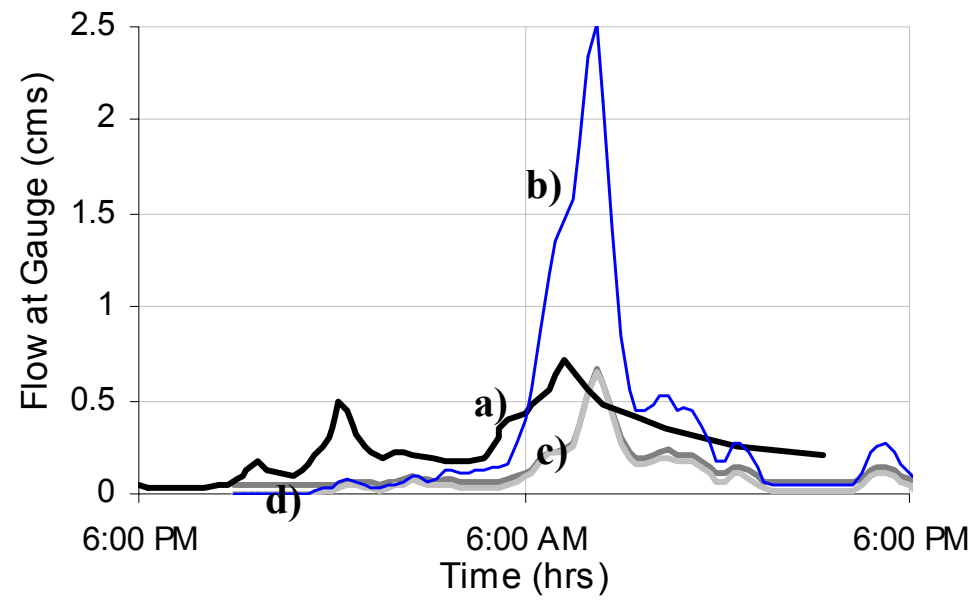

Figure 3.5.4. Observed and predicted hydrographs for Coweeta 10, June 15, 1949 storm: a) observed hydrograph (black line); b) predicted hydrograph with original curve numbers (blue line); c) predicted hydrograph with optimized curve numbers (light gray line); d) predicted hydrograph with baseflow addition (dark gray line). 


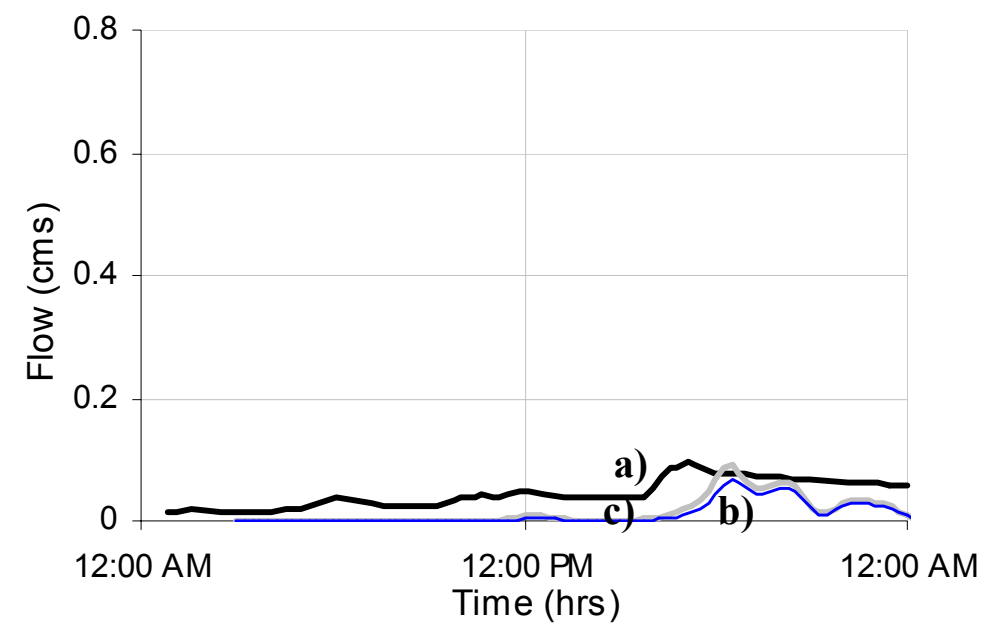

Figure 3.5.5. Observed and predicted hydrographs for Coweeta 34, January 31, 1957 storm: a) observed hydrograph (black line); b) predicted hydrograph with original curve numbers (blue line); c) predicted hydrograph with optimized curve numbers (light gray line).

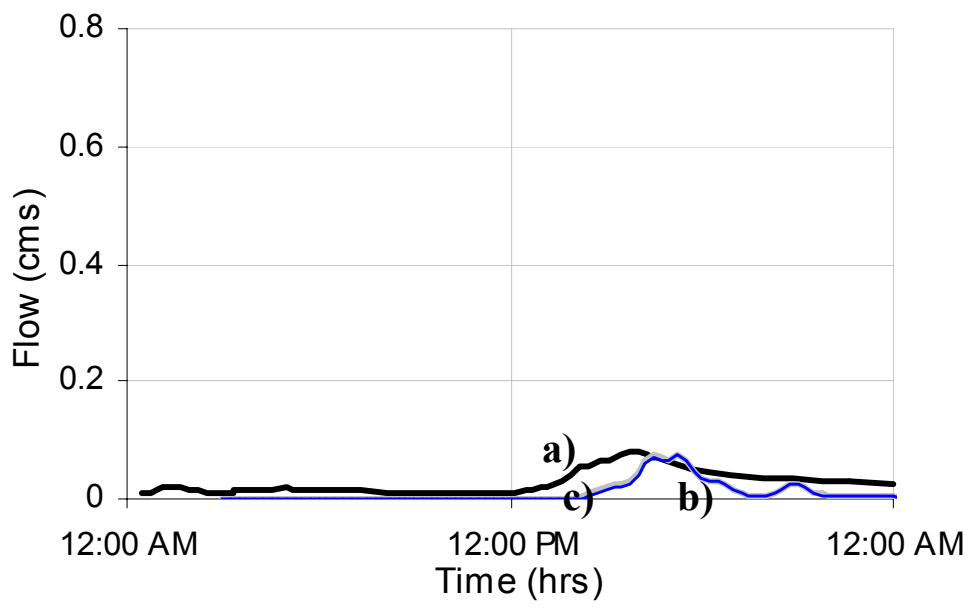

Figure 3.5.6. Observed and predicted hydrographs for Coweeta 34, June 28,1957 storm: a) observed hydrograph (black line); b) predicted hydrograph with original curve numbers (blue line); c) predicted hydrograph with optimized curve numbers (light gray line). 


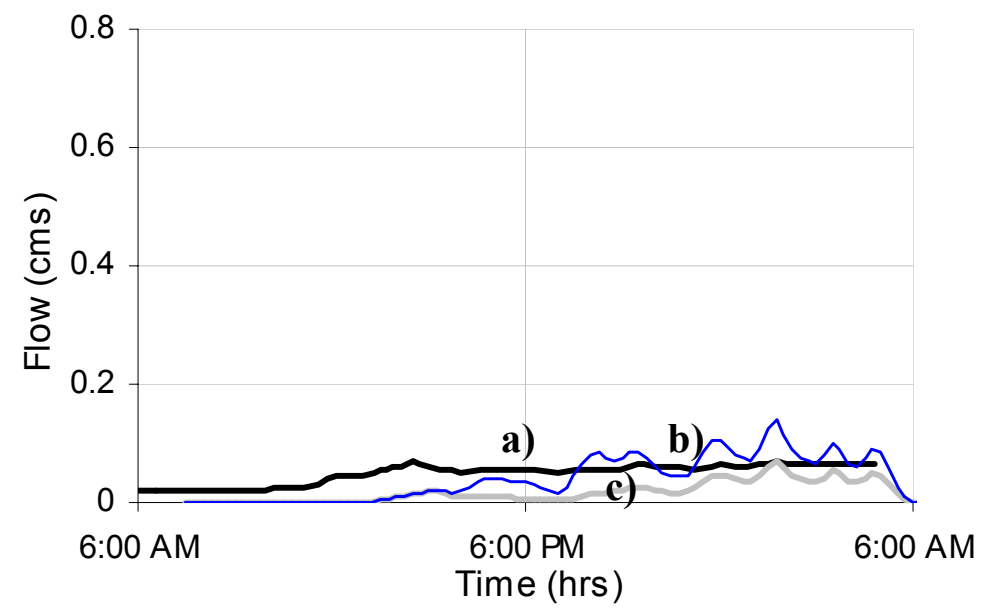

Figure 3.5.7. Observed and predicted hydrographs for Coweeta 34, April 4, 1957 storm: a) observed hydrograph (black line); b) predicted hydrograph with original curve numbers (blue line); c) predicted hydrograph with optimized curve numbers (light gray line).

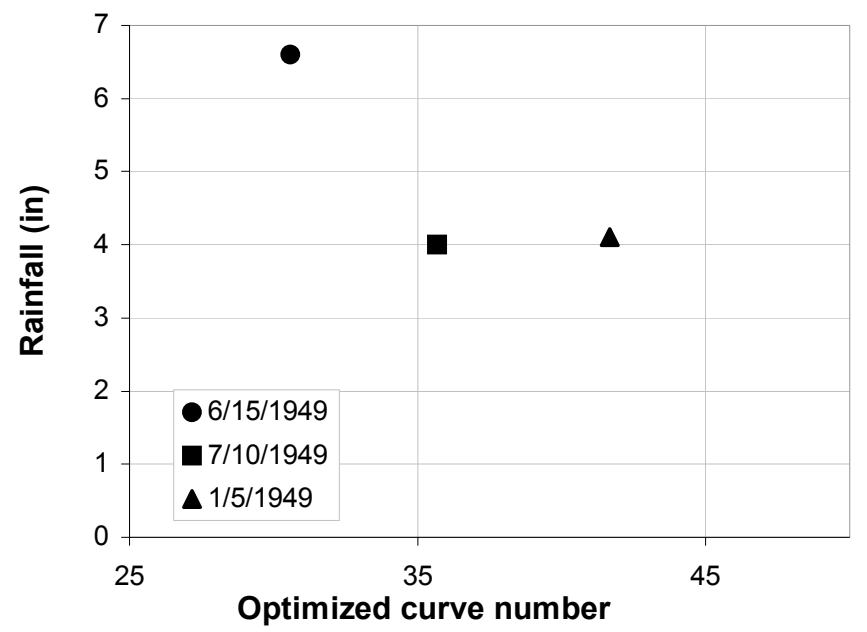

Figure 3.5.8. Relation of optimized curve number to rainfall amount for Coweeta Watershed 10 . 


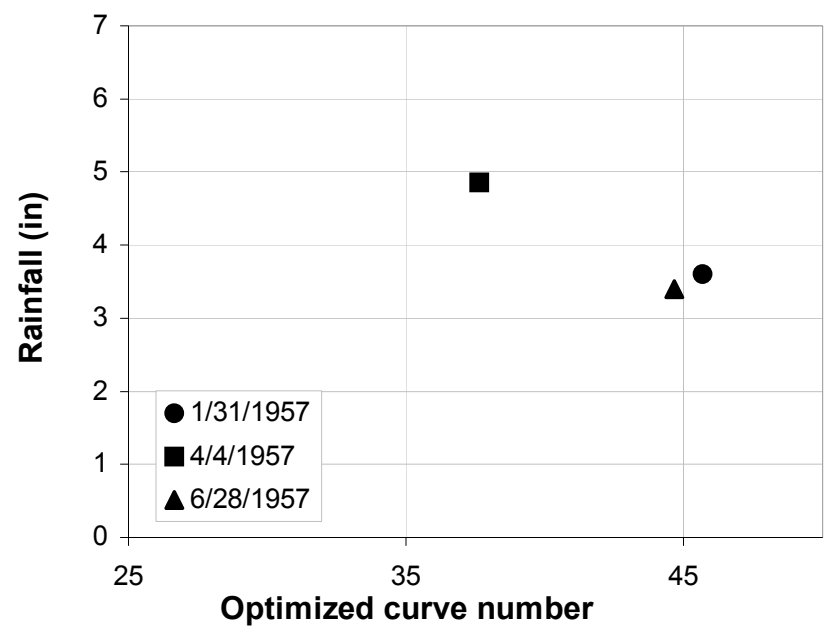

Figure 3.5.9. Relation of optimized curve number to rainfall amount for Coweeta Watershed 34 .

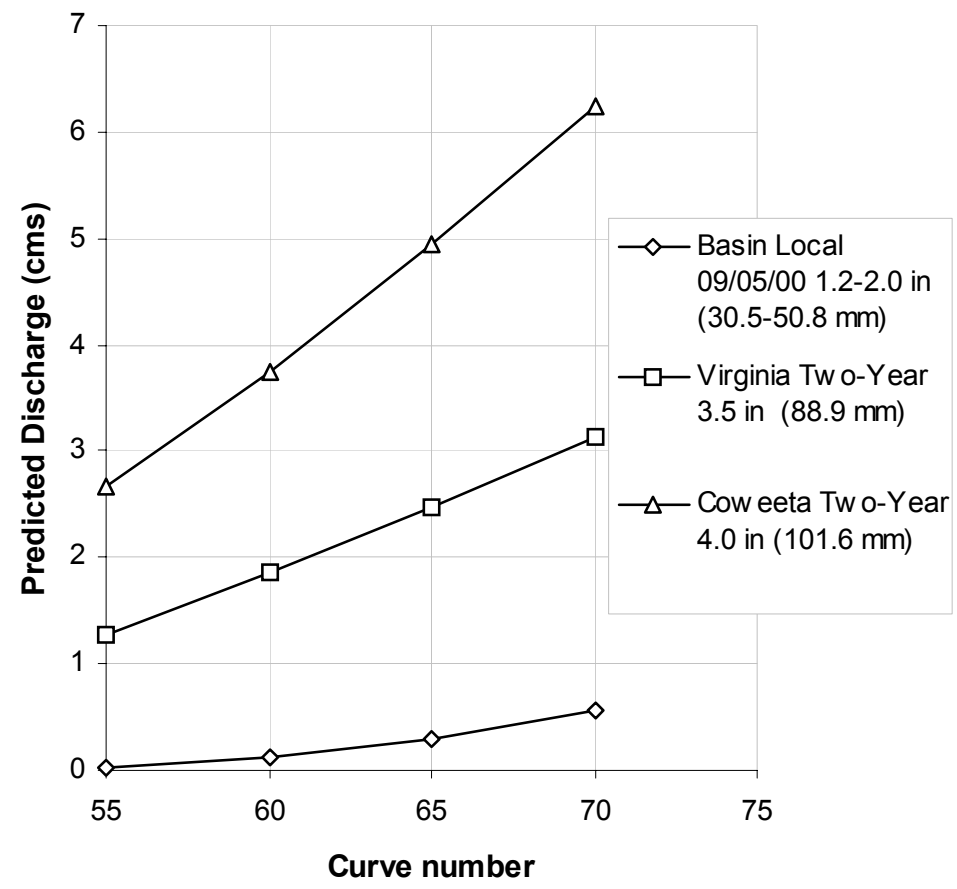

Figure 3.5.10. Relation of predicted peak discharge to curve number and 24-hour rainfall amount for Allen Hollow. 


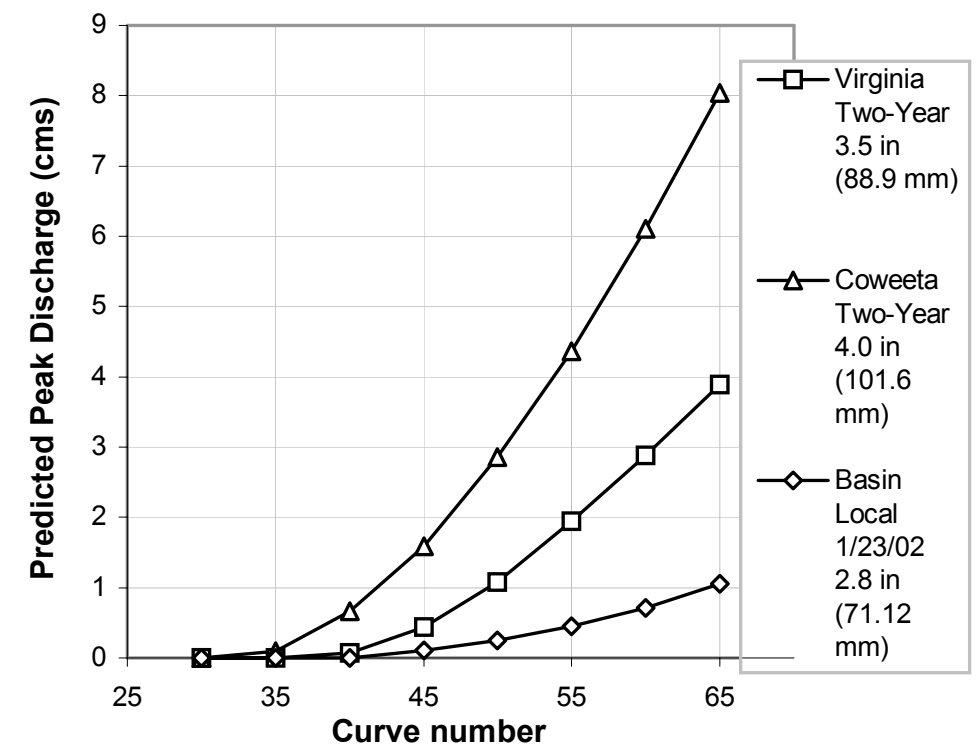

Figure 3.5.11. Relation of predicted peak discharge to curve number and 24-hour rainfall amount for Indian Spring.

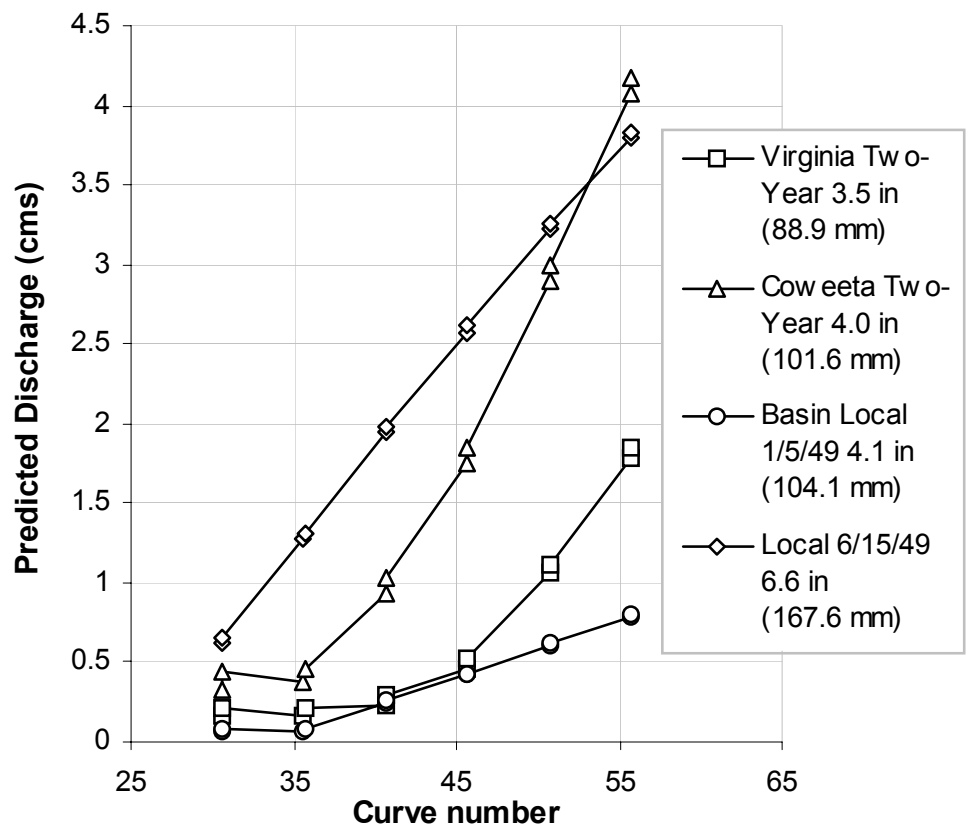

Figure 3.5.12. Relation of predicted peak discharge to curve number and 24-hour rainfall amount for Coweeta Watershed 10. Two markers close together indicate an increase in curve number for the roaded portion of the watershed, while the curve number in the unroaded portion remains the same. The trend line for the 6.6 in storm is linear because soil moisture storage capacity is surpassed by the large amount of rainfall, even for the lowest curve numbers (30). 
Table 3.5.1. Peak discharge calibration for observed storm, September 5, 2000 at Allen Hollow.

\begin{tabular}{|c|c|c|c|c|c|c|}
\hline $\begin{array}{c}\text { Allen } \\
\text { Hollow } \\
\text { Observed } \\
\text { Flow }\end{array}$ & $\begin{array}{l}\text { Maximum } \\
\text { 15-minute } \\
\text { Rainfall } \\
\text { Intensity } \\
\text { (in) }\end{array}$ & $\begin{array}{l}\text { Observed } \\
\text { Peak Flow } \\
\text { (cms) }\end{array}$ & $\begin{array}{l}\text { Observed } \\
\text { Peak Flow } \\
\text { (csm) }\end{array}$ & $\begin{array}{c}\text { Curve } \\
\text { Number } \\
\text { Selected } \\
\text { from USFS } \\
\text { chart }\end{array}$ & $\begin{array}{l}\text { Optimized } \\
\text { Curve } \\
\text { Number }\end{array}$ & $\begin{array}{c}\text { Predicted } \\
\text { Peak Flow } \\
\text { (cms) }\end{array}$ \\
\hline $\begin{array}{c}\text { September } 4, \\
2000 \\
(1.2-2.0 \text { in })\end{array}$ & 0.57 & 0.56 & 56.6 & 70 & 70 & 0.55 \\
\hline
\end{tabular}

Table 3.5.2. Data from Coweeta Watershed 10 peak discharge calibration.

\begin{tabular}{|c|cccccc|}
\hline $\begin{array}{c}\text { Coweeta 10 } \\
\text { Peak Flow } \\
\text { Calibration }\end{array}$ & $\begin{array}{c}\text { Maximum } \\
\text { 15-minute } \\
\text { Rainfall } \\
\text { Intensity } \\
\text { (in) }\end{array}$ & $\begin{array}{c}\text { Observed } \\
\text { Peak Flow } \\
\text { (cms) }\end{array}$ & $\begin{array}{c}\text { Observed } \\
\text { Peak Flow } \\
\text { (csm) }\end{array}$ & $\begin{array}{c}\text { Number } \\
\text { Selected } \\
\text { from } \\
\text { USFS } \\
\text { Chart }\end{array}$ & $\begin{array}{c}\text { Optimized } \\
\text { Curve } \\
\text { Number }\end{array}$ & $\begin{array}{c}\text { Predicted } \\
\text { Peak Flow } \\
\text { (cms) }\end{array}$ \\
\hline $\begin{array}{c}\text { July 10, 1949 } \\
\mathbf{( 4 ~ i n ) ~}\end{array}$ & 1.11 & 0.512 & 52.1 & $44 / 68$ & $35 / 66$ & 0.505 \\
$\begin{array}{c}\text { January 5, 1949 } \\
(\mathbf{4 . 1} \text { in) }\end{array}$ & 0.12 & 0.295 & 29.6 & $44 / 68$ & $41 / 66$ & 0.292 \\
$\begin{array}{c}\text { June 15, 1949 } \\
(6.6 \text { in) }\end{array}$ & 0.38 & 0.708 & 72.0 & $44 / 68$ & $30 / 64$ & 0.660 \\
\hline
\end{tabular}

Table 3.5.3. Data from Coweeta Watershed 34 peak discharge calibration.

\begin{tabular}{|c|cccccc|}
\hline $\begin{array}{c}\text { Coweeta 34 } \\
\text { Peak Flow } \\
\text { Calibration }\end{array}$ & $\begin{array}{c}\text { Maximum } \\
\text { 15-minute } \\
\text { Rainfall } \\
\text { Intensity } \\
\text { (in) }\end{array}$ & $\begin{array}{c}\text { Observed } \\
\text { Peak Flow } \\
\text { (cms) }\end{array}$ & $\begin{array}{c}\text { Observed } \\
\text { Peak Flow } \\
\text { (csm) }\end{array}$ & $\begin{array}{c}\text { Curve } \\
\text { Number } \\
\text { Selected } \\
\text { from } \\
\text { USFS } \\
\text { Chart }\end{array}$ & $\begin{array}{c}\text { Optimized } \\
\text { Curve } \\
\text { Number }\end{array}$ & $\begin{array}{c}\text { Predicted } \\
\text { Peak Flow } \\
\text { (cms) }\end{array}$ \\
\hline $\begin{array}{c}\text { June 28, 1957 } \\
\mathbf{( 3 . 4} \text { in) }\end{array}$ & 0.27 & 0.084 & 22.5 & $44 / 64$ & $44 / 67$ & 0.078 \\
$\begin{array}{c}\text { January 31, 1957 } \\
\text { (3.6 in) }\end{array}$ & 0.14 & 0.099 & 26.9 & $44 / 64$ & $45 / 67$ & 0.092 \\
$\begin{array}{c}\text { April 4, 1957 } \\
\text { (4.86 in) }\end{array}$ & 0.29 & 0.072 & 19.3 & $44 / 64$ & $37 / 64$ & 0.070 \\
\hline
\end{tabular}


Table 3.5.4. Data from Coweeta Watershed 10 volume calibration prior to baseflow addition to model.

\begin{tabular}{|c|c|cccc|}
\hline $\begin{array}{c}\text { Coweeta 10 } \\
\text { Volume } \\
\text { Calibration } \\
\text { No Baseflow }\end{array}$ & $\begin{array}{c}\text { Optimized } \\
\text { Curve } \\
\text { Number }\end{array}$ & $\begin{array}{c}\text { Observed } \\
\text { Peak Flow } \\
\text { (cms) }\end{array}$ & $\begin{array}{c}\text { Predicted } \\
\text { Peak Flow } \\
(\mathbf{c m s})\end{array}$ & $\begin{array}{c}\text { Observed } \\
\text { Volume }\left(\mathbf{m}^{\mathbf{3}}\right)\end{array}$ & $\begin{array}{c}\text { Predicted } \\
\text { Volume }\left(\mathbf{m}^{3}\right)\end{array}$ \\
\hline $\begin{array}{c}\text { July 10, 1949 } \\
\mathbf{( 4} \text { in) }\end{array}$ & $35 / 66$ & 0.512 & 0.505 & 5918 & 2470 \\
$\begin{array}{c}\text { January 5, 1949 } \\
\mathbf{( 4 . 1} \text { in) }\end{array}$ & $41 / 66$ & 0.295 & 0.292 & 15745 & 3610 \\
$\begin{array}{c}\text { June 15, 1949 } \\
(\mathbf{6 . 6} \text { in) }\end{array}$ & $30 / 64$ & 0.708 & 0.660 & 21164 & 7485 \\
\hline
\end{tabular}

Table 3.5.5. Data from Coweeta Watershed 10 volume calibration after baseflow addition to model.

\begin{tabular}{|c|c|c|c|c|c|}
\hline $\begin{array}{c}\text { Coweeta } 10 \\
\text { Volume } \\
\text { Calibration } \\
\text { Baseflow Added }\end{array}$ & $\begin{array}{c}\text { Optimized } \\
\text { Curve } \\
\text { Number }\end{array}$ & $\begin{array}{c}\text { Baseflow } \\
\text { Addition } \\
\text { (cms) }\end{array}$ & $\begin{array}{c}\text { Predicted } \\
\text { Peak Flow } \\
\text { (cms) }\end{array}$ & $\begin{array}{c}\text { Observed } \\
\text { Volume }\left(\mathbf{m}^{3}\right)\end{array}$ & $\begin{array}{c}\text { Predicted } \\
\text { Volume }\left(\mathbf{m}^{3}\right)\end{array}$ \\
\hline $\begin{array}{c}\text { July } 10,1949 \\
\text { (4 in) }\end{array}$ & $35 / 64$ & 0.04 & 0.487 & 5918 & 5640 \\
\hline $\begin{array}{c}\text { January } 5,1949 \\
\text { (4.1 in) }\end{array}$ & $40 / 64$ & 0.06 & 0.312 & 15745 & 9499 \\
\hline $\begin{array}{c}\text { June } 15,1949 \\
(6.6 \text { in })\end{array}$ & $30 / 59$ & 0.04 & 0.662 & 21164 & 10218 \\
\hline
\end{tabular}




\subsection{Discharge Modeling}

Discharge modeling was performed at each reach based on channel measurements from cross sectional surveys. Two discharges predicted by HEC-HMS hydrologic modeling were modeled for use in sediment transport calculations: a modified IFLOWS storm discharge approximating the two year 24 hour rainfall in the Virginia basins (VA-2 storm) and an abrupt 4 inch storm from 1949 Coweeta rainfall data that produced a two year discharge for the area (NC-2 storm). Collectively, the VA-2 storm in Virginia basins and NC-2 storm in North Carolina basins are referred to as the 2-year storms. The VA-2 storm was also applied in the North Carolina basins in order to have a uniform rainfall to compare across the region. A third flow, the bankfull discharge, was also modeled for use in sediment transport calculations. The local storm discharges produced by hydrologic modeling (see section 3.4) were modeled as well (Appendices A-I, cross section Figs.) and used for study of variation in Manning's $n$ in Allen Hollow, but were not used in final sediment transport calculations.

The 2-year storms approximate a discharge with a recurrence interval similar to bankfull in higher order, perennial streams, which typically recurs one to three years (Wolman and Miller, 1960). The modeled bankfull discharge, however, is the flow that fills the channel to bankfull height and would be considered the channel-forming flow in perennial lowland streams. The bankfull peak discharge was compared to peak discharges for the 2-year storms in order to better constrain the recurrence interval of channel-forming flows in headwater streams.

Modeled discharges at each surveyed reach were analyzed for their magnitude and width-depth relations, and as well as their velocity, stream power, and ability to entrain the particles present on the streambed (stream competence). These hydraulic variables are used as indicators of controls on channel forming flow and erosion processes under varying climatic, geologic, drainage area, and land use conditions. 


\subsubsection{Methods}

\section{Hydraulic Modeling}

2-year storm and bankfull discharges were modeled at each surveyed reach using step-backwater analysis with HEC-RAS 3.0 (Army Corp. of Engineers software; (Brunner, 2001). Step-backwater analysis accounts for non-uniform flow conditions common in natural channels (Jarrett, 1984) by evaluating energy losses between cross sections using the standard step method (Brunner, 2001). Therefore, it provides a more thorough evaluation of the hydraulics through a reach than using slope-area computation (see below Selection of Manning's $n$ ) at a single cross-section.

The method requires the assumption of steady flow conditions, which is reasonable for peak flows over short distances, as they should experience little change in stage and approximate steady flow (Grimm et al., 1995). However, it also requires the assumption of uniform conditions throughout a reach, in which the area, hydraulic radius, and depth are constant, and the water surface is parallel to the streambed. Cross sections were chosen in order to maximize uniformity within a reach (see section 2.2.4), but many surveyed reaches vary from these assumptions. Furthermore, HEC-RAS is recommended for streams with slopes below 10\% (Brunner, 2001) and many of the modeled reaches exceed 10\% slope.

\section{Discharge magnitude}

Discharge values for the 2-year storms were derived from hydrologic modeling and are subject to all hydrologic modeling uncertainty (see section 3.5). Bankfull discharge values were estimated to best match field-surveyed bankfull features at each reach, and therefore are subject to errors in the identification of these features. 2-year discharge magnitude and bankfull discharge magnitude were compared and the relation of 2-year flow height to bankfull features was assessed visually. All 2-year and bankfull flow heights are subject to uncertainty in selection of Manning's $n$, as well as the effects of channel scour and fill during flows (see below Selection of Manning's $n$ ).

Errors in discharge estimation can also be caused by the scour and fill effects. During flood flows, a stream may scour the channel bed and redeposit the material as the flood recedes (Linsley et al., 1975). However, discharge estimation relies on the assumption that 
the surveyed channel cross section is similar to the one present during the modeled flow. In the absence of field data on scour and fill effects during flows, error must be minimized by using stable boundary reaches (bedrock or coarse alluvium) to model flows (Wohl, 2000).

Fortunately, the majority of the reaches surveyed were bedrock or cobble and boulder, and therefore less likely to scour during the 2-year storm and bankfull flows modeled. However, their channel geometry is also generally deep and narrow, and thus maximizes change in stage with discharge. If the effect of scour and fill were present, it would be reasonable to expect discharges at alluvial reaches to reach relatively higher in the channel form than discharges at bedrock reaches. The opposite is true in Coweeta Watershed 10 (Appendix H, Figs. H.7-13), as the 2-year storm comes closer to reaching bankfull height in bedrock reaches, but flows well below bankfull height in nearby reaches with predominantly cobble/gravel substrate. Bedrock-floored cross sections were also surveyed in 7 of the other 8 channels (Given Branch has no bedrock), and their 2-year discharge height does not differ greatly from the 2-year discharge height at the nearest alluvial cross sections (Appendices A-I, cross section Figs). Therefore, the effect of scour and fill during the modeled flows is believed to be minimal.

\section{Bankfull selection}

The bankfull flow is widely regarded as a one to three year recurrence flow that shapes the alluvial stream channel by moving the most sediment over time (Wolman and Miller, 1960). It can be identified using features such as the top of the channel banks, the location of minimum width-depth ratio of the cross section, changes from annual to perennial vegetation, and changes in substrate (Radecki-Pawlik, 2002). The steep, confined, colluvial nature of mountain streams made bankfull a difficult concept to apply to the streams in this study. However, bankfull height identified for each modeled cross section based on the assumption that the flow that would fill the main channel is meaningful even if it is not an exact analog to bankfull in lower gradient alluvial systems. Bankfull heights chosen in the field were typically based on the top of the channel banks, as this was the most consistently identifiable characteristic of the boundary between the main channel and floodplain or overbank region (Appendices A-I, cross section Figs.). 
The only location where it was possible to test the bankfull identification techniques used in this study was at Coweeta watershed 34. Swift (1993) previously identified bankfull features just above the gauging station, producing a bankfull discharge estimate of $0.10 \mathrm{cms}$ with a recurrence interval of one year. The modeled 2-year storm Coweeta discharge at the gauging station is twice as big as Swift's bankfull estimate $(0.19 \mathrm{cms})$, yet the modeled 2year storm discharge does not fill the channel to bankfull features as identified in this study. However, the cross sections surveyed in this study were upstream from the gauge, at a different location than Swift's bankfull identification site. It is possible that the bankfull relation changes upstream, as the channel changes from alluvial to more bedrock and boulder, or that bankfull as identified in this study overestimates bankfull discharge. Furthermore, it has been noted previously that bankfull identification in steep mountain streams is better viewed as a range of heights than a specific location (Radecki-Pawlik, 2002).

\section{Selection of Manning's $n$}

Discharge modeling is heavily dependent on the assessment of flow roughness of within the channel. In Manning's formula for discharge estimation, commonly referred to as slope-area computation (Eq. 3.6.1), discharge $(q)$ is inversely proportional to flow roughness (n). Manning's formula is used by HEC-RAS to generate depth and velocity values at each cross section for balancing of the energy equation used in the standard step method (Brunner, 2001).

$$
q=\frac{A R^{2 / 3} S^{1 / 2}}{n} \text { (SI units) }
$$

Where: $A=$ Cross sectional area of flow

$R=$ Hydraulic radius (area/wetted perimeter)

$S=$ Slope of flow (channel bed slope often used)

Discharge estimates in steep mountain streams are subject to over- or underestimation by $100 \%$ or more due to errors in Manning's $n$ (Jarrett, 1986). Numerous methods exist for estimating $n$ values, and three of these were compared to analyze potential variation in Manning's $n$ : Jarrett's equation (1984), Limerinos' equation (1970), and Barnes' (1967) guidelines for $n$ calculation in natural channels. 
Limerinos (1970) and Jarrett (1984) developed equations for Manning's $n$ in steep, boulder streams such as the nine streams studied. Limerinos' equation (Eq. 3.6.2) bases roughness to a ratio of hydraulic radius $(R)$ and streambed particle size $\left(d_{84}\right)$ :

$$
n=\frac{(0.0926) R^{1 / 6}}{1.16+2.0 \log \left(\frac{R}{d_{84}}\right)}
$$

Jarrett's (1984) roughness coefficient (Eq. 3.6.3) bases $n$ on channel slope $(S)$ and hydraulic radius $(R)$, based on measurements in high gradient channels:

$$
n=0.39 S^{0.38} R^{-0.16}
$$

Barnes' (1967) pictures of selected streams during various flows may be used to visually choose $n$ values and are commonly used for Manning's $n$ determination in wildland channels. However, Barnes' $n$ values are typically applied to larger, lower gradient streams than those in this study.

Limerinos' equation was chosen for determination of Manning's $n$ in the main channel because it represents roughness variations using the $R / d_{84}$ ratio, and therefore better captures roughness variations due to particle size changes as they occur in the surveyed cross sections. Furthermore, it provides a wider range of $n$ values for different discharges at the same cross section than Jarrett or Barnes' methods. This range of $n$ values reflects the drop in roughness during larger flows, as streambed particles are overtopped and the flood profile flattens. Floodplain values of Manning's $n$ were selected using Arcement and Schneider's guidelines for natural channels and floodplains (1989), except in cases where the floodplain was composed of the same boulder and cobble as the channel (i.e. Little Stony Tributary and Sarver Hollow), in which case Limerinos' $n$ was used.

Discharges from the local, VA-2, and NC-2 storms were modeled in four cross sections in Allen Hollow using each of the three Manning's $n$ methods for the main channel. Results for the two cross sections with the greatest difference in slope and particle size (x1 and $\mathrm{x} 4$ ) are shown in tables 3.5.1 and 3.5.2. Barnes' $n$ stays relatively low (0.6-0.8), while the two equations produce a greater range of $n$ values that include much higher $n$ values $(0.05$ -0.28). The increase in Jarrett's and Limerinos' $n$ upstream is due to slope and particle size 
increase, while Barnes' $n$ is uniform. Jarrett and Limerinos' equations also account for roughness increases at smaller discharges due to lower water depths, whereas Barnes' photos are typically of streams flowing at bankfull depth or higher. As a result, modeled hydraulic variables used in sediment transport estimation, such as average depth and velocity, shear stress, and stream power, are different. Jarrett's and Limerinos' equations produce similar values for these variables, but Barnes' method produces values that are approximately 50$75 \%$ higher (Tables 3.5.1 and 3.5.2). For example, there is a threefold increase in stream power from Limerinos' to Barnes' method at one cross section. This would result in a twofold increase in the predicted mobile particle size. In contrast, the difference in stream power caused by variation from Jarrett's to Limerinos' equation is so small that it would not change the estimate of particle size entrained.

Cross sections with higher slopes and larger particle sizes have a greater Manning's $n$ uncertainty, as they lie outside the range of applicability for any roughness equation. The large difference between Barnes' method and Jarrett and Limerinos' equations demonstrates that Barnes' method is too limited for use in high gradient channels. However, neither Jarrett's nor Limerinos' $n$ was calibrated to streams containing slopes or particle sizes as large as those in the present study, so for some reaches, the $n$ values calculated represent a best approximation of flow roughness. The potential error in percent of the streambed mobile associated with uncertainty in Manning's $n$ is roughly estimated at 5\%.

Manning's $n$ was given a vertical range of values with change in flow depth for the main channel. Preliminary slope-area discharge computation was performed at the center cross section of each reach using Limerinos' and Manning's equation in Excel to generate a range of $n$ values. HEC-RAS software interpolated between these values in order to determine Manning's $n$ for the main channel (area between the bankfull indicators, characterized by the pebble count particle size distribution) at the modeled discharges (Appendices A-I, cross section Figs.). Manning's $n$ was also varied horizontally, as there is typically a change in roughness at the edge of the main channel due to a change in substrate from cobble and boulder streambed to forest floor floodplain (Appendices A-I, cross section Figs.). 


\section{Calculation of Hydraulic Variables}

The width-depth ratio was calculated by dividing the top flow width by the average depth of the main channel (area between bankfull marks). All width-depth ratios are subject

to the uncertainty in hydraulic modeling (see section 3.5) and uncertainty in defining bankfull features (see above Bankfull Selection).

Average velocity, the rate of steam flow in the main channel, was calculated by HECRAS. Stream power, the average velocity multiplied by the shear stress (specific weight of water * hydraulic radius * slope of the energy gradient) in the main channel (Feldman, 2000), was also calculated directly by HEC-RAS. The slope of the energy gradient is calculated by HEC-RAS from energy losses due to friction or expansion/contraction over the length of a reach.

Stream competence, the percent of the streambed mobile during modeled flows, was estimated using Costa's (1983) unit stream power $(\omega)$ relations for the entrainment of particles $50-4000 \mathrm{~mm}$ in the Colorado Front Range:

$$
\omega=0.030 d_{I}^{1.686}
$$

Where: $d_{\mathrm{I}}=$ mobile particle size at intermediate axis $(\mathrm{mm})$

Estimates of mobile particle size for each reach were compared to the local particle size distribution, generating a percentage of the streambed particles that would be mobile, or the stream competence.

Costa's (1983) stream power relation was originally developed to estimate discharge in paleofloods from the largest particles transported during a flood. The unit stream power required for particle entrainment was calculated using Bagnold's (1966) concept of stream power (product of mean velocity and bed shear stress) and fitting a regression equation to empirical data of particle size and stream power. Costa fit both an envelope curve and a regression plot to the data (Fig. 3.6.1). The envelope curve represents the lower bound of stream power needed to move particles of a certain size, and results in higher particle size estimates. Use of the regression curve is preferred for particle entrainment estimation in our study, as it represents an average stream power required to move a certain particle size. Variability in particle shape and imbrication, for example, create variability in the stream 
power needed for entrainment, and use of the regression curve incorporates these effects into the particle size estimate.

Costa discussed large uncertainties in the stream power - mobile particle size relations (Costa, 1983), which have been described by Grimm (1995) as an order of magnitude estimate of particle size based on hydraulic parameters. However, no simple or accurate method for sediment transport prediction in steep, coarse mountain channels exists (Wohl, 2000). For example, Zimmerman and Church (2001) found that where Shield's equation (1936) estimated that the channel could move the largest boulders present, step-pool high gradient (0.5-0.1) channels were actually stable. Effects of imbrication and interlocking of stones around large keystones stabilized the channel (Zimmerman and Church, 2001). The advantage of using Costa's stream power-particle size relation is that it is based on data from a variety of flume and field conditions where coarse-particle movement was observed. Therefore, the prediction equation accounts for a range of conditions, such as particle sizes, shapes, and channel bedforms. Conditions such as these vary greatly in the streams studied and make the use of a single bedload transport equation difficult.

A difficulty with Costa's stream power relation is that it was based on particles $>50$ $\mathrm{mm}$. Therefore, the estimated particle size entrained during 2-year and bankfull flows for three reaches in this study are outside the range of the original data. However, the vast majority of the reaches (49) have particle sizes $>50 \mathrm{~mm}$ entrained at 2-year and bankfull flows.

Observations of particle movement at Allen Hollow x1 due to the September 4, 2000 storm (Appendix D, Fig. D.12) permit one test of Costa's equation in the studied headwater channels. The largest painted particle moved in the flow was $80 \mathrm{~mm}$ at its intermediate axis, and Costa's equation predicts a mobile particle size of $68 \mathrm{~mm}$. This difference in particle size translates to a $3 \%$ difference in stream competence, though a similar error in a different grain size distribution could translate to greater error. Still, it indicates that in this case, Costa's equation provides a reasonable approximation of mobile stream particle size.

The stream competence values generated using Costa's equation are meaningful even with potential error, as they can be considered a first approximation of the ability of the stream to transport the sediment present in the channel. Additionally, the relative values of 
stream competence between and within channels provide a means for evaluating differences in their erosive power. 


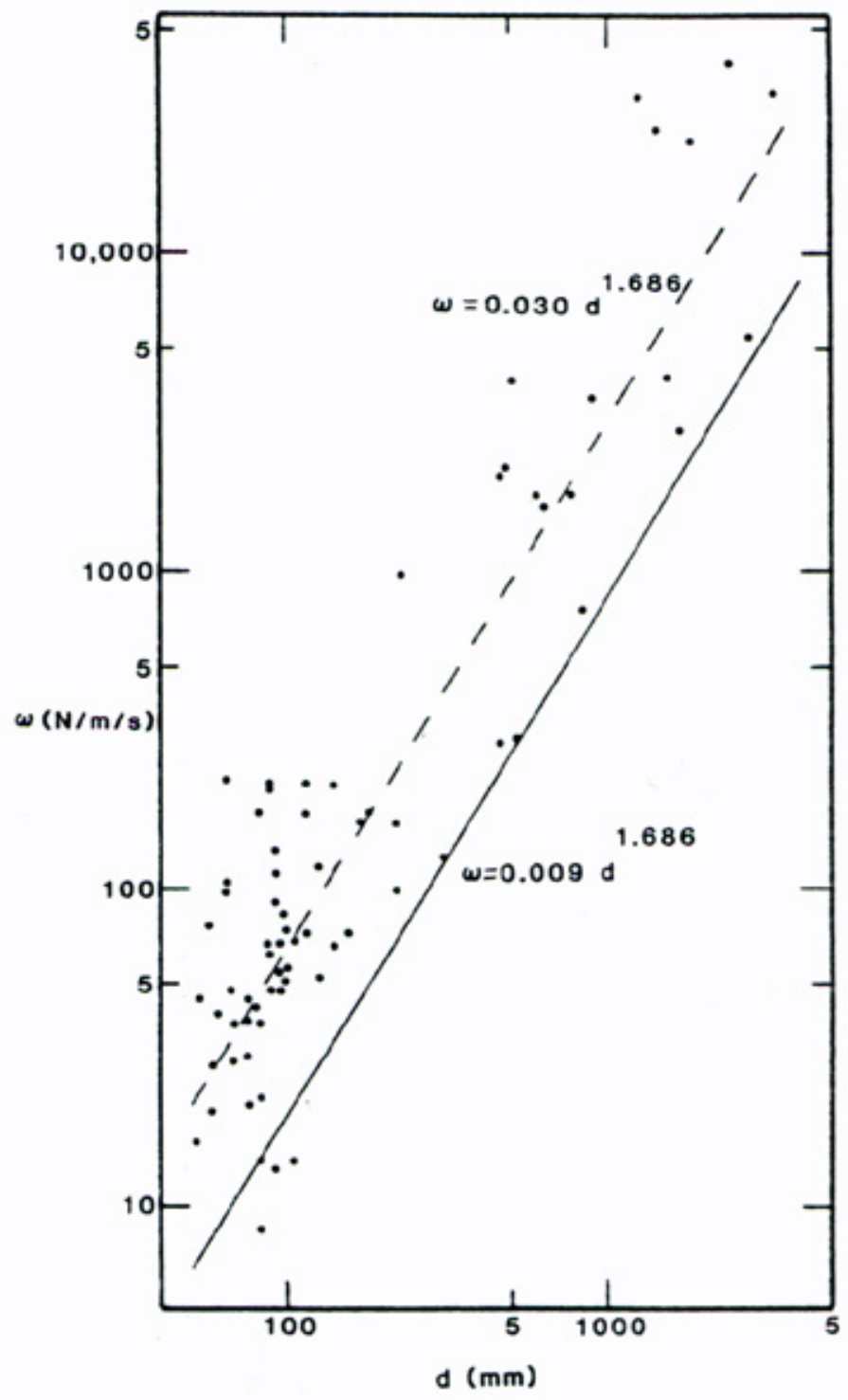

Figure 3.6.1. Costa's (1983) regression (dotted line) and envelope (solid line) curves for unit stream powerparticle size data. 
Table 3.6.1. Comparison of hydraulic parameters produced in discharge modeling using different methods of calculating Manning's $n$ for Allen Hollow x1.

\begin{tabular}{|c|c|c|c|c|c|c|c|}
\hline $\begin{array}{c}\text { Allen } \\
\text { Hollow x1 }\end{array}$ & Method & Manning's $n$ & $\begin{array}{c}\text { Slope of } \\
\text { energy } \\
\text { grade }\end{array}$ & $\begin{array}{c}\text { Ave. U } \\
(\mathrm{m} / \mathrm{s})\end{array}$ & $\begin{array}{l}\text { Ave. } \tau \\
\left(\mathrm{N} / \mathrm{m}^{2}\right)\end{array}$ & $\begin{array}{c}\text { Stream } \\
\text { Power (kg / } \\
\mathrm{m} \mathrm{s})\end{array}$ & $\begin{array}{c}\text { Ave D } \\
\text { (m) }\end{array}$ \\
\hline \multirow{3}{*}{$\begin{array}{c}\text { Local } \\
\begin{array}{c}Q=0.555 \\
\text { cms }\end{array}\end{array}$} & Limerinos & 0.084 & 0.031520 & 0.60 & 60.98 & 36.69 & 0.21 \\
\hline & Jarrett & 0.129 & 0.032496 & 0.73 & 82.01 & 59.81 & 0.26 \\
\hline & Barnes & 0.045 & 0.028020 & 1.29 & 55.86 & 71.85 & 0.21 \\
\hline \multirow[t]{2}{*}{ VA-2 Q } & Limerinos & 0.057 & 0.032398 & 1.05 & 140.76 & 147.25 & 0.47 \\
\hline & Jarrett & 0.113 & 0.034025 & 1.23 & 181.95 & 224.01 & 0.56 \\
\hline$\underline{\mathrm{cms}}$ & Barnes & 0.045 & 0.028639 & 2.28 & 132.65 & 302.56 & 0.49 \\
\hline \multirow{3}{*}{$\begin{array}{c}\mathrm{NC}-2 \\
\mathrm{Q}=6.240 \\
\mathrm{cms}\end{array}$} & Limerinos & 0.051 & 0.033342 & 1.32 & 202.09 & 267.75 & 0.65 \\
\hline & Jarrett & 0.108 & 0.035511 & 1.53 & 254.71 & 389.66 & 0.75 \\
\hline & Barnes & 0.045 & 0.026643 & 2.78 & 174.96 & 485.75 & 0.69 \\
\hline $\begin{array}{c}\text { Average } \% \\
\text { difference from } \\
\text { Limerinos' to } \\
\text { Jarrett's } n\end{array}$ & $\begin{array}{c}\text { Overall } \\
\% \text { diff }= \\
25.21\end{array}$ & 87.86 & 4.87 & 18.24 & 29.93 & 53.56 & 19.45 \\
\hline $\begin{array}{c}\text { Average } \% \\
\text { difference from } \\
\text { Limerinos' to } \\
\text { Barnes' } n \\
\end{array}$ & $\begin{array}{c}\text { Overall } \\
\% \text { diff }= \\
47.08 \\
\end{array}$ & -26.42 & -14.27 & 114.25 & -9.19 & 94.24 & 3.47 \\
\hline
\end{tabular}


Table 3.6.2. Comparison of hydraulic parameters produced in discharge modeling using different methods of calculating Manning's $n$ for Allen Hollow x4.

\begin{tabular}{|c|c|c|c|c|c|c|c|}
\hline $\begin{array}{c}\text { Allen } \\
\text { Hollow x4 }\end{array}$ & Method & Manning's $n$ & $\begin{array}{l}\text { Slope of } \\
\text { energy } \\
\text { grade }\end{array}$ & $\begin{array}{l}\text { Ave. U } \\
(\mathrm{m} / \mathrm{s})\end{array}$ & $\begin{array}{l}\text { Ave. } \tau \\
\left(\mathrm{N} / \mathrm{m}^{2}\right)\end{array}$ & $\begin{array}{c}\text { Stream } \\
\text { Power (kg / } \\
\mathrm{m} \mathrm{s})\end{array}$ & $\begin{array}{c}\text { Ave D } \\
\text { (m) }\end{array}$ \\
\hline \multirow{3}{*}{$\begin{array}{c}\text { Local } \\
Q=0.094 \\
\text { cms }\end{array}$} & Limerinos & 0.280 & 0.104907 & 0.69 & 100.79 & 69.38 & 0.10 \\
\hline & Jarrett & 0.230 & 0.104266 & 0.69 & 100.31 & 68.89 & 0.10 \\
\hline & Barnes & 0.08 & 0.260722 & 1.11 & 185.36 & 205.69 & 0.08 \\
\hline \multirow[t]{2}{*}{$\underline{\mathrm{VA}-2} \quad \mathrm{Q}$} & Limerinos & 0.166 & 0.106784 & 1.25 & 248.77 & 311.81 & 0.27 \\
\hline & Jarrett & 0.210 & 0.106771 & 1.25 & 248.74 & 311.77 & 0.27 \\
\hline$\underline{\mathrm{cms}}$ & Barnes & 0.08 & 0.223203 & 1.90 & 398.39 & 755.62 & 0.20 \\
\hline \multirow{3}{*}{$\begin{array}{c}\text { NC-2 } \\
Q=1.418 \\
\text { cms }\end{array}$} & Limerinos & 0.098 & 0.119992 & 1.67 & 394.11 & 658.42 & 0.38 \\
\hline & Jarrett & 0.197 & 0.118894 & 1.67 & 391.57 & 652.35 & 0.38 \\
\hline & Barnes & 0.08 & 0.198600 & 2.29 & 512.29 & 1171.57 & 0.30 \\
\hline $\begin{array}{c}\text { Average } \% \\
\text { difference from } \\
\text { Limerinos' to } \\
\text { Jarrett's } n\end{array}$ & $\begin{array}{c}\text { Overall } \\
\% \text { diff }= \\
0.29\end{array}$ & 36.56 & -0.51 & 0.00 & -0.38 & -0.55 & 0.00 \\
\hline $\begin{array}{c}\text { Average } \% \\
\text { difference from } \\
\text { Limerinos' to } \\
\text { Barnes' } n\end{array}$ & $\begin{array}{c}\text { Overall } \\
\% \text { diff }= \\
75.39 \\
\end{array}$ & -47.20 & 107.69 & 50.00 & 58.01 & 138.91 & -22.33 \\
\hline
\end{tabular}




\section{Chapter 4}

\section{Modeling Results}

\subsection{Discharge Magnitude and Bankfull Height}

Discharge increases with drainage area for all basins in the VA-2 and 2-year storms (Figs. 4.1a and 4.1b), just as in perennial streams. However, discharge does not increase with drainage area for bankfull flows (Fig. 4.1c). Bankfull discharge in headwater regions $\left(<0.4 \mathrm{~km}^{2}\right)$ is typically greater than the 2-year discharge (Fig. 4.2a). In downstream regions $\left(>1.2 \mathrm{~km}^{2}\right)$, bankfull discharge is less than the 2-year discharge (Fig. 4.2a). Bankfull height occurs at different parts of the channel in different storms, and does not occur throughout the channel at a set precipitation amount. This is unlike perennials, where there is a fundamental relation between a one to three year recurrence flow and bankfull discharge throughout a channel. The increase from 2-year to bankfull discharge is greater in higher slope cross sections, suggesting slope partially controls the size of the bankfull channel form (Figure $4.2 b)$.

The VA-2 storm produces greater discharge in Virginia than North Carolina for an equivalent rainfall (Figure 4.1a), demonstrating that the Virginia basins produce more runoff than the North Carolina basins. The 2-year storm also produces greater discharge in the Virginia basins than the North Carolina basins, even though North Carolina is receiving greater rainfall (Figure 4.1b). The 2-year discharge is lower in North Carolina due to a different rainfall-runoff response, indicating that the two regions, with different climatic and lithologic conditions, are not the same geomorphic unit.

Bankfull discharge magnitude is similar in Virginia and North Carolina (Fig. 4.1c), as if it is a fundamental feature of headwater systems. It is normalized among all the channels more so than along a single one. This is probably because the basins are similar within an order of magnitude in their drainage area, precipitation, and relief.

Although North Carolina 2-year discharges are smaller than Virginia, their bankfull sizes are comparable. Thus, bankfull height is not attained at same frequency in North Carolina as Virginia. So even though bankfull discharge magnitude is a fundamental feature of both systems, it occurs with different frequency depending on local conditions. This is 
different from perennial channels, which are thought to share a common bankfull recurrence interval of one to three years.

Bankfull height is met by the modeled 2-year discharges irregularly, sometimes overtopping the channel banks (Appendix C, Figs. C.7-8) and sometimes flowing far below them (Appendix I Fig. I.7-10). The VA-2 discharge matches bankfull features fairly well in the Virginia streams, while the NC-2 discharge typically overflows the channel form. This indicates that the storms selected for runoff modeling are good representatives of the 2-year storm and a less frequent recurrence flow for Virginia. However, bankfull occurs with a slightly different frequency between the Virginia basins. Bankfull height at Pepper Run is overtopped by the VA-2 storm and at Little Stony Tributary is better matched by the NC-2 storm. These channels may be adjusted to a different magnitude of bankfull discharges, because of differences in annual precipitation and storm intensities (Table 2.1).

The NC-2 storm matches bankfull height fairly well in North Carolina, indicating that the chosen storm does represent a two-year recurrence storm for the region. However, the NC-2 storm does not match bankfull features in North Carolina as well as the VA-2 does in Virginia. Bankfull height is better matched in the Joyce Kilmer channels than in the Coweeta channels, where the 2-year storm sometimes falls far below bankfull features. This is probably due to larger precipitation differences than in the Virginia basins, as Coweeta receives 20-40 cm greater annual rainfall than Joyce Kilmer (Table 2.1). Indian Spring is the only one of the North Carolina channels to have bankfull features that are overtopped by the 2-year storm. This could be due to its adjustment to a lower rainfall regime than Coweeta or to the absence of historic logging in the basin.

Average bankfull discharge roughly increases with total basin relief (Fig. 4.3). Greater relief creates steeper basin slopes that produce more runoff, and therefore greater bankfull discharge. However, geologic effects are present, as two Virginia basins (Sarver Hollow and Little Stony Tributary) have lower bankfull discharge than would be expected for their relief. These basins have large, resistant boulders that mantle their upper slopes of these channels. Storm flow travels partially under the boulders and therefore cannot carve large observable bankfull features. Smaller bankfull discharges are also present at the uppermost reaches of these channels, due to a low gradient morphology forced by the oversteeped slopes below. Land use impacts may also influence the relief-bankfull trend, as 
Indian Spring has low bankfull discharge values for its high relief, possibly due the lack of human impact on its runoff processes. Despite its positive correlation with relief, bankfull discharge has no correlation to channel slope.

\subsection{Channel Form - Width-Depth Ratio}

Width-depth ratios are comparable for all basins at the VA-2, 2-year, and bankfull flows, and do not change much in a given channel between discharges (Figs. 4.4a, 4.4b, 4.4c). The average width-depth ratio for the 2-year and bankfull discharges is 12.5 in Virginia and 13.5 in North Carolina. The overall average indicates that a width-depth ratio of approximately 13 is a fundamental characteristic of Appalachian headwater streams. This is similar to the range previously found in Appalachian streams at small drainage areas (Hack, 1957).

Width-depth ratios for North Carolina decrease irregularly downstream, but Virginia width depth ratios are variable (Figs. 4.4a and 4.4b). This is different from perennial channels, which increase in width-depth ratios downstream (Leopold and Maddock, 1953). The sense of minor changes in width-depth ratios from the 2-year to bankfull flows also differs throughout the channels, because in some cross sections bankfull discharge is greater than the 2-year and in some it is smaller (Figs. $4.4 \mathrm{~b}$ and $4.4 \mathrm{c}$ ). Near the channel head, bankfull flows are greater and width-depth ratios decrease at bankfull flows due to the increase in flow depth. In downstream regions, width-depth ratios increase at bankfull flows, as discharge and flow depth decrease at the 2-year flow. The change in width-depth ratio is an extension of the relation between bankfull discharge increase between the two storms and drainage area (Fig. 4.2a).

The general variability in width-depth ratios, particularly in Virginia, is not systematic with position in the watershed or other aspects of channel form. The width-depth ratios do not relate strongly to slope (Figs. 4.5a and 4.5b) or grain size (Figs. 4.6a and 4.6b), which is surprising, as previous work attributed width depth differences in perennial channels to bedrock differences (Hack, 1957). Any bedrock control of form in the headwater channels is not represented by channel slope or grain size relationship to width-depth ratio. 


\section{$\underline{4.3}$ Average Velocity}

Average velocity is comparable in Virginia and North Carolina for 2-year and bankfull flows and has relations similar to the previously discussed discharge relations. Virginia has slightly higher average velocities at the 2-year flow, but the difference is lost at bankfull flows (Figs. 4.7a 4.7b, 4.7c). This is due to smaller discharge in North Carolina for 2-year flows. Pepper Run has high average velocity at 2-year flows but it decreases at bankfull, due to decreasing discharge. North Carolina streams have the biggest average velocity increases from the 2-year to bankfull flow, due to discharge increases. Surprisingly, the large differences in annual and storm precipitation between Virginia and North Carolina do not translate to big velocity difference at bankfull flows.

There is a weak trend of increasing velocity with drainage area at the 2-year flows, as is seen in perennial channels. However, there is a general irregularity in velocity at all drainage areas that reflect variable headwater stream morphology. Velocity values are increased at bankfull flows in the headwater regions and decreased downstream. Given Branch velocity values show a particularly strong reversal from the 2-year to bankfull flow, because of the associated reversal in discharge values.

Average velocity is negatively correlated with slope in Virginia for the 2-year flow, but is not in North Carolina (Figs. 4.8a and 4.8b). The slope relation is most apparent in Given Branch, Sarver Hollow, and Little Stony Tributary. In contrast, average velocity at bankfull flows increases with slope values up to $0.3(30 \%)$, and then decreases at slope values above 0.3 (Figs. 4.9a and 4.9b). The relation is stronger in Virginia and weaker in North Carolina. The velocity increase with slope increase is easily understood, as greater channel slopes create higher flow velocities. The decrease in velocity at slopes above $30 \%$ is due to greater flow roughness caused by steep slopes. There is a stronger negative correlation in Virginia above 30\% slope because steep slopes are associated with large grain sizes that also cause flow roughness and decrease velocity.

Similarly, velocity is negatively correlated with grain size in Virginia, but weakly positive in North Carolina for the 2-year flow (Figs. 4.10a and 4.10b). The grain size relation is most evident in Little Stony Tributary, the channel most thoroughly mantled with resistant boulder input. The relation reverses in North Carolina, particularly Horse Cove and Indian Spring, because a geologic cause for the negative slope-velocity relation is not present in 
North Carolina. However, there is no velocity-grain size relation for Virginia or North Carolina at bankfull, due to irregular increases in discharge at bankfull flows.

\subsection{Stream Power}

Stream power for the VA-2 storm is comparable in all basins, even though discharge is higher in Virginia (Fig. 4.11a). Stream power for 2-year and bankfull discharges is comparable as well, except for a few anomalies; Pepper Run, Horse Cove, and two cross sections in Indian Spring and Coweeta Watershed 10 (Figs. 4.11b and 4.11c). Pepper Run stream power is high at 2-year flows due to large discharge values, but the effect disappears at bankfull flows. High stream power in Horse Cove may be related to its large grain sizes. It could also indicate a land use effect, as its stream power is generally higher than paired basin Indian Spring. Local high stream power at Coweeta Watershed 10 and Indian Spring is associated with step-pool channel forms and steep energy grades in the flow. These anomalies may indicate the potentially great variability in headwater stream power due to local channel conditions.

Stream power has no correlation with discharge at 2-year storms and a positive correlation at bankfull flows (Figs. 4.12a and 4.12b), as discharge is a component of stream power. There is scatter in the relationships because of other contributing factors to stream power such as slope and flow velocity. The complex distribution of velocity and slope effects steam power greatly at 2-year storms, as it does not increase uniformly downstream in the VA-2 or 2-year flows (Figs. 4.11a and 4.11b), even though discharge does. Even though bankfull stream power increases with discharge, it does not change uniformly downstream, either, because bankfull discharges have no systematic relation with drainage area (Fig. 4.11c). Virginia channels decrease more regularly downstream than North Carolina channels, but still show variability (Little Stony Tributary).

Stream power does not correlate with slope for the 2-year storm (Fig. 4.13a). For example, the highest stream power in Horse Cove, for example, does not occur at its highest slope. Stream power does correlate with low slope for bankfull discharges, but has variability at high slopes (Fig. 4.13b). At low slopes, stream power is systematically low, and generally increases with slope because high slopes increase shear stress. However, other 
factors, such as discharge magnitude, local step-pool morphology, and large grain sizes create the large range of stream power values found at high slopes.

Stream power and grain size are roughly correlated at 2-year and bankfull flows (Fig. $4.14 \mathrm{a}$ and $4.14 \mathrm{~b}$ ). In general, low power occurs at small grain sizes and high power occurs at large grain sizes. As with slope, the individual channels are irregular, with their highest stream power not necessarily at their largest grain sizes. Furthermore, the stream powergrain size relation could due to grain size controlling stream power or vice versa. Therefore, it is hard to conclude that influx of large particles forces channel morphology that increases power.

\subsection{Stream Competence}

Stream competence for VA-2, 2-year, and bankfull flows are highly variable, with a range of values from $30-100 \%$ (Figs. $4.15 \mathrm{a}, 4.15 \mathrm{~b}$, and $4.15 \mathrm{c}$ ). There is no clear difference between Virginia and North Carolina, suggesting that climatic differences do not translate to different fluvial erosion rates. There is oscillation in stream competence at different cross sections within channels at a given flow, and variable changes in stream competence at a specific reach during different storms. For example, the uppermost cross section in Little Stony Tributary has high steam competence (96\%) at the 2-year storm while the six downstream cross sections are below $75 \%$ stream competence. However, at bankfull, the uppermost cross section decreases to $71 \%$ competence while all the downstream cross sections increase.

At bankfull flows, reaches nearer the channel head are higher in stream competence and downstream reaches are lower, as with discharge and stream power. There is an increase in stream competence between the VA-2 and 2-year or bankfull flows, due to increases in discharge magnitude. Indian Spring has lower stream competence at the VA-2 storm than Horse Cove, but the two are comparable at the 2-year and bankfull flows. This may indicate an erosive threshold is crossed in Indian Spring between the VA-2 and 2-year storm that is crossed by Horse Cove at flows lower than the modeled storms.

Stream competence for the 2-year and bankfull flows decreases with increasing grain size (Figs. 4.16a and 4.16b), demonstrating that stream competence is largely controlled by what grain size is present, not what stream power is present. For example, Little Stony 
Tributary is particularly low in stream competence throughout the channel due to influx of boulders, and Given Branch is particularly high due to its fine substrate. For this reason, stream competence is a better measure of site-specific erosive capacity than stream power, and shows where fluvial work is most or least effective. However, it does not account for the bedrock portion of the bed, and as a result overestimates the ability of the stream to erode its bed in certain cross sections (Fig. 4.16a). 


\section{$\underline{4.6}$ Discussion}

\subsubsection{Discharge magnitude - bankfull height}

A specific storm such as the VA-2 produces higher discharge in the Virginia basins than the North Carolina basins. The 2-year storms also produce greater discharge in Virginia, even though North Carolina has a higher rainfall amount. The relations for the VA2 and 2-year discharges result from soil interpretations and calibration performed in hydrologic modeling (see sections 3.1-3.5). For example, Coweeta sandy loam soils are exceptionally deep and stream gauge records demonstrate their large storage capacity, while shallow clayey soil in Allen Hollow has high runoff rates that have been observed during storm flow (see Appendix D, Fig. D.12). Differences in the magnitude of VA-2 and 2-year discharges are also partially due to the geologic parent material present in a basin. For example, Allen Hollow, with impermeable shale bedrock, produces greater discharge for the same rainfall than Little Stony Tributary, which has sandstone and limestone bedrock with higher infiltration capacity (Fig. 4.1). These discharge magnitude relations are also linked to land use, as human impacted (grazed or logged) basins are modeled as having higher runoff rates.

Bankfull height is attained during different storms throughout the channels. The variation in bankfull discharge recurrence occurs between and within channels, indicating that the individual channels and the southern Appalachian Mountains as a whole are not in equilibrium with specific storms. In particular, storms with an expected two-year recurrence do not fill headwater reaches to bankfull but overflow the bankfull height in downstream reaches.

The discharge magnitude results indicate that irregular bankfull channel size is a fundamental feature of headwater streams. Their morphology, slope, and substrate are more strongly controlled by local geologic influences than drainage area. Therefore, bankfull at specific channel reaches is adjusted to higher or lower discharge amounts than other reaches. This is in direct contrast with perennial lowland streams, whose equilibrium channel form is adjusted to regularly occurring discharges and controlled largely by drainage area (Leopold 
and Maddock, 1953). As the estimate of bankfull discharge magnitude is based on field surveys of channel cross sections, it is not subject to hydrologic modeling uncertainty.

Although the North Carolina basins receive more rainfall than the Virginia basins, they achieve bankfull less frequently. Bankfull discharges are comparable between the two regions, yet the North Carolina basins produce a lower 2-year discharge. There are exceptions in both regions, however. Pepper Run is generally overflowed by the 2-year discharge while bankfull features in Little Stony Tributary are generally not met. Furthermore, the 2-year storm in North Carolina more closely matches bankfull features in the Joyce Kilmer channels than the Coweeta channels, which have noticeably lower discharges. The difference in rainfall-runoff response indicates that headwater systems adjust differently to local storms under different geologic and climatic boundary conditions, producing bankfull flows with different recurrence intervals. This makes them fundamentally different from lowland steams in the way they equilibrate to local conditions, possibly because they are smaller systems that are more sensitive to hillslope processes. Perennial trunk streams are fed by a number of tributaries, and therefore are buffered from the local conditions in the smaller basins. In contrast, headwater streams have few or no upland tributaries and the dominant channel response is to local hillslope conditions.

One example of a local effect that can control headwater channel response is variation in lithology and climate that results in soil development differences. High rainfall rates on metamorphic bedrock have created deeply weathered soils with immense storage capacity at Coweeta, averaging 2 meters deep (Hewlett, 1961). Joyce Kilmer soils, developed in a slightly drier regime on metamorphic bedrock, still average over 1.3 meters deep (Daniels, 1985). Virginia soils, developed on tilted sedimentary strata in a regime with about half the annual rainfall of Coweeta, range from $5 \mathrm{~cm}$ to $0.5 \mathrm{~m}$ deep (Creggar et al., 1985). The soil development in these basins controls the amount of runoff from rainfall, which is smaller in basins with deep soils (North Carolina), and greater in basins with shallow soils (Virginia). The 2-year rainfall will be better able to fill the channel to bankfull and erode the channel bed in Virginia, and less able to fill the channel to bankfull and erode the channel bed in North Carolina. However, since the Virginia basins receives less annual rainfall and less extreme storms than the North Carolina basins, it does not possess a much greater ability 
overall to do work on the streambed. Rather, the systems have both reached a unique equilibrium due to different bedrock susceptibility to weathering and weathering capabilities.

Local geology may also control channel form, so much so that bankfull does not have meaning in headwater streams as a channel flow associated with a specific recurrence interval. For example, steeply imbricated boulders from local outcrops can mantle the valley and stream channel, and are immobile at most regularly recurring flows. In these areas (e.g. upper Sarver Hollow, upper Little Stony Tributary, Horse Cove), modeled flows may be higher than bankfull features because of high roughness values caused by the bouldery channel. They may also overtop bankfull features due to the inability to account for belowboulder flow. The opposite relation is present in weak bedrock or where boulders are not present, because channel incision is possible. Channel sections characterized by finer particle sizes and lack of bedrock outcrops (Given Branch) are deeply downcut and modeled flows are unable to fill the main channel or access the floodplain.

Local geology also influences channel form through its control of slope, as in the case of the most upstream cross sections in Little Stony Tributary and Sarver Hollow. These reaches are above resistant bedrock breaks, and are characterized by narrow, low-gradient channels with alluvial substrate. Bankfull features in both of these reaches are overflowed by 2-year storms, in contrast to reaches in other streams with similar drainage area. The resistant bedrock forces ponding of water in the low gradient reaches above it, thus altering their bankfull relations so that it recurs more frequently. The change in basin hydrology above a resistant bedrock break is evidenced by a ferny bog above the initiation point of Little Stony Tributary and a moist site suitable for human habitation near the top of Sarver Hollow.

Bankfull discharge magnitude may also be affected by land use. Bankfull discharge is approximately two times greater in Horse Cove than Indian Spring at all reaches except for the most upstream. This could be an indicator of channel downcutting and enlargement in Horse Cove due to increased runoff from logging. However, width-depth ratios for the channels are similar and differences in bankfull discharge could reflect geologic control, such as Horse Cove's higher streambed particle sizes. Basins in Virginia with erodable geology also have reaches that may reflect the impacts of logging, such as Allen Hollow x 3 and Given Branch x4. The magnitude of bankfull discharge at these reaches is disproportionately 
greater than other reaches in the same basin. The increase in bankfull discharge at these sites is possibly due to channel downcutting that may have resulted from historic logging and land clearing. However, in the absence of an unlogged watershed with similar geology, this cannot be tested.

\subsubsection{Channel Form - Width-Depth Ratio}

Channel shape of headwater streams is fairly standard. Width-depth ratios are comparable for all basins, indicating that there is little climatic, geologic, topographic, or land use effect on the hydraulic geometry of the channels. The average width-depth ratio for all flows and cross sections is 14 , and appears to be a regular geometric feature of these headwater streams.

There is a general downstream variability in width-depth ratios in Virginia, while they decrease downstream in North Carolina. This is unlike perennial trunk systems, in which width-depth ratios increase in the downstream direction. The downstream decrease in width-depth in North Carolina is due to exceptionally wide channels in the upper basins near the initiation points. These reaches are wide even at bankfull flows, and may reflect channel initiation conditions of constant, low velocity seep flow instead of occasional high velocity overland flow. Seep flow was observed at North Carolina channel heads even during dry summer months, and may be due to a continual base flow from their deep, loamy soils. The high width-depth ratios may also indicate transport-limited conditions in these reaches, as seep flow would rarely generate enough power to incise the channel bed.

Width depth may be controlled by geology. For example, width-depth ratios are higher in channels with resistant bedrock, either in the form of resistant boulder input (Little Stony Tributary) or exposed bedrock substrate. Resistant bedrock is harder to erode, therefore channels have difficulty cutting down into the hillslope and are wider (transportlimited). However, width-depth ratios have the opposite relation in Coweeta Watershed 10, where cross sections with bedrock substrate ( $\mathrm{x} 2$ and $\mathrm{x} 4$ ), just above major bedrock waterfalls, have lower width-depth ratios than the surrounding alluvial cross sections. It is possible that local base level drop just below these points creates drawdown that can incise the bedrock channel, or that the bedrock just above the knickpoint is softer. Width-depth ratios are generally lower in basins with erodable geology, like Allen Hollow and Given Branch. 
However, this cannot be tested with a correlation plot, as there is no quantifiable number for differences in bedrock erodability. Surprisingly, width-depth ratio in headwater streams does not correlate well with either channel slope or particle size.

The effect of land use on width-depth variability is unclear. The unlogged Indian Spring has width-depth values similar to its paired, logged basin, Horse Cove, at all flows except for the VA-2. This indicates that logging has not created an incised hydraulic geometry at Horse Cove during channel forming flows. Some channels appear incised (Given Branch, Allen Hollow) and have erodable geology that might be sensitive to human impact, but there are no control basins for comparison.

\subsubsection{Average Velocity}

Average velocity relations generally increase with increased discharge, but are also controlled by slope and in Virginia, grain size. The positive correlation of bankfull velocity with slopes below $30 \%$ indicates that in this lower slope domain, fluvial processes dominate and are not greatly influenced by hillslope input. However, velocity is negatively correlated with slopes above $30 \%$, because in the higher slope regions, local hillslope processes dominate. For example, resistant boulder fields in steep sections of Little Stony Tributary and Sarver Hollow slow channel flow by creating roughness. This hillslope effect is also observable in the negative relation between flow velocity and grain size that exists in Virginia.

\subsubsection{Stream Power}

Stream power is comparable in the Virginia and North Carolina basins for all flows modeled, even though the Virginia basins produce greater discharge for VA-2 and 2-year storms. North Carolina streams produce similar stream power values with less discharge due to higher slopes that form over resistant bedrock. Stream power increases at smaller drainage areas from the 2-year to the bankfull flow, and decreases at lower drainage areas, indicating a difference in equilibrium for upper and lower reaches of the channels.

Although stream power values are comparable for most basins and some generalizations about their drainage area relations can be made, there is great variability among and within the basins. The channels have a complex response to local geologic 
conditions that cannot be explained by a simple stream power dependence on slope, grain size, discharge, or velocity. These parameters relate differently in different channel reaches.

In some cases, boulder input on steep slopes slows water velocity (Little Stony Tributary), so stream power is lower than would be expected for its high slope. In these areas the channel is transport-limited, as it cannot move the boulders present during regularly occurring flows. In other cases, steep boulder (Horse Cove) or bedrock (Coweeta 10 and 34) reaches have high stream power values that would be expected given their steep slope. In these areas, the channels seem to be better adjusted to move the coarse debris or erode the resistant bedrock that is present. Other reaches have exceptionally high stream power values for their slope and grain size values, due to local step-pool scour hydraulics.

Channels with more erodable geology typically have low stream power values that are adjusted to fine particle sizes and low slopes. However, bankfull stream power in some reaches (Coweeta 10 and 34, Given Branch) appears to be much greater than required for other reaches with equivalent particle sizes. These reaches may exemplify detachmentlimited conditions, as stream power could be high in order to erode resistant bedrock exposed in the channel floor (Coweeta 10 and 34). In other cases the channel may be over-adjusted for the particle sizes present, incising the channel bed at bankfull flows (Given Branch).

The complex stream power response may also be land-use-influenced, as Horse Cove has much higher stream power values than Indian Spring (apart from Indian Spring x3), suggesting it has greater erosive power for a similar storm. However, stream power may be higher in Horse Cove due to its larger particle sizes.

\subsubsection{Stream Competence}

A careful examination of stream competence relations shows that it is variable at any point in most of the channels and there are irregular changes between different flows in every channel. The difference in 2-year and bankfull discharge translates to differences in the percent of the streambed mobile in upper and lower sections of the channels. When the channel form is filled to bankfull at upstream cross sections, a higher percentage of the streambed is mobile than at bankfull flows in downstream cross sections. This could be an indicator of a different equilibrium condition - one in which the channel shape at small drainage areas is formed in less frequent flows that move a large portion of the streambed. 
That shape is then retained through smaller flows with more frequent recurrence intervals that shape the channel downstream.

The variation in stream competence is also due to variations in bedrock resistance related to its type, layer thickness and orientation, joint spacing, weathering, and cleavage. These characteristics control whether the channel is mantled with boulders, bedrock-floored, or fine-grained. For example, Little Stony Tributary, which has exceptionally low stream competence for most of its length, is largely comprised of quartzite boulders originating from a flat-lying bed of Tuscarora sandstone that creates a high-relief plateau. Little Stony tributary is thus armored and transport-limited below the Tuscarora outcrop, but has a much higher percent mobile on the plateau above, where channel substrate is small cobble. High stream competence, reflecting detachment-limited conditions, can be caused by resistant or highly erodable bedrock. Reaches in Indian Spring, Coweeta Watershed 10, and Coweeta Watershed 34 are floored by massive metasandstone or gneiss bedrock substrate that rarely produces large blocks. Therefore, these reaches have a high percent mobile and the majority of the stream power is exerted to erode the bedrock channel floor. In contrast, high steam competence in Given Branch is due to fine, easily transported, alluvial substrate from the erodable, interbedded sandstone and limestone bedrock.

The role of land use in stream competence variability is unclear. Stream competence in Indian Spring is comparable to Horse Cove in all but the smallest flow (VA-2), in which it is lower. Indian Spring has a higher width-depth ratio at the VA-2 flow than the 2-year or bankfull flow, suggesting that it is adjusted to more efficient channel erosion at larger, less frequent discharges. It is possible that the Horse Cove has increased erosion efficiency at lower flows due to changes in its hydraulic geometry that resulted from changes in the basin hydrology during logging. Decreased infiltration and increased runoff could cause channel incision and enlargement, as could reduced roughness due to tree and log removal. However, smaller storms such as the VA-2 are not necessarily important for channel maintenance in the higher precipitation regime of western North Carolina. Furthermore, slight differences in otherwise similar metamorphic bedrock, such as changes in joint spacing, cannot be ruled out as the cause for differences in stream competence and hydraulic geometry.

Overall, the channels are not at precise equilibrium along their length during specific storms. The channels are, however, moving most of the grains present at 2-year flows. 
Thus, they are in some broad state of equilibrium, actively functioning during regularly occurring flows, just as perennial lowland streams. Sediment transport in detachment-limited reaches, such as bedrock reaches and those with exceptionally large grain sizes, is achieved through selective transport of finer sediment during 2-year flows. As a result, erosion and formation of the channel form in these reaches occurs at a slower pace (bedrock) or less frequent recurrence interval (large particle size) than in finer, alluvial reaches that are transport-limited. Thus, bedrock resistance largely controls the rate at which the hillslopes erode and topography is lowered. 


\subsubsection{Summary Points}

1) Fundamental characteristics of headwater channel morphology

- At small drainage areas $\left(<0.4 \mathrm{~km}^{2}\right)$, channels are formed by larger, less frequent flows than the 2-year recurrence flow

- At larger drainage areas $\left(2 \mathrm{~km}^{2}>1.2 \mathrm{~km}^{2}\right)$, channels are formed by flows close to or slightly less than a 2-year recurrence interval

- Channel-forming flow recurrence is controlled by slope as well as drainage area

- Hydraulic geometry does not change regularly downstream as in lowland channels

- Channel width-depth ratios have an average value of 13

\section{2) Effect of climate}

- Greater precipitation does not translate to greater headwater channel discharge or stream competence

- 2-year discharge magnitude is lower in the higher precipitation regime of North Carolina due to increased weathering capability that creates deep soils

- Bankfull discharge is attained less frequently in North Carolina due to this low rainfall-runoff response

\section{3) Effect of hillslope interaction}

- Headwater channels are the interface between the hillslope and fluvial processes

- Hillslope processes, such as boulder input, local bedrock conditions, and soil moisture storage capacity, have a strong local influence on fluvial erosion and create a complex, variable hydraulic response in channel-forming flow recurrence and stream competence both between and within channels 


\section{4) Effect of bedrock}

- Short-wavelength variations in bedrock erosion resistance due to differences in lithology, cementation, jointing, and orientation cause a complex, variable response in channel hydraulics and morphology

- Resistant bedrock creates local base level control through the formation of bedrock knickpoints that are lowered more slowly than the surrounding bedrock

- Knickpoints lower channel gradient and particle size upstream, increasing the recurrence of channel-forming flows, and increase channel gradient and particle size downstream, decreasing the recurrence of channel forming flows

- Headwater streams with predominantly erodable bedrock have higher stream competence, reflecting transport-limited conditions

- Flat-lying resistant bedrock layers create greater relief basins than equivalent layers that are tilted due to reduced stream competence

- Bedrock weathering characteristics also control soil depth, as metamorphic bedrock in the Blue Ridge channels forms exceptionally deep soils that minimize storm runoff and therefore make channel forming flows less frequent

\section{5) Effect of local land use}

- Historic logging may create larger channels with greater bankfull discharges and stream power, as well as higher stream competence at frequently recurring flows

- Due to the complex and variable nature of headwater channel morphology, it is hard to isolate land use as the sole cause of channel morphology differences 


\section{6) Implications for long-term landscape evolution}

- Overall, headwater channels are removing fine hillslope material at a rate comparable to the removal of valley material by trunk streams

- In areas of highly resistant bedrock, the inability of the channel to move the material will lead to a increase in basin relief, and the bedrock will act as a local base level and decrease upstream erosion rates by limiting slope increase

- Boulder fields present in the Valley and Ridge cause very low stream competence in headwater channels and may persist until climate change activates their movement, therefore increasing basin relief

- Differences in bedrock and climate have created deep soils in the North Carolina Blue Ridge, which lowers stream competence through its control of basin runoff. This lowering of stream competence, thus hillslope erosion rates, may account for the higher elevations than in the Virginia Valley and Ridge

- Flat-lying resistant bedrock layers create basins with lower stream competence and higher relief, demonstrating the effect that leads to higher elevations in the Appalachian Plateau and suggesting that more steeply tilted Valley and Ridge sequences have higher erosion rates 


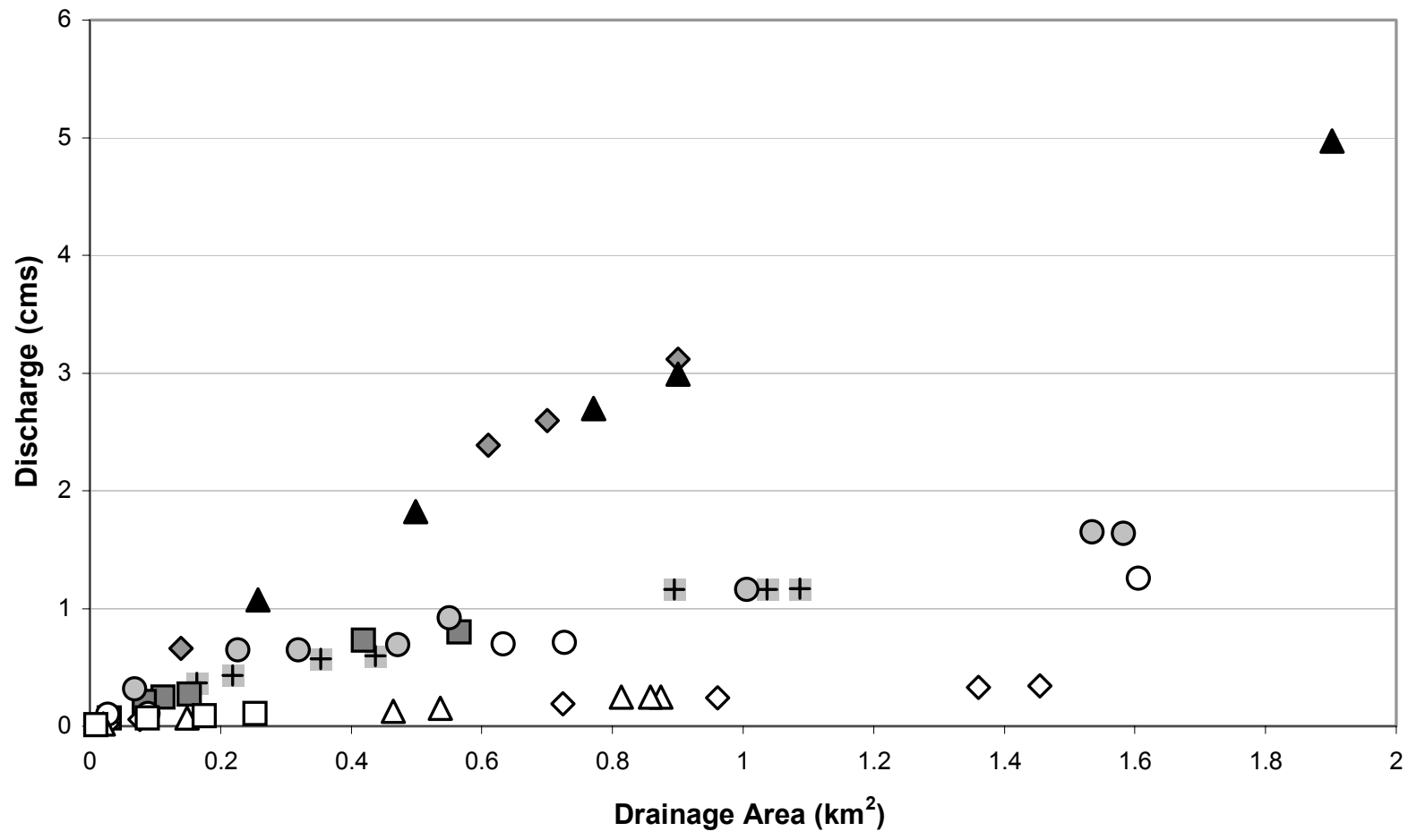

+ Stony Trib

口Given Branch

o Sarver Hollow

$\diamond$ Allen Hollow

$\Delta$ Pepper Run

$\diamond$ Indian Spring

O Horse Cove

$\Delta$ Coweeta 10

口Coweeta 34

Figure 4.1a. Discharge vs. drainage area for VA-2 stormflow at each cross section.

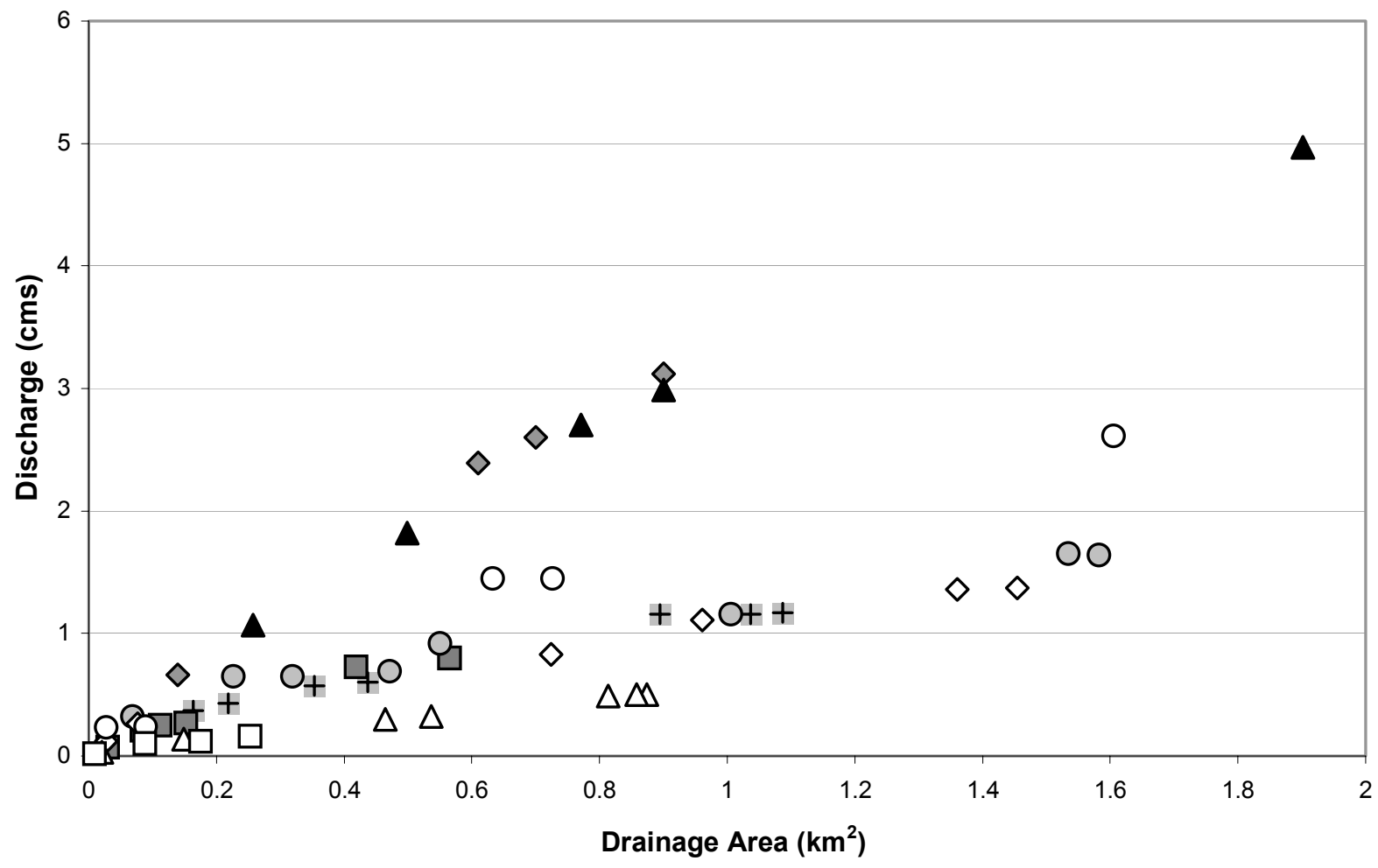

+ Stony Trib

口Given Branch

o Sarver Hollow

$\diamond$ Allen Hollow

$\Delta$ Pepper Run

$\diamond$ Indian Spring

O Horse Cove

$\Delta$ Coweeta 10

口Coweeta 34

Figure 4.1b. Discharge vs. drainage area for 2-year stormflow at each cross section - VA-2 for Virginia streams and NC-2 for North Carolina streams. 


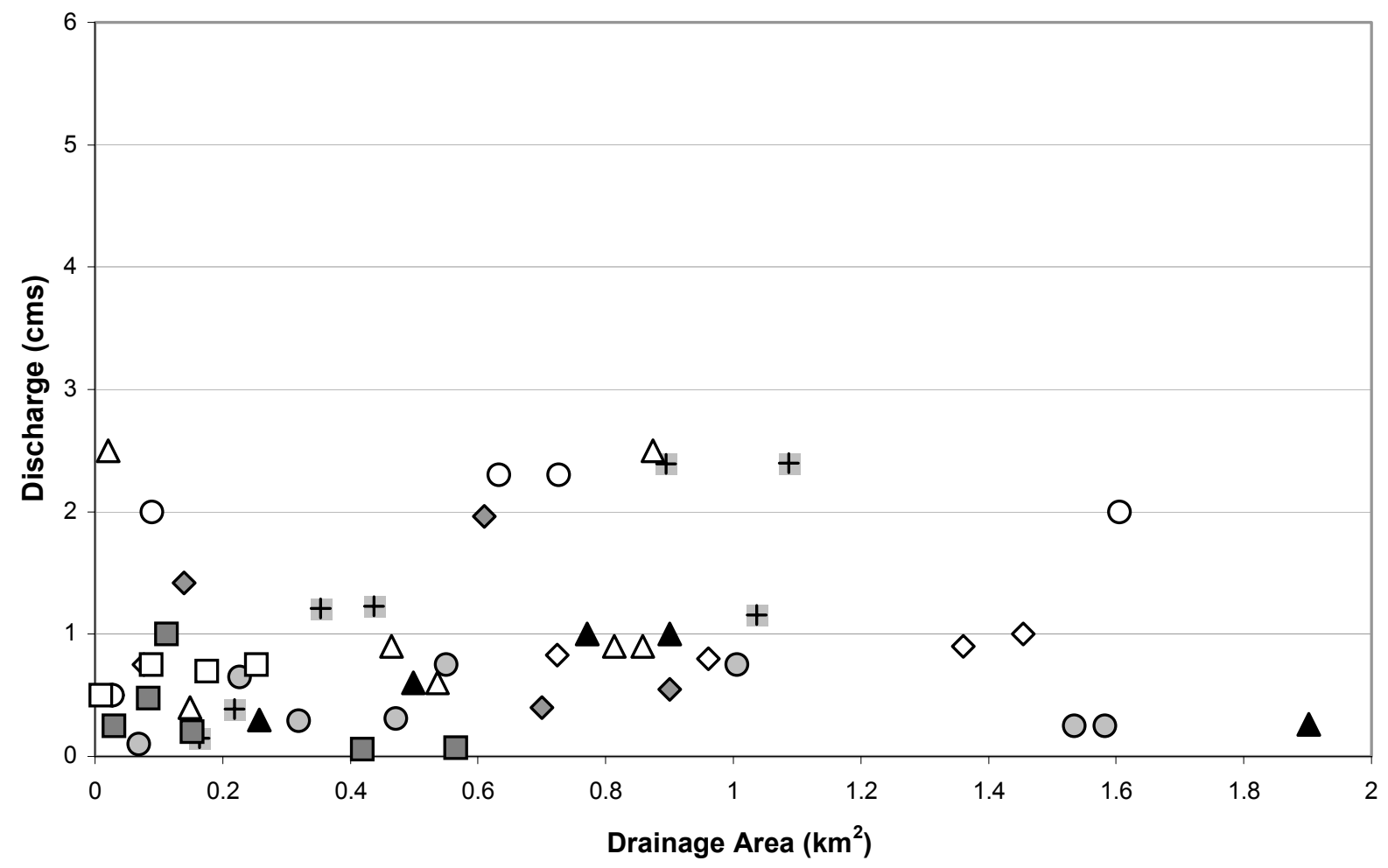

+ Stony Trib

口Given Branch

o Sarver Hollow

$\diamond$ Allen Hollow

$\Delta$ Pepper Run

$\diamond$ Indian Spring

O Horse Cove

$\Delta$ Coweeta 10

口Coweeta 34

Figure 4.1c. Discharge vs. drainage area for bankfull flow at each cross section.

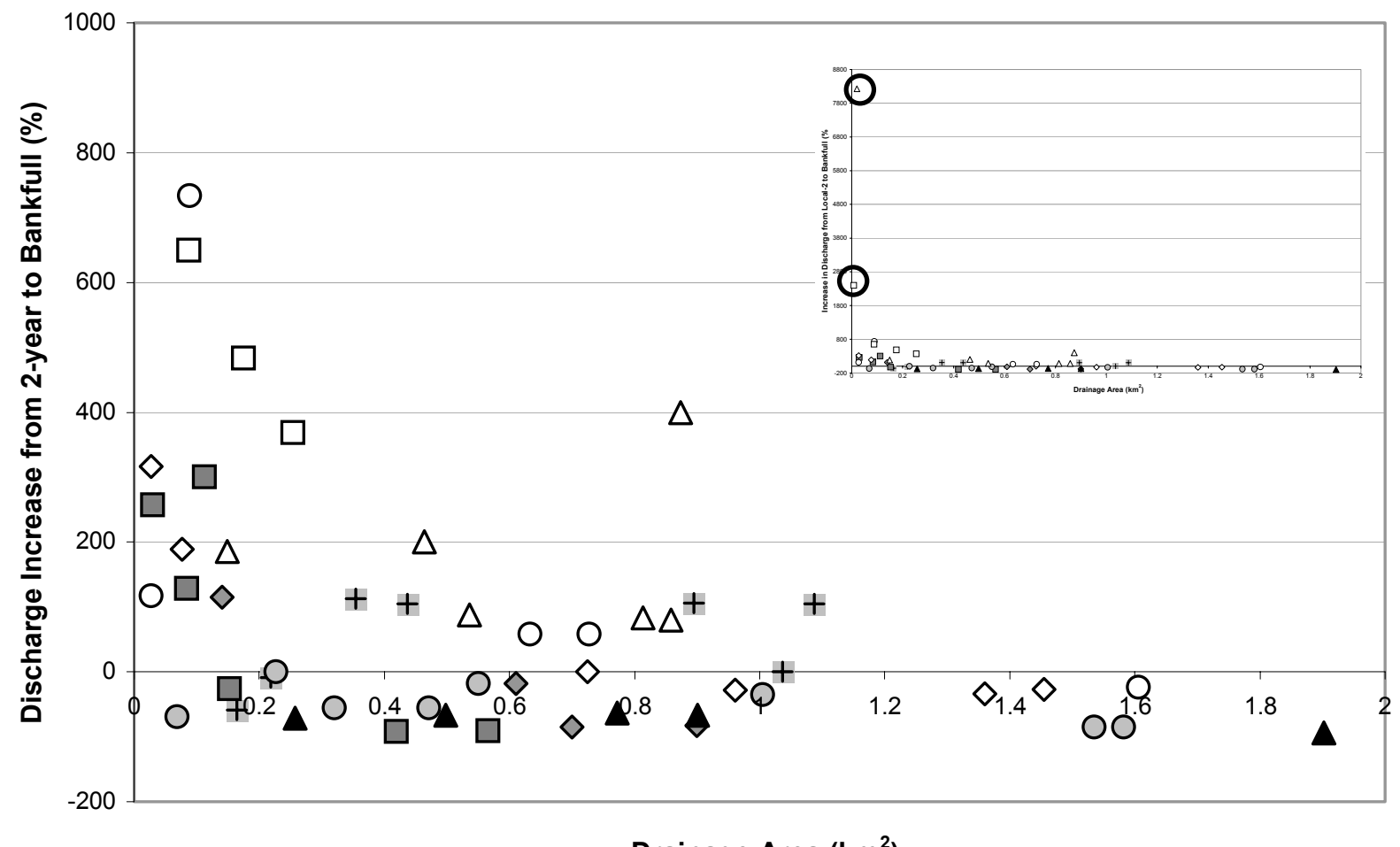

+ Stony Trib

口Given Branch

o Sarver Hollow

$\diamond$ Allen Hollow

$\Delta$ Pepper Run

$\diamond$ Indian Spring

O Horse Cove

$\Delta$ Coweeta 10

口Coweeta 34

Figure 4.2a. Percent increase in discharge from 2-year stormflow to bankfull flow vs. drainage area at each cross section. Positive values indicate that bankfull discharge is larger than 2-year discharge, and negative values indicate that bankfull discharge is smaller than 2-year discharge. Cross sections at smaller drainage areas have greater increases in discharge at bankfull flows. Two cross sections, Coweeta Watershed $10 \times 7$ and Coweeta Watershed $34 \times 4$, have much higher percent increases (see inset) and do not appear on the large graph. 


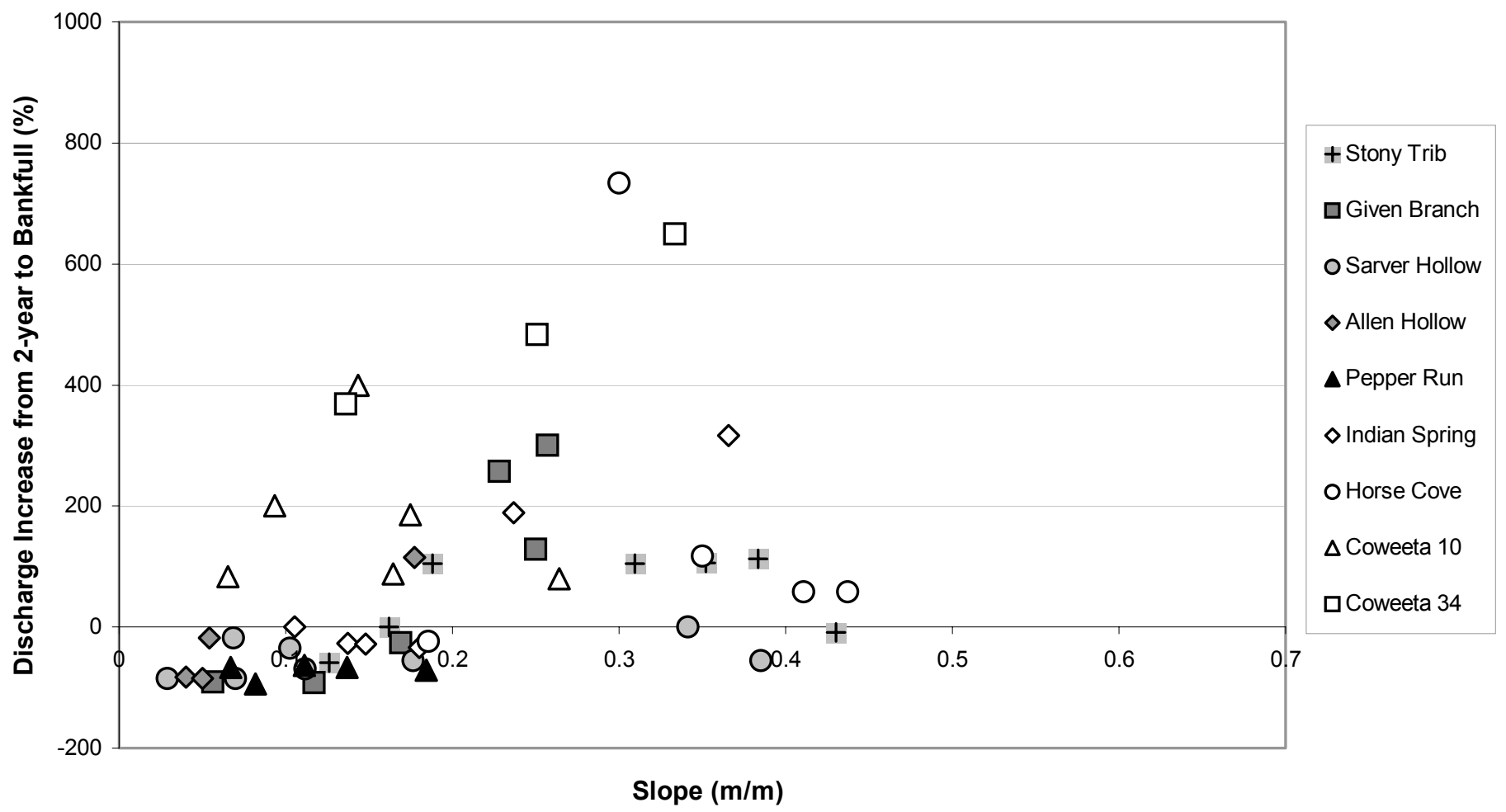

Figure 4.2b. Percent increase in discharge from 2-year stormflow to bankfull flow vs. channel slope at each cross section. Cross sections with higher slope values ( $>0.2)$ typically have increased discharge at bankfull, while most lower slope cross sections have smaller bankfull discharge. Coweeta Watershed 10 cross sections defy this trend.

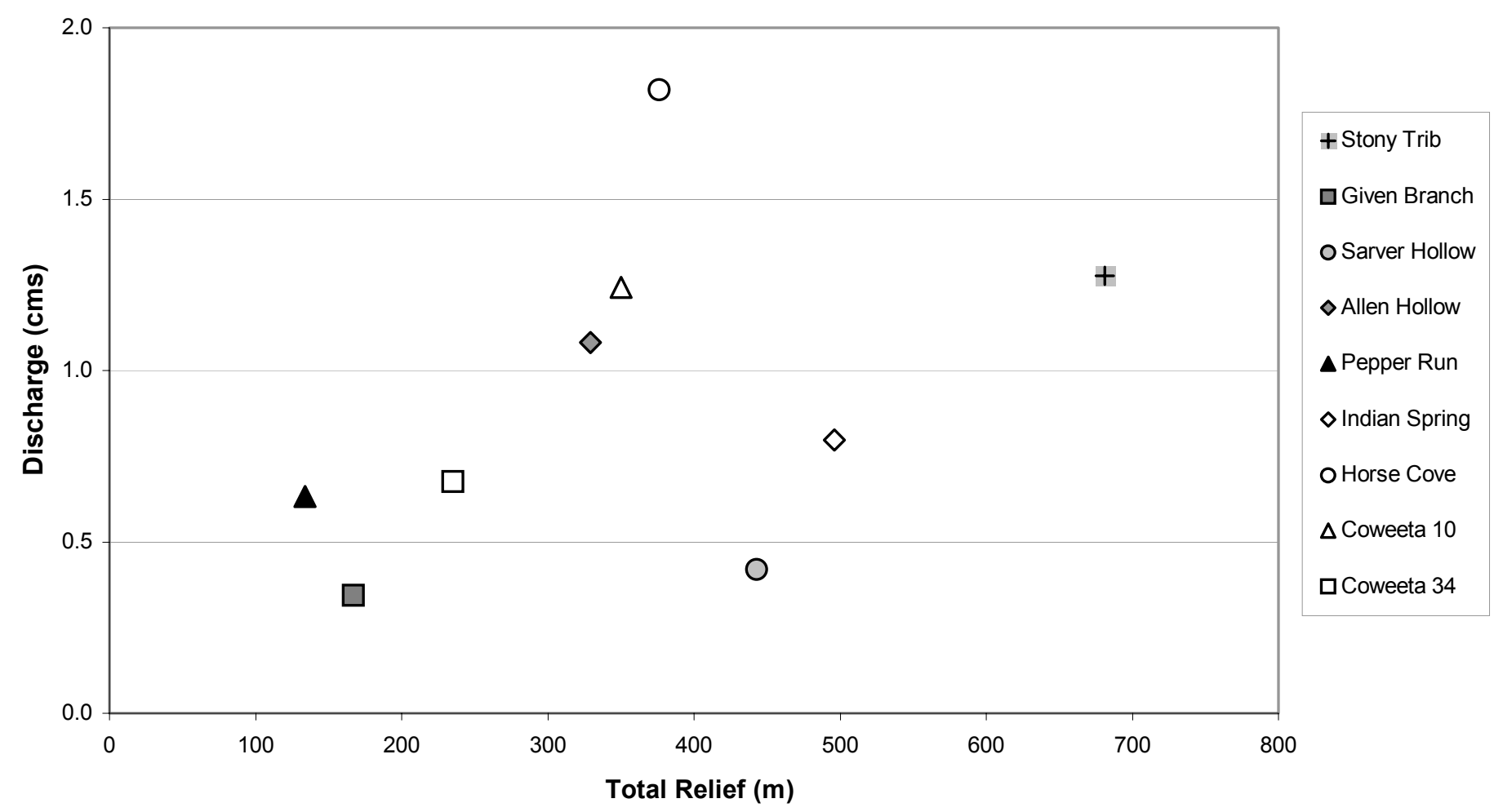

Figure 4.3. Average bankfull discharge of all cross sections in a channel vs. total basin relief. 


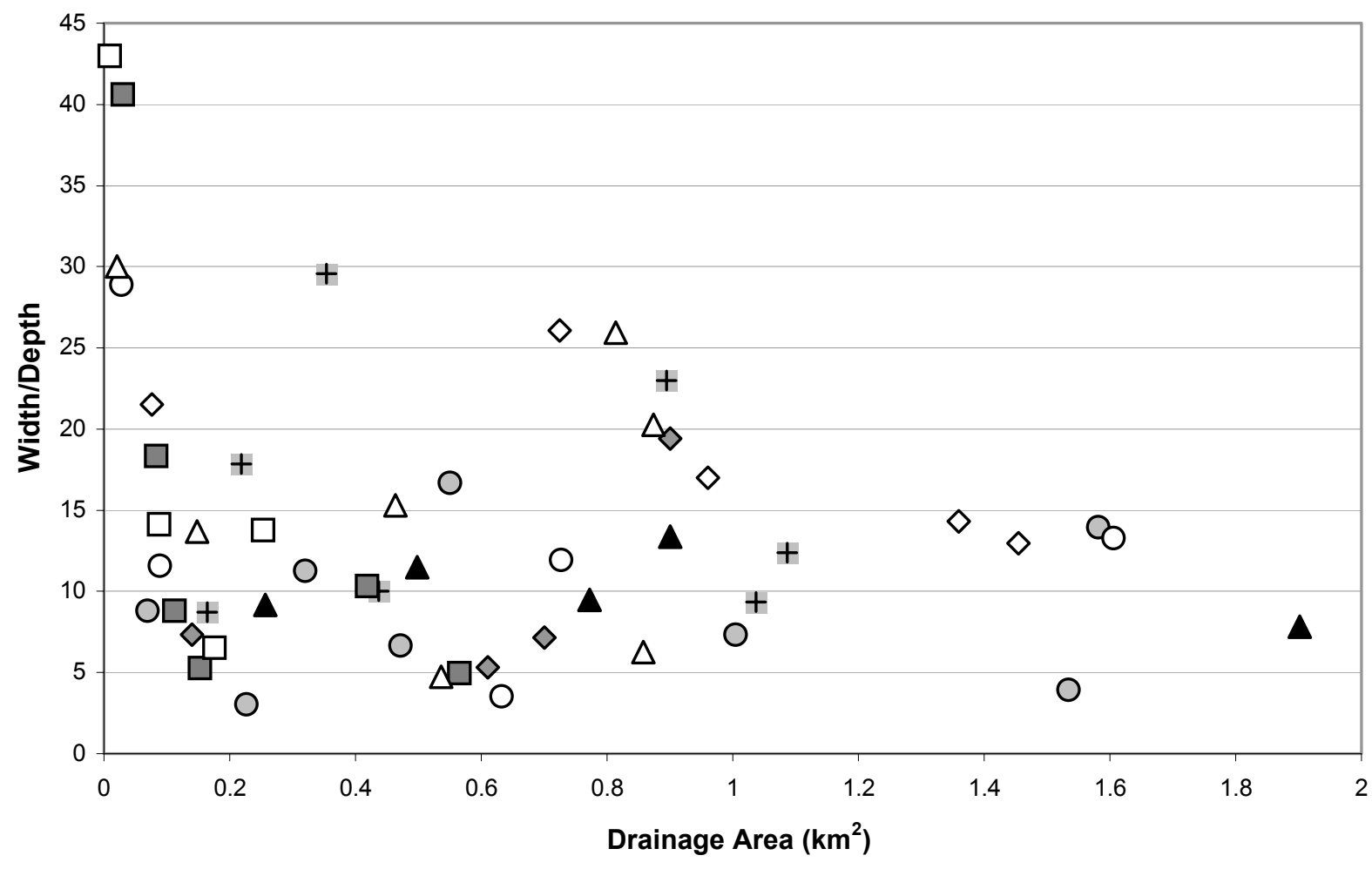

+ Stony Trib

口Given Branch

o Sarver Hollow

$\diamond$ Allen Hollow

Pepper Run

$\diamond$ Indian Spring

O Horse Cove

$\Delta$ Coweeta 10

$\square$ Coweeta 34

Figure 4.4a. Width-depth ratio vs. drainage area for VA-2 stormflow at each cross section.

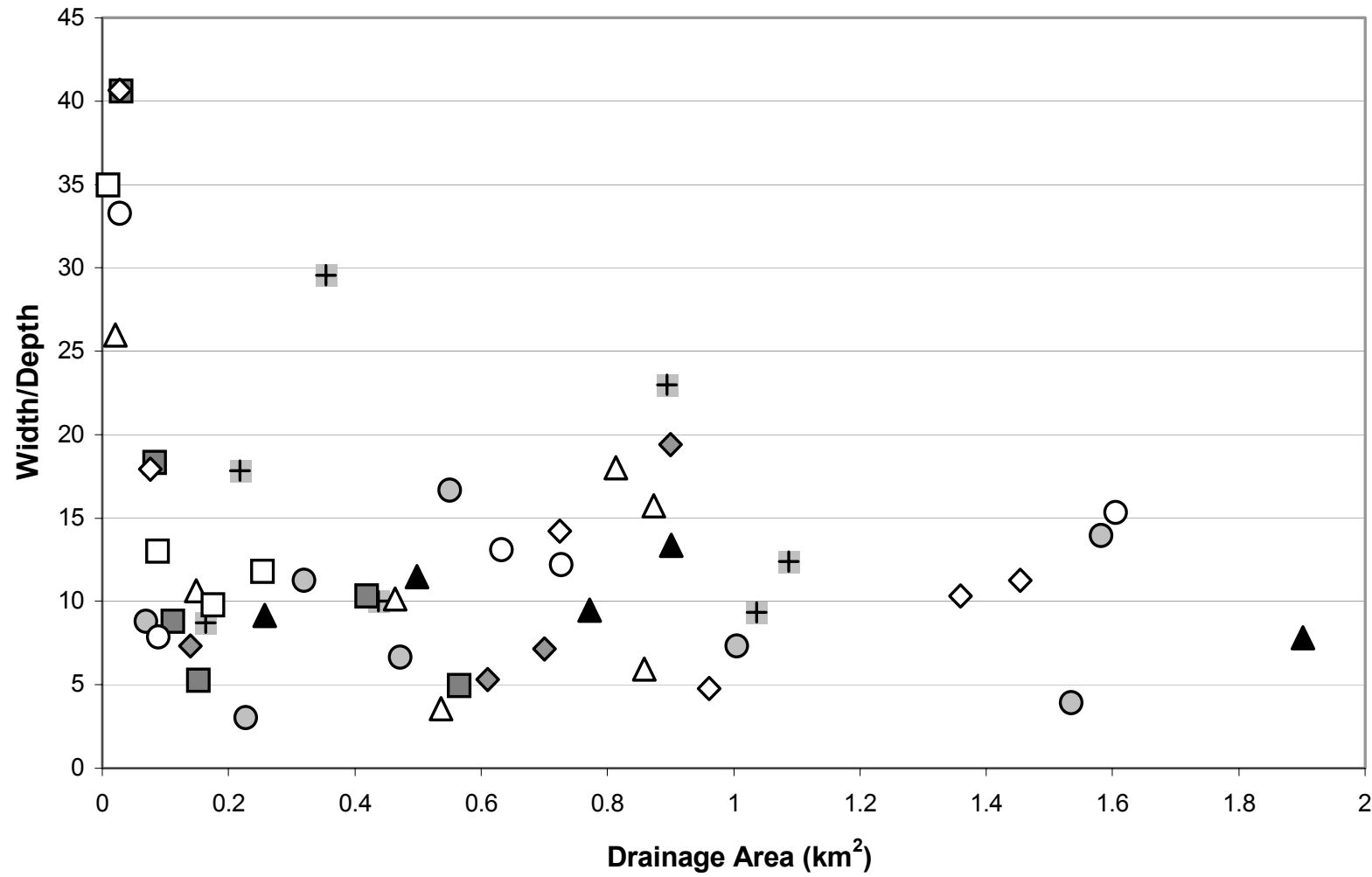

+ Stony Trib

口Given Branch

O Sarver Hollow

$\diamond$ Allen Hollow

$\Delta$ Pepper Run

$\diamond$ Indian Spring

O Horse Cove

$\Delta$ Coweeta 10

둘eeta 34

Figure 4.4b. Width-depth ratio vs. drainage area for 2-year stormflow at each cross section. 


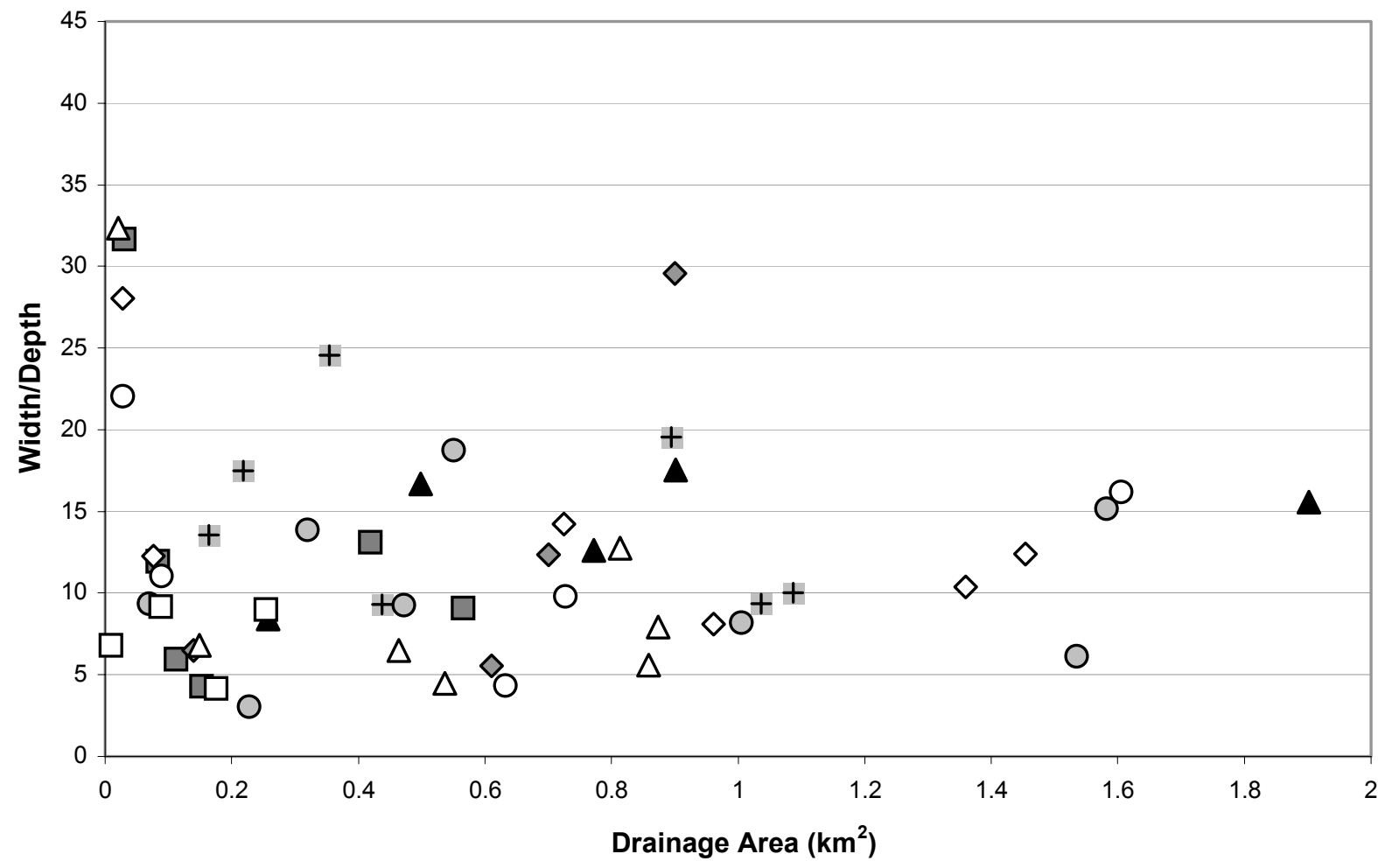

+ Stony Trib

口Given Branch

o Sarver Hollow

$\diamond$ Allen Hollow

$\Delta$ Pepper Run

$\diamond$ Indian Spring

O Horse Cove

$\Delta$ Coweeta 10

口Coweeta 34

Figure 4.4c. Width-depth ratio vs. drainage area for bankfull flow at each cross section.

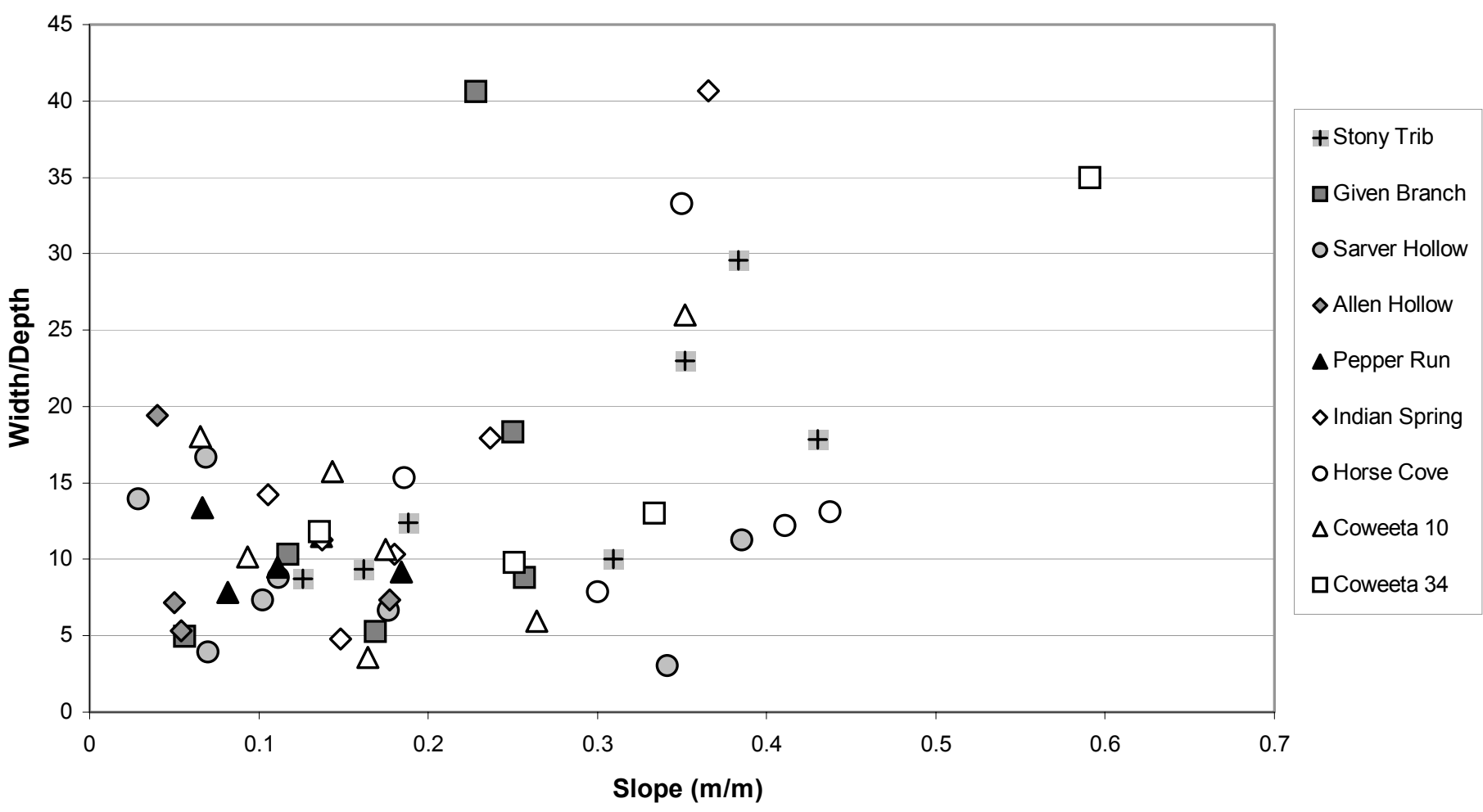

Figure 4.5a. Width-depth ratio vs. slope for 2-year stormflow at each cross section. 


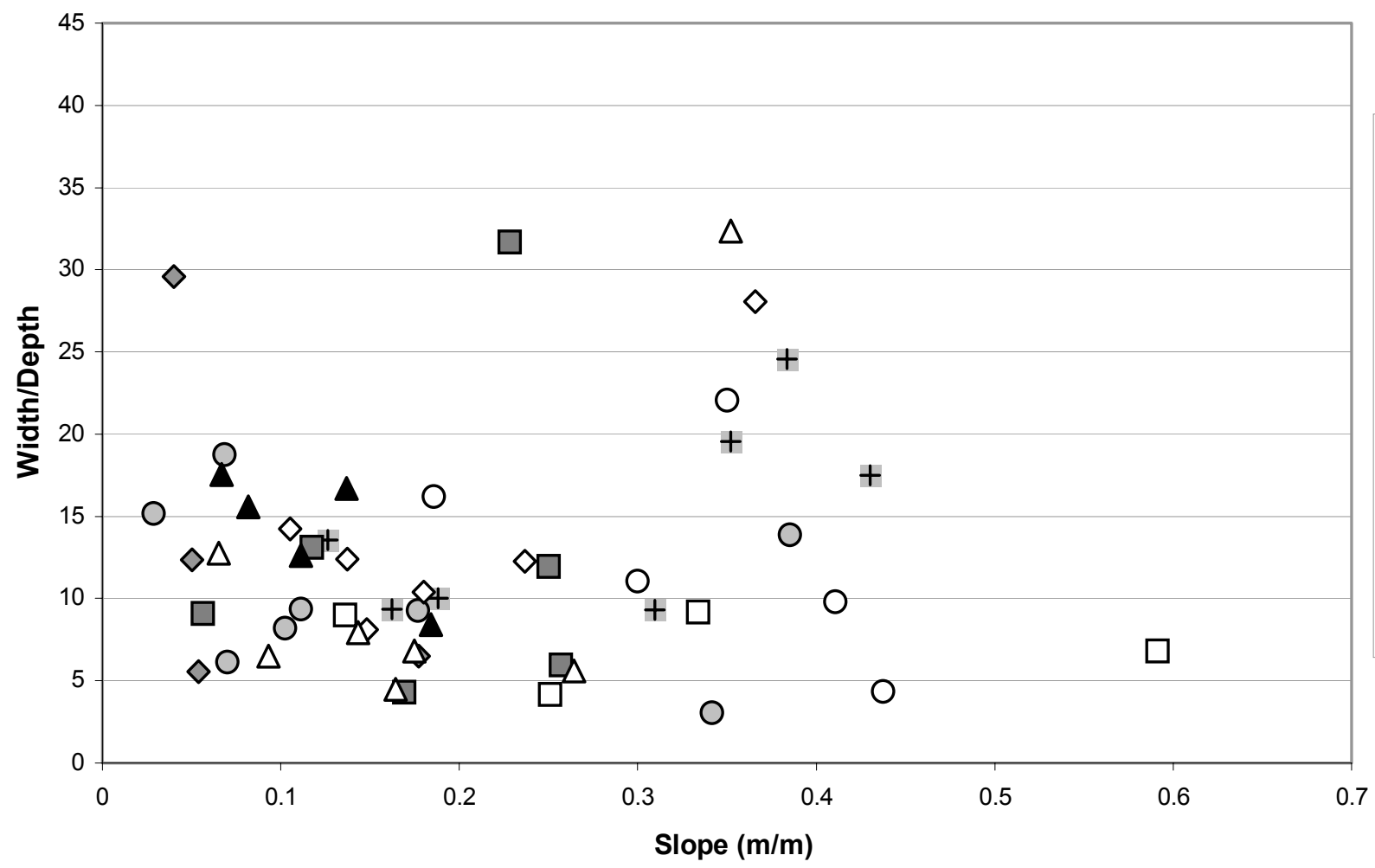

+ Stony Trib

$\square$ Given Branch

O Sarver Hollow

$\diamond$ Allen Hollow

$\Delta$ Pepper Run

$\diamond$ Indian Spring

O Horse Cove

$\Delta$ Coweeta 10

口Coweeta 34

Figure 4.5b. Width-depth ratio vs. slope for bankfull flow at each cross section.

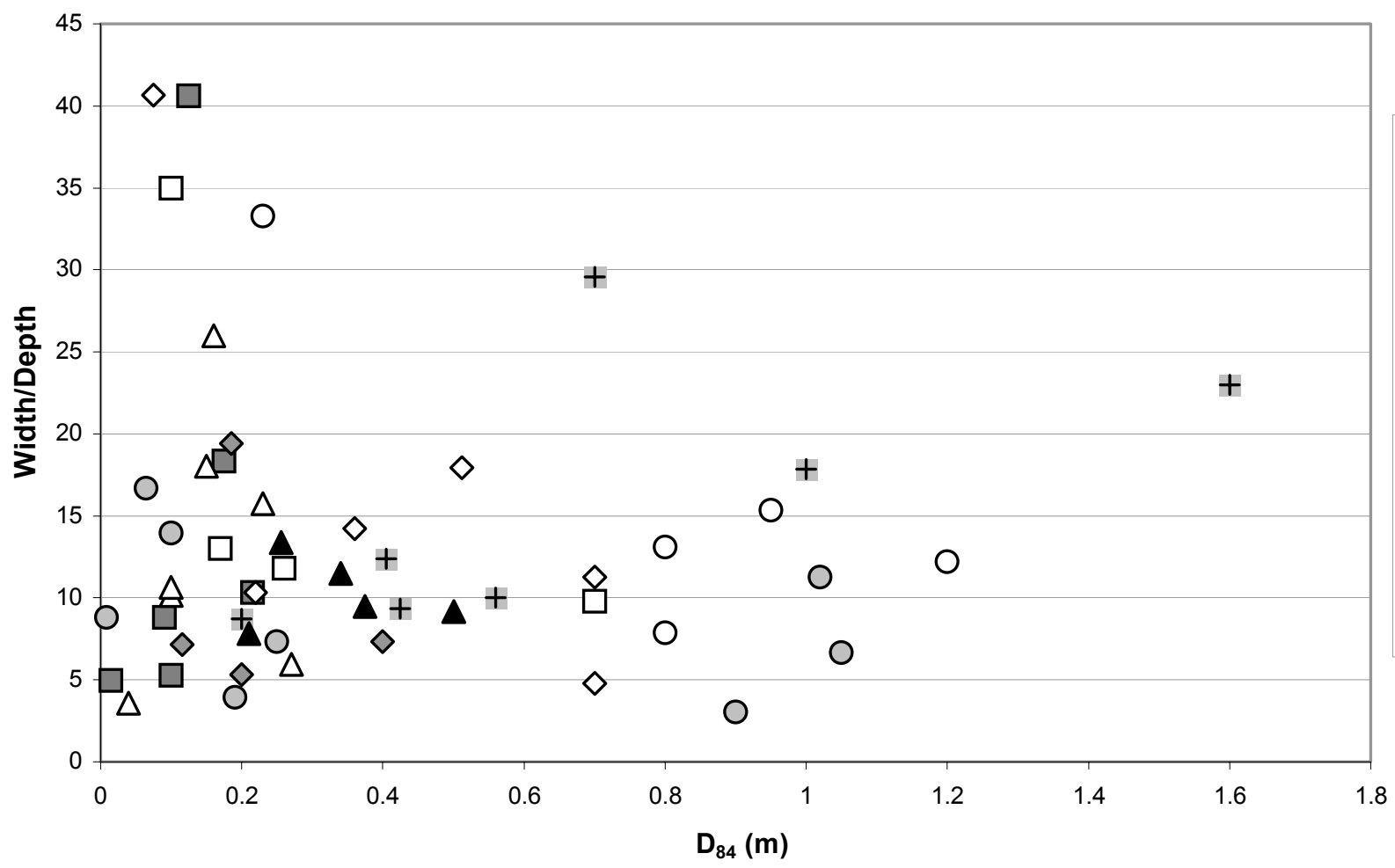

+ Stony Trib

$\square$ Given Branch

o Sarver Hollow

$\diamond$ Allen Hollow

\ Pepper Run

$\diamond$ Indian Spring

O Horse Cove

$\Delta$ Coweeta 10

$\square$ Coweeta 34

Figure 4.6a. Width-depth ratio vs. $\mathrm{D}_{84}$ grain size for 2 -year stormflow at each cross section. 


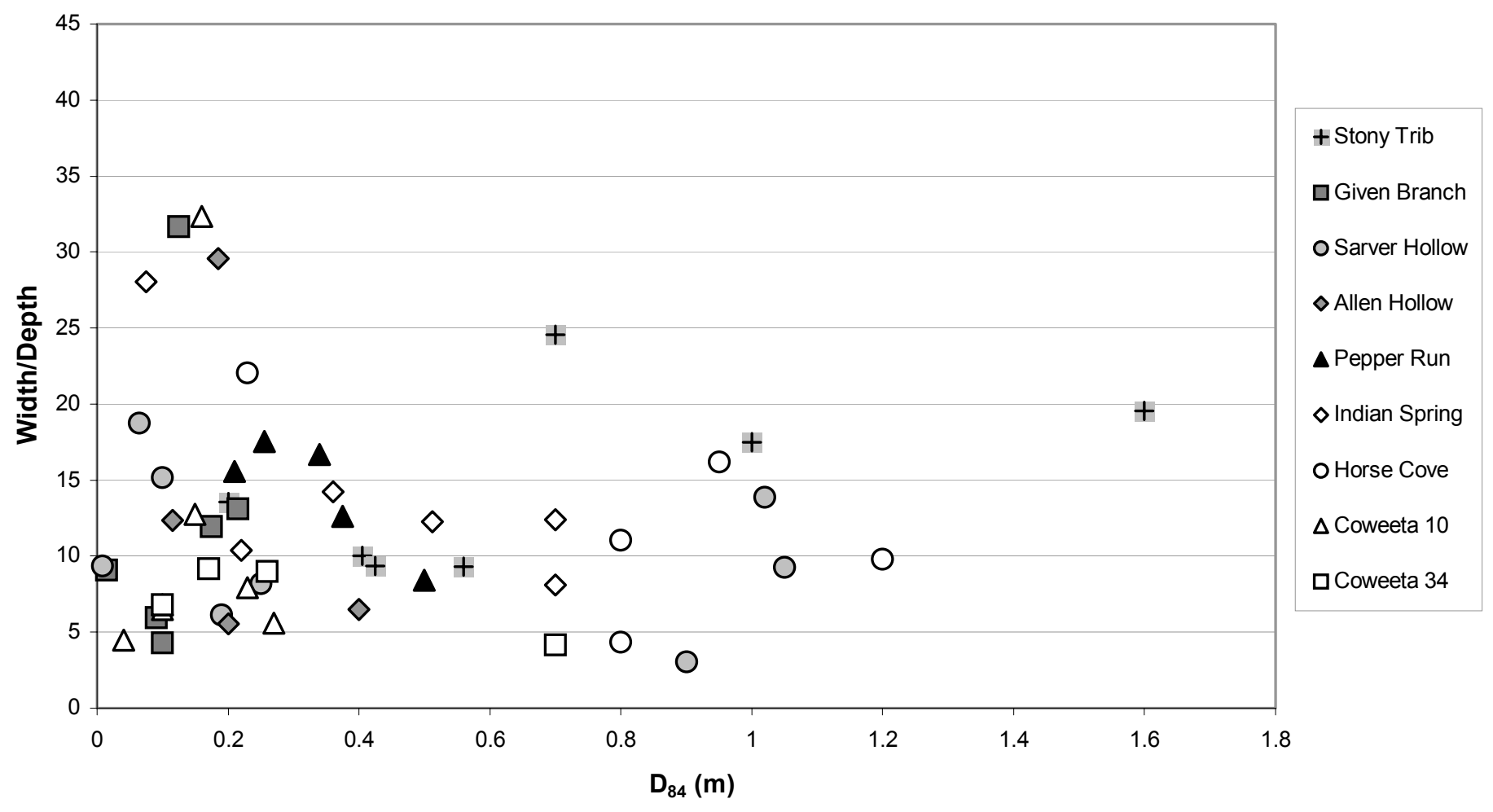

Figure 4.6b. Width-depth ratio vs. $\mathrm{D}_{84}$ grain size for bankfull flow at each cross section.

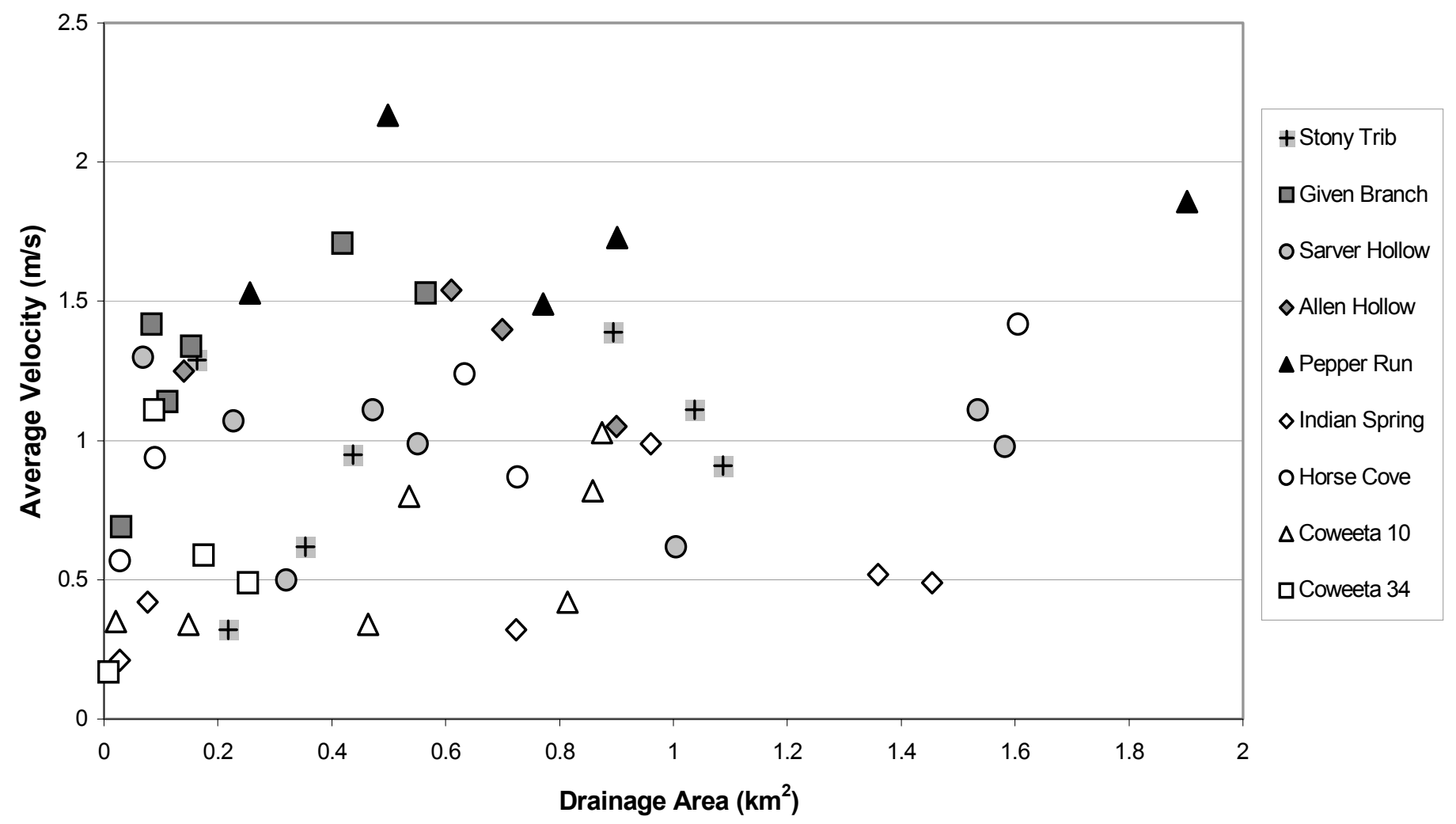

Figure 4.7a. Average velocity vs. drainage area for VA-2 stormflow at each cross section. 


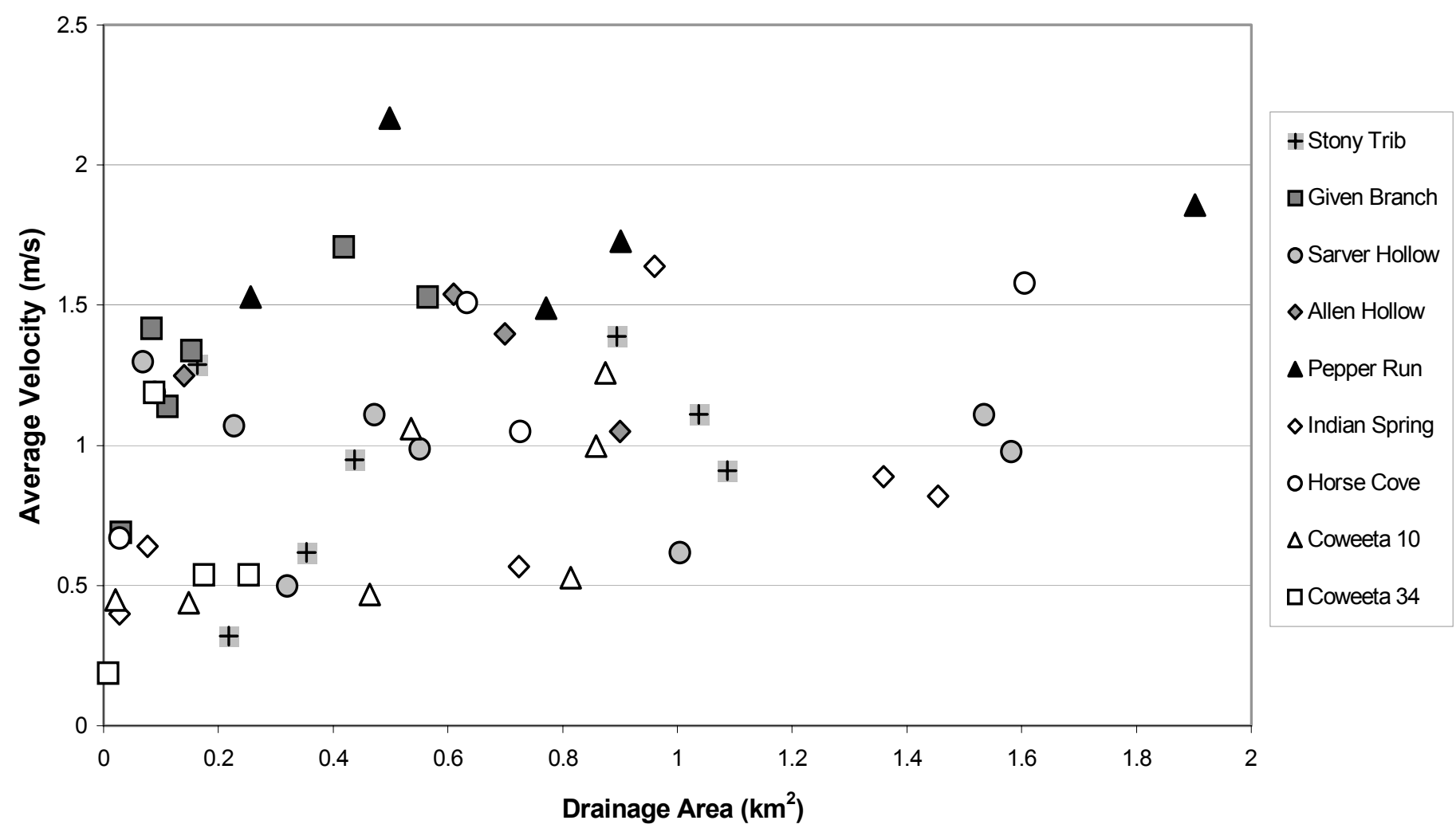

Figure 4.7b. Average velocity vs. drainage area for 2-year stormflow at each cross section.

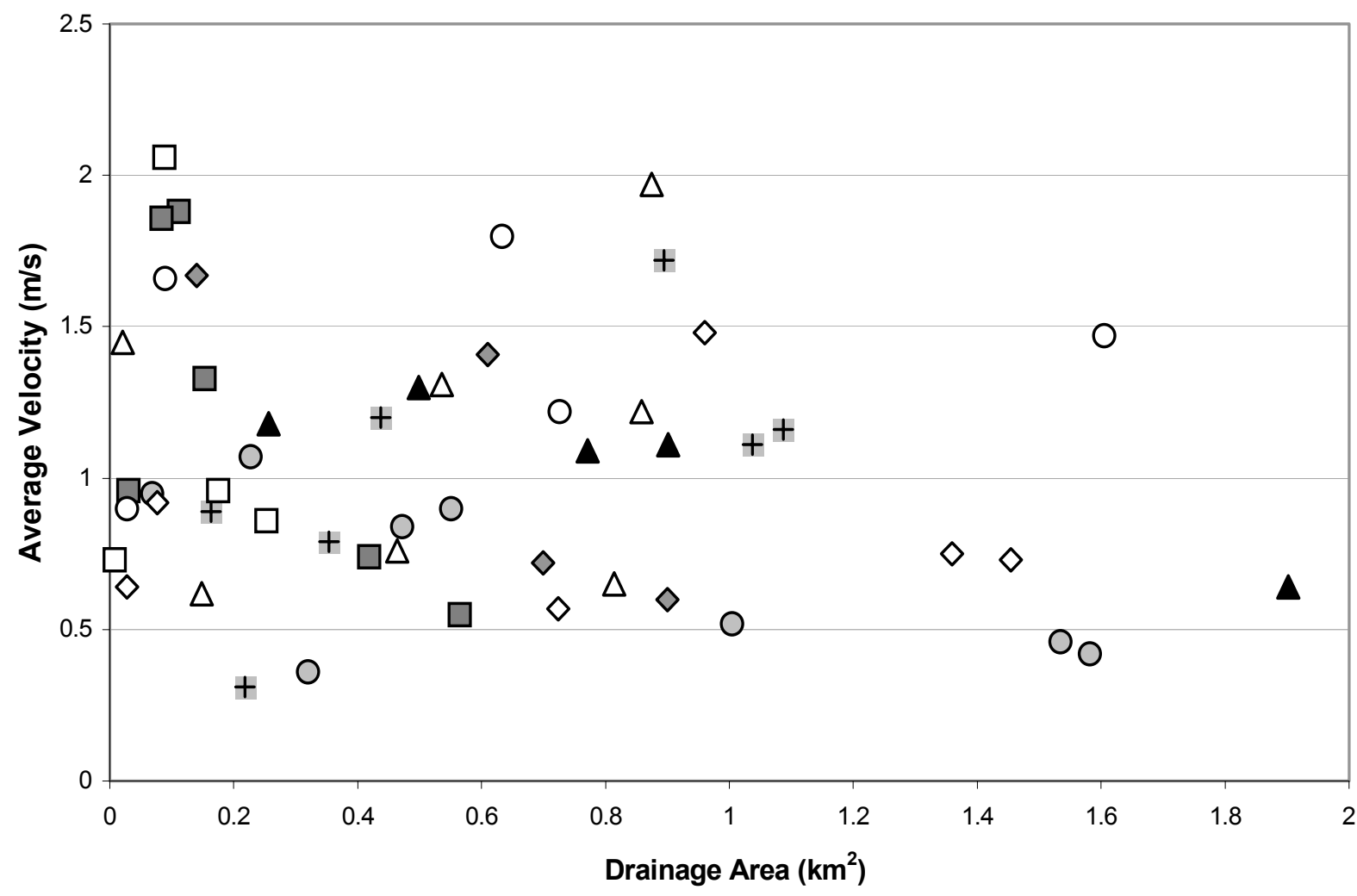

+ Stony Trib

口Given Branch

o Sarver Hollow

$\diamond$ Allen Hollow

$\triangle$ Pepper Run

$\diamond$ Indian Spring

O Horse Cove

$\Delta$ Coweeta 10

口Coweeta 34

Figure 4.7c. Average velocity vs. drainage area for bankfull flow at each cross section. 


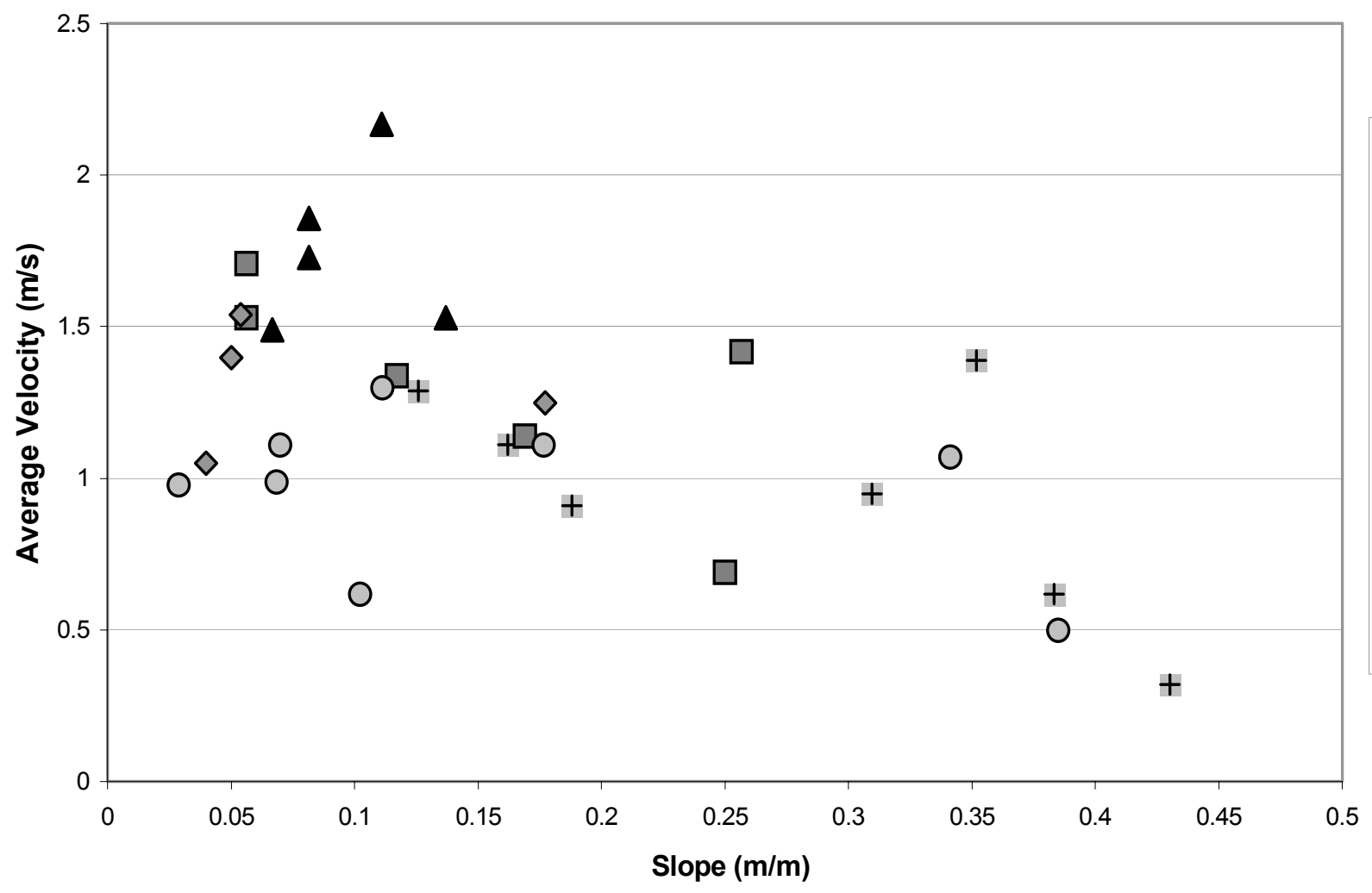

+ Stony Trib

口Given Branch

O Sarver Hollow

$\diamond$ Allen Hollow

$\Delta$ Pepper Run

Figure 4.8a. Average velocity vs. slope for 2-year stormflow at Virginia cross sections.

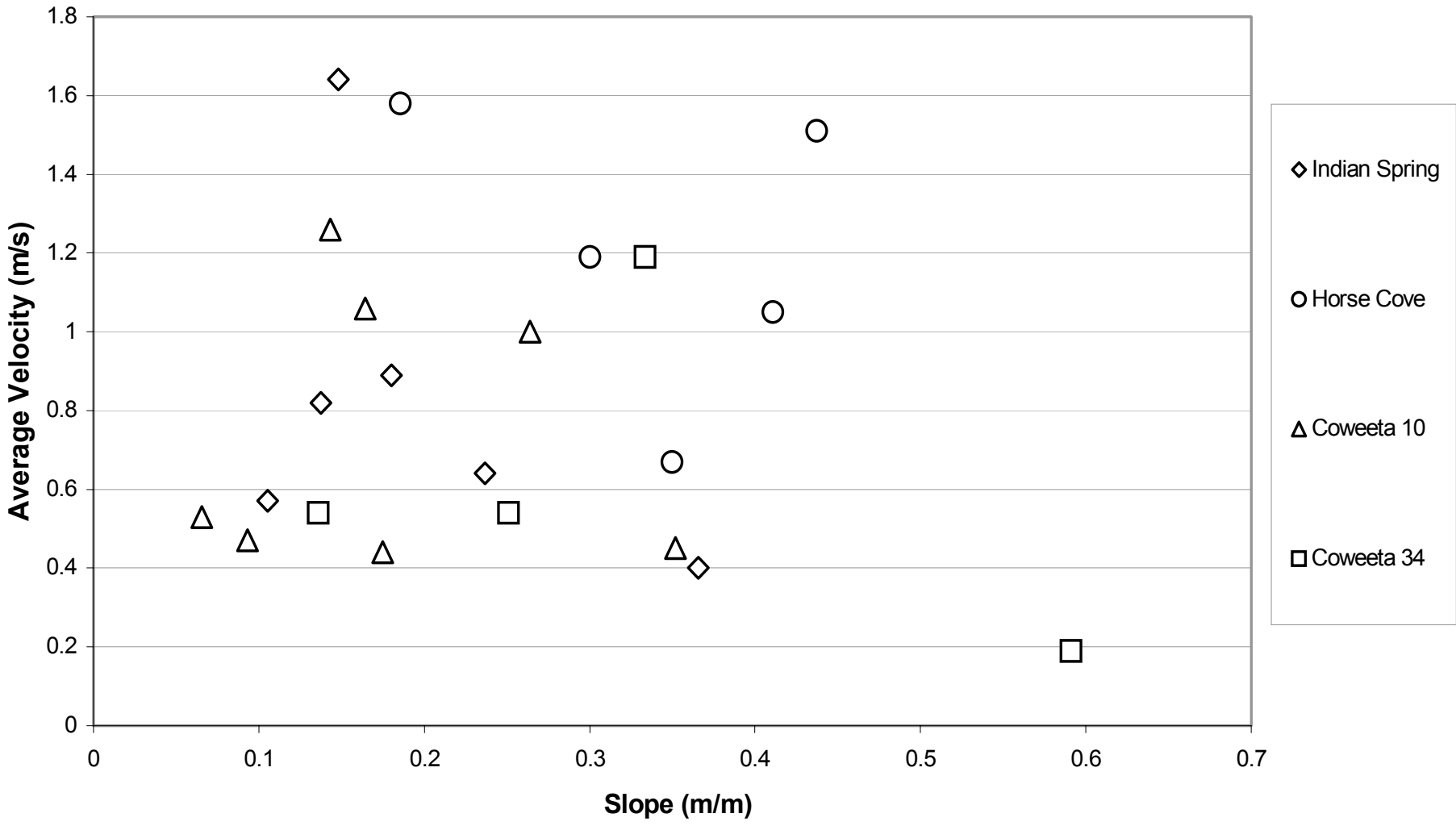

Figure 4.8b. Average velocity vs. slope for 2-year stormflow at North Carolina cross sections. 


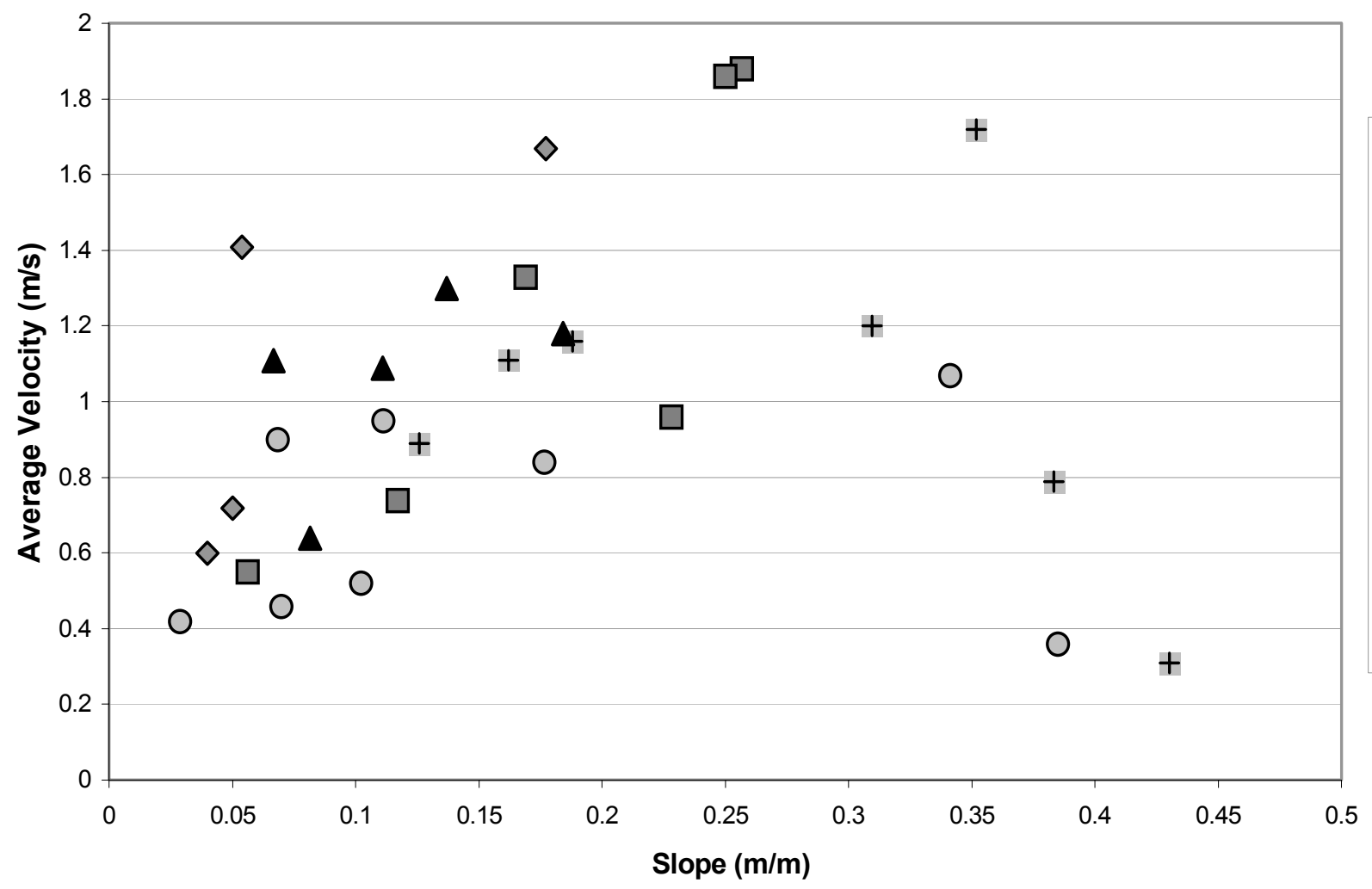

+ Stony Trib

口Given Branch

O Sarver Hollow

$\diamond$ Allen Hollow

$\Delta$ Pepper Run

Figure 4.9a. Average velocity vs. slope for bankfull flow at Virginia cross sections.

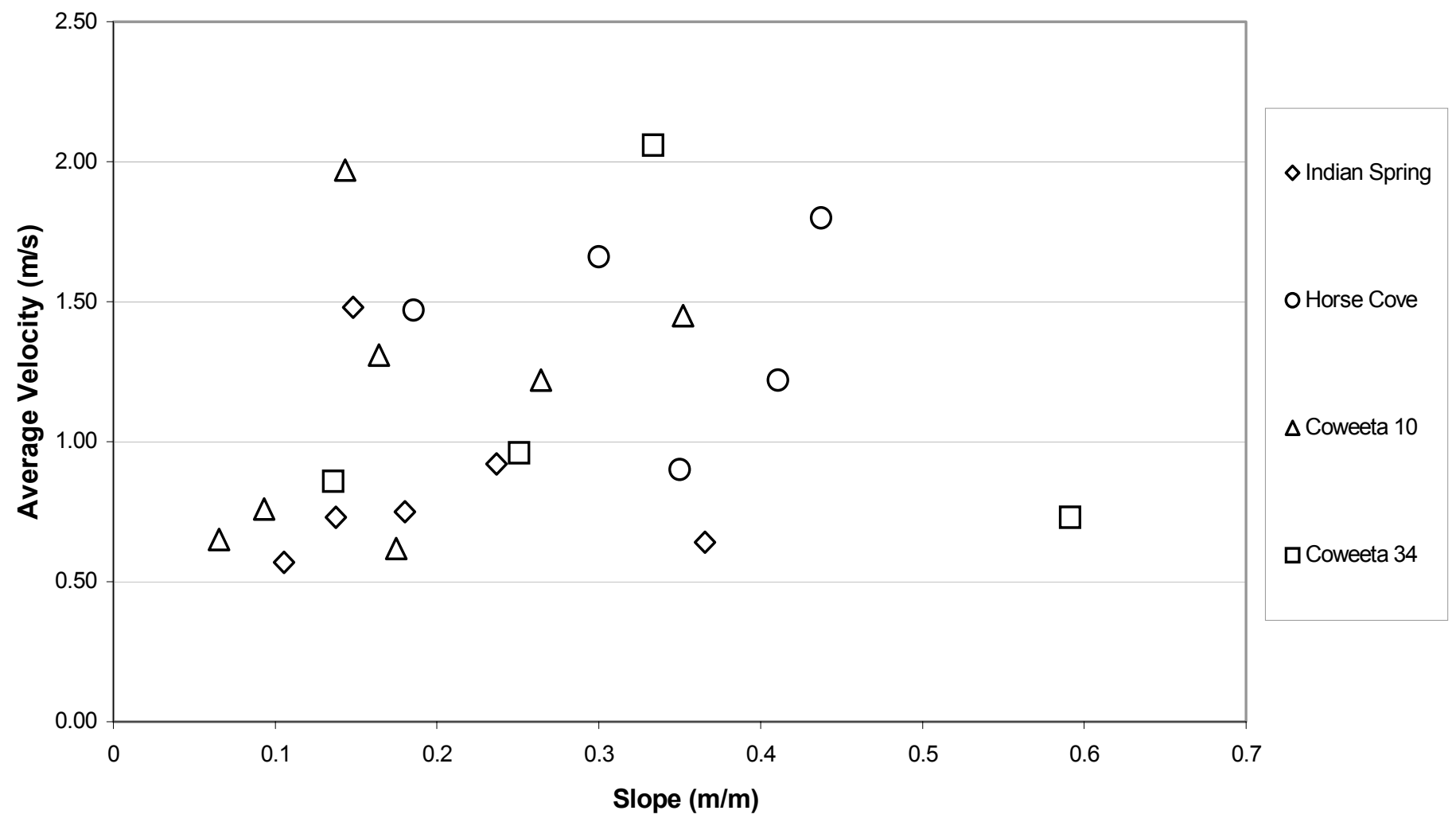

Figure 4.9b. Average velocity vs. slope for bankfull flow at North Carolina cross sections. 


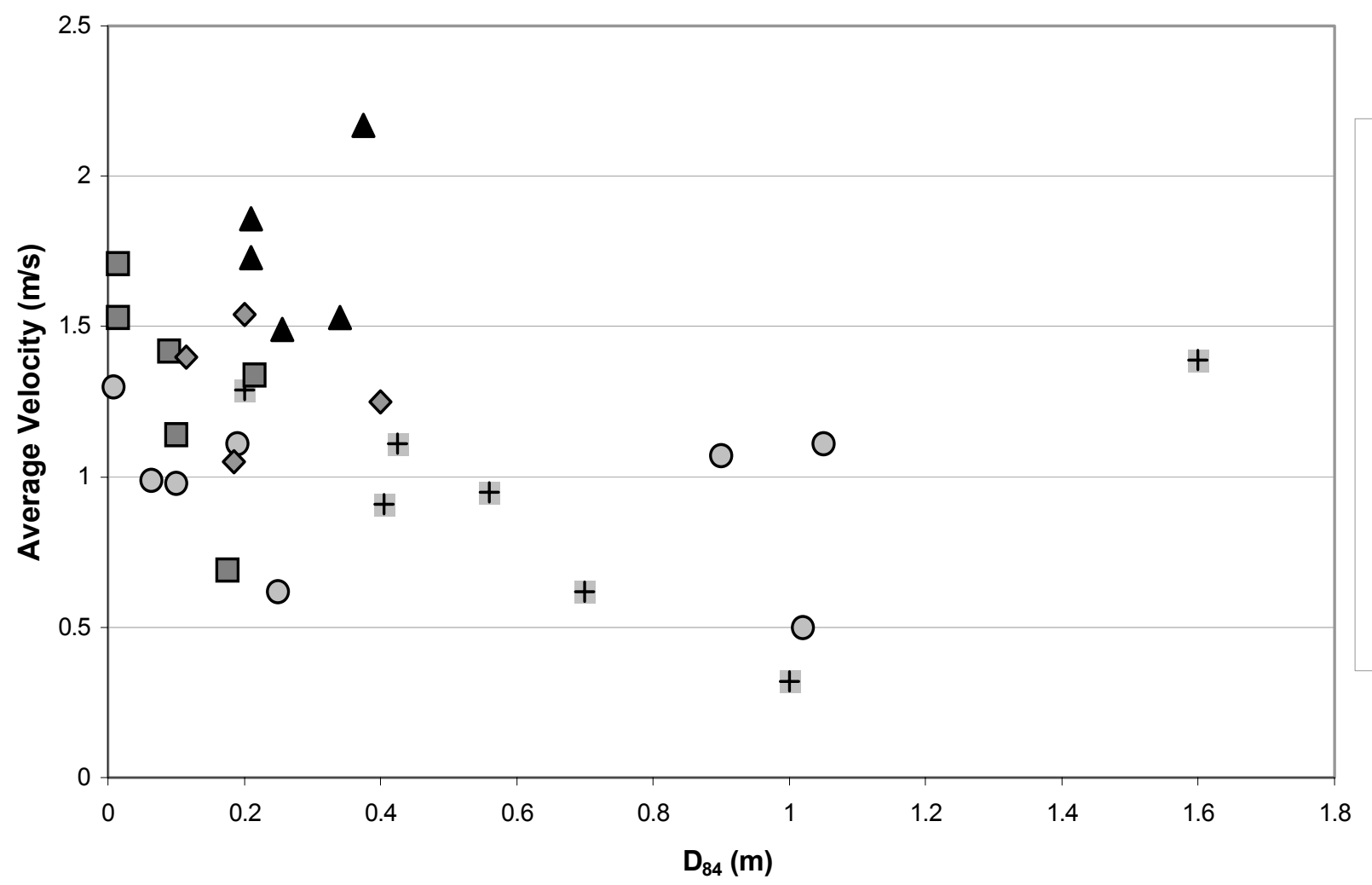

Figure 4.10a. Average velocity vs. $D_{84}$ grain size for 2-year stormflow at Virginia cross sections.

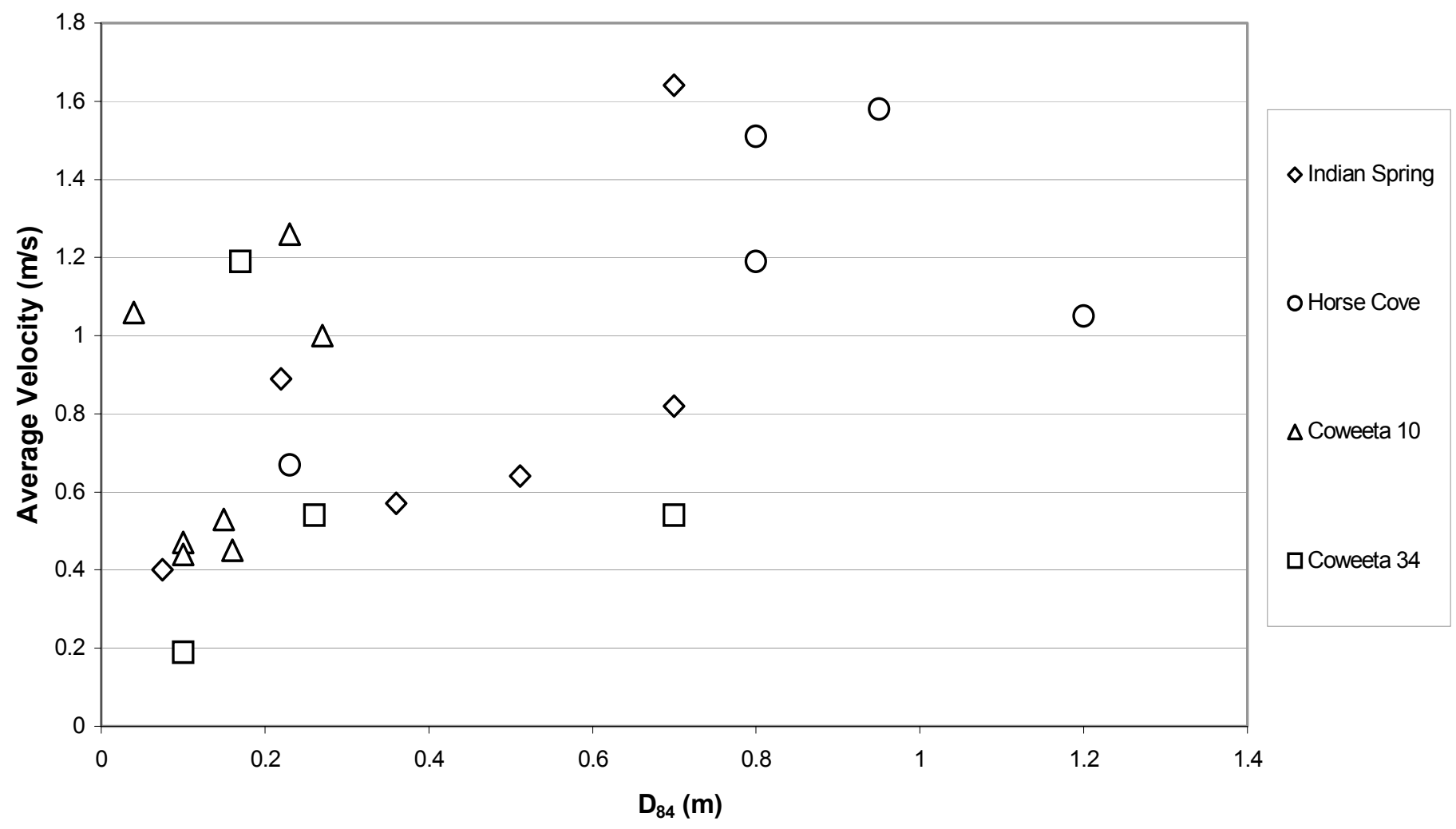

Figure 4.10b. Average velocity vs. $\mathrm{D}_{84}$ grain size for 2-year stormflow at North Carolina cross sections. 


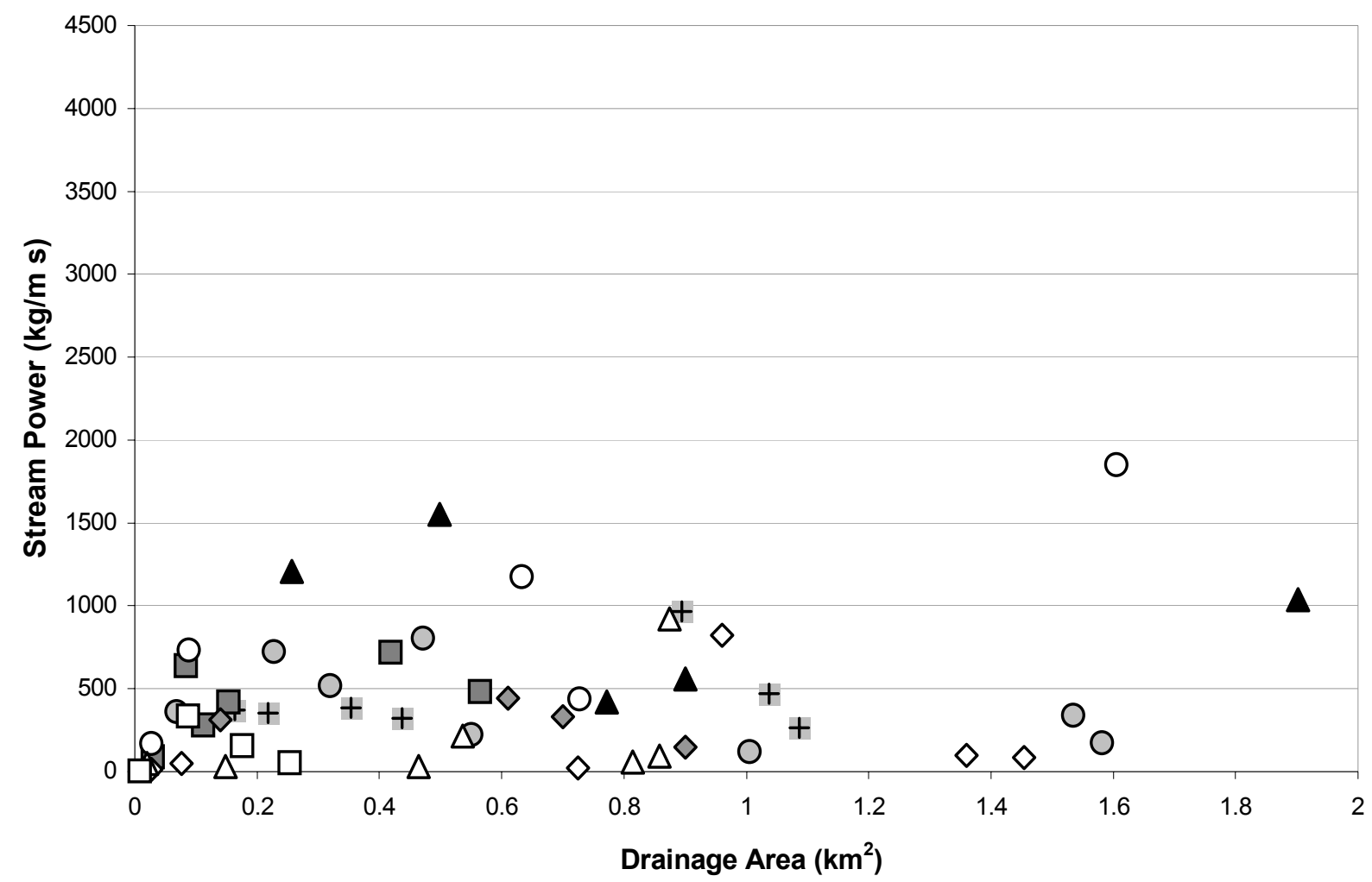

+ Stony Trib

$\square$ Given Branch

O Sarver Hollow

$\diamond$ Allen Hollow

$\Delta$ Pepper Run

$\diamond$ Indian Spring

O Horse Cove

$\Delta$ Coweeta 10

口 Coweeta 34

Figure 4.11a. Stream power vs. drainage area for VA-2 stormflow at each cross section.

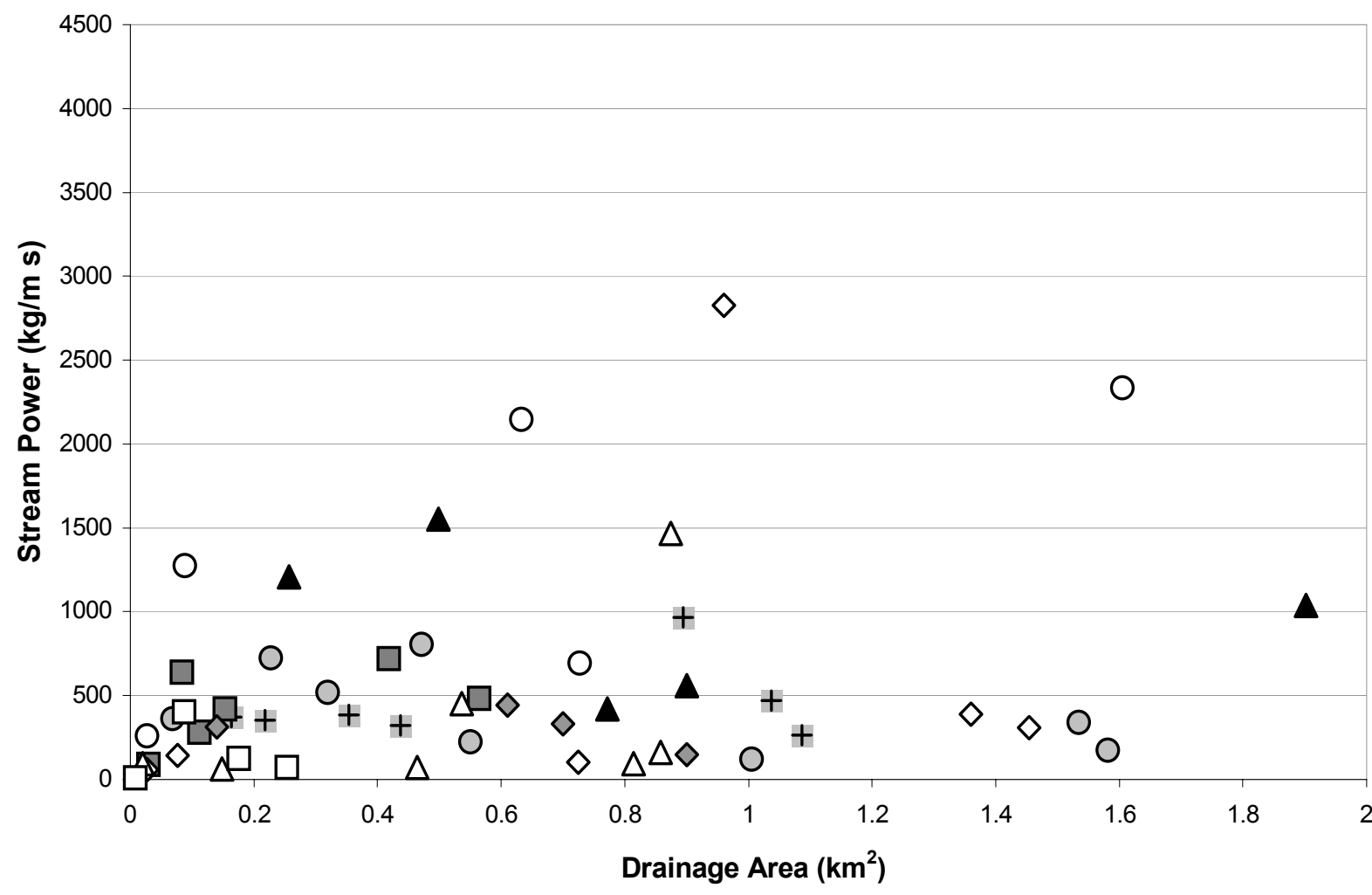

+ Stony Trib

$\square$ Given Branch

o Sarver Hollow

$\diamond$ Allen Hollow

$\Delta$ Pepper Run

$\diamond$ Indian Spring

O Horse Cove

$\Delta$ Coweeta 10

口Coweeta 34

Figure 4.11b. Stream power vs. drainage area for 2 -year stormflow at each cross section. 


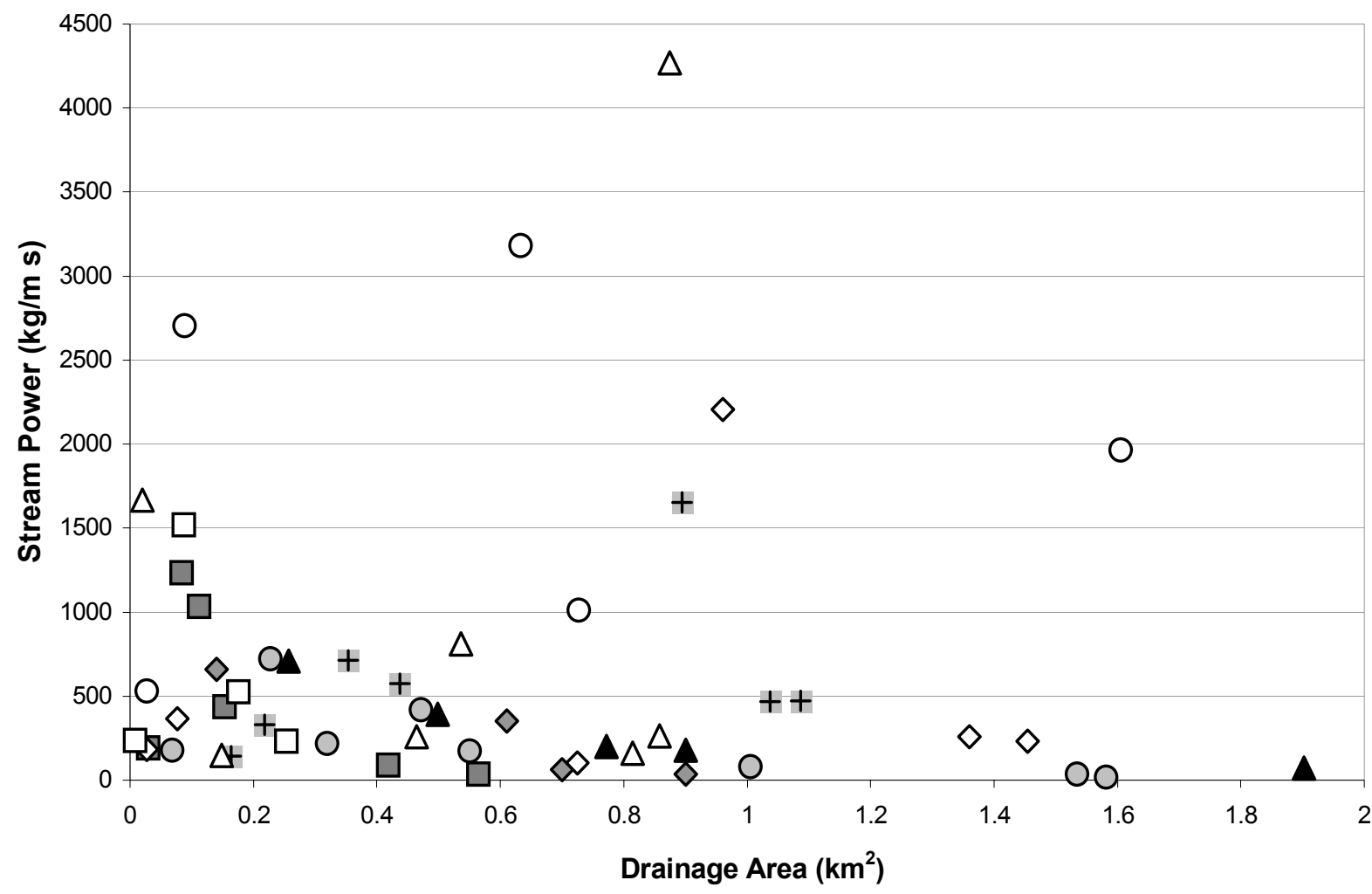

+ Stony Trib

口Given Branch

o Sarver Hollow

$\diamond$ Allen Hollow

$\Delta$ Pepper Run

$\diamond$ Indian Spring

O Horse Cove

$\Delta$ Coweeta 10

口 Coweeta 34

Figure 4.11c. Stream power vs. drainage area for bankfull flow at each cross section.

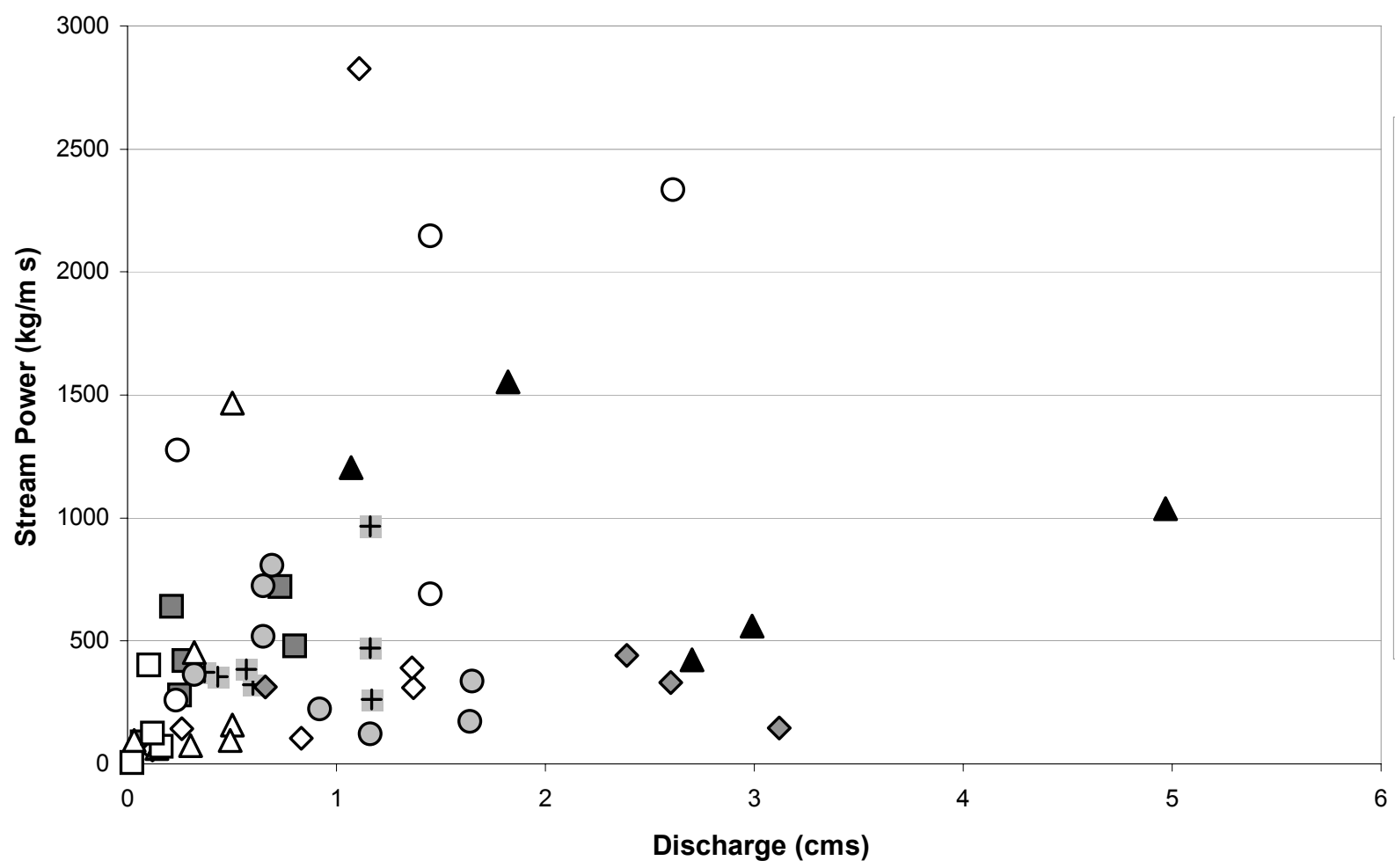

+ Stony Trib

口Given Branch

o Sarver Hollow

$\diamond$ Allen Hollow

$\Delta$ Pepper Run

$\diamond$ Indian Spring

O Horse Cove

$\Delta$ Coweeta 10

口Coweeta 34

Figure 4.12a. Stream power vs. discharge for 2 -year stormflow at each cross section. 


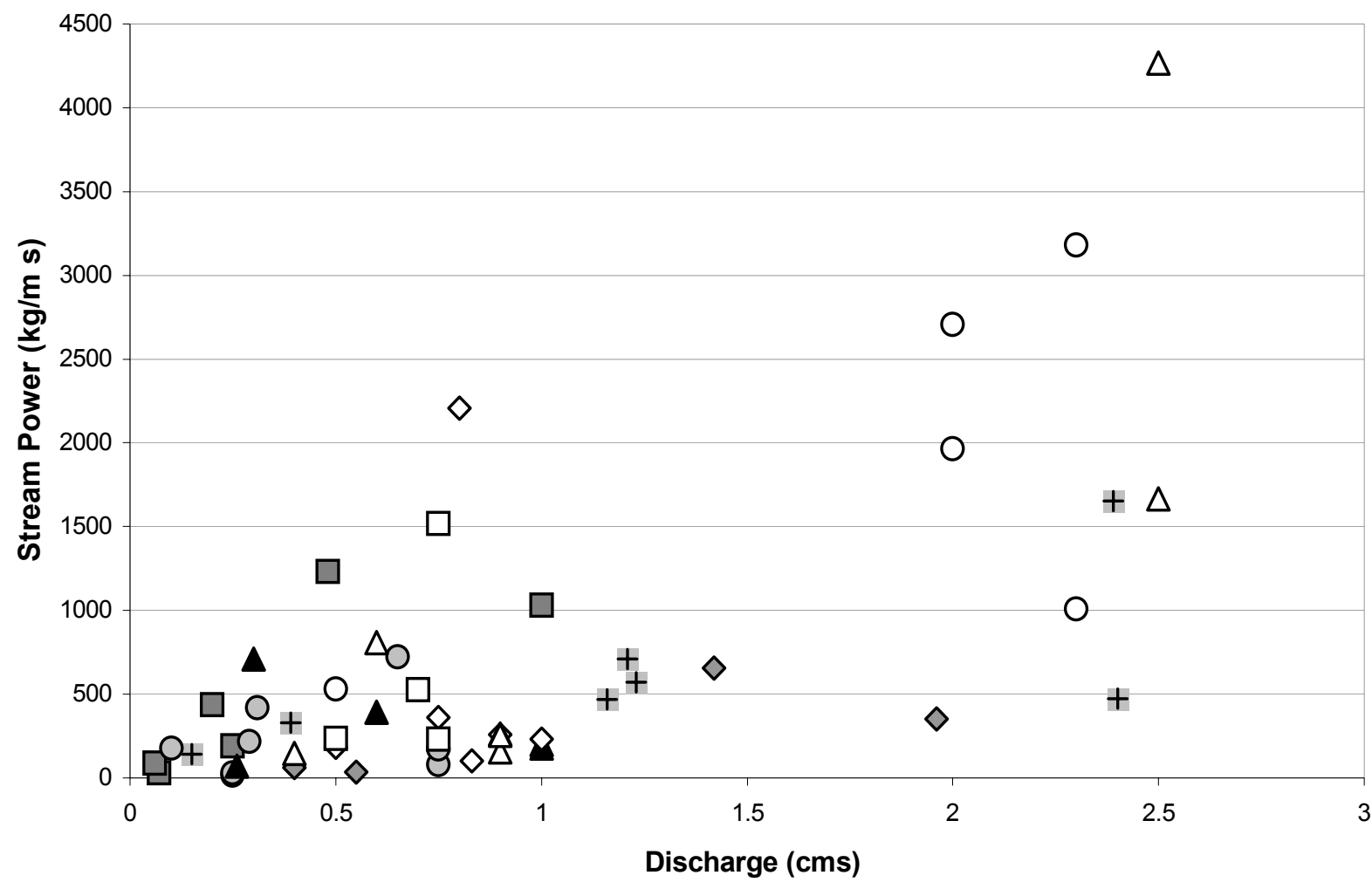

Figure 4.12b. Stream power vs. discharge for bankfull flow at each cross section.

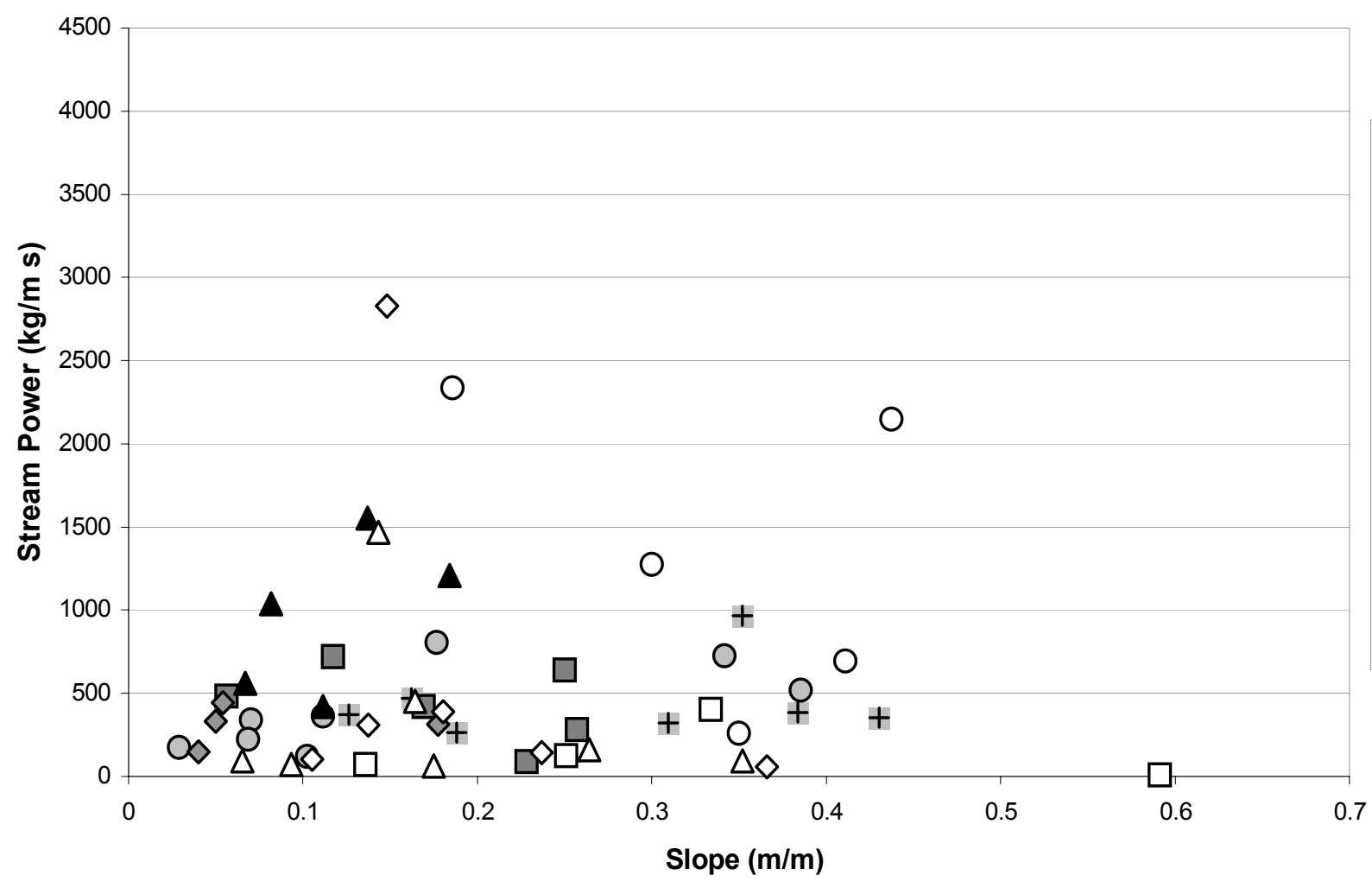

+ Stony Trib

口Given Branch

O Sarver Hollow

$\diamond$ Allen Hollow

$\Delta$ Pepper Run

$\diamond$ Indian Spring

O Horse Cove

$\Delta$ Coweeta 10

口Coweeta 34

Figure 4.13a. Stream power vs. slope for 2 -year stormflow at each cross section. 


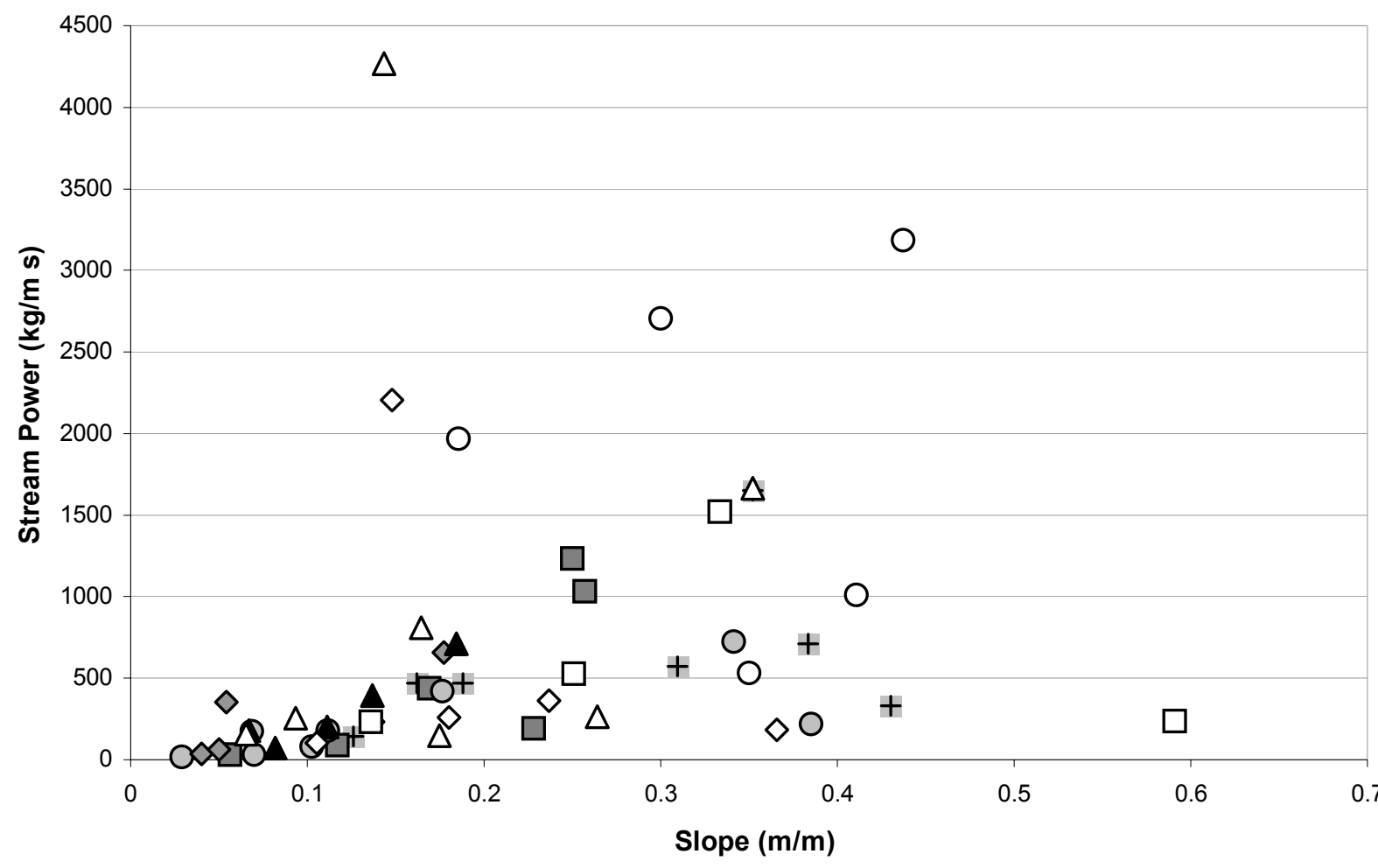

+ Stony Trib

口Given Branch

o Sarver Hollow

$\diamond$ Allen Hollow

$\Delta$ Pepper Run

$\diamond$ Indian Spring

O Horse Cove

$\Delta$ Coweeta 10

口Coweeta 34

Figure 4.13b. Stream power vs. slope for bankfull flow at each cross section.

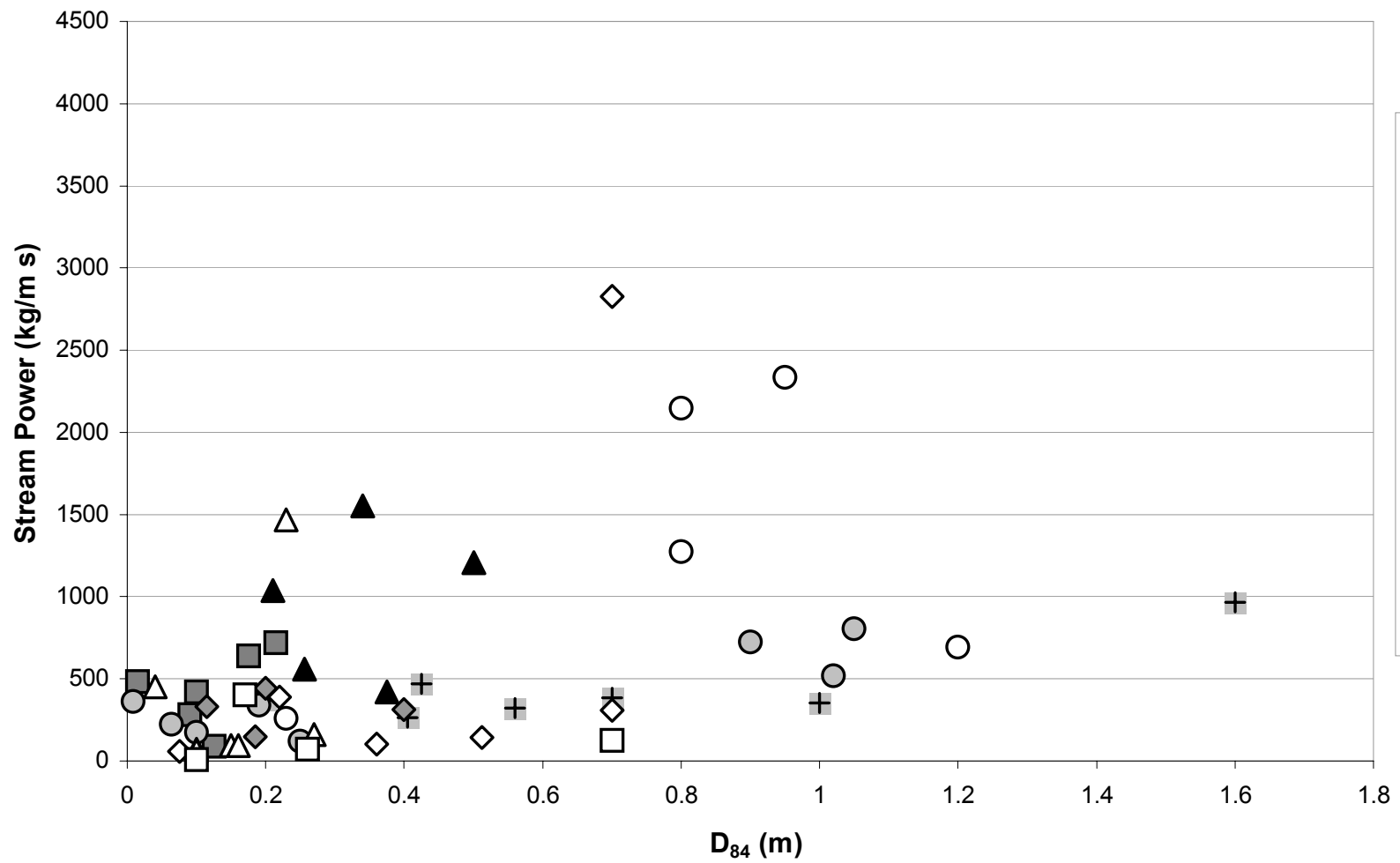

+ Stony Trib

Given Branch

o Sarver Hollow

$\diamond$ Allen Hollow

$\Delta$ Pepper Run

$\diamond$ Indian Spring

O Horse Cove

$\Delta$ Coweeta 10

口Coweeta 34

Figure 4.14a. Stream power vs. $\mathrm{D}_{84}$ grain size for 2 -year stormflow at each cross section. 


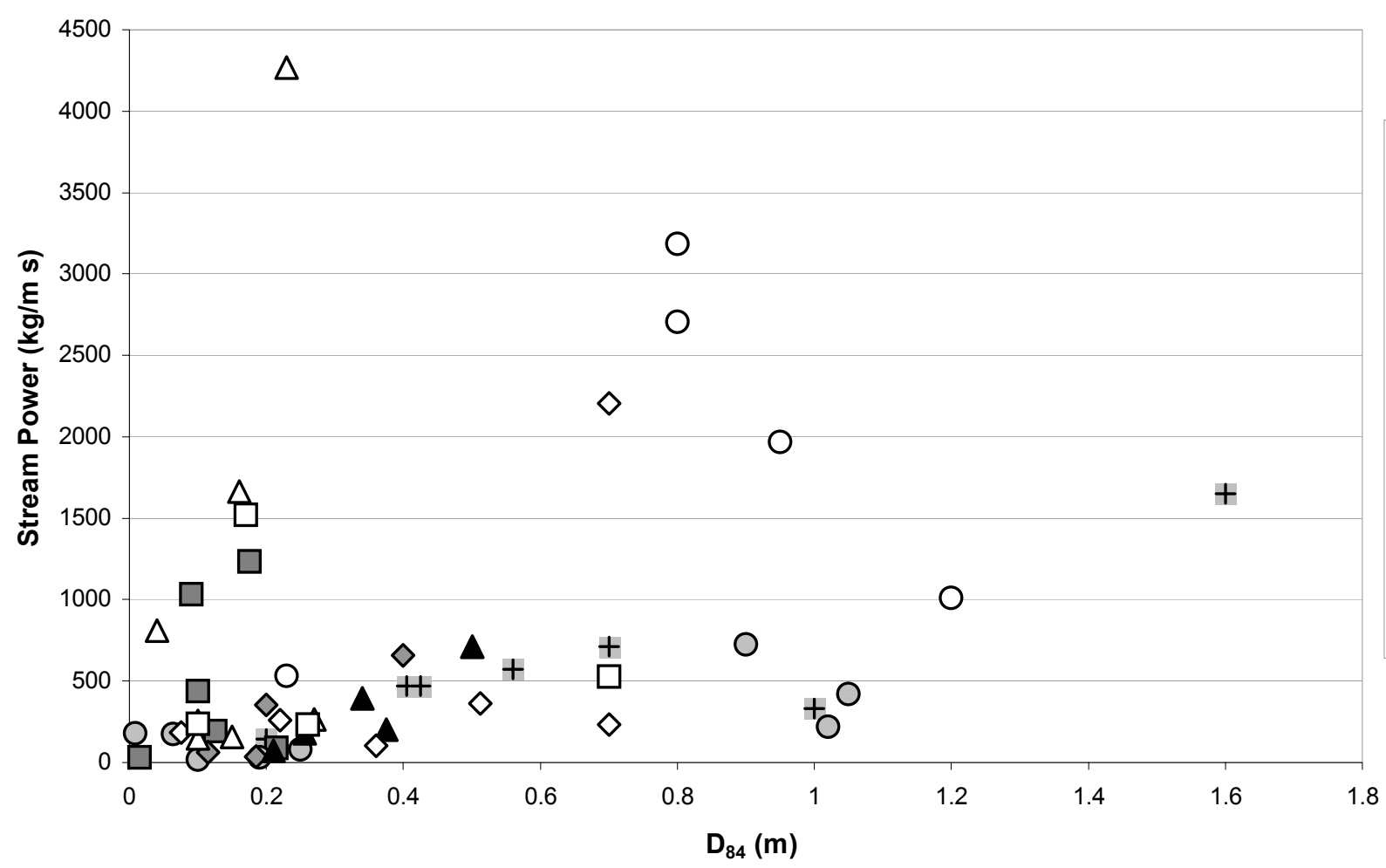

+ Stony Trib

Given Branch

O Sarver Hollow

$\diamond$ Allen Hollow

A Pepper Run

$\diamond$ Indian Spring

O Horse Cove

$\Delta$ Coweeta 10

달eeta 34

Figure 4.14b. Stream power vs. $\mathrm{D}_{84}$ grain size for bankfull flow at each cross section.

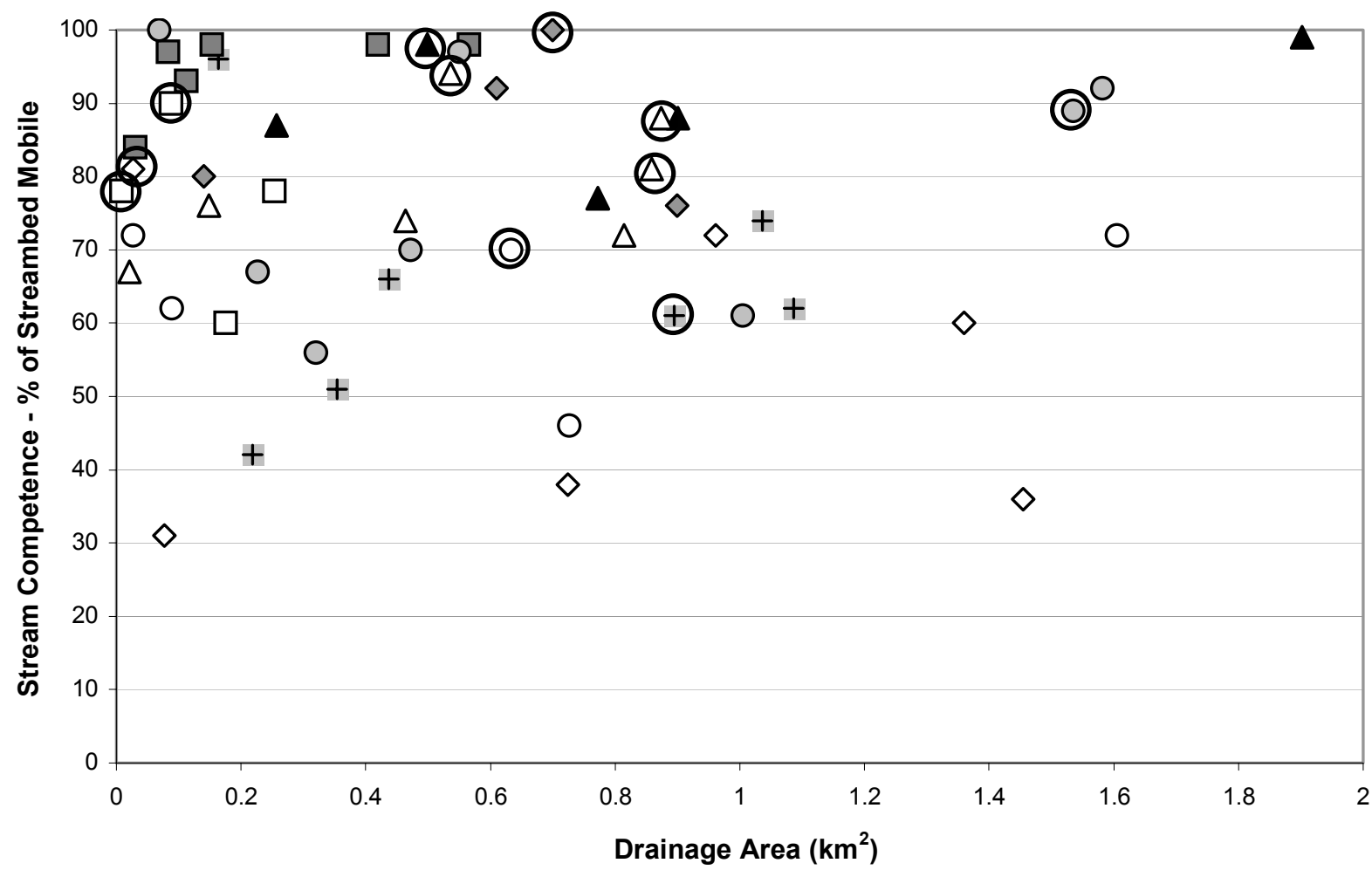

+ Stony Trib

口Given Branch

o Sarver Hollow

$\diamond$ Allen Hollow

$\Delta$ Pepper Run

$\diamond$ Indian Spring

O Horse Cove

$\Delta$ Coweeta 10

口Coweeta 34

Figure 4.15a. Stream competence vs. drainage area for VA-2 stormflow at each cross section. Circled cross sections are those with greater than $10 \%$ bedrock substrate. 


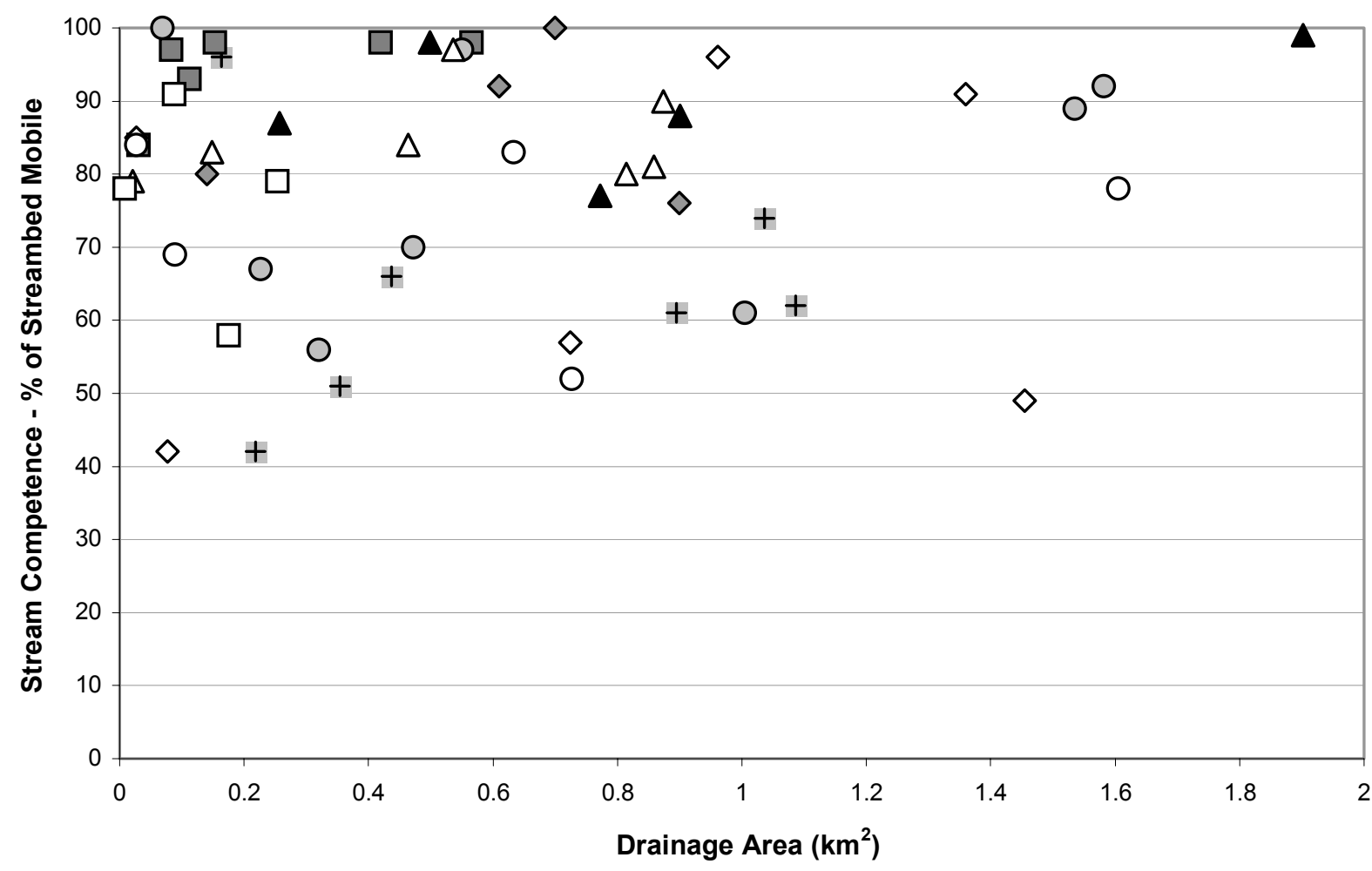

+ Stony Trib

口Given Branch

O Sarver Hollow

$\diamond$ Allen Hollow

A Pepper Run

$\diamond$ Indian Spring

O Horse Cove

$\Delta$ Coweeta 10

Coweeta 34

Figure 4.15b. Stream competence vs. drainage area for 2-year stormflow at each cross section.

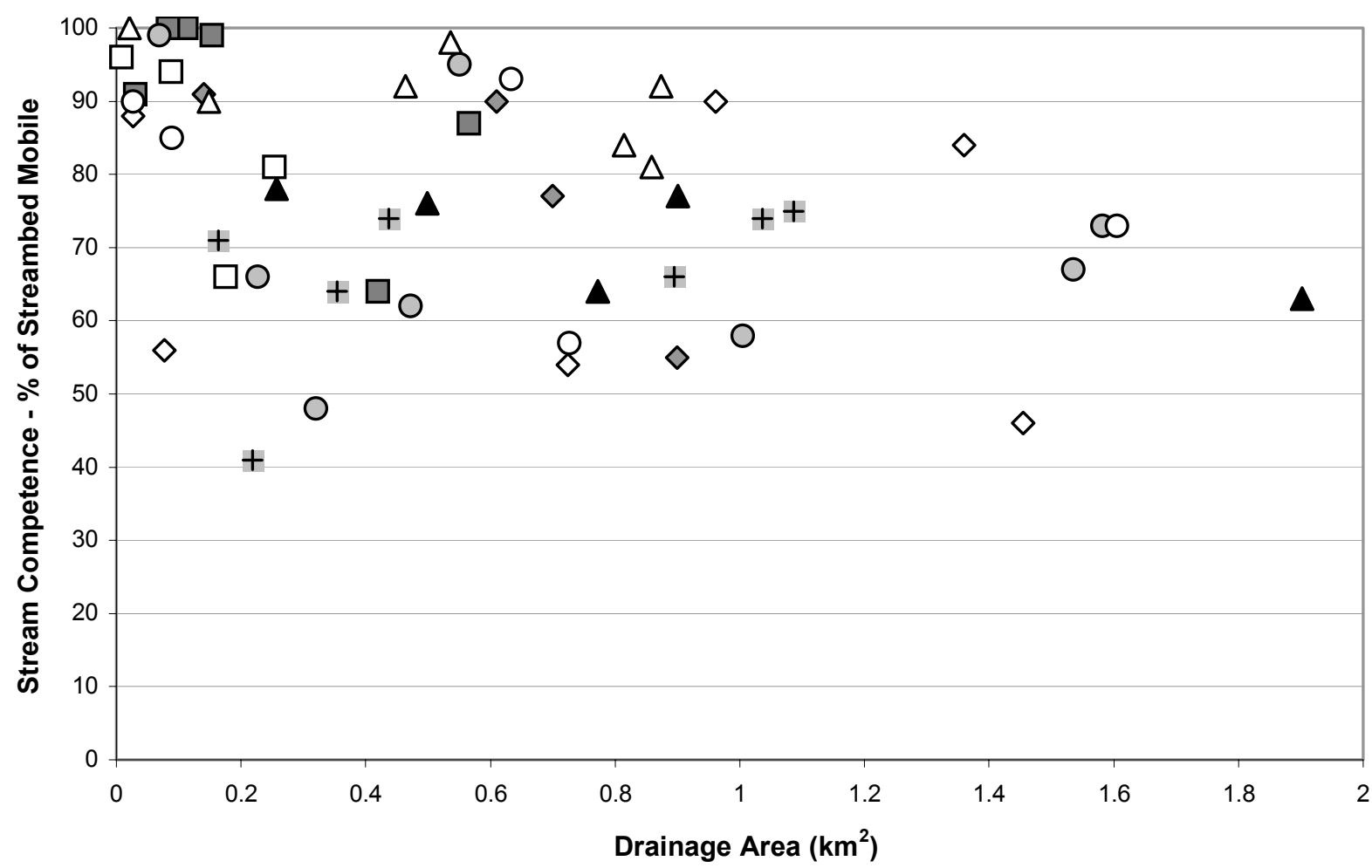

+ Stony Trib

口Given Branch

o Sarver Hollow

$\diamond$ Allen Hollow

$\Delta$ Pepper Run

$\diamond$ Indian Spring

O Horse Cove

$\Delta$ Coweeta 10

口Coweeta 34

Figure 4.15c. Stream competence vs. drainage area for bankfull flow at each cross section. 


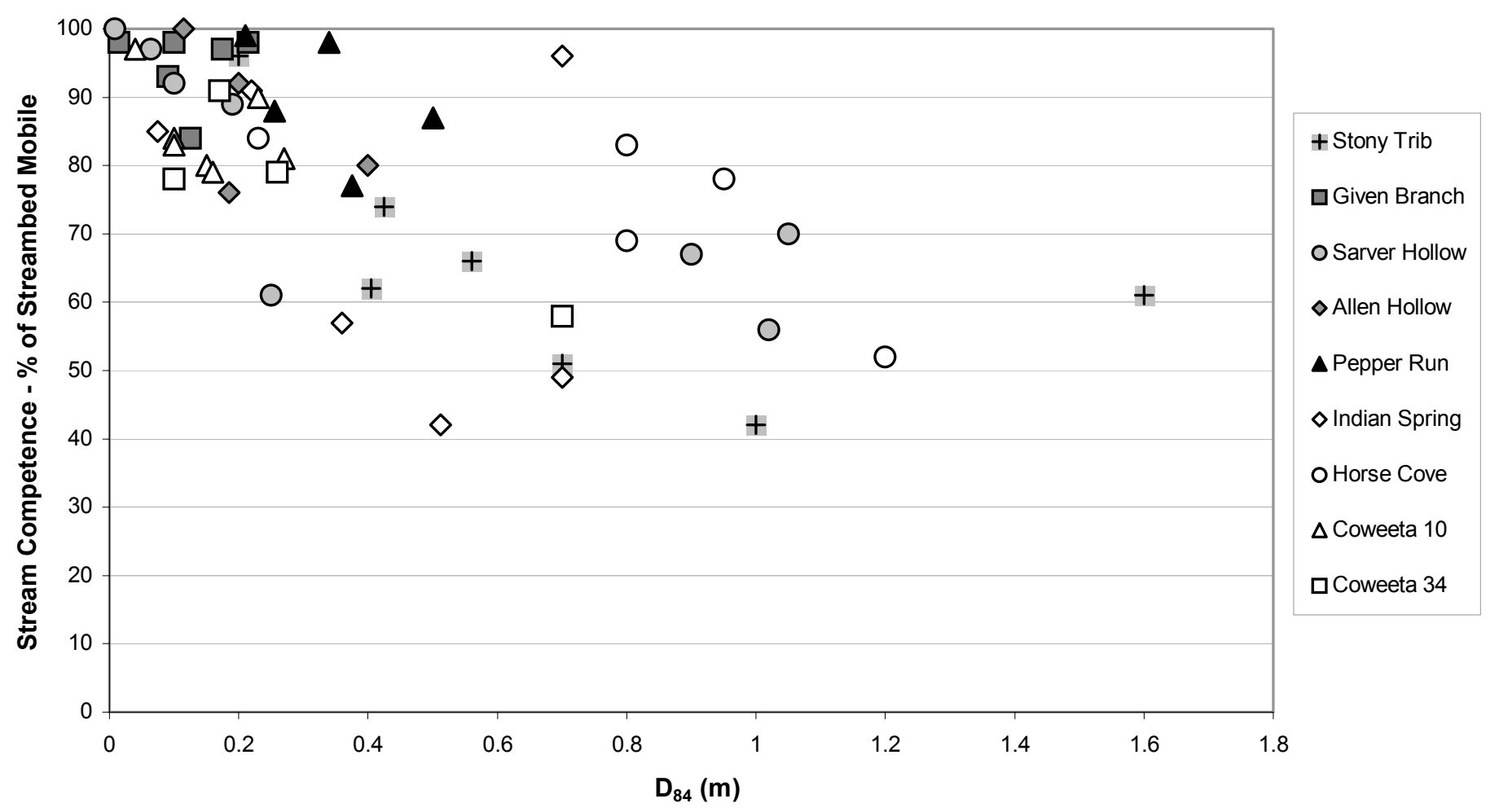

Figure 4.16a. Stream competence vs. $D_{84}$ grain size for 2-year stormflow at each cross section.

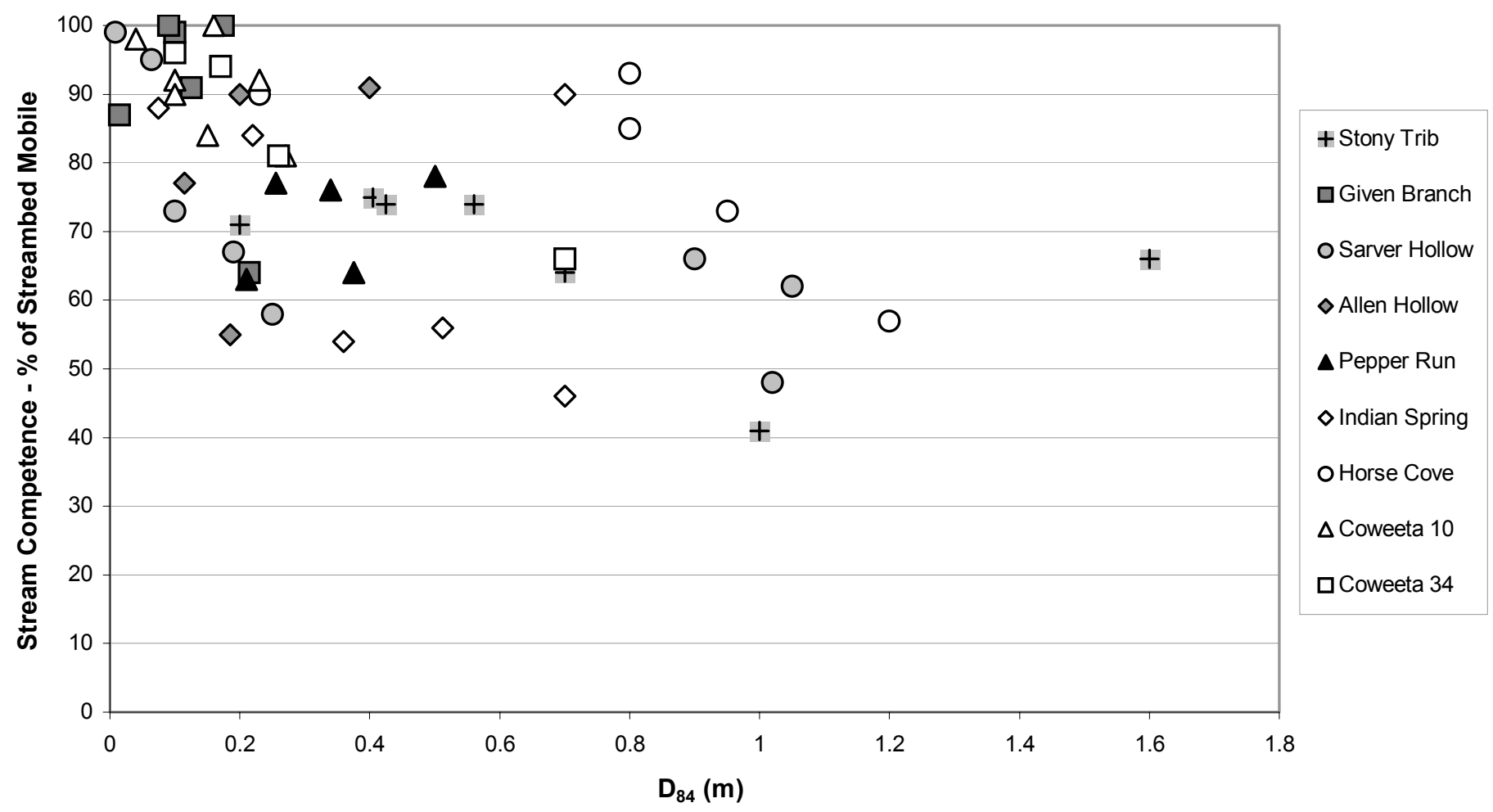

Figure 4.16b. Stream competence vs. $\mathrm{D}_{84}$ grain size for bankfull flow at each cross section. 


\section{Chapter 5}

\section{Conclusions}

The results of our study show that a fundamental characteristic of headwater channel morphology and sediment transport is variability. They are highly sensitive to local hillslope conditions that are controlled largely by bedrock, such as the influx of fine or coarse grains, the presence of in-situ resistant bedrock, and soil profile development. Thus, general fluvial principals developed in perennial lowland channels, which are largely dependent on drainage area relations, cannot be applied to headwater streams. Headwater stream longitudinal and cross-sectional form does not change regularly downstream, and varies greatly between channels. The recurrence of channel forming flows is also variable, decreasing with drainage area and unexpectedly with increasing precipitation.

Of the boundary conditions investigated in this study, bedrock lithology and structure has a greater impact on headwater channel form and function than any other. There is immense variation within and between channels in channel slope, grain size, and stream competence due to bedrock control of channel form at all scales. Base level, which is controlled locally and regionally by bedrock resistance, also influences overall channel slope and relief. Climate appears to influence channel initiation processes and channel forming flow recurrence, and may be partially responsible for differences in relief, slope, and bedrock exposure between climatic regions.

Variations in headwater stream processes shown in the modeling results are reflected

in field observations of channel form. Reaches with low modeled stream competence due to boulder influx or resistant bedrock exposure create oversteepenings because the major channel substrate is not moved at regularly occurring flows. These higher slope areas are visible in the field-surveyed channel profiles as knickpoints and convex boulder fields, creating lower slope areas upstream where erosion is retarded. Channel process also varies due to bedrock and climate influence on soil development, which controls basin discharge response and therefore the recurrence of channel-forming flows. The deep soil in the Blue Ridge streams, particularly Coweeta, reduces recurrence of channel forming flows and this may be reflected in the empirical results that Blue Ridge channels have steeper slopes, greater relief, and greater bedrock exposure. 
These findings are important for understanding of hillslope erosion and landscape evolution in the Southern Appalachian Mountains. This study has shown that resistant bedrock controls ridge and mountain erosion not only at the formation level, but also at fine scale variations in resistance. Slight differences in bedrock structure, orientation, and jointing can retard hillslope erosion, creating steeper slopes and greater relief. In the Valley and Ridge, these differences are present downstream within a single hillslope, on opposite sides of a ridge, and between ridges, creating variations in channel form and sediment transport. In the Blue Ridge, dendritic drainages on metamorphic bedrock make such differences more difficult to predict. This study suggests that even neighboring, parallel streams on the same metamorphic rock unit will not have parallel form and stream competence. Increased precipitation may increase soil development, thereby slowing erosion and partially explaining the greater relief, slope, and bedrock exposure in Blue Ridge steams. However, greater soil depths are also linked to differences in bedrock weathering. The only generalization that can be made for hillslope erosion is that the headwater streams studied have the ability to transport the finer portion of their bed at regularly occurring flows.

The channels investigated in this study provide a first look at fluvial processes in very small, mountainous basins. However, the modeling performed in this study proved to be more complicated than expected, and may still lack the complexity needed to accurately predict basin hydrology and sediment transport processes in steep mountain channels. More real-time observation of storm flow and sediment transport in headwater channels, such as in Allen Hollow, is needed. Observations in various slope, grain size, and soil conditions would improve understanding of headwater basin response to rainfall and the grain sizes that must be entrained for channel formation. Furthermore, observations in numerous channels that vary only in climate or land use could better constrain the role these boundary conditions play in soil development, channel geometry, and channel-forming flows.

Headwater systems appear so complicated and variable that generalizations based on broad boundary conditions may not be possible even with further investigation. This is important for predictive models of landscape evolution in mountainous regions. Models such as these often generalize fluvial processes over a broad area, not accounting complexity in boundary conditions, such as bedrock resistance, that can have a dramatic effect on patterns of erosion within a mountainous area. Consideration of headwater sensitivity to local 
conditions will improve predictions of landscape evolution in mountainous areas. Other scientific disciplines such as stream ecology and wildland hydrology may also improve the validity of comparative studies in headwater channels by first considering their natural variability. 


\section{Literature Cited}

Ashmore, P. E., and Day, T. J., 1988. Effective discharge for suspended sediment transport in streams of the Saskatchewan River basin: Water Resources Research, v. 24, p. 864870.

Bales, J., and Betson, R. P., 1982, The curve number as a hydrologic index, in Singh, V., ed., Rainfall-Runoff Relationship, Highlands Ranch, CO, Water Resource Publications, p. 371-386.

Beschta, R. L., 1979. Debris removal and its effects on sedimentation in an Oregon Coast Range stream: Northwest Science, v. 53, p. 71-77.

Beven, K. J., 2000, Rainfall-Runoff Modeling: The Primer: New York, NY, John Wiley and Sons, Inc., $360 \mathrm{p}$.

Bilby, R. E., 1981. Role of organic debris dams in regulating the export of dissolved organic and particulate matter from a forested watershed: Ecology, v. 62, p. 1234-1243.

Bisese, J. A., 1994, Methods for estimating the magnitude and frequency of peak discharges of rural, unregulated streams in Virginia, Richmond, VA, U .S. Geological Survey, 70 p.

Blizzard, C. R., and Wohl, E. E., 1998. Relationships between Hydraulic Variables and Bedload Transport in a Subalpine Channel, Colorado Rocky Mountains, U.S.A.: Geomorphology, v. 22, p. 359-371.

Bradford, B. H., 1977, Precipitation frequency in mountainous terrain, Georgia Institute of Technology cooperative agreement Progress Report, Coweeta Hydrologic Laboratory, Otto, NC, USDA Forest Service.

Bridges, E. M., 1990, World Geomorphology: Cambridge, Cambridge University Press, 260 p.

Brunner, G. W., 2001, HEC-RAS, River Analysis System Hydraulic Reference Manual, U.S. Army Corps of Engineers Hydrologic Engineering Center CPD-69, 262 p.

Burrough, P. A., 1986, Principles of Geographical Information Systems for Land Resources Assessment, New York, Oxford University Press, 50 p.

Carling, P., 1988. The concept of dominant discharge applied to two gravel-bed streams in relation to channel stability thresholds: Earth Surface Processes and Landforms, v. 13, p. 355-367. 
Costa, J. E., 1983. Paleohydraulic Reconstruction of Flash-flood Peaks from Boulder Deposits in the Colorado Front Range: Geological Society of America Bulletin, v. 94, p. 986-1004.

Creggar, W. H., Hudson, H. C., and Porter, H. C., 1985, Soil Survey of Montgomery County, Virginia, Washington DC, USDA Soil Conservation Service, 158 p.

Crowder, D., and Diplas, P., 1997. Sampling Heterogeneous Deposits in Gravel-Bed Streams: Journal of Hydraulic Engineering.

Daniels, W. L., 1985, Virgin Hardwood Forest Soils of Western North Carolina: Unpub. Ph.D. thesis, Virginia Polytechnic Institute and State University, 166 p.

Dietrich, W. E., Wilson, C. J., Montgomery, D. R., and McKean, J., 1993. Analysis of erosion thresholds, channel networks, and landscape morphology using a digital terrain model: Journal of Geology, v. 101, p. 259-278.

Diplas, P., and Lohani, V. K., 1997. Application of the Pebble Count: Notes on Purpose, Method, and Variants, by Mathias Kondolf: Journal of the American Water Resources Association, v. 33, p. 1397-1399.

Doan, J. H., 2000, Hydrologic model of Buffalo Bayou using GIS, in Maidment, D., and Djokic, D., eds., Hydrologic and Hydraulic Modeling Support with Geographic Information Systems, Redlands, CA, ESRI Press, p. 113-143.

Douglass, J. E., 1974, Flood frequencies and bridge and culvert sizes for forested mountains of North Carolina, SE-4, General Technical Report, Ashville, NC, Southeast Forest Experiment Station, USDA Forest Service, $21 \mathrm{p}$.

ESRI, 1999, ArcView help.

Feldman, A., 2000, Hydrologic Modeling System - HEC-HMS - Technical Reference Manual, Davis, California, Army Corp. of Engineers, 149 p.

Frederick, R. H., Myers, V. A., and Auciello, E. P., 1977, Five to 60 minute precipitation frequency for the Eastern and Central United States, NWS-35, Silver Spring, MD, US Dep. Commerce, National Weather Service, National Oceanic and Atmospheric Administration, $36 \mathrm{p}$.

Garbrecht, J., and Martz, L. W., 1994. Grid size dependency of parameters extracted from digital elevation models: Computers and Geosciences, v. 20, p. 85-87.

Goldsten, E. F., and Gettys, W., 1953, Soil Survey of Graham County, North Carolina, Washington DC, USDA Soil Conservation Service, 81 p. 
Grant, G. E., Swanson, F. J., and Wolman, M. G., 1990. Pattern and origin of stepped-bed morphology in high-gradient streams, Western Cascades, Oregon: GSA Bulletin, v. 102, p. 340-352.

Grimm, M. M., Wohl, E. E., and Jarrett, R. D., 1995. Coarse-Sediment Distribution as Evidence of an Elevation Limit for Flash-flooding, Bear Creek, Colorado: Geomorphology, v. 14, p. 199-210.

Hack, J. T., 1957, Studies of Longitudinal Stream Profiles in Virginia and Maryland, U.S. Geological Survey.

—, 1973, Drainage adjustment in the Appalachians, in Morisawa, M., ed., Publications in Geomorphology, Binghamton, N.Y., State University of New York, p. p. 51-69.

—, 1980, Rock controls and tectonism - their importance in shaping the Appalachian Highlands, U.S. Geological Survey, 17 p.

—, 1982, Physiographic Divisions and Differential Uplift in the Peidmont and Blue Ridge, Washington, D.C., U.S. Geological Society, 49 p.

Hack, J. T., and Goodlet, J. C., 1960, Geomorphology and forest ecology of a mountain region in the central Appalachians, U.S. Geological Survey, 66 p.

Hatcher, R. D., 1980, Geologic map and mineral resources summary of the Prentiss quadrangle, North Carolina, including geologic map of the Coweeta Laboratory: North Carolina Division of Land Resources Geological Survey Section.

Hayman, J. W., 1972, The significance of some geologic factors in the karst development of the Mt. Tabor area, Mongomery county, Virginia, Virginia Polytechnic Institute and State University $47 \mathrm{p}$.

Hershfield, D. M., 1961, Rainfall frequency atlas of the United States for durations from 30 minutes to 24 hours and return periods from 1 to 100 years, TP-40, Washington DC, US Dep. Commerce, Weather Bureau, 115 p.

Hewlett, J. D., 1961, Soil moisture as a source of base flow from steep mountain watersheds, Station Paper 132, Asheville, NC, USDA Forest Service Southeastern Forest Experiment Station, $11 \mathrm{p}$.

Hewlett, J. D., and Cunningham, G. B., 1977. The effect of rainfall intensity on storm flow and peak discharge from forest land: Water Resources Research, v. 13, p. 259-266.

Hewlett, J. D., Cunningham, G. B., and Troendle, C. A., 1977. Predicting stormflow and peakflow from small basins in humid areas by the R-index method: Water Resources Bulletin, v. 13, p. 231-253. 
Hewlett, J. D., and Helvey, J. D., 1970. Effects of forest clear-felling on the storm hydrograph: Water Resources Research, v. 6, p. 768-782.

Hibbert, A. R., and Troendle, C. A., 1988, Streamflow generation by variable source area, in Swank, W. T., and Crossley, D. A. J., eds., Forest Hydrology and Ecology at Coweeta, New York, NY, Springer-Verlag, p. 111-128.

Hoblit, B. C., and Curtis, D. C., 2000. Next generation rainfall data: ASCE Watershed and Operations Management Conference, $7 \mathrm{p}$.

—, 2001, Integrating radar rainfall estimates with digital elevation with digital elevation models and land use data to create an accurate hydrologic model, San Diego, CA, Floodplain Management Association Spring 2001 Conference, 9 p.

Hoover, M. D., and Hursh, C. R., 1943. Influence of topography and soil-depth on runoff from forest land: Transactions of the American Geophysical Union, p. 693-698.

Ickes, H., 1935, Little waters: Their use and relations to the land: Washington, D.C. Soil Conservation Service, XX p.

Jarrett, R. D., 1984. Hydraulics of High-Gradient Streams: Journal of Hydraulic Engineering, v. 110, p. $1519-1539$.

—, 1986, Evaluation of the Slope-area Method of Computing Peak Discharge, in Subitzky, S., ed., Selected Papers in the Hydrological Sciences, U.S. Geol. Surv. Water-Supply Pap., p. 13-26.

Jenson, S. K., and Dominique, J. O., 1988. Extracting topographic structure from digital elevation data for geographic information systems analysis: Photogrammetric Engineering and Remote Sensing, v. 54, p. 1593-1600.

Johnson, C. A., Yung, A. C., Nixon, K. R., and Legates, D. R., 2001, The use of HECGeoHMS and HEC-HMS to perform grid-based analysis of a watershed, Houston, TX, Dodson \& Associates, Inc., 4 p.

Jones, M. D., 2000, Effects of Disturbance History on Forest Soil Characteristics in the Southern Appalachian Mountains: Unpub. Master's thesis, Virginia Polytechnic Institute and State University $121 \mathrm{p}$.

Kavage, R., 2001, Effect of resolution and reprojection on geomorphic and hydrologic analysis, Blacksburg, VA, Virginia Tech, 14 p.

Kibler, D. F., 2002, Overland flow, in Kavage, R., ed., Blacksburg, VA.

Leopold, L. B., 1994, A View of the River: Cambridge, MA, Harvard University Press, 298 p. 
Leopold, L. B., and Maddock, T. J., 1953, The hydraulic geometry of stream channels and some physiographic implications, Washington, D.C., US Geological Survey, 57 p.

Lesure, F. G., and al, e., 1977, Mineral Resources of the Joyce Kilmer-Slickrock Wilderness, North Carolina, Tennessee, U.S. Geological Survey, 89 p.

Lieberman, J. A., and Hoover, M. D., 1948a. The effect of uncontrolled logging on stream turbidity: Water and Sewage Works, v. 95, p. 255-258.

—, 1948b. Protecting quality of stream flow by better logging: Southern Lumberman, v. 177, p. 236-240.

Limerinos, J. T., 1970, Determination of the Manning Coefficient from Measured Bed Roughness in Natural Channels, U.S. Geol. Surv. Water-Supply Pap. 1898-B, 47 p.

Linsley, R. K., Kohler, M. A., and Paulhus, J. L., 1975, Hydrology for engineers, McGrawHill, Inc., 482 p.

McTammany, M., 2001, Coweeta baseflow conversation, Blacksburg, VA.

Miller, E. V., and Hubbard, D. A. J., 1986, Selected slope categories and karst features of Giles County, Virginia: Division of Mineral Resources.

Mills, H. H., 1987, Surficial geology and geomorphology of the Mountain Lake area, Giles County, Virginia, including sedimentological studies of colluvium and boulder streams, Denver, CO, U.S. Geological Survey, 57 p.

Mills, H. H., Brakenridge, R. G., Jacobson, R. B., Newell, W. L., Pavich, M. J., and Pomeroy, J. S., 1987, Appalachian mountains and plateaus, in Graf, W. L., ed., Geomorphic Systems of North America: Geological Society of America Centennial Special, Boulder, CO, p. 5-50.

Montgomery, D. R., and Dietrich, W. E., 1988. Where do channels begin?: Nature, v. 336, p. 232-234.

—, 1989. Source areas, drainage density, and channel initiation: Water Resources Research, v. 25 , p. 1907-1918.

Nutter, W. L., 1971, The role of soil water in the hydrologic behavior of upland basins: Field Soil Water Regime, New York, p. 181-193.

Overton, D. E., and Meadows, M. E., 1976, Storm water modeling: New York, NY, Academic Press, 58-88 p. 
Patric, J. H., 1972, Deforestation effects on soil moisture, streamflow, and water balance in the central Appalachians, p. 1-12.

Radecki-Pawlik, A., 2002. Bankfull discharge in mountain streams: Theory and practice: Earth Surface Processes and Landforms, v. 27, p. 115-123.

Rallison, R. E., and Miller, N., 1982, Past, present, and future SCS runoff procedure, in Singh, V., ed., Rainfall-Runoff Relationship, Highlands Ranch, CO, Water Resource Publications, p. 353-364.

Schultz, A. P., 1993, Geologic map of large block slides at Sinking Creek Mountain, Appalachian Valley and Ridge province, southwestern Virginia, and comparison with Colorado Front Range: US Geological Survey.

Schultz, A. P., and al., e., 1986, Geologic map of Giles County, Virginia: VADMR.

Soil Conservation Service, 1986, Urban Hydrology for Small Watersheds, TR-55, Washington DC, USDA Soil Conservation Service Engineering Division, 156 p.

Spatial Climate Analysis Service, 2000, Average Annual Precipitation: Oregon State University.

Swank, W. T., and Crossley, D. A. J., 1988, Introduction and Site Description, in Swank, W. T., and Crossley, D. A. J., eds., Forest Hydrology and Ecology at Coweeta, New York, NY, Springer-Verlag, p. 3-16.

Swank, W. T., Swift, L. W. J., and Douglass, J. E., 1988, Streamflow changes associated with forest cutting, species conversions, and natural disturbances, in Swank, W. T., and Crossley, D. A. J., eds., Forest Hydrology and Ecology at Coweeta, New York, NY, Springer-Verlag, p. 297-312.

Swecker Jr., P. L., Cauley, P. M., Van Dine, J. W., and Conner, R. K., 1985, Soil Survey of Giles County, Virginia, Southern and Central Parts, Washington DC, USDA Soil Conservation Service, $136 \mathrm{p}$.

Swift, L. W. J., Cunningham, G. B., and Douglass, J. E., 1988, Climatology and hydrology, in Swank, W. T., and Crossley, D. A. J., eds., Forest Hydrology and Ecology at Coweeta, New York, NY, Springer-Verlag.

Thomas, D. J., 1996, Soil Survey of Macon County, North Carolina, Washington DC, USDA Natural Resources Conservation Service, 322 p.

Tucker, G. E., and Bras, R. L., 1998. Hillslope processes, drainage density, and landscape morphology: Water Resources Research, v. 34, p. 2751-2764. 
U.S. Department of the Interior Bureau of Reclamation, 1960, Estimating rainfall runoff from soil and cover data, Design of Small Dams, Washington DC, US Government Printing Office, p. 413-431.

U.S. Geological Survey, 1997, Standards for Digital Elevation Models, Reston, VA, US Department of the Interior, $17 \mathrm{p}$.

USDA-NRCS, 1995, Soil Survey Geographic (SSURGO) Data Base Data Use Information, Fort Worth, TX, Natural Resources Conservation Service, p. 31.

Virginia Department of Mineral Resources, Blue line geologic map of the 1:24,000 Newport quadrangle: unpublished.

Wagner, P. F., 2001, Legacies of Early 20th Century Logging in Southern Appalachian Streams: Unpub. Doctorate thesis, Virginia Polytechnic Institute and State University $203 \mathrm{p}$.

Whiting, P. J., Stamm, J. F., Moog, D. B., and Orndorff, R. L., 1999. Sediment-transporting flow in headwater streams: GSA Bulletin, v. 111, p. 450-466.

Wohl, E. E., 2000, Mountain Rivers: Water Resources Monograph, v. 14: Washington, D.C., American Geophysical Union, 320 p.

Wolman, M. G., and Miller, J. P., 1960. Magnitude and Frequency of Forces in Geomorphic Processes: Journal of Geology, v. 68, p. 54-74.

Zimmerman, A., and Church, M., 2001. Channel morphology, gradient profiles and bed stresses during flood in a step-pool channel: Geomorphology, v. 40, p. 311-327. 


\section{Appendix A \\ Little Stony Tributary}

\section{Qualitative Observations}

Little Stony Tributary initiates on a plateau on the top of Butt Mountain at a small hole in the ground. A narrow soil channel comes from a large ferny bog above the hole, and where the two meet, the stream channel begins. The channel is shallow and cobbly, with many small channels and flowpaths nearby, and vegetation is shrubby and fairly dense. This portion of the channel was flowing when observed during a thunderstorm, and dry when observed at a later date.

The channel changes drastically at the Tuscarora sandstone outcrop, where it passes over a five-meter high waterfall. The channel then flows down a wide, steep, bouldery hillside, where the channel is hard to discern and discontinuous, as much of the flow is underneath the boulders.

The bouldery hillside continues the majority of the way downstream, and slope and boulder size steadily decrease. The channel develops recognizable step-pool form with large cobble and small boulder about two-thirds of the distance to its junction with Little Stony. Flow in the channel is intermittent over the entire length downstream. At one point in the channel, about one-third of the way up from this junction, flat bedrock forms the channel bottom for approximately $20 \mathrm{~m}$. In this section the valley is particularly confined and the channel is incised, and flow is present in the channel. Vegetation is much less dense below the Tuscarora outcrop due to the boulder input. There is little rhododendron and the forest is open with little underbrush.

Rebecca Kavage, Doug Marchakitus, and Jeffrey Adams surveyed Little Stony Tributary on June 5-7, 11, and 25, 2001. 


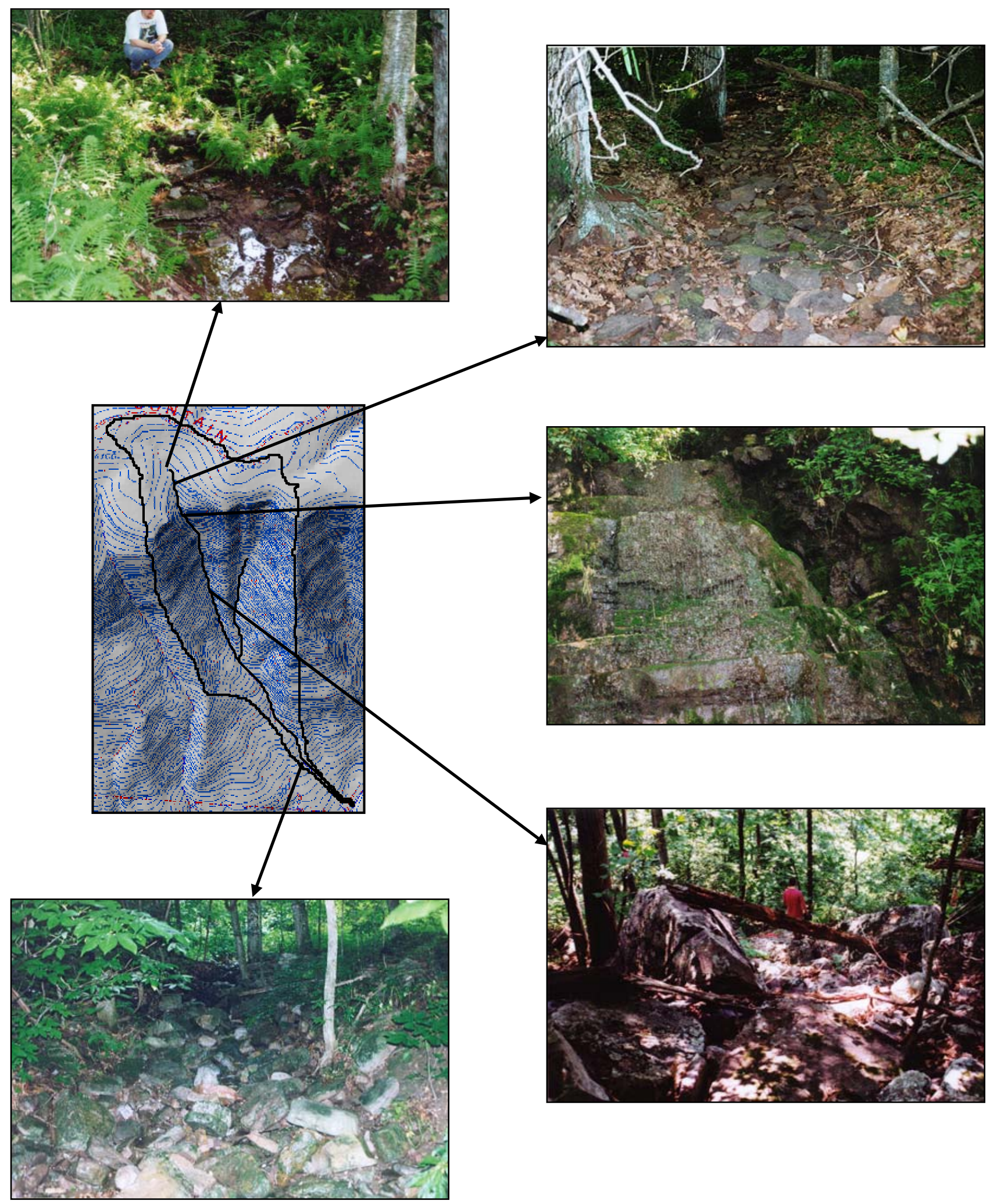

Figure A.1. Photographs of Little Stony Tributary, clockwise from the top left: channel initiation point; channel above Tuscarora outcrop (x7); Tuscarora outcrop creating waterfall; boulder hillslope where channel first disappears; and step-pool morphology in bottom $1 / 3$ of channel. 


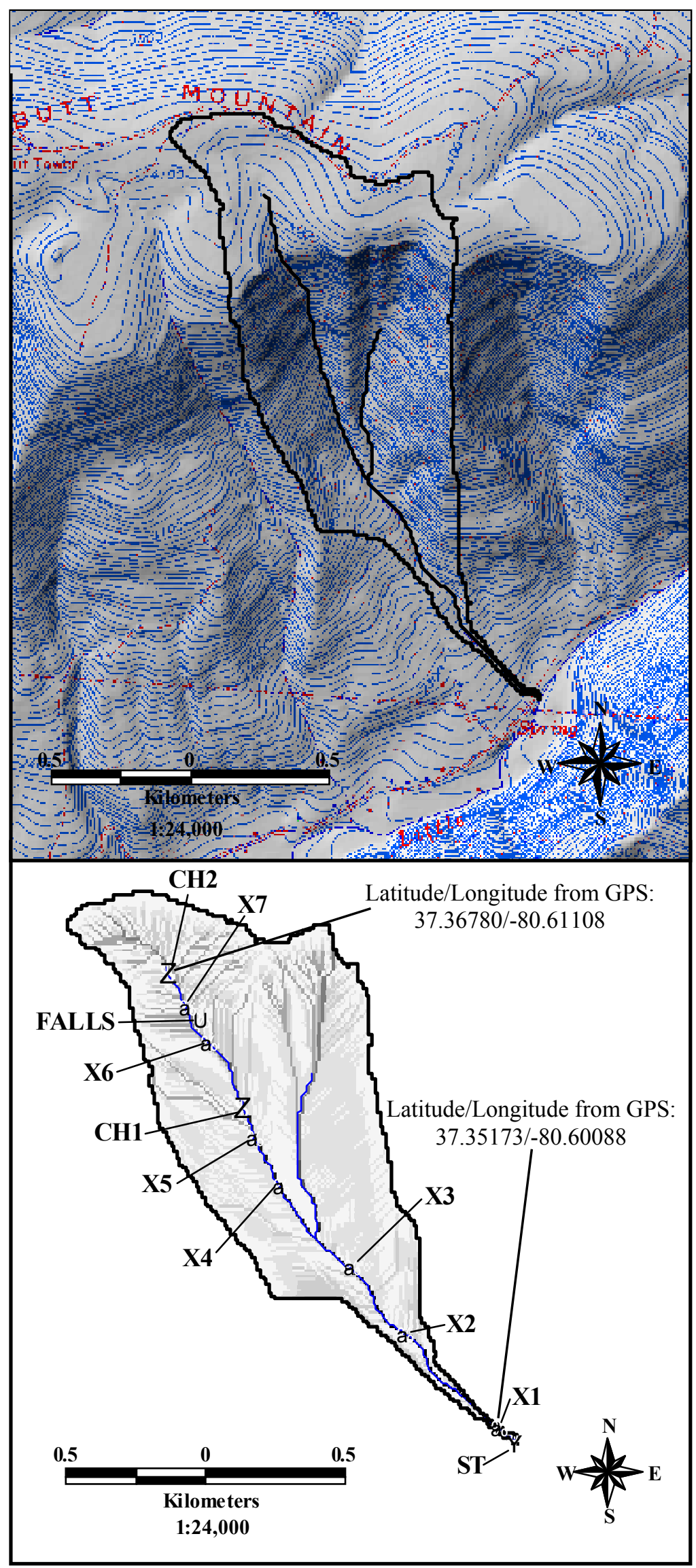

Figure A.2. Topographic and drainage network maps of Little Stony Tributary Basin, denoting survey points. 


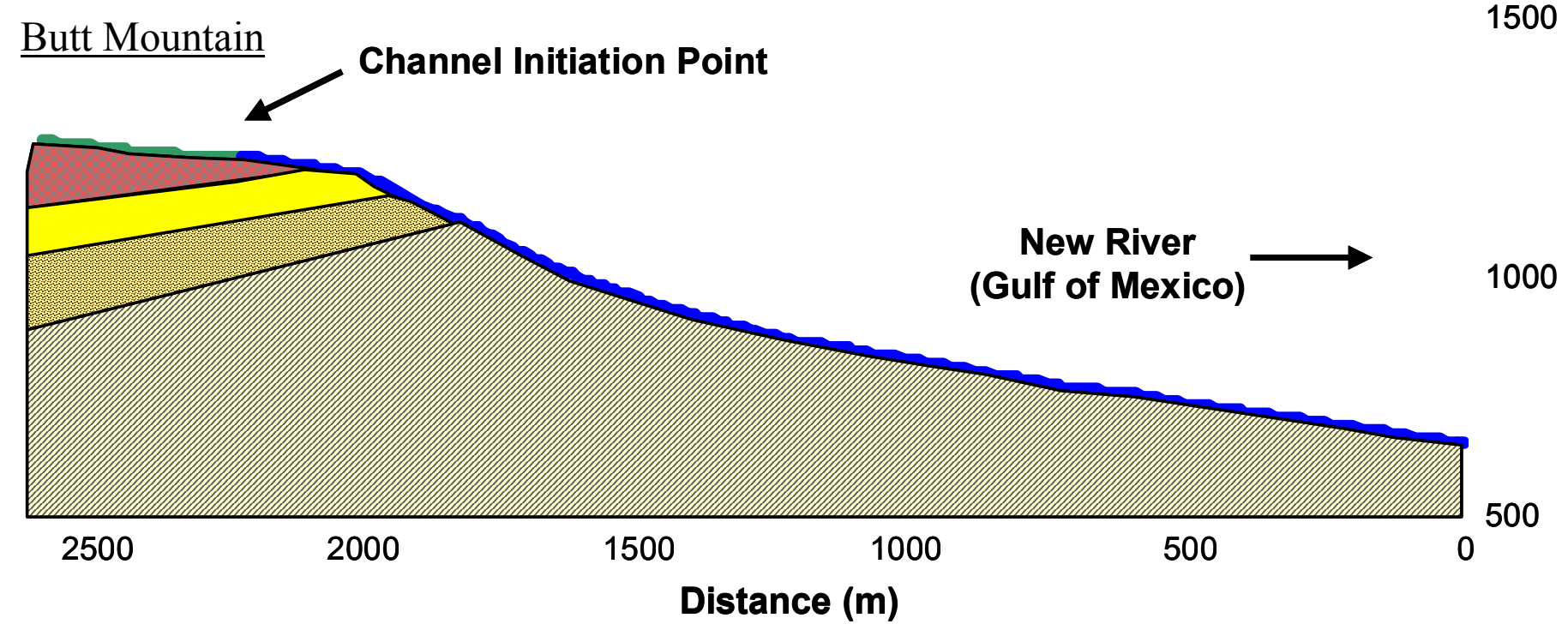

Figure A.3. Bedrock geology, channel initiation point, and base level for Little Stony Tributary. Bedrock geology taken from Schultz (1986) and Mills (1987).

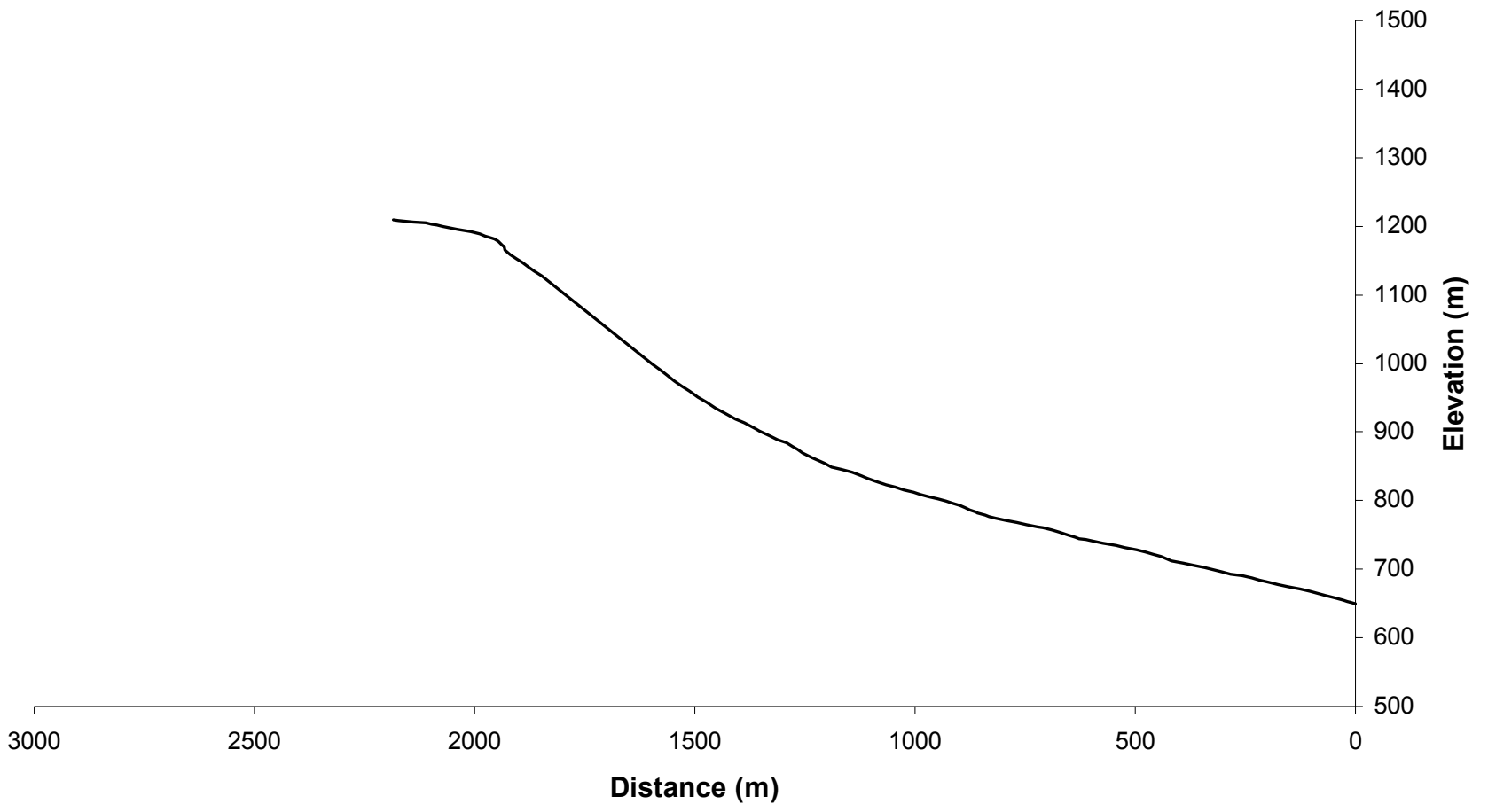

Figure A.4. Little Stony Tributary longitudinal profile, from survey data. 


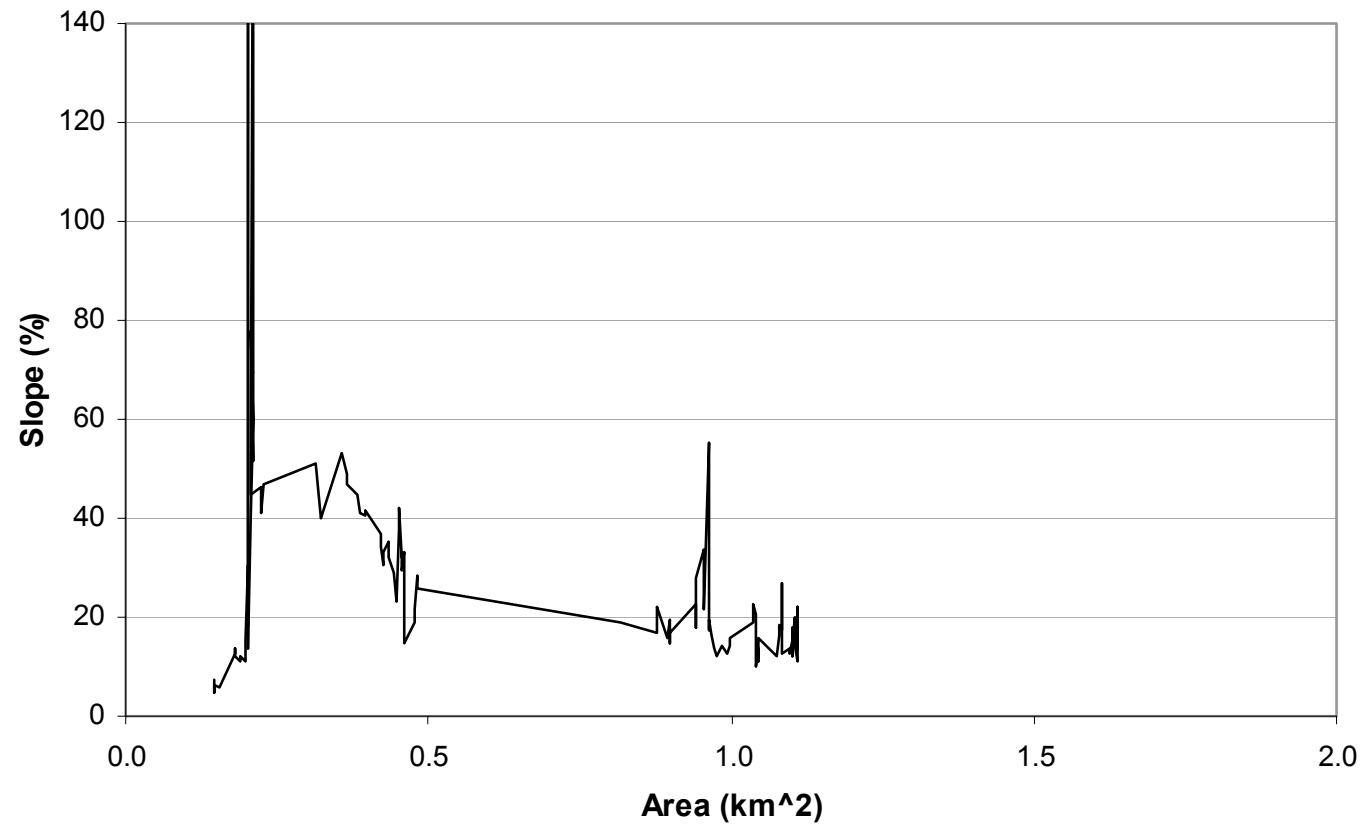

Figure A.5. Slope-area plot for surveyed portion of Little Stony Tributary channel, using field surveyed slope values and DEM-generated drainage area values.

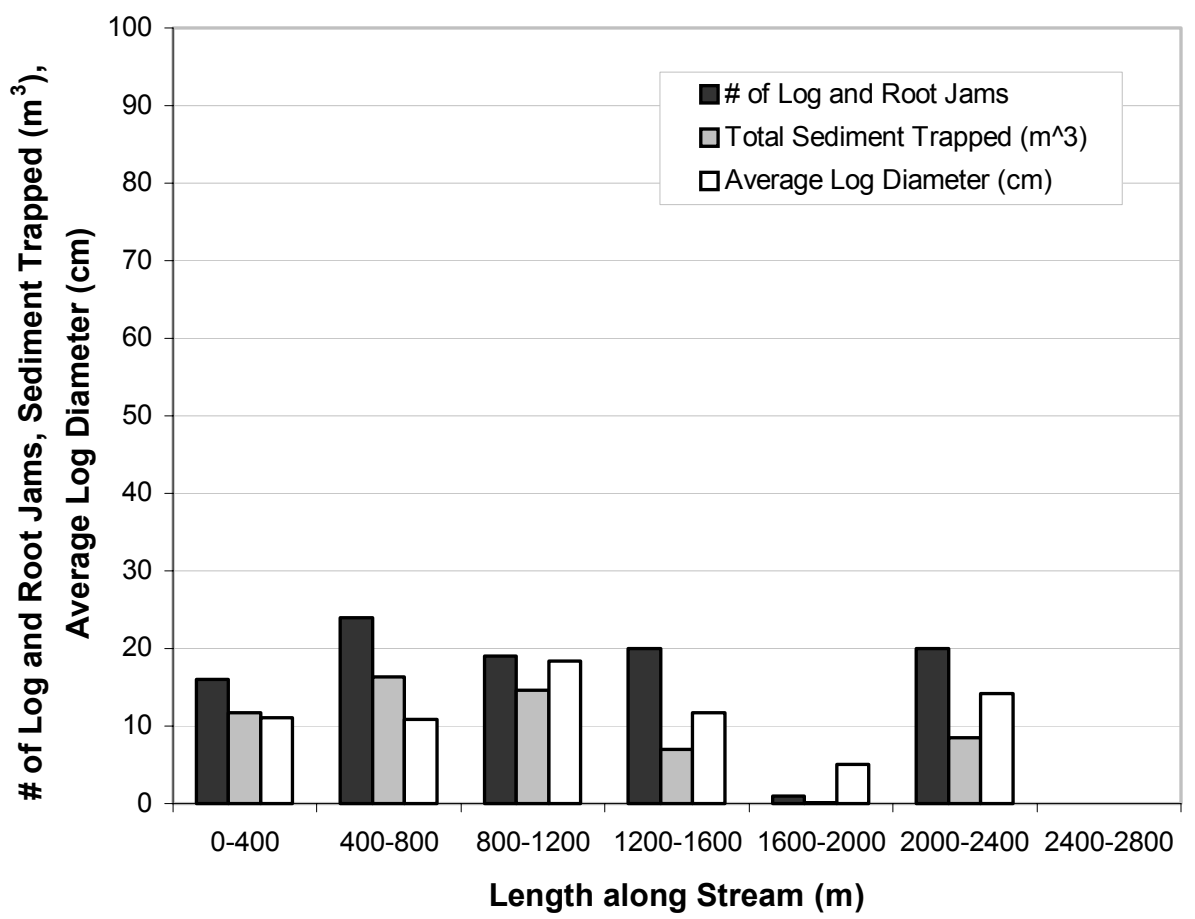

Figure A.6. Log and root jam frequency, total sediment trapped in jams, and average log diameter binned for $400 \mathrm{~m}$ length stream segments of Little Stony Tributary. 

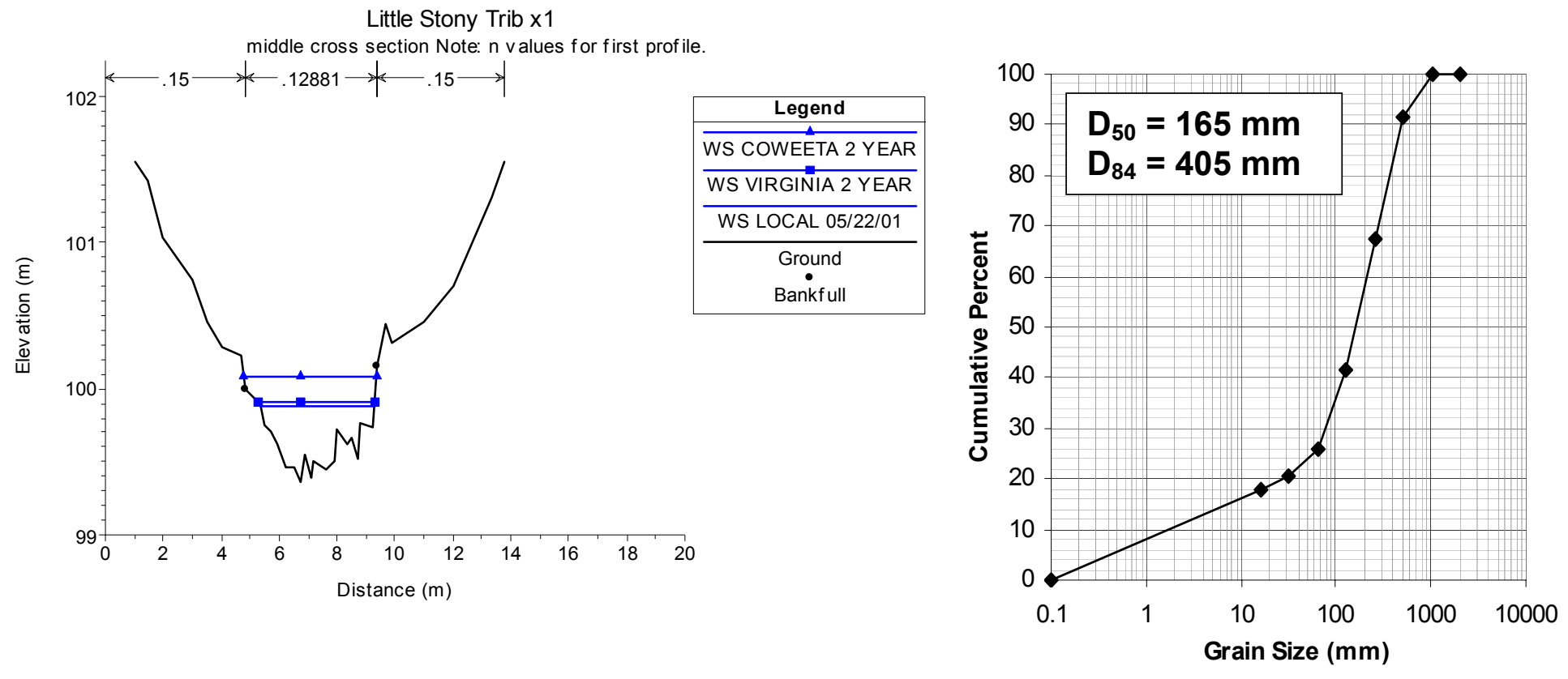

Figure A.7. Little Stony Tributary reach 1, middle cross section (left), and cumulative grain size distribution from Wolman pebble count (right). Reach 1 was located in a cobble-boulder step-pool section of channel just above the road.
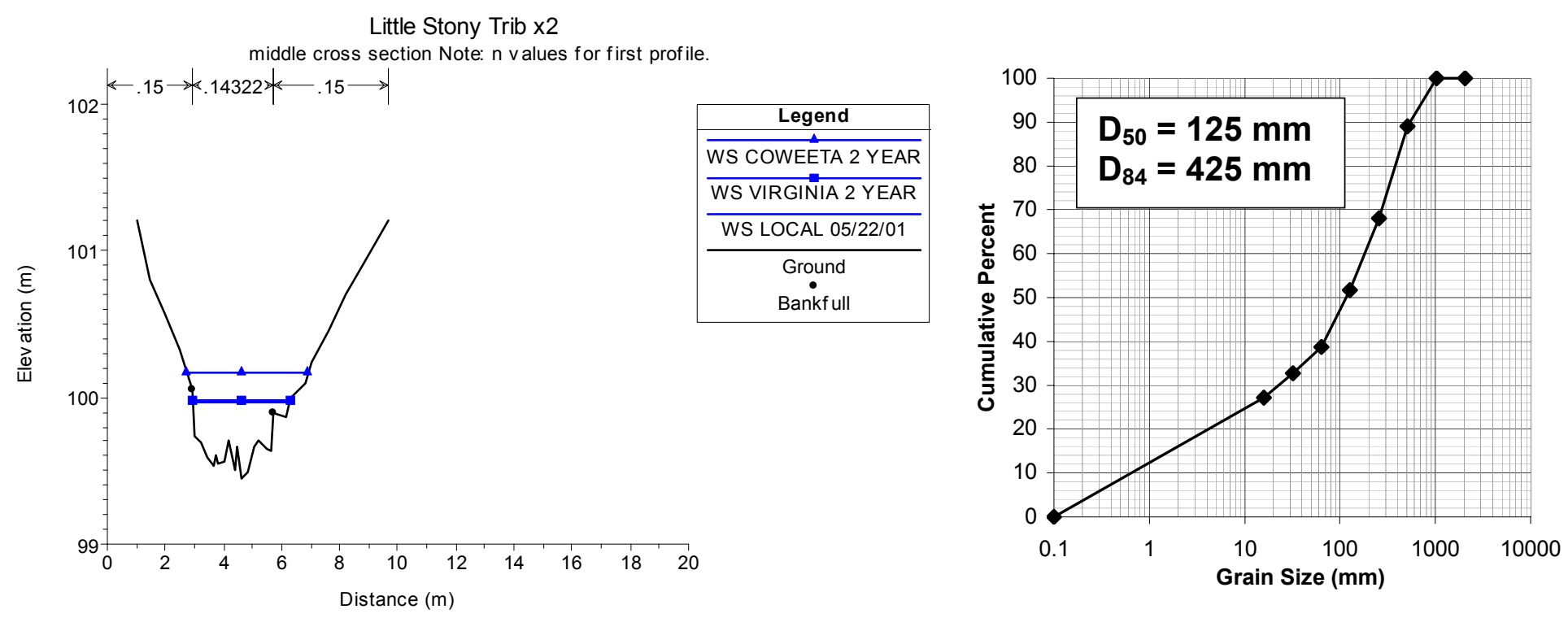

Figure A.8. Little Stony Tributary reach 2, middle cross section (left), and cumulative grain size distribution from Wolman pebble count (right). Reach 2 was located in a cobble-boulder section with a well-defined channel shape, representative of the lower $1 / 5$ of the stream. 

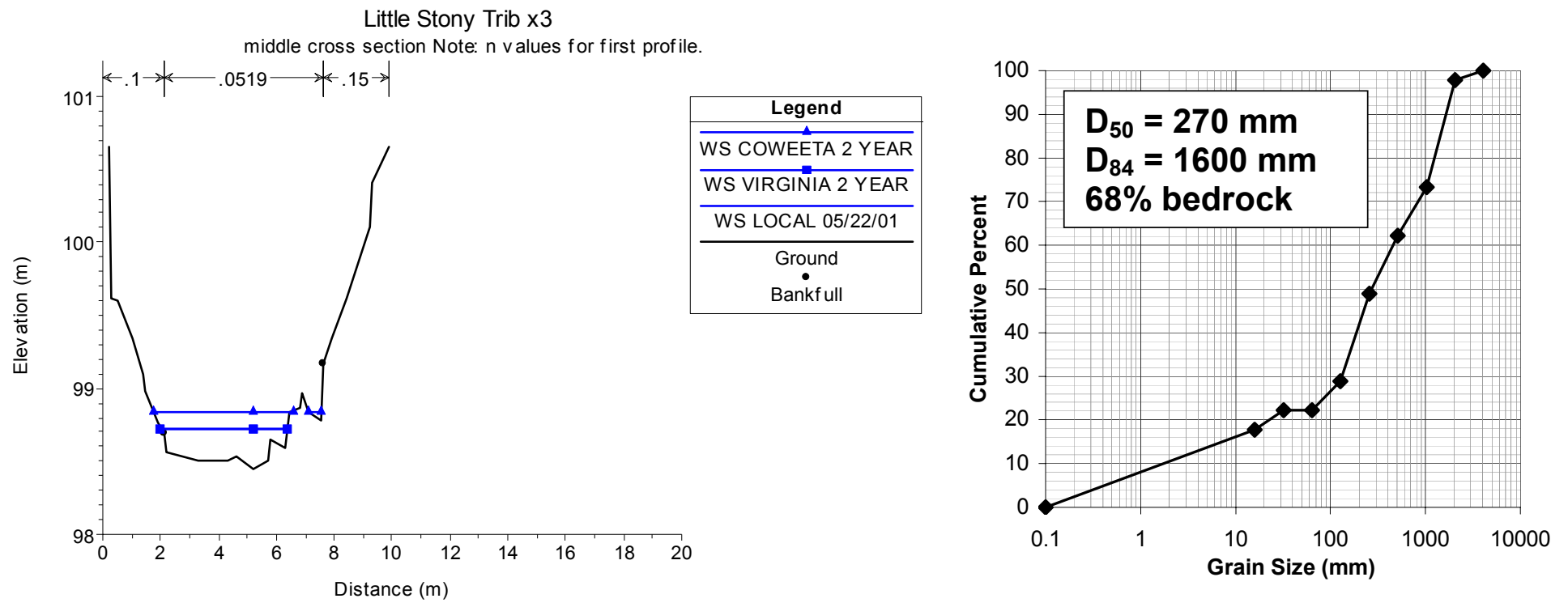

Figure A.9. Little Stony Tributary reach 3, middle cross section (left), and cumulative grain size distribution from Wolman pebble count (right). Reach 3 was located at a wide, flat section of bedrock-floored channel, with large boulders on one side of the channel and a steep hillslope on the other.
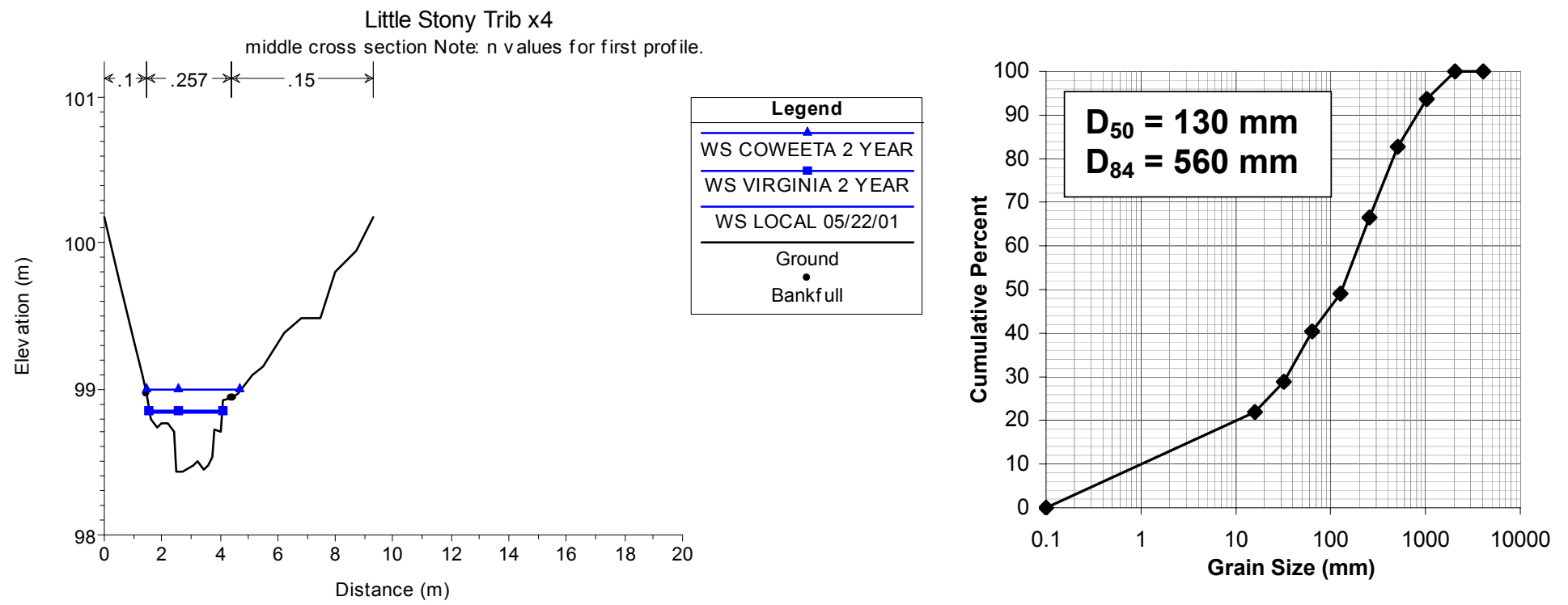

Figure A.10. Little Stony Tributary reach 4, middle cross section (left), and cumulative grain size distribution from Wolman pebble count (right). Reach 4 was located in a deep section of channel with a steep, shale hillslope on the left side (looking downstream). 

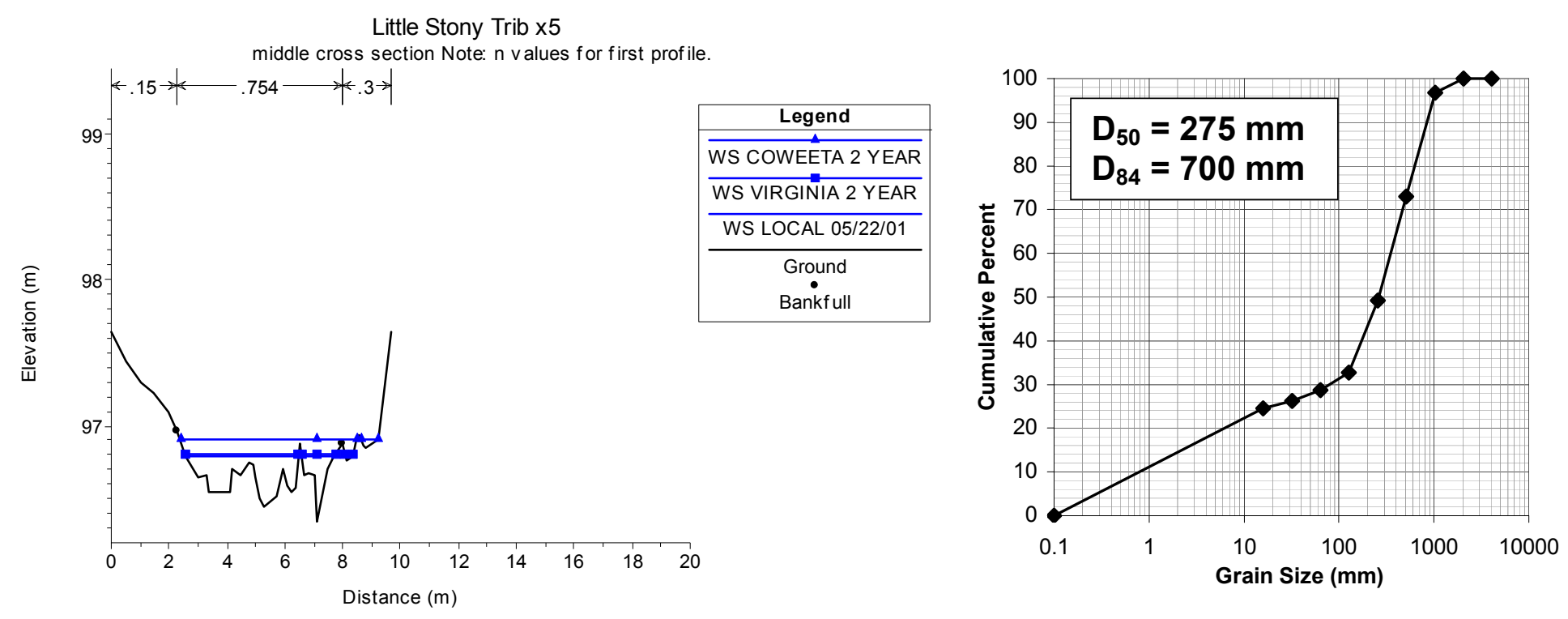

Figure A.11. Little Stony Tributary reach 5, middle cross section (left), and cumulative grain size distribution from Wolman pebble count (right). Reach 5 was located in a wide, bouldery section of channel representative of the upper slopes of the basin.
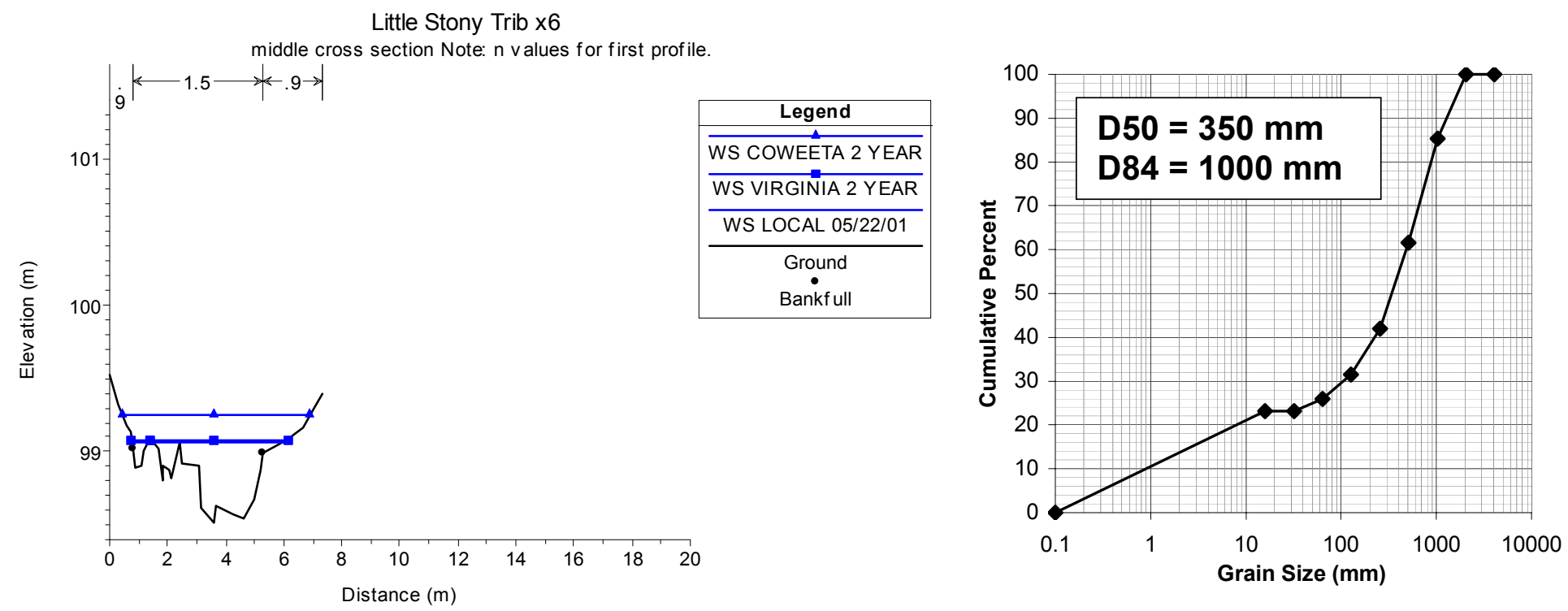

Figure A.12. Little Stony Tributary reach 6, middle cross section (left), and cumulative grain size distribution from Wolman pebble count (right). Reach 6 was located below the Tuscarora sandstone outcrop, in a very steep, boulder section of channel. 

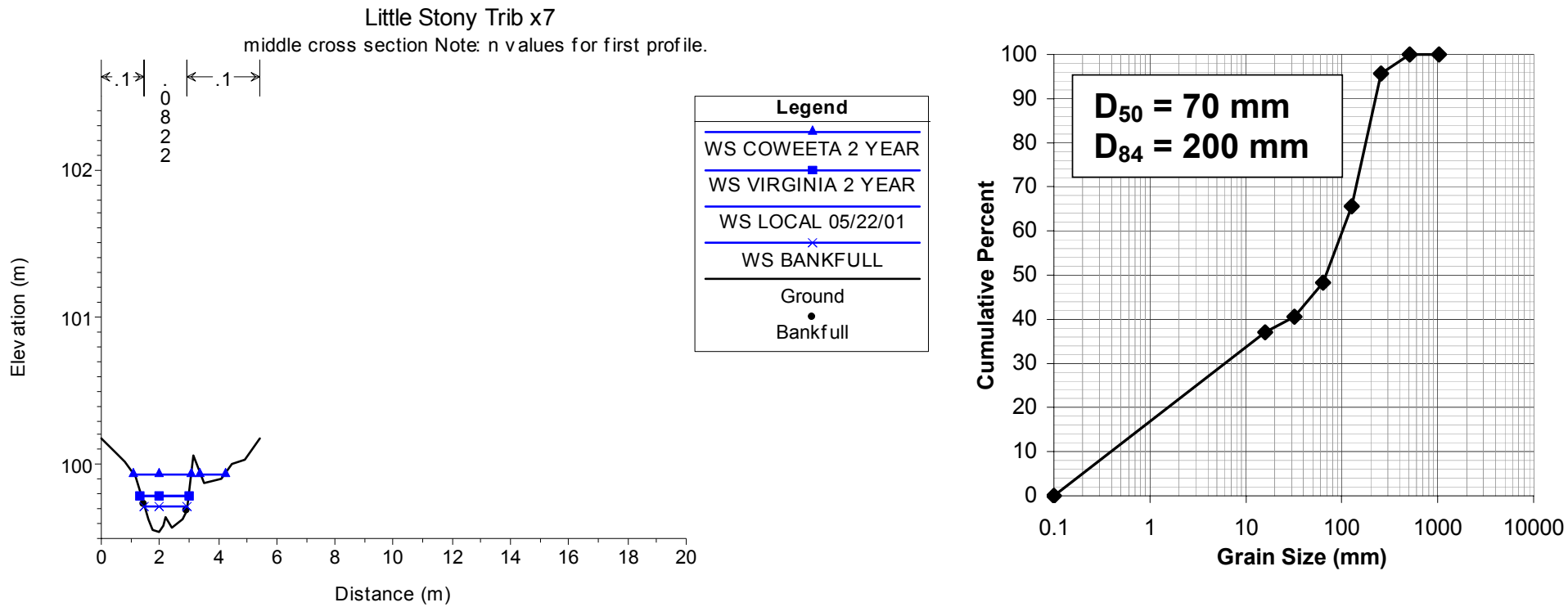

Figure A.13. Little Stony Tributary reach 7, middle cross section (left), and cumulative grain size distribution from Wolman pebble count (right). Reach 7 was located above the Tuscarora sandstone outcrop, in a lowgradient, cobble section of channel, very unlike the rest of the downstream sections, but representative of the channel above the outcrop. 


\section{Appendix B}

\section{Given Branch}

\section{Qualitative Observations}

Given Branch initiates from a wide, seepy, bowl-shaped cove that has cobble and abundant small vegetation. Downstream it becomes a wide, cobbly channel with divergent flow as it passes over a convex, bowl-shaped valley. The valley becomes confined, and the channel narrows and deepens before entering another convex, bowl-shaped valley. Here the channel is again wide and shallow, and then becomes narrow and deeply incised (x4) as it cuts through another confined valley. This upper section is open, wet hardwood forest and not very dense little brush or rhododendron. The channel slowly becomes narrower and the banks highly vegetated as it continues down through grassy, shrubby forest. As slope decreases, the channel enters grazed pasture and at this point is greatly modified (x1), recently backhoed to improve flow for livestock water. It has a steep, sharp V shape with little vegetation on the banks or surrounding open valley besides some grass. Low flows are present throughout the channel.

Rebecca Kavage and Doug Marchakitus surveyed Given Branch from June 18-20, 2001. 


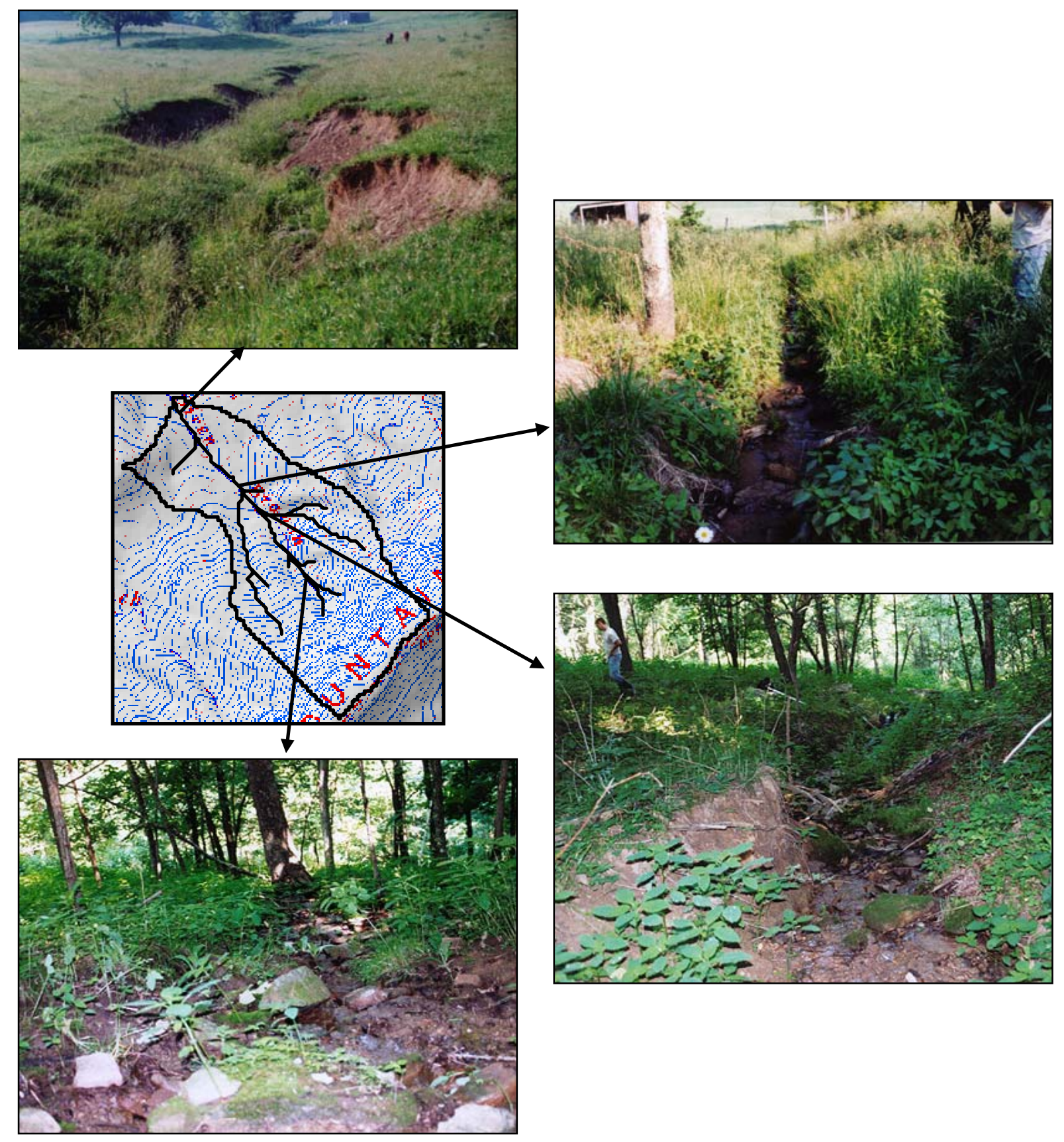

Figure B.1. Photographs of Given Branch, counterclockwise from lower left: wide, cobbly channel in convex, open valley (x5); deeply incised channel in confined valley $(x 4)$; small, narrow channel in grassy orchard between mountain and valley (x2); and V-shaped backhoed channel in grazed valley area. 


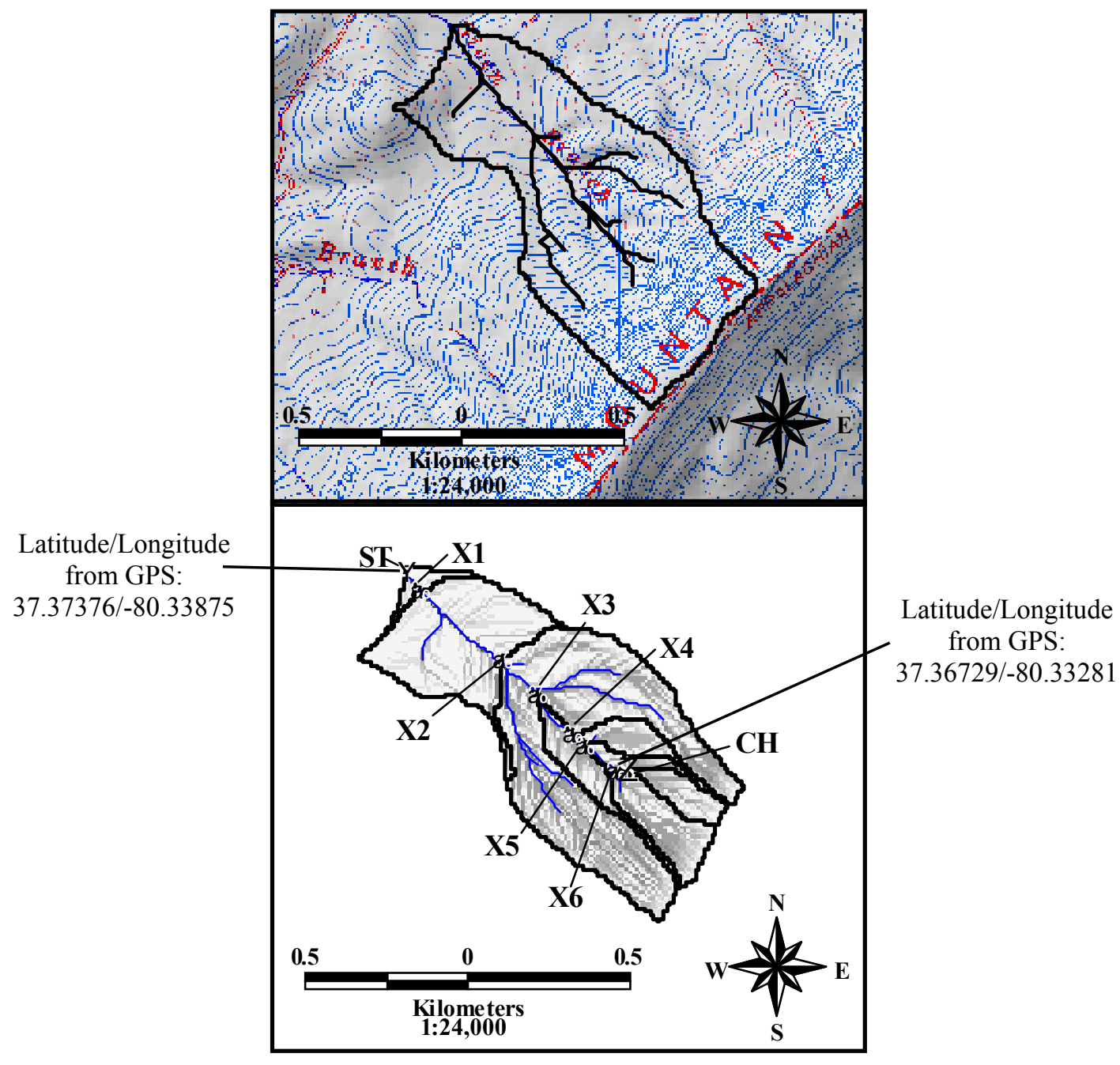

Figure B.2. Topographic and drainage network maps of Given Branch Basin, denoting survey points. 


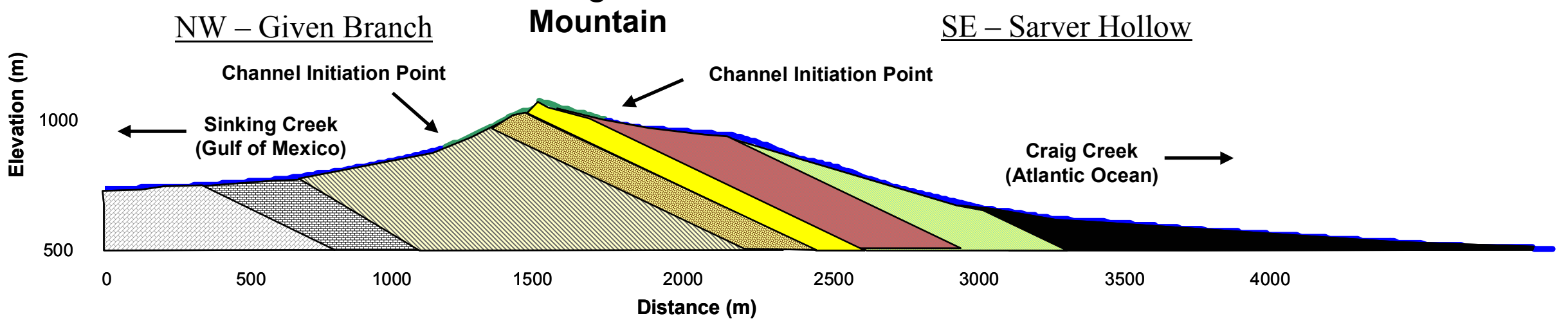

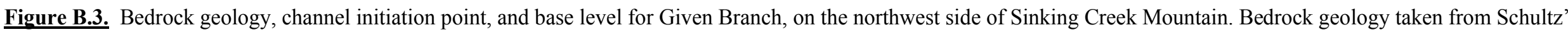
$(1986,1993)$ geologic maps of Giles County and Sinking Creek mountain.

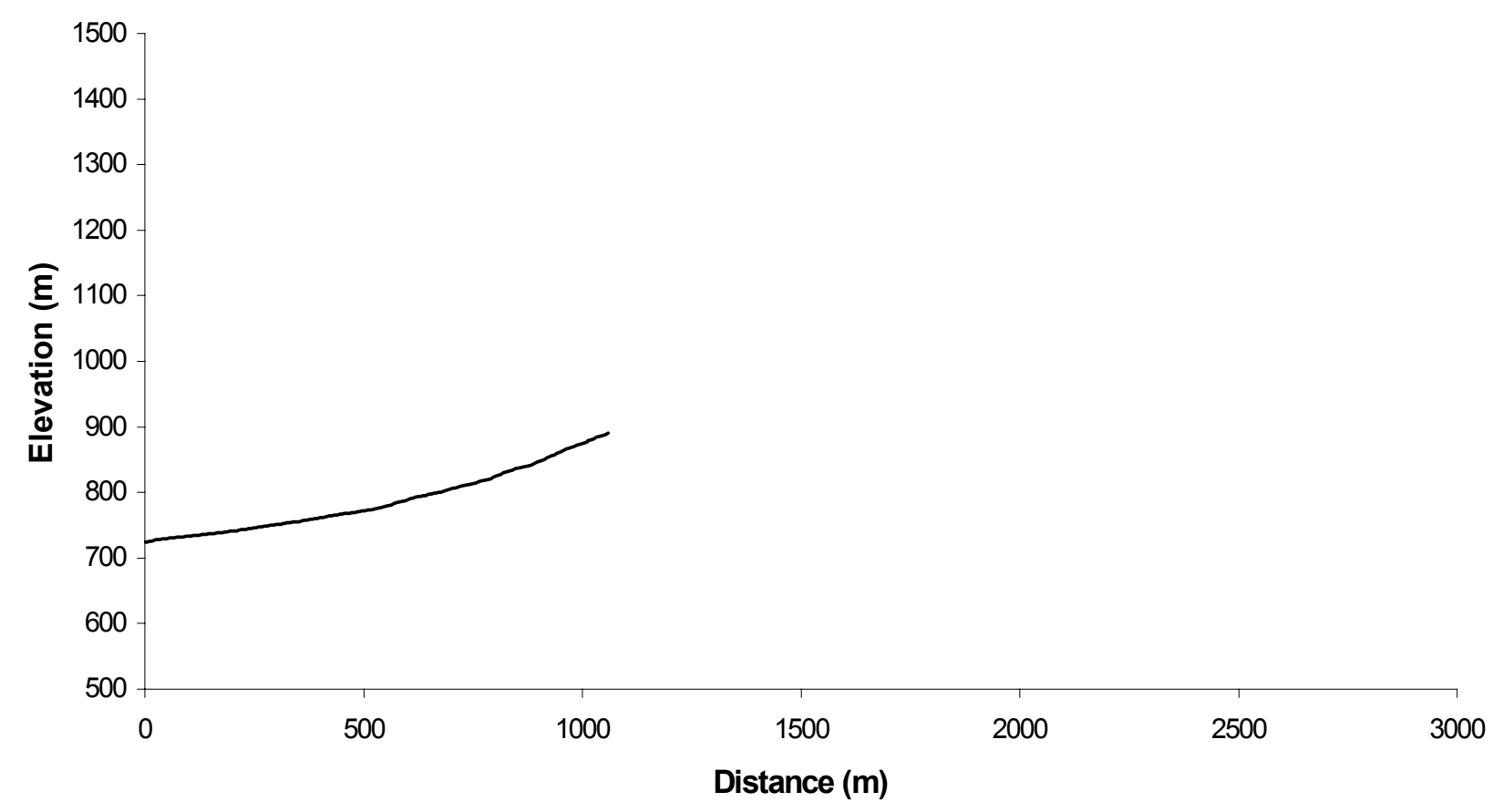

Figure B.4. Given Branch longitudinal profile, from survey data. 


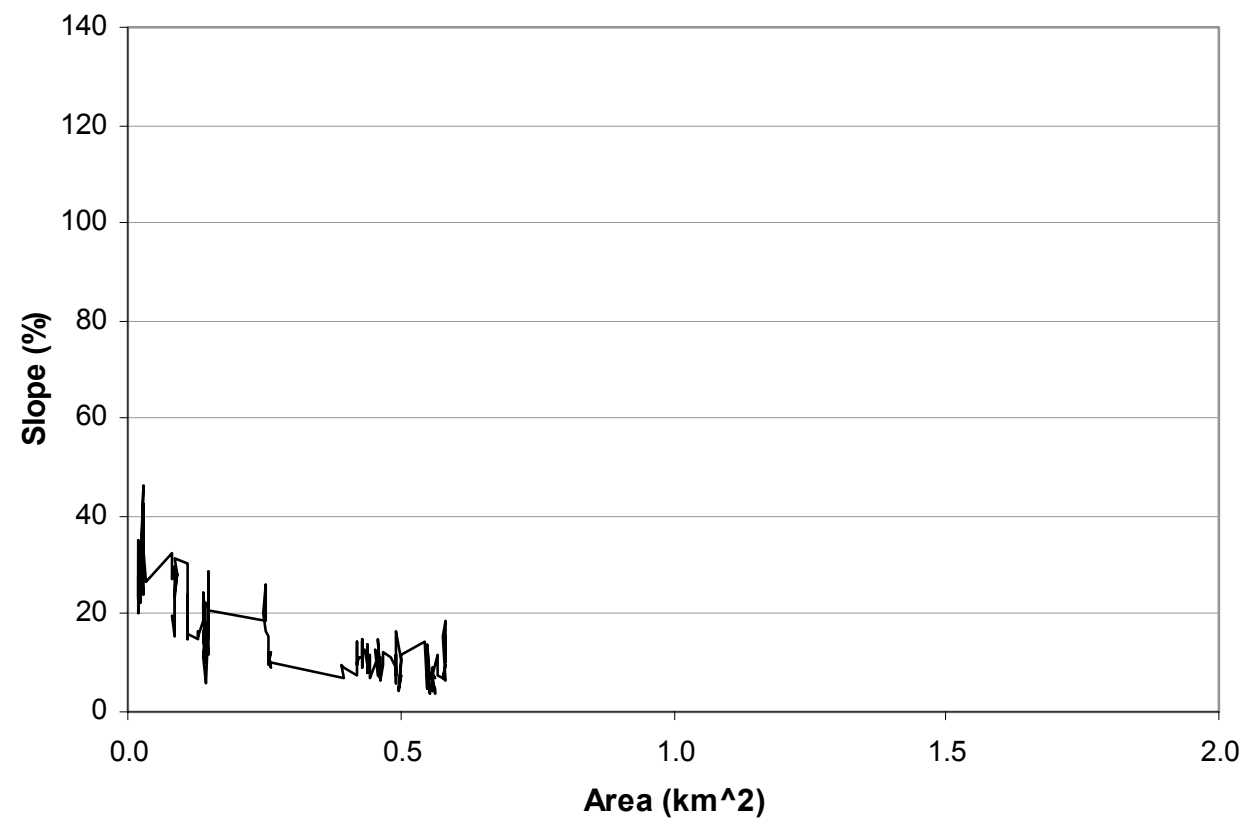

Figure B.5. Slope-area plot for surveyed portion of Given Branch channel, using field surveyed slope values and DEM-generated drainage area values.

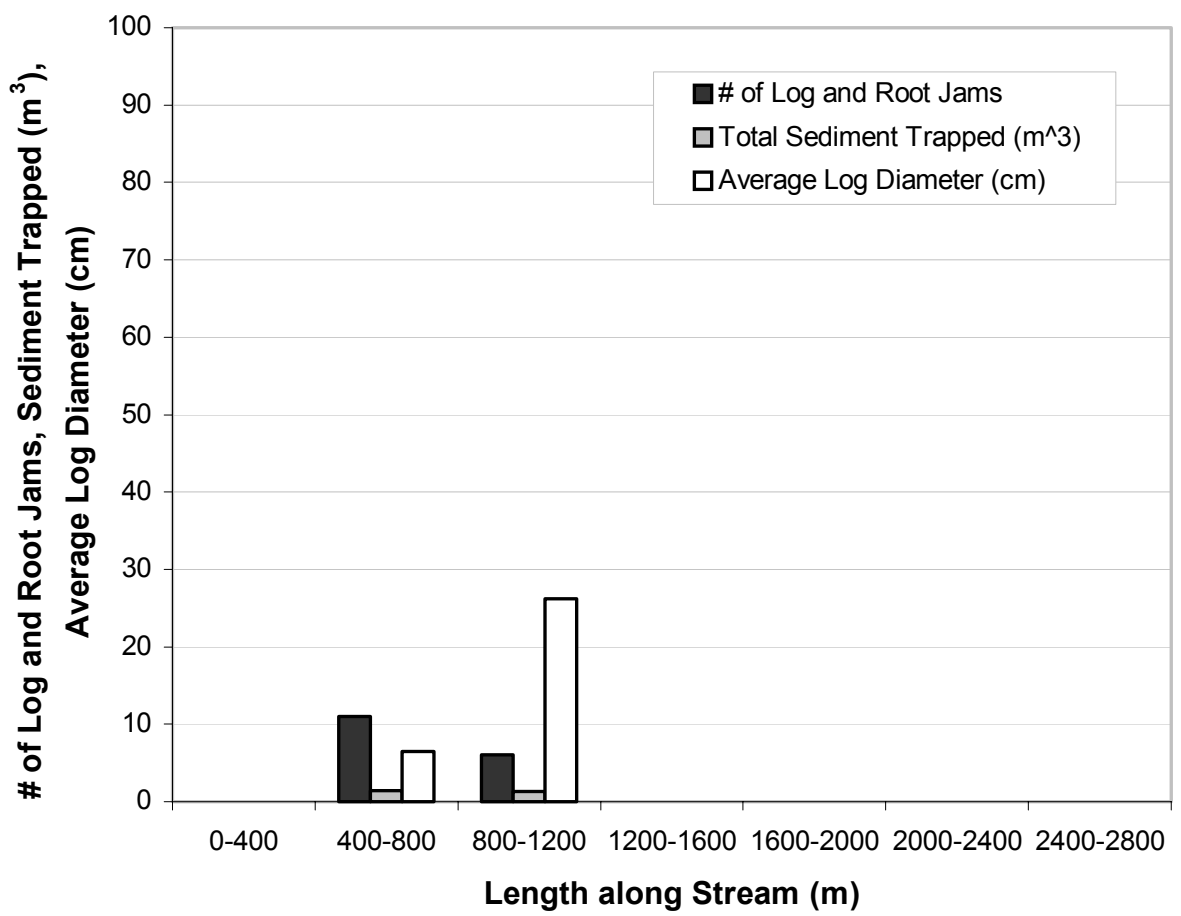

Figure B.6. Log and root jam frequency, total sediment trapped in jams, and average log diameter binned for $400 \mathrm{~m}$ length stream segments of Given Branch. 

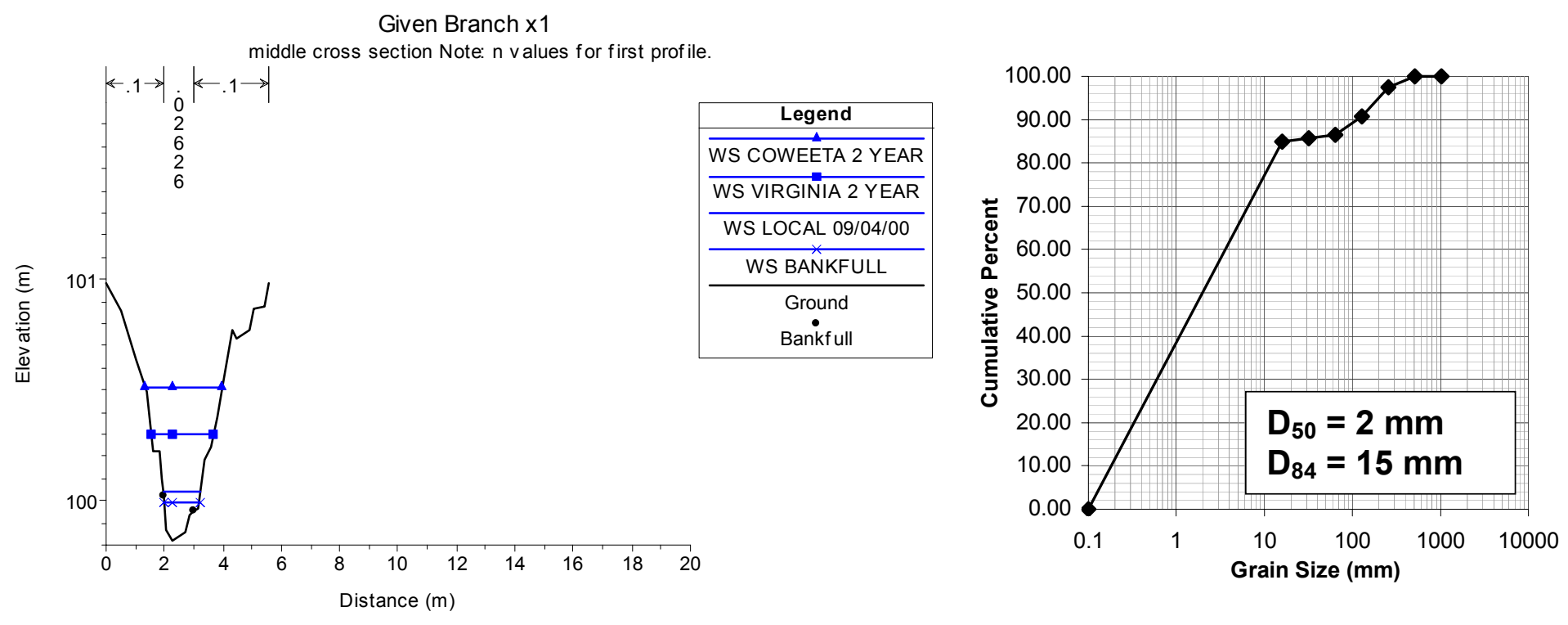

Figure B.7. Given Branch reach 1, middle cross section (left), and cumulative grain size distribution from Wolman pebble count (right). Reach 1 was located in a heavily grazed open field, in a modified (backhoed) section of the channel with a narrow $\mathrm{V}$-shape and many fines.
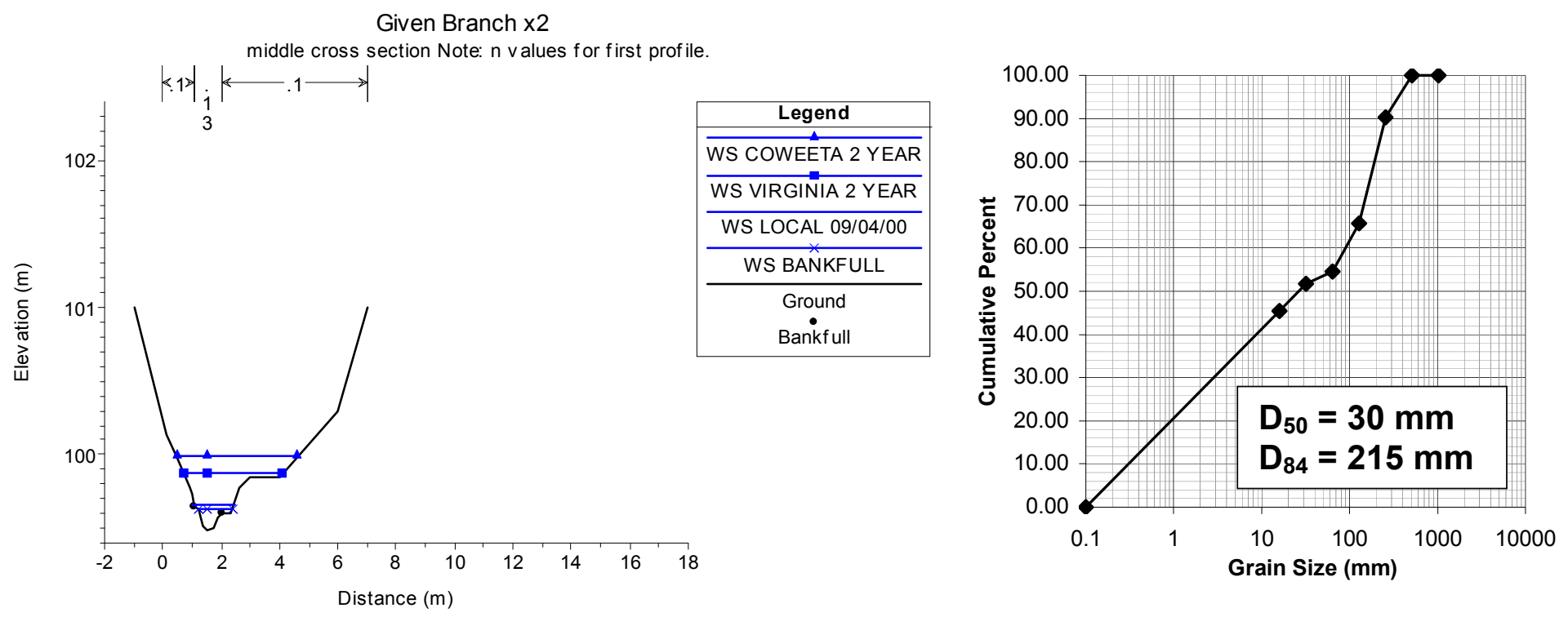

Figure B.8. Given Branch reach 2 middle cross section (left), and cumulative grain size distribution from Wolman pebble count (right). Reach 2 was located just above the grazed field, on private grass/forest property. The channel was small and narrow with grassy banks and cobble substrate. 
Given Branch x3
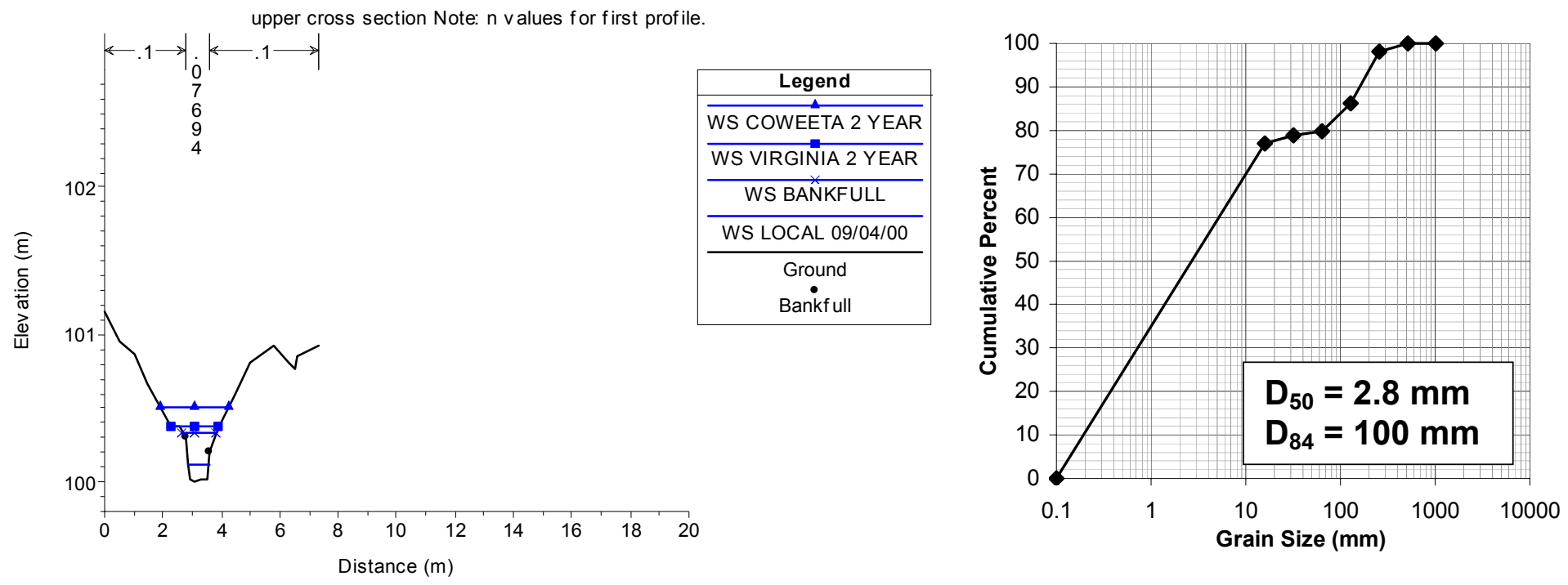

Figure B.9. Given Branch reach 3, middle cross section (left), and cumulative grain size distribution from Wolman pebble count (right). Reach 3 was located in a grassy, partially forested area leading up to the forested hillside. The channel was deep, narrow, and fine, with well-vegetated banks.
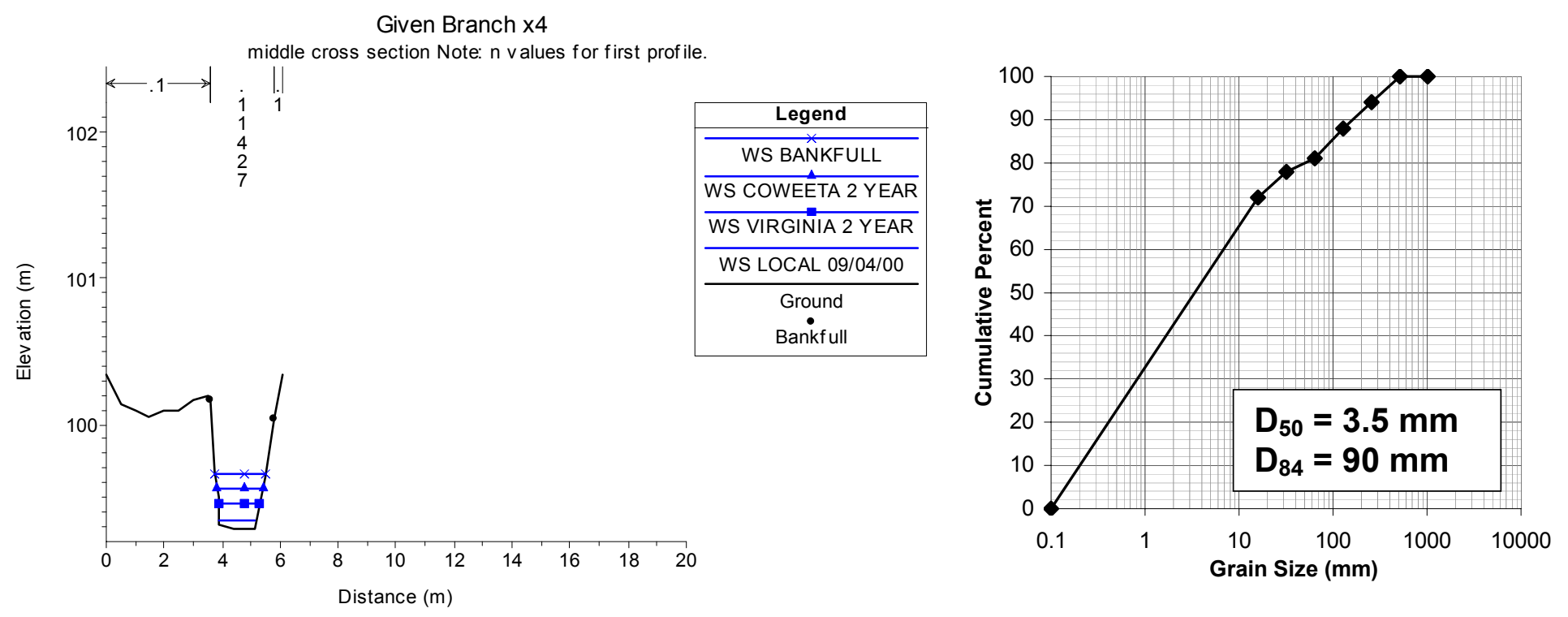

Figure B.10. Given Branch reach 4, middle cross section (left), and cumulative grain size distribution from Wolman pebble count (right). Reach 4 was located in a confined, deeply incised section of channel with very fine substrate and little vegetation on the banks. 

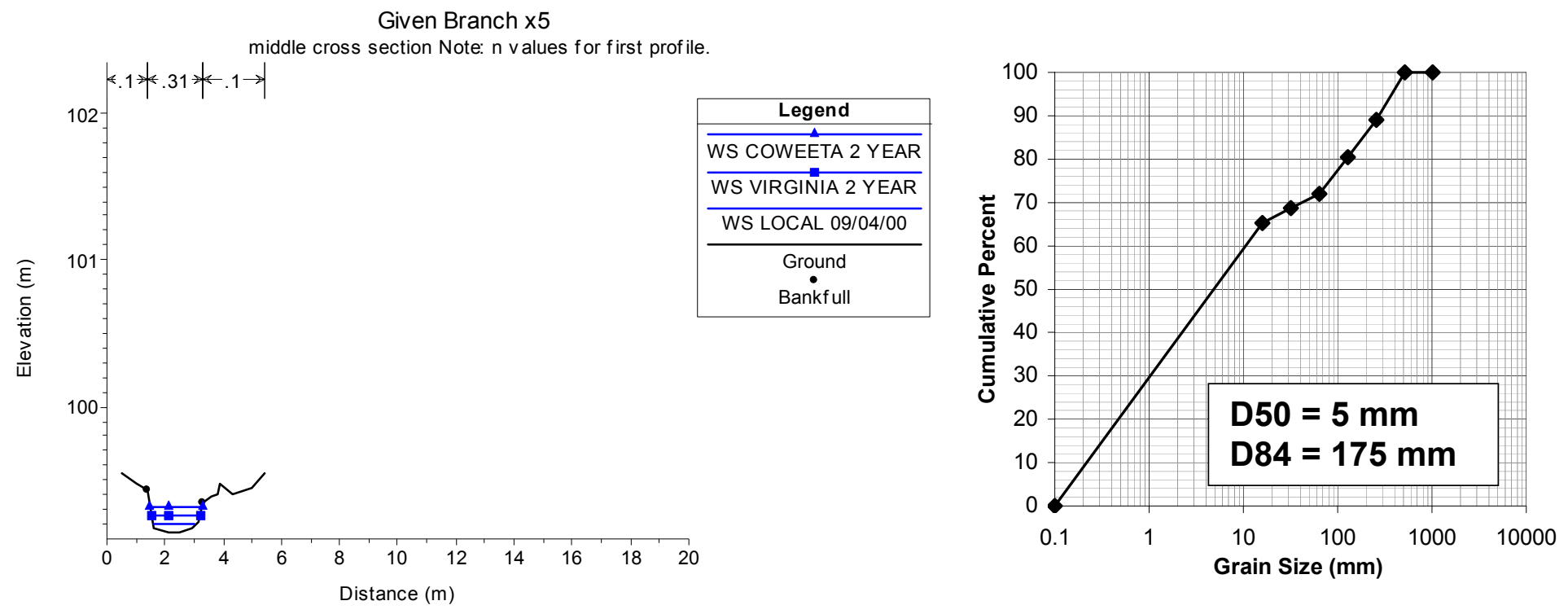

Figure B.11. Given Branch reach 5 middle cross section (left), and cumulative grain size distribution from Wolman pebble count (right). Reach 5 was located in an open, bowl-shaped section of the basin, representative of the wide, cobbly channel form in this area.
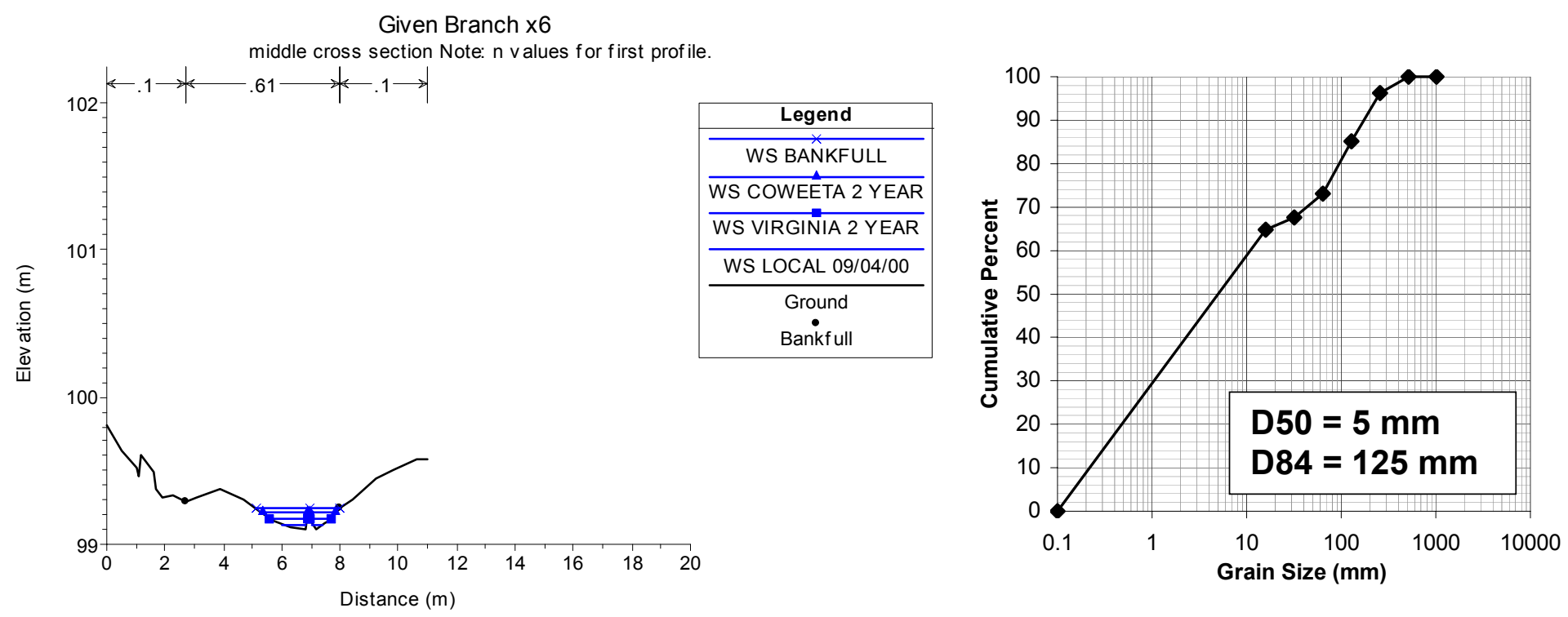

Figure B.12. Given Branch reach 6 middle cross section (left), and cumulative grain size distribution from Wolman pebble count (right). Reach 6 was located below the channel initiation point where the channel entered its first convex, bowl-shaped basin section. Its shape was very wide and cobbly, with a poorly defined channel form. 


\section{Appendix C \\ Sarver Hollow}

\section{Qualitative Observations}

Sarver Hollow varies greatly over its length. It initiates from a hole in the ground in a wide, flat break in topography below the ridgeline of Sinking Creek Mountain. It then becomes a narrow cobbly channel through a wet, low gradient area. This area is largely clear of vegetation and rocks, as the Sarver family up until the 1920's homesteaded it. The Sarvers modified portions of the channel in this section by stacking rocks up against the edge of the stream. The channel was flowing when surveyed after a heavy rainstorm, but dry when observed later, without prior rainfall.

The channel then enters a steep section of bouldery hillside. Flow (and the channel form) disappears beneath the boulders at a particularly steep point in the hillside. Rushing water was heard underneath the boulders in this section when surveying after a rainstorm. Eventually flow reappears and continues downstream at varying degrees of steepness, valley confinement and boulder size. The vegetation throughout this boulder section is mainly rhododendron and brushy trees, which are more abundant when the boulders are sparser.

Halfway down the mountain, there is a topographic break where slope decreases dramatically. The channel becomes finer-grained, wider, more sinuous, and there are some bedrock outcrops in the channel bottom. The valley in this lower section is very flat and wide, and dry hardwood forest dominates, with some rhododendron. As the channel progresses toward the road crossing, it becomes a typical alluvial trapezoidal shape, with gravel and cobble substrate. Throughout this lower section, channel flow is present.

Rebecca Kavage and Doug Marchakitus surveyed Sarver Hollow from May 21-22, 29$30,2001$. 

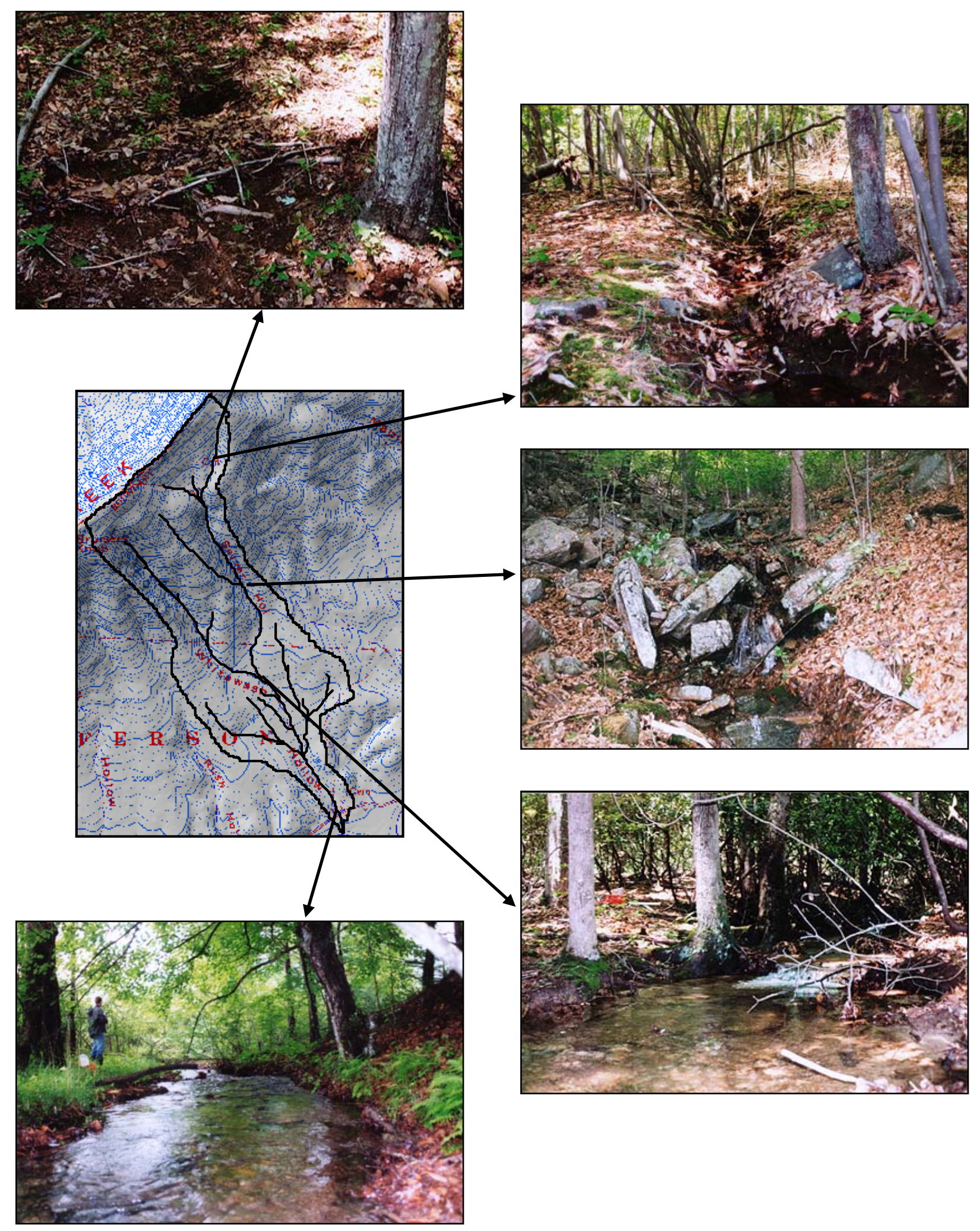

Figure C.1. Photographs of Sarver Hollow, clockwise from top left: hole where channel initiates; narrow low gradient channel above old Sarver homestead site; steep boulder channel in upper section (x6); low-gradient cobble channel in lower section (x4); and sinous gravel and cobble channel near road (x1). 

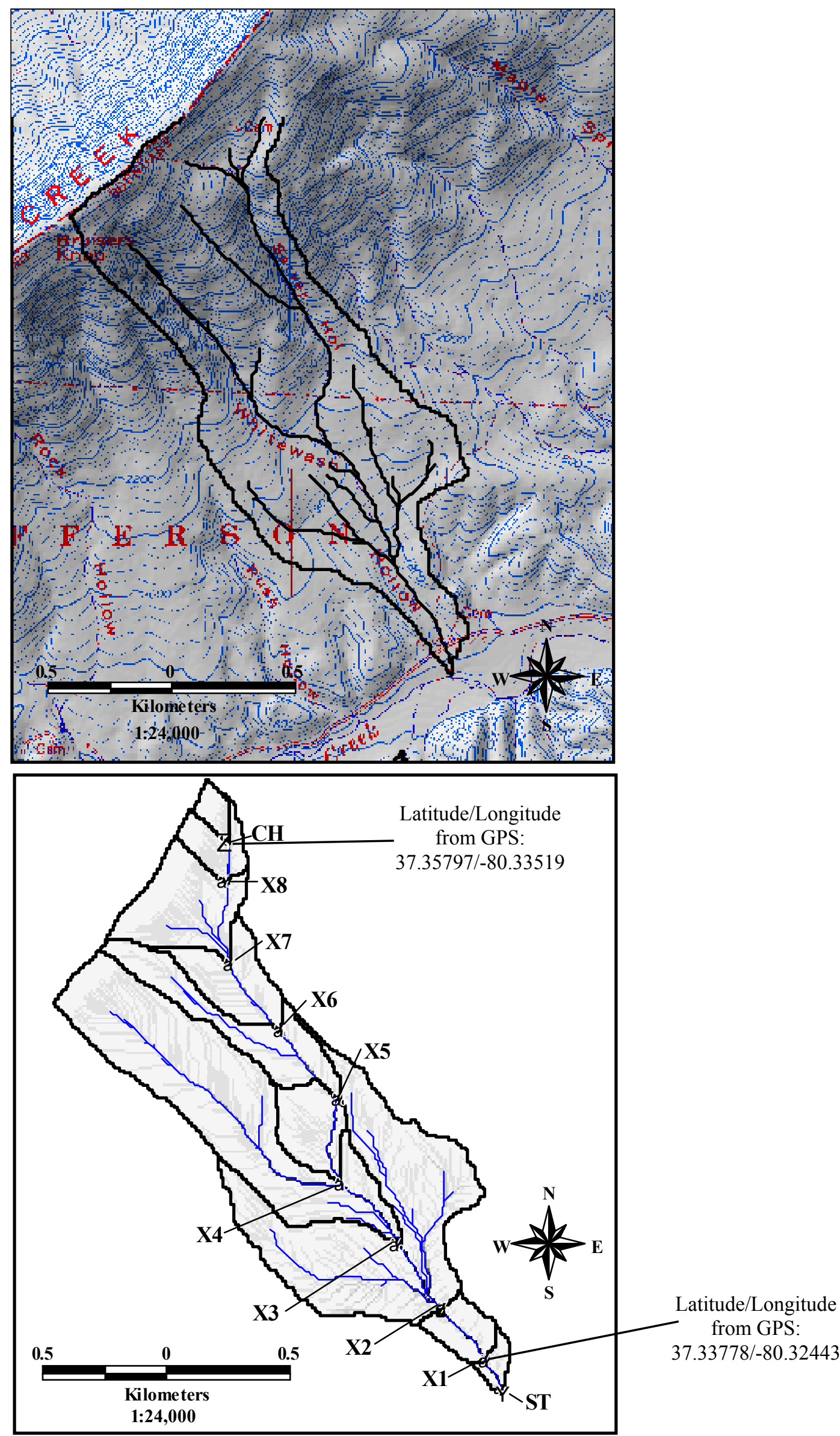

Figure C.2. Topographic and drainage network maps Sarver Hollow Basin, denoting survey points. 


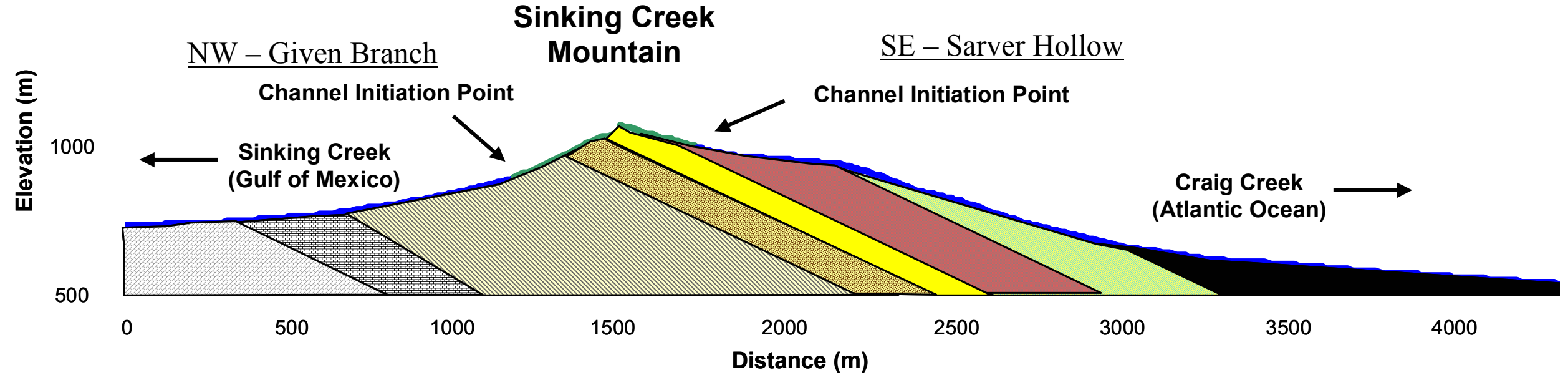

Figure C.3. Bedrock geology, channel initiation point, and base level for Sarver Hollow, on the southeast side of Sinking Creek Mountain. Bedrock geology taken from Schultz' $(1986,1993)$ geologic maps of Giles County and Sinking Creek mountain.

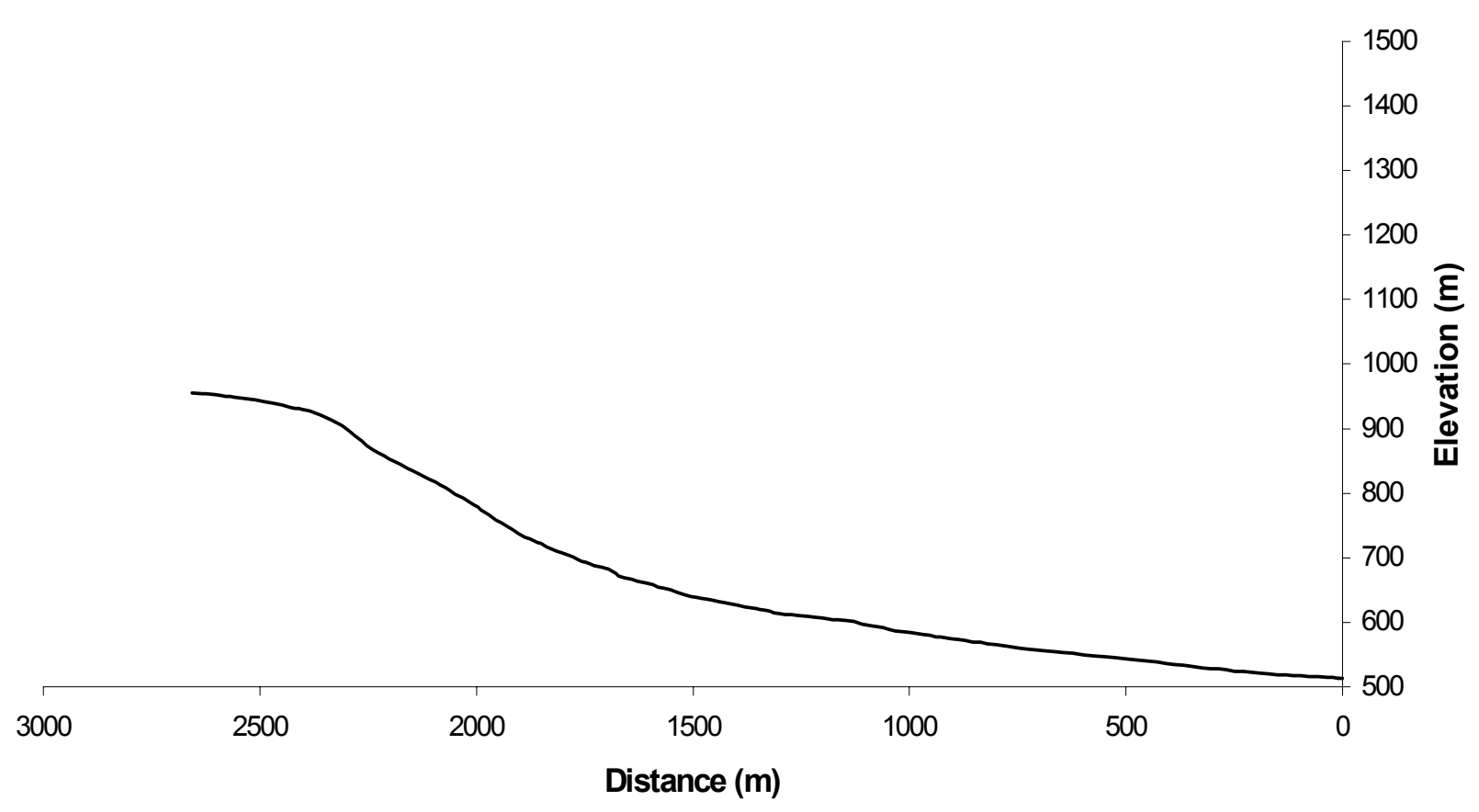

Figure C.4. Sarver Hollow longitudinal profile, from survey data. 


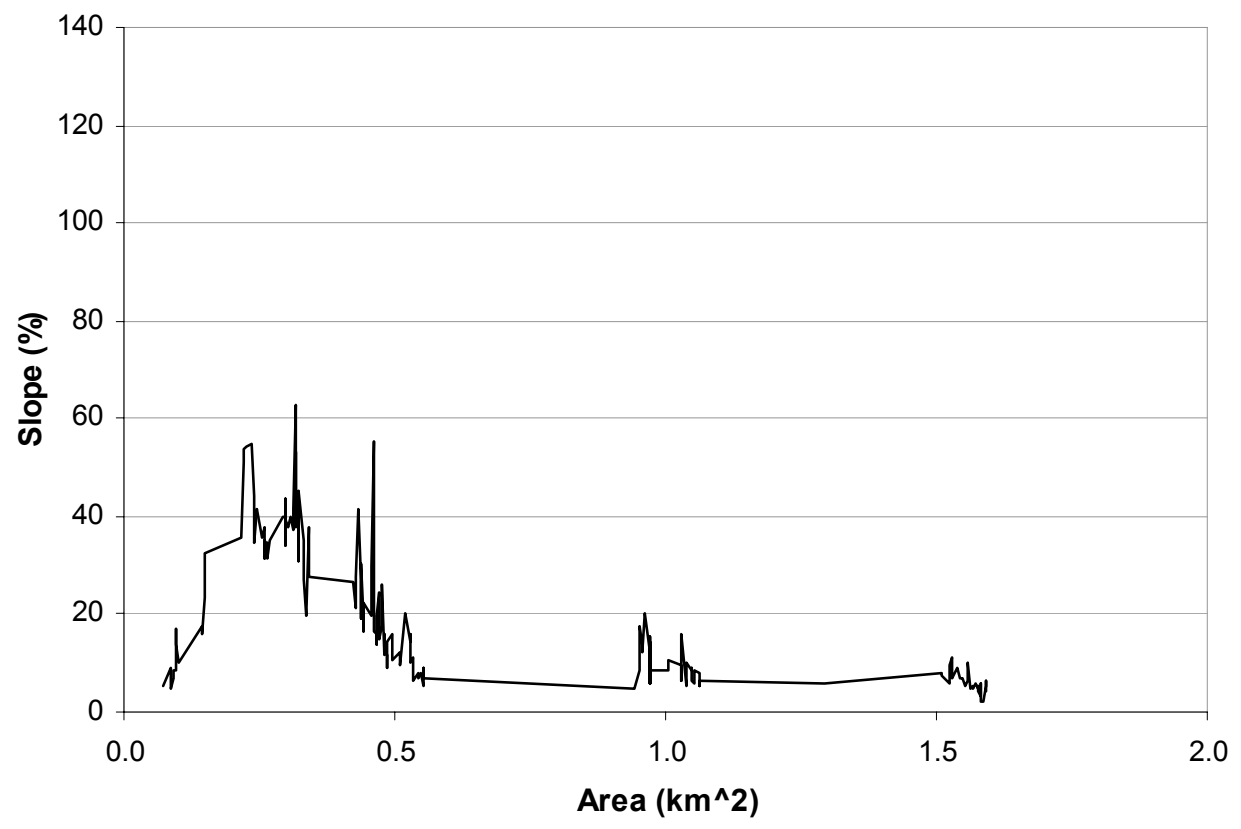

$\underline{\text { Figure C.5. }}$ Slope-area plot for surveyed portion of Sarver Hollow channel, using field surveyed slope values and DEM-generated drainage area values.

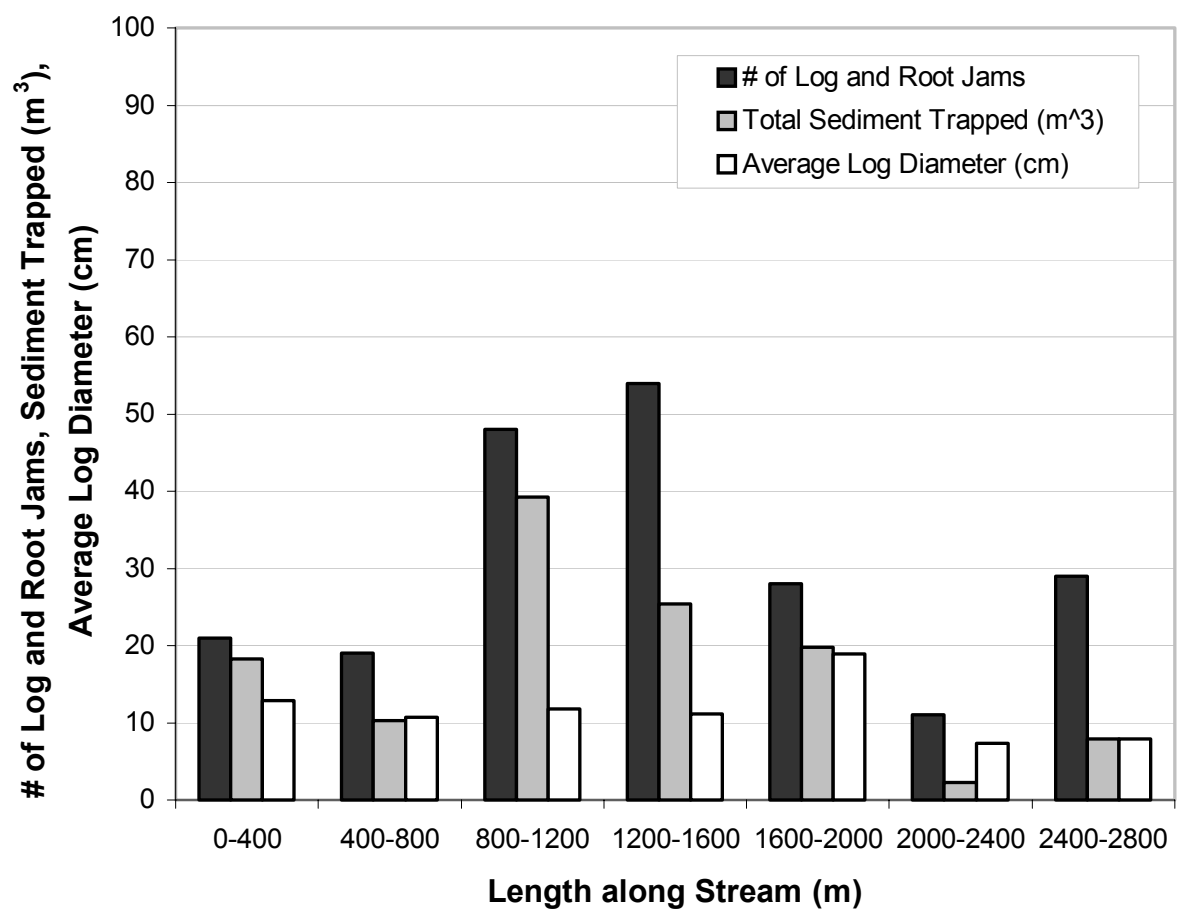

Figure C.6. Log and root jam frequency, total sediment trapped in jams, and average log diameter binned for $400 \mathrm{~m}$ length stream segments of Sarver Hollow. 

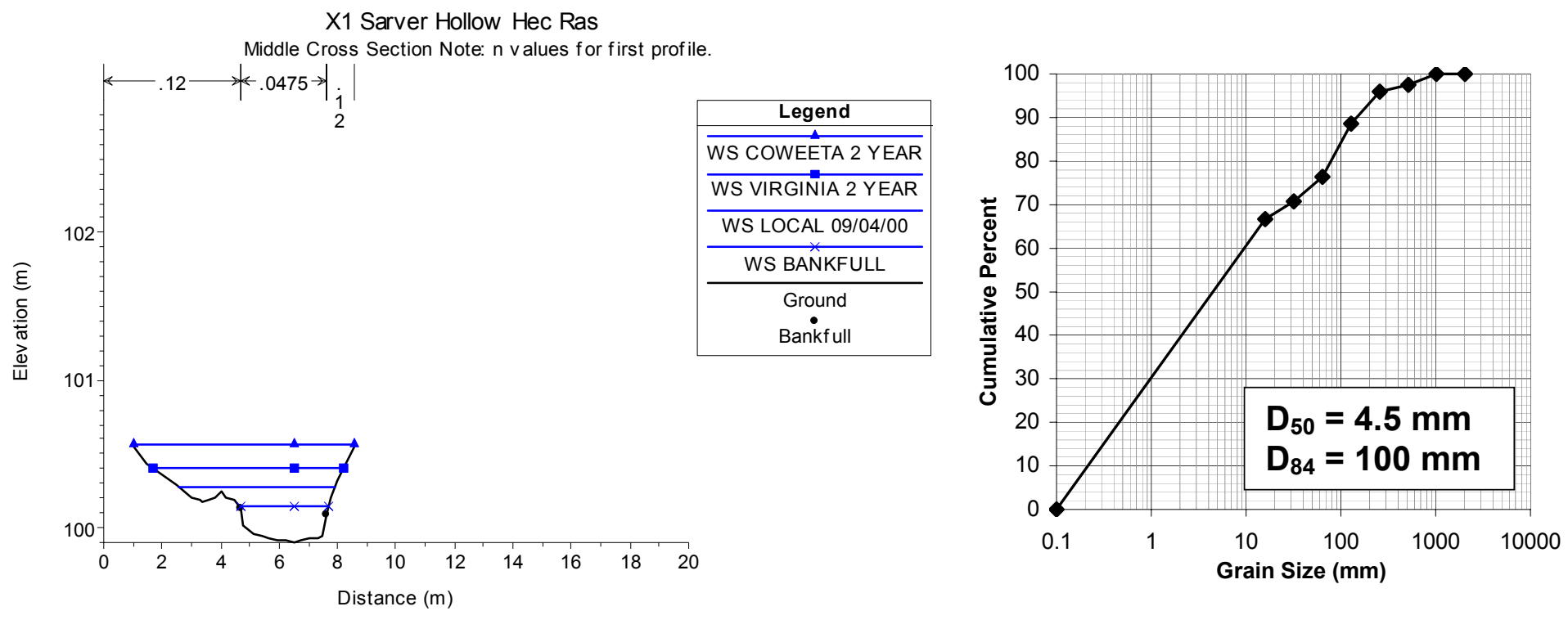

Figure C.7. Sarver Hollow reach 1, middle cross section (left), and cumulative grain size distribution from Wolman pebble count (right). Reach 1 was located in an alluvial cobble-fines section of channel just above the road.
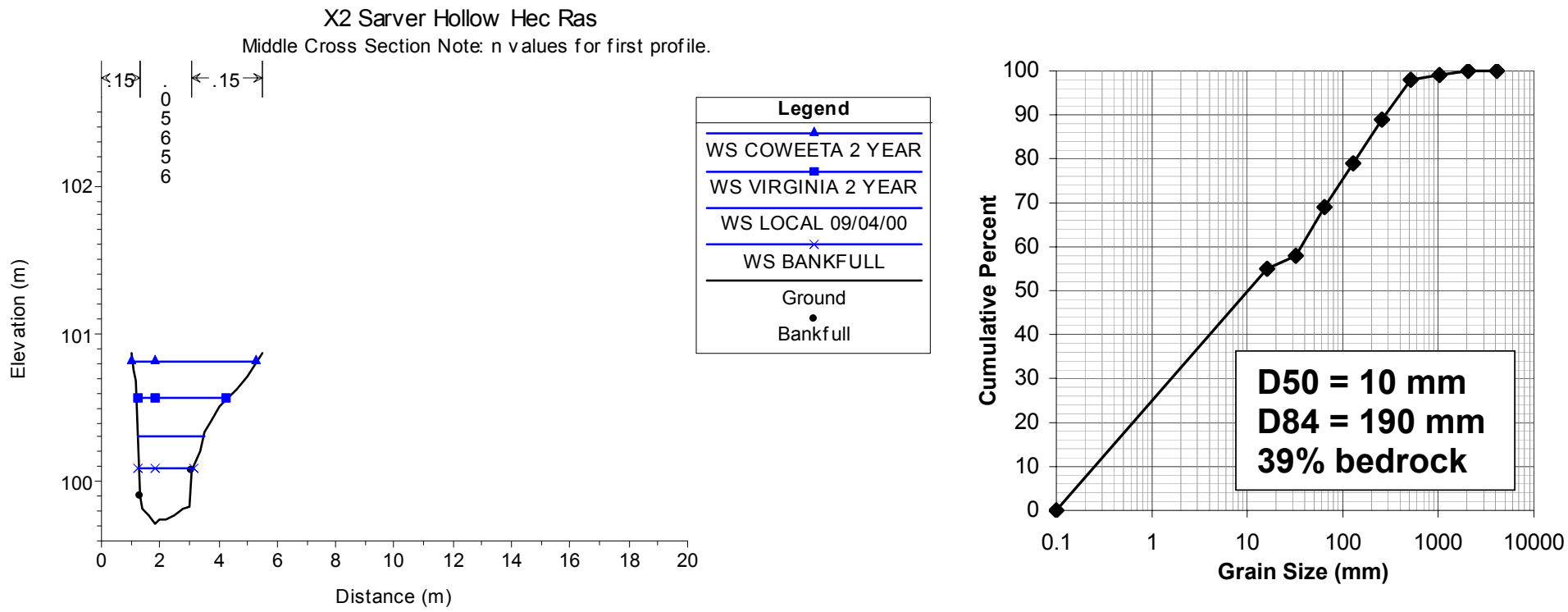

Figure C.8. Sarver Hollow reach 2, middle cross section (left), and cumulative grain size distribution from Wolman pebble count (right). Reach 2 was located in a deep, U-shaped section of channel carved into shale bedrock. 

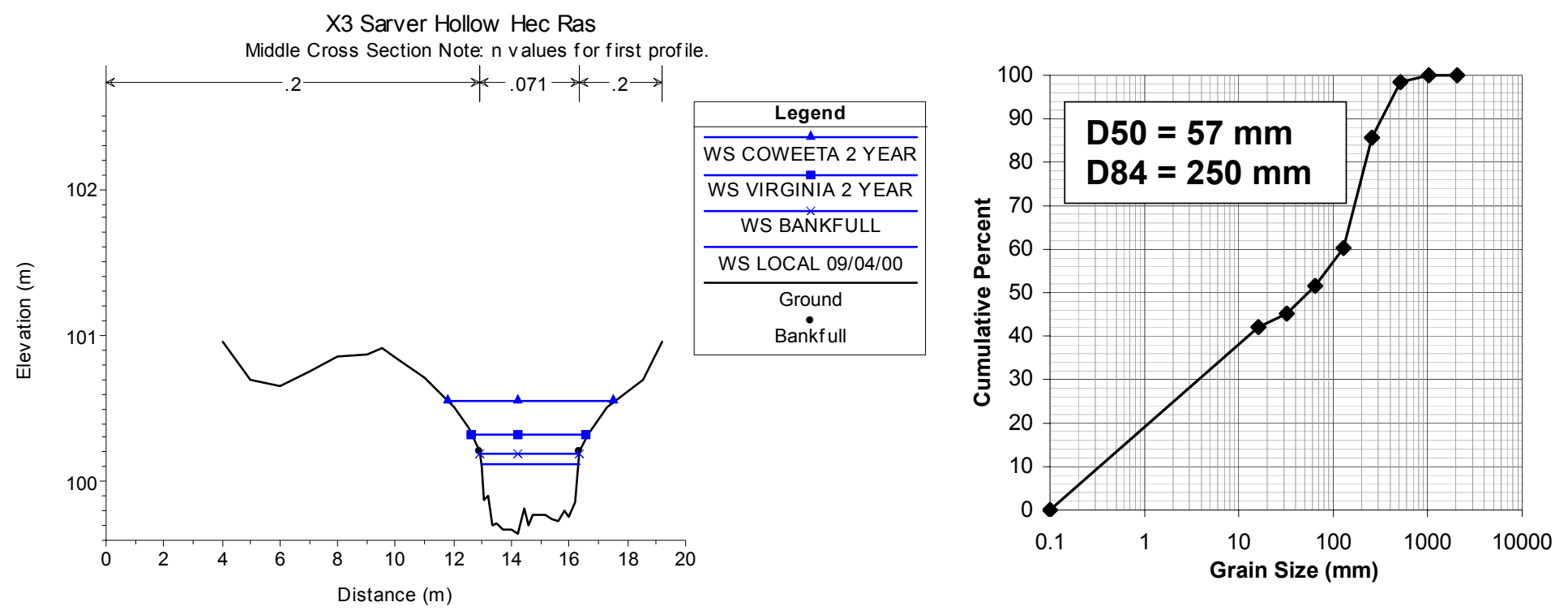

Figure C.9. Sarver Hollow reach 3, middle cross section (left), and cumulative grain size distribution from Wolman pebble count (right). Reach 3 was located in a cobble-small boulder section just below the confluence of Whitewash Hollow.
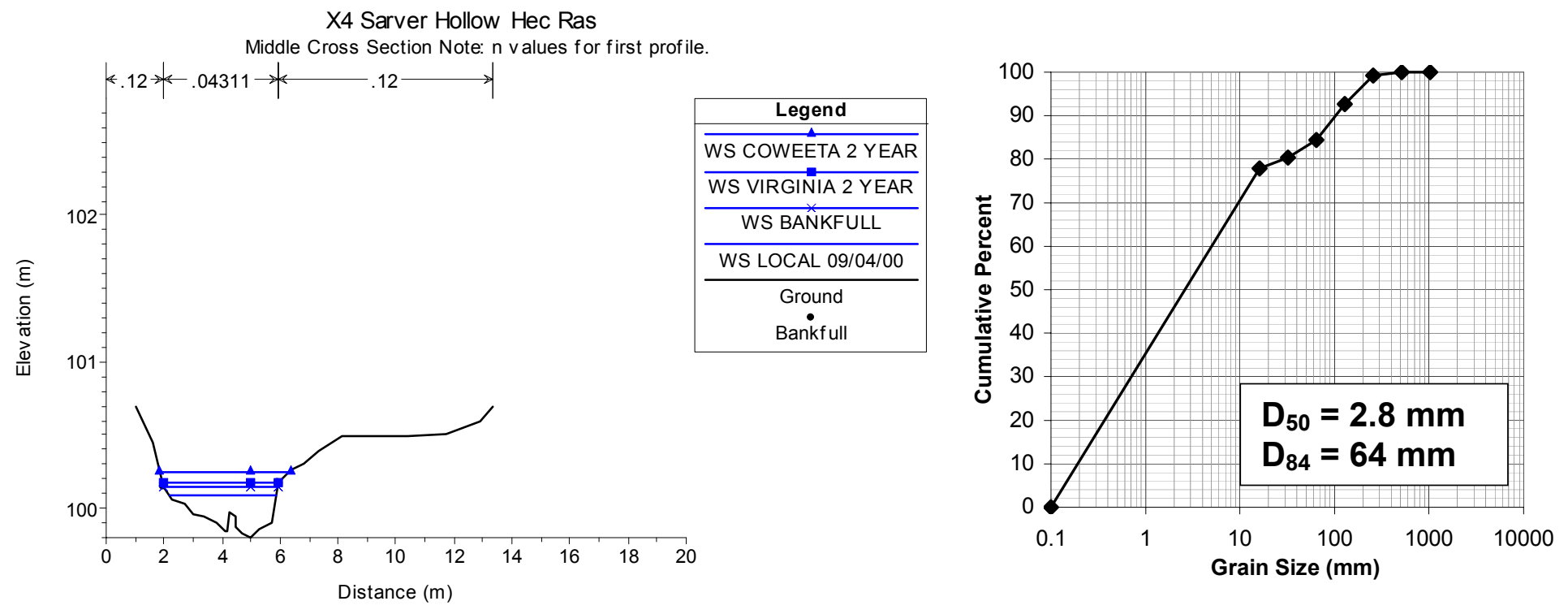

Figure C.10. Sarver Hollow reach 4, middle cross section (left), and cumulative grain size distribution from Wolman pebble count (right). Reach 4 was located in a wide, shallow section of channel that included a log jam and was mostly fines. It is representative of the channel in this area, just below the steep break in topography. 

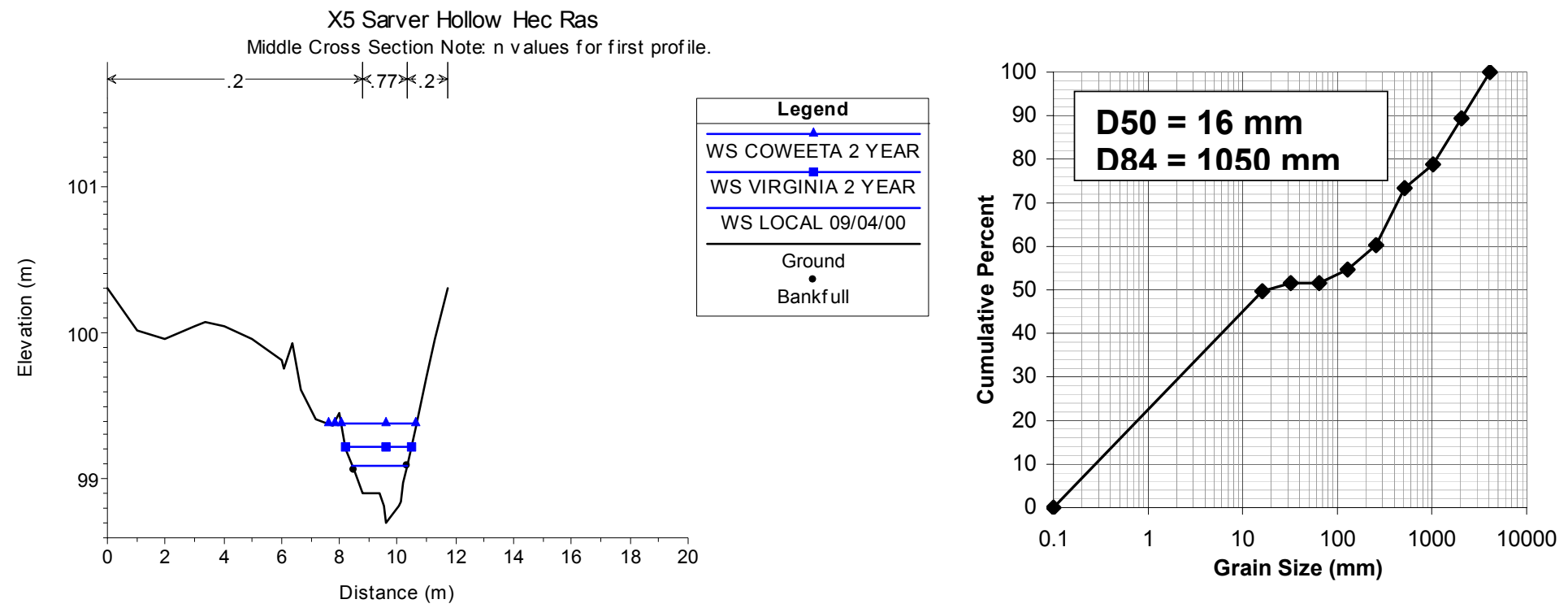

Figure C.11. Sarver Hollow reach 5, middle cross section (left), and cumulative grain size distribution from Wolman pebble count (right). Reach 5 was located in a very steep, boulder section representative of the channel after topography steepens in its upper half.
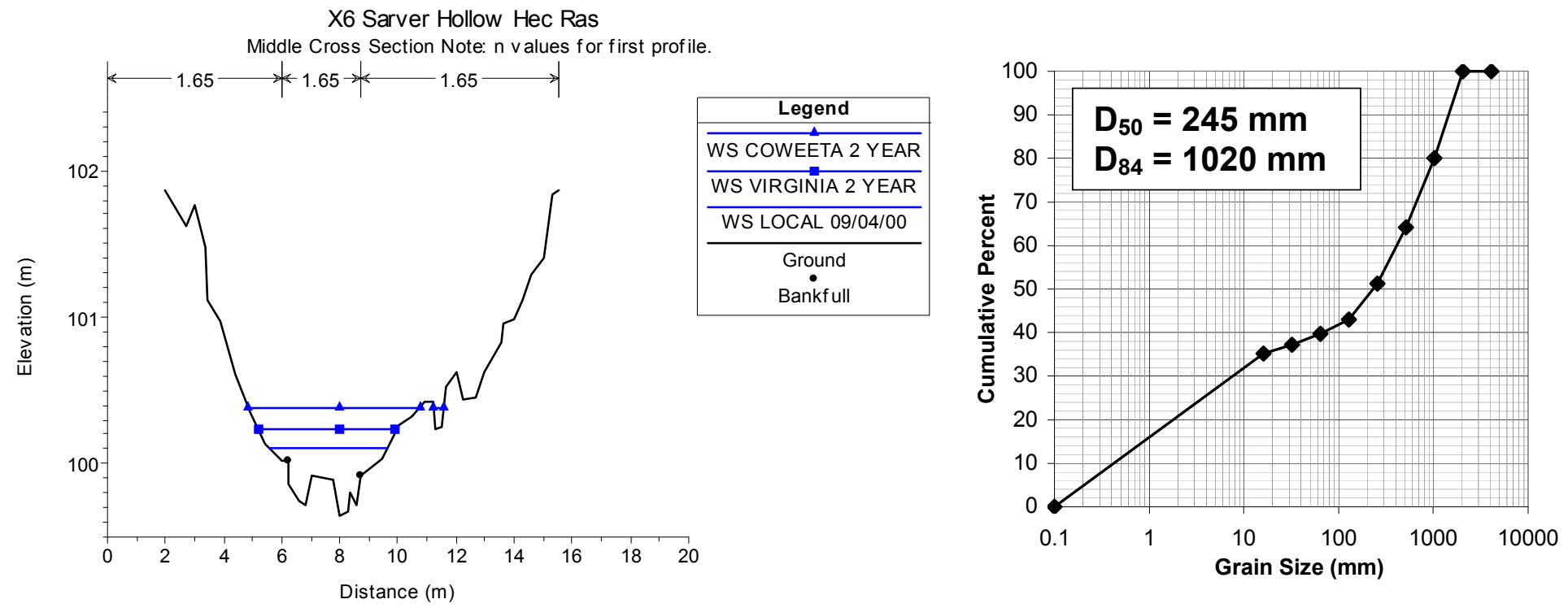

Figure C.12. Sarver Hollow reach 6, middle cross section (left), and cumulative grain size distribution from Wolman pebble count (right). Reach 6 was located in a very steep, boulder section of channel just downstream of where flow is underneath the boulder mantle. 

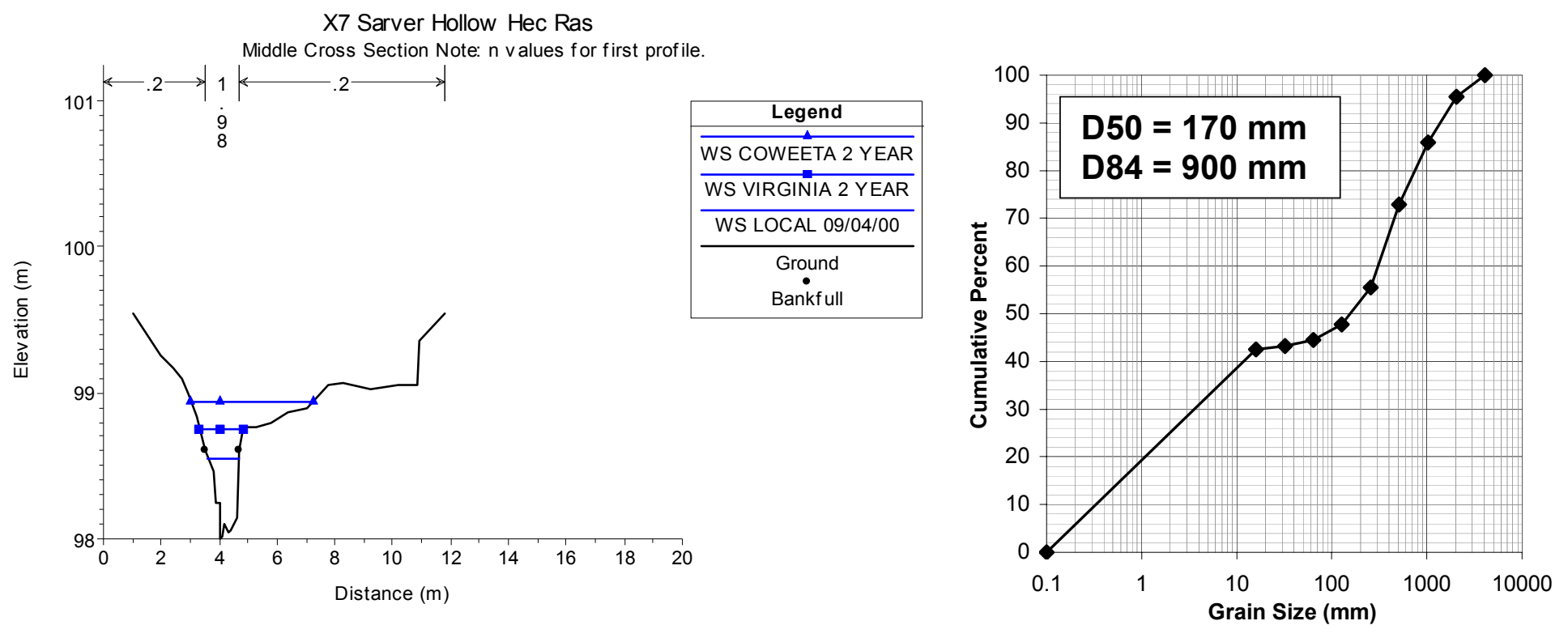

Figure C.13. Sarver Hollow reach 7, middle cross section (left), and cumulative grain size distribution from Wolman pebble count (right). Reach 7 was located in a steep, boulder section just upstream of where flow is underneath the boulder mantle.
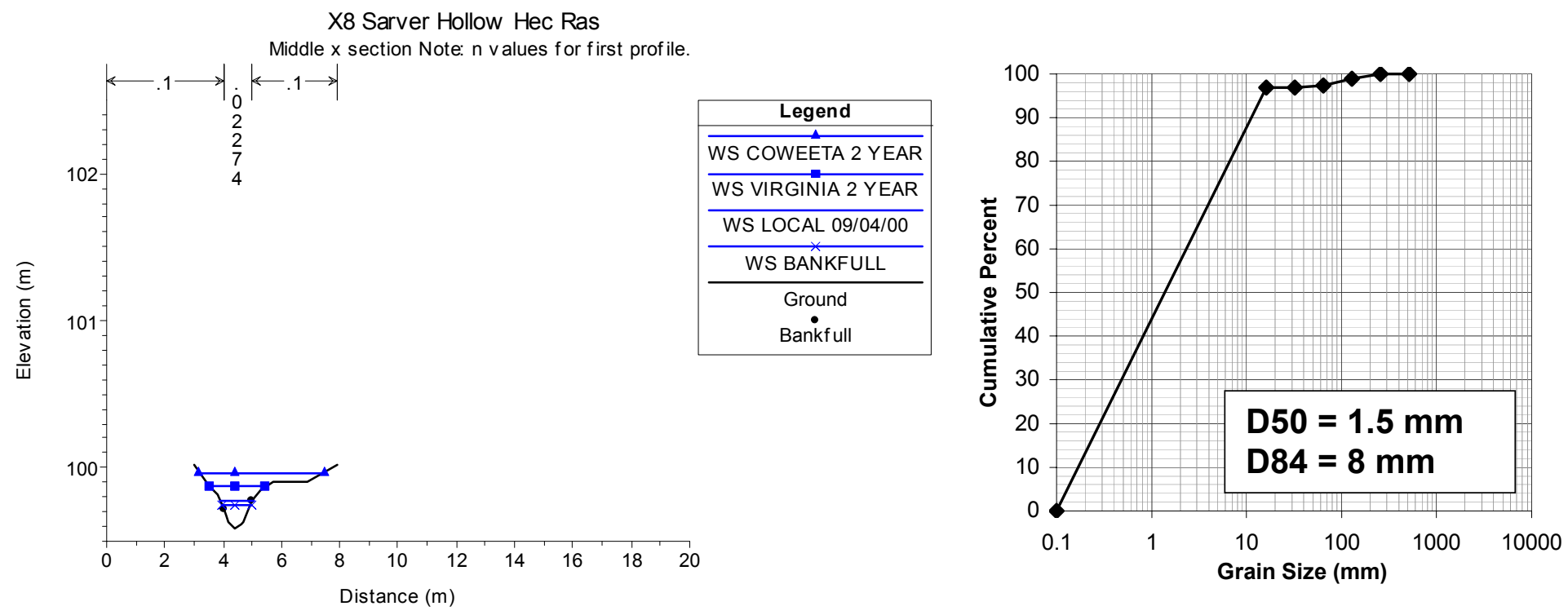

Figure C.14. Sarver Hollow reach 8, middle cross section (left), and cumulative grain size distribution from Wolman pebble count (right). Reach 8 was located in a low gradient section of the channel, dominated by fines and gravel. It represents the upper $1 / 8$ of the channel, near the initiation point, and is in the area inhabited by the Sarvers. 


\section{Appendix D}

\section{Allen Hollow}

\section{Qualitative Observations}

The stream channel in Allen Hollow initiates in a steep, dry, hardwood forest hollow not far from the ridge of Brush Mountain. It appears to result solely from overland flow, as it lacks any evidence of groundwater flow or saturation. The channel then runs downstream through a steep, narrow, confined valley, and is typically dry. It is mantled with flat shale cobble and leaves except for occasional bedrock-floored chutes and waterfalls formed by coarse bedrock sequences. Further downstream, as the valley widens and gradient decreases, several channel sections are incised with raw banks and logs form large jams behind which cobble and fines accumulate. The valley continues to widen and channel slope decreases further, until the channel becomes covered by thick layers of cobble and is sinuous. Incised reaches in this section are typically present below log and root jams that create local scour. After its confluence with Hazelnut Hollow, the channel is choked with shale cobble and becomes a wide, shallow, braided system in the valley floor. Throughout the lower section, flow in the channel is intermittent and appeared consistently only at bedrock-floored sections.

Rebecca Kavage, Jeffrey Adams, and Gary Kappesser surveyed Allen Hollow from August 2000 to January 2001. 


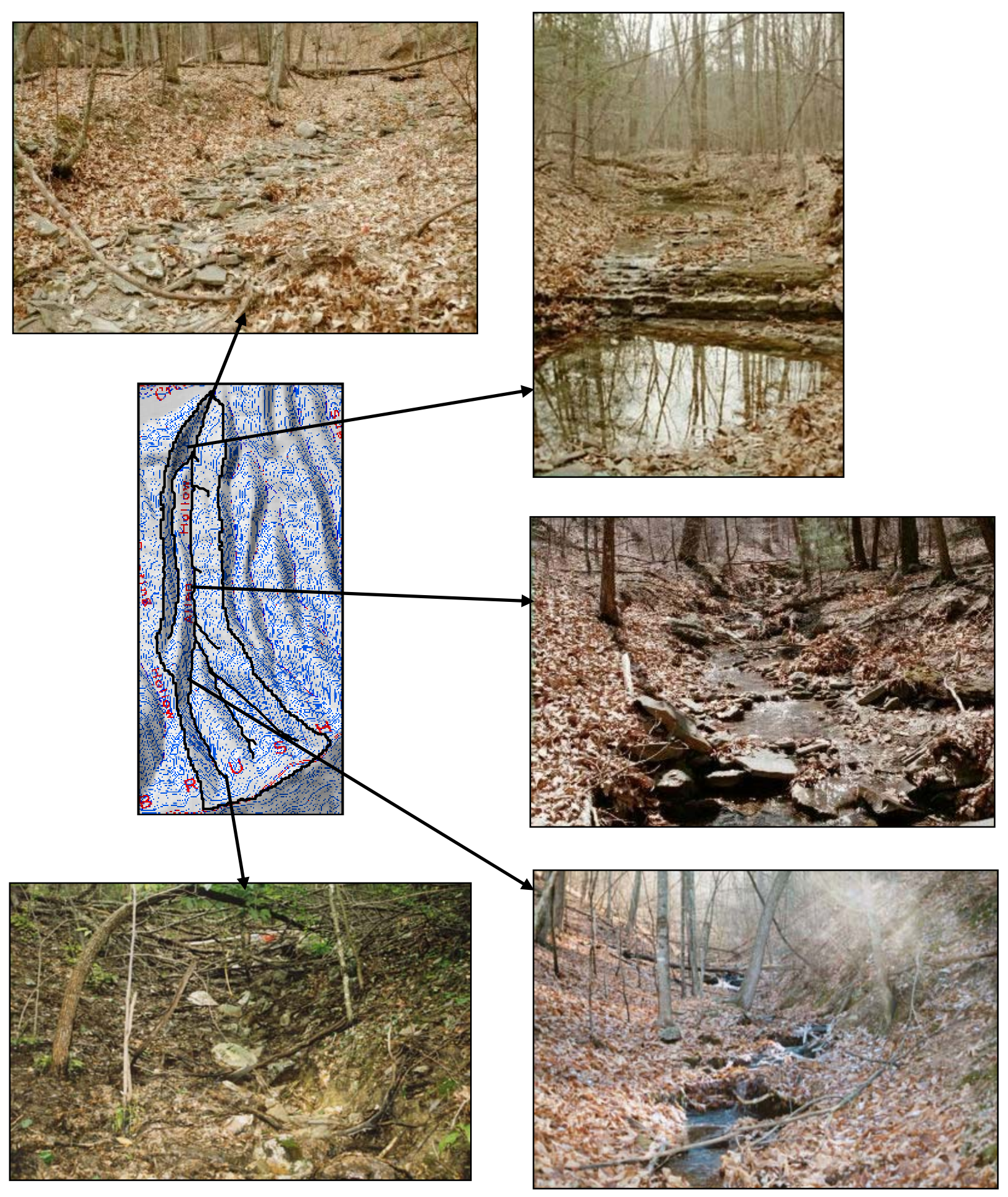

Figure D.1. Photographs of Allen Hollow counterclockwise starting from left bottom: channel initiation point; confined upper channel; middle channel (x3); bedrock bounded lower channel; and sinuous, cobble-covered lower section $(\mathrm{x} 1)$. 


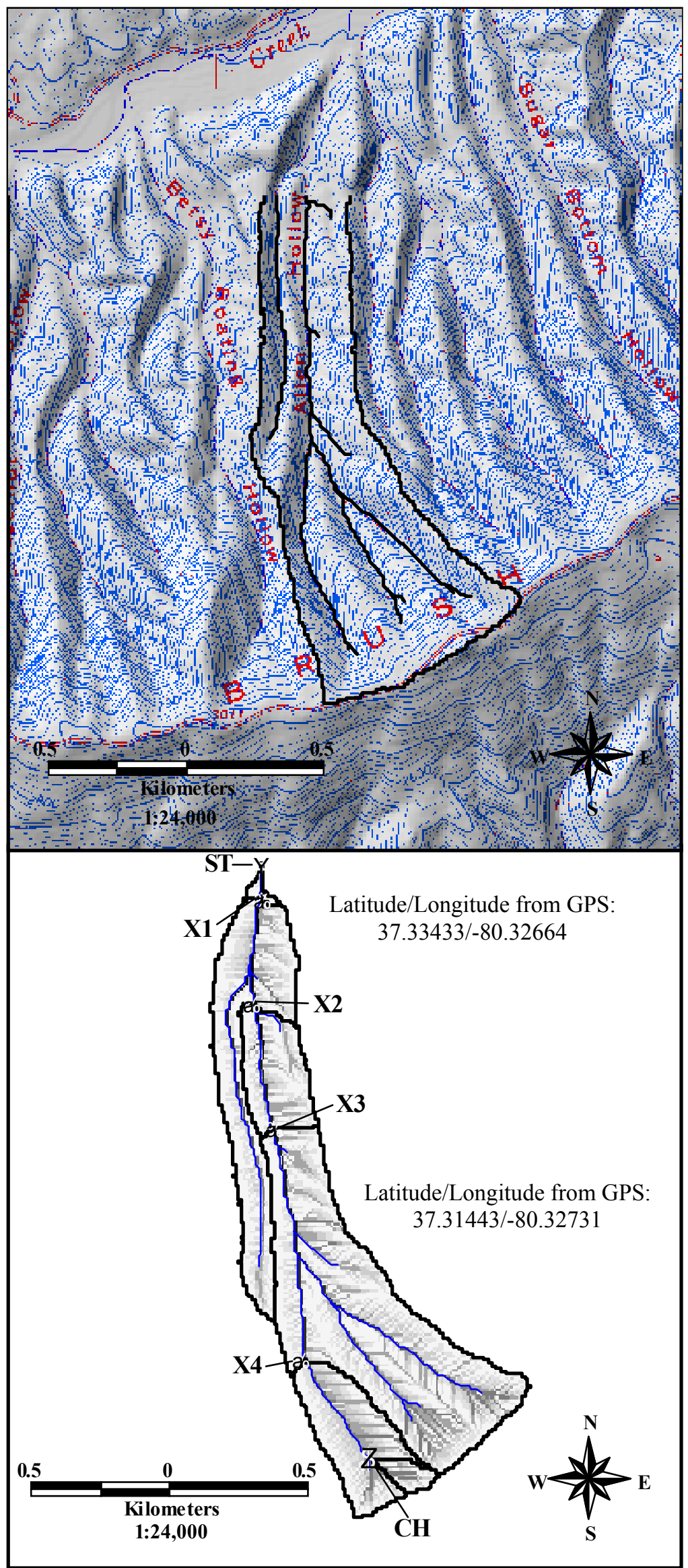

Figure D.2. Topographic and drainage network maps of Allen Hollow Basin, denoting survey points. 


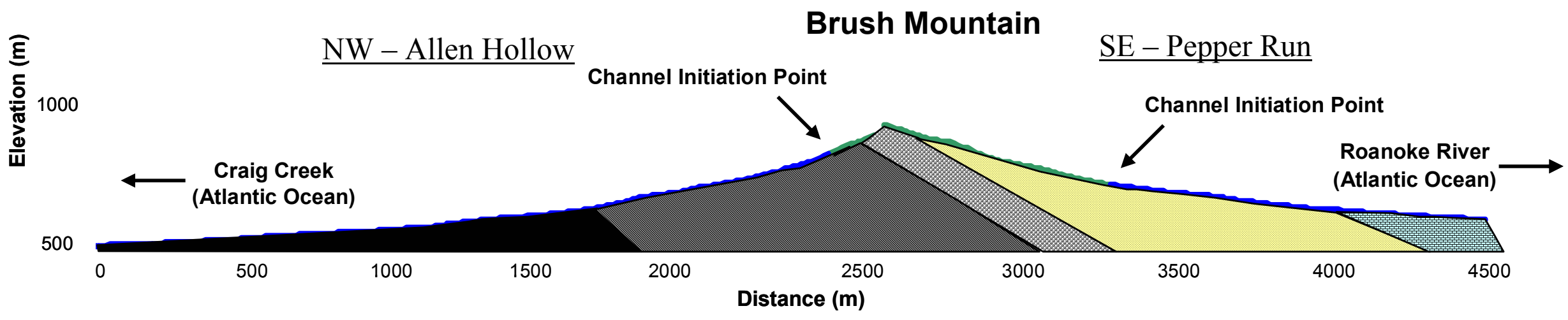

Figure D.3. Bedrock geology, channel initiation point, and base level for Allen Hollow, on the northwest side of Brush Mountain. Bedrock geology taken from 1:24,000 blue line geologic map of Newport Quadrangle, Virginia Division of Mineral Resources. Channel initiation point is from field surveyed GPS.

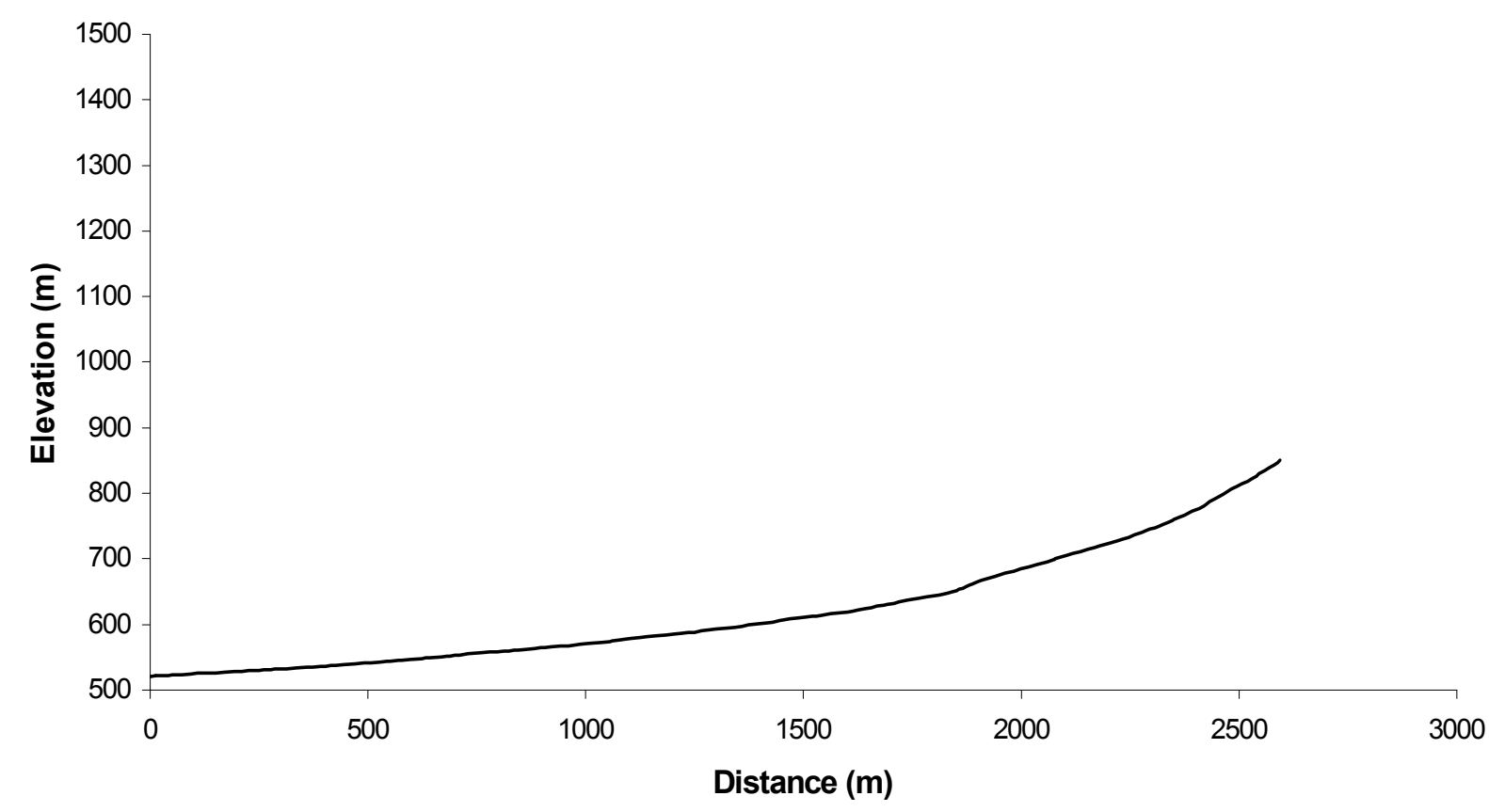

Figure D.4. Allen Hollow longitudinal profile, from survey data. 


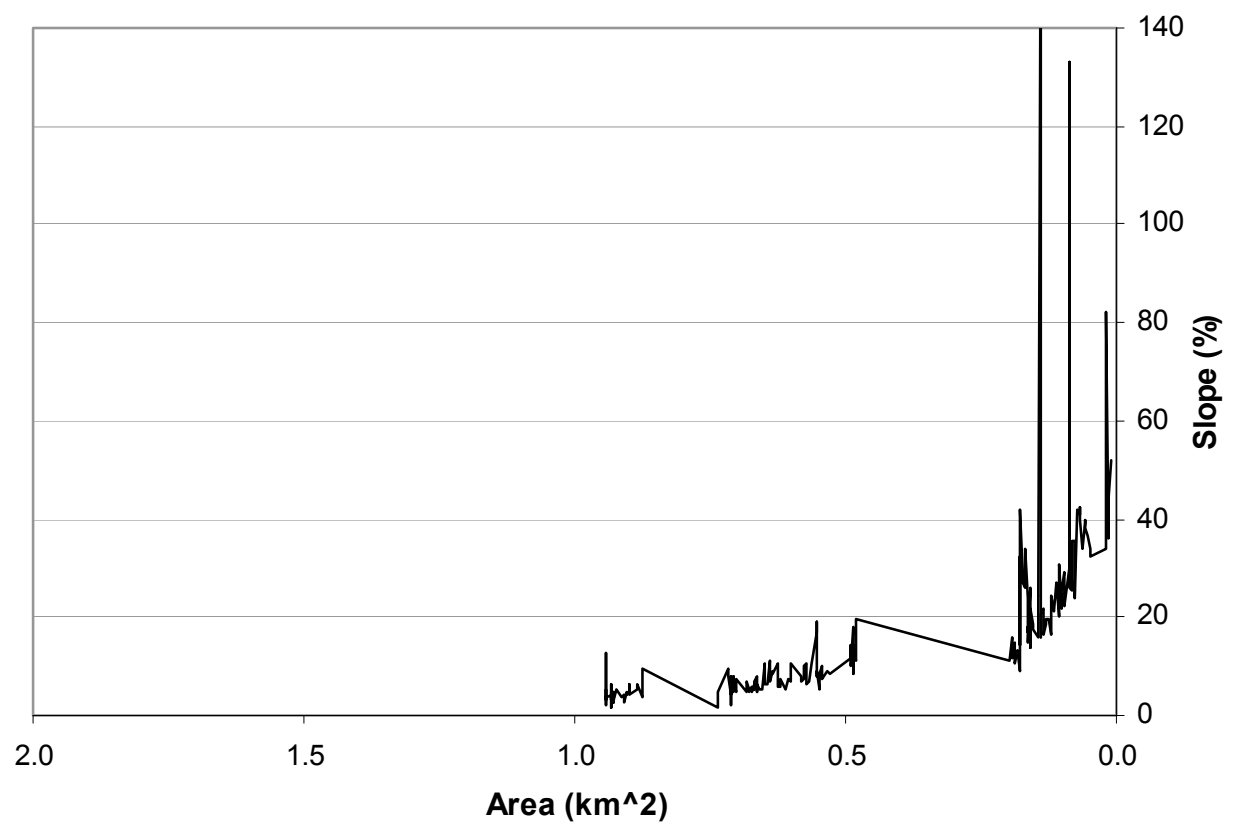

Figure D.5. Slope-area plot for surveyed portion of Allen Hollow channel, using field surveyed slope values and DEM-generated drainage area values.

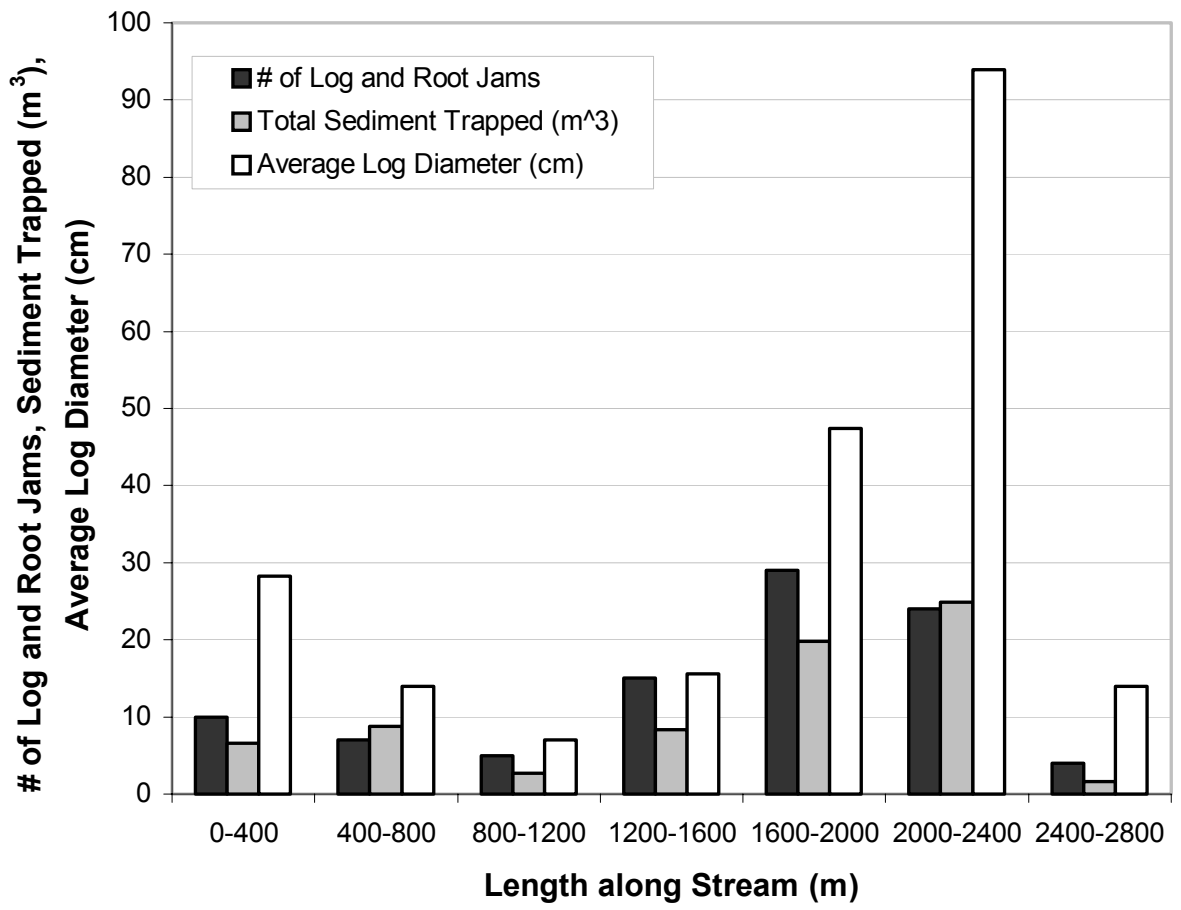

Figure D.6. Log and root jam frequency, total sediment trapped in jams, and average log diameter binned for $400 \mathrm{~m}$ length stream segments of Allen Hollow. 


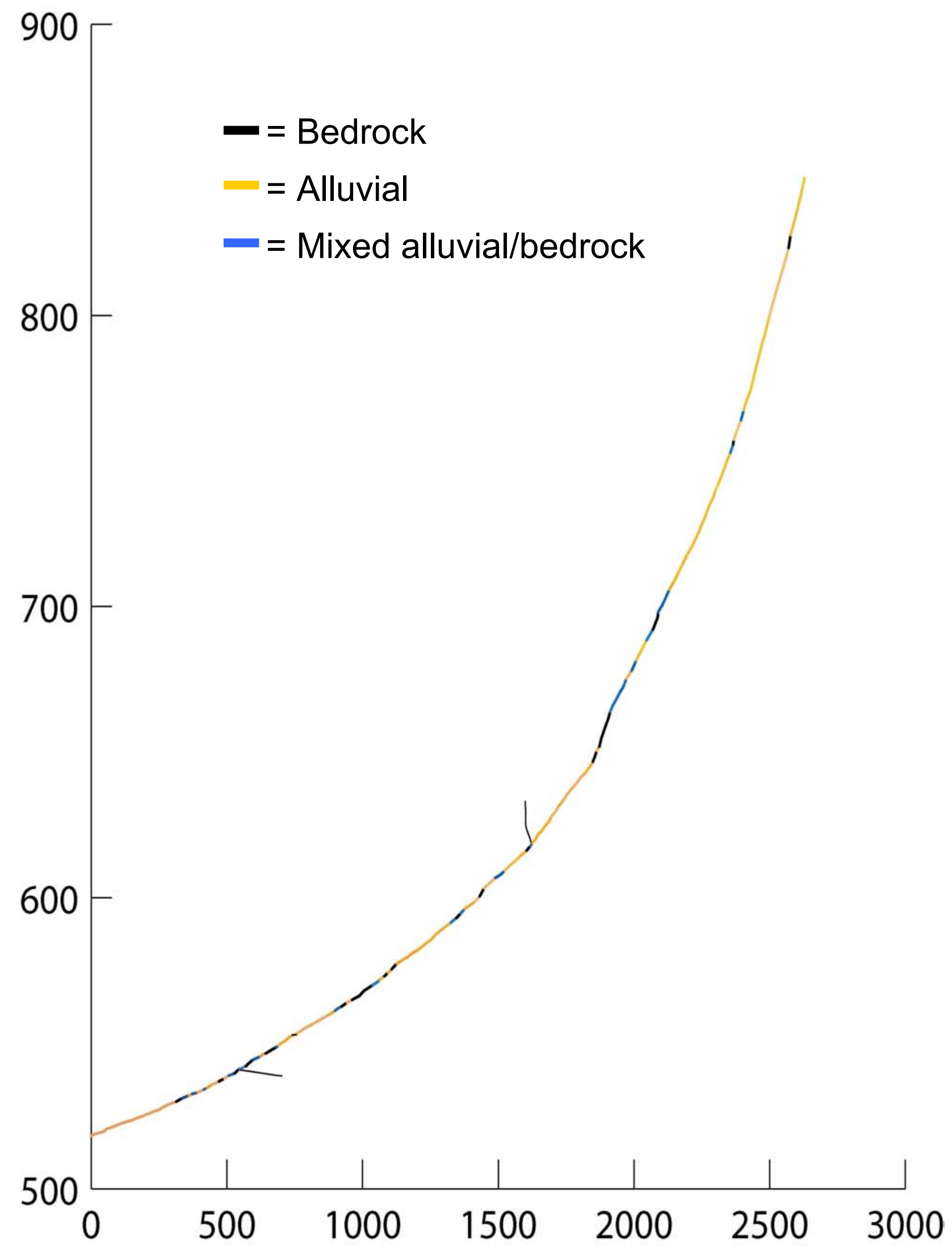

Figure D.7. Longitudinal profile annotated with channel substrate. 

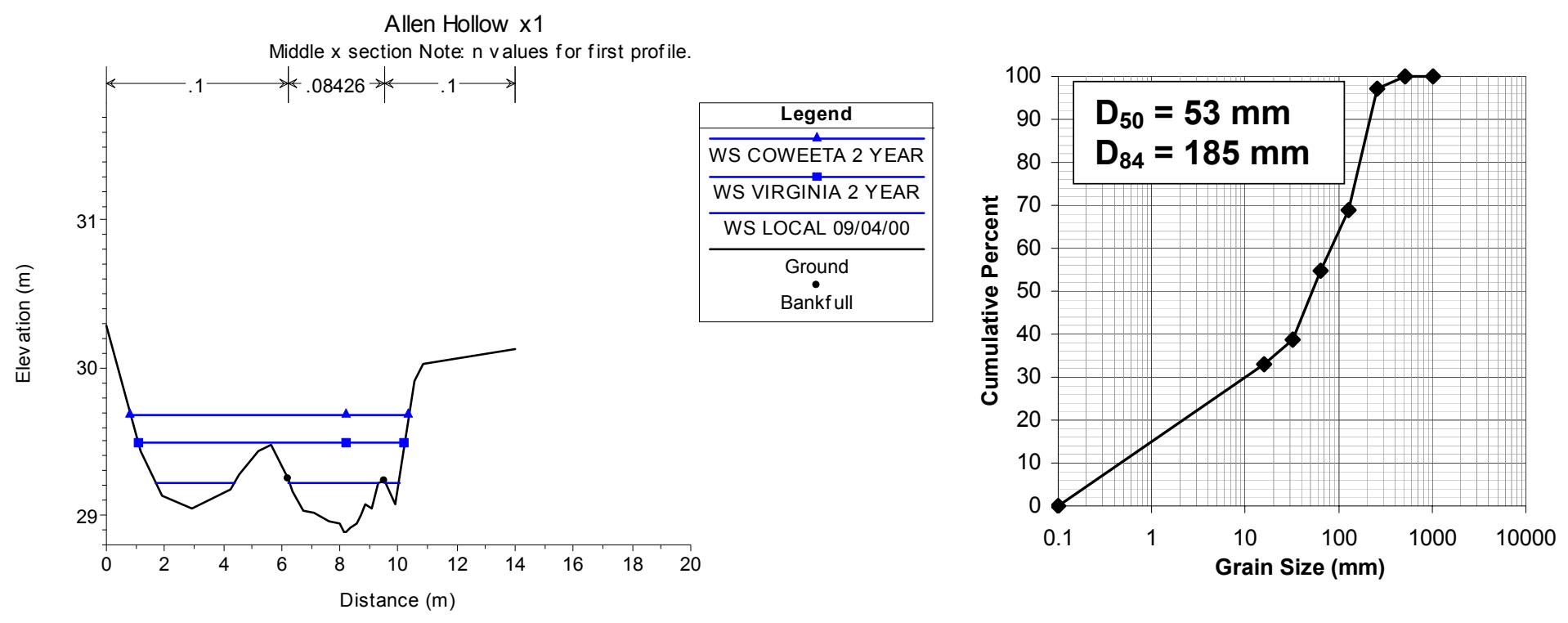

Figure D.8. Allen Hollow reach 1, middle cross section (left), and cumulative grain size distribution from Wolman pebble count (right). Reach 1 was located in a sinuous, low gradient, cobble section representative of the lower $1 / 4$ of the channel.
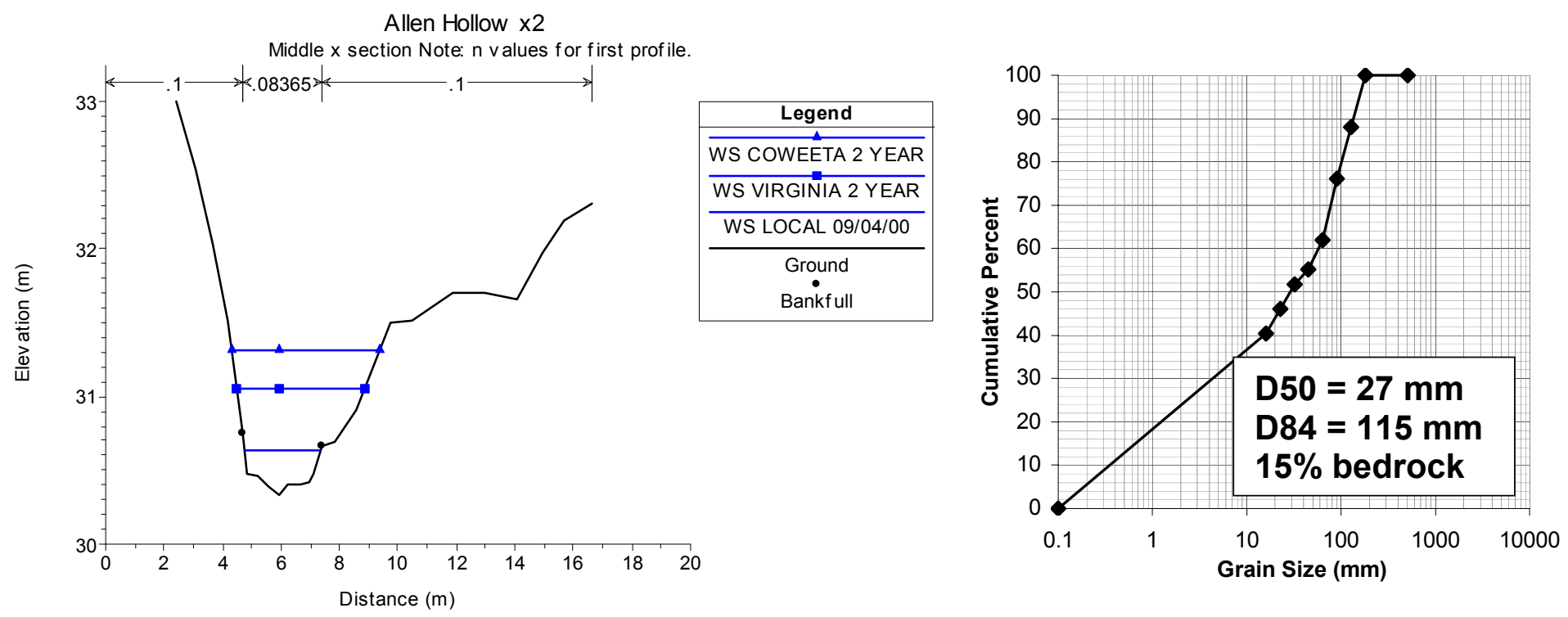

Figure D.9. Allen Hollow reach 2, middle cross section (left), and cumulative grain size distribution from Wolman pebble count (right). Reach 2 was located in a more confined valley section, with a hillslope on the left side (looking downstream) and a bedrock floor overlain by cobble. 

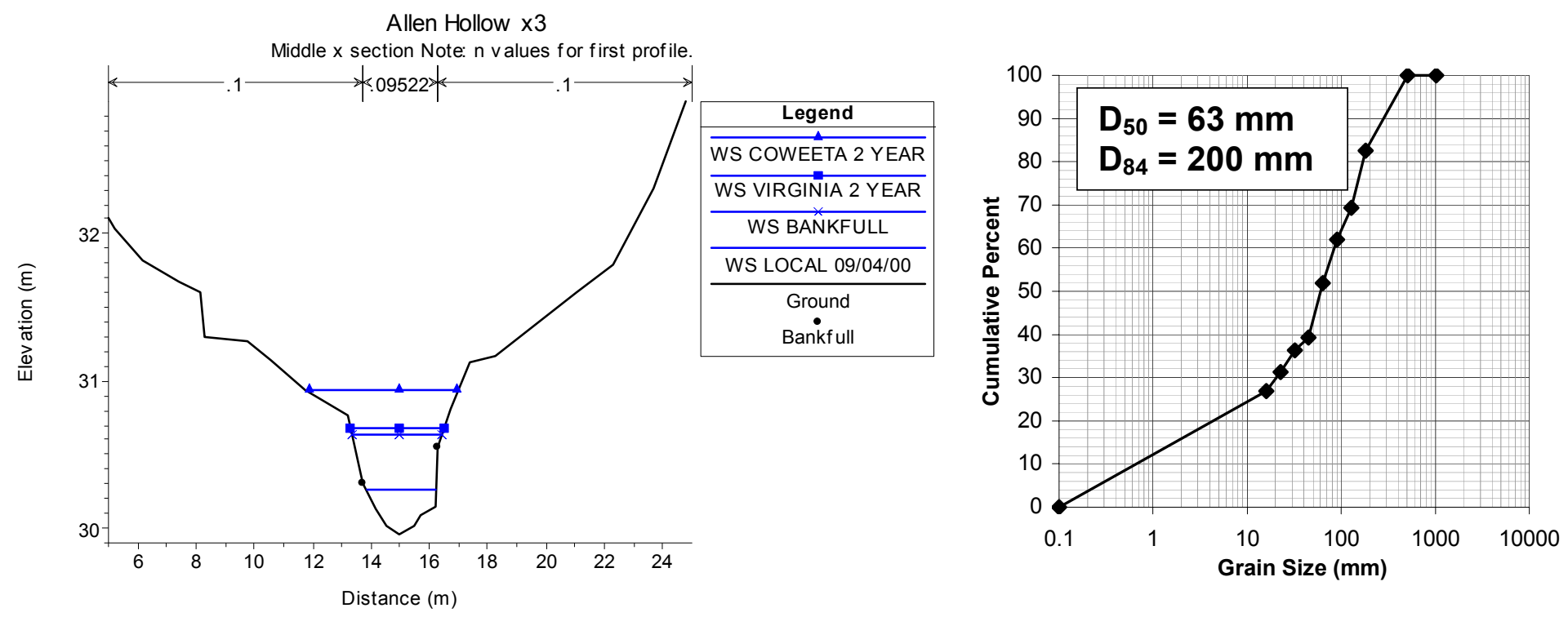

Figure D.10. Allen Hollow reach 3, middle cross section (left), and cumulative grain size distribution from Wolman pebble count (right). Reach 3 was located in a confined valley section, with cobble substrate and incised channel form, representative of channel in confined sections.
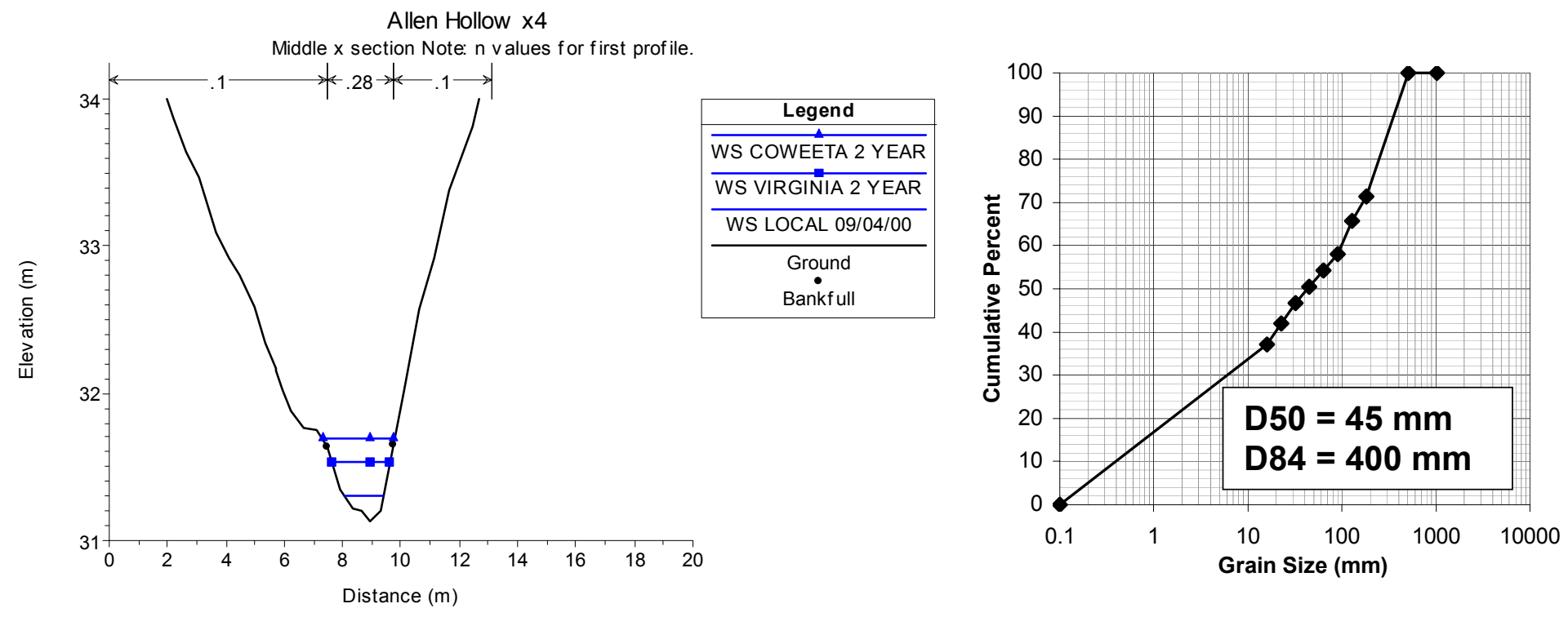

Figure D.11. Allen Hollow reach 4, middle cross section (left), and cumulative grain size distribution from Wolman pebble count (right). Reach 4 was located in a steep, cobble-boulder section with hillslopes on both sides and a narrow, confined channel. 


\section{Storm Event Observation}

Twenty pebbles in a $3 \times 3 \mathrm{~m}$ grid were painted, and the size of painted pebbles was recorded. Observations of water depth, scour marks, and movement of painted particles were made the morning after 1.5 inches of rain fell on Brush Mountain on September 4, 2000. The largest mobile particle during the storm event was $80 \mathrm{~mm}$ at its intermediate axis.

Approximately $60 \%$ of the particles sampled on the streambed were smaller than the largest mobile particle. Hydraulic modeling of the peak flow height based on the observed scour marks and the techniques described in section 3.6 resulted in a discharge estimate of 0.56 cms. This flow is estimated to recur every one to five years for a $0.9 \mathrm{~km}^{2}$ watershed (Bisese, 1994).

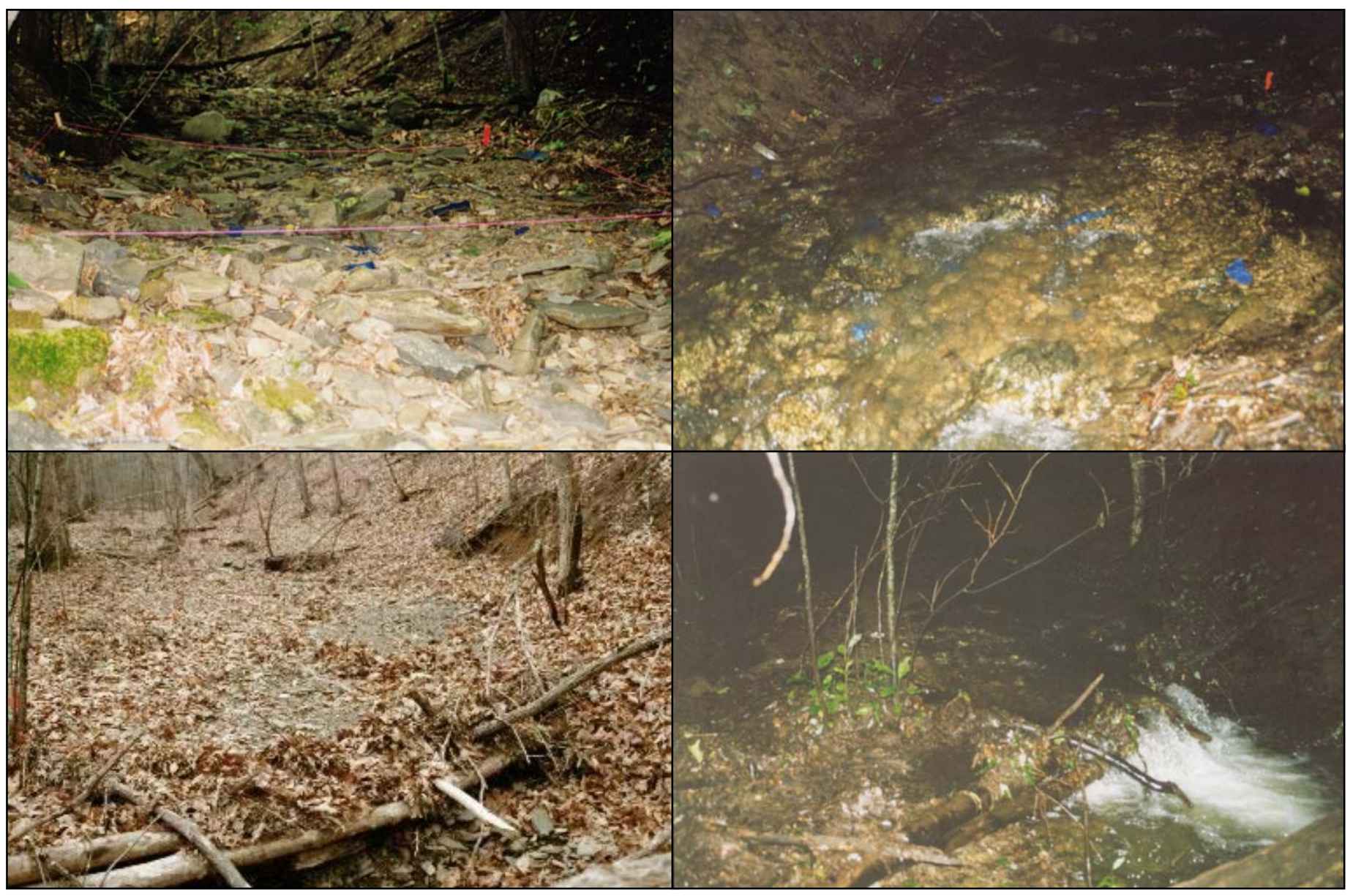

Figure D.12. Photographs of Allen Hollow observation points, clockwise from top left: $x 1$ after delineating grid and painting pebbles; $x 1$ flowing the morning after the September 4, 2000 storm event; a log jam just upstream of $\mathrm{x} 1$ the morning after the September 4, 2000 storm event; and the same log jam when dry. 


\section{Appendix E}

\section{Pepper Run}

\section{Qualitative Observations}

Pepper Run initiates at the lower end of a large, convex field of conglomerate boulders below the ridge of Brush Mountain. Flow emerges from a hole underneath the boulders into a narrow cobble and boulder channel. The channel continues downstream in a narrow, confined valley with occasional bedrock steps and incised alluvial reaches. The forest is a dry, open hardwood stand with dense rhododendron around the channel at times. Channel flow throughout the section is intermittent.

Channel slope gradually decreases until the junction with an unnamed tributary, after which the channel widens and has a more typical cobble alluvial form (x3). Prior to reaching private property, there is a short, steep drop at that forms a sandstone bedrock waterfall. The channel then enters a heavily grazed area that is wide, lacking roughness, and is obviously affected by cow trample. It crosses through a culvert under a road, and emerges as a narrow, silty, grass-lined channel flowing through a private yard. After another junction with a tributary from the east, the channel widens and becomes predominantly bedrock and cobble floored. Throughout this lower section, low channel flows were present.

Rebecca Kavage, Doug Marchakitus, and Jeffrey Adams surveyed Pepper Run from June 12-14, 2001. 


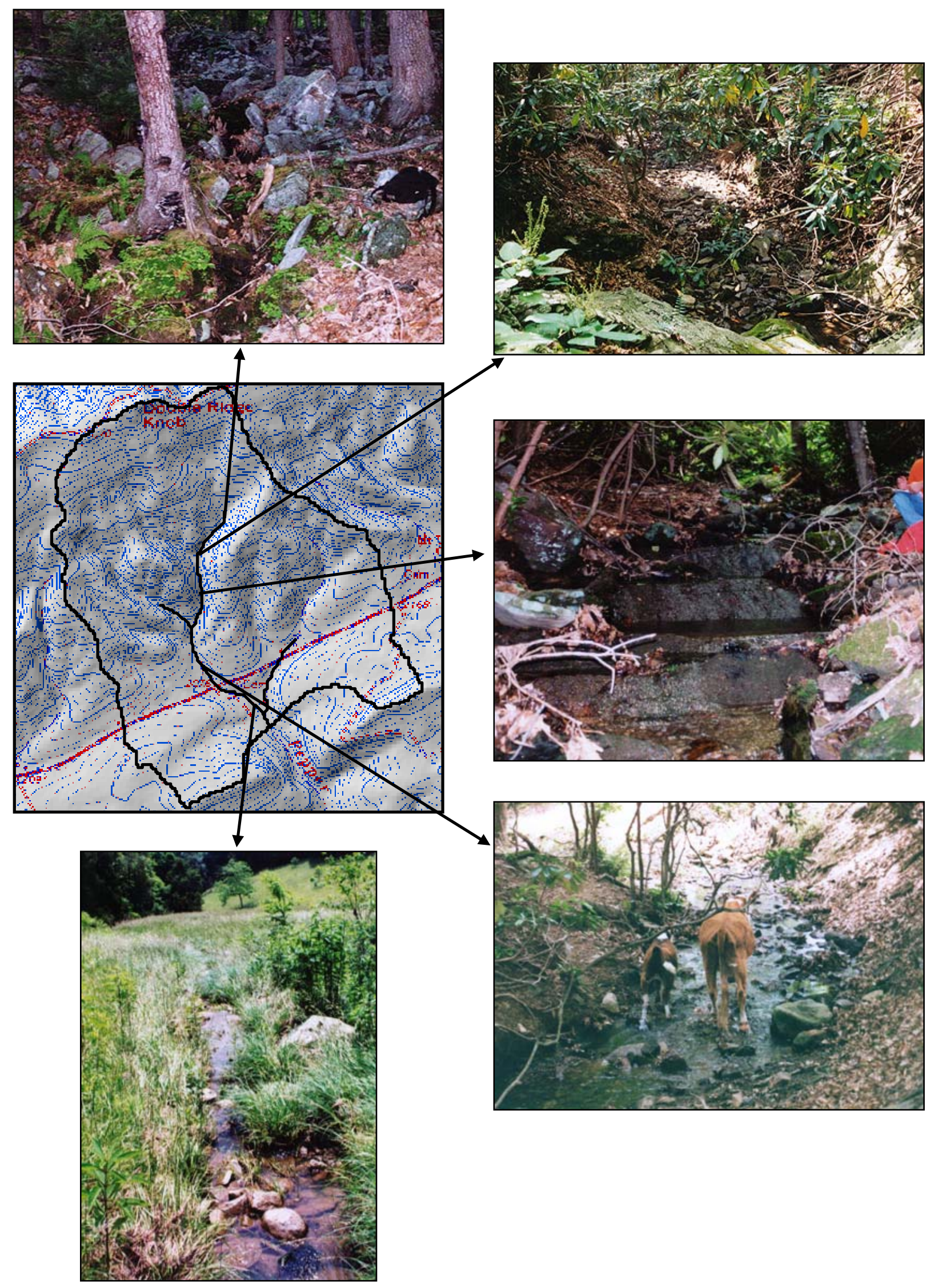

Figure E.1. Photographs of Pepper Run, clockwise from top left: channel initiation point from boulder field; incised channel just after conglomerate boulder input ceases; bedrock step channel (x4); mama cow and calf in channel above $x 2$; and narrow grassy channel below road. 


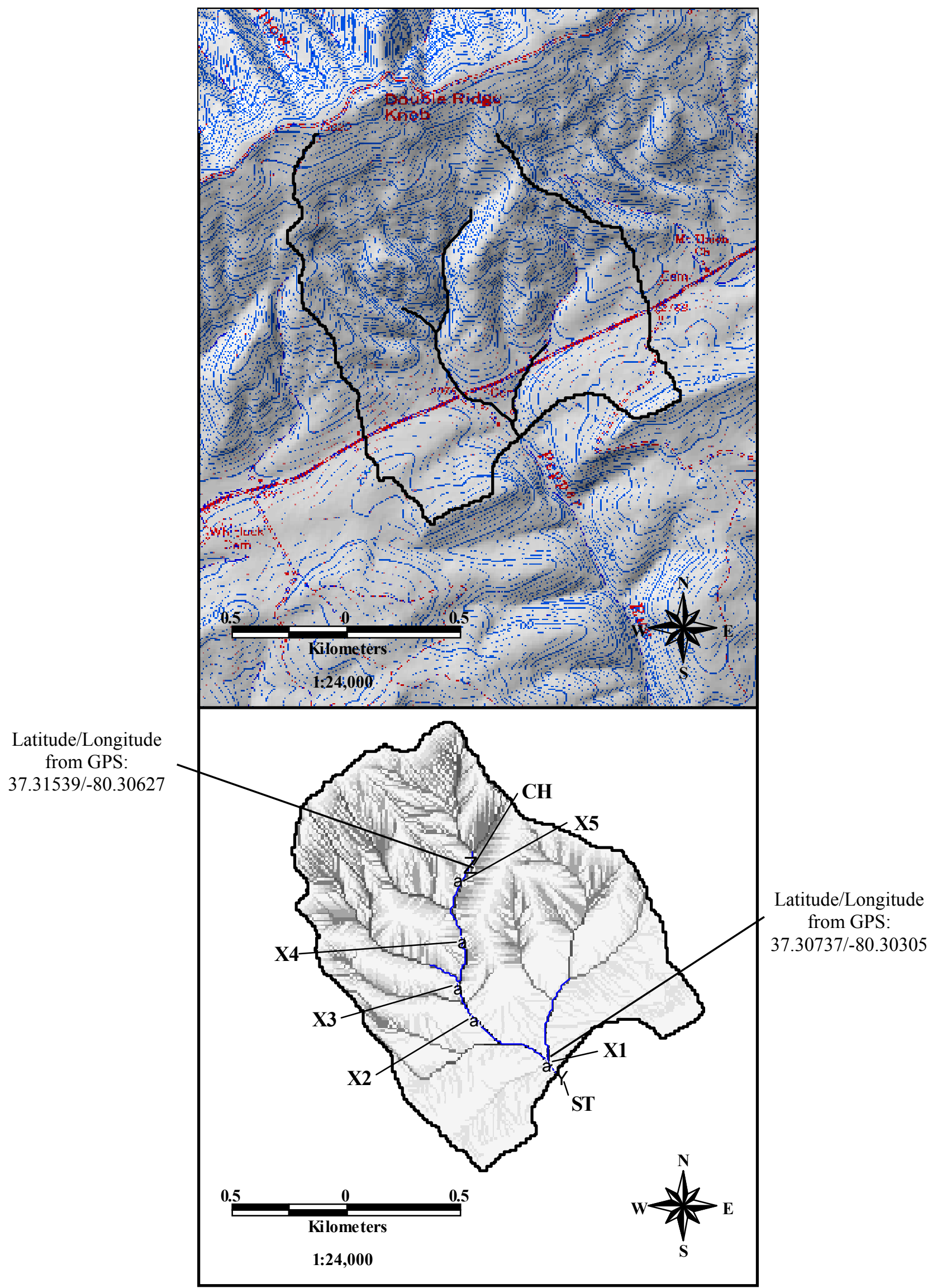

Figure E.2. Topographic and drainage network maps of Pepper Run Basin, denoting survey points. 


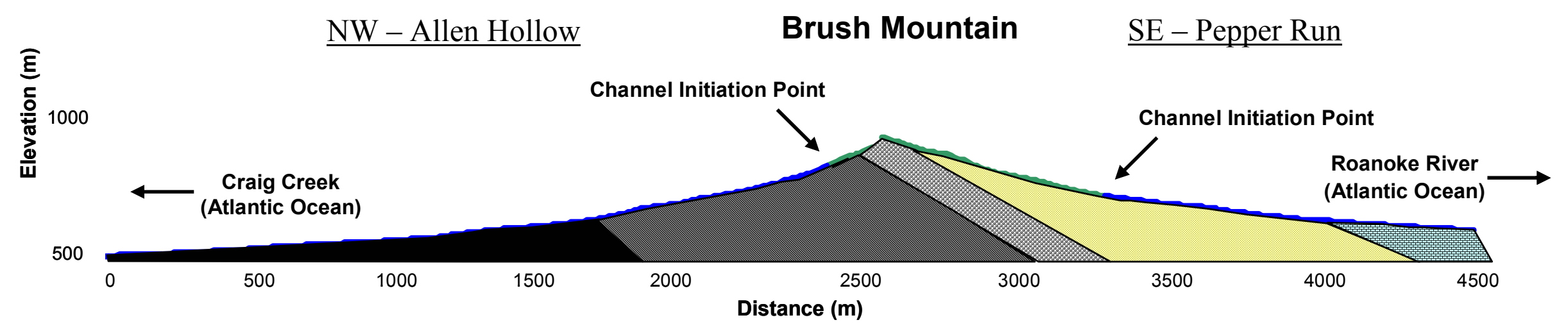

Figure E.3. Bedrock geology, channel initiation point, and base level for Pepper Run, on the southeast side of Brush Mountain. Bedrock geology taken from 1:24,000 blue line geologic map of Newport Quadrangle, Virginia Division of Mineral Resources. Channel initiation point is from field surveyed GPS.

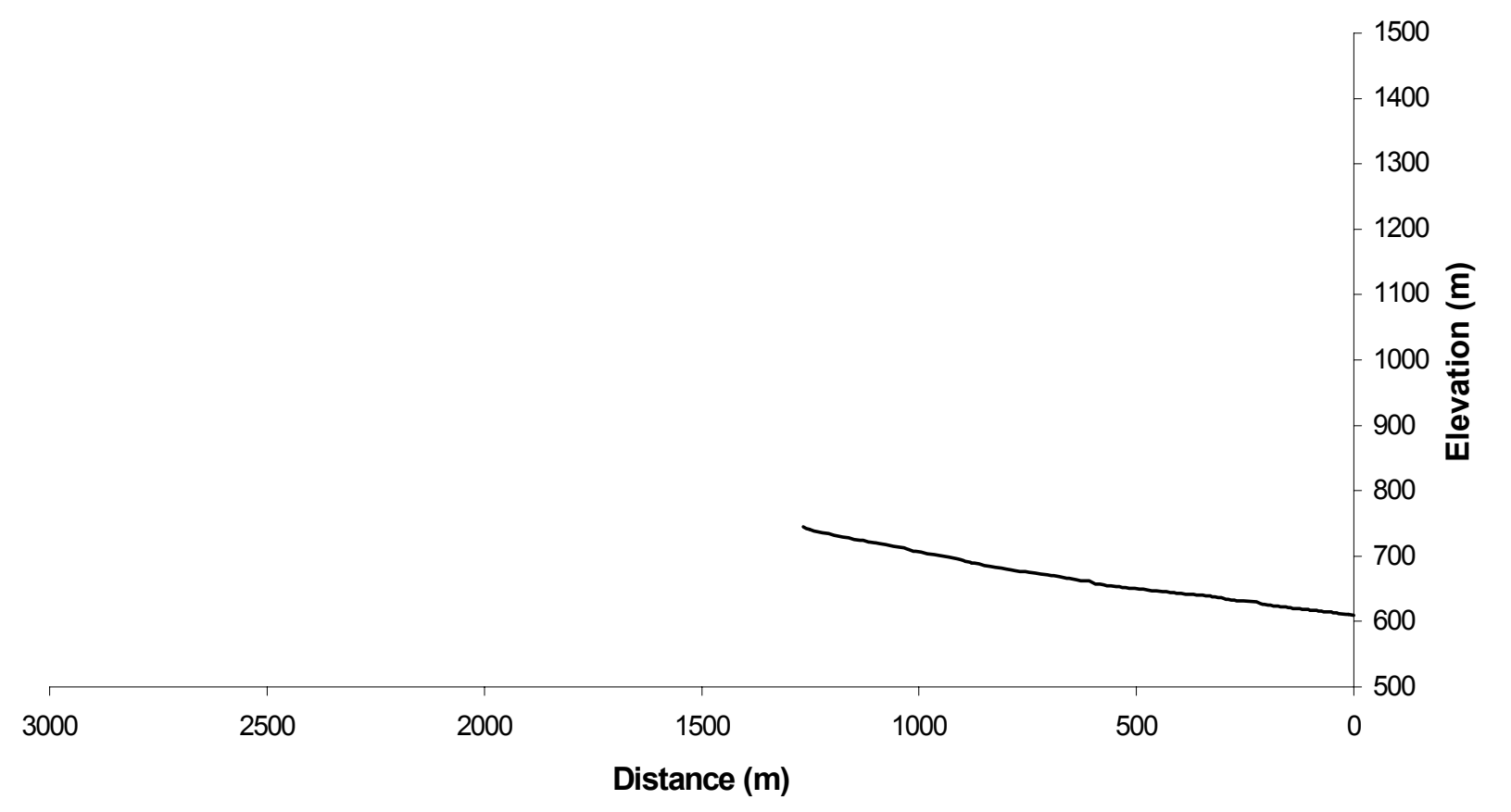

Figure E.4. Pepper Run longitudinal profile, from survey data. 


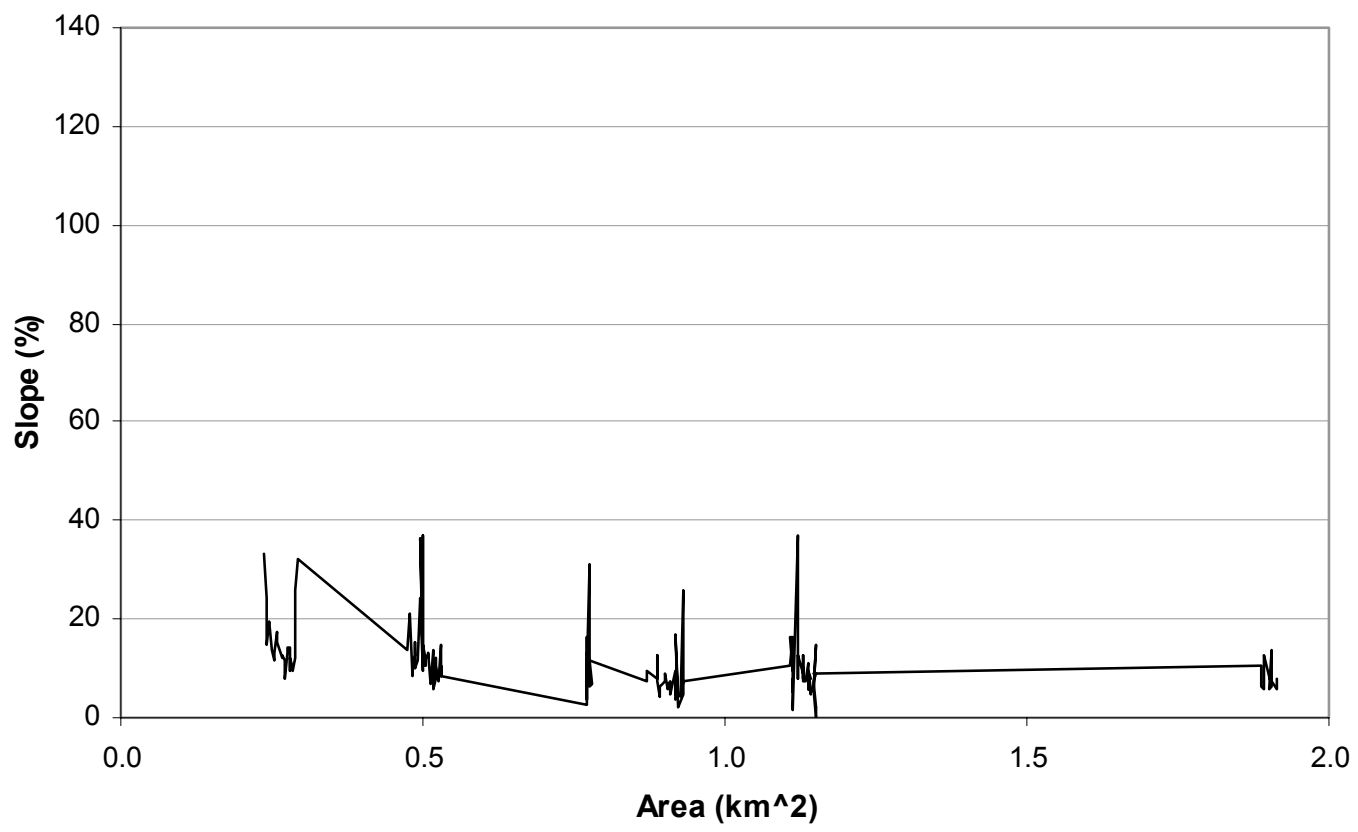

Figure E.5. Slope-area plot for surveyed portion of Pepper Run channel, using field surveyed slope values and DEM-generated drainage area values.

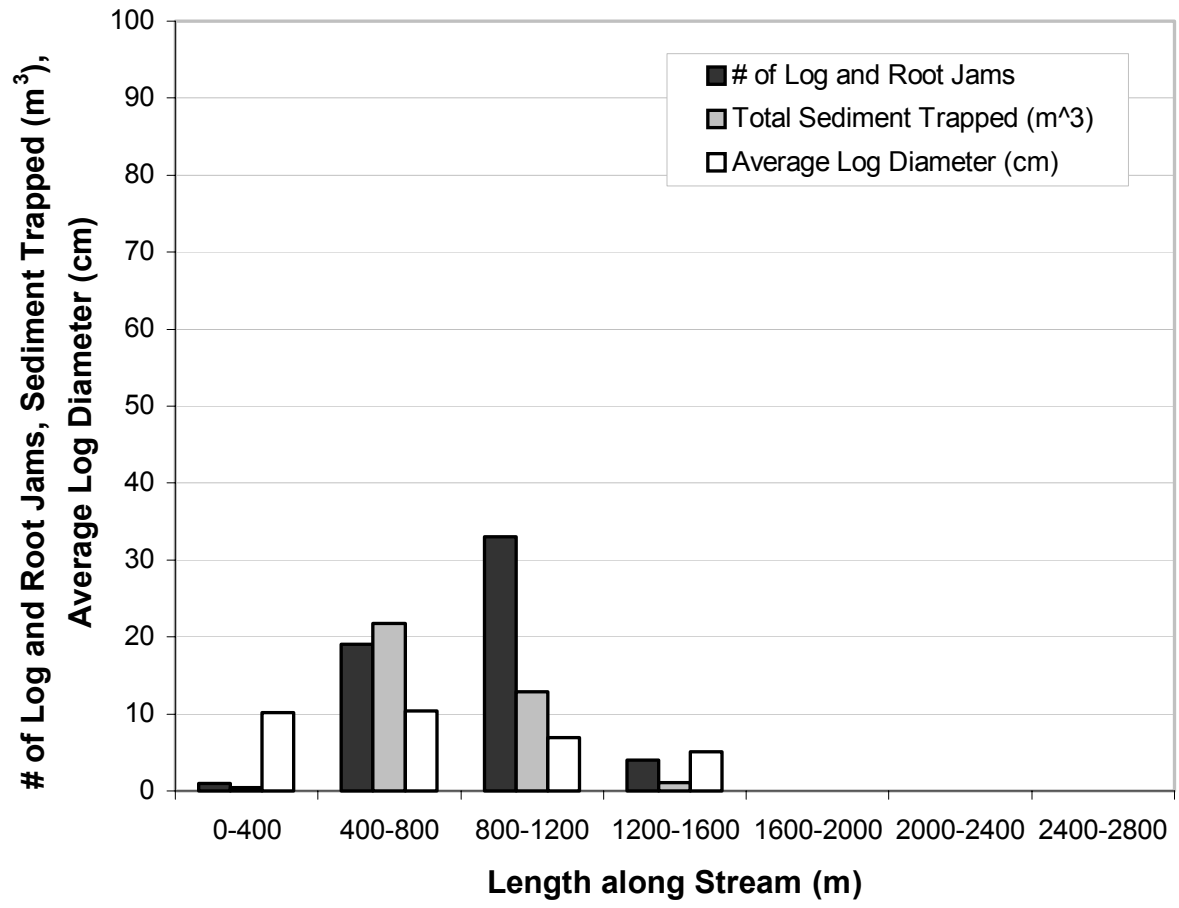

Figure E.6. Log and root jam frequency, total sediment trapped in jams, and average log diameter binned for $400 \mathrm{~m}$ length stream segments of Pepper Run. 
Pepper Run $x 1$
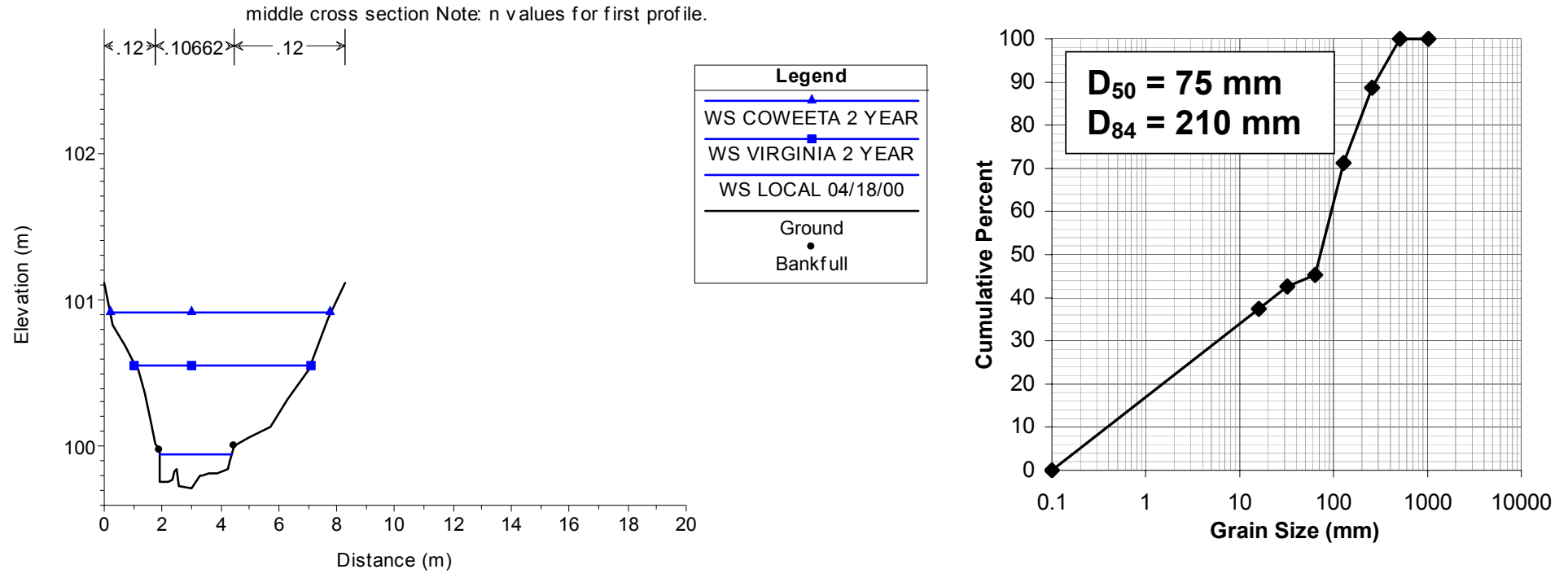

Figure E.7. Pepper Run reach 1, middle cross section (left), and cumulative grain size distribution from Wolman pebble count (right). Reach 1 was located below the confluence with an eastern tributary, representative of the channel after the junction, with cobble substrate and grassy overbank.
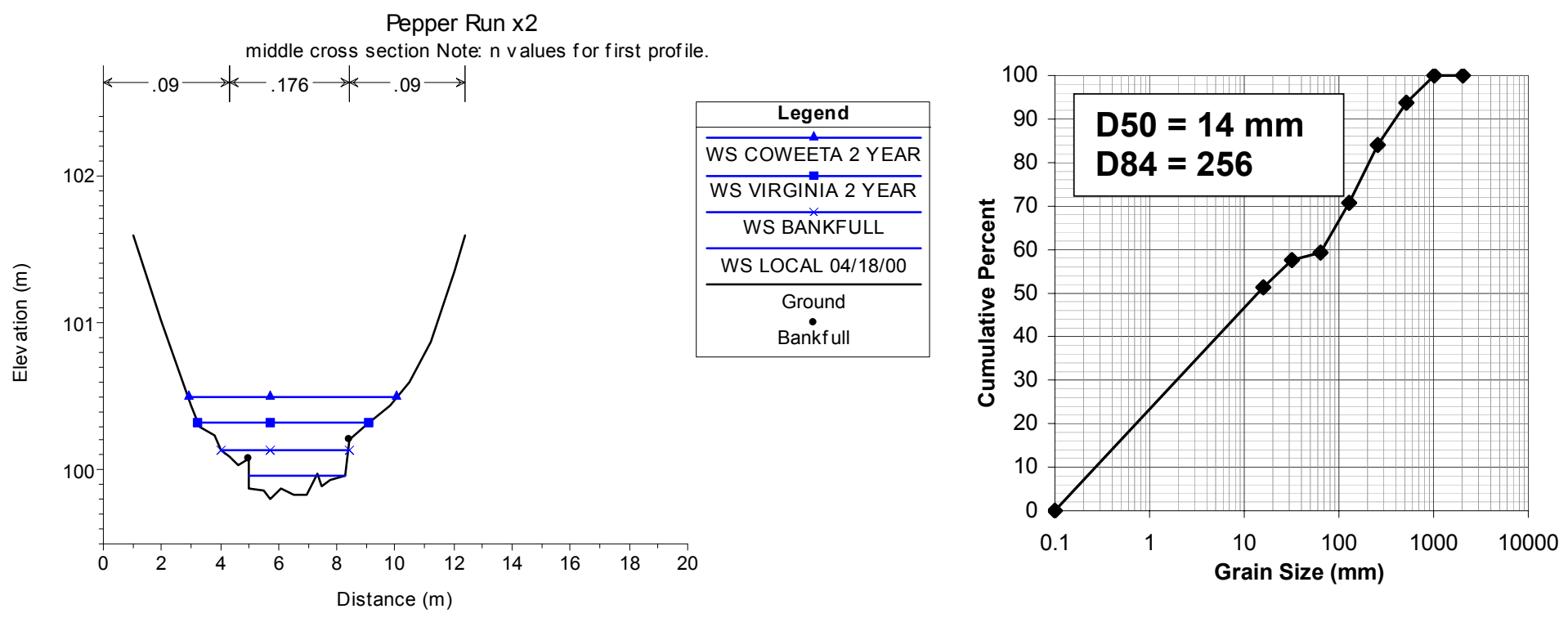

Figure E.8. Pepper Run reach 2, middle cross section (left), and cumulative grain size distribution from Wolman pebble count (right). Reach 2 was located in a deep, wide U-shaped section of channel with heavy grazing and cow trample impacts. 

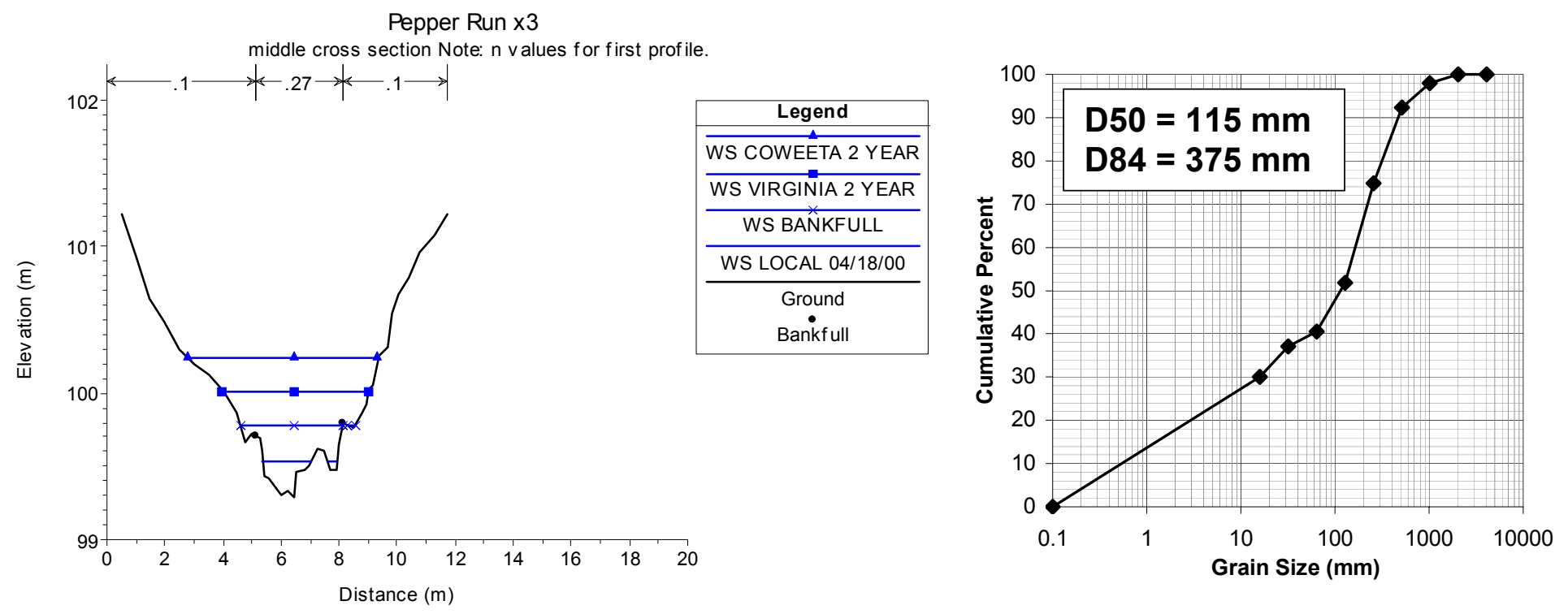

Figure E.9. Pepper Run reach 3, middle cross section (left), and cumulative grain size distribution from Wolman pebble count (right). Reach 3 was located above the sandstone waterfall but below the split with a western tributary. Its shape was wide, with alluvial, cobble-boulder substrate.
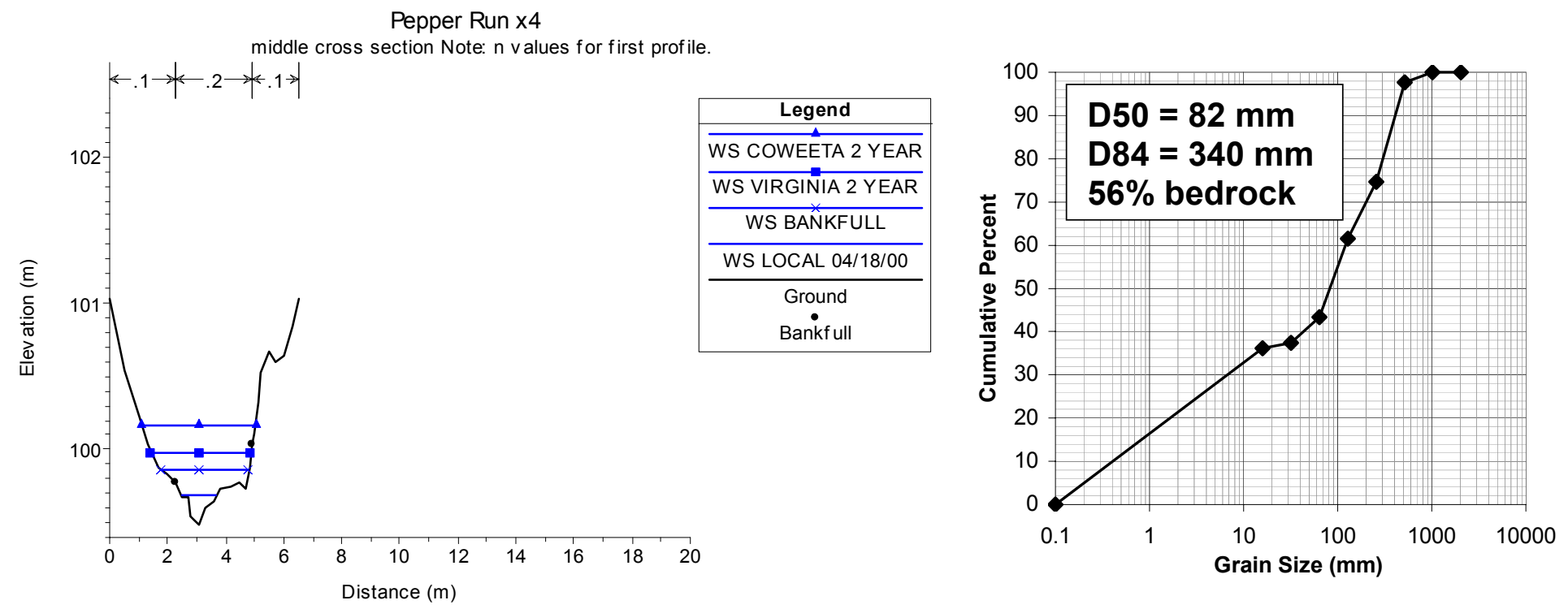

Figure E.10. Pepper Run reach 4, middle cross section (left), and cumulative grain size distribution from Wolman pebble count (right). Reach 4 was located in a confined channel section with bedrock step substrate, well above the split with the western tributary. 

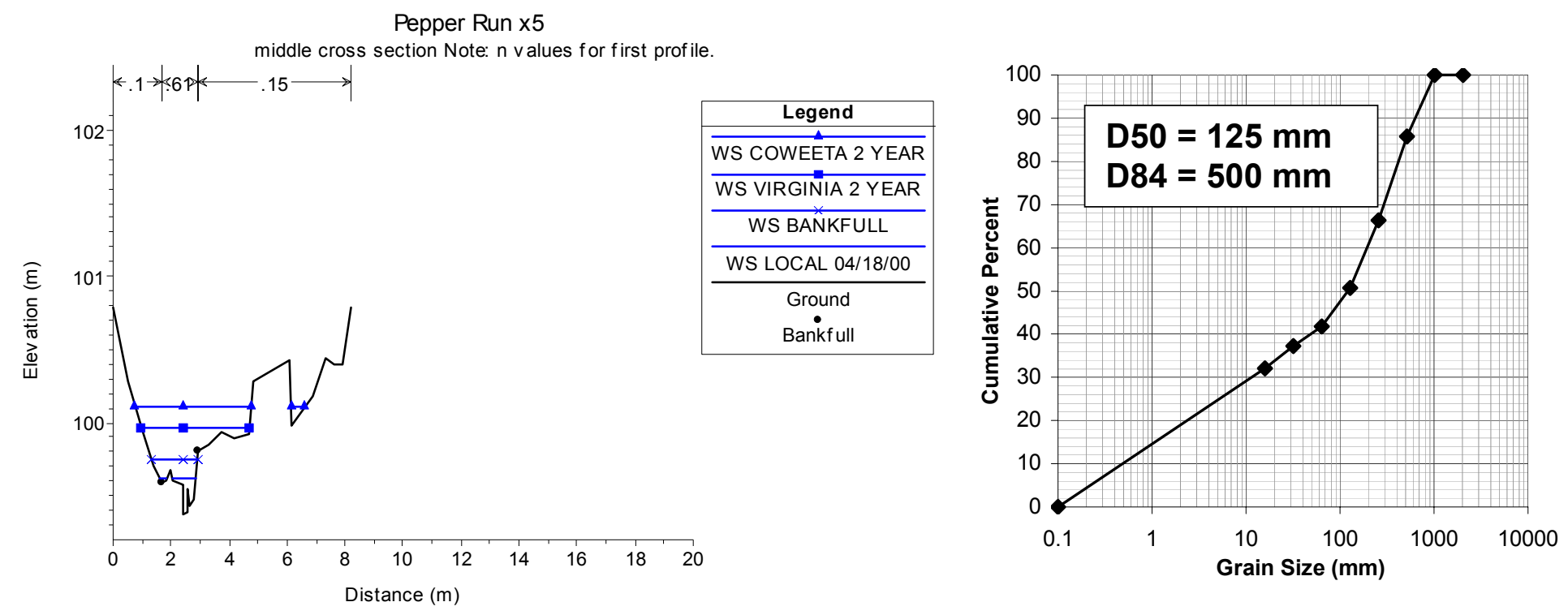

Figure E.11. Pepper Run reach 5, middle cross section (left), and cumulative grain size distribution from Wolman pebble count (right). Reach 5 was located just below the channel head in a boulder section with a steep hillslope to the left (looking downstream) and boulder influx from the right. 


\section{Appendix F}

\section{Indian Spring}

\section{Qualitative Observations}

Indian Spring initiates from a small hole with a fine, narrow, dirt channel in a relatively low gradient area. It then grades into a slightly larger, cobbly channel with banks well vegetated by grasses and wildflowers in an open hardwood stand. The channel widens further and becomes bedrock floored as it approaches a large, steep bedrock slope over which the channel is not discernible. The bedrock slope grades into bedrock steps downstream, and then becomes a boulder channel. Shortly thereafter numerous tributaries converge and vegetation increases dramatically, with thick rhododendron in and near the channel that is sometimes impassable. Channel flow throughout this section is intermittent, typically observable above and on the bedrock break but not in the boulder section below it.

The channel substrate is consistently mixed downstream, a series of steep bedrock steps and slides and alluvial reaches that vary in height and length. Near the channel bottom, the main channel at times is not discernible and a network of channels disappears and reappears in boulders and thick vegetation, suggesting (though I did not hear it) a lot of underground flow/throughflow. After its confluence with a tributary from the east, Indian Spring becomes a bouldery alluvial channel with more typical alluvial form. Prior to reaching the trail bridge where the survey started, it becomes floored by a smooth bedrock base. Channel flow is typically low in this section, and is intermittent and difficult to follow near the channel bottom in the network of channels. Flow becomes more consistent and easier to follow after the tributary joins from the east.

Rebecca Kavage, Lee Taylor, and Jeffrey Adams surveyed Indian Spring July6, and August 12-16, 2001. The majority of the survey (August 12-16) was completed during several days of light rain interspersed with heavy thundershowers. Cross section locations in the lower

section of the channel were chosen largely for accessibility, as rhododendron made surveying difficult in many places. 


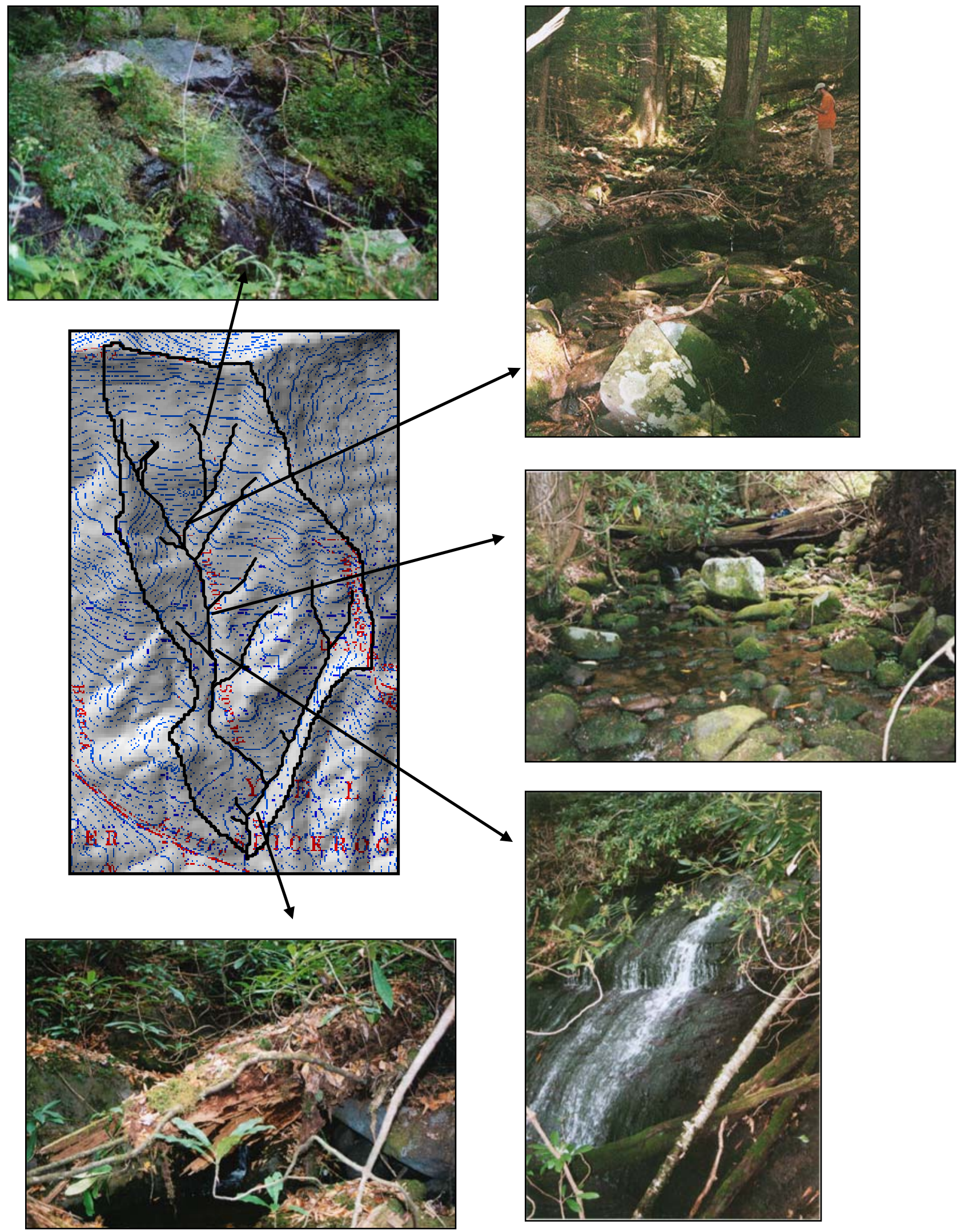

Figure F.1. Photographs of Indian Spring, clockwise from top left: steep bedrock slope below channel initiation point; bouldery channel just above convergence of many tributaries; scoured alluvial section (x3); resistant bedrock falls; and large logs lying on top of boulders, ineffective as log jams. 

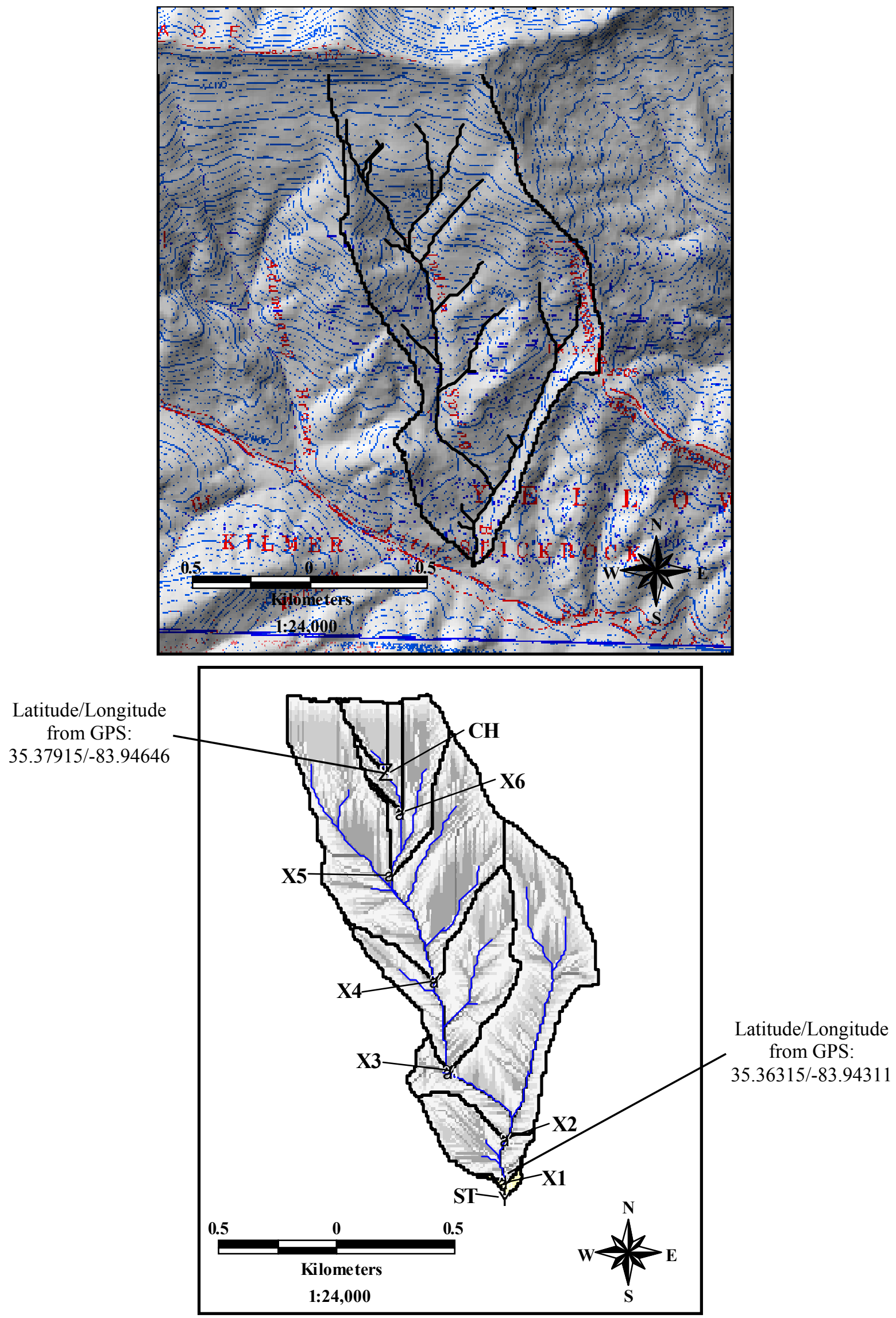

Figure F.2. Topographic map and drainage network maps of Indian Spring Basin, denoting survey points. 


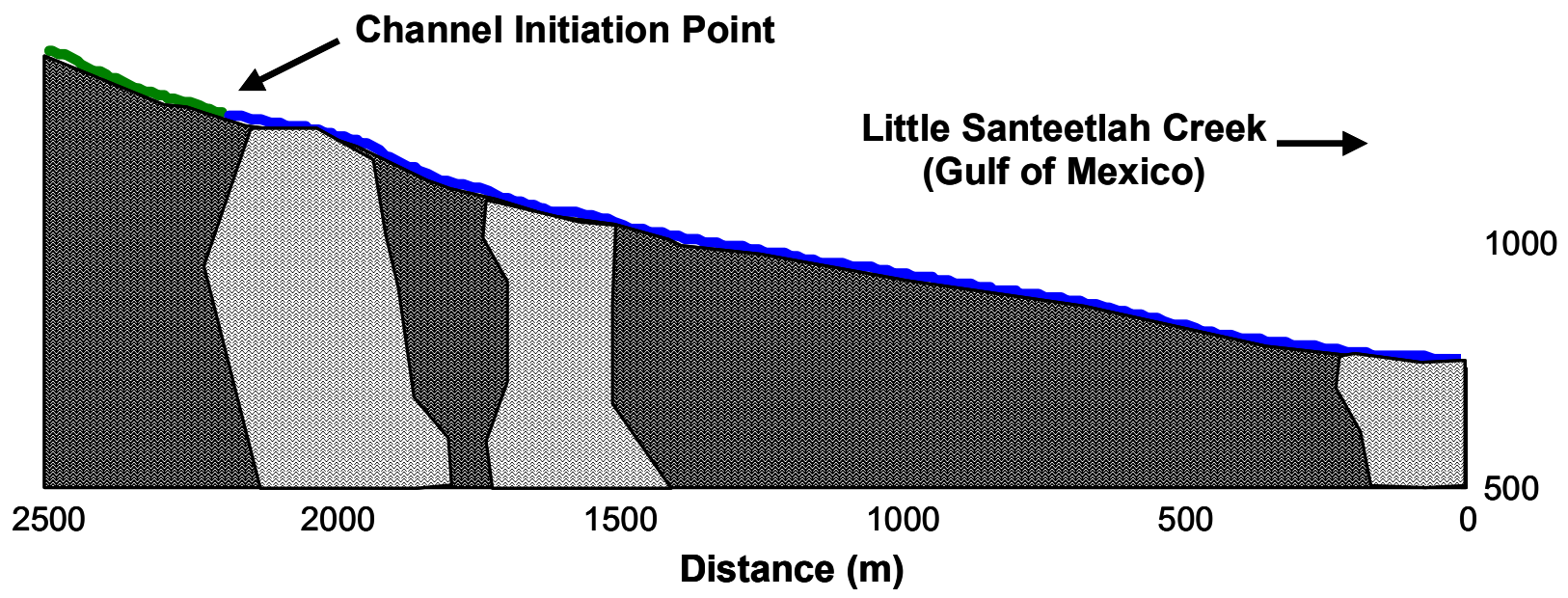

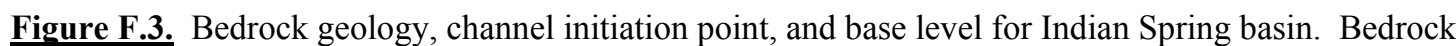

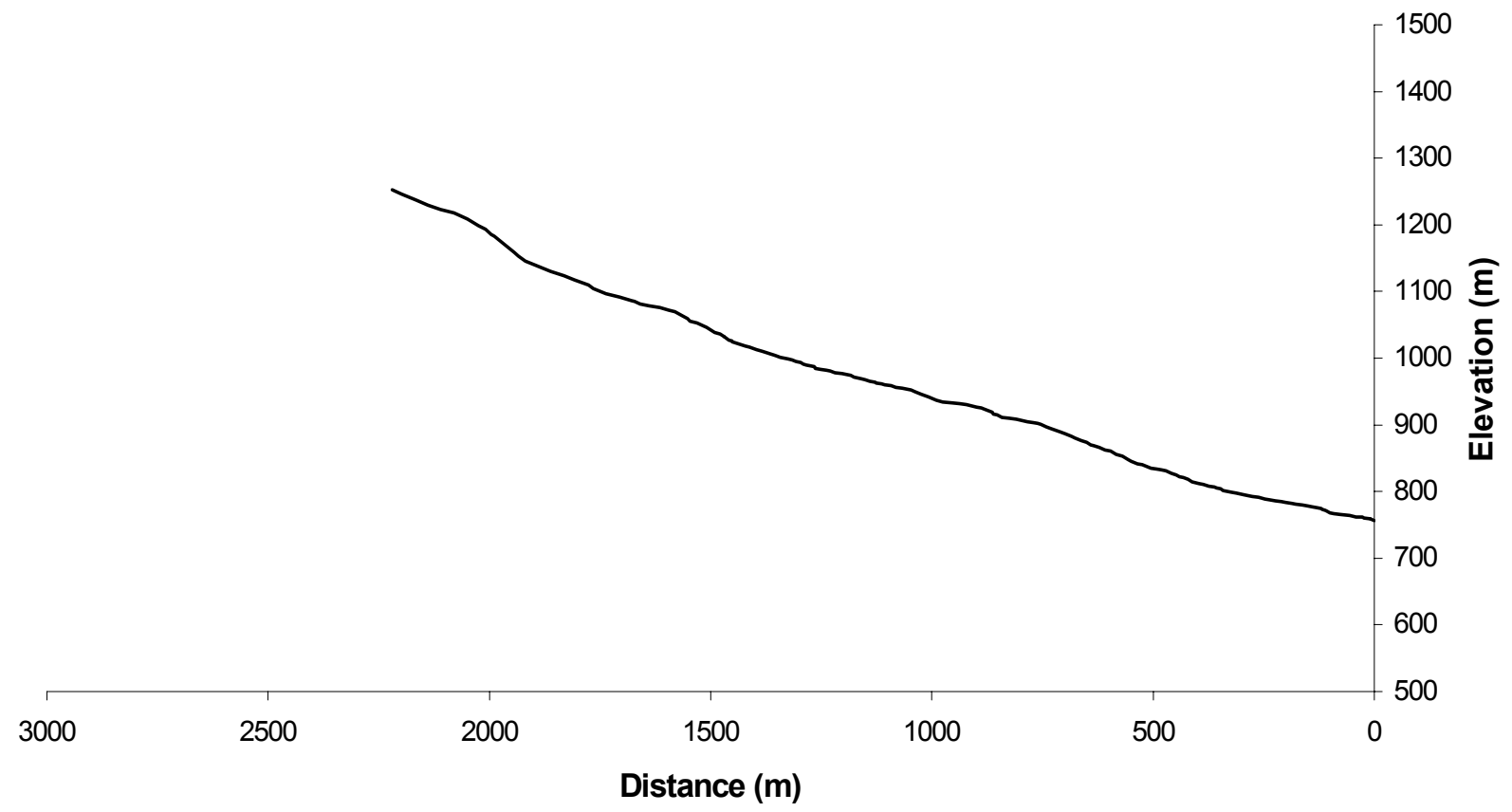

geology taken from Lesure et. al. (1977).

Figure F.4. Indian Spring longitudinal profile, from survey data. 


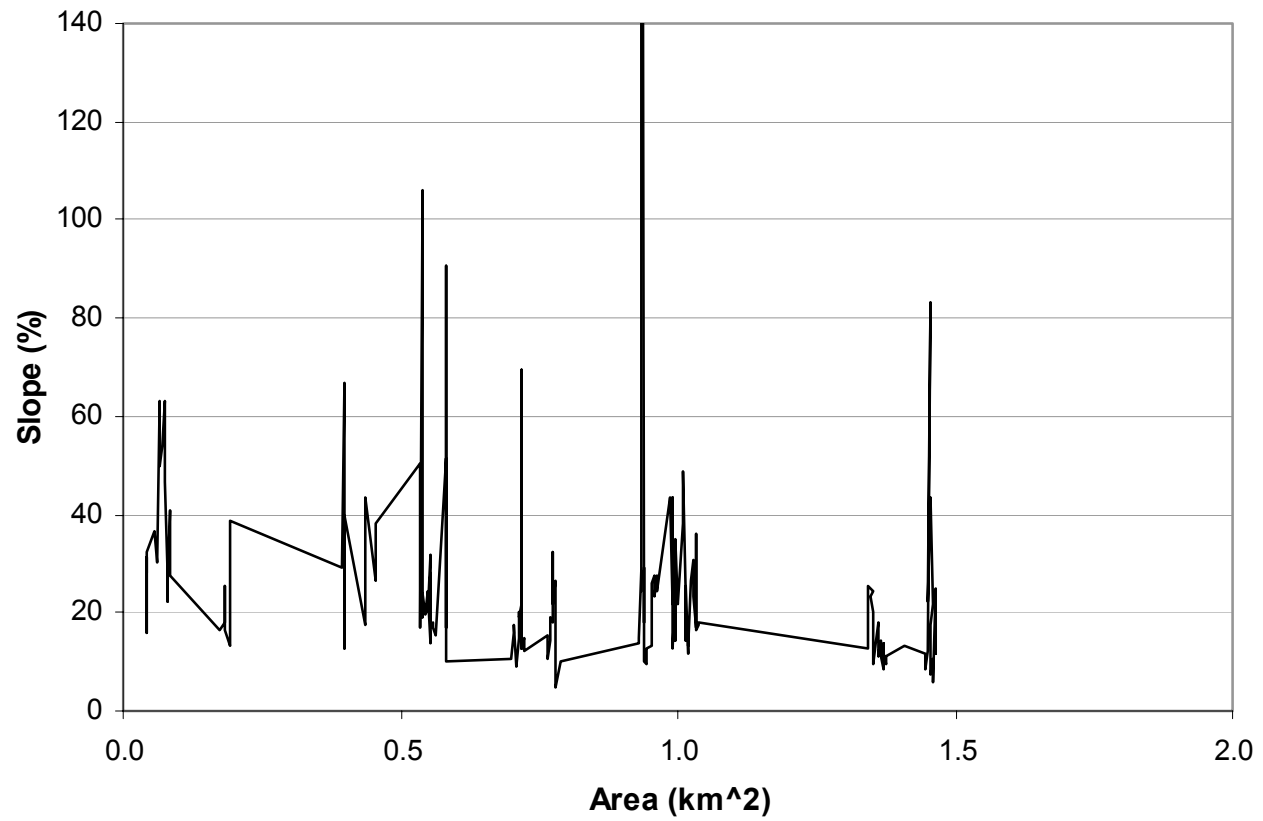

Figure F.5. Slope-area plot for surveyed portion of Indian Spring channel, using field surveyed slope values and DEM-generated drainage area values.

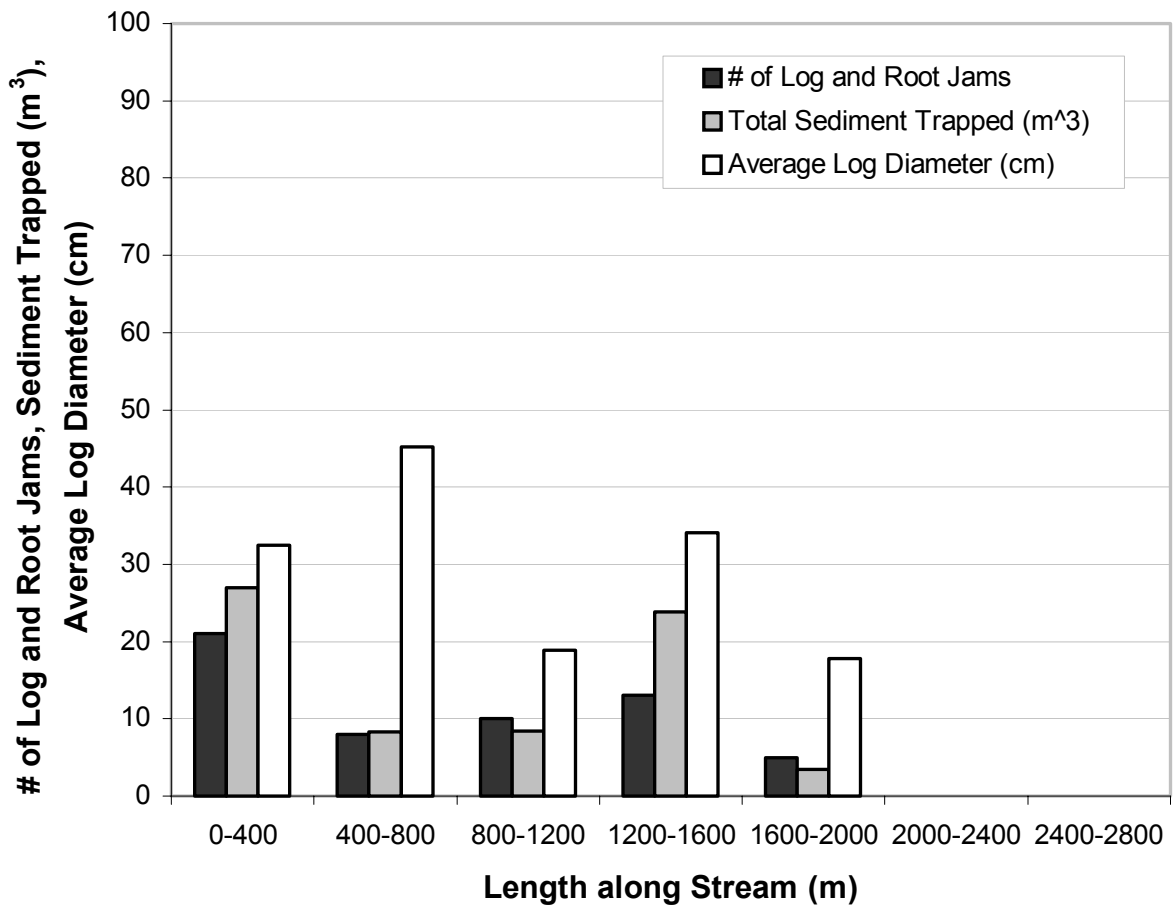

Figure F.6. Log and root jam frequency, total sediment trapped in jams, and average log diameter binned for $400 \mathrm{~m}$ length stream segments of Indian Spring. 

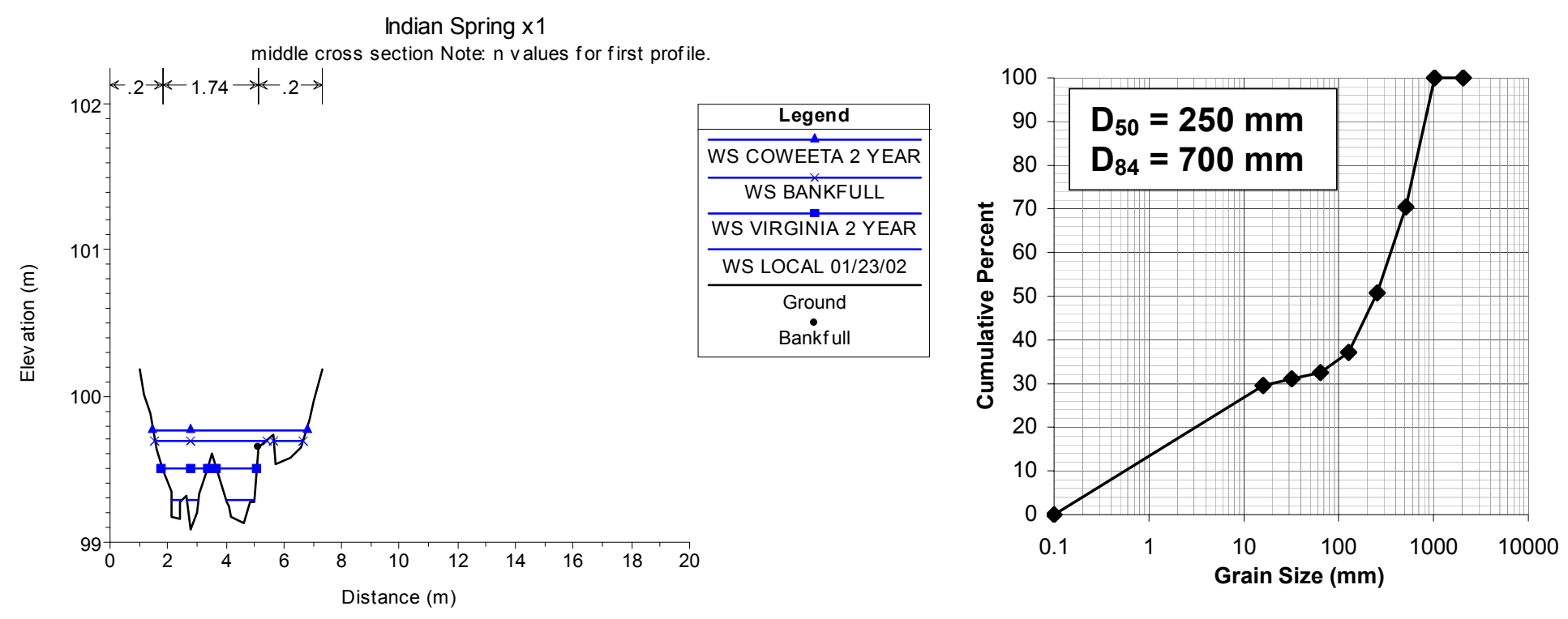

Figure F.7. Indian Spring reach 1, middle cross section (left), and cumulative grain size distribution from Wolman pebble count (right). Reach 1 was located in a low-gradient cobble-boulder section of channel below the confluence with an eastern tributary.
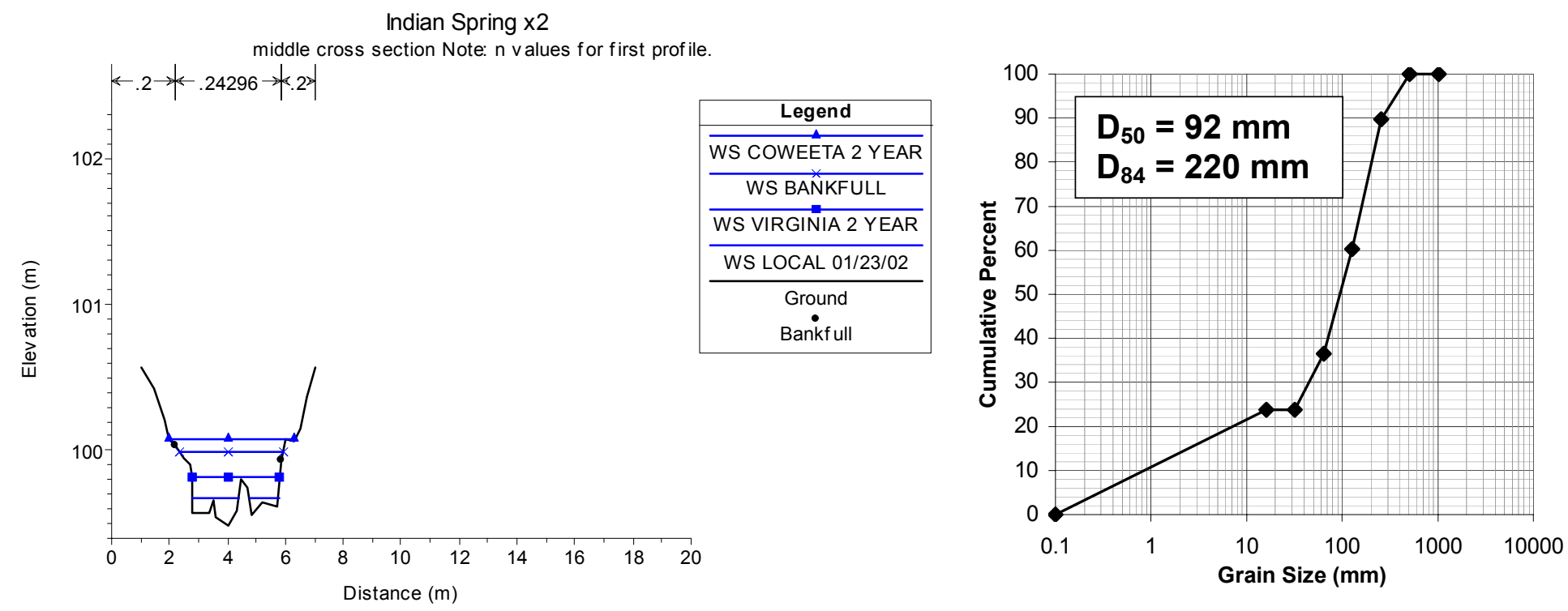

Figure F.8. Indian Spring reach 2, middle cross section (left), and cumulative grain size distribution from Wolman pebble count (right). Reach 2 was located in a cobble-boulder section of channel upstream of the junction with the eastern tributary. 

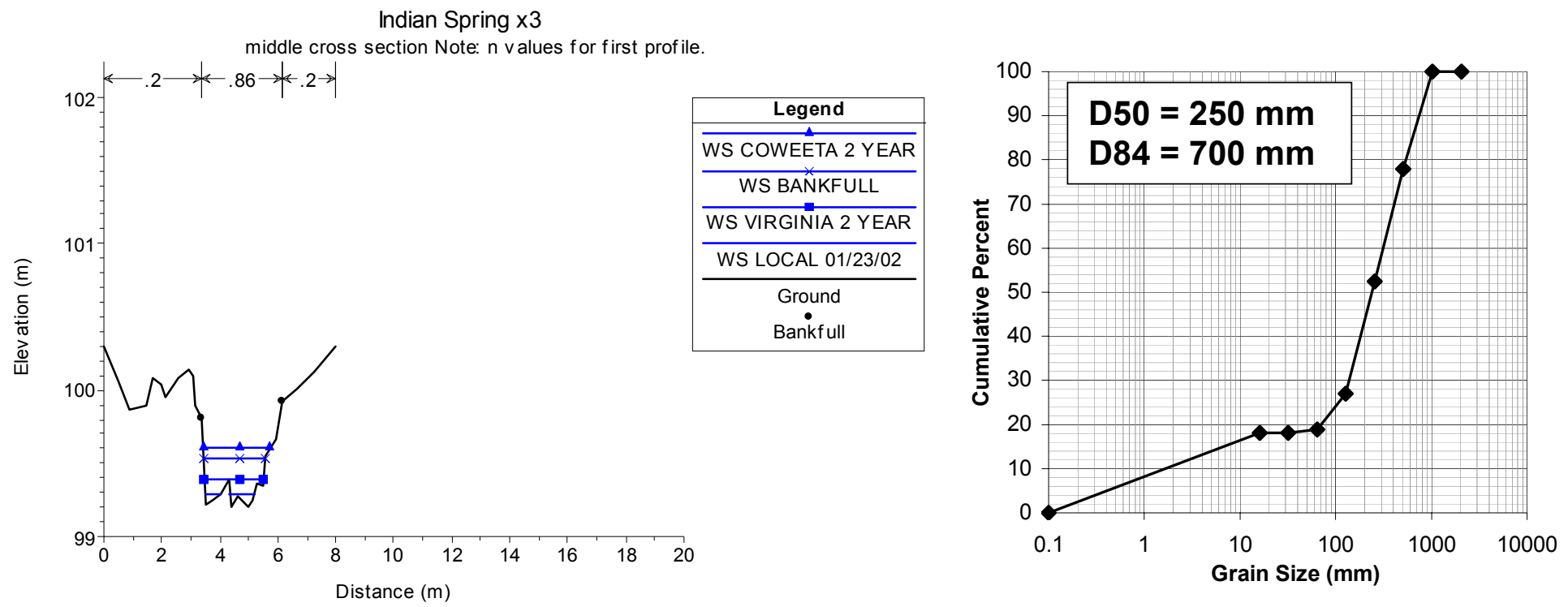

Figure F.9. Indian Spring reach 3, middle cross section (left), and cumulative grain size distribution from Wolman pebble count (right). Reach 3 was located below a big falls, midway up the channel, in a boulder steppool section of channel.
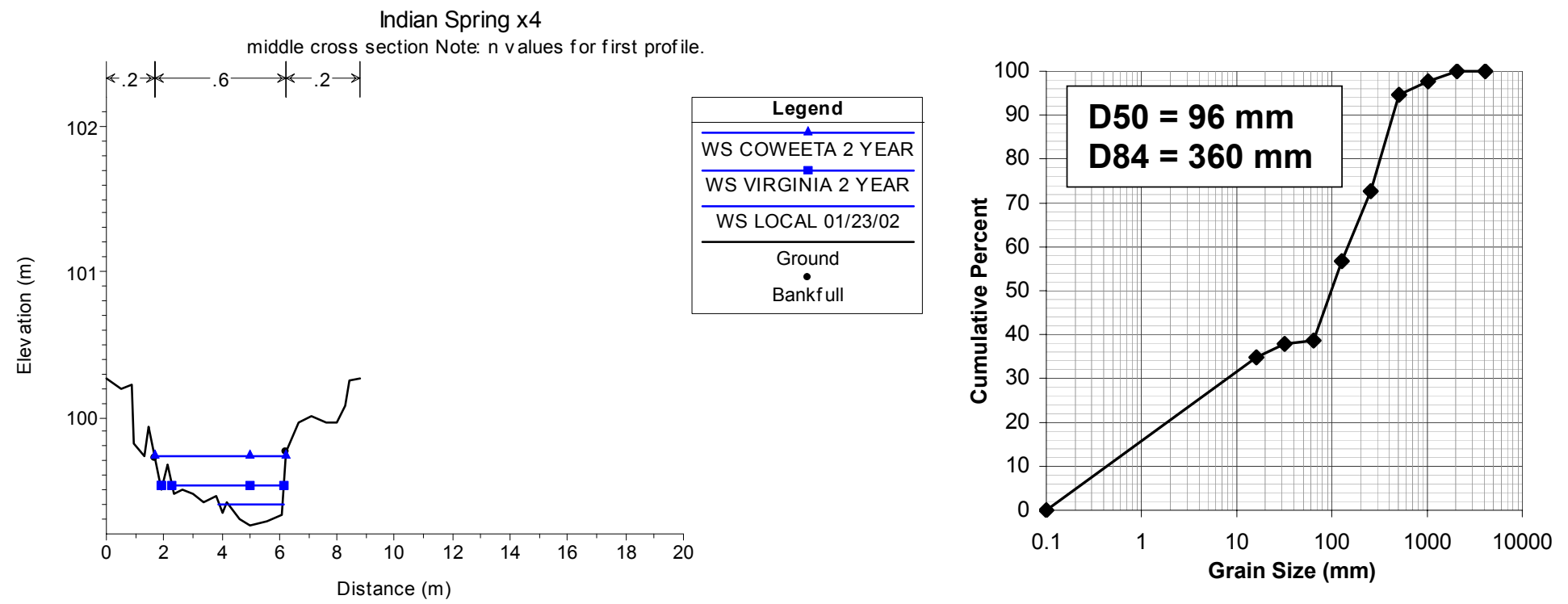

Figure F.10. Indian Spring reach 4, middle cross section (left), and cumulative grain size distribution from Wolman pebble count (right). Reach 4 was located in a cobble section just below a series of bedrock steps, and includes a log jam at its upstream end. A large root wad is turned up to form the left bank (looking downstream). 

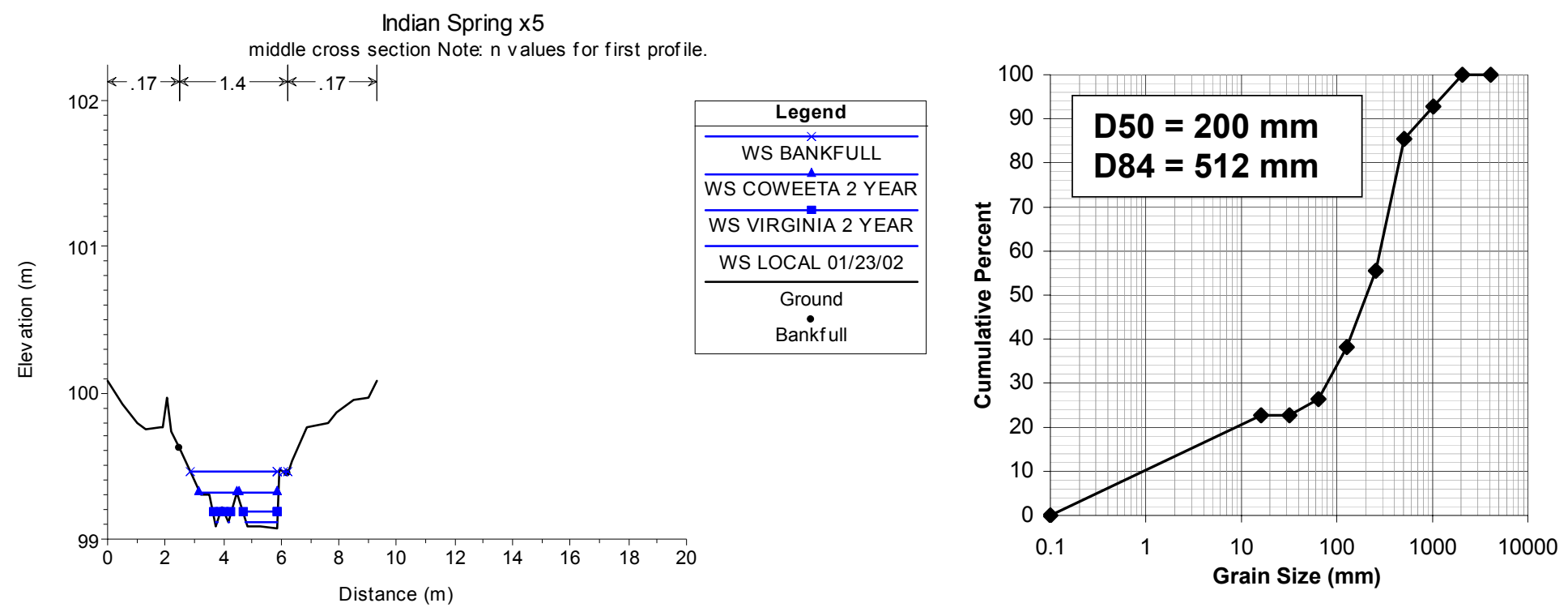

Figure F.11. Indian Spring reach 5, middle cross section (left), and cumulative grain size distribution from Wolman pebble count (right). Reach 5 was located just above a point where many tributaries converge. The section is wide and bouldery and flow is underground.
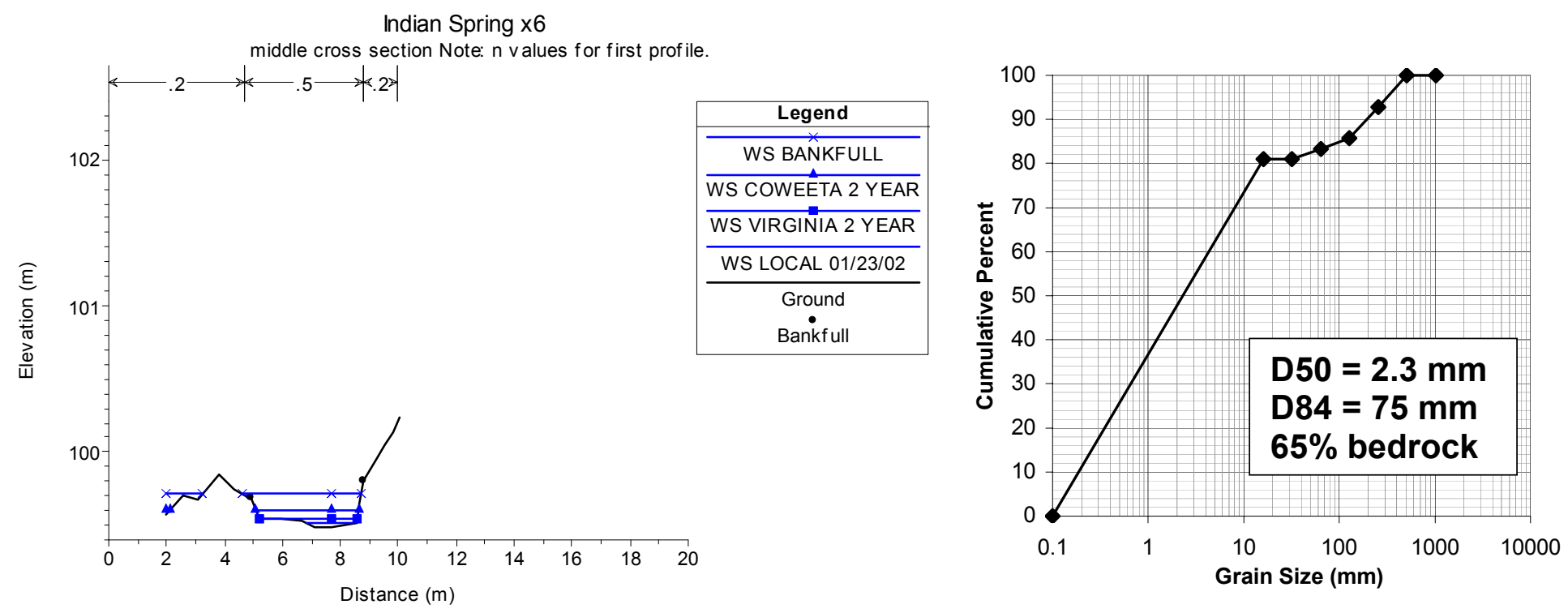

Figure F.12. Indian Spring reach 6, middle cross section (left), and cumulative grain size distribution from Wolman pebble count (right). Reach 6 was located in a wide, shallow, bedrock-floored section of channel directly above the large bedrock slope near the top of the channel. 


\section{Appendix G}

\section{Horse Cove}

\section{Qualitative Observations}

Horse Cove initiates from a hole underneath several boulders on a steep, open hillside. It then becomes a wide, steep channel with a mixed floor of bedrock covered by cobble, brush, and rhododendron. The channel is hard to discern at times due to the grasses growing within it but there is a trapezoidal depression that is evident down the hillside. As the slope of the hillside decreases, many tributaries converge and it is hard to tell which is the main channel, as none have consistent flow. The pattern of channel disappearance and reemergence in this area is similar to the bottom section of Indian Spring, except that there is noticeably less vegetation in Horse Cove to obscure the view. The forest is open and lacks rhododendron. Old log roads are apparent on the hillsides and in the channel bottom, as are stumps.

Prior to the first major log road bridge the channel becomes deeply incised and water is consistently present in the channel. After passing under the log bridge, the channel becomes steeper, the valley narrows, and streamside vegetation (rhodendron, etc.) increases greatly. Bedrock steps appear, and about halfway down the channel giant blocks of bedrock create a large waterfall. The blocks ring the hillside, creating an amphitheatre-shape. Below the waterfall, the channel is steep and comprised of large boulders over a bedrock floor. After passing under another log bridge, the channel gradient decreases, as the channel becomes more a typical alluvial form with large cobble and boulder substrate.

Rebecca Kavage and Jeffrey Adams surveyed Horse Cove from October 25-26, 2001. 

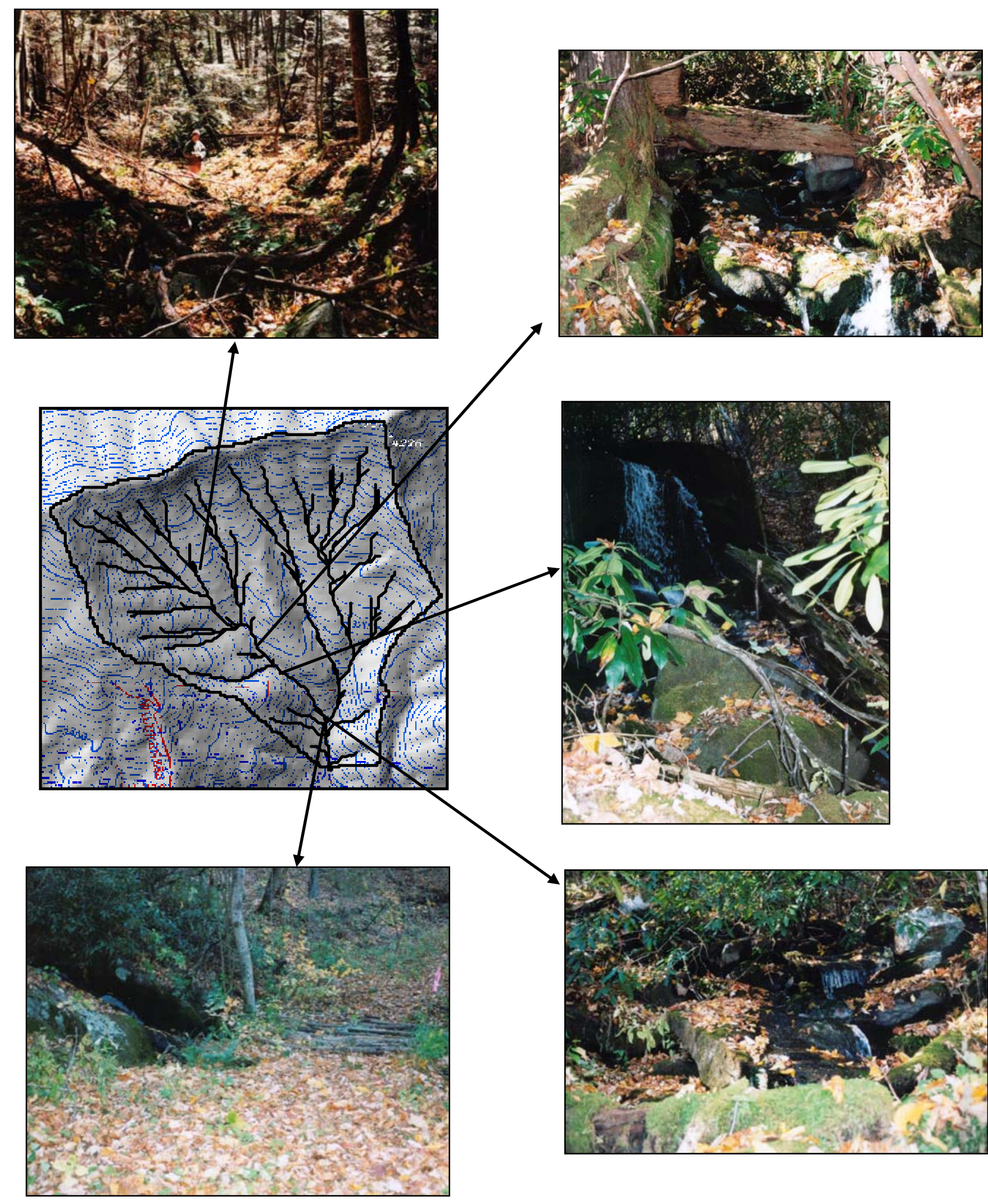

Figure G.1. Photographs of Horse Cove, clockwise from top left: dry, shallow channel in upper reaches (x4); bedrock step channel with old log bridge (x3); waterfall, steep boulder channel below waterfall (x2); and old log road crossing, just below x2. 

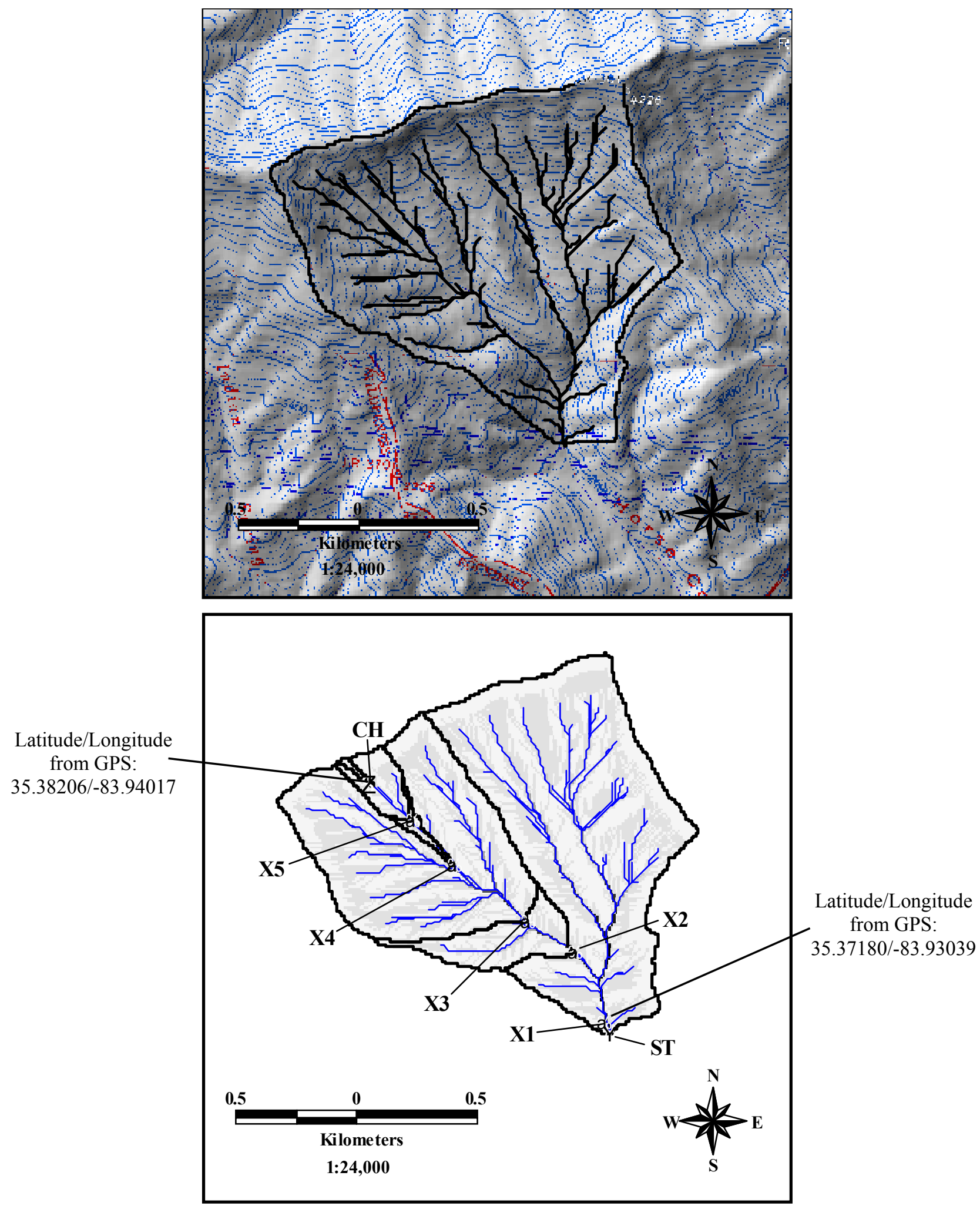

Figure G.2. Topographic and drainage network map of Horse Cove basin, denoting survey points. 


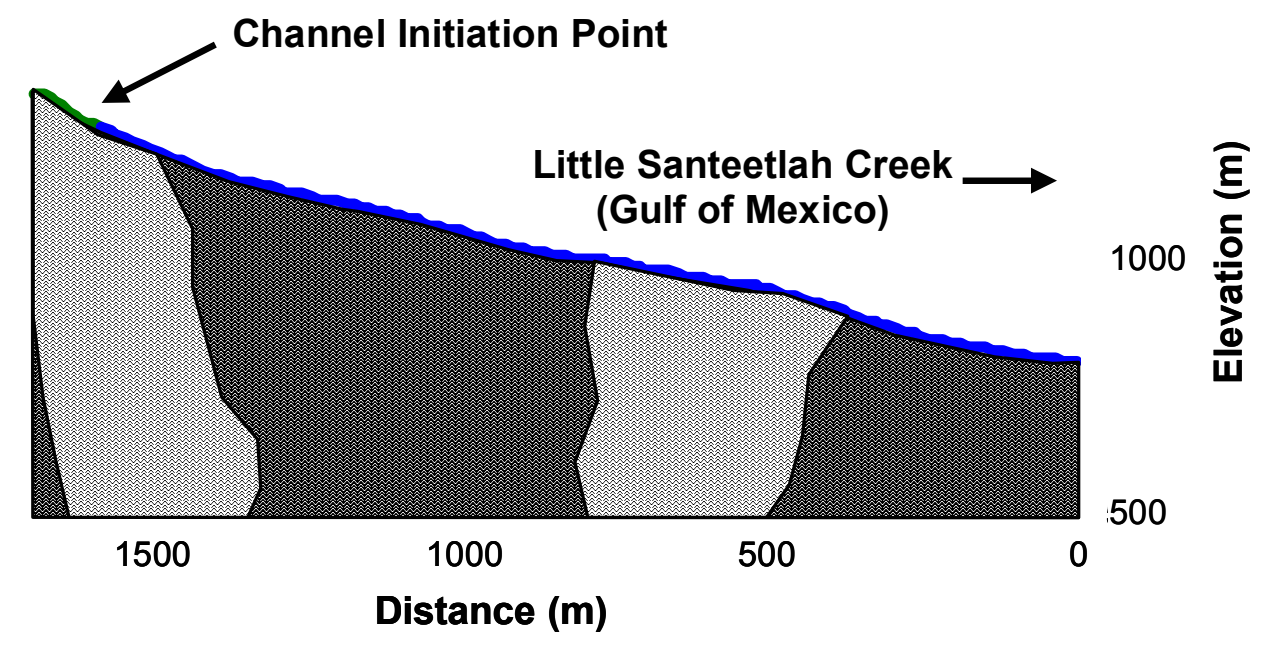

Figure G.3. Bedrock geology, channel initiation point, and base level for Horse Cove basin. Bedrock geology taken from Lesure et. al. (1977).

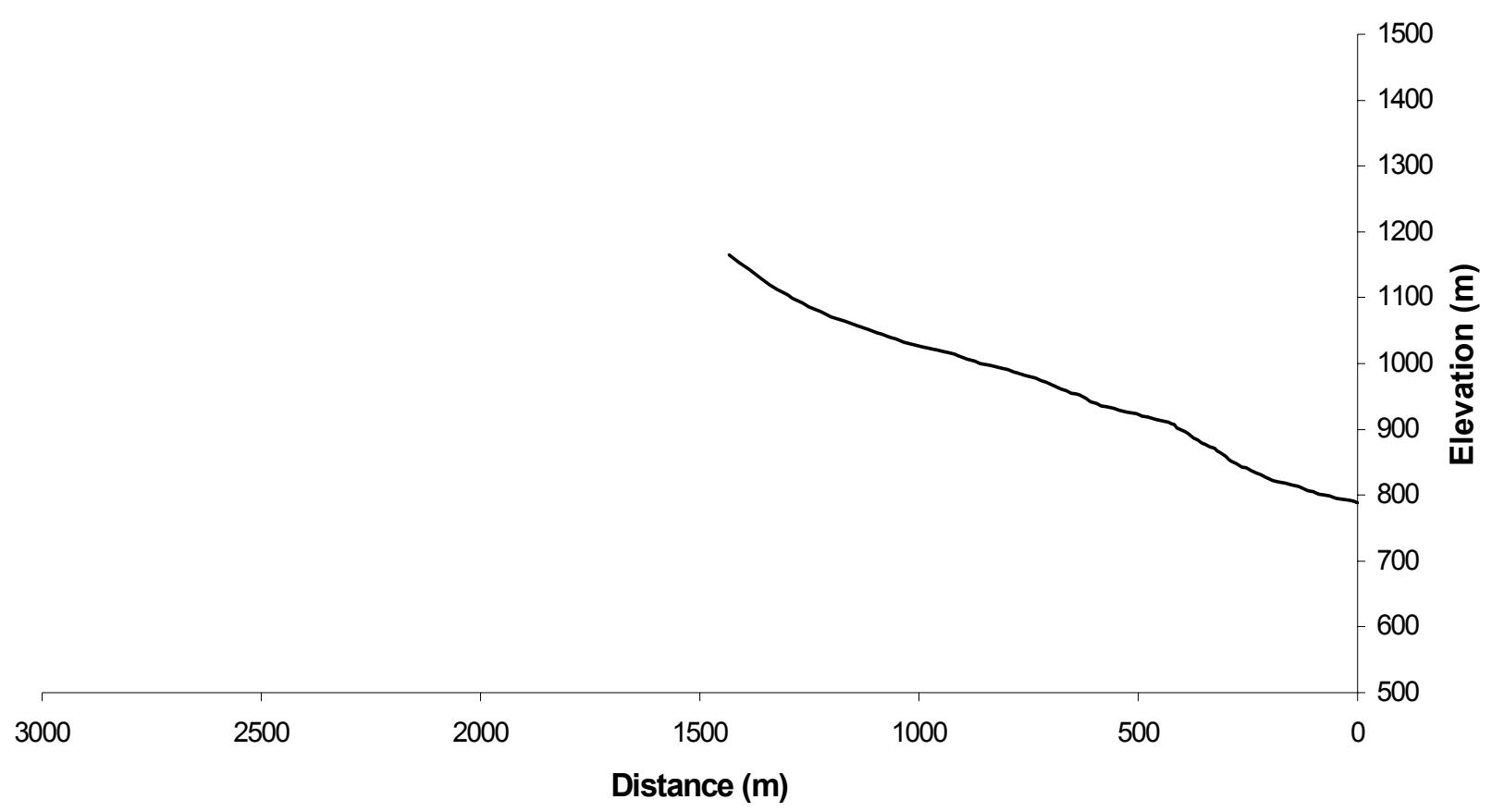

Figure G.4. Horse Cove longitudinal profile, from survey data. 


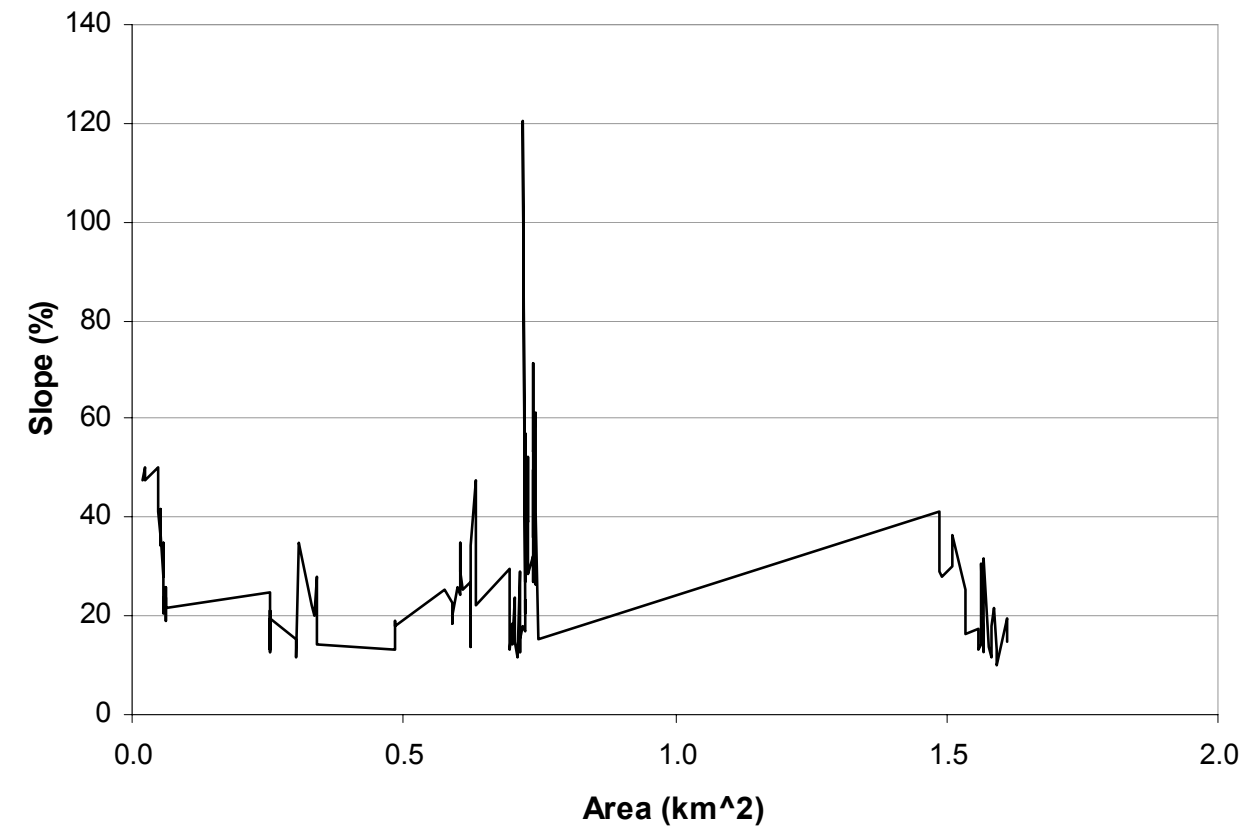

Figure G.5. Slope-area plot for surveyed portion of Horse Cove channel, using field surveyed slope values and DEM-generated drainage area values.

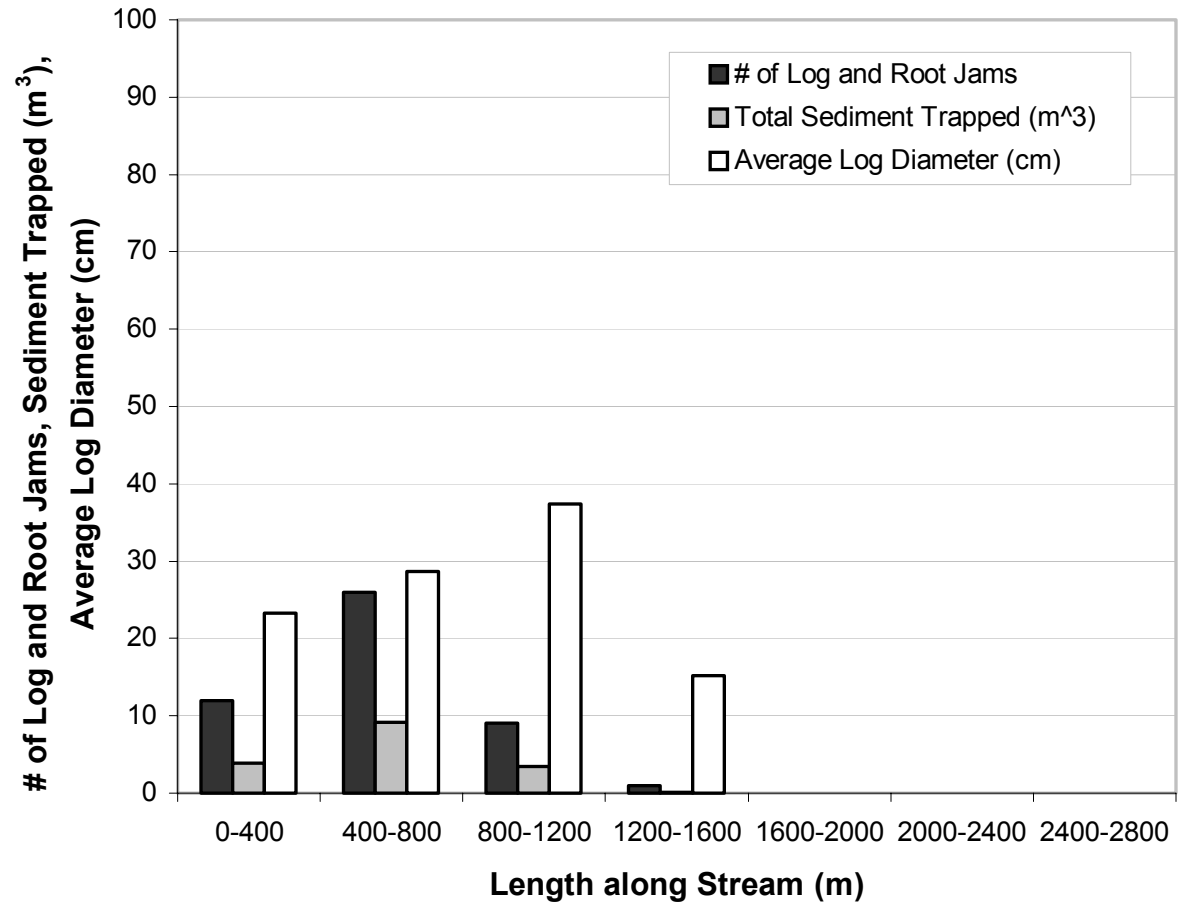

Figure G.6. Log and root jam frequency, total sediment trapped in jams, and average log diameter binned for $400 \mathrm{~m}$ length stream segments of Horse Cove. 

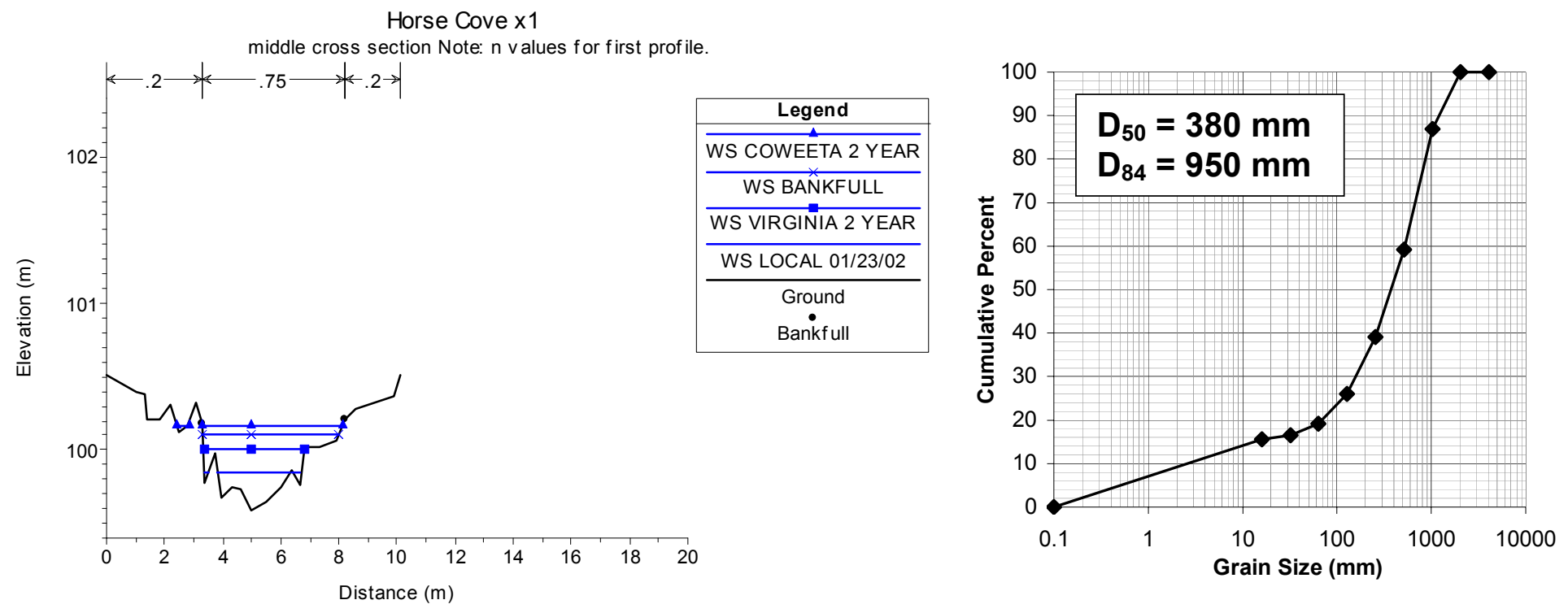

Figure G.7. Horse Cove reach 1, middle cross section (left), and cumulative grain size distribution from Wolman pebble count (right). Reach 1 was located in alluvial step-pool morphology representative of the lower $1 / 5$ of the channel.
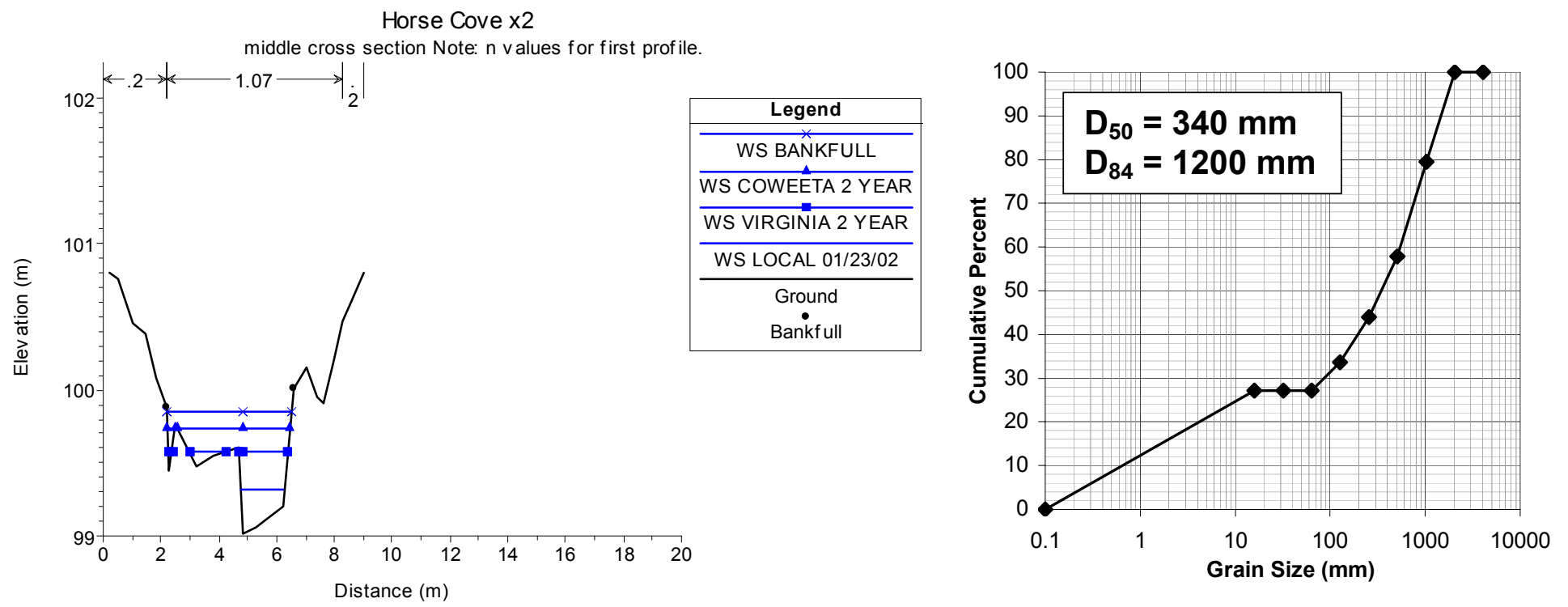

Figure G.8. Horse Cove 10 reach 2, middle cross section (left), and cumulative grain size distribution from Wolman pebble count (right). Reach 2 was located in a very steep boulder section above a steep bedrockfloored section of the channel, and below a large waterfall. 

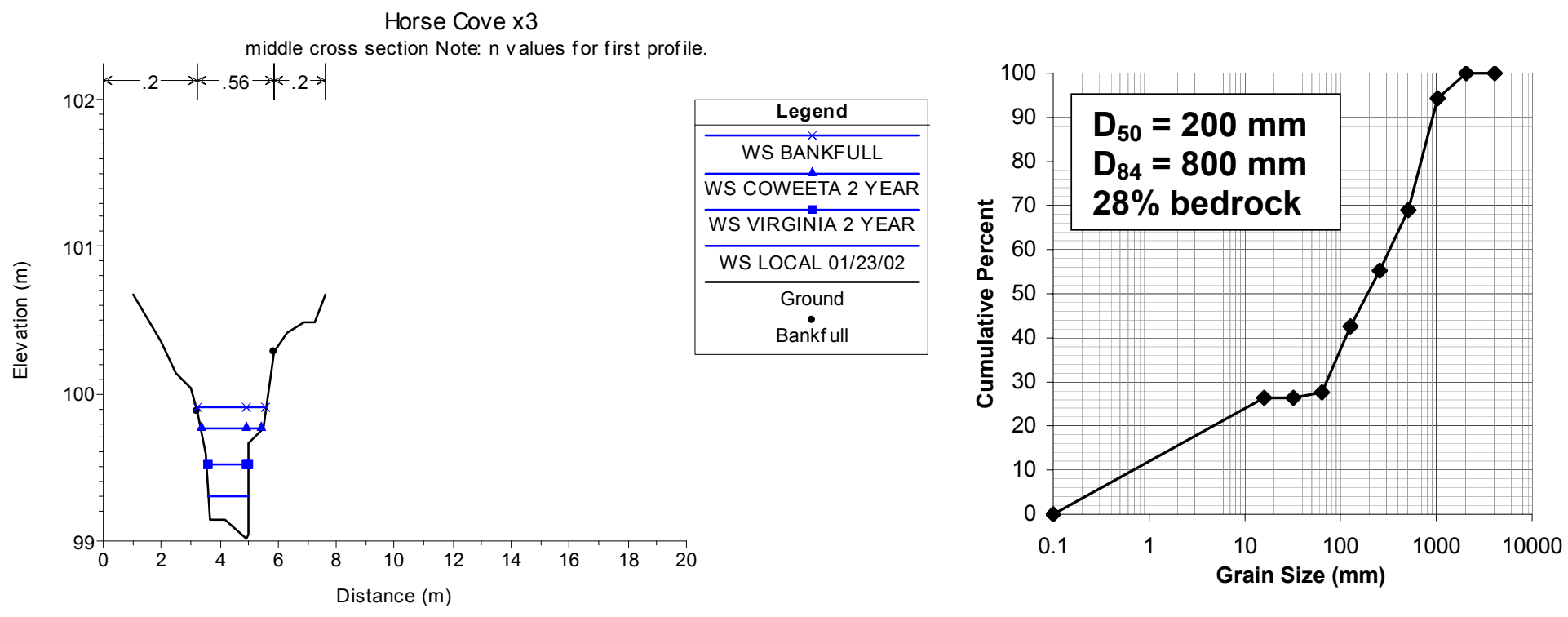

Figure G.9. Horse Cove reach 3, middle cross section (left), and cumulative grain size distribution from Wolman pebble count (right). Reach 3 was located in a confined, bedrock step channel section representative of the middle section of the channel.
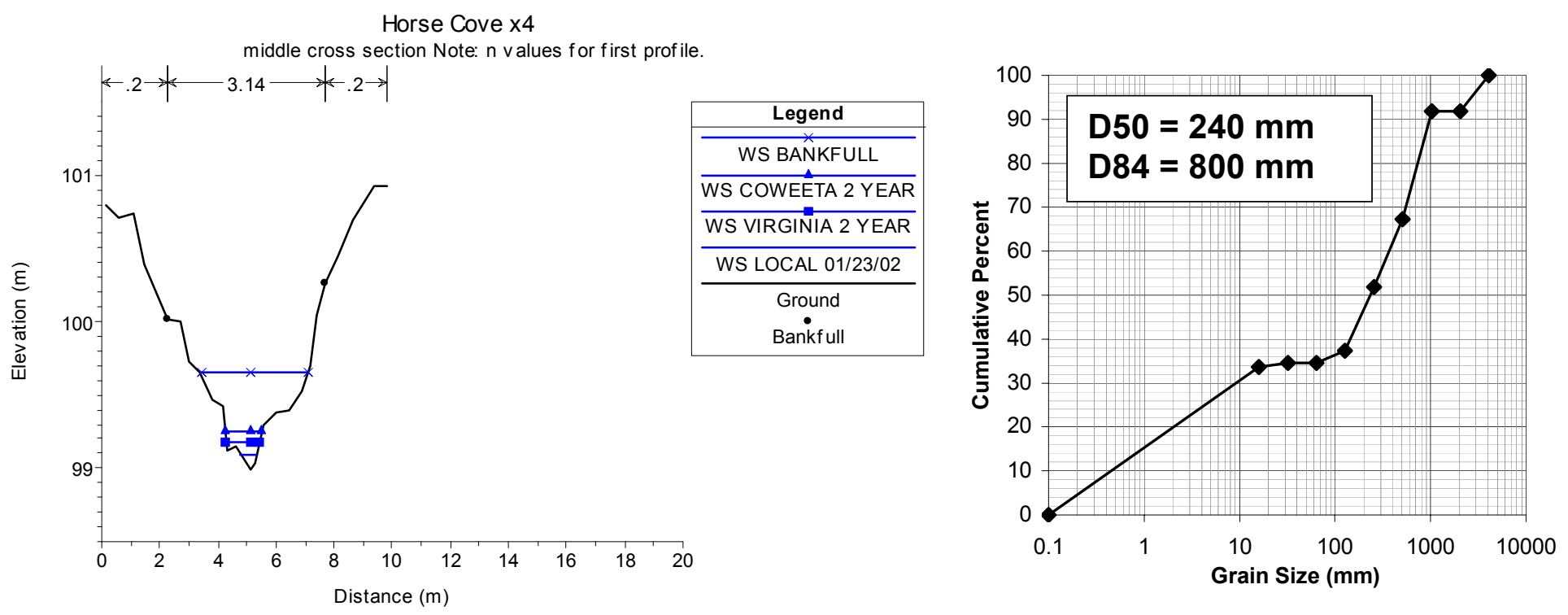

Figure G.10. Horse Cove reach 4, middle cross section (left), and cumulative grain size distribution from Wolman pebble count (right). Reach 4 was located in a dry section of channel where many wide shallow channels were present, and old log roads were evident. 

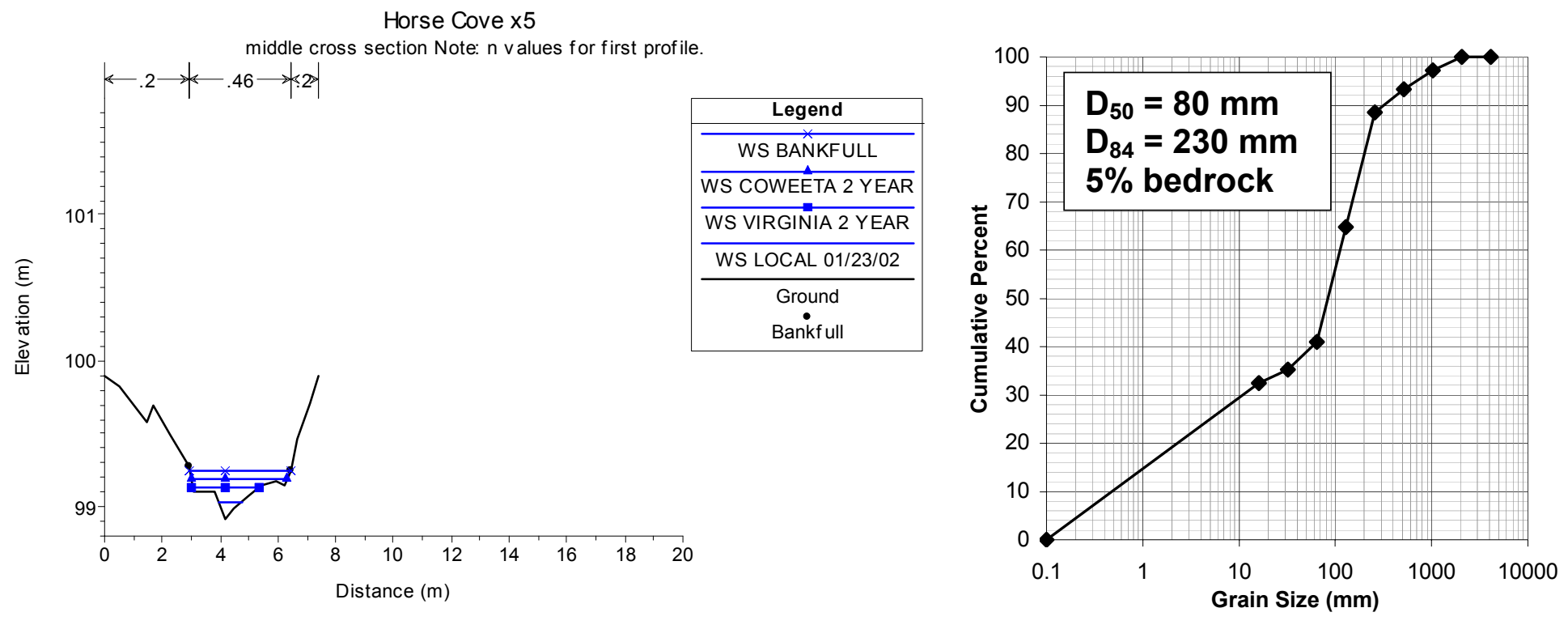

Figure G.11. Horse Cove reach 5, middle cross section (left), and cumulative grain size distribution from Wolman pebble count (right). Reach 5 was located on the steep upper slope of the basin, a wide shallow cobble channel overlying bedrock and covered in vegetation, with only trickling flow. 


\section{Appendix H \\ Coweeta Watershed 10}

\section{Qualitative Observations}

Coweeta Watershed 10 initiates in a wide, cobbly seep area. The channel remains wide and full of large and small cobble until reaching the first road crossing, after which it becomes more incised and has larger boulders present. The vegetation is thick with a great deal of rhododendron, apart from the location of old log roads or present day roads.

Evidence of logging is present; large logs used for stream crossing bridges are still in place or a short ways downstream from their original location. Areas of the channel near these old log crossings are incised and rectangular (x5).

There are few bedrock steps in the channel except for two very large waterfalls (50$100 \mathrm{~m}$ high). The channel reaches just above them are bedrock floored and have some bedrock steps. Above these bedrock reaches are low gradient alluvial reaches. Huge particle sizes are present below the waterfalls, especially the larger, more downstream waterfall, which forms an amphitheatre-shaped hillside. The channel below this waterfall has bouldery step-pool morphology. Flows are low but consistently present in the channel, despite it being a dry spring [Kloeppel, $2001 \# 160]$.

Rebecca Kavage, Lee Taylor, and Doug Marchakitus surveyed Coweeta Watershed 10 from May 12-14, 2001. 

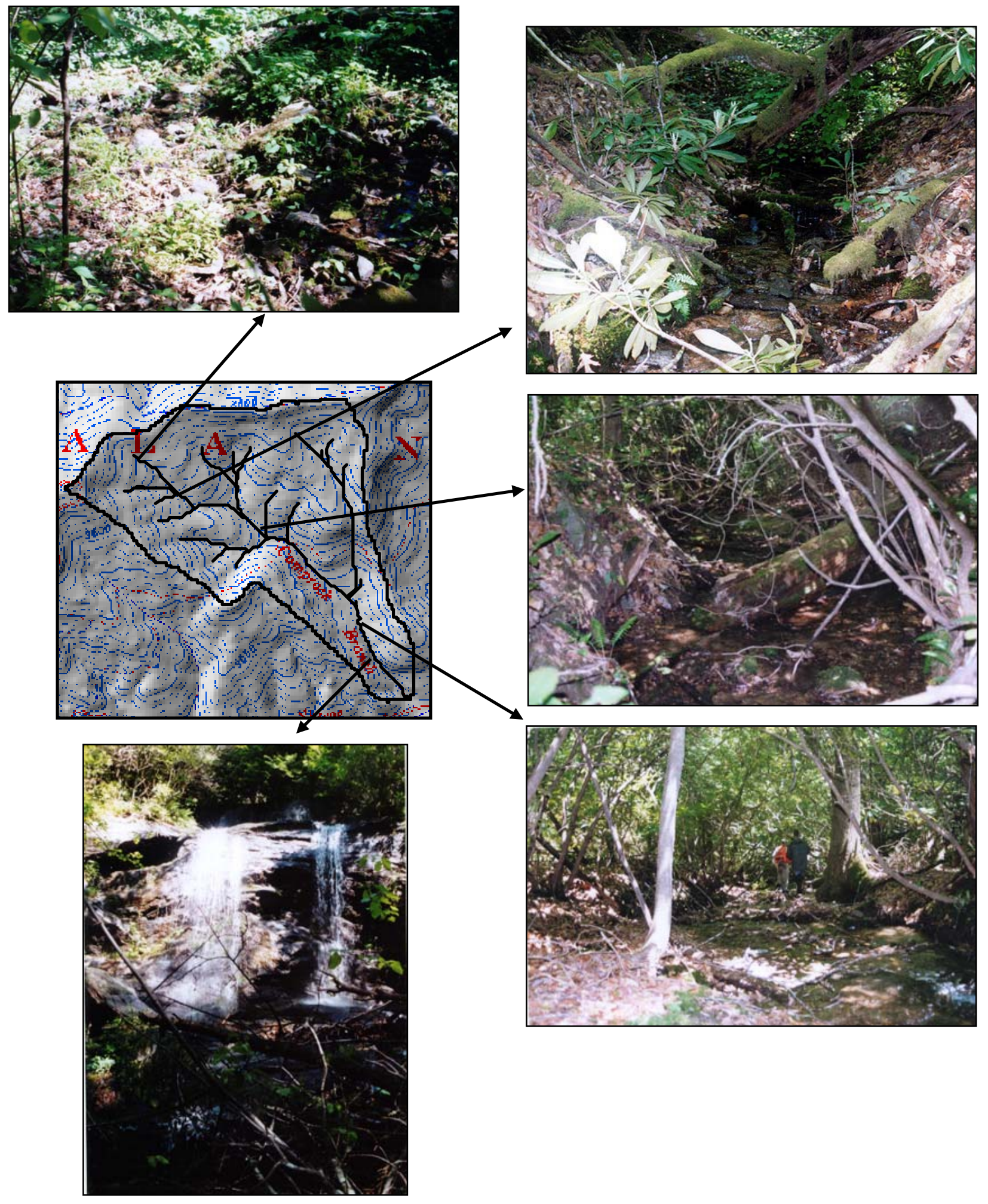

Figure H.1. Photographs of Coweeta Watershed 10, clockwise from top left: cobbly vegetated initiation point; confined upper reaches (x6); incised reach (x5) with large log from old log bridge; low gradient alluvial reach above lower waterfall; and lower waterfall created by gneiss bedrock. 


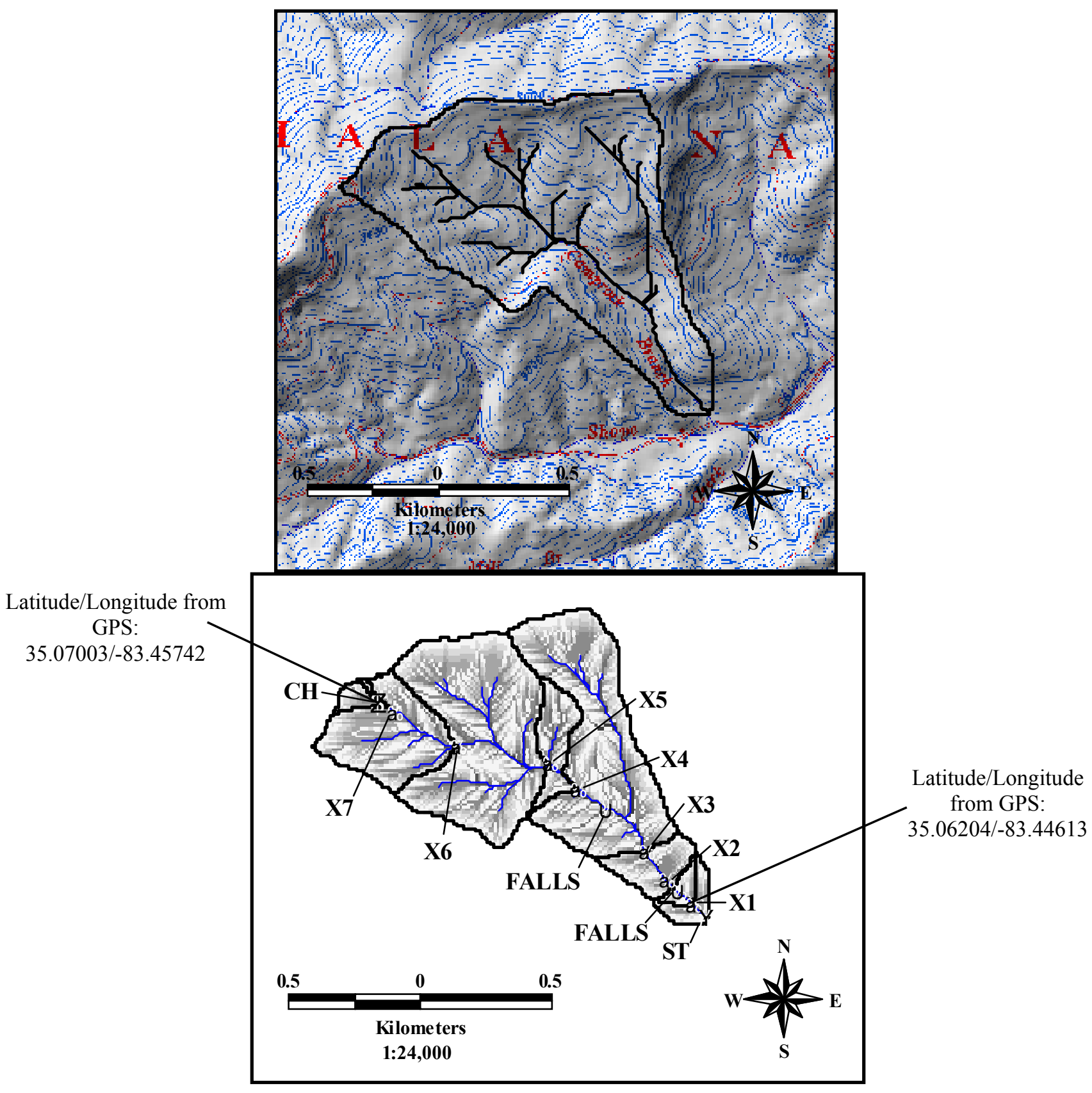

Figure H.2. Topographic and drainage network maps of Coweeta Watershed 10 basin, denoting surveyed points. 


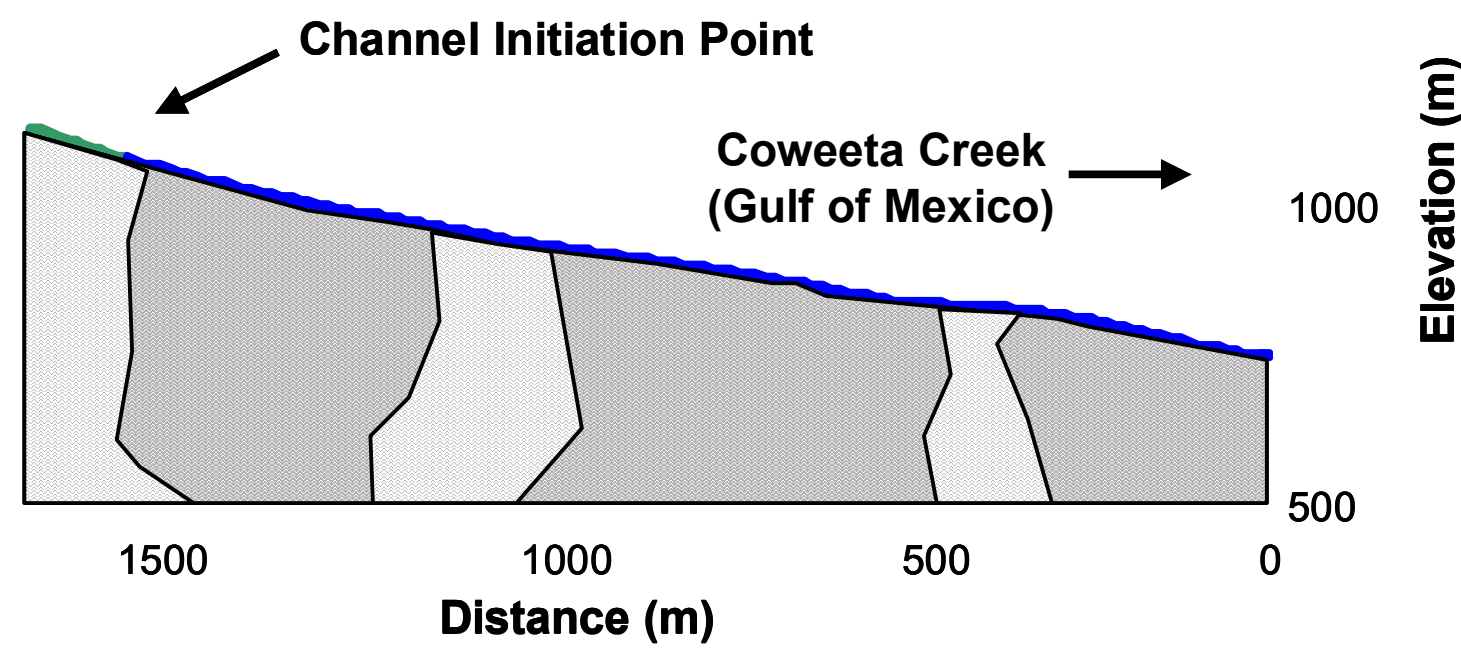

Figure H.3. Bedrock geology, channel initiation point, and base level for Coweeta Watershed 10 basin. Bedrock geology taken from Hatcher (1980).

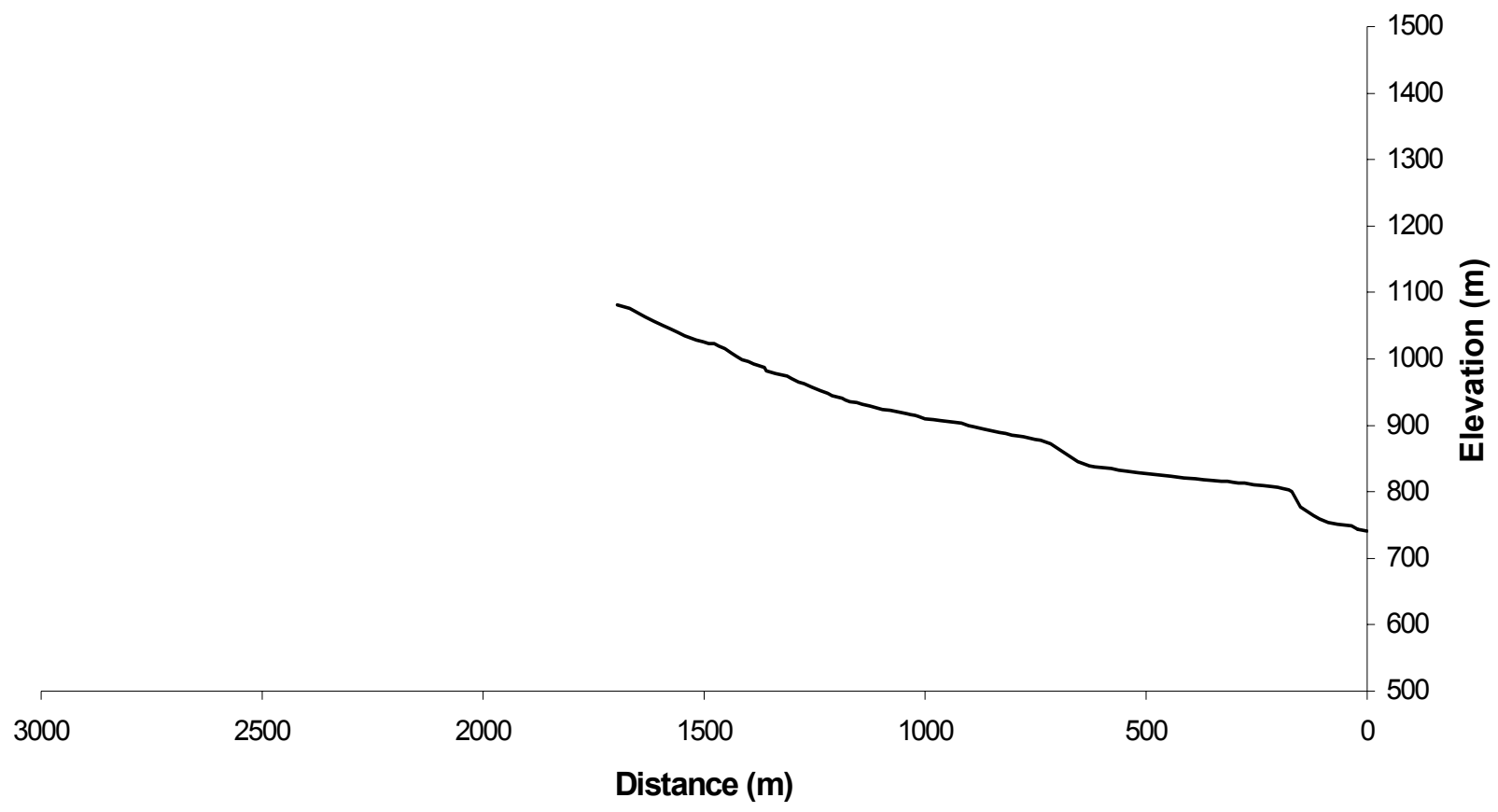

Figure H.4. Coweeta Watershed 10 longitudinal profile, from survey data. 


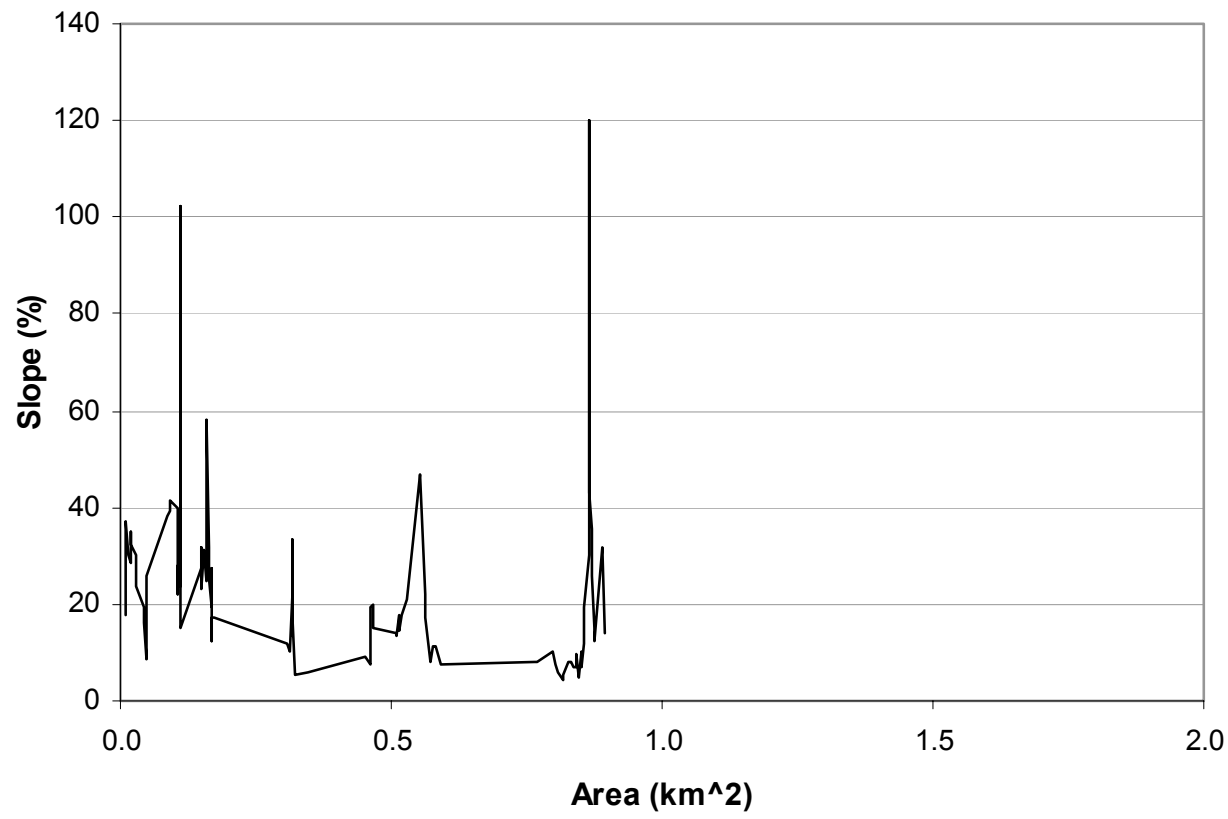

Figure H.5. Slope-area plot for surveyed portion of Coweeta Watershed 10 channel, using field surveyed slope values and DEM-generated drainage area values.

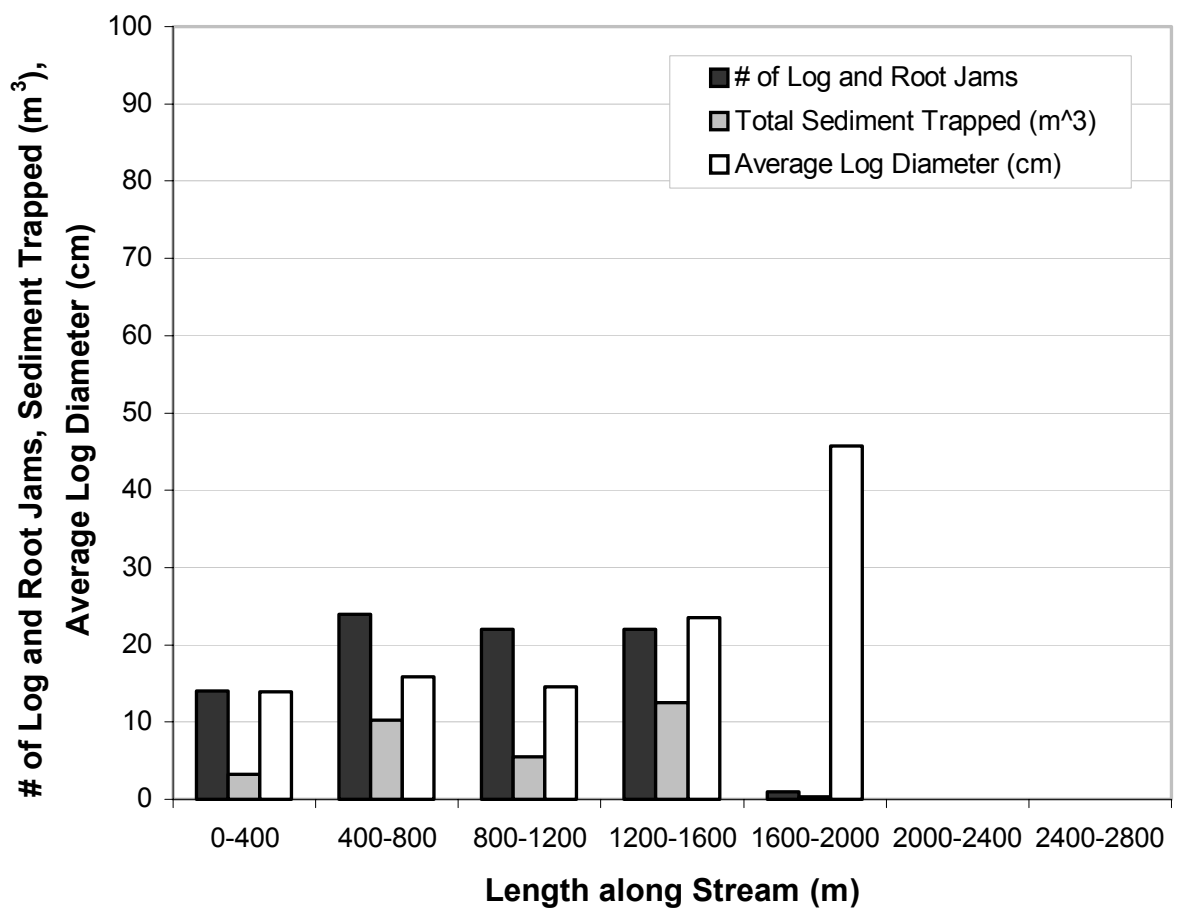

Figure H.6. Log and root jam frequency, total sediment trapped in jams, and average log diameter binned for $400 \mathrm{~m}$ length stream segments of Coweeta Watershed 10. 

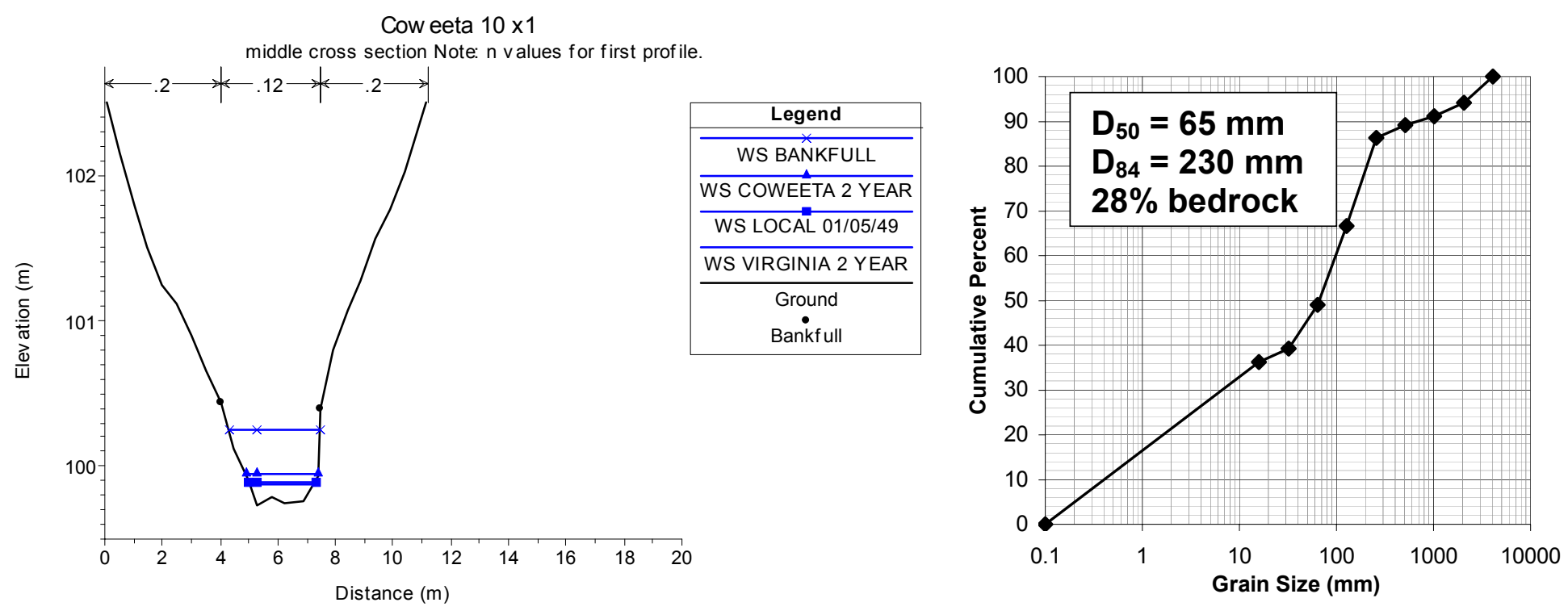

Figure H.7. Coweeta Watershed 10 reach 1, middle cross section (left), and cumulative grain size distribution from Wolman pebble count (right). Reach 1 was located below the first big waterfall in a bouldery step-pool section of channel.
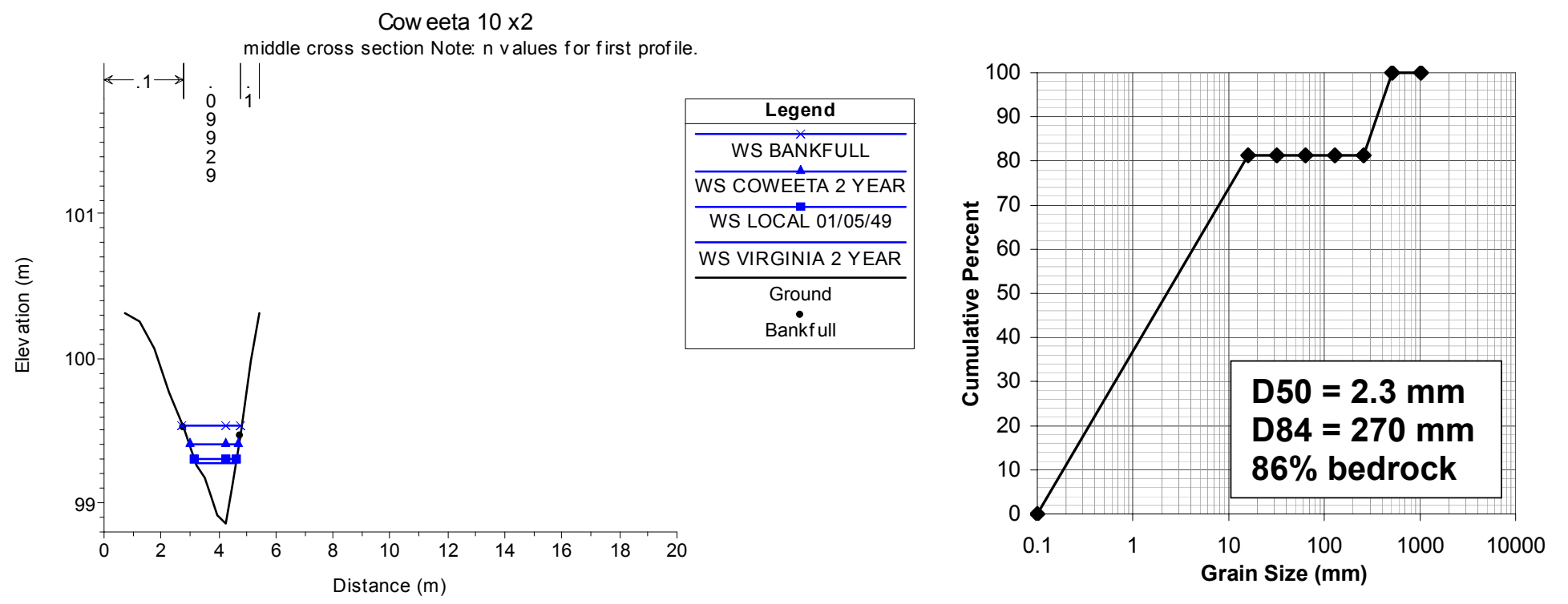

Figure H.8. Coweeta Watershed 10 reach 2, middle cross section (left), and cumulative grain size distribution from Wolman pebble count (right). Reach 2 was located in a narrow bedrock chute leading down to the first waterfall. 

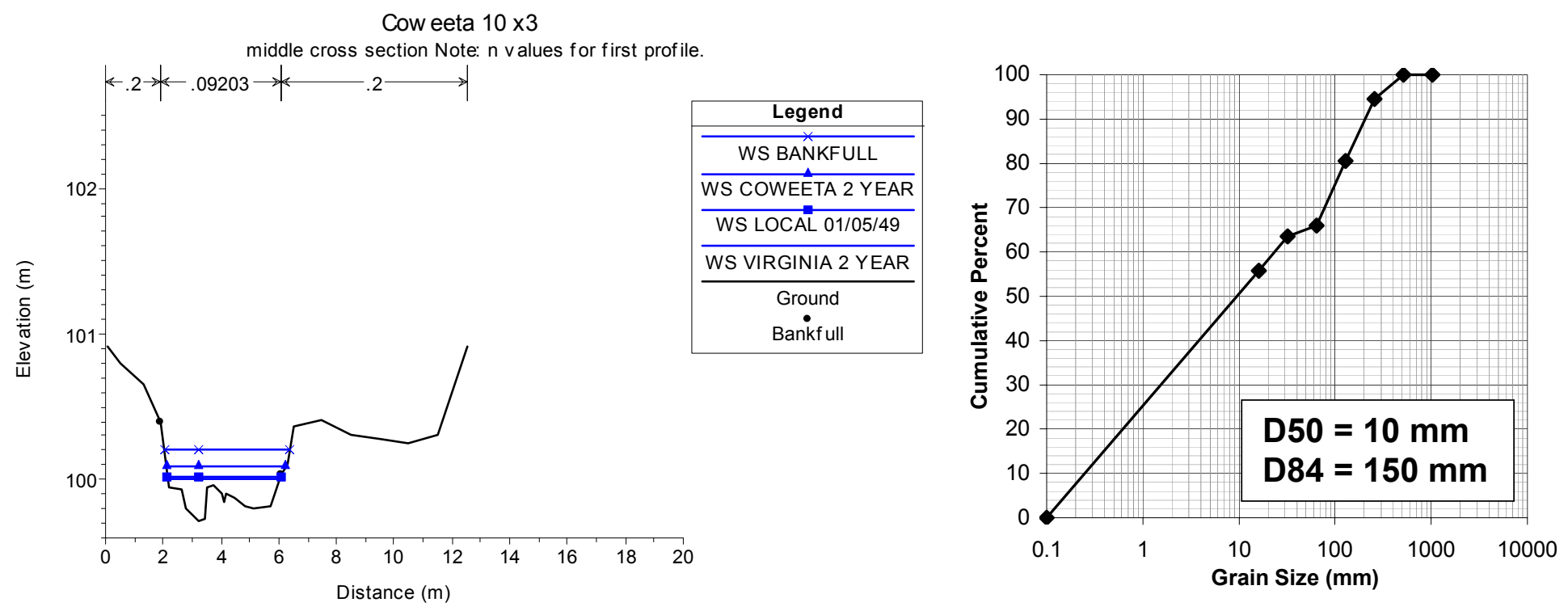

Figure H.9. Coweeta Watershed 10 reach 3, middle cross section (left), and cumulative grain size distribution from Wolman pebble count (right). Reach 3 was located just downstream of an old log road, in a low-gradient cobble-fines section of channel.
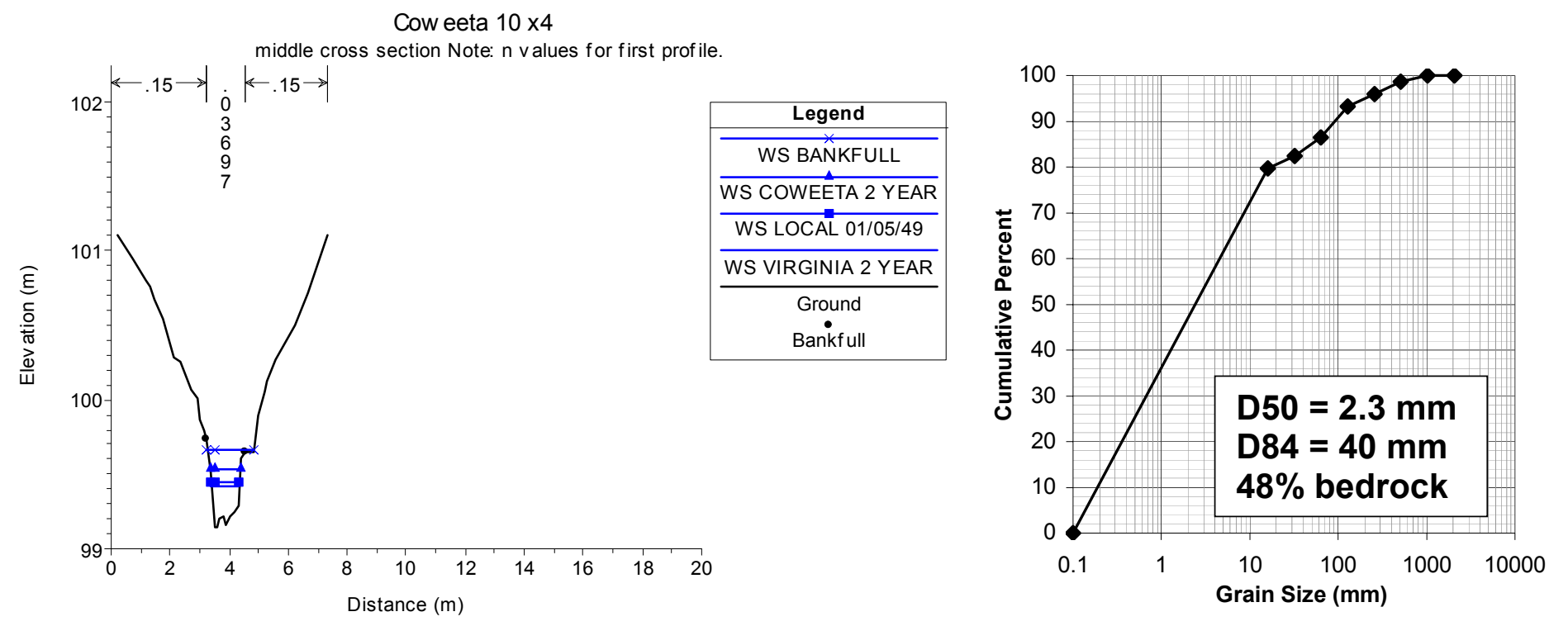

Figure H.10. Coweeta Watershed 10 reach 4, middle cross section (left), and cumulative grain size distribution from Wolman pebble count (right). Reach 4 was located just above the second major waterfall in a bedrock step section. 

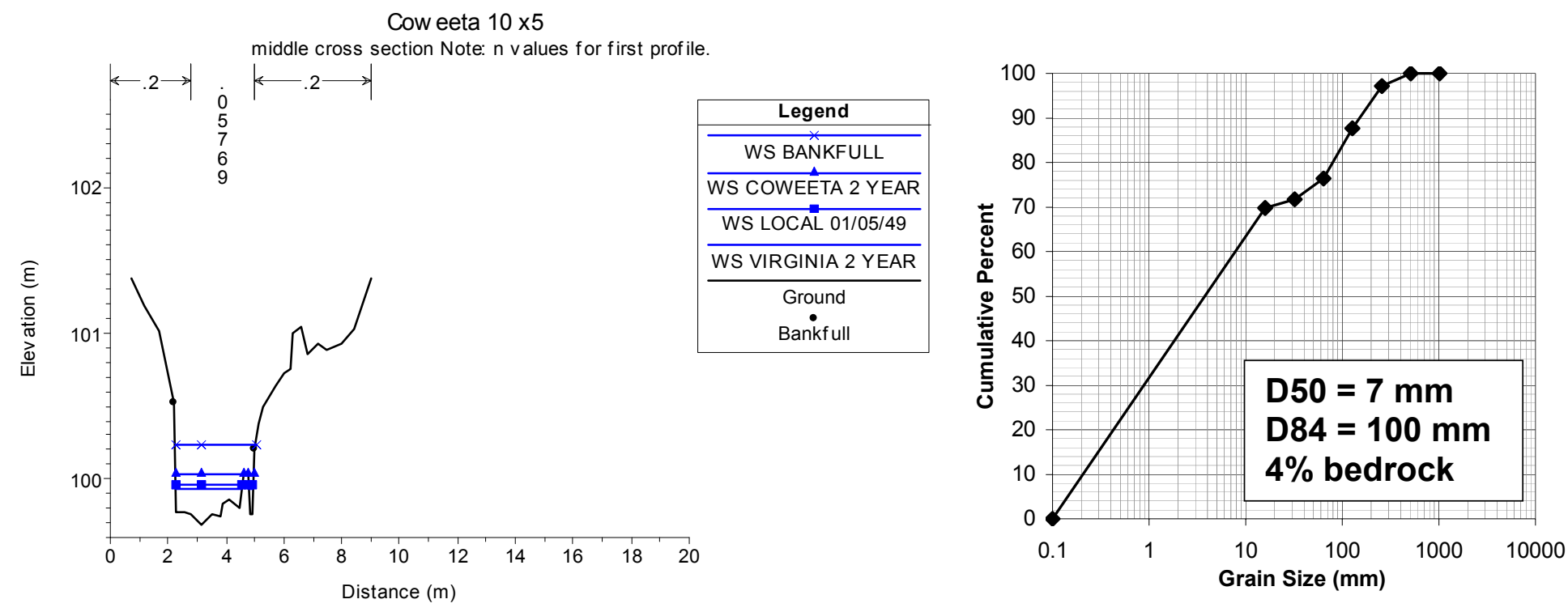

Figure H.11. Coweeta Watershed 10 reach 5, middle cross section (left), and cumulative grain size distribution from Wolman pebble count (right). Reach 5 was located below an old log bridge stream crossing in a deep,
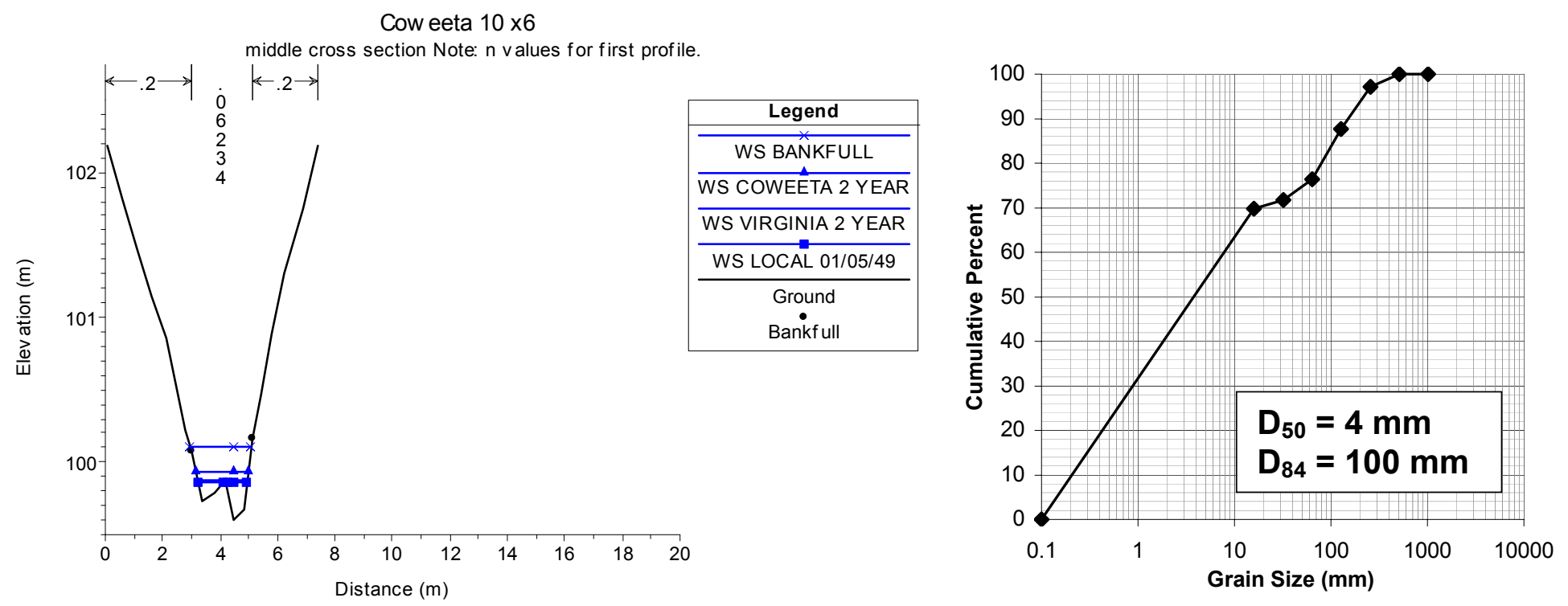

rectangular, alluvial section of channel.

Figure H.12. Coweeta Watershed 10 reach 6, middle cross section (left), and cumulative grain size distribution from Wolman pebble count (right). Reach 6 was located below an old log road in the upper portion of the channel and includes a log jam (hump observable in middle of channel cross section). 

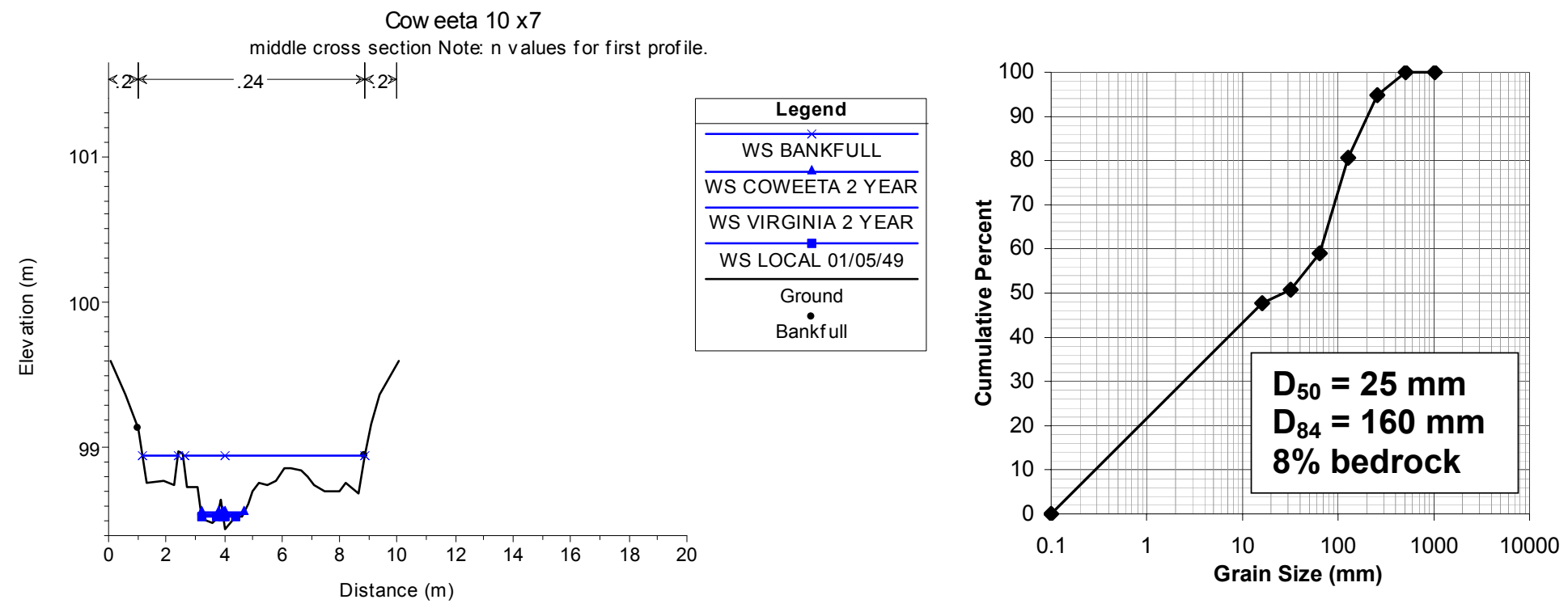

Figure H.13. Coweeta Watershed 10 reach 7, middle cross section (left), and cumulative grain size distribution from Wolman pebble count (right). Reach 7 was located in a very wide, cobbly, seepy section of channel. It was covered with vegetation, and just below the channel initiation point. 


\section{Appendix I \\ Coweeta Watershed 34}

\section{Qualitative Observations}

Coweeta Watershed 34 initiation point was obscured by impassable downed and live vegetation (dead trees, rhododendron, briars) that was a result of recent hurricane damage [Kloeppel, 2001 \#160]. The uppermost portion of the channel is steep, a mixture of bedrock steps and large cobble and boulder, with fines only collecting above a step or behind log obstructions. The channel remains steep downstream, in a confined valley with a consistently mixed channel bed and frequent bedrock steps. The frequency of these steps decreases in the lower portions of the channel as the valley widens. The channel becomes more alluvial and has a more typical alluvial cross section. The vegetation throughout this channel is extremely thick, noticeably thicker than Coweeta Watershed 10, with a dense hardwood forest and abundant rhododendron in and around the channel, impassable in places. Flow in the channel is low but consistently present, despite it being a dry spring [Kloeppel, 2001 \#160].

Rebecca Kavage, Lee Taylor, and Doug Marchakitus surveyed Coweeta Watershed 34 from May 11-15, 2001. 


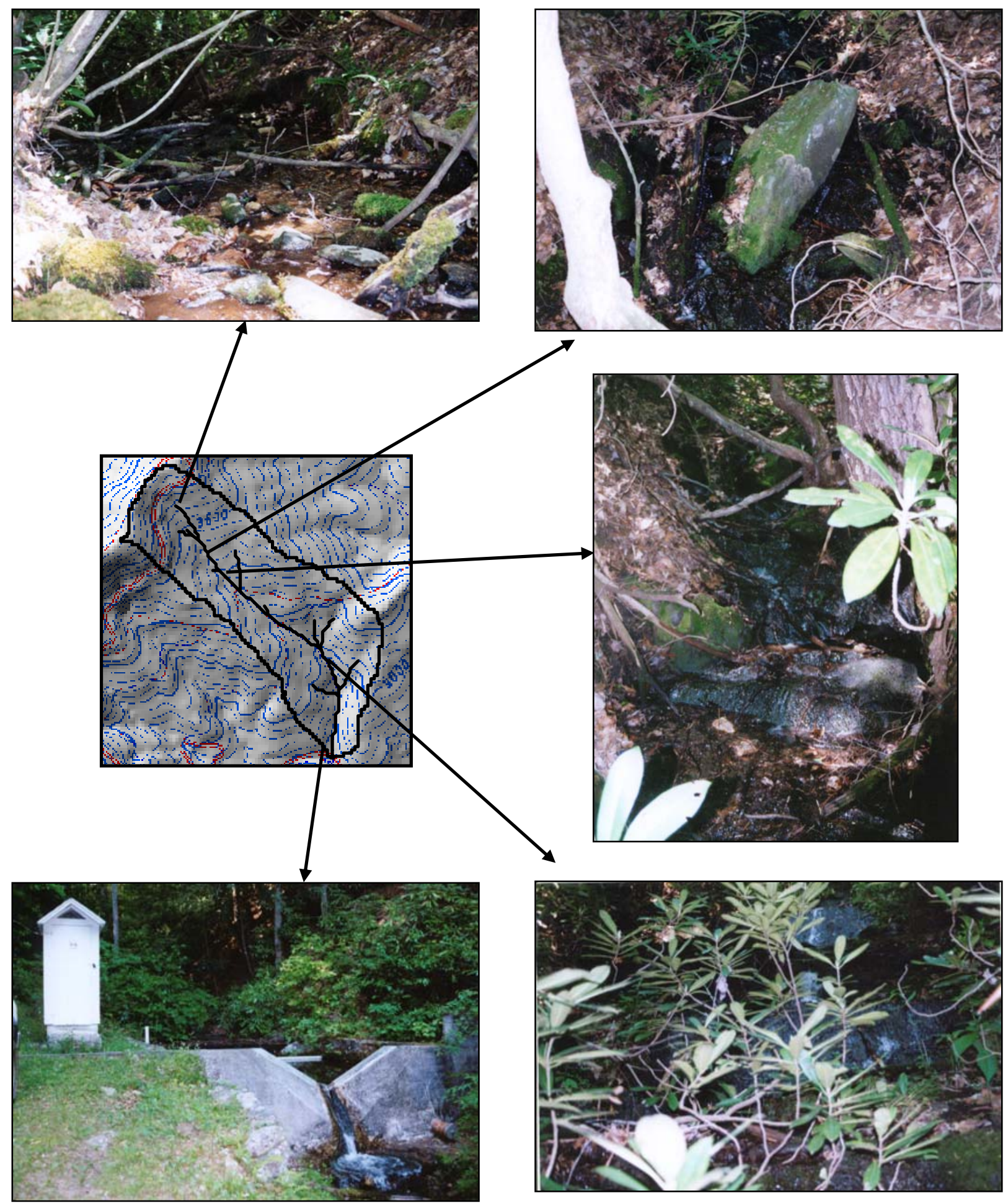

Figure I.1. Photographs of Coweeta Watershed 34, clockwise from upper left: upper alluvial reach above bedrock break (x4), steep bedrock reach with large boulder (x3), steep bedrock step channel, bedrock steps behind rhododendron leaves, and stream gauging station below survey start point. 


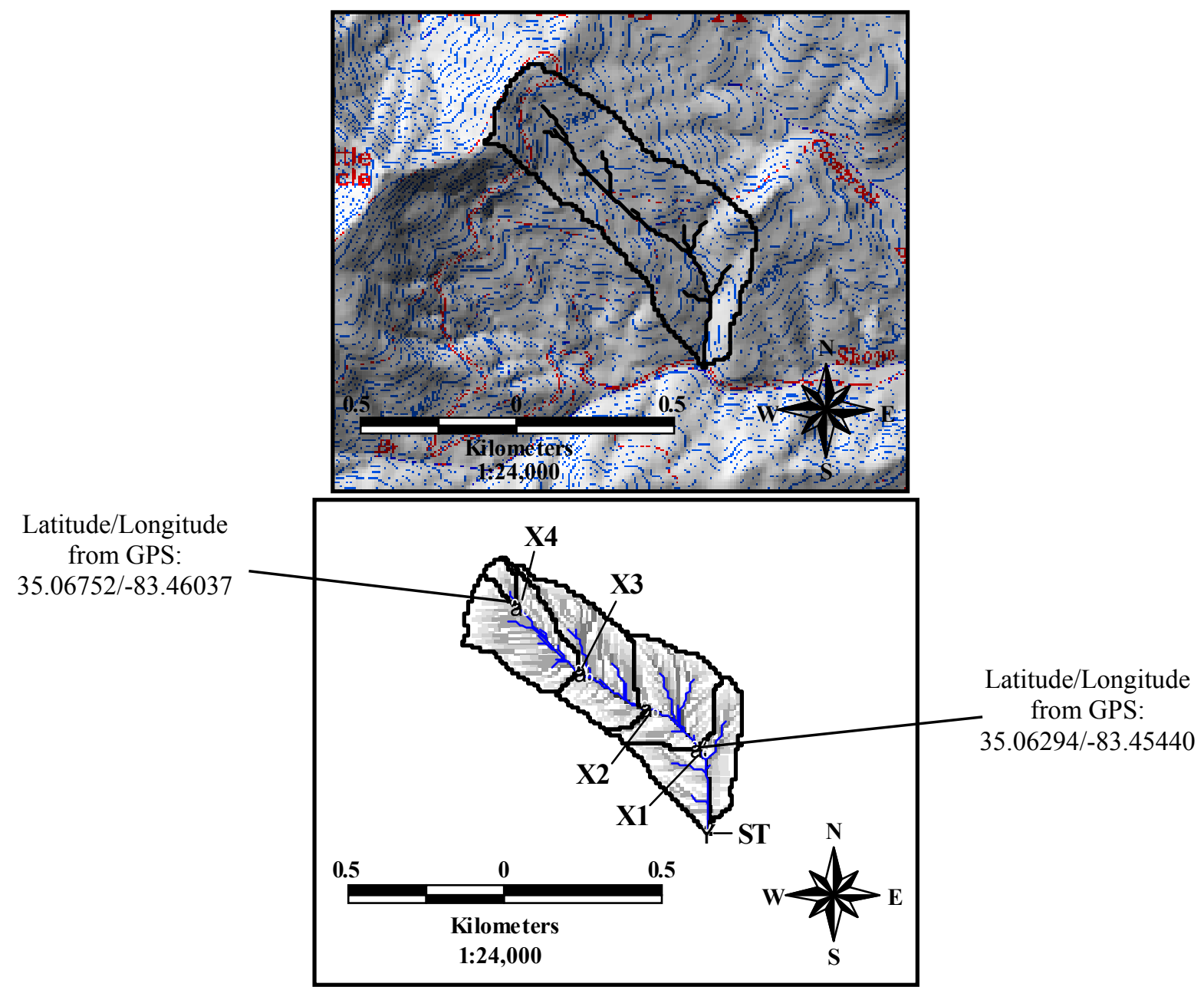

Figure I.2. Topographic and drainage network maps of Coweeta Watershed 34 basin, denoting survey points. 


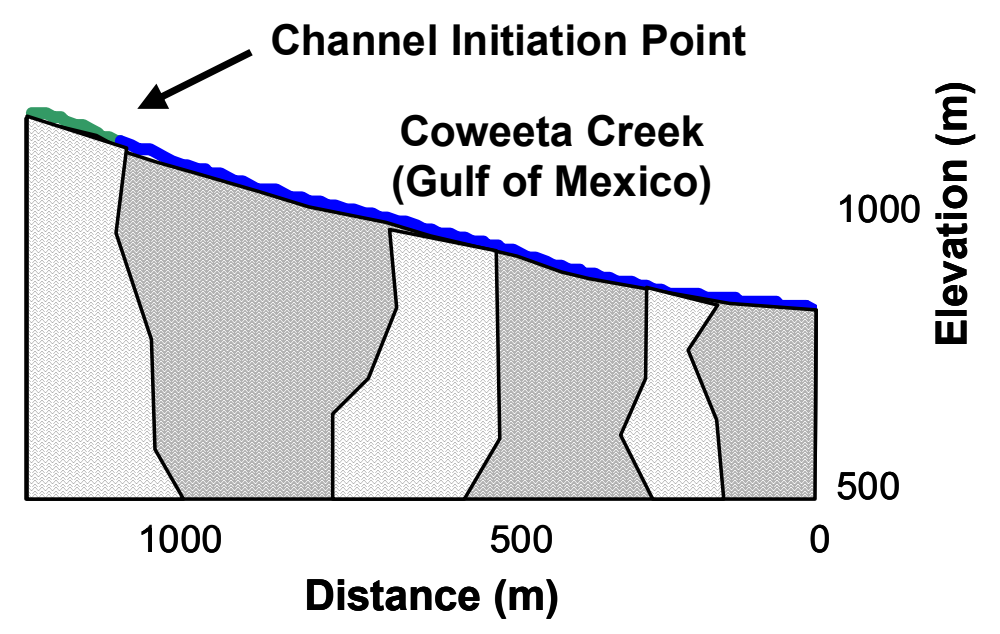

Figure I.3. Bedrock geology, channel initiation point, and base level for Coweeta Watershed 34 basin. Bedrock geology taken from Hatcher (1980).

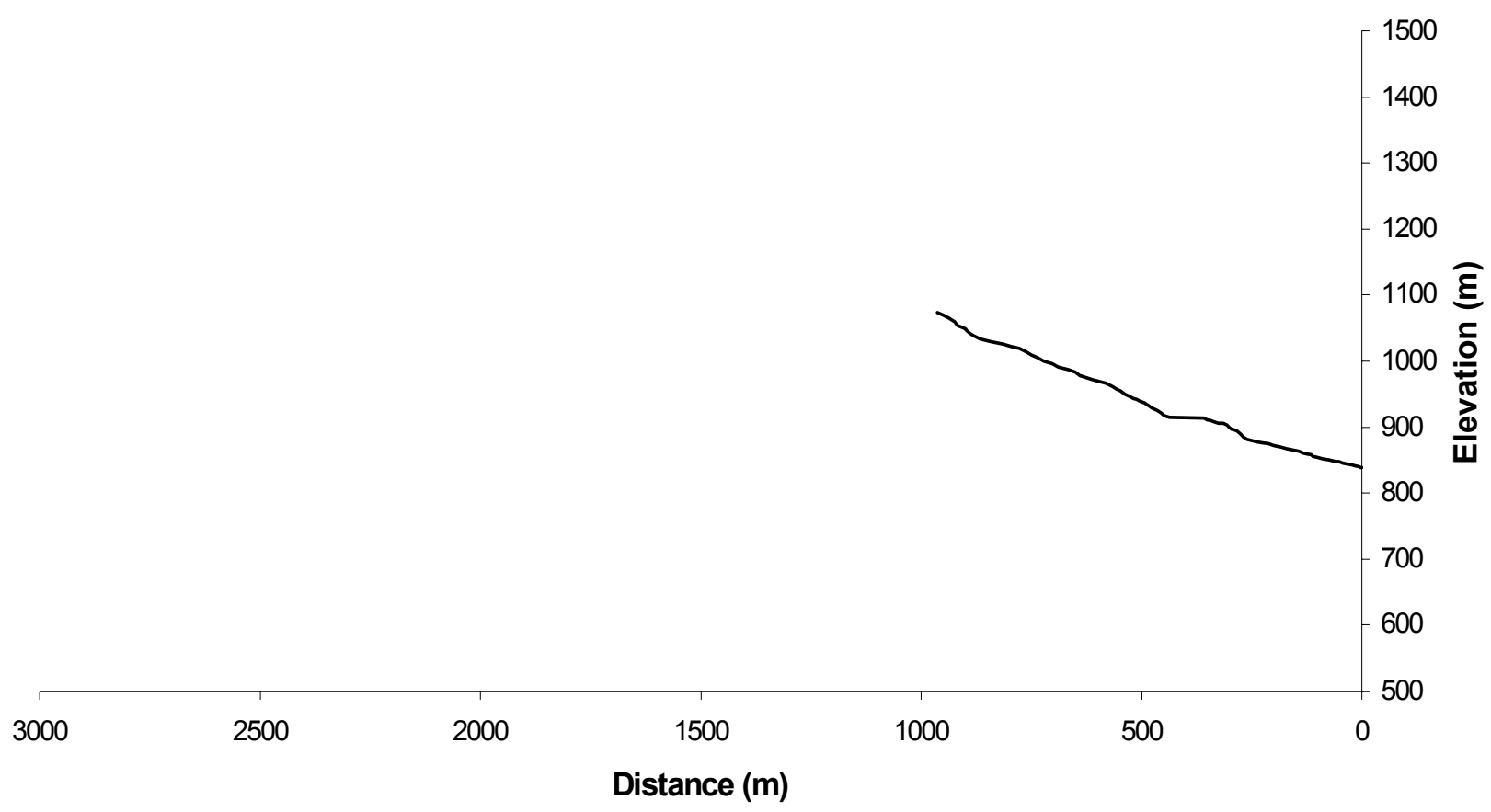

Figure I.4. Coweeta Watershed 34 longitudinal profile, from survey data. 


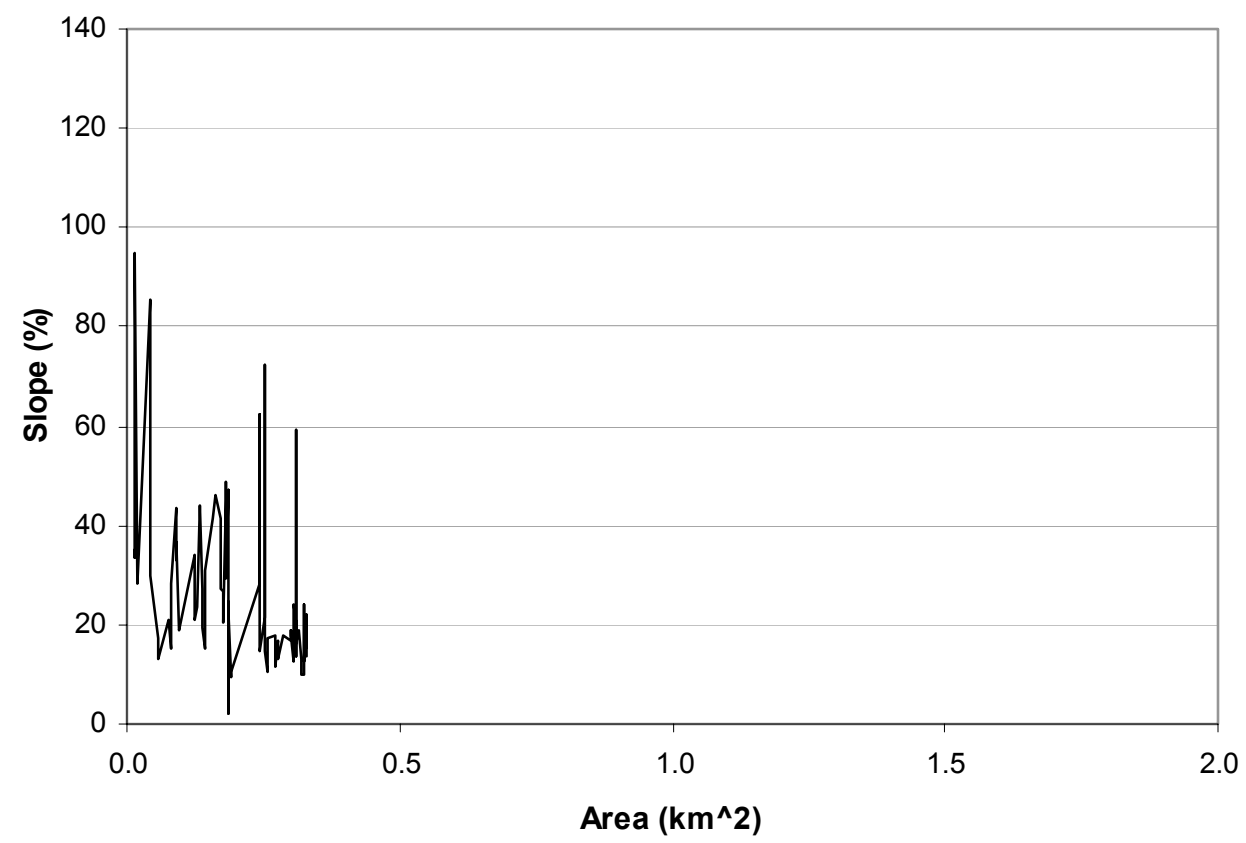

Figure I.5. Slope-area plot for surveyed portion of Coweeta Watershed 34 channel, using field surveyed slope values and DEM-generated drainage area values.

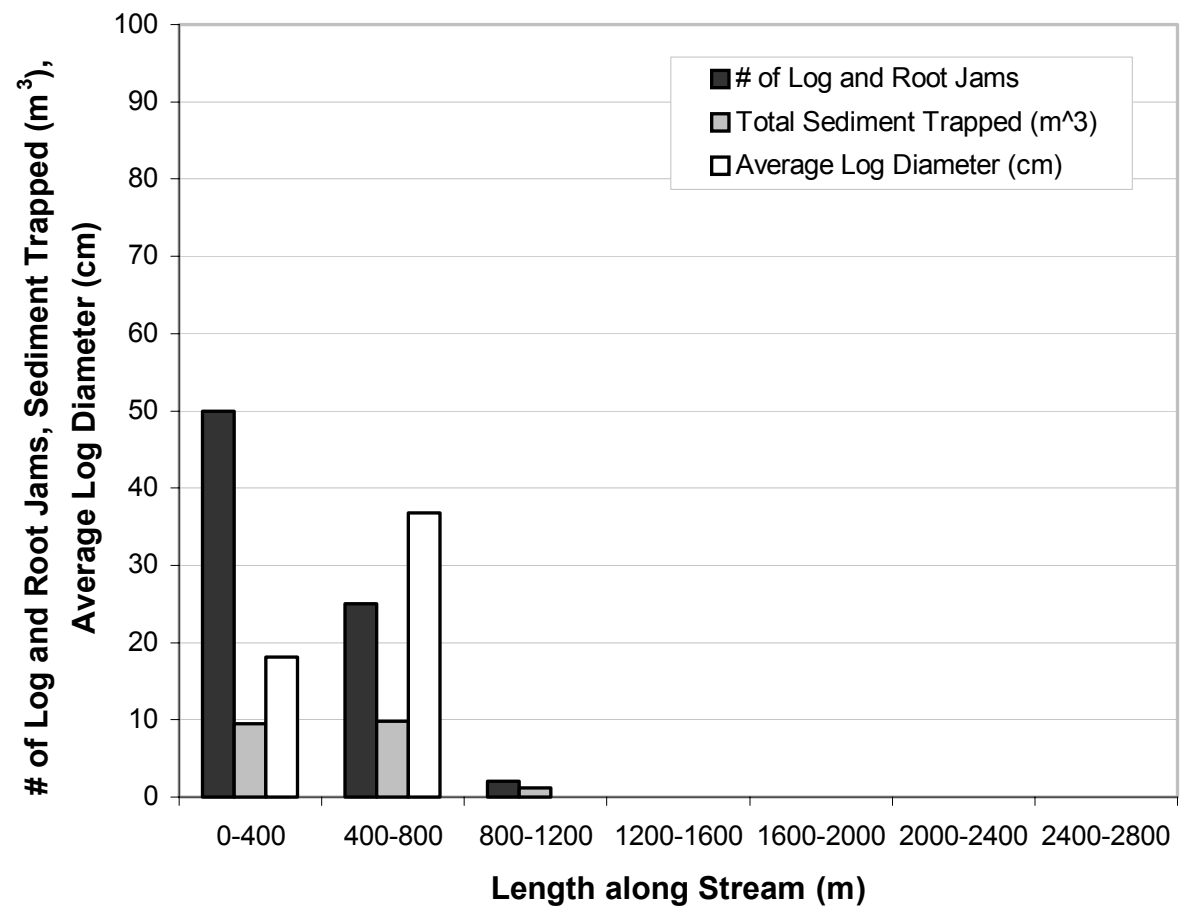

Figure I.6. Log and root jam frequency, total sediment trapped in jams, and average log diameter binned for $400 \mathrm{~m}$ length stream segments of Coweeta Watershed 34. 

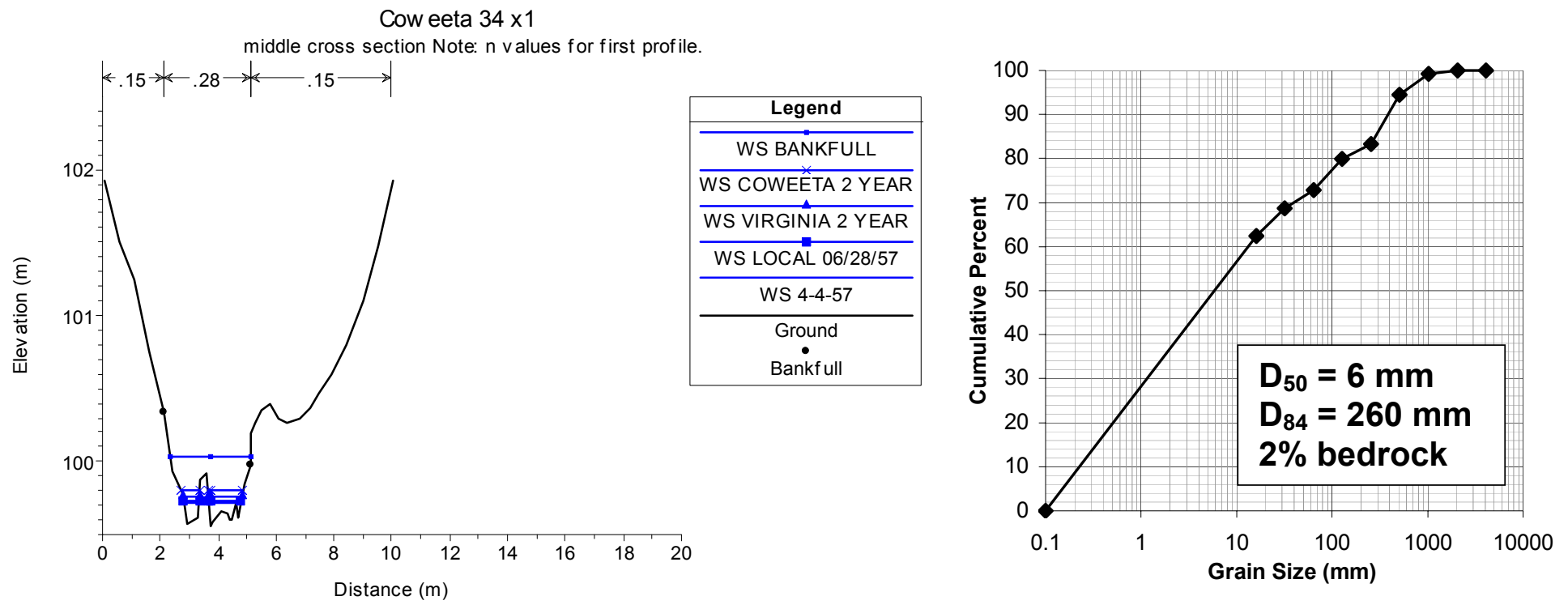

Figure I.7. Coweeta Watershed 34 reach 1, middle cross section (left), and cumulative grain size distribution from Wolman pebble count (right). Reach 1 was located downstream of the first major series of bedrock steps in an alluvial step-pool section of channel.
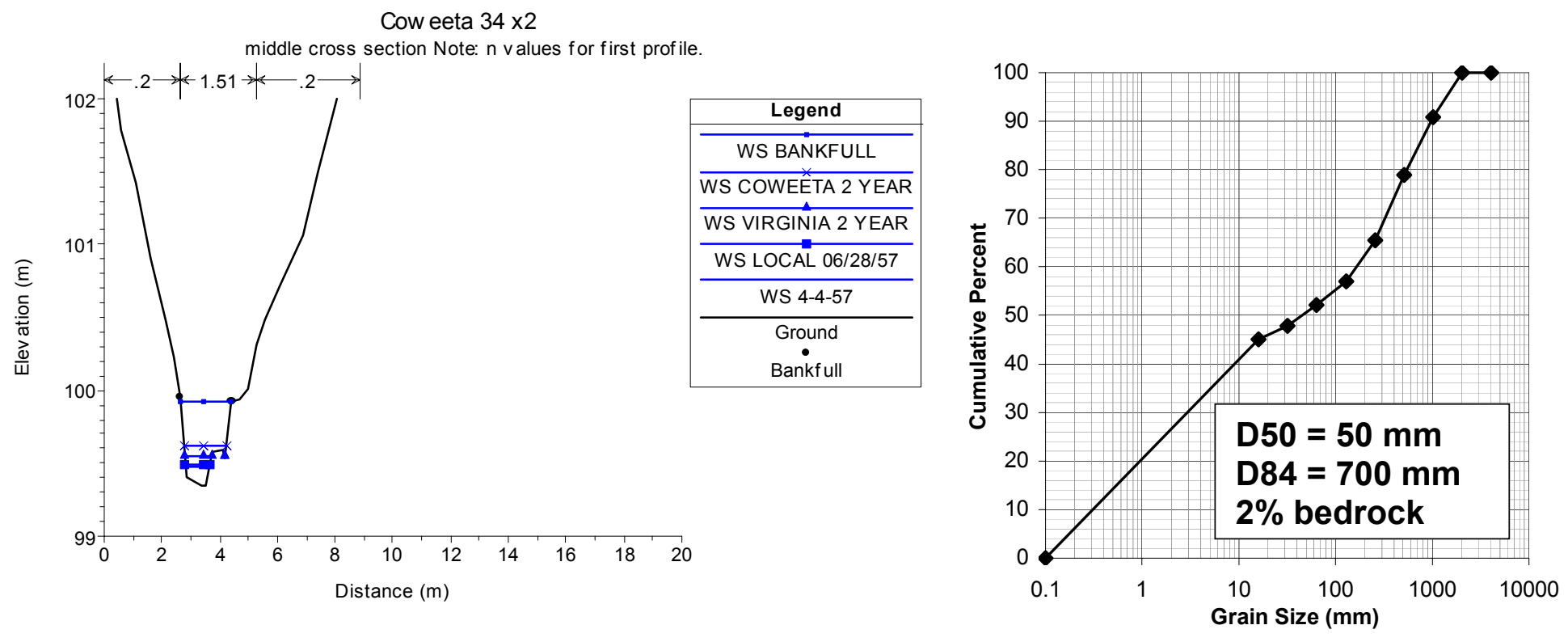

Figure I.8. Coweeta Watershed 34 reach 2, middle cross section (left), and cumulative grain size distribution from Wolman pebble count (right). Reach 2 was located above a bedrock falls, in a steep boulder-cobble section of channel. 

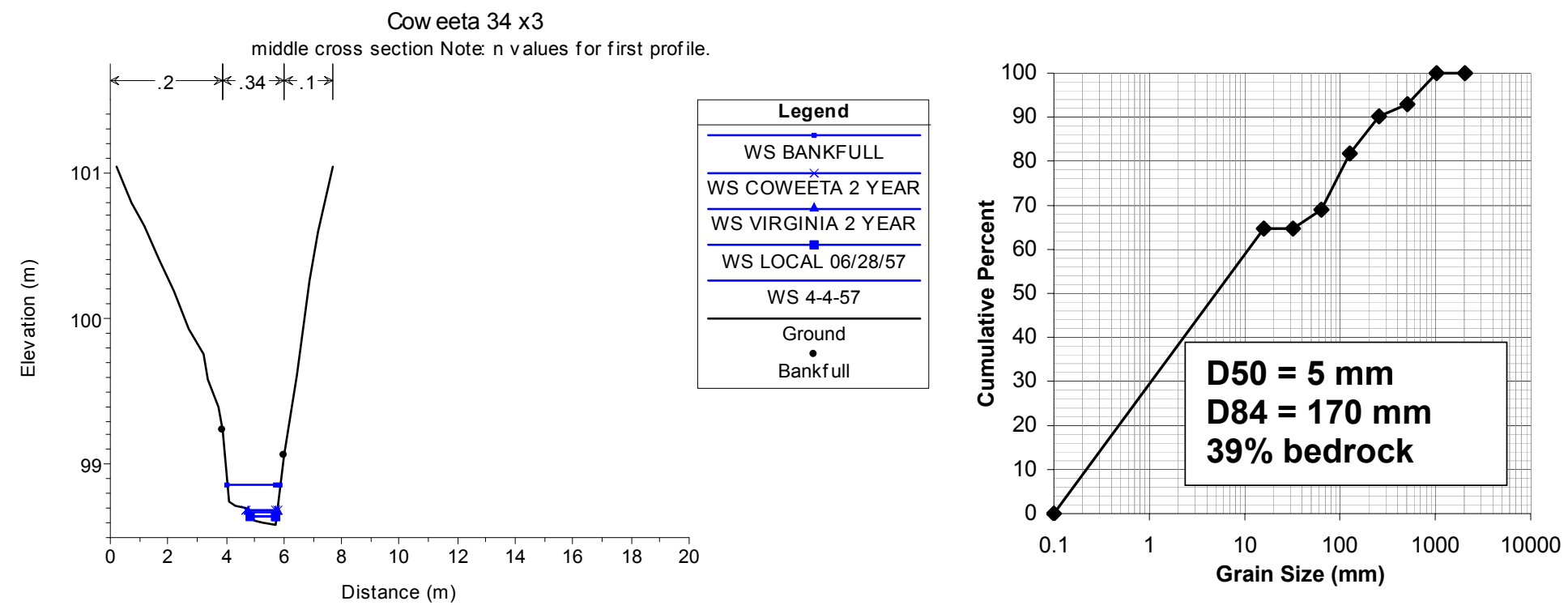

Figure I.9. Coweeta Watershed 34 reach 3, middle cross section (left), and cumulative grain size distribution from Wolman pebble count (right). Reach 3 was located just downstream of the only major split in the channel, in a steep bedrock section with a boulder in the middle of it.
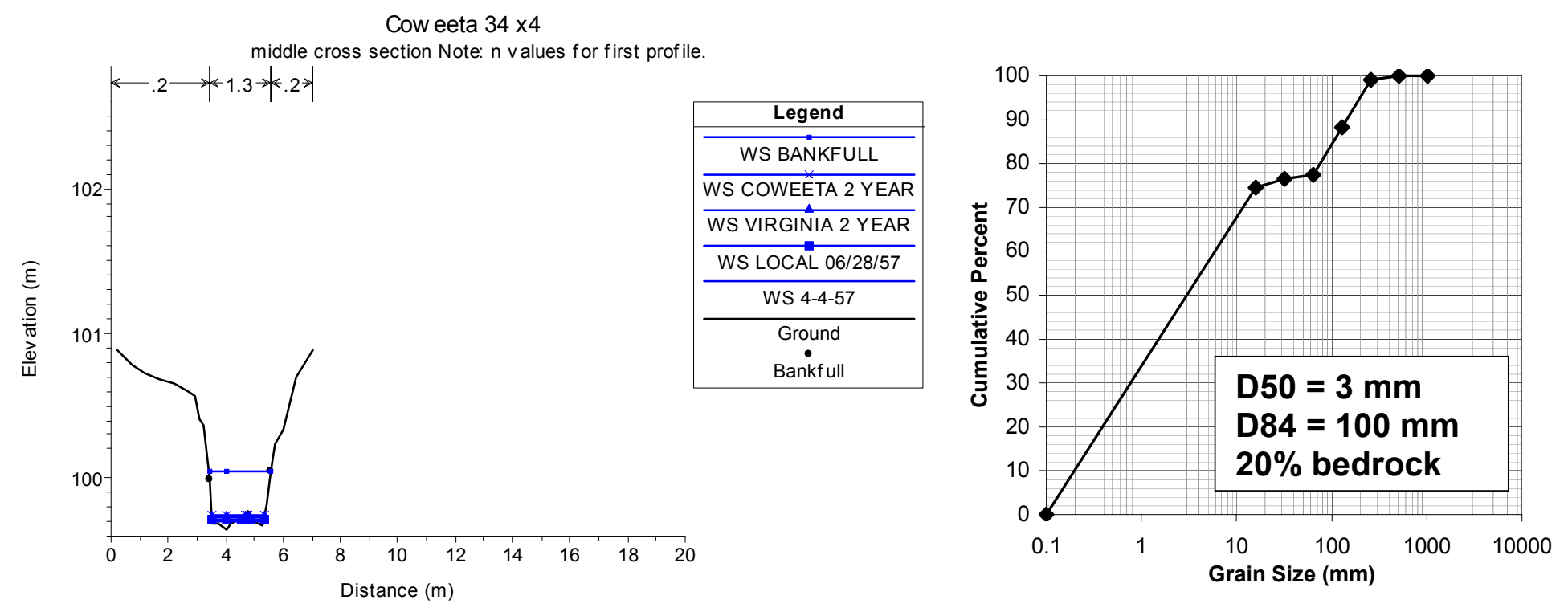

Figure I.10. Coweeta Watershed 34 reach 4, middle cross section (left), and cumulative grain size distribution from Wolman pebble count (right). Reach 4 was located just below the bail-out point where vegetation became impassable. It was just above a bedrock step, in a cobble-fines section of channel below a large downed tree. 


\section{Appendix J \\ Bedrock Geology Legend}

$\underline{\text { Paleozoic Sedimentary (listed in order of most to least resistant) }}$

Tuscarora Fm. sandstone (massive)

Cloyd conglomerate

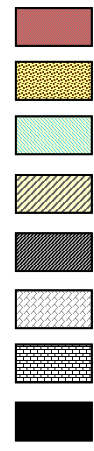

Rose Hill Fm. sandstone

Price Fm. sandstone

Juniata Fm. sandstone-siltstone

Keefer sandstone and Tonolowa limestone

Martinsburg Fm. sandstone-shale-limestone

Chemung Fm. sandstone-siltstone-shale

Knox Fm. dolostone-limestone

Ordovician limestones

集㯺 Elbrook Fm. dolostone-limestone

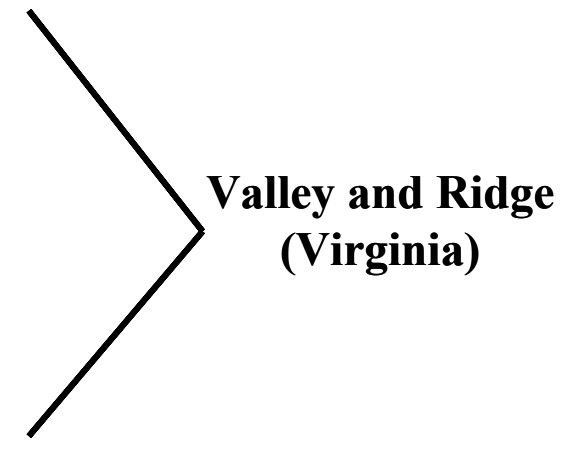

Millboro Fm. and Braillier Fm. shale

\section{Metamorphic}
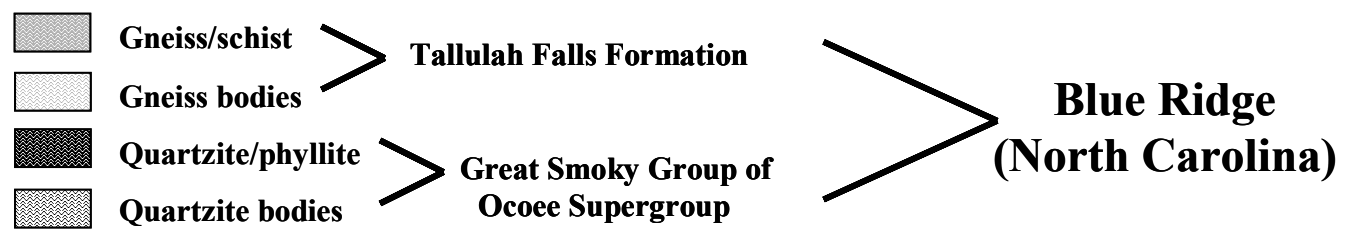

Rough bedrock pattern based on existing geologic maps of study area Fine scale variations within formations are present but not represented 
Vita

\section{Rebecca Hope Kavage Adams}

Rebecca Adams was born in Columbus, Ohio in 1975. She graduated from Big Walnut High School in Sunbury, Ohio, in 1993. She obtained a Bachelor of Science degree from Virginia Tech in Forestry and a Master of Science from Virginia Tech in Geological Sciences. She is currently living in Blacksburg, Virginia, with her husband, Jeff, and their cat, Gurdy. She hopes to publish her thesis work and then pursue a career with the U.S. Forest Service as a hydrologist. 